\title{
Mollusc species response to drivers in space and time
}

Rise and demise of the unique Pontocaspian fauna

Sabrina van de Velde

Utrecht Studies in Earth Sciences

No. 207 


\section{Members of the dissertation committee}

Prof. dr. Marius Stoica

University of Bucharest, Department of Geology and Geophysics, Bucharest, Romania

Prof. dr. Wout Krijgsman

University of Utrecht, Department of Earth Sciences, Utrecht, the Netherlands

Prof. dr. Friederike Wagner-Cremer

University of Utrecht, Department of Physical Geography, Utrecht, the Netherlands

Prof. dr. Jelle Reumer

University of Utrecht, Department of Earth Sciences, Utrecht, the Netherlands

Dr. Willem Renema

Naturalis Biodiversity Center, Leiden, the Netherlands

This research was sponsored by the PRIDE (Pontocaspian RIse and DEmise) project, which received funding from the European Union's Horizon 2020 research and innovation programme under the Marie Sklodowska-Curie grant agreement No. 642973.

ISBN/EAN: 978-90-6266-570-9

ISSN: 2211-4335

Copyright (C) 2020 Sabrina van de Velde

All rights reserved. No part of this publication may be reproduced in any form, by print or photo print, microfilm or any other means, without written permission by the publisher. Niets uit deze uitgave mag worden vermenigvuldigd en/of openbaar gemaakt door middel van druk, fotokopie of op welke andere wijze dan ook zonder voorafgaande schriftelijke toestemming van de uitgevers.

Printed in the Netherlands by Ipskamp.

Author contact: sabrina.vandevelde@naturalis.nl

Front cover: Pontocaspian area (Black Sea and Caspian Sea) as seen from the air. Image credit: NASA images. 


\title{
Mollusc species response to drivers in space and time
}

Rise and demise of the unique Pontocaspian fauna

\author{
Реакция фауны моллюсков к изменениям \\ среды в пространстве и времени \\ Расцвет и упадок уникальной Понтокаспийской фауны \\ (С аннотацией на русском языке)
}

\section{Biodiversiteit van mollusken in tijd en ruimte}

De opkomst en ondergang van de unieke Pontokaspische fauna

(met een samenvatting in het Nederlands)

\begin{abstract}
Proefschrift
ter verkrijging van de graad van doctor aan de Universiteit Utrecht op gezag van de rector magnificus, prof.dr. H.R.B.M. Kummeling, ingevolge het besluit van het college voor promoties in het openbaar te verdedigen op
\end{abstract}

vrijdag 2 oktober 2020 des ochtends te 11.00 uur

door

Sabrina van de Velde

geboren op vrijdag 17 mei 1985

te Rotterdam 
Promotor: $\quad$ Prof. dr. L. J. Lourens

Copromotoren: Dr. F. P. Wesselingh

Dr. T. A. Neubauer 
To live content with small means; to seek elegance rather than luxury, and refinement rather than fashion; to be worthy, not respectable, and wealthy, not, rich; to listen to stars and birds, babes and sages, with open heart; to study hard; to think quietly, act frankly, talk gently, await occasions, hurry never; in a word, to let the spiritual, unbidden and unconscious, grow up through the common. This is my symphony.

William Ellery Channing 


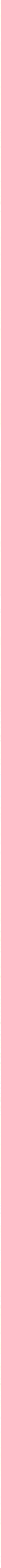




\section{Contents}

I General Summary (in English) 9

II Samenvatting (General summary in Dutch) 11

III Аннотация (General summary in Russian) 13

$1 \quad$ Introduction and synopsis $\quad 17$

$2 \quad$ Quaternary Pontocaspian mollusc history - an overview 33

3 Mollusc species from the Pontocaspian region - an expert opinion list 59

$4 \quad$ Late Pleistocene Caspian gastropod diversity (Selitrennoye, Russia) 141

$5 \quad$ Late Pleistocene Caspian mollusc diversity (Selitrennoye, Russia) 195

$6 \quad$ Holocene Caspian mollusc diversity (Turali, Russia) 221

7 Appendix: Data report on mollusc assemblages from Late Quaternary borehole of the northern Caspian Sea $\quad 249$

8 Late Holocene mollusc biodiversity of the western Black Sea (Razim-Sinoie lake, Romania) 265

9 Appendix: Data report on early Holocene Pontocaspian mollusc assemblages from the Black Sea $\quad 291$

$10 \quad$ Synthesis \& future perspectives $\quad 297$

11 Acknowledgements 309

12 About the author 313

13 Peer reviewed publications $\quad 315$

14 References 317 


\section{3.

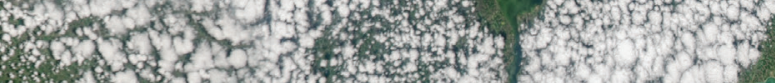

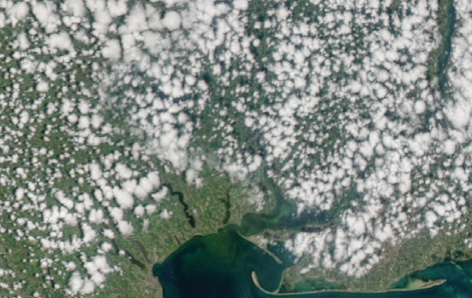

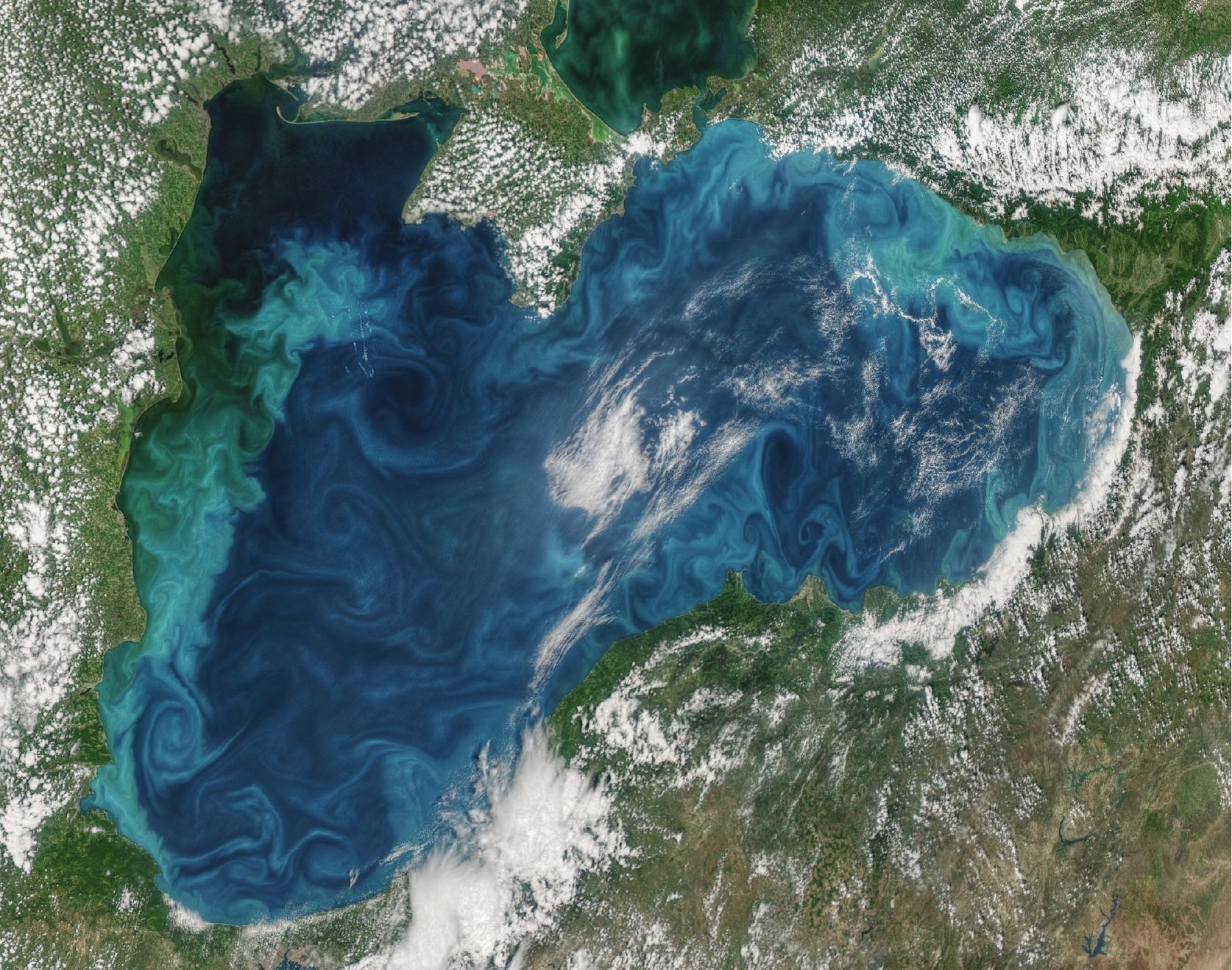

(x)

(1)

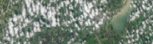

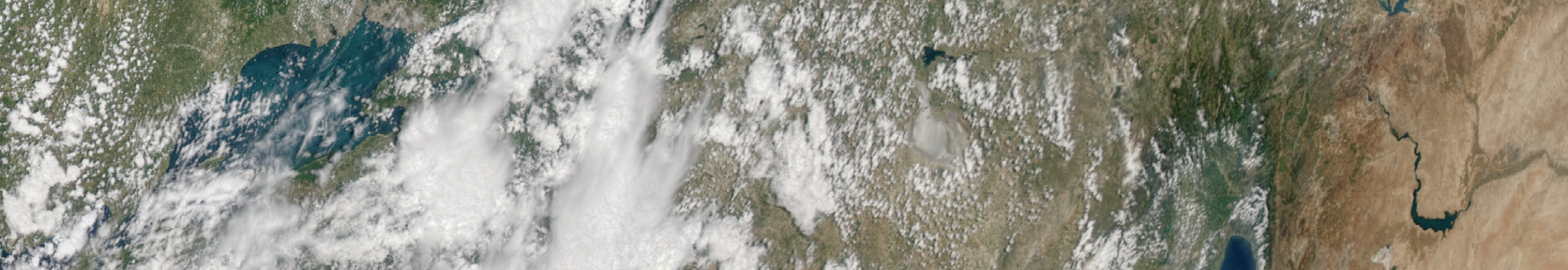

23.20 $-4+2$

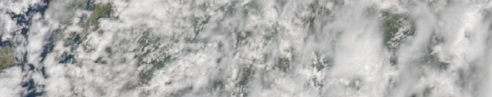

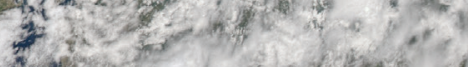
teth

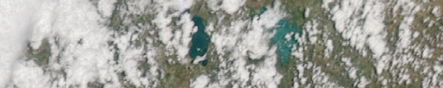

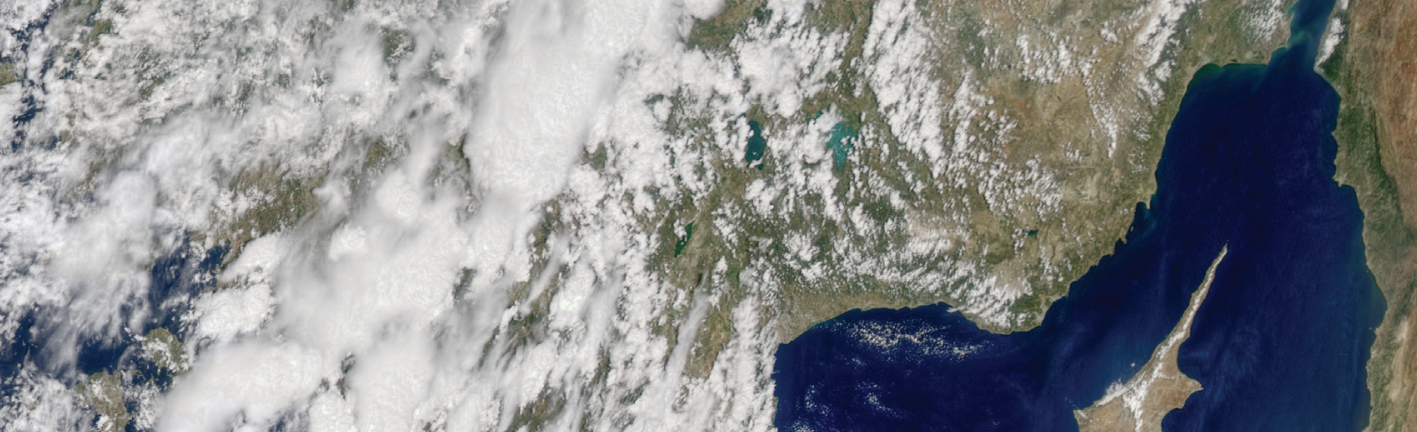




\section{General Summary}

The evolution of the Pontocaspian lakes and seas (Caspian Sea, Black Sea, Aral Sea) is characterised by major changes in water levels, which developed into a pulsating system of connected and isolated basins. During the late Quaternary (Late Pleistocene and Holocene), these basins have hosted a unique endemic biodiversity that experienced species turnover events. There are indications that the Pontocaspian species diversity is now in demise because of anthropogenic modifications of the ecosystem, such as habitat alteration, poaching, pollution and invasive species. Little data is available on faunal changes and resilience of Pontocaspian species to help discerning the effect of natural drivers and anthropogenic drivers on the endemic fauna, which is of direct relevance for conservation strategies.

This thesis aims to characterize species richness and abundance of fossil faunas to establish a baseline for comparison with the changing biodiversity of today. Mollusc species are used as the study group as they easily fossilize and are abundant in the geological record. They inform us about the composition of communities and how they change, and enable us to reconstruct environments ('habitats'). This is necessary in order to compare biodiversity through different time intervals and establish whether comparable habitats existed as those of today. A baseline of Pontocaspian mollusc faunas was achieved by analysing snapshots from the Caspian Sea basin and the Black Sea basin. Caspian mollusc assemblages are analysed from late Pleistocene (corresponding to the late Khazarian, Hyrcanian, early Khvalynian and late Khvalynian regional stages) and pre-20th century Holocene (Novocaspian) assemblages. Black Sea assemblages from the late Neoeuxinian and late Holocene are described. They are both compared with modern day assemblages.

This study shows clear indications of a Pontocaspian mollusc diversity crisis. Overall, in the $20^{\text {th }}-21^{\text {st }}$ century, Pontocaspian molluscs have experienced a severe decline in species richness and abundance: a strong turnover towards invasive species in the Caspian basin, a strong habitat decline in parts of the Black Sea basin and a total obliteration in the Aral basin. The late Quaternary mollusc fauna snapshots demonstrate that endemic species dominated the Caspian communities with minor contributions of native species until the late Holocene. The Pontocaspian mollusc species richness in the Caspian Sea basin is higher than in the Pontocaspian habitats of the Black Sea basin, or the Aral Sea basin. Throughout the Late Quaternary, the strong natural fluctuations of Caspian Sea level affected shallow water bivalve species of the genus Didacna, but barely changed the overall composition of the mollusc faunas. Late Quaternary mollusc fauna snapshots of the Black Sea basin show very little change in the Pontocaspian species community since humans impacted the habitats. 
However, the Black Sea Pontocaspian mollusc communities are currently under severe threat of habitat deterioration and destruction.

This research indicates that the Caspian Sea could act as a source for Pontocaspian biota, hence conservation efforts are imperative there. The deeper parts ( $>50 \mathrm{~m}$ water depth) possibly present a (partial) refuge, and urgent research is required to assess these habitats and their faunas. Future research should focus on improving the taxonomic framework to elucidate the identity of some Pontocaspian cryptic and sister species. We need more distribution and ecological data of current Pontocaspian species and more detailed biodiversity time series coupled with detailed environmental proxies to assess the nature of the Pontocaspian biodiversity crisis more comprehensively and plan conservation actions accordingly. 


\section{SAMENVATTING}

Het Zwarte Zee, Kaspische Zee, Aralmeer gebied staat bekend als de Pontokaspische regio. De evolutie van meren en zeeën in deze regio kan worden gekenmerkt als een pulserend systeem van verbonden en geïsoleerde waterbekkens waarin grote schommelingen van de zee- en meerspiegel voorkwamen. Tijdens het Laat Kwartair ontwikkelde zich in deze bekkens een unieke, endemische soortenrijke fauna. Er zijn duidelijke aanwijzingen dat de Pontokaspische diversiteit en het ecosysteem nu fors achteruitgaan vanwege menselijk handelen zoals aanpassingen aan de habitats, stroperij, vervuiling en het introduceren van invasieve soorten. Er zijn op dit moment weinig gegevens beschikbaar over biodiversiteitsveranderingen en de reactie van Pontokaspische soorten op deze bedreigingen. Deze gegevens zijn nodig om het effect van natuurlijke en antropogene veranderingen op de endemische fauna te helpen vaststellen, wat van direct belang is voor natuurbehoud.

Dit proefschrift heeft als doel de soortenrijkdom van fossiele fauna's te karakteriseren om zo een natuurlijke basis te schetsen ter vergelijking met de biodiversiteit van vandaag. In dit onderzoek worden schelpen gebruikt omdat ze gemakkelijk fossiliseren en overvloedig aanwezig zijn in de fossiele overlevering. Ze informeren ons niet alleen over de samenstelling van gemeenschappen en hoe deze veranderen door de tijd heen, maar ze stellen ons ook in staat om de omgeving ('habitat') te reconstrueren. Dit is nodig om fauna's van vergelijkbare milieus door de tijd heen te kunnen vergelijken. Het creëren van de Pontokaspische referentie fauna's wordt bereikt door het analyseren van geologische monsters die momentopnames vormen uit het Kaspische Zeebekken en het Zwarte Zeebekken. De Kaspische monsters omvatten zes niveaus uit de laatste 100.000 jaar. Twee fauna's uit de Zwarte Zee worden beschreven. De fauna's uit beide bekkens wordt vergeleken met de moderne fauna uit dezelfde bekkens, en met het Aralmeer gebied.

Deze studie geeft duidelijke aanwijzingen voor een Pontokaspische biodiversiteitscrisis. Over het algemeen laten Pontokaspische schelpen in laatste paar decennia een sterke afname van soortenrijkdom en soortenovervloed zien; een sterke verandering naar invasieve soorten in het Kaspische bekken, een sterke achteruitgang van habitats in delen van het Zwarte-Zeebekken en een totale vernietiging in het Aral bekken. Endemische soorten domineerden de Kaspische Zee tot aan het Laat Holoceen met een klein aandeel aan inheemse soorten. De Pontokaspische schelpensoortenrijkdom in het Kaspische Zeebekken is hoger dan in de Pontokaspische habitats van het Zwarte Zeebekken of het Aralmeerbekken. De sterke natuurlijke schommelingen van de Kaspische Zeespiegel beïnvloedde soorten van het tweekleppige geslacht Didacna die in ondiep 
water leven, maar veranderden nauwelijks de algehele samenstelling van de schelpenfauna's. Laat Kwartaire momentopnames van het Zwarte Zeebekken vertonen zeer weinig verandering in de Pontocaspian-soortengemeenschap voor en na antropogene invloed. De Pontokaspische schelpen gemeenschappen in de Zwarte Zee worden momenteel echter ernstig bedreigd door vernietiging van hun habitat. Dit onderzoek geeft aan dat de Kaspische Zee zou kunnen fungeren als een bron voor Pontokaspische biota, daarom wordt aangeraden om natuurbehoud allereerst op dit bekken te concentreren. De diepere delen van de Kaspische Zee (> 50 m waterdiepte) bieden mogelijk een toevluchtsoord en er is dringend onderzoek nodig om deze habitats en hun fauna's te analyseren. Toekomstig onderzoek moet gericht zijn op het verbeteren van de Pontokaspische taxonomie om de identiteit van sommige Pontokaspische cryptische- en zustersoorten op te helderen. We hebben meer distributie- en ecologische gegevens nodig van de huidige Pontokaspische soorten en meer gedetailleerde tijdreeksen voor biodiversiteit in combinatie met gedetailleerde milieuvariabelen om de aard van de Pontokaspische biodiversiteitscrisis beter te kunnen beoordelen en dienovereenkomstige natuurbehoudsmaatregelen te plannen. 


\section{Аннотация}

Эволюция Понтокаспийских бассейнов (Каспийское, Чёрное и Аральское моря) связана с постоянными колебаниями уровня воды, которые приводили к соединению между этими бассейнами и их изоляции. В течение позднечетвертичного времени (поздний плейстоцен и голоцен) эти бассейны обладали уникальным эндемичным биоразнообразием, которое временами претерпевало экологические перестройки. В настоящее время, Понтокаспийские виды численно сокращаются из-за антропогенного изменения условий обитания, браконьерства, загрязнения и разведения инвазивных видов. Недостаток данных об изменениях и устойчивости Понтокаспийских экосистем затрудняет понимание роли естественных и атропогенных причин кризиса биоразнообразия, что в свою очередь делает разработку стратегии сохранения видов невозможным.

Основная цель данной диссертации заключается в оценке видового состава и распространенности ископаемой Понтокаспийской фауны в геологических разрезах Четвертичного возраста, что создаёт основу для сравнения текущих и прошлых изменений биоразнообразия. Ископаемые моллюски были выбраны в качестве изучаемой группы из-за их хорошей сохранности в геологических разрезах. Изменение в видовом составе ископаемых моллюсков, как правило, отображает изменения окружающей среды, что позволяет сравнить эти изменения в разных отрезках времени, а также установить, случались ли подобные экологические кризисы ранее и по какой причине. Данные по Понтокаспийской фауне моллюсков были получены путём анализа проб из Каспийского и Чёрного морей. Для Каспийского региона, были проанализированы пробы из позднего Плейстоцена (отвечает позднехазарскому, гирканскому, раннехвалынскому и позднехвалынскому региональным подъярусам (прим.: в соответствие с международной стратиграфической номенклатурой) и Голоцена (до промышленной революции, новокаспийский ярус). Для Черноморского региона, были описаны группы из позднего плейстоцена (неоэвксинский) и позднего голоцена (черноморский). Сообщества из обоих регионов сравниваются с современными.

Данная работа подтверждает современный, активный кризис биоразнообразия Понтокаспийского региона. Позднечетвертичная фауна моллюсков показывает, что в каспийских сообществах, вплоть до позднего голоцена доминировали эндемичные виды с малым участием инвазивных видов. Видовое разнообраие ископаеиых Понтокаспийских моллюсков намного выше в Каспийском бассейне по сравнению с бассейнами Чёрного и 
Аральского морей. В течение позднечетвертичного времени, сильные колебания уровня Капиского моря оказывали влияние на мелководных двустворок рода Didacna, но в целом практически не повлияли на видовой состав фауны моллюсков. Позднечетвертичная фауна моллюсков Чёрного моря имеет незначительные различия с современными видами, претерпевшими антропогенное воздействие условий обитания. Тем не менее, условия обитания черноморских представителей Понтокаспийской фауны моллюсков находятся под угрозой уничтожения. В целом, в течение 20-21 веков, Понтокаспийские моллюски претерпели сильное видовое и количественное снижение: биологический кризис в Каспийском море, характеризующийся распространением инвазивных видов, ухудшение условий обитания Понтокаспийских видов в Черноморском и полное исчезновение в Аральском бассейнах.

Данные представленные в этой диссертации также указывают на то, что значительная часть Понтокаспийских видов до сих пор может быть скрыта в глубоководной части Каспийского моря (>50 м глубины), поэтому, природоохранные мероприятия и срочные исследования в этом бассейне должны быть произведены в ближайшее время. Будущие исследования должны быть сосредоточены на уточнении таксономии для лучшей идентификации некоторых скрытых и родственных Понтокаспийских видов. Необходим также сбор данных о распространении и экологии современных Понтокаспийских видов в совокупности с применением других экологических методов для полной и всесторонней оценки и понимания причин кризиса Понтокаспийского биоразнообразия и разработки соответственных природоохранных мероприятий.

Translated by Sergei Lazarev 


\section{INTRODUCTION AND SYNOPSIS}

\subsection{Introduction}

Ecosystems and biodiversity are threatened worldwide, and multiple anthropogenic drivers are linked to the changes (IPBES, 2019). Five human actions have been identified as the most important threats: change in land and sea use, direct exploitation of organisms, climate change, pollution, and invasive species (Díaz et al., 2019; IPBES, 2019; Isbell et al., 2017; Tilman et al., 2017). One of the greatest centres of continental aquatic biodiversity today is the Pontocaspian region (Mamaev, 2002; Neubauer et al., 2015a; Wesselingh et al., 2019; Zaitsev and Mamaev, 1997). The Caspian Sea basin and parts of the Black Sea basin host a unique biodiversity of which the majority of species are endemic to these particular waters (Dumont, 2000; Kosarev and Yablonskaya, 1994). Several studies have indicated that Pontocaspian species richness in the two basins are now in demise because of anthropogenic threats to the ecosystem (Barannik et al., 2004; Mamaev, 2002; van de Velde et al., 2019c, 2019a; Wesselingh et al., 2019).

To be able to develop adequate management and conservation programs, it is of great importance to understand how biodiversity changes and what the effects of natural and anthropogenic drivers are on diversity (Dietl et al., 2015). Often, conservation biology is focussed on local fluctuations in species richness (Primack et al., 2018) or short time series to analyse the anthropogenic effect on the diversity of species (Dornelas et al., 2014). While comparing species richness of human-disturbed sites versus recovered sites helps understanding the relative difference between the two moments in time and the ability of species to recover (Moreno-Mateos et al., 2017), it does not give any information on baseline data of biodiversity before human disturbance. To test ecological hypotheses about the influence of human drivers, we need to capture larger temporal fluctuations in diversity from ecosystems prior to human impact (Primack et al., 2018).

Historical baseline studies of diversity prior to human influence are scarce, which hampers our ability to estimate the nature and magnitude of the biodiversity decline. In this thesis, time series from the Pontocaspian basins are used to document late Quaternary faunal and biodiversity change, in order to capture mollusc diversity under natural variation and under current human impact. Characterising biodiversity variation in combination with independent reconstruction of past habitats is an essential step. Thereby it is necessary to constrain the paleohabitat to ensure similar habitats are compared in time. Diversity assessments from boreholes and snapshots from outcrops allow us to (1) examine faunal response (the change in diversity and abundance of species) to environmental change through time, (2) compare the communities prior to human impact to the 


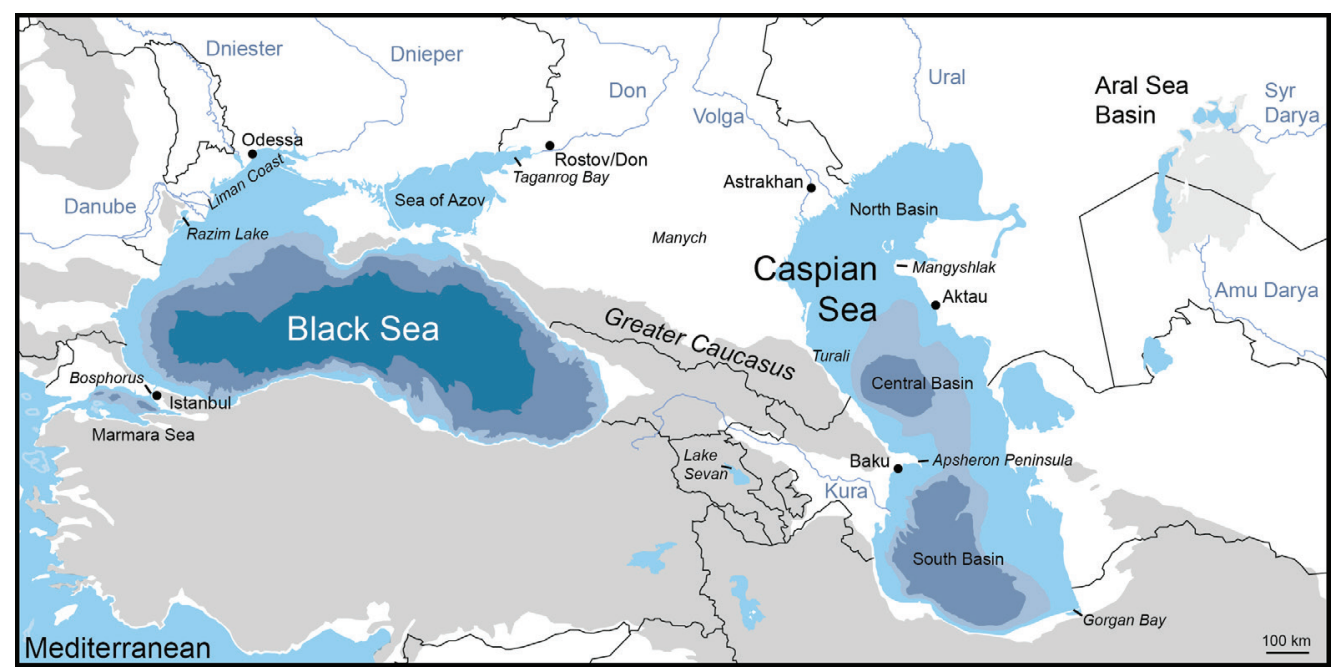

Fig. 1.1: Map of the Pontocaspian region with the indication of major basins, rivers, regions (from Wesselingh et al., 2019). Today's brackish Black Sea, Caspian Sea, Azov and Aral Sea are the modern day water bodies that are the remaining fragments of the ancient seaway.

community structure under anthropogenic influence, and (3) improve conservation strategies to sustain biodiversity.

\subsection{Biodiversity change in response to different drivers}

Species diversity is influenced by the interaction of organisms, or the interaction between organisms and the environment (biotic and abiotic interactions respectively) (Jones et al., 1994). Within aquatic environments, abiotic factors determining species occurrences include oxygen, salinity, $\mathrm{pH}$, nutrient levels, temperature regimes, sunlight, and lake floor sediment type. Biotic interactions include predation, parasitism, competition, and disease. Especially invasive species can have a disastrous effect on the diversity of species as they can bring foreign pathogens and/or outcompete native biota (Bax et al., 2003; Meinhardt and Gehring, 2012; Van Elsas et al., 2012). In the past few centuries, human activities have strongly increased a number of these drivers, including the expansion of invasive species, alteration or destruction of habitats, and pollution (Díaz et al., 2019; IPBES, 2019; World Wide Fund For Nature (WWF), 2018).

The resilience of species and communities is the resistance to change and the ability to recover (Levin and Lubchenco, 2008), in other words the capacity to survive perturbations caused by biotic and abiotic interactions. Organisms can recover from disturbances in their environment by either adapting to the new circumstances, shift their distribution ranges or by evolving into new species (Folke et al., 2010). Yet, the strong, concerted disturbances aggravated by humans seem above the capacity of many biota to recover, and organisms are facing increasing extinction (Folke et al., 2004; Lake et al., 2000). Independent of what factors influence the resilience of species, the resulting 


\begin{tabular}{|c|c|c|c|c|c|c|}
\hline $\begin{array}{l}\text { Salinity } \\
\text { (psu) }\end{array}$ & $\begin{array}{l}\text { Ocean and } \\
\text { river systems }\end{array}$ & $\begin{array}{l}\text { Lakes and } \\
\text { lagoons }\end{array}$ & $\begin{array}{l}\text { Venice } \\
\text { classification }\end{array}$ & \multicolumn{2}{|c|}{$\begin{array}{c}\text { Black Sea basin + } \\
\text { connected seas }\end{array}$} & $\begin{array}{c}\text { Caspian Sea } \\
\text { basin }\end{array}$ \\
\hline$>40$ & hypersaline & hypersaline & hypersaline & & & Garabogazköl \\
\hline $30-40$ & marine & \multirow{6}{*}{ anomalohaline } & euhaline & \multicolumn{2}{|c|}{$\begin{array}{c}\text { Aegean Sea }+ \\
\text { Mediteranean Sea }\end{array}$} & \\
\hline $18-30$ & \multirow{5}{*}{ brackish } & & polyhaline & \multicolumn{2}{|c|}{ Marmara Sea } & \\
\hline $10-18$ & & & upper mesohaline & \multicolumn{2}{|c|}{ Black Sea } & $\mathrm{CCB}+\mathrm{SCB}$ \\
\hline $5-10$ & & & lower mesohaline & \multirow{3}{*}{$\begin{array}{l}\text { Coastal } \\
\text { lakes } \\
\text { (Razim- } \\
\text { Sinoie) }\end{array}$} & \multirow{3}{*}{$\begin{array}{l}\text { Estuaries } \\
\text { (Dniepr, } \\
\text { Taganrog) }\end{array}$} & \multirow{3}{*}{$\begin{array}{l}\text { North Caspian } \\
\text { basin (NCB) }\end{array}$} \\
\hline $1.5-5.0$ & & & upper oligohaline & & & \\
\hline $0.5-1.5$ & & & lower oligohaline & & & \\
\hline $0-0.5$ & fresh water & fresh water & fresh water & \multicolumn{2}{|c|}{ Danube river } & Volga river \\
\hline
\end{tabular}

Fig. 1.2: Classifying the waterbodies that are involved in the history of the water balance of the Pontocaspian realm. Ocean-River system adapted from Bulger et al. (1993), Venice classification based on Strydom et al. (2003. Anomalohaline definition adapted from van Harten (1990). CCB = central Caspian Sea basin, SCB = south Caspian Sea basin.

evolution or extinction of species all cause a change in diversity (Micklin, 2007; Quintero et al., 2010; Richter et al., 1997). Currently the global diversity is rapidly declining and extinction levels are much higher than natural background rates (IPBES, 2019).

Ecosystems are dynamic by nature and it is difficult to distinguish the drivers (natural of human) or combinations of drivers of species extinctions and diversity change. To identify the diversity of untouched ecosystems, historical snapshots of biota and geological records are needed that capture long-term variability of environments and species (Magurran et al., 2010; Willis et al., 2010). Once the compositional variability of communities under natural conditions is known, useful comparisons can be made with communities under human impact. Understanding natural resilience and the drivers of biodiversity change is essential to understand the current trajectories of biota (Martinelli et al., 2017; Seddon et al., 2016).

\subsection{The Pontocaspian region as model system for biodiversity change}

The Pontocaspian realm (Fig. 1.1), which includes the Caspian Sea, Black Sea, Azov Sea and Aral Sea, is a suitable model system for measuring biodiversity change. The region contains excellent geological successions, documenting both faunal evolution and the drivers of natural paleoenvironmental change, and is therefore appropriate for large temporal and spatial analysis of diversity (Yanina, 2012a). The Pontocaspian species that are now under threat of human activities share a history that resulted in a high degree of endemism and unique communities (Dumont, 1995; Kosarev and Yablonskaya, 1994; Lattuada et al., 2019b; Mamaev, 2002; Shiganova and Ozturk, 2009; van de Velde et al., 2019b, 2019a; Wesselingh et al., 2019). 
The Caspian Sea is an oligohaline to mesohaline lake (Fig. 1.2). It is primarily fed by the Volga river in the north, which accounts for $80 \%$ of all fresh water input resulting in a strong north-south salinity gradient (Dumont, 1998). The current Black Sea is connected to the world oceans via the Sea of Marmara and is an upper mesohaline sea (Fig. 1.2). Dense saline water from the Mediterranean Sea, intermix with the fresh water layer that arrives from rivers into brackish conditions.

The Pontocaspian seas and lakes are the remains of an inland sea that stretched from Europe to central Asia in the Miocene (Laskarev and Cvijić, 1924; Piller et al., 2007; Popov et al., 2006; van der Boon et al., 2018). This huge marine water body, the Paratethys Sea, was formed by separation from the Proto-Mediterranean ocean through mountain uplift in the early Oligocene (Piller et al., 2007; Van Baak et al., 2013). Since then, the basin connectivity of the Black Sea and Caspian Sea basins, as well as their water balances, bathymetries, salinity regimes and the evolution of their faunas has been strongly controlled by tectonics and climate (Krijgsman et al., 2019).

During the late Miocene, the Central Paratethys evolved into the brackish Lake Pannon, while the Eastern Paratethys Sea covered the Dacian basin, Black Sea basin and the Caspian Sea basin (Popov et al., 2006). Faunas that developed in Lake Pannon probably migrated episodically through lake outflow into the Eastern Paratethys (Müller et al., 1999). Within the successive Paratethyan basins water budgets became dominated by river runoff, and a range of salinity regimes developed. The faunas evolved or were replaced by faunas adapted to anomalohaline settings (Krijgsman et al., 2019).

The Black Sea basin and the Caspian Sea basin became separated during the Pliocene (Van Baak et al., 2013). Throughout the Pleistocene history the Black Sea and the Caspian Sea basins have been irregularly reconnected through overflows, resulting in different lake sizes, salinity fluctuations and changes in biotic assemblages (Forte and Cowgill, 2013; Svitoch, 2012; Yanina, 2014; Yanko-Hombach et al., 2007). During lowstands the basins were separated, and lake levels in the Pontocaspian domain were regulated by hydro-climatological processes (Kroonenberg et al., 2005; Nandini-Weiss et al., 2019; Yanina, 2014; Yanina et al., 2017b). During highstands of the Caspian Sea the basins were connected through the Manych strait and the exchange of (Pontocaspian) faunas could take place (Yanina, 2014). Interglacial highstands of the Mediterranean Sea connected the Black Sea basin to marine waters, which enabled marine faunas to enter the Black Sea basin and marginalise the Pontocaspian biota to the coastal regions (Yanina, 2012b). Marine settings and biota never reached the Caspian Sea basin during the Quaternary (Dumont, 1998; Krijgsman et al., 2019). The successive lake phases in the Caspian Sea basin were characterised by anomalohaline conditions and variable influence of major rivers (Popov et al., 2006; Van Baak et al., 2013). The Aral Sea basin, a shallow basin to the north-east of the Caspian Sea, has at times also been connected to the Pontocaspian system (for example, during the Akchagylian lake phase; Krijgsman et al., 2019). The precarious water balance resulted in repeated desiccation of the lake, even before human times (Boomer et al., 2000; Filippov and Riedel, 2009; Micklin, 2007). In the $20^{\text {th }}$ century the Aral 


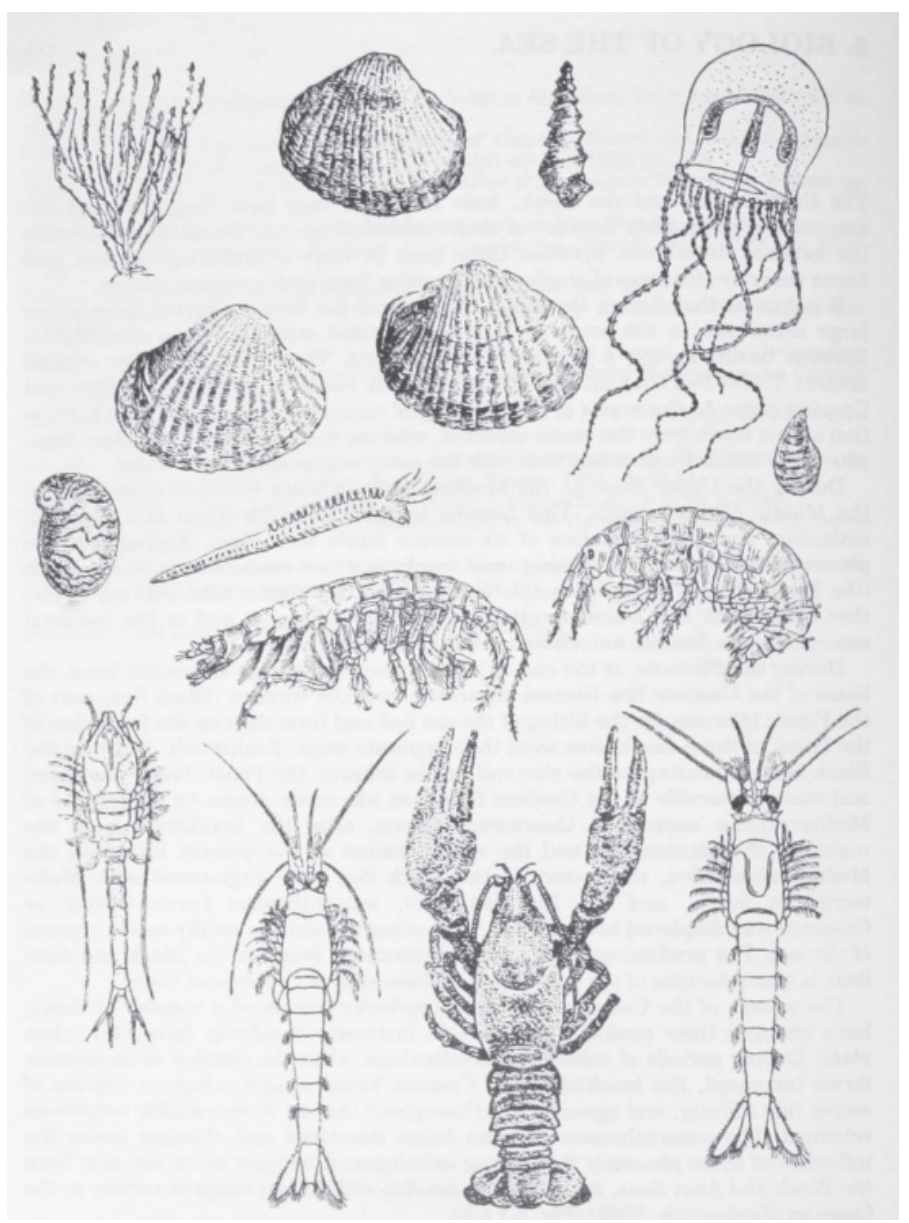

Fig. 1.3: Examples of endemic Caspian species diversity: hydroids, molluscs, jellyfish, polychaete worms, shrimps and crayfish (from: Kosarev and Yablonskaya, 1994).

lake almost completely vanished, thereby severely impacting the entire fauna (Boomer et al., 2000; Mainguet et al., 1997).

The Pontocaspian biota includes a high number of endemic species across a wide variety of systematic groups (Kosarev and Yablonskaya, 1994). They range from mammals, fish, and plants, to benthic fauna groups like molluscs, crustaceans and oligochaetes (Kosarev and Yablonskaya, 1994; Kostianoy et al., 2005; Wesselingh et al., 2019; Fig. 1.3). Probably the best known species of the aquatic fauna is the Caspian seal, and the economically most valuable species for its caviar is the beluga (sturgeon). Within coastal areas Pontocaspian communities blend into fluvial communities: several Pontocaspian species occur within the deltas and lower river courses of adjacent rivers (Dumont, 1998; Grigorovich et al., 2003; Popov, 1970; Zhadin, 1952). In the Black 
Sea basin, a transition between Pontocaspian and marginal marine communities exists with little overlap of species occurrences (van de Velde et al., 2019a). The current level of Pontocaspian endemism is estimated between $42 \%$ (Dumont, 2000) and 60\% (Kosarev and Yablonskaya, 1994) for the Caspian Sea, and 9.6\% for the Black Sea (Shiganova and Ozturk, 2009). For individual groups, ratios of endemism may be even higher. For example, Wesselingh et al. (2019) estimated the ratio of endemism for Caspian molluscs at around 87\% (85 endemic mollusc species out of a total of 98 mollusc species).

The Pontocaspian ecosystems are altered and threatened by human activities. Within the Black Sea basin major human-driven changes are habitat alteration, eutrophication, contamination overfishing and invasions by alien species (Bologa and Sava, 2012; Leppäkoski and Mihnea, 1996; Zaitsev and Mamaev, 1997; Zolotarev, 1996). A very destructive form of eutrophication comes from waste matter from domestic, urban, agricultural and industrial establishments, which arrives via river run-off and decreases the quality of the sea water (Leppäkoski and Mihnea, 1996; Zaitsev and Mamaev, 1997). Brought by ballast water or attached to the surface of ships, invasive species have directly changed the composition of the Black Sea ecosystem (Gomoiu et al., 2002; Zaitsev et al., 2004; Zolotarev, 1996). Several exotic species have arrived accidentally, like the jellyfish Mnemiopsis leidyi, but many other species were intentionally introduced as food source for fish stock, to reduce mosquito populations or as experiment to restore habitats (Gomoiu et al., 2002). Another serious problem is the changing coastline along the Black Sea (Zaitsev and Mamaev, 1997). Habitats are modified by erosion, building dams or changing river courses for economic purposes, thereby changing the water level and salinity gradients (Leppäkoski and Mihnea, 1996; Zaitsev and Mamaev, 1997).

In the Caspian Sea basin similar anthropogenic processes affect the environment and Pontocaspian biota, of which the biggest contributions come from poaching, chemical pollution and invasive species (Agusa et al., 2004; Lattuada et al., 2019b). Industrial, domestic and agricultural waste waters flow via rivers into the sea, changing the physical and chemical properties of the water (Dumont, 1995; Kostianoy et al., 2005; Lattuada et al., 2019b). The chemical pollution with oil, oil products, phenols and detergents in the northern Caspian Sea is affecting specifically the shallow Caspian ecosystems (Dumont, 1995; Kostianoy et al., 2005; Lattuada et al., 2019b). Moreover, the regulation of rivers by dams starting in the 1930s changed the natural hydrological regime of the Caspian Sea; the disruption of the continuous water flow moreover hindered migration of fish (Dumont, 1995; Kosarev and Yablonskaya, 1994). Like in the Black Sea, the greatest impact on Pontocaspian biota in the Caspian Sea in the $20^{\text {th }}$ century has been caused by the invasion of alien species (Albrecht et al., 2014; Grigorovich et al., 2003; Heiler et al., 2010; Kosarev and Yablonskaya, 1994; Lattuada et al., 2019b; Orlova et al., 2004; Riedel et al., 2006; Therriault et al., 2004). An estimated 1800-fold increase in new species invasions rate in the Caspian Sea have been caused by anthropogenic activities, compared to the natural background rate in the previous two million years (Grigorovich et al., 2003). As for the Black Sea, some species were introduced accidentally, like the 
bay barnacle that arrived with ships (Grigorovich et al., 2003), other species were introduced on purpose, like the worm Nereis diversicolor or the bivalve Abra segmentum (Kostianoy et al., 2005).

The successful spreading of invasive species in both the Black Sea and the Caspian Sea seems to be the result of a combination of two processes: the high adaptive capability of these invasive species, and the probably low competition potential of the endemic fauna (Zolotarev, 1996). A small portion of the Pontocaspian species have become invasive elsewhere, such as the two Dreissena species D. polymorpha and D. bugensis, which have invaded western-central Europe and North American fresh water ecosystems since the $19^{\text {th }}$ century (Orlova et al., 2004, 2005).

The biggest anthropogenic threat altering the Pontocaspian habitat in the Aral Sea has been irrigation (Aladin et al., 2008; Boomer et al., 2000; Micklin, 2007; Plotnikov et al., 2016). The extraction of water tipped the very sensitive evaporation/precipitation balance of the Aral basin catchment, resulting in almost complete desiccation since the 1950s and the near-total obliteration of its faunas. By diverting water that comes from the two main feeding rivers the volume of the lake has been reduced by 60-90\%, which increased the salinity from 9 psu to 30 psu and in some places even 100 psu (Aladin et al., 2008; Boomer et al., 2000; Micklin, 2007). Other anthropogenic threats include the pollution of rivers entering the lake with chemicals such as fertilisers, pesticides and defoliants (Boomer et al., 2000).

\subsection{Molluscs as study group}

The rich fossil record in the Pontocaspian region enables the documentation of the evolution of its biota (Krijgsman et al., 2019). Fossil occurrences inform us about past environments ("habitats") as well as compositions of communities. Due to their strong outer shell, omnipresence and abundance in geological records molluscs are ideal fossils to use as paleoenvironmental proxies and to perform studies on deep-time species diversity. The autecology of mollusc species and communities, together with their taphonomic signature, sedimentology and isotope geochemistry, enables us to reconstruct habitats through time, which is imperative for comparison of biodiversity through time.

Four families dominate Pontocaspian mollusc faunas: Cardiidae and Dreissenidae are the main bivalve families and Hydrobiidae and Neritidae are the main gastropod families (Wesselingh et al., 2019). The modern endemic Pontocaspian cardiid species belong to four genera: Adacna, Monodacna, Hypanis and Didacna (Bogutskaya et al., 2013; Büyükmeriç and Wesselingh, 2018; Wesselingh et al., 2019). The latter genus lives today only in the Caspian Sea basin, species of the other genera occur both in the Black Sea basin and Caspian Sea basin. The four Pontocaspian dreissenid species all belong to the genus of Dreissena (Wesselingh et al., 2019). Two out of three Caspian Dreissena species probably became extinct in the $20^{\text {th }}$ century. Pontocaspian neritids include only one genus, Theodoxus, of which four species are native to the Black Sea and one to the Caspian Sea (Wesselingh et al., 2019). The hydrobiids include the largest number of endemic Pontocaspian species, of which the main genera are Caspia, Clathrocaspia, Ulskia, Clessiniola, Laevicaspia, Turricaspia, Abeskunus, and Andrusovia (Neubauer et al., 2018; Wesselingh et al., 
2019). The latter three genera occur today only in the Caspian basin. The generic classification of Pontocaspian hydrobiids is still a matter of debate (compare Anistratenko et al., 2019 and Neubauer et al., 2018).

The Pontocaspian genus Didacna has been thoroughly studied and is known for their use as indicator species (see extensive references in Nevesskaja, 2007; Yanina, 2013). Today the genus is restricted to the Caspian Sea basin, but in the past Didacna species occurred in the Black Sea basin as well as in the Dacian basin of Romania and the Anatolian basins of south-west Turkey (Wesselingh et al., 2019). Rapid evolution within this genus in both Black Sea basin and Caspian Sea basin has helped to establish precise biochronological zones subdividing the Quaternary records and identify episodes of basin connection (Nevesskaja, 2007; Yanina, 2012c). Yet in some cases the morphological variability in this genus still hampers clear species definitions. Attempts to resolve the taxonomic status with DNA analyses have been prevented by the scarcity of the living material that is available (Albrecht et al., 2014, A. Martínez Gándara, pers. comm. 2019).

Any diversity assessment is hampered by the lack of a sound taxonomic framework (Neubauer et al., 2018). Moreover, the phenotypic variability of many Pontocaspian molluscs is impeding our understanding of the species boundaries and numbers (Neubauer et al., 2018; Vinarski and Kantor, 2016; Wesselingh et al., 2019). Especially the Pontocaspian gastropods are well known for their big morphological variability (Neubauer et al., 2018). Their overlap in size and minor morphological deviations in shape and whorl outline have caused confusion since their discovery (Filippov and Riedel, 2009; Kantor and Sysoev, 2006; Sitnikova et al., 1992). In the $20^{\text {th }}$ century a plethora of species have been introduced, based on very small differences in shell shape and/or occurrences (Logvinenko and Starobogatov, 1969; Zhadin, 1952). Lately, DNA analyses and systematic analyses of species traits have again reduced the number of species based on a more refined understanding of the phenotypic plasticity of the Pontocaspian species (Anistratenko et al., 2017; Bouchet et al., 2018; Neubauer et al., 2018; Wesselingh et al., 2019).

Today, introduced invasive mollusc species are one of the main factors severely impacting Pontocaspian mollusc diversity (Albrecht et al., 2014; Grigorovich et al., 2003; Heiler et al., 2010; Kosarev and Yablonskaya, 1994; Riedel et al., 2006). Due to the different geographic, environmental and salinity settings of the Pontocaspian basins, different species have become invasive in each basin. For example, the bivalves Mytilaster minimus, Abra segmentum and Cerastoderma glaucum have lived as native species alongside Pontocaspian species in the Black Sea basin, but have become invasive to the Caspian Sea basin (Kosarev and Yablonskaya, 1994; Latypov, 2015; Wesselingh et al., 2019). Brought by ballast water or attached to the surface of ships, Rapana venosa, Mya arenaria, and Anadara inaequivalvis are the main invasive mollusc species affecting the marine biocoenoses of the Black Sea basin, but these species have not been able to disrupt Pontocaspian communities there (Gomoiu et al., 2002; Zaitsev et al., 2004; Zolotarev, 1996). Mytilopsis leucophaeata arrived by ship from the United States and is invasive in both basins (Heiler et al., 2010; Zhulidov et al., 2018). The Mediterranean Mytilaster minimus and the Pontocaspian Dreissena bugensis and Monodacna 


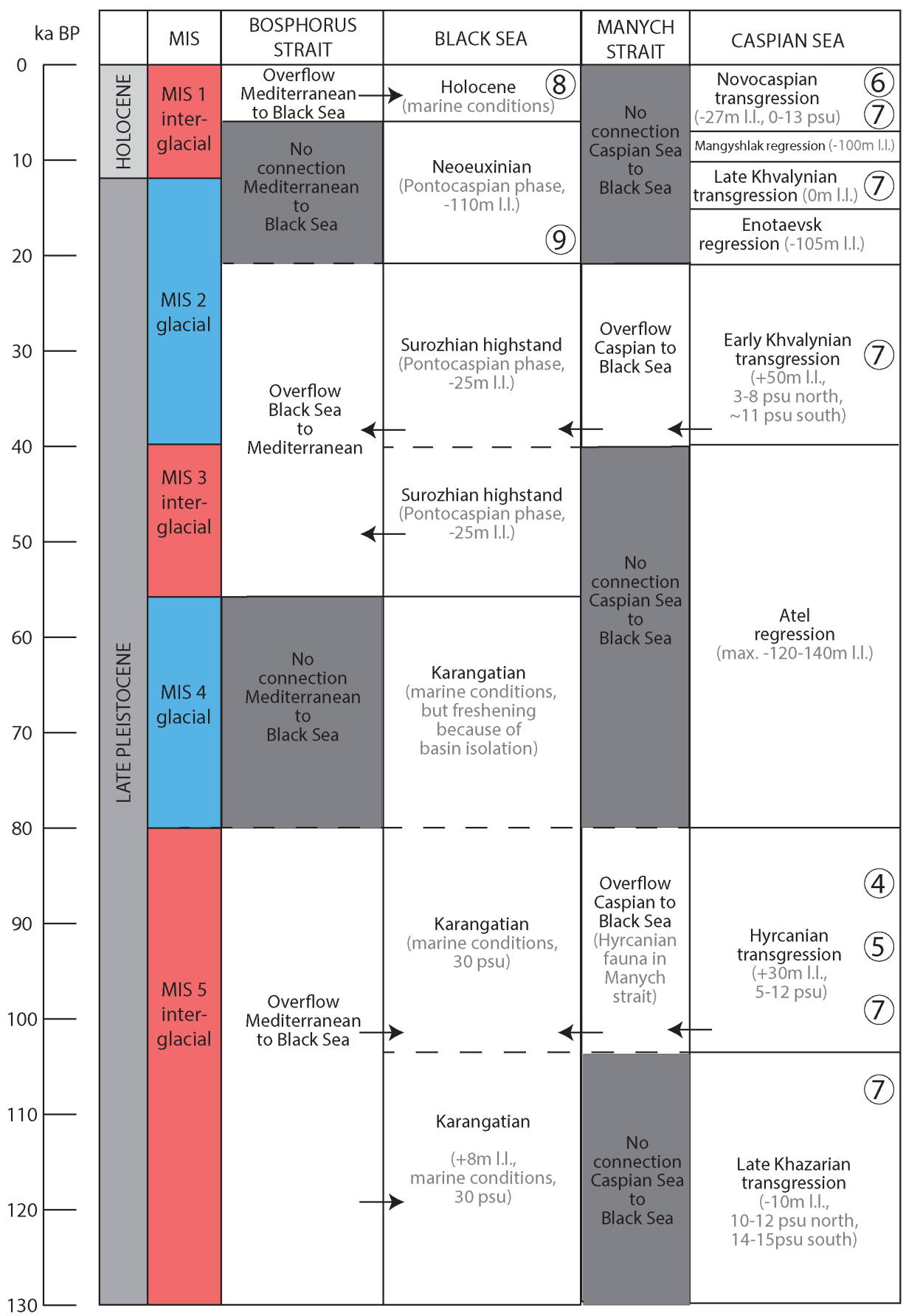

Fig. 1.4: Overview of Quaternary palaeographical events in the Pontocaspian region, updated from Yanina (2014). Encircled numbers correspond to related chapters in this thesis. 1.l. = lake level 


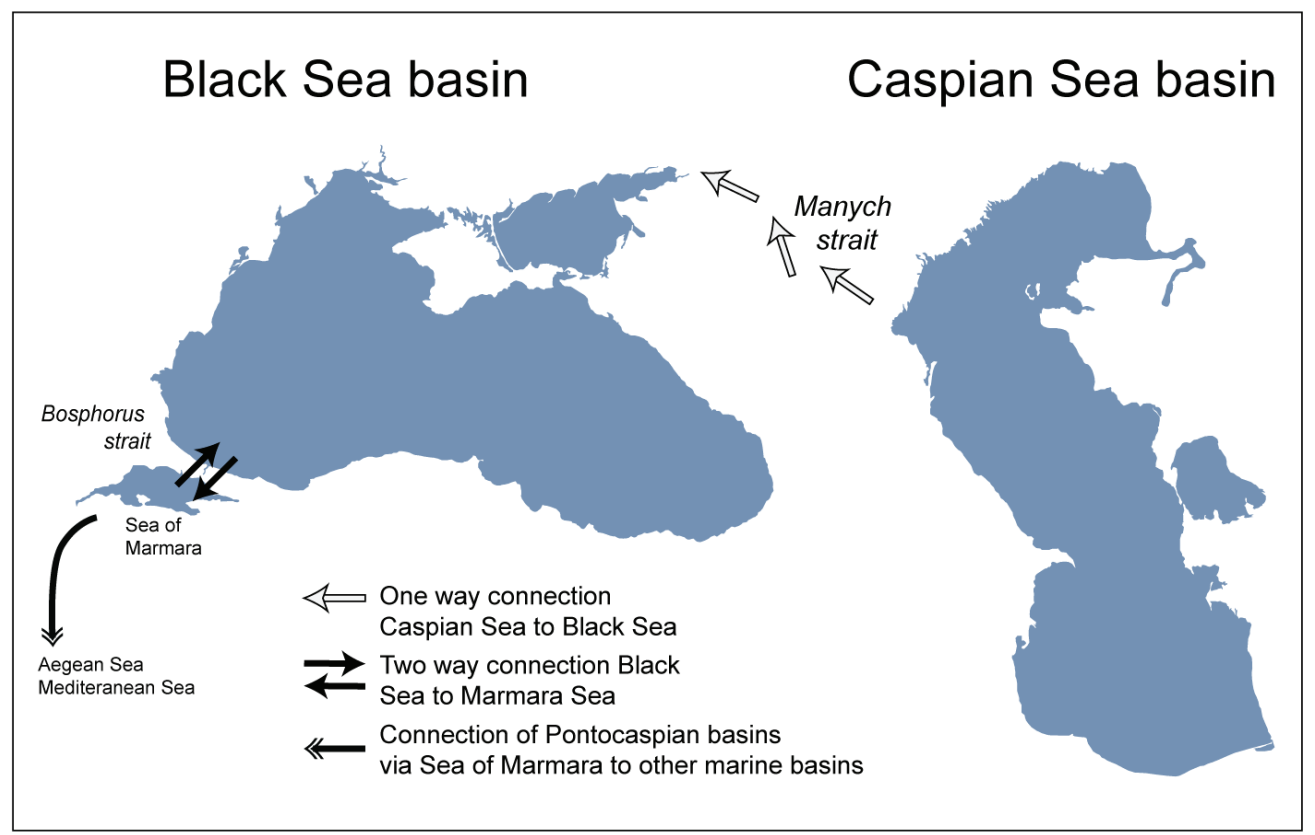

Fig. 1.5: Ways of connecting the Black Sea basin, Caspian Sea basin and marine basins.

colorata, who were endemic to the northern Black Sea, are now invasive in the Caspian Sea (Wesselingh et al., 2019).

Currently, the endemic mollusc communities of the Pontocaspian realm are found in salinities between 0 psu and 13 psu. The Caspian Sea and its surrounding deltas are the main body of Pontocaspian habitat. In the Black Sea Pontocaspian communities are marginalised to coastal areas by impoverished marine Mediterranean fauna that occupy the main body (Bologa and Sava, 2012; Grigorovich et al., 2003; Kosarev and Yablonskaya, 1994; Mamaev, 2002; Wesselingh et al., 2019). The northern coastal zone of the Black Sea is where the major habitats for the Pontocaspian species can be found these days (Wesselingh et al., 2019). In the Azov Sea (which is an extension of the Black Sea) Pontocaspian species are abundant in the Taganrog Bay (Golikov and Starobogatov, 1966). The environment of the Aral Sea has been obliterated and all endemic Pontocaspian molluscs have been eradicated (Aladin et al., 2004, 2008; Wesselingh et al., 2019). Few Pontocaspian mollusc elements are found in satellite basins in Anatolia and its surrounding rivers (Sands et al., 2019b).

\subsection{Aim and approach}

The aim of this thesis is to establish natural baseline data for Late Quaternary community changes in the Pontocaspian region by using the geological record. By targeting faunas in the Caspian Sea basin and Black Sea basin it is possible to make an interbasinal comparison. Within each basin similar habitats through time are chosen. The documentation of biodiversity before human impact 
allows for identification of biodiversity change under anthropogenic impact of today, which will give insight into the resilience of Pontocaspian biota. To reach the objective, an interdisciplinary approach is used that combines conservation paleobiology, taphonomy, sedimentology, biostratigraphy and taxonomy.

\subsubsection{Conservation paleobiology}

Conservation paleobiology is a rapidly developing, socially relevant field that uses information from geohistorical records to address current problems in the conservation and restoration of biodiversity and ecosystem services (Dietl et al., 2015; Dietl and Flessa, 2011). By gathering core data from lakes, large amounts of data can be analysed relatively quickly and they cover long time frames of environmental and biological history (Wilke et al., 2016). Snapshots of well-preserved mollusc faunas can serve as detailed natural baselines for the spatial comparison of diversity and the reconstruction of palaeoenvironments (van de Velde et al., 2019c).

Biodiversity assessments are done by comparing species and communities within similar habitats: shallow waters of 0-50 m depth with a salinity of around 5-8 psu (practical salinity unit: dissolved salts in parts per thousand (\%o)). Two components of species diversity are commonly used to quantitatively compare diversity across time and space: species richness, which reflects the number of different species in a community, and species abundance, which is the proportion of each species relative to the total number of organisms in the community. A variety of metrics are available for measuring these two factors (Humphries et al., 1995). Rarefaction is a technique to standardise and check the representativeness of samples (assess whether samples are large enough to show "true" diversity) by using rarefaction curves (James and Rathbun, 1981) and comparing richness and abundance directly between sites. This method is used in this thesis.

\subsubsection{Taphonomy, sedimentology and biostratigraphy}

The paleohabitats need to be constrained to ensure reasonable comparison of similar habitats in time. Sedimentological characteristics of the deposits are assessed to infer processes of deposition, transport and diagenesis of the molluscs therein. A taphonomic analysis of the molluscs, by studying their fossilisation processes, also helps in constraining the habitats (Dietl et al., 2015; Hart, 2012; Kidwell, 2013; Wesselingh et al., 2006). For example, energy levels, biotic interactions during life, post-mortem transport and time-averaging can then be identified (Kidwell, 2013). Time-averaging may severely distort the outcome of diversity analyses and thus our understanding of former community compositions and their change through time. Taphonomic approaches help to identify relatively undistorted associations (Hart, 2012; Kidwell, 2013). By combining this with sedimentology and autecology of the fauna, palaeoenvironments can be reconstructed and compared with similar habitats today. 


\subsubsection{Taxonomy}

The extent or nature of biodiversity loss cannot be properly evaluated without general agreement on the species identities (Sigwart et al., 2018). Within each studied fauna assemblage, a large series of specimens was used whenever possible, to assess morphological variability and assess species boundaries. The taxonomy of Pontocaspian molluscs is still in need of revision for many systematic groups, but a few recent studies have already contributed to our understanding (Anistratenko et al., 2018, 2017; Sands et al., 2019a; van de Velde et al., 2019b; Wesselingh et al., 2019). In this thesis, the identified species are typically shortly discussed and illustrated in order to enable further discussion on Pontocaspian species concepts.

\subsubsection{Time period under study}

The Pontocaspian mollusc fauna has witnessed several minor and major turnover events during the Quaternary in both the Black Sea basin and the Caspian Sea basin (Krijgsman et al., 2019). The faunas under study represent the Late Pleistocene and Holocene stages (Marine Isotope Stages 1-5) and include glacial and interglacial intervals (Fig. 1.4). They capture the intervals of connection and isolation of the different basins (Fig. 1.4, 1.5). Faunas from successive Caspian Sea stages were studied across short and long time series. The studied sections/wells include known turnover events in the Pontocaspian basins, such as those during the Late Khazarian, Hyrcanian, Early Khvalynian, Late Khvalynian and Novocaspian transgressions, and the Neoeuxinian phase in the Black Sea. The studied time intervals contain essentially modern Pontocaspian faunas, which developed after the Apsheronian-Bakunian transition in the early-Middle Pleistocene (Lazarev et al., 2019).

\subsection{Thesis outline}

In this thesis, natural baseline data are established for Late Quaternary mollusc communities in the Pontocaspian region, thereby focussing on phases and locations where environmental conditions were similar to the conditions of today's Pontocaspian habitats. In Chapter 2, a holistic approach is used to understand the dynamic history of the entire Pontocaspian system and its mollusc fauna since the Pleistocene. Major changes in water levels resulted in a system of basins that were sometimes connected and sometimes isolated, to which the Pontocaspian biota responded. Understanding regional history, including lake water levels and fauna evolutionary factors, is limited by ambiguous stratigraphic nomenclature and conflicting time constraints of regional sedimentary facies. An overview of the existing stratigraphy and geochronology of the Caspian Sea, the Black Sea and adjacent continental domains is presented. It allows for a better understanding of the succession of geological events, especially dealing with the major changes in interbasinal connectivity, which shaped faunal evolution. For this thesis the paleoenvironmental change and the characterization of known mollusc species from six stages in the Caspian Sea (Akchagylian, Apsheronian, Bakunian, Khazarian, Khvalynian and Novocaspian) and seven stages in the Black Sea (Kuyalnikian, Gurian, Chaudian, Uzunlarian, Karangatian, Neoeuxinian and Chernomorian) set the background for the 
remaining chapters. Anthropogenic drivers that impact the current Pontocaspian ecosystems are discussed. Chapter 3 assesses the problematic taxonomy of current Pontocaspian mollusc species. It compiles a list of the current Pontocaspian mollusc species, necessary for Holocene mollusc biodiversity estimates. It discusses the species concepts, taxonomic uncertainties and an updated estimate of current species richness, which is used in the following chapters. Invasive mollusc species associated to Pontocaspian habitats are also assessed.

To be able to make an interbasinal comparison, the focus is first on the Caspian Sea basin mollusc assemblages. In Chapter 4 a Caspian Sea gastropod fauna of the Late Pleistocene is analysed. A revised taxonomic and systematic framework is proposed, with new concepts for selected the genera and species, with special focus on the revision of hydrobiid gastropods. A summary of the diversity of Late Pleistocene gastropods from the Caspian Sea is the first step necessary for the complete Pontocaspian mollusc fauna analysis of the Caspian Sea. Chapter 5 details the bivalve fauna from the same Late Pleistocene assemblage. By combining the bivalve fauna with the gastropod fauna from Chapter 4, a natural Caspian mollusc diversity rich in endemic Pontocaspian species is described. The well-preserved in-situ assemblage serves as a natural baseline of a pre-invasive Pontocaspian fauna living in a shallow, lower mesohaline open-lake environment of the north Caspian Sea. Both species richness and relative abundances are assessed. It is the first completely documented Late Pleistocene in-situ fauna from the Caspian Sea. In Chapter 6 a baseline is set for pre- $20^{\text {th }}$ century Holocene mollusc assemblages of the Caspian Sea. The snapshot describes a diverse shoreface mollusc community that lived c. 2500 yrs BP. The mesohaline molluscs serve as the second reference point against which modern human-impacted mollusc diversity of the Caspian Sea can be evaluated. Chapter 7 gives an overview of the mollusc diversity within a $65 \mathrm{~m}$ long north Caspian Sea core dating back to the early Khazarian (upper part of the Middle Pleistocene). For each of the time periods in the core an overview of the Pontocaspian mollusc diversity is given. The Late Khazarian, Hyrcanian, Early Khvalynian, Late Khvalynian assemblages serve as baselines prior to human impact. They are compared to Holocene assemblages of the Novocaspian transgression and to existing monitoring data of the current Caspian Sea mollusc assemblages. It is the first time a complete overview of mollusc richness and abundance is shown from several time intervals captured in a single spot.

The next two chapters focus on the Black Sea basin mollusc diversity. In Chapter 8 the Holocene mollusc diversity of Pontocaspian species in the Razim-Sinoie lagoon (at the western margin of the Black Sea) is described and analysed through time and space. The past 2000year history of the system is reconstructed and analysed to how Pontocaspian species reacted to changes in this highly dynamic environment. Our insights into faunal development and resilience have direct relevance for outlining conservation strategies for Pontocaspian biota. Chapter 9 gives an overview of a $124 \mathrm{~cm}$ Black Sea core that includes Holocene, Neoeuxinian and Surozhian (Late Pleistocene) faunas. The focus is on the Neoeuxinian fauna, which serves as the baseline of a preinvasive Pontocaspian fauna living in the Black Sea. At this time, the Black Sea was an oligohaline to 
lower mesohaline lake with a largely endemic fauna, similar to the current Pontocaspian habitats in the marginalized areas on the Black Sea basin.

In Chapter 10, a synthesis of the results is presented and the findings are put in a broader perspective. Pontocaspian mollusc diversity patterns through space are summarized and compared (i.e. across the different basins), and the underlying processes are analysed and discussed. In addition, the resilience of Pontocaspian species is discussed, a light is thrown on the Pontocaspian biodiversity crisis and the mitigation of the crisisis is elaborated on. The final part of the discussion is focussed on recommendations for future research and actions 
INTRODUCTION AND SYNOPSIS 


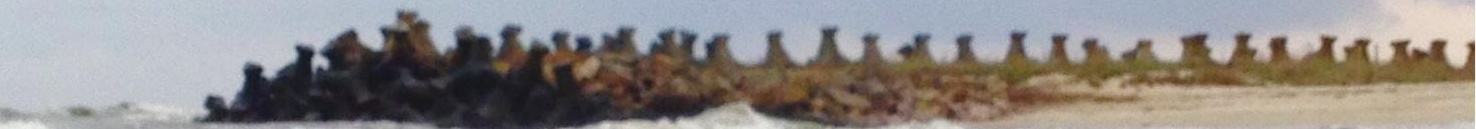

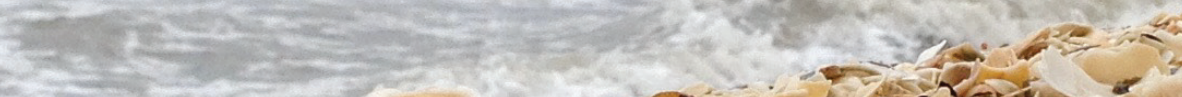

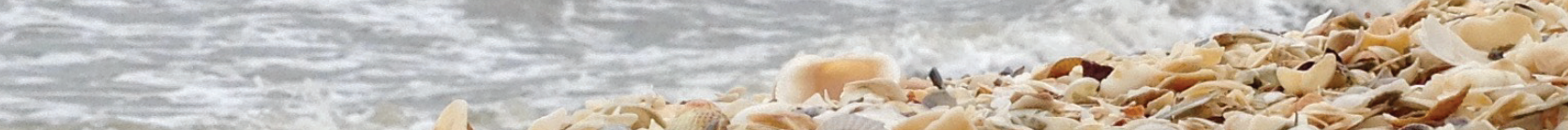

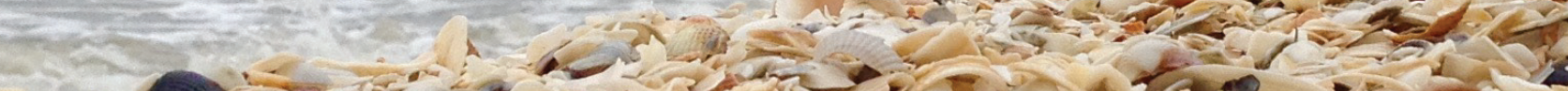

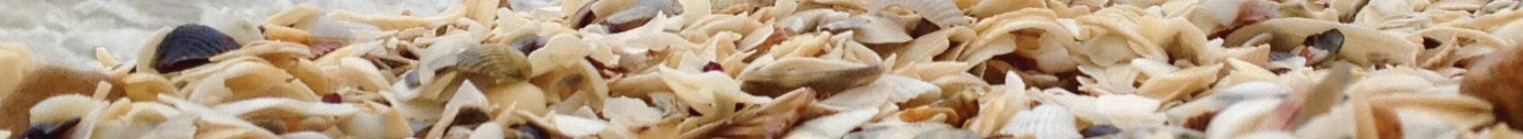

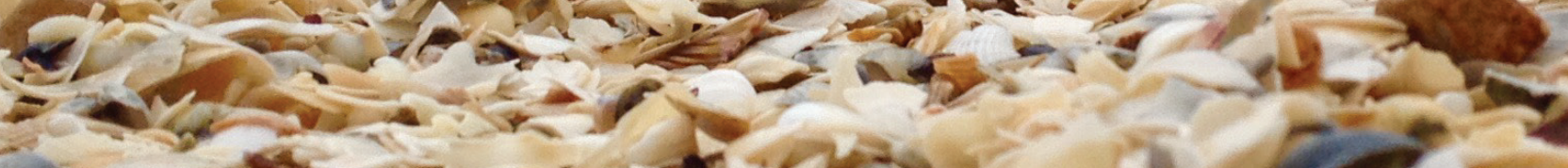

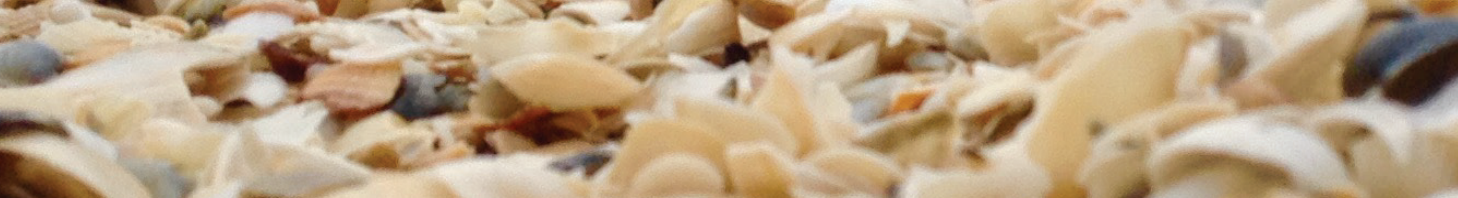




\title{
Quaternary Pontocaspian MOLLUSC HISTORY - AN OVERVIEW
}

\begin{abstract}
Abridged from:
Krijgsman, W., Tesakov, A.S., Yanina, T.A., Lazarev, S., Danukalova, G.A., Van Baak, C.G.C., Agustí, J., Alçiçek, M.C., Aliyeva, E., Bista, D., Bruch, A., Büyükmeriç, Y., Bukhsianidze, M., Flecker, R., Frolov, P., Hoyle, T.M., Jorissen, E.L., Kirscher, U., Koriche, S.A., Kroonenberg, S.B., Lordkipanidze, D., Oms, O., Rausch, L., Singarayer, J., Stoica,, M., van de Velde, S., Titov V.V., Wesselingh, F.P., 2019. Quaternary time scales for the Pontocaspian domain: Interbasinal connectivity and faunal evolution. Earth-Science Rev. 188, 1-40. http://doi.org/10.1016/j.earscirev.2018.10.013
\end{abstract}

\begin{abstract}
The Pontocaspian (Black Sea-Caspian Sea) region has a very dynamic history of basin development and biotic evolution. The region is the remnant of a once vast Paratethys Sea. It contains some of the best Eurasian geological records of tectonic, climatic and paleoenvironmental change. The PlioceneQuaternary co-evolution of the Black Sea-Caspian Sea is dominated by major changes in water (lake and sea) levels resulting in a pulsating system of connected and isolated basins. Understanding the history of the region, including lake level and faunal evolution, is hampered by indistinct stratigraphic nomenclature and contradicting time constraints for regional sedimentary successions. In this chapter we review the Quaternary mollusc fauna of the Pontocaspian domain.
\end{abstract}

\subsection{Introduction}

The Black Sea and Caspian Sea basins are the present-day remnants of the ancient Paratethys Sea (Laskarev, 1924), an epicontinental water-mass that developed since the earliest Oligocene in central Eurasia as the northern branch of the Tethys Ocean. It was separated from the southern, Mediterranean branch by the Alpine-Caucasus-Himalayan orogenic belt that progressively formed by ongoing tectonic collision of the Eurasian plate with the African-Arabian and Indian plates (Popov et al., 2006; Rogl, 1999). In Oligo-Miocene times, the Paratethys Sea covered large parts of Europe and Asia, stretching from southern Germany in the west to western China in the east. A complex combination of Mio-Pliocene tectonic uplift, glacio-eustatic sea level fluctuations, and sedimentation by major deltaic systems, progressively filled the marginal sedimentary basins in the west and east. Consequently, the Paratethys sea drastically retreated, which influenced the regional 
climate of Eurasia (Ramstein et al., 1997) and facilitated mammal (including hominid) migration between Africa, Asia and Europe (Bar-Yosef and Belmaker, 2011).

Throughout its entire history, Paratethys formed a series of restricted basins, separated by shallow, tectonically active, gateways, that were extremely sensitive to small climatic and tectonic variations (e.g., Popov et al., 2006; Palcu et al., 2017). The semi-enclosed basin configuration resulted in extreme paleoenvironmental dynamics including anoxic, hypersaline, brackish to fresh water conditions. Some salinity regimes in the basin, that were supposed to require connectivity to the open ocean, have been a major scientific puzzle for many centuries (Fig. 2.1: Kircher, 1678). The long-lived isolated position of the basins, combined with the exceptional paleoenvironmental conditions, created faunal communities that are endemic to the Paratethys region, and that waxed and waned through geological history (e.g., Harzhauser et al., 2002). They obtained maximum extension during the latest Messinian (Lago-mare) times 5.5 Ma, when Paratethyan faunas occupied the entire Mediterranean basin as well (e.g., Guerra-Merchán et al., 2010; Stoica et al., 2016). Today the Paratethyan faunas are at their minimum: the so-called Pontocaspian communities are now almost entirely restricted to small enclaves in the major deltaic and estuarine systems of the northern Black Sea as well as the Caspian Sea (Grigorovich et al., 2003; Yanina, 2012b). The origin, evolution and migration of these characteristic Pontocaspian faunal elements is still not fully understood (e.g., Wesselingh et al., 2008).

The Pliocene-Quaternary co-evolution of the Black Sea-Caspian Sea is dominated by major changes in sea/lake levels. These may have been driven by external components, resulting from opening and closing gateways to the Mediterranean or Arctic ocean, as well as by internal components where hydrological and climatic changes induced by glacial-interglacial cycles may have created periods of intermittent interbasinal connectivity (e.g., Badertscher et al., 2011; Yanina, 2014). A simplified scenario is that the two basins were isolated during lowstands, when individual water levels, environmental conditions, and faunal composition were largely determined by the local hydrological budgets. The two basins became connected during highstands of the Caspian Sea. During such periods, overflow of the Caspian Sea through the Manych low-land connection north of the Greater Caucasus enabled faunal exchange (Fig. 2.1). Environmental conditions became similar in both basins by mixing of the water masses and consequently migration and blending of the Pontocaspian fauna took place. Additionally, the Black Sea became connected to marine waters of the Mediterranean during interglacial highstands and the Pontocaspian biota were marginalized. These marine transgressions did not reach the Caspian basin. Sea/lake level changes in the Pontocaspian region have been gigantic. Over $1000 \mathrm{~m}$ lake level rise has been proposed for the late Pliocene Productive Series - Akchagylian transition in the South Caspian basin (see van Baak et al., 2017 and references therein). Also on short time scales, lake level changes were very significant as shown by Caspian Holocene variations of $\sim 100 \mathrm{~m}$ affecting historic settlements on the Caspian coast (Kroonenberg et al., 2007). The Quaternary sea/lake level history of the Black Sea-Caspian Sea domain is still enigmatic and awaits consistent interpretations, although significant progress has 


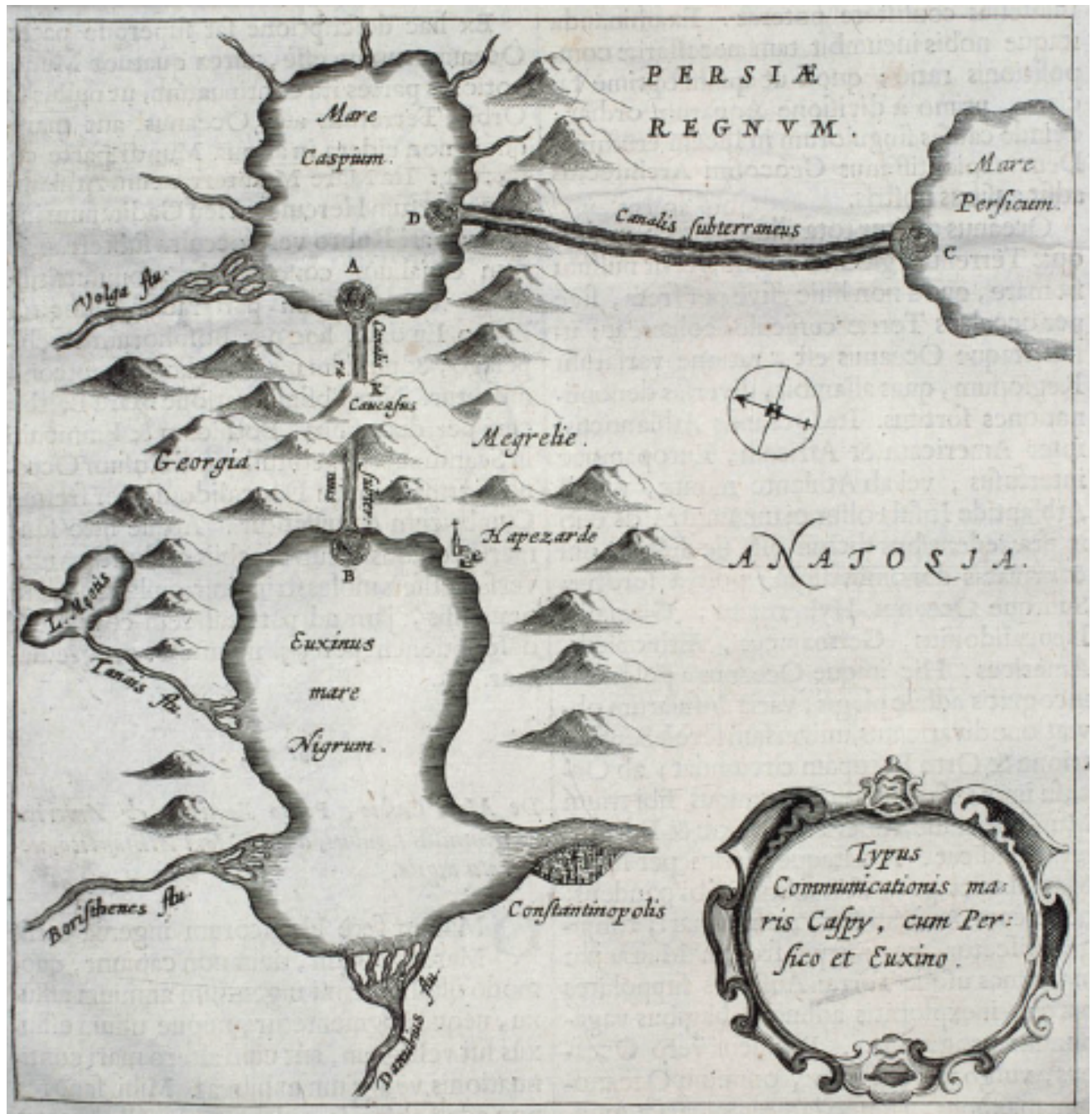

Fig. 2.1: Ancient map of the Pontocaspian region after Kircher (1678), who in his "Mundus Subterraneus" already envisaged that the Caspian basin must have been connected to the open ocean to explain its relatively high salinity (>10 psu) today. The Caspian Sea is in fact an isolated long-lived lake since at least 2.6 Ma. Kircher considered a subterraneous channel to the Persian Gulf for the marine connection. The location of this marine connection is still enigmatic today.

been made recently by geochemical proxies (e.g. strontium ratios, oxygen isotopes) that may clarify the timing and amount of connectivity (Badertscher et al., 2011; Major et al., 2006).

Understanding the fundamental mechanisms and processes that influenced both the geological and historical changes in sea level, connectivity, climate, and environment (e.g. salinity, anoxia, etc.) 


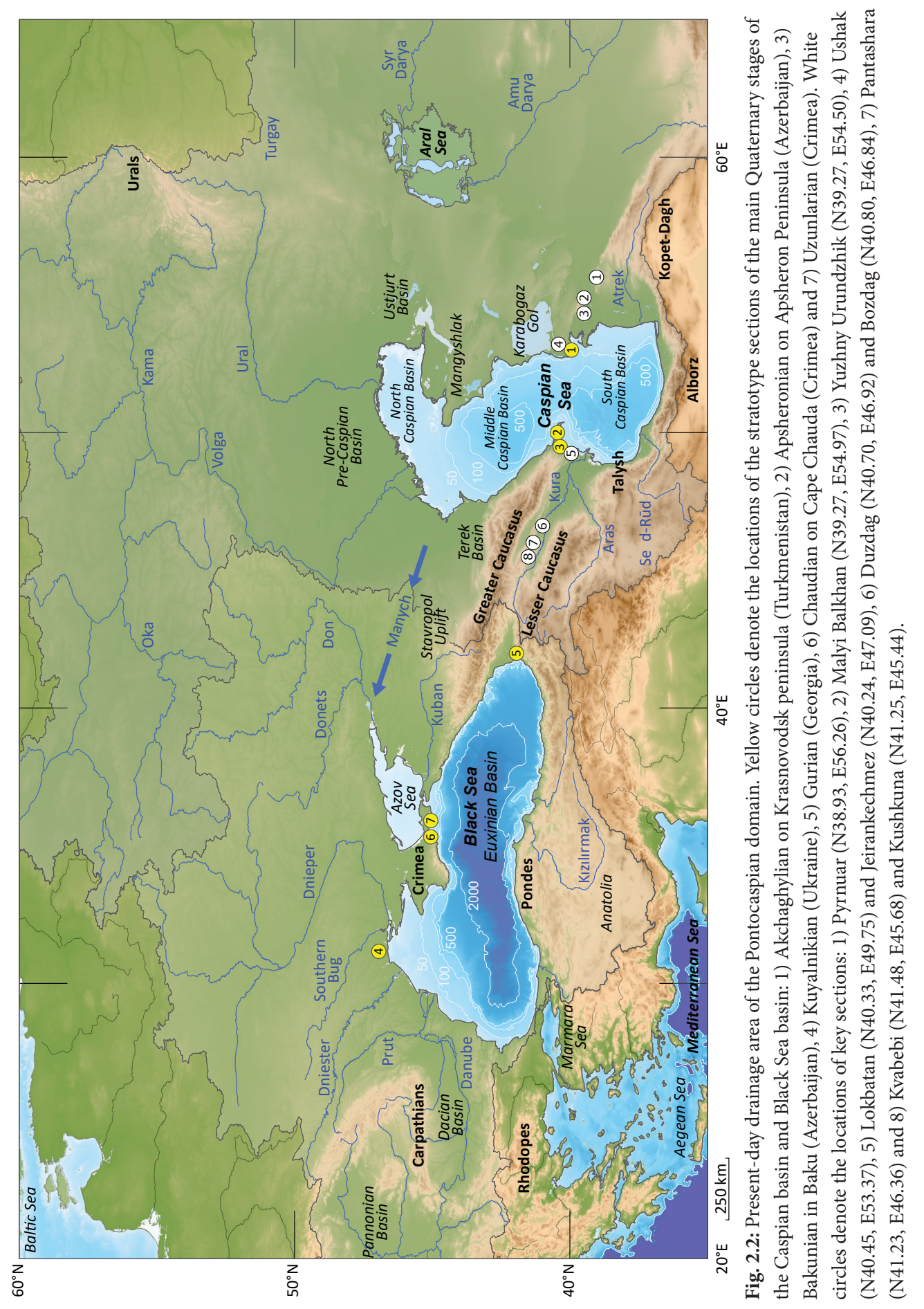


is also crucial for a coherent understanding of the future economical and sustainable developments in the region. The immensely rich hydrocarbon fields of both the Black Sea and especially the South Caspian basin are the product of changing interbasinal connectivity, that generated the anoxic source rocks of the Oligocene Maikop Series, the deltaic reservoir rocks of the Pliocene "Productive Series" and the brackish water cap rock of the Plio-Pleistocene Akchagylian clays (e.g., Hinds et al., 2004; Vincent et al., 2010). Paleoenvironmental changes in the region are causing the biodiversity crisis that the Pontocaspian fauna is experiencing today (e.g., Grigorovich et al., 2003; Popa et al., 2009).

One of the key problems to understand the complex and intertwined geological history of the Pontocaspian region is the absence of reliable stratigraphic correlations between the Black Sea and Caspian Sea and between the lake/marine and continental domains. The lack of open marine faunal assemblages in the Paratethys generally hampers a straightforward correlation to the standard geological time scale, and the presence of mainly endemic faunas resulted in regional time scales for the different Paratethyan subbasins (e.g., Hilgen et al., 2012; Nevesskaja et al., 2003). For the Quaternary, individual time scales have been developed for the Caspian and the Black Sea region, both mainly based on their own characteristic faunal (usually mollusc) assemblages from rich, but local sites (e.g., Yanina, 2014). Cross-correlation has mainly been done on biostratigraphic arguments, because radiometric, magnetostratigraphic and astronomical data are scarce and/ or their results controversial. Carbon dating has been thoroughly applied to Holocene rocks (e.g., Yanina, 2014 and references therein), but radiometric datings (K/Ar or Ar/Ar) of older Quaternary rocks are very rare, because of the common lack of intercalated volcanic ashes (e.g., Chumakov and Byzova, 1992). Magnetostratigraphic correlations to the geomagnetic polarity time scale have been widely produced for the lower Quaternary successions (e.g., Molostovsky, 1997). They are more problematic for rocks younger than $780 \mathrm{kyr}$ (last full reversal of the magnetic field), because there this technique only works if it is possible to sample with a resolution that is high enough $(<1$ ka) to pick up the reversal excursions of the Brunhes chron (Laj and Channell, 2007; Singer et al., 2014). Consequently, many of the regional stage boundaries are still poorly dated and serious age uncertainties exist between the current geological time scales for the region.

Here, we present a comprehensive overview of the existing stratigraphic and geochronologic data for the Caspian Sea and the Black Sea. The main result will be an update of the Quaternary geological time scale for the Pontocaspian region which will allow better understanding of the succession of geological events, especially dealing with the major changes in interbasinal connectivity and faunal evolution. 


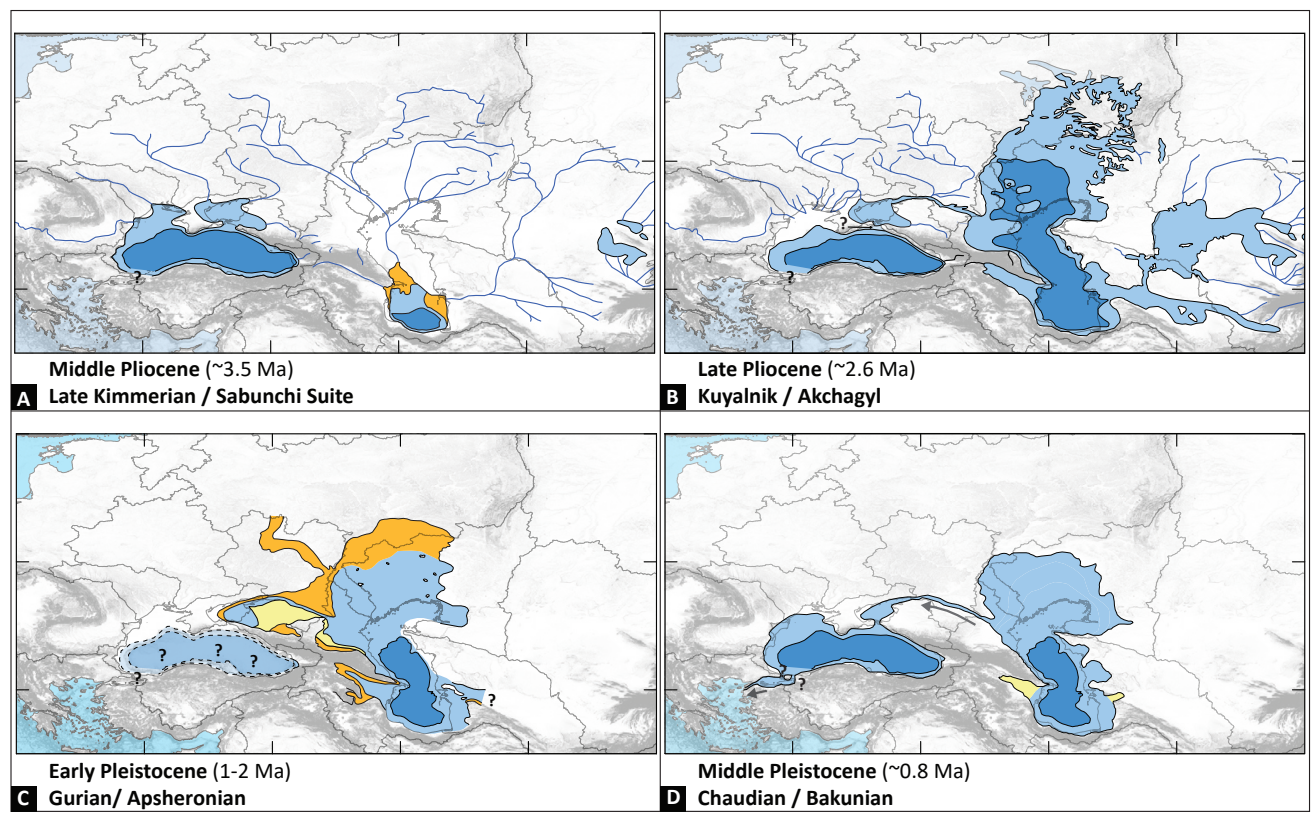

Legend - paleogeographic maps

Deep water Shallow water

Fluvial plains Coastal plains

Fig. 2.3: Paleogeographic maps for the Plio-Pleistocene Pontocaspian region. a) Middle Pliocene; b) Late Pliocene; c) Early Pleistocene; d) Middle Pleistocene. Based on Vinogradov, 1961, 1969 and Abdurakhmanov et al. (2002).

\subsection{Quaternary Time Scales of the Pontocaspian domain}

\subsubsection{The Caspian Sea region}

The Caspian Sea is a lake: it is the world's largest endorheic water body (Fig. 2.2) extending over $1200 \mathrm{~km}$ in latitude $\left(36^{\circ}-47^{\circ} \mathrm{N}\right)$, and $195-435 \mathrm{~km}$ in longitude $\left(46^{\circ}-56^{\circ} \mathrm{E}\right)$. The surface area and water volume of the Caspian basin critically depend on the regional hydrological balance. The Caspian Sea is divided into three subbasins of roughly similar surface area, but widely differing in depth and volume. The north Caspian basin ( $<15 \mathrm{~m}$ deep, $1 \%$ volume) is separated by the Mangyshlak sill from the Middle Caspian basin $(<800 \mathrm{~m}, \sim 33 \%)$ which is in turn separated by the Apsheron threshold from the South Caspian basin $(<1025 \mathrm{~m}, \sim 66 \%)$ (Panin et al., 2005; Zonn et al., 2011). At present, Caspian water level is $\sim 27 \mathrm{~m}$ below global sea level, which gives a surface area of $\sim 371,000 \mathrm{~km}^{2}$ and volume of $\sim 78,200 \mathrm{~km}^{3}$. The Caspian basin is a huge reservoir of anomalohaline (often referred to as brackish) water. It is highly sensitive to climatic changes in its catchment area (3.5 million $\mathrm{km}^{2}$ ), which extends far northward to the central part of the East European Plain (Panin et al., 2005; Zonn et al., 2011). During the Quaternary, the catchment extended to include almost entire Central 
Asia. Today, the Caspian catchment contains forests and steppes in the Volga and Ural valleys and mountainous forests and arid regions in the Caucasus and Transcaspian areas. The salinity of the present-day Caspian Sea changes from 1 psu near the Volga delta in the north to 13.5 psu in the south (Dumont, 1998). The Volga discharge provides $85-90 \%$ of the total fresh water influx and forms the main element in the hydrological budget (Agapova and Kulakova, 1973; Mamedov, 1997; Zonn et al., 2011).

In late Miocene (Pontian) times the Caspian basin was still connected to the Black Sea, forming the final phase of the ancient Paratethys Sea (Krijgsman et al., 2010; Popov et al., 2006, 2004). The Caspian basin became isolated from the Black Sea in the earliest Pliocene (van Aartsen et al., 2016a), when a major drop in its water level resulted in far southward retreat of lake environments and an associated progradation of the Volga's fluvio-deltaic deposits that reached the South Caspian basin (Fig. 2.3a). This so-called Productive Series is the main South Caspian hydrocarbon reservoir unit (e.g., Hinds et al., 2004). The nature and extent of lake conditions in the southern basin at the time are unknown as these deposits are often several $\mathrm{km}$ below surface. Since its isolation from the Black Sea and open ocean, the Caspian basin has experienced numerous transgressions and regressions with water level fluctuations of several tens to hundreds of meters resulting in enormous changes of its shoreline, especially in the flat northern part (Svitoch, 2010a; Varuschenko et al., 1987; Yanina, 2014). Our review of the Caspian stratigraphy starts with the late Pliocene Akchagylian transgression that resulted in the first of several lake phases that extend all the way to the modern Caspian Sea. Here we review the definitions and commonly used Plio-Quaternary stratigraphic subdivisions in the Pontocaspian domain, including their geochronological constraints, which allow a detailed correlation of the Caspian Sea with the Black Sea and the terrestrial and global ocean records.

\subsubsection{Akchagylian}

During the Akchagylian age (late Pliocene-earliest Pleistocene) the largest Caspian transgression occurred, with shores extending well into the middle Volga and southern Urals to the north as well as the Sea of Azov in the west and the Aral Sea in the east (Fig. 2.3b). The Caspian basin was a saline lake with major endemic faunal radiations but also events occurred that saw the introduction of marine foraminifera.

The Akchagylian mollusc faunas are best characterised by the high number of endemic mactrid and cardiid bivalve species (Danukalova, 1996). The Akchagylian is often subdivided into three substages, based on its mollusc assemblages (Ali-Zade, 1954; Golubyatnikov, 1908, 1904; Kolesnikov, 1940; Paramonova, 1994; Yakhimovich et al., 1970). The lower substage is marked by low variety of genera and species containing Aktschagylia subcaspia, A. karabugasica, A. inostrantzevi, Cerastoderma dombra. The middle substage is characterized by high species numbers within the genera Aktschagylia, Andrussovicardium, Miricardium and Avicardium. The upper substage is characterized by low numbers of mollusc species including Aktschagylia subcaspia, A. 


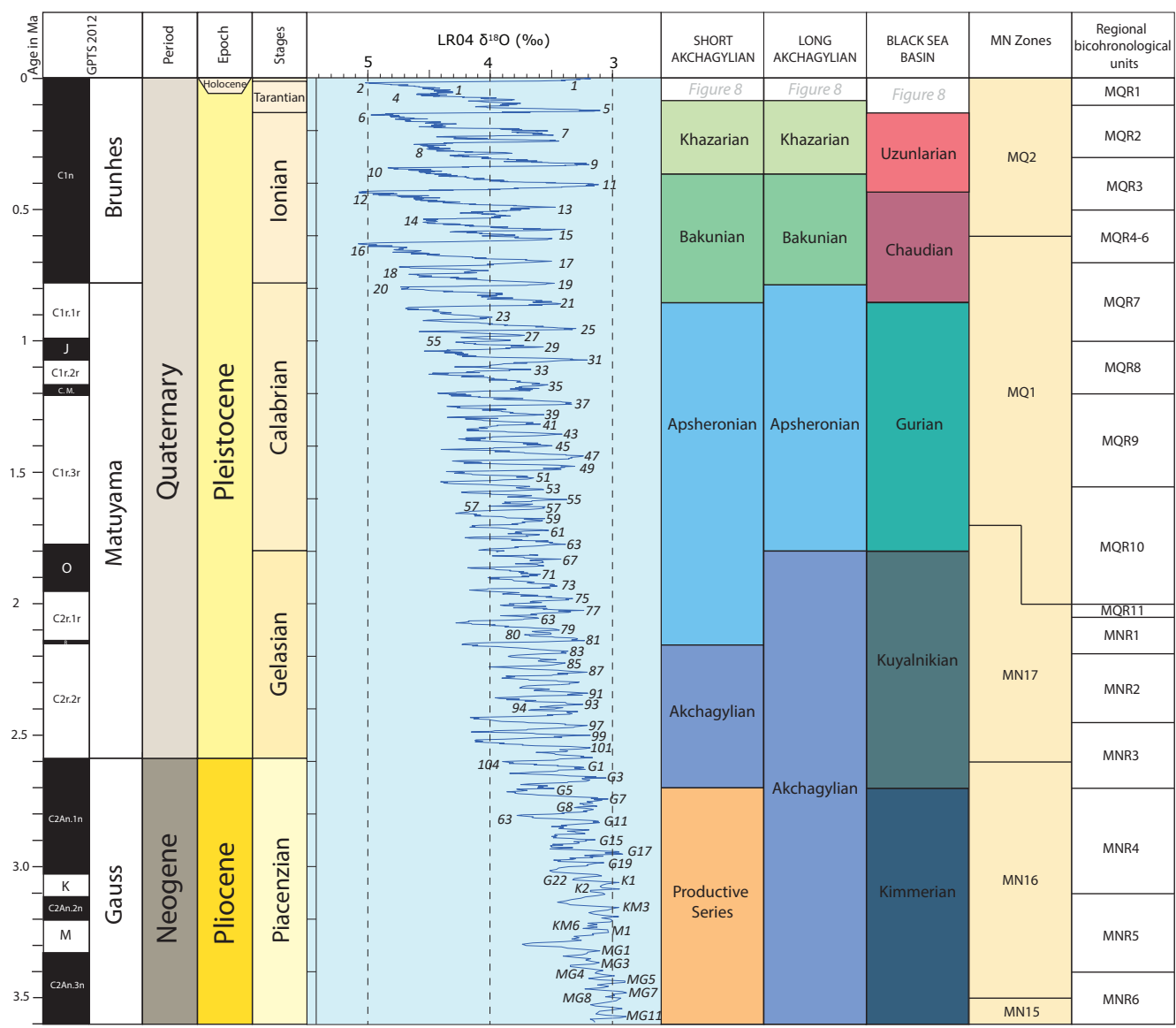

Fig. 2.4: Plio-Quaternary time scales for the Pontocaspian domain. GPTS with Systems and Stages are after Hilgen et al. (2012), oxygen isotope curve with numbered Marine Isotope Stages (MIS) is after Lisiecki and Raymo (2005). M=Mammoth (C2An.2r), K=Kaena (C2An.1r), R= Reunion (C2r.1n), O=Olduvai (C2n), C.M.= Cobb Mountain (C1r.2n), J=Jaramillo (C1r.1n). Ages of the Cobb Mountain Subchron are after Channell (2017). On the right side are the time scales for the Caspian basin, Black Sea basin and the terrestrial domain (mammal (MN/MQ) zonation and regional (MNR/MQR) biochronological units).

ossoskovi, Cerastoderma dombra and species of Dreissena and Theodoxus. The gastropods Pirenella caspia s.l., "Clessiniola" intermedia, "C." utvensis, and "C." vexatilis occur in all substages. The usage of this threefold scheme may lead to an arbitrary allocation of units, especially as it is only based on high or low mollusc species richness. For example, other investigations demonstrated that middle Akchagylian molluscs appeared at different stratigraphical levels, which led to an alternative subdivision of the Akchagylian in two substages (Danukalova, 1996; Nevesskaja et al., 2003; Popov, 1969; Trubikhin, 1977). 


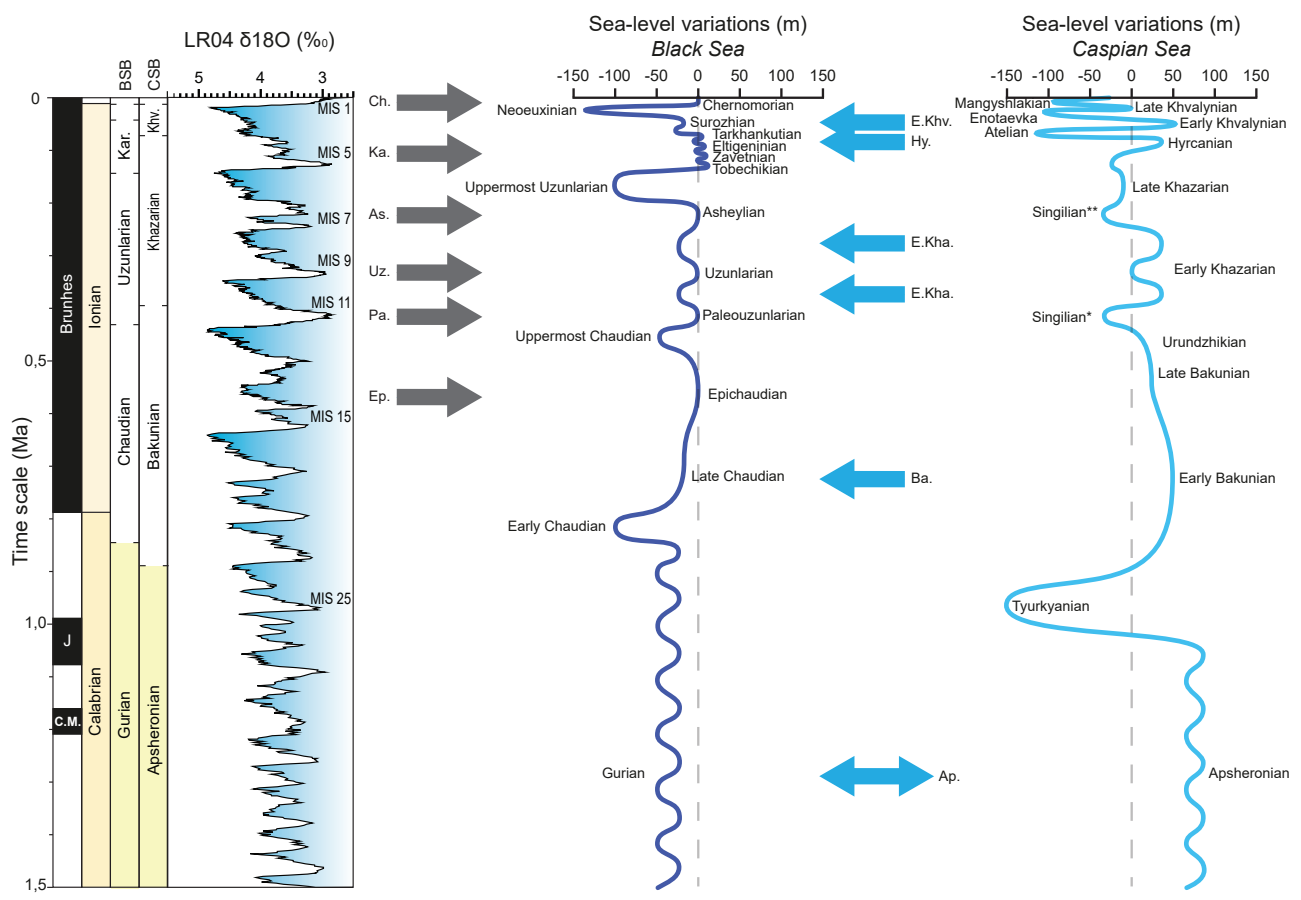

Fig. 2.5: Schematic reconstruction of the Black Sea and Caspian Sea water-level curves in comparison to global oxygen isotopes records of Lisiecki and Raymo (2005) during the Pleistocene to Holocene. Associated interbasinal water exchanges marked by arrows pointing to the right for Mediterranean waters flooding into the Black Sea, arrows pointing to the left for Caspian Sea waters flooding into the Black Sea and double arrows for bidirectional water exchange between Black Sea and Caspian Sea. N.B. Two options exist in literature regarding the position of the Singilian: ${ }^{\star}$ Svitoch (2013b and references therein) and ${ }^{*}$ Zastrozhnov et al. (2018 and references therein).

Most evidence and interpretations converge towards two different ages for the base of the Akchagylian (Fig. 2.4). The "classic option" mainly relies on the magnetostratigraphic correlation of the Pyrnuar section and dates the base of the Akchagylian to the base of the Gauss at an age of 3.6 Ma. This is the officially accepted age in Russian stratigraphy (Interdepartmental Stratigraphic Committee of Russia (ISC), 2003; Nevesskaja et al., 2005). The "young option" mainly depends on sections in Azerbaijan, where the integration of ${ }^{40} \mathrm{Ar} /{ }^{39} \mathrm{Ar}$ dating and magnetostratigraphy indicates an age of 2.7 Ma for the base of the Akchagylian, in the uppermost normal part of the Gauss chron (Khramov, 1960; Van Baak, 2015). 


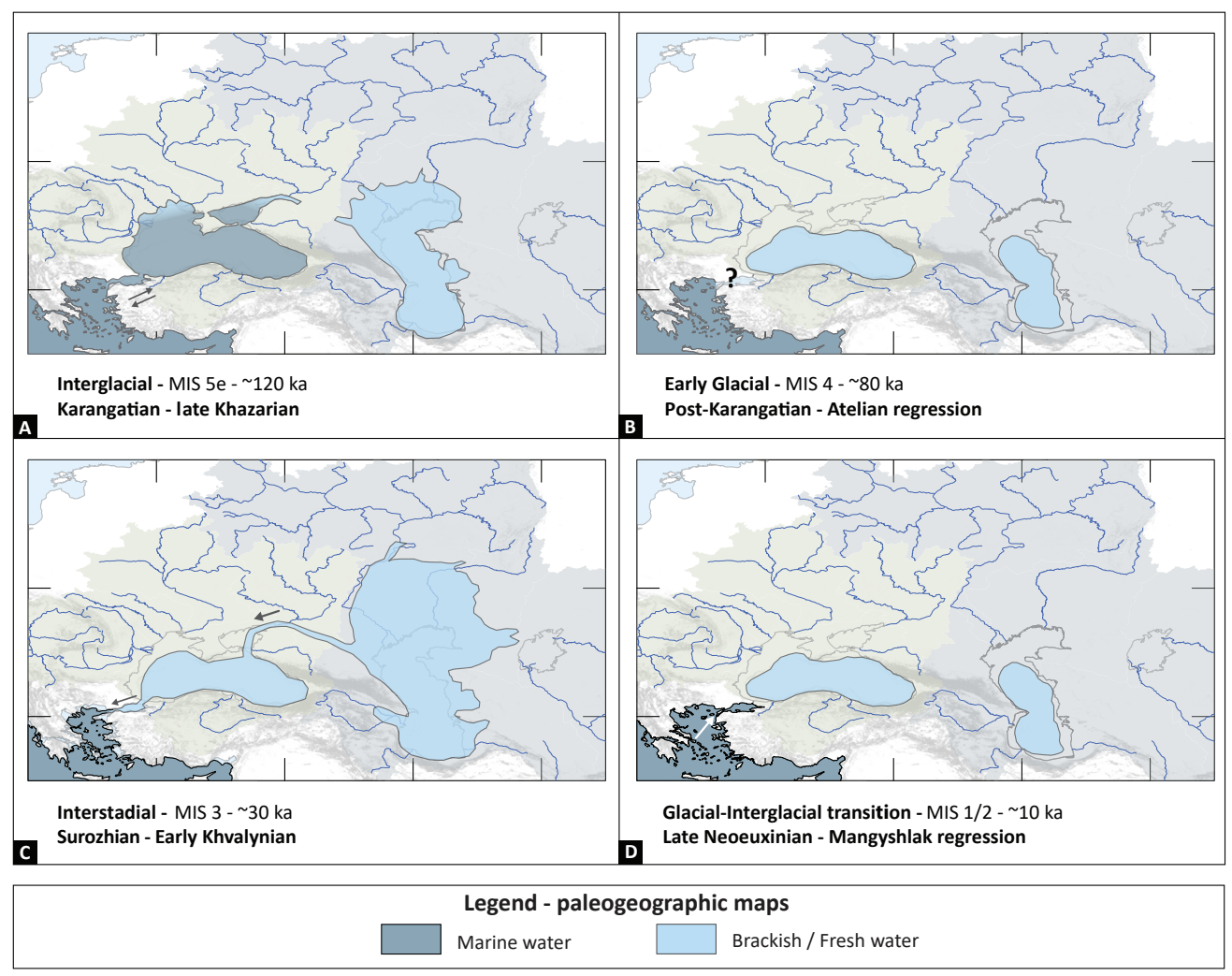

Fig. 2.6: Paleogeographic maps for the Late Pleistocene Pontocaspian region. Arrows indicate the water flow direction in the gateway regions. All maps are based on Yanina (2014).

\subsubsection{Apsheronian}

Caspian Sea conditions in the Early Pleistocene Apsheronian were similar to today. The Caspian basin was occupied by an anomalohaline lake. A major salinity decrease during the late Akchagylian corresponds with the almost complete extinction of characteristic Akchagylian bivalve faunas and subsequently the typical Apsheronian fauna evolved. This endemic fauna became increasingly dominated by extant endemic Caspian groups. During the Apsheronian, the Caspian basin was mostly an isolated basin that may have had rare, short-lived connections only to the Black Sea via the Manych Strait (Fig. 2.3c).

The Apsheronian Stage is subdivided into three substages, based on changes in the composition of the mollusc fauna (Andrusov, 1923; Kolesnikov, 1940; Zhidovinov et al., 2000; Sidnev, 1985). The lower substage is characterized by a species-poor assemblage of low saline to fresh water bivalves (Dreissena, Corbicula, Apsheronia) and gastropods (Lymnaea, Streptocerella, Turricaspia, Theodoxus). The middle substage is marked by the first occurrence of the mollusc genera Parapsheronia and Didacna. The upper zone is characterized by a general depletion of the saline fauna and the 
disappearance of the ribbed apsheronids of the middle interval. This upper (Tyurkyanian) interval is poorly recognizable in many parts of the Caspian basin and in some regions only a twofold division has been used (Stratigraphy..., 1982).

The Tyurkyanian stage was defined by Khain (1950) for the continental deposits (up to $100 \mathrm{~m}$ ) between the Apsheronian and Bakunian successions (Stratigraphy..., 1984). These deposits contain fresh water molluscs (Viviparus diluvianus, Valvata piscinalis, V. antiqua, Bithynia sp., Lithoglyphus naticoides, Pisidium amnicum, P. cf. supinum, P. cf. subtruncatum, Sphaerium rivicola, Unio sp., Dreissena sp.) and correspond to a strong ( $150 \mathrm{~m}$; Fig. 2.5) regression phase (Danukalova et al., 2017; Svitoch, 2013; Yanina, 2012; Zastrozhnov et al., 2018). We consider the Tyurkyanian as the upper part of the Apsheronian.

Two different ages exist for the top of the Akchagylian/base of the Apsheronian (Fig. 2.4). The official geological time scale of Russia dates the Akchagylian/Apsheronian boundary at $1.8 \mathrm{Ma}$, resulting in a "long Akchagylian" of 1.8 Myr. The alternative correlation, based on the Duzdag section of Azerbaijan, dates this boundary at >2.1 Ma, suggesting a "short Akchagylian" of 0.6 Myr if the age of 2.7 for the base Akchagylian in Azerbaijan is used, or an "intermediate Akchagylian" of 1.5 Myr if the age of 3.6 Ma for the base of the Akchagylian is used (Fig. 2.4).

\subsubsection{Bakunian}

Conditions in the Middle Pleistocene Bakunian stage resembled the modern Caspian Sea in size, fauna and salinity regimes (Fig. 2.3d). During highstands punctuated overflows towards the Black Sea existed. Widespread carbonate rocks formed during warmer phases of the Bakunian in the South Caspian basin; these are the main source for building material there.

The mollusc fauna of the Bakunian stratotype is characterised by a number of bivalve species including Didacna parvula, D. catillus, D. rudis, D. carditoides, D. eulachia, D. mingetschaurica, D. pravoslavlevi, $D$. lindleyi. The taxa $D$. parvula and $D$. catillus are index-species, while D. rudis and D. carditoides are considered characteristic species (Bogachev, 1932a, 1932b; Fedorov, 1978, 1957; Nevesskaja, 2007; Svitoch et al., 2013, 1992; Vekilov, 1969; Yanina, 2005).

The base of the Bakunian is determined by a significant transgression that reached its maximum extent in the first half of the Middle Pleistocene (=lower Neopleistocene), but was much smaller than the Akchagylian transgression (Fig. 2.3c). The presence of Bakunian Didacna parvula, D. rudis, D. carditoides, D. catillus in the Black Sea (Chaudian Stage) and in the Manych Depression (Fedorov, 1978; Popov, 1983a; Svitoch et al., 1998, 2010; Yanina, 2005, 2006) represents Caspian overflows into the Black Sea basin through the Manych Strait.

The Bakunian Stage is commonly subdivided into two substages based on different mollusc fauna, in particular the bivalve genus Didacna (Yanina, 2012a). Three morphological groups of the Didacna genus exist: the crassoidal, catilloidal and trigonoides groups (Nevesskaja, 2007; Svitoch, 1967; Yanina, 2005; Yanina et al., 2013). The faunas of the lower Bakunian are dominated by the first two groups and furthermore includes taxa like Didacna parvula, D. catillus and D. fedorovi. In 
addition, Dreissena rostriformis is widely distributed. The most characteristic species are Didacna parvula and D. catillus. The upper Bakunian predominantly contains Didacna's of the transitional crassoidal-catilloidal group (D. rudis, D. carditoides) and crassoidal group (D. eulachia, D. mingetchaurica, D. pravoslavlevi, D. bacuana) and representatives of the catilloidal and trigonoidal groups are rare. The most characteristic species are Didacna rudis, D. carditoides and D. eulachia (Nevesskaja, 2007; Yanina, 2013a, 2013b).

The Urundzhikian stage has been defined by Fedorov (1946) as an independent stratigraphic unit corresponding to the final stage of the Bakunian transgressive cycle (Fedorov, 1999, 1993). Urundzhikian deposits are characterized by numerous Didacna species: D. eulachia, D. mingetschaurica, D. pravoslavlevi, D. colossea, D. shirvanica, D. bergi, D. karelini, D. porsugelica, D. čelekenica, D. rudis, and D. carditoides. Trigonoidal and catilloidal Didacna's are rare. Characteristic species are D. eulachia, D. pravoslavlevi and D. kovalevskii. The size of the endorheic Urundzhikian lake phase slightly exceeded the area of the modern Caspian Sea. Here, we consider the Urundzhikian as the upper part of the Bakunian.

The large size and thickness of Didacna shells and the high carbonate content of Urundzhikian sediments suggest warm climatic conditions. The Urundzhikian transgression is consequently correlated to the interglacial stage MIS 11 (Svitoch and Yanina, 2007; Yanina, 2012b). The age of the lower Bakunian boundary is constrained to the age interval between 0.88 and $0.75 \mathrm{Ma}$ (Fig. 2.4). The official geological time scale of Russia places the Apsheronian/Bakunian boundary at the Brunhes/ Matuyama reversal at an age of $0.78 \mathrm{Ma}$.

\subsubsection{Khazarian}

During the Middle-Late Pleistocene Khazarian and Hyrcanian phases the Caspian Sea experienced large sea level changes and episodic overflow into the Black Sea occurred (Fig. 2.5). In between these high-stands, deep regressions took place and essentially the modern Caspian system evolved.

The early Khazarian transgression corresponds to a sea level high stand of $+15 \mathrm{~m}$ (Fedorov, 1957; Rychagov, 1997; Vasiliev, 1961) or +20-25 m (Svitoch and Yanina, 2007). It is characterized by the broad development of the trigonoidal group of didacnas (Didacna subpyramidata, D. paleotrigonoides, D. gurganica, D. mishovdagica, D. trigonula, D. trigonoides chazarica), representatives of the crassoidal group (Didacna pravoslavlevi, D. nalivkini, D. delenda, D. apscheronica, D. ovatocrassa, D. subcrassa, D. pontocaspia tanaitica) and rare species of the catilloidal group (Didacna dilatata, D. subcatillus, D. vulgaris, D. lindleyi, D. adacnoides). Characteristic species for the lower Khazarian are Didacna subpyramidata and D. paleotrigonoides. Numerous other anomalohaline molluscs are present as well (Monodacna caspia, Hypanis plicatus, Adacna vitrea, etc.).

The late Khazarian transgression (Fig. 2.6a) corresponds to a sea level high stand of $-10 \mathrm{~m}$ (Kaplin et al., 1977; Popov, 1983a; Svitoch and Yanina, 1997), but lacked any connection with the Black Sea basin (Fig. 2.5). Common gigantism of shells, high carbonate content in the sediment, and 
the presence of oolites indicates warm climate conditions (Yanina, 2014). Salinities ranged between 10 to $12 \mathrm{psu}$ in the northern part and up to 14-15 psu in the southern part of the Caspian basin, i.e. higher than today (Yanina, 2014). Pollen assemblages testify to moderately warm interglacial climates (Abramova, 1974).

The upper Khazarian is marked by widespread species of the crassoidal Didacna group (Didacna surachanica, D. subcrassa, D. hyrcana, D. nalivkini, D. delenda, D. ovalis, D. karabugasica, D. subovalis, D. ovatocrassa, D. schuraosenica). Trigonoidal and cattiloidal forms are rare. The index species of the upper Khazarian is Didacna surachanica (Fedorov, 1957; Nevesskaja, 2007; Yanina, 2005). In more oligohaline and fresh-water deposits Corbicula fluminalis is common.

After the main late Khazarian transgression, but before the Khvalynian transgression, another transgression has been described from boreholes in the north Caspian basin; the Hyrcanian (or Girkanian) transgression (Fig. 2.5; Popov, 1955, 1967; Goretskiy, 1957; Yanina, 2013; Sorokin et al., 2018). Hyrcanian deposits contain "Khvalynian-like" fauna of Didacna subcatillus, D. cristata, D. pallasi, D. subcrassa, but also the mainly freshwater Corbicula fluminalis. The widespread occurrence of $C$. fluminalis is indicative of the warm water character of the basin. The Hyrcanian mollusc fauna in the Manych Depression shows that Caspian waters were draining to the Black Sea (coevally with the last phase of the Karangatian transgression in that basin) through the Manych Strait (Popov, 1983a; Yanina, 2014).

The Khazarian sediments (including the Hyrcanian in their upper part) are generally separated from the lower Khvalynian deposits by the Atelian regression (Fig. 2.5), when the Caspian Sea level was significantly lowered (Fig. 2.6b). Based on seismic-acoustic profiling, the maximum lowstand during the Atelian is estimated at -120 to $-140 \mathrm{~m}$ (Lokhin and Maev, 1990; Maev, 1994). Vast areas of the Caspian shelf were exposed and river incisions were deep (Fedorov, 1978; Rychagov, 1997)..

Most age constraints indicate that the upper Khazarian deposits have an age between 125-85 ka, corresponding to MIS 5 (Fig. 2.7). The Hyrcanian transgression corresponds to the final part of the interglacial interval MIS $5 \mathrm{a}(85 \mathrm{ka})$. The Atelian regression then most likely peaked at an age of $85-75 \mathrm{ka}$. The final phase of regression is dated by OSL at $48 \pm 3$ (Yanina et al., 2017c) and by ${ }^{14} \mathrm{C}$ at 45-41 ka (Bezrodnykh et al., 2017) suggesting it corresponds to the first half of the interstadial warming of MIS 3.

\subsubsection{Khvalynian}

The Khvalynian stage developed in the Late Pleistocene glacial period. Very high transgressions with an overflow event towards the Black Sea interchanged with very deep regressions. The Khvalynian transgression is by far the most extensive sea-level rise in the Late Pleistocene history of the Caspian Sea (e.g., Yanina, 2014) (Fig. 2.6c). Salinities were somewhat depressed compared to today and a unique landscape (Baer knolls) developed in the north Caspian plains. Palynological data confirm a cold climate (Abramova, 1974; Yakhimovich et al., 1986). The early Khvalynian water level reached $+50 \mathrm{~m}$, and Caspian Sea water spilled over to the Black Sea via the Manych Strait (e.g., 


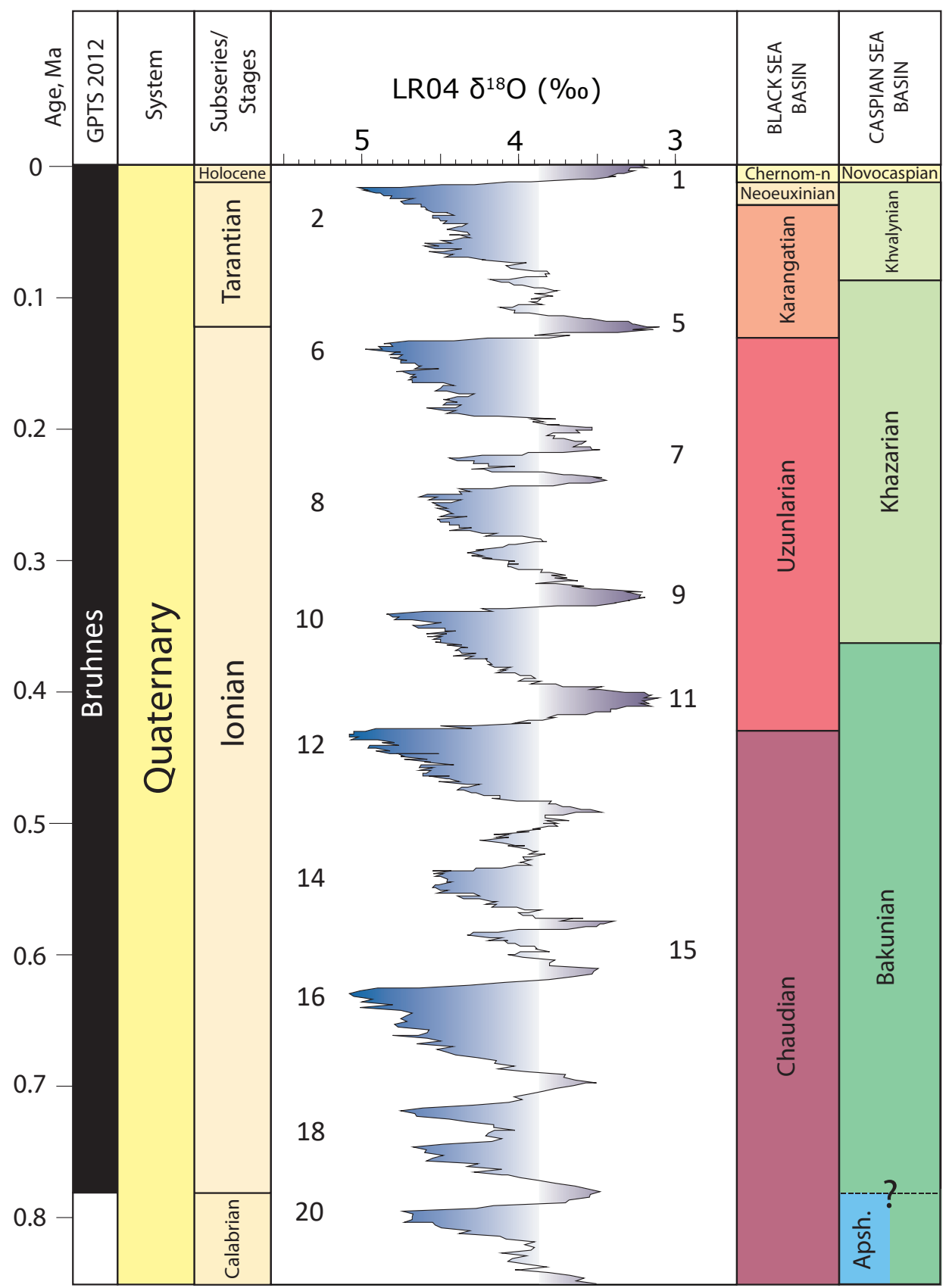

Fig. 2.7: Quaternary time scales for the Pontocaspian domain. GPTS with Systems and Stages is after Hilgen et al. (2012), oxygen isotope curve with numbered Marine Isotope Stages (MIS) is after Lisiecki and Raymo (2005). On the right side are the time scales for the Caspian basin and the Black Sea basin. 
Popov, 1983; Varuschenko et al., 1987; Yanina, 2014). During this period the northern Caspian basin was much larger than today (Fig. 2.6c).

The lower Khvalynian and upper Khvalynian are separated by the Enotaevka regression (Brotsky and Karandeeva, 1953), which reached a maximum lowstand at -105 m (Maev, 1994). According to pollen data, arid cool climate conditions existed (Sorokin et al., 1983). During the late Khvalynian transgressive stage, sea level reached about $0 \mathrm{~m}$ (which is $27 \mathrm{~m}$ above todays Caspian levels: (Fedorov, 1957; Leontiev et al., 1975; Varuschenko et al., 1987). No overflow to the Black Sea existed.

In the lower Khvalynian Didacna ebersini, D. parallella, D. protracta are abundant, while D. cristata, D. subcatillus, D. praetrigonoides, D. delenda and D. zhukovi are rare. Characteristic species are $D$. parallella and D. protracta. On the eastern coast, these species are replaced by D. cristata and D. zhukovi. The thin shells of these molluscs indicate relatively low water temperatures compared to the present-day Caspian Sea. The structure of mollusc fauna is indicative of relatively low salinities, although regional variations existed. Salinities in the northern Caspian basin (3-4 psu) were slightly higher than today, whereas salinities in the southern basin $(\sim 11 \mathrm{psu})$ were slightly lower (Yanina, 2014). The upper Khvalynian deposits comprise clays, silts and sands with Monodacna caspia, Dreissena polymorpha, D. grimmi, and gastropods. Multiple Didacna species include D. praetrigonoides, D. parallella, D. protracta, and more rarely D. subcatillus. Didacna praetrigonoides, a rare species in the early Khvalynian, became dominant. The salinity of the main water body of the late Khvalynian basin was very similar to the early Khvalynian (Yanina, 2014). The relative abundance and thick shells of the molluscs indicate warmer conditions in late Khvalynian times then during early Khvalynian. Palynological data confirm a general warming of the Caspian region (Abramova, 1974; Grichuk, 1954; Sorokin et al., 1983; Vronsky, 1976, 1974; Yakhimovich et al., 1986).

Most age constraints for the base of the Khvalynian converge on an age of $35 \mathrm{ka}$ (young option), while the top is estimated at $\sim 10 \mathrm{ka}$ (Fig. 2.7). The age of the maximum Enotaevka regression separating the lower and upper Khvalynian is around $\sim 15 \mathrm{ka}$.

\subsubsection{Novocaspian}

The Holocene Novocaspian stage represents the modern Caspian Sea settings and faunas. The Novocaspian is separated from the upper Khvalynian by the regressive Mangyshlakian facies (defined by Zhukov, 1945), that represents the deltaic progradation of the Volga and Ural rivers during a major sea level fall up to $-80 \mathrm{~m}$ or even $-113 \mathrm{~m}$ (Fig. 2.5, 2.6d) (Bezrodnykh et al., 2015, 2004; Varuschenko et al., 1987). The Mangyshlakian deposits contain peats and sands with plant detritus and species poor assemblages of fresh water and oligohaline molluscs (Dreissena polymorpha, Lymnaea, Unio) but lack Didacna species (Sorokin, 2011).

The Novocaspian mollusc fauna is marked by various Didacna species of the crassoidal and trigonoidal groups: Didacna crassa, D. baeri, D. trigonoides, D. pyramidata, D. longipes, D. barbotdemarnii. In addition, numerous other anomalohaline molluscs are present like Monodacna 
caspia, Hypanis plicatus, Adacna vitrea, etc. Characteristic for the Novocaspian are the species D. baeri and D. trigonoides, plus the entry of Cerastoderma glaucum (Fedorov, 1953, 1957). The uppermost beds contain Mytilaster minimus and Abra segmentum, which were anthropogenically introduced into the Caspian from the Azov/Black Sea during the 20th century. Spores and pollen spectra contain up to $25 \%$ of tree pollen, mainly pine and birch, indicative of the relatively humid climate in the Holocene (Sorokin, 2011).

Judging from the absolute age determinations, the Mangyshlakian regression peaked between 10 and $8 \mathrm{ka}$, and the Novocaspian deposits are all younger than $7 \mathrm{ka}$ (Fig. 2.7). The AMS ${ }^{14} \mathrm{C}$ data from boreholes in the Volga delta suggest a lowstand around 8000 yrs BP. Volga delta data indicate a continuously rising sea level between 5000 and 3000 yrs BP until a highstand was reached at -25 $\mathrm{m}$ around 2600 yrs BP (Overeem et al., 2003; Kroonenberg et al., 2008). During the historically well-known mediaeval Derbent regression (Rychagov, 1997) Caspian Sea levels dropped to -34 m, and possibly even $-45 \mathrm{~m}$ as recorded in the deeper parts of the offshore Kura delta in Azerbaijan. A second highstand around $300 \mathrm{yrs}$ BP is documented in an outermost barrier in Dagestan (Kroonenberg et al., 2007). The two highstands appear to coincide with two well-known periods of increased precipitation in Eurasia, the 2600 yrs BP event (Van Geel and Renssen, 1998) and the Little Ice Age, whereas the Derbent regression seems to be coeval with the Warm Mediaeval Period (Kroonenberg et al., 2007).

\subsubsection{The Black Sea region}

The Black Sea is today a marginal sea of the Mediterranean (Fig. 2.2) and has a surface area of $436,400 \mathrm{~km}^{2}$ (excluding the Sea of Azov), a maximum depth of 2,212 $\mathrm{m}$, and a volume of 547,000 $\mathrm{km}^{3}$. Its E-W extent is about $1175 \mathrm{~km}\left(27^{\circ} 27^{\prime}-41^{\circ} 42^{\prime}\right)$ and it stretches $\sim 800 \mathrm{~km} \mathrm{~N}-\mathrm{S}\left(46^{\circ} 33^{\prime}-\right.$ $\left.40^{\circ} 56^{\prime}\right)$. At present, it is the world's largest meromictic water body; deep waters do not mix with the upper water layers that receive oxygen from the atmosphere. As a result, over $90 \%$ of the deep Black Sea volume is anoxic. Circulation patterns are primarily controlled by basin topography and fluvial inputs, which result in a strongly stratified vertical structure. The Black Sea has a positive freshwater balance: it receives more fresh water from the rivers and rainfall than it loses from evaporation. The Black Sea consequently experiences an estuarine type of water transfer with the Mediterranean Sea via a shallow threshold $(35-40 \mathrm{~m})$ at the Bosporus Strait, with bottom inflow of dense Mediterranean water below a surface outflow of fresh Black Sea water into the Marmara Sea. The salty Mediterranean inflow mixes with the basin's fresher waters, which results in an average salinity of 18-22 psu for the Black Sea surface waters, i.e. much lower than the Mediterranean (37-38 psu).

During Quaternary to Recent times, periods of isolation and episodic connection with the Mediterranean Sea (through the Marmara and Aegean seas) largely controlled the paleoenvironmental conditions in the Black Sea (Badertscher et al., 2011; van Aartsen et al., 2016b; Zubakov, 1988). The ancient Bosporus Strait may have been slightly deeper than today, as the sill 
depth in the Palaeozoic bed rock is estimated at $\sim 85 \mathrm{~m}$ in the Dardanelles Strait (Algan et al., 2001). However, the Bosporus gateway itself evolved only in the Middle Pleistocene (McHugh et al., 2008). When global/Mediterranean Sea levels were above the Bosporus sill, marine water connections existed all the way to the Black Sea. During such connection phases the Black Sea level tracked that of global sea levels. When the Mediterranean levels were below the sill, the Black Sea turned into an isolated, saline lake basin. Major rivers like the Danube, Dniester, Dnieper, and Don (via the Sea of Azov), supply fresh water to the Black Sea; together they drain a large part of continental Europe (Fig. 2.2). During intervals with a positive water balance the Black Sea level remained at the sill height and one-directional flow towards the Mediterranean Sea occurred. In times of negative water budgets, lake levels dropped until the total inflow (precipitation and river influx) equalled the evaporation in the Black Sea basin (e.g., de la Vara et al., 2016). Salinities during these lake phases were typically in the oligohaline-mesohaline ranges, very similar to today's Caspian Sea.

In the northeast, the Black Sea is connected to the Sea of Azov through the Kerch Strait (Fig. 2.2). The Sea of Azov ( $\left.45^{\circ} 12 \bigotimes-47^{\circ} 17 \bigotimes \mathrm{N}, 33^{\circ} 38 \mathrm{X}-39^{\circ} 18 \bigotimes \mathrm{E}\right)$ has a surface area of $39,100 \mathrm{~km}^{2}$ and is 13 $\mathrm{m}$ deep in its central part. Two large rivers, the Don and Kuban, flow into the Sea of Azov. Annually $49.2 \mathrm{~km}^{3}$ waters flows to the Black Sea, while $33.8 \mathrm{~km}^{3}$ returns, resulting in an average salinity of $\sim 11$ psu. Recently, anthropogenic reduction of river drainage strengthened the inflow of the Black Sea waters and increased the average salinity up to $13.8 \mathrm{psu}$. In the geological history, the Sea of Azov frequently desiccated during glacio-eustatic lowstands and the Don and Kuban rivers directly drained into the Black Sea, south of the modern Kerch Strait (Yanina, 2012b).

During the Pontian (6.1-5.6 Ma), the Black Sea was connected to the Mediterranean in the south, the Dacian basin of Romania in the west and to the Caspian basin in the east (Popov et al., 2004, 2006; Krijgsman et al., 2010; Van Baak et al., 2015b, 2016a, 2017). During early Pliocene times (regional Kimmerian age) the Black Sea basin became isolated and transformed into a long-lived lake (Fig 2.3a). During the late Pliocene-early Quaternary (Kuyalnikian), modern Pontocaspian faunal elements appeared in the Black Sea basin, where a succession of saline lake stages developed, increasingly punctuated (from the Middle Pleistocene onwards) by short marine connectivity phases similar as today. Here we review the stratigraphic development of the Black Sea domain during the Plio-Quaternary.

\subsubsection{Kuyalnikian}

At the onset of the Pleistocene, the Pontocaspian domain consisted of two autonomous provinces; the mesohaline-polyhaline Akchagylian basin of the Caspian region and the oligohaline-mesohaline Kuyalnikian basin of the Black Sea region (Fig. 2.3b). The configuration of the Kuyalnikian basin was relatively similar to the present-day Black Sea basin (Fig. 2.3b), and included the south Ukrainian shelf and the Azov-Kuban and Rioni gulfs (Popov et al., 2006). The Kuyalnikian basin had no direct connection with the open ocean, but an ephemeral connection probably existed with the Akchagylian basin of the Caspian region as Akchagylian molluscs like Aktschagylia subcaspia 
and Cerastoderma dombra are known from Kuyalnikian sequences (Taman beds) in the Azov area (Nevesskaja et al., 1986). However, there is no other evidence that Akchagylian faunas penetrated the Black Sea basin.

The Kuyalnikian stage is commonly represented by a two-fold subdivision with a lower Kuyalnikian containing bivalves like Dreissena, Pseudocatillus, Prosodacna and Lymnocardium and an upper Kuyalnikian ("Taman Beds" of Eberzin, 1935) that comprises Akchagylian-type molluscs like Avimactra subcaspia and Cerastoderma dombra (Nevesskaja et al., 1986; Popov et al., 2006). Kuyalnikian deposits are widely distributed in the south-western part of Georgia (Taktakishvili, 1984; Molostovsky, 1997; Kirscher et al., 2017). Characteristic mollusc fossils there include Pontalmyra medeae, Pseudocatillus pleonexia and Pseudocatillus postdonacoides (Nevesskaja et al., 2003).

Most paleomagnetic data indicate that the lower boundary of the Kuyalnikian is located in the upper part of the Gauss chron. Consequently, we place the boundary here at a tentative age of 2.7 Ma, which makes it similar to the base of the "short" Akchagylian in the Caspian region (Fig. 2.4).

\subsubsection{Gurian}

During the Early Pleistocene, the Black Sea basin was occupied by the anomalohaline Guria Lake. In this lake an endemic Pontocaspian fauna evolved. No connections existed with the marine realm. Possibly only ephemeral connections existed with the Caspian basin through the Manych Strait north of the Caucasus.

The Gurian strata of Georgia were first described by Ilyjn $(1929,1930)$ and are subdivided into two lithostratigraphic units: the Khvarbetian and Naderbazetian. The two units have been divided on the basis of their cardiid assemblages (Kvaliashvili, 1976). The Khvarbetian is only found in southern Georgia and comprises shallow "brackish" lacustrine greyish-bluish marls with dreissenids in its lower part and small gastropods including Laevicaspia and Turricaspia in the top. The Naderbazetian is more widespread and dominated by bioclastic calcarenites (Ilyjn, 1930) that contain shells of Digressodacna (Taktakishvili, 1984).

Although there are many uncertainties in the published magnetostratigraphic results, we tentatively place the base of the Gurian at the top of the Olduvai subchron at an age of $1.8 \mathrm{Ma}$ (Fig. 2.4). This correlation makes the Gurian roughly coeval with the Apsheronian of the Caspian region and synchronous with the Calabrian stage of the Mediterranean and standard GTS (Kirscher et al., 2017).

\subsubsection{Chaudian}

During the Middle Pleistocene Chaudian, the Black Sea basin was dominated by anomalohaline lake conditions (Fig. 2.3d). Several episodes of connection with the Caspian basin occurred. Also, several overflow events into the Marmara basin occurred where Chaudian faunas were established temporarily. At the same time the Black Sea first experienced marine incursions from 
the Mediterranean Sea during interglacial highstands. The Chaudian basin was characterized by multiple changes in water level ranging from -140 to -30m (Sorokin and Babak, 2011).

The Chaudian has been subdivided into a lower Chaudian and an upper Chaudian (Fedorov, 1963). The lower Chaudian is represented by sediments and fossils indicating a freshened basin with an average salinity of 8-10 psu (Yanina, 2015). Lower Chaudian deposits are characterized by the molluscs Tschaudia tschaudae, T. guriana, Didacna guriensis, D. supsae, D. pseudocrassa and D. baericrassa (Yanina, 2014).. According to diatoms, spores and pollen, cold climatic conditions with periglacial vegetation prevailed (Chernyshova, 1980; Zhuze et al., 1980) The early Chaudian climate was warmer and altitudinal zonation more distinct than in the late Chaudian, which appears to have been temperate at most elevations (Shatilova et al., 2011). Major glaciers developed in the Caucasus, while cold pluvial conditions marked the lower areas (Dumitrashko et al., 1977).

The upper Chaudian strata are represented by shallow-water carbonates with abundant fauna consisting of Didacna pseudocrassa, D. baericrassa, D. olla, D. tamanica, Monodacna subcolorata, M. cazecae, Hypanis plicatus, Dreissena chaudae, D. pontocaspia (Yanina, 2012a). The salinity of the basin was on average 12-13 psu (Yanina, 2005). In addition, upper Chaudian strata also contain Didacna species characteristic of the upper Bakunian in the Caspian Sea (Didacna rudis, D. carditoides, D. catillus, D. eulachia), leading to the term Chauda-Bakunian (Fedorov, 1963; Popov, 1983a; Yanina, 2005). This suggests one or several connections through the Manych Strait existed with drainage of Caspian waters into the Azov region (Fedorov, 1963; Popov, 1983a; Yanina, 2005). On the periphery of the late Chaudian basin and near the mouths of large rivers, coastal lagoons with anomalohaline water fauna formed.

The upper part of the Chaudian deposits contains shells of Mediterranean euryhaline molluscs such as Cerastoderma glaucum, Mytilus galloprovincialis and Scrobicularia plana (Andrusov, 1896; Fedorov, 1978; Keraudren, 1970), suggesting episodic marine incursions. On the Caucasian coast, a terrace with a species poor Mediterranean mollusc fauna has been determined as "pre-Uzunlarian" (Solov'ev, 1977), expressing the first Pleistocene influx of Mediterranean waters into the Black Sea basin. This semi-marine basin is also referred to as Epichaudian (Fedorov, 1978), Patrayian (Zubakov, 1988) or Karadenizian (Chepalyga, 1997).

In several geological time scales of the Black Sea region (e.g., Shatilova et al., 2009), the lower boundary of the Chaudian is indicated as being coeval with the Brunhes-Matuyama boundary, which has an age of $780 \mathrm{ka}$ (Hilgen et al., 2012). In other time scales, however, the BrunhesMatuyama boundary is placed between lower and upper Chaudian (Nevesskaja et al., 2005; Zubakov, 1988). Recently, the Gurian-Chaudian transition was magnetostratigraphically determined in the Khvarbeti section (at level $157 \mathrm{~m}$ ) of Georgia, where it occurs in a reversed interval interpreted to correspond to chron C1r.1r and an age of $\sim 0.85 \mathrm{Ma}$ (Kirscher et al., 2017) (Fig. 2.4). The marine transgression that caused the first penetration of Mediterranean molluscs into the late Chaudian is correlated with MIS 15 or 13 (Yanina, 2012b). 


\subsubsection{Uzunlarian}

The Middle Pleistocene Uzunlarian is a continuation of the conditions of the Chaudian in the Black Sea basin. Pontocaspian faunas were widespread but less diverse and several marine connections occurred during interglacial highstands.

The Uzunlarian (Arkhangelsky and Strakhov, 1938) is a transgressive stage, that follows the regression at the end of the Chaudian. The stratotype section of the Uzunlarian is the Uzunlar section on the Kerch Peninsula (Fig. 2.2: Arkhangelsky and Strakhov, 1938; Fedorov, 1963; Chepalyga et al., 1989). In the lower, sandy part of the section molluscs adapted to unusual salinities occur such as Didacna pontocaspia, D. pallasi, D. subpyramidata, D. baericrassa, Monodacna, Hypanis and Dreissena spp. In the upper part, Pontocaspian species were replaced by euryhaline Mediterranean molluscs such as Cerastoderma glaucum, Abra segmentum and Chamelea gallina. The Uzunlarian represents an interval of repeated marine conditions in the Black Sea basin (Fedorov, 1978, 1963; Zubakov, 1988). The connection with the Mediterranean Sea was re-established via the Bosporus Strait, salinity increased from 10-13 psu to 15-17 psu, and euryhaline species resistant to salinity variations (e.g. Cerastoderma glaucum) penetrated the Black Sea (Fedorov, 1978). Two different levels with lower Khazarian molluscs in the sedimentary successions of the Manych Depression and the Azov region prove that Caspian waters drained at least twice through the Manych Strait into the Black Sea basin (Fedorov, 1978; Popov, 1983a; Yanina, 2012b).

The Uzunlarian deposits comprise evidence of both warm and cold periods. Marine transgressions of Mediterranean waters took place in interglacial periods, while ingressions of cold and brackish Caspian waters occurred during glacials. During interglacial intervals the Black Sea basin became populated by euryhaline Mediterranean molluscs like Paphia, Scrobicularia, Cerastoderma, Abra, Chione, Mytilus and Ecrobia spp. (Svitoch et al., 1998). Most of them co-occurred with Didacna species. Sea level was close to zero and salinity reached 15-17 psu. During glacial episodes the Black Sea basin became isolated from the Mediterranean and became populated with Didacna baericrassa, D. pontocaspia, D. borisphenica, D. raricostata, D. akschaena, and the Caspian (early Khazarian) species Didacna pallasi, D. subpyramidata and D. pallasi. The water level was well below today's and salinity decreased to $\sim 7$ psu near the river mouths and 11-12 psu in the open basin (Nevesskaja, 1963, 2007; Svitoch et al., 1998; Yanina, 2005, 2012b).

Accurate absolute age determinations of Uzunlarian deposits are very rare. According to Zubakov (1988), the Uzunlarian is dated between 580 and $300 \mathrm{ka}$ and corresponds to MIS 15 . Later, it was established that the Uzunlarian transgression took place in the second half of the Middle Pleistocene at an age of 250 ka (e.g., Svitoch, 2003). Based on OSL dating, the upper part of the Uzunlarian was dated at $\sim 227,5 \mathrm{ka}$ (Sychev et al., 2017). According to palaeogeographical reconstructions based on Didacna species, Yanina (2012b) correlated the three marine transgressive phases (Fig. 2.5) with MIS 11 (Palaeouzunlarian), MIS 9 (Uzunlarian) and MIS 7 (Asheylian). In this scenario, the age of the lower Uzunlarian boundary is located below MIS 11 at around $400 \mathrm{ka}$ (Fig. 2.4 and 2.8). 


\subsubsection{Karangatian}

The Karangatian represents the most widespread marine conditions in the Black Sea basin established during the penultimate Eemian (MIS 5e) interglacial and its transition into the last glacial (Fig. 2.6a). During MIS 5, basin settings were very similar as today, but sea level and salinity were higher. Towards MIS4 and MIS 3 the Black Sea basin became isolated.

The Karangatian deposits are represented by shell beds and shelly sandstones with numerous Ostrea edulis, Flexopecten glabra, Mimachlamys varius, Mytilus galloprovincialis, Chamelea gallina, Acanthocardia tuberculatum, Cerastoderma glaucum, Aporrhais pespelecani, Cerithium vulgatum, etc. They overlie a $60 \mathrm{~m}$ thick clay sequence of Uzunlarian age with freshwater molluscs (Lymnea and Planorbis) and rare Didacna (Zubakov, 1988).

The Karangatian transgression was the largest of the entire Quaternary history of the Black Sea, with a maximum water level approximately 6-8 $\mathrm{m}$ higher than today. Warm saline Mediterranean waters entered the Black Sea basin through the Bosporus Strait and a one-way migration of euryhaline and stenohaline Mediterranean fauna took place. At the maximum of the transgression, the salinity of the Karangatian sea was about 30 psu (Nevesskaja, 1965). High salinities were also characteristic for the southern part of the Sea of Azov, the Manych and the Don estuary. The Karangatian transgression extended all the way into the Manych Depression but marine mollusc species never entered the Caspian basin. The Karangatian sea was further marked by relatively warm waters, as shown by subtropical diatom species (Zhuze et al., 1980). Palynological data also indicate warm and moderately dry conditions (Artyushenko et al., 1973, 1972; Koreneva, 1980; Vronsky, 1976). During the second half of the Karangatian, the climate cooled and coastal lagoons transformed into lakes inhabited by fresh-water molluscs (Planorbis, Lymnea, and others).

We estimate that the Karangatian represents an interval of approximately 50-60 thousand years with its base at the beginning of MIS $5 \mathrm{e}$ at an age of $\sim 130 \mathrm{ka}$ and the maximum of the Karangatian transgression roughly corresponding to the global sea level highstand during the Eemian during MIS 5e (Fig. 2.7) (Chepalyga, 1997; Velichko, 2002; Yanina, 2014). The presence of Hyrcanian (Caspian) mollusc species in the Tarkhankutian beds (Popov, 1983a; Yanina, 2014) suggests that this stage corresponds to the terminal transition from the Eemian interglacial (MIS5a) to the MIS4 glacial epoch. The Surozhian highstand (up to $-25 \mathrm{~m}$ ) took place during MIS 3 (Yanina, 2014).

\subsubsection{Neoeuxinian}

The Late Pleistocene Neoeuxinian forms the final Pontocaspian lake phase in the Black Sea basin. The Neoeuxinian lake had low salinities and lake levels were predominantly very low. However, at least one overflow event from the Caspian occurred and at least one relative highstand resulted in a Black Sea-Marmara Sea connection judging from Neoeuxinian communities there (Fig. 2.6c). The Neoeuxinian phase was terminated with early Holocene marine ingressions which restricted Pontocaspian biota to the modern coastal habitats along the north-western Black Sea coast and the marginal areas of the Azov Sea. 
The Neoeuxinian includes two intervals. The lower Neoeuxinian corresponds to a deep regression with mostly fresh water molluscs like Dreissena, Viviparus, Valvata and Unio. The connection with the Sea of Marmara was disrupted during this regressive phase and the Black Sea transformed into a freshwater to oligohaline basin with salinities not exceeding 1.5-3.0 psu. At this time, the Black Sea reached a minimum level of -110 m (Balabanov and Izmaylov, 1989; Ostrovsky et al., 1977) to $-150 \mathrm{~m}$ (Ryan et al., 1997).

The upper interval is dominated by Pontocaspian mollusc species such as Dreissena cf. bugensis, Monodacna caspia, M. colorata, Adacna vitrea and Hypanis plicatus. Caspian (Khvalynian) shells of Didacna ebersini (Andrusov, 1918; Fedorov, 1963; Semenenko and Sidenko, 1979). This interval corresponds to a rise in water level to $-20 \mathrm{~m}$, and to Caspian waters flowing through the Manych Strait (Svitoch and Yanina, 2007). At the same time, the presence of Neoeuxinian faunas in the Marmara basin and northern Aegean shows Black Sea overflow (Büyükmeriç, 2016; Islamoğlu and Chepalyga, 1998; Taviani et al., 2014).

The age of the Neoeuxinian regression is estimated at 22-16 ka (Balabanov and Izmaylov, 1989; Scherbakov et al., 1977) or at 25-22 ka (Degens and Ross, 1972). From 16 to $12.5 \mathrm{ka}$, the water level is thought to have increased because of the influx of Caspian (Khvalynian) waters overspilling into the Black Sea as a result of intensive thawing after the last glacial maximum (LGM) (Balabanov, 2006; Balabanov and Izmaylov, 1989; Murdmaa et al., 2006; Svitoch and Yanina, 2007; Yanchilina et al., 2017). The age of the Khvalynian molluscs from the Manych Strait is 14.7-12.6 ka (Svitoch et al., 2010; Yanina, 2014). Hence, we conclude that the Neoeuxinian basin developed during MIS 2 with the deep regression coinciding with the LGM and the late Neoeuxinian transgression with the deglaciation phase (Fig. 2.7).

\subsubsection{Chernomorian}

The Chernomorian represents the modern Holocene conditions in the Black Sea. The Neoeuxinian/ Chernomorian boundary is based on the first emergence of the Mediterranean molluscs Cerastoderma glaucum and Abra segmentum. The Chernomorian is subdivided in two subunits, the Old Chernomorian and Neochernomorian, based on different mollusc assemblages (Fedorov, 1978). Old Chernomorian sediments are dominated by brackish-water species and the emergence of euryhaline Mediterranean elements. The Neochernomorian contains a more diverse assemblage of Mediterranean molluscs. Nevesskaja $(1963,1965)$ described four different stages in Chernomorian mollusc assemblages (Bugazian, Vityazevian, Kalamitian, and Dzhemetian) and concluded that both sea level and salinity gradually increased until the present. According to Fedorov (1978, 1982), the maximum Neochernomorian transgression reached 2-2.5 m above modern sea level and corresponds to the highest salinities of the Holocene Black Sea. During the Chernomorian, Pontocaspian habitats became suppressed by the Black Sea ingression into deltaic and coastal lakes and lagoons, as shown by Vespremeanu-Stroe et al. (2017) for the Danube delta area. 
Numerous publications have discussed the problem of reconstructing the exact mode of sea level rise in the Holocene Black Sea basin. According to Ryan et al. (1997), Mediterranean waters filled the Black Sea basin with an enormous speed, flooding the entire region within a couple of years. These authors furthermore link this catastrophic deluge to the Biblical Flood of Noah (Ryan and Pitman, 1999). In contrast, many others showed that sea level increased gradually in a reciprocating mode, with various speed and depending on different mechanisms (Aksu et al., 2002; Balabanov, 2006; Balabanov and Izmailov, 1988; Taviani et al., 2014; Yanchilina et al., 2017).

The Holocene transgression of the Black Sea, caused by Mediterranean inflow, is dated at $11 \mathrm{ka}$ (Balabanov, 2006), at 10 ka (Ostrovsky et al., 1977), 9 ka (Degens and Ross, 1972), 8-9 ka (Kuprin and Sorokin, 1982; Vinogradov et al., 1963) and 7-8 ka (Fedorov, 1978; Kvasov, 1975). According to Ryan et al. (1997), Noah's flood happened 7.2 kyr ago. The age of the Neochernomorian phase is determined by radio-carbon dating at 5-3 ka (Svitoch et al., 1998, 1995, 1994); at 5.5-5 ka and 4.5-4 ka (Fedorov, 1982; Selivanov, 1996), and at 4.2-3.8 ka (Arslanov et al., 1988)

\subsection{The Pontocaspian in the Anthropocene}

Pontocaspian lake systems and biota have experienced rapid and profound changes throughout its geological history. Yet a variety of human activities has accelerated changes and are affecting the region and its unique biota even further. Planned large scale engineering works in the Caspian Sea and Black Sea basin together with climate change may pose even further challenges for the Pontocaspian ecosystems.

Pontocaspian ecosystems in the Black Sea basin are currently restricted to the coastal zones (deltas, estuaries/limans, lagoons) and adjacent lower river basins of the north-western shelf and the Sea of Azov. The most important anthropogenic impacts in these ecosystems are (1) increased sediment load associated with forest clearing since the middle ages (Giosan et al., 2012), (2) damming of rivers modifying flow regimes and restricting mobility of faunas (Semenchenko et al., 2015) effectively providing sharp upper boundaries of Pontocaspian habitats (that normally grade into fluvial habitats), (3) strong nutrient increase due to waste water and use of agricultural fertilizers and pollution (e.g. (Kosarev and Yablonskaya, 1994), (4) conversion of Pontocaspian wetlands into pasture (Popa et al., 2009), (5) shipping lane dredging affecting major salinity gradients in the Pontocaspian habitats (Zhulidov et al., 2018) and (6) the introduction of alien species strongly affecting the native biota (e.g. Grigorovich et al., 2002; Kosarev and Yablonskaya, 1994). The current conservation status of Pontocaspian biota in the Black Sea basin is not well understood. Strong reductions in distribution areas (Popa et al., 2009) and reduced abundances of Pontocaspian species (Abdurakhmanov et al., 2002; Yanina, 2015) have been reported. For several species no recent records of living populations have been obtained suggesting strong decline.

The Caspian Sea coastal areas and river basins were impacted by human activities in similar ways as the Black Sea Pontocaspian habitats (Grigorovich et al., 2002; Kosarev and Yablonskaya, 1994). Invasive species established in the Caspian basin through accidental introduction with ships 
and a range of exotic species were deliberately introduced in the $20^{\text {th }}$ century to increase food production for local fish. Invasions are ongoing: the latest invasive species is Mytilopsis leucophaeta, a mussel native to the Caribbean, that in the past few years has invaded many of the ports (Heiler et al., 2010). The invasions have resulted in very strong decline of Pontocaspian communities within decennia (examples in Kosarev and Yablonskaya, 1994). Several formerly widespread species, such as Dreissena caspia and D. elata appear to have gone extinct and for many more, including hydrobiid species groups, no recent records exist of living populations. The Caspian biodiversity crisis has been described as ecocide by Dumont (1995). However, the true scale of the biodiversity crisis is uncertain as there is a paucity of recent data. Rapid sea level changes in the Caspian Sea (up to a few metres/decade during the later $20^{\text {th }}$ century) apparently are natural variation.

The situation in Lake Aral is even more dramatic: the lake itself is a precarious balance of inflowing Central Asian rivers and evaporation and in the Holocene Lake Aral experienced draughts (Filippov and Riedel, 2009). Yet the almost entire disappearance of the lake between 1957 and 2015 has been driven by extraction of river waters for agriculture. As a result, most of the Pontocaspian species in Lake Aral have vanished (Andreeva, 1989; Boomer et al., 2000).

In general, the continuity of many Pontocaspian lineages, is in peril. The centre of Pontocaspian diversity is located in the Caspian Sea and the demise of the native faunas is of major concern. Several planned and unplanned activities pose further threats to Pontocaspian ecosystems. Higher global sea levels associated with projected global warming will affect coastal Pontocaspian habitats of the Black Sea. The proposed Istanbul shipping lane may have impacts on the marine properties of the Black Sea basin and provide another gateway for alien species. Climate change also may strongly impact the precipitation/evaporation balances of the Caspian and Aral catchments. These precarious balances drove lake level variations in the past. Plans for massive water extraction from the Caspian Sea to alleviate water shortages on the Iranian plateau may tip the balance.

The Pontocaspian region has a very long and dynamic history of lake basin evolution and fauna evolution resulting in a unique fauna adapted to the unusual salinity settings and partial isolation of the basins. Human activities are driving unprecedented change in many parts of the region, changing the nature of this system profoundly and permanently.

\section{Acknowledgements}

This research was supported by the project PRIDE (Pontocaspian RIse and DEmise), which has received funding from the European Union's Horizon 2020 research and innovation program, under the Marie Sklodowska-Curie [grant agreement No 642973]. Many thanks go to Keith Richards, Amelie Vialet and Suzanne Leroy for helpful discussions. TY acknowledges support from the Russian Science Foundation Project 16-17-10103 (investigation of the Caspian Sea) and the Russian Foundation for Basic Research Projects 18-05-00296, 18-05-00684 (investigation of the Black Sea). JA acknowledges support from projects CGL2016-80000-P (Ministerio de Economía y Competitividad, Spain) and SGR2017-859 (AGAUR, Gencat). MCA acknowledges the Turkish 
Academy of Sciences (TUBA) for a GEBIP grant. We thank managing editor Andre Strasser, Marco Taviani and an anonymous reviewer for their thorough and constructive comments that significantly improved the manuscript. 



\title{
Mollusc SPeCies From the Pontocaspian REGION - AN EXPERT OPINION LIST
}

\section{Published as:}

Wesselingh, F.P., Neubauer, T.A., Anistratenko, V.V., Vinarski, M.V., Yanina, T.A., ter Poorten, J.J., Kijashko, P.V., Albrecht, C., Anistratenko, O.Y., D’Hont, A., Frolov, P., Martínez Gándara, A., Gittenberger, A., Gogaladze, A., Karpinsky, M.G., Lattuada, M., Popa, L.O., Sands, A.F., van de Velde, S., Vandendorpe, J., Wilke, T., 2019. Mollusc species from the Pontocaspian region - an expert opinion list. Zookeys 827, 31-124. http://doi.org/10.3897/zookeys.827.31365

\begin{abstract}
Defining and recording the loss of species diversity is a daunting task, especially if identities of species under threat are not fully resolved. An example is the Pontocaspian biota. The mostly endemic invertebrate faunas that evolved in the Black Sea-Caspian Sea-Aral Sea region and live under variable salinity conditions are undergoing strong change, yet within several groups species boundaries are not well established. Collection efforts in the past decade have failed to produce living material of various species groups whose taxonomic status is unclear. This lack of data precludes an integrated taxonomic assessment to clarify species identities and estimate species richness of Pontocaspian biota combining morphological, ecological, genetic, and distribution data. In this chapter, we present an expert-working list of Pontocaspian and invasive mollusc species associated to Pontocaspian habitats. This list is based on published and unpublished data on morphology, ecology, anatomy, and molecular biology. It allows us to (1) document Pontocaspian mollusc species, (2) make species richness estimates, and (3) identify and discuss taxonomic uncertainties. The endemic Pontocaspian mollusc species richness is estimated between 55 and 99 species, but there are several groups that may harbour cryptic species. Even though the conservation status of most of the species is not assessed or data deficient, our observations point to deterioration for many of the Pontocaspian species.
\end{abstract}

\subsection{Introduction}

The aquatic Pontocaspian (or Ponto-Caspian) biota is constituted by taxa that evolved in saline water bodies in the Caspian Sea-Black Sea-Aral Sea region and surrounding rivers in the past few million years. They include diverse groups such as diatoms, dinoflagellates, foraminifera's, 


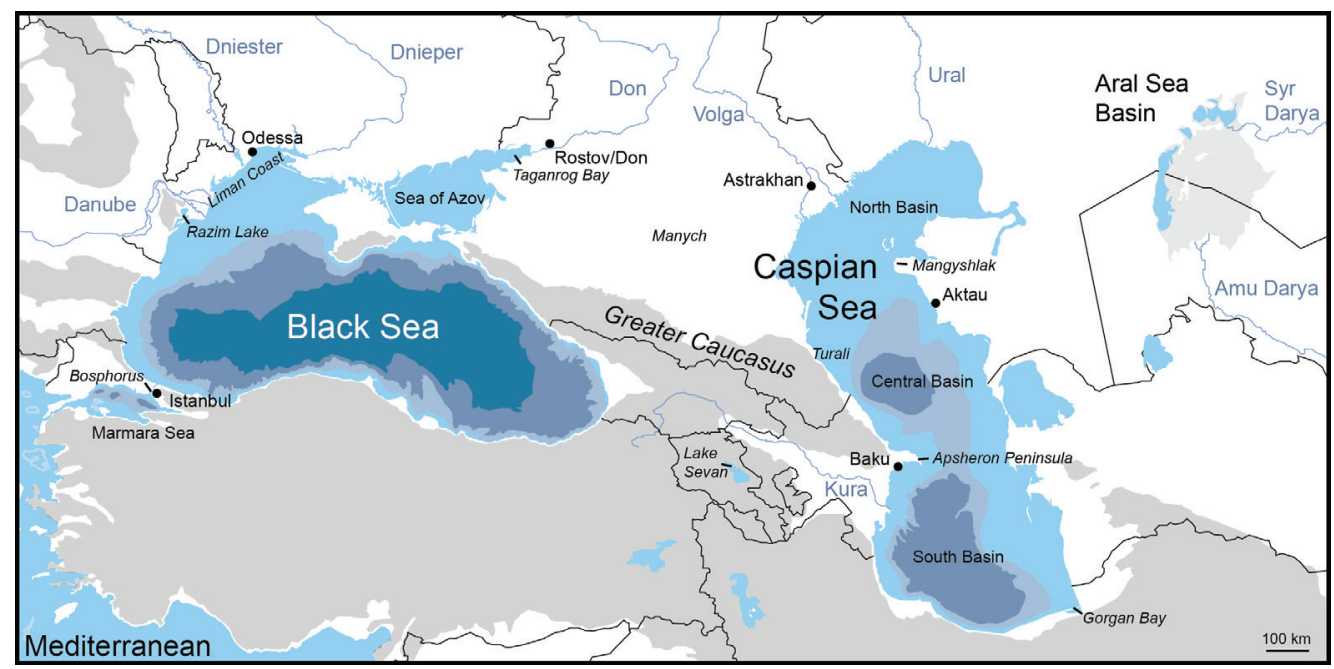

Fig. 3.1: Map of the Pontocaspian region with the indication of major basins, rivers, regions, and cities referred to in the text.

crustaceans, molluscs, as well as fish and the Caspian seal. Major Pontocaspian habitats are located in the northern coastal zone of the Black Sea (mostly confined to the Romanian and Ukrainian coasts) and the Sea of Azov (mostly in the Taganrog Bay), cover the entire Caspian Sea and, until recently, the Aral Sea (Fig. 3.1). However, Pontocaspian habitats are impacted by human activities such as pollution, habitat modification and introduction of invasive species (Barannik et al., 2004; Bologa et al., 1995; Gomoiu et al., 2002; Grigorovich et al., 2003; Occhipinti-Ambrogi and Savini, 2003; Popa et al., 2009; J. P. Selifonova, 2008; Z. P. Selifonova, 2008; Shalovenkov, 2005; Stolberg et al., 2006; UNEP [United Nations Environment Programme], 2006; Zaitsev and Mamaev, 1997; Zolotarev, 1996), as well as the entire obliteration of environments in the case of the Aral Sea in the second half of the $20^{\text {th }}$ century (Andreev and Andreeva, 2003; Mainguet and Létolle, 1997; Plotnikov et al., 2016).

Faunas in the Pontocaspian region have strongly changed in the past century. Pontocaspian species that were abundant only a century ago, such as Dreissena elata and D. caspia in the Caspian Sea, have vanished in the mid-20 $0^{\text {th }}$ century (Kosarev and Yablonskaya, 1994). For the Aral Sea, the faunas appear to have largely disappeared with the demise of the lake system since the 1950s (Andreeva and Andreev, 2003). Abundances of several other species in the Caspian Sea and Black Sea basin have severely declined (Bologa et al., 1995; Zaitsev and Mamaev, 1997; Barannik et al., 2004; Popa et al., 2012).

However, we cannot evaluate the extent or nature of biodiversity loss as there is no general agreement on the species that it might concern. Much of the diversity in Pontocaspian mollusc groups is contained within a limited number of genera. Changing taxonomic approaches through time (e.g., (Alexenko and Starobogatov, 1987; Anistratenko, 2007a; Bogutskaya et al., 2013; 
Logvinenko and Starobogatov, 1969; Munasypova-Motyash, 2006a, 2006b; Neubauer et al., 2018; Sitnikova and Starobogatov, 1999; Vinarski and Kantor, 2016; Zhadin, 1952) combined with large morphological variability and few diagnostic characters in certain groups, as well as the paucity of living material and partial disappearance of type material, has precluded critical reassessment of species boundaries and thus species richness. For the Caspian Sea, multiple efforts to collect fresh material in the past decade failed to produce sufficient living material to elucidate these taxonomic matters for most of the groups. Sampling efforts include coastal sampling around Turali, Russia (FW, 2003); northern Azerbaijan (FW, 2016), middle and southern Azerbaijan (VA, ML, AFS, TW, 2017); Mangyshlak region coastal areas, Kazakhstan (OA, VA, 2016, 2017); the transition of the northern to middle Caspian Sea basin in Kazakhstan (PRIDE expedition, 2017); and the Gorgan Bay in Iran (AFS, 2018). A faunal inventory of the deep-water southern Caspian Sea basin $(<200 \mathrm{~m}$ water depth) of southern Azerbaijan was published lately by Mirzoev and Alekperov (2017). We are uncertain whether it concerns living material nor can we assess the species identities. Their records are mentioned below but require further confirmation. We did find some living endemic species ourselves, and from coastal areas low numbers of such species have been reported elsewhere (e.g., Latypov 2015). Yet, many species and even groups of species (e.g., Turricaspia species) have not been encountered alive despite our attempts. Our inability to collect life specimens for several groups has made a combined molecular-morphological approach to delineate species impossible. As a result, a reliable estimate of the number of species involved is lacking, and therefore the potential magnitude of the biodiversity decline is speculative. Hence, we need an alternative approach to outline the species boundaries and estimate the numbers affected.

By pooling all insights, data (published and unpublished) and expert opinions on the Pontocaspian mollusc species through taxonomists we aim to provide a list of Pontocaspian mollusc species that can serve as a base for further research. We use molluscs as a model group since they are (1) an important, representative and well-known part of the Pontocaspian fauna, (2) have a number of taxonomic specialists available, and (3) can often be identified based on their shell characters even when living populations have vanished. The Pontocaspian aquatic mollusc species list will highlight uncertainties in species complexes as to give guidance to further research in resolving taxonomic matters. The aim of this work is to compile a list of Pontocaspian mollusc species with the underlying arguments why we consider these species as (likely) valid species, to outline taxonomic uncertainties and to provide an updated estimate of species richness.

\subsection{Materials and methods}

A preliminary Pontocaspian mollusc species list was assembled during a PRIDE program workshop in Giessen, Germany, in May 2018. The PRIDE ("Drivers of Pontocaspian Rise and biodiversity Demise") program is an EU funded Innovative Training Network that studies the drivers of the rise and demise of Pontocaspian faunas. Using listings in Vinarski and Kantor (2016) supplemented with further information from the participants, this initial list was then circulated among a wider 
community of taxonomic workers for further updates and comments. Data on distribution and type material were derived from Vinarski and Kantor (2016) and further completed and amended. The systematic order above the species level follows Bouchet et al. (2017) and MolluscaBase (2018a). In case we deviate from the supraspecific classification, arguments are discussed below.

The list comprises aquatic Holocene Pontocaspian mollusc faunas. A substantial number of Pontocaspian species has been described from empty shells from beach material or derive from grab samples. Such samples typically are dominated by time-averaged Holocene shell assemblages, which may or may not yield living specimens and in very rare occasions also contain older (Pleistocene) material (see, e.g., Leroy et al. 2018). For the Black Sea basin, the Holocene time interval largely coincides with the date of the marine flooding through the Bosporus and subsequent marginalization of Pontocaspian species to the NW coastal zone (Danube Delta to Dnieper Estuary) and the Sea of Azov (Mordukhai-Boltovskoi, 1960). For the Caspian Sea, the time interval corresponds to the so-called Novocaspian period that started after the very deep Mangyshlak regression 8 ka (Fedorov, 1953; Nevesskaja, 1958, 2007; Yanina, 2005). The time interval contains the earliest impact of humans on native faunas, such as the introduction of Cerastoderma glaucum in the Caspian basin during the early Holocene (Fedorov, 1957; Svitoch et al., 2009). It also contains the large faunal changes of the $20^{\text {th }}$ century related to pollution, invasive species and obliteration of habitats (Kosarev and Yablonskaya, 1994).

One of the greatest difficulties is to establish the identities of taxa reported as geographic subspecies. Many species have forms, varieties, and subspecies described from the Aral Sea, the Caspian Sea basin, and the Black Sea basin (including the Azov Sea). Often, such distinctions are made based on the geographical isolation alone or on a range of morphological characters whose variation seems to be overlapping in geographical subpopulations. In order to assess whether the geographical populations are indeed species, we need combined morphological, ecological, and molecular data, but only few studies produced this information to date (e.g., Popa et al. 2012 for Black Sea basin Monodacna). For the Aral Sea, we expect difficulties to obtain fresh material of almost all species for molecular analyses due to the obliteration of most of the lake and its fauna in the $20^{\text {th }}$ century (Andreev and Andreeva, 2003; Plotnikov et al., 2016). To date, hardly any molecular data on closely related species that are (potentially) shared between the Caspian and Black Sea have been published with the exceptions of Dreissena grimmi/D. bugensis (e.g., Stepien et al., 2013; Therriault et al., 2004) and Ecrobia maritima/E. grimmi (Haase et al., 2010). For several potentially shared species, ecological tolerances and preferences between Caspian and Black Sea basin populations are overlapping, but in some cases (like for D. grimmi/D. bugensis) they are not. We have adopted a conservative approach, and as long as no additional arguments (morphological, ecological or genetic differences) were found, we consider the Aral, Caspian and Black Sea varieties/subspecies synonyms. Another difficulty in especially Caspian taxa is the erection of so called "bathymetric" subspecies, which seem to be distinguished mostly based on their depths of occurrence. As long 
Table 3.1: Definitions we use to characterise the status of species.

\begin{tabular}{|c|c|}
\hline $\begin{array}{l}\text { Pontocaspian } \\
\text { endemic }\end{array}$ & Centre of evolutionary history in Pontocaspian lakes \\
\hline Native & $\begin{array}{l}\text { Present in the Pontocaspian region today and in the Quaternary (not introduced by man) but centre of } \\
\text { evolution not necessarily in that region: e.g., planorbid species with a Palearctic distribution, Cerastoderma } \\
\text { glaucum. }\end{array}$ \\
\hline Introduced & $\begin{array}{l}\text { Species introduced in the Pontocaspian from elsewhere, usually anthropogenic: some Pontocaspian species } \\
\text { have migrated between Pontocaspian basins and their status is explained in detail there (e.g., Monodacna } \\
\text { colorata/Dreissena bugensis: introduced in Caspian from natural ranges in Black Sea basin). }\end{array}$ \\
\hline Invasive & Species that have become disruptive in the ecosystem after introduction. \\
\hline
\end{tabular}

as no other (morphological, genetic) arguments are available, we synonymise such bathymetrical forms.

A listing of synonyms and important past misidentifications from the literature is given. The list is not exhaustive and intended to show major shifts in taxonomic thinking about Pontocaspian and invasive species. The format of synonymy lists follows mostly suggestions of Matthews (1973). Asterisks in front of a record indicate valid first descriptions, a superscript "o" a prior yet invalidly introduced synonym. The status of each species is defined according to criteria outlined in Table 3.1.

As for the conservation status we have indicated the IUCN Red List status as of July 2018 from [www.iucnredlist.org] and added our own observations. For updated stratigraphic terminology and age estimates we refer to Krijgsman et al. (2019).

Abbreviations used are:

ZIN Zoological Institute of the Russian Academy of Sciences, St. Petersburg, Russia.

RGM Naturalis Biodiversity Center, collections of fossil Mollusca, Leiden, the Netherlands.

For personal observations of the various authors we used the following abbreviations:

$\begin{array}{llll}\text { FW } & \text { Frank P. Wesselingh, } & \text { AFS } & \text { Arthur F. Sands, } \\ \text { TN } & \text { Thomas A. Neubauer, } & \text { MV } & \text { Maxim V. Vinarski, } \\ \text { VA } & \text { Vitaliy V. Anistratenko, } & \text { TW } & \text { Thomas Wilke. } \\ \text { OA } & \text { Olga Anistratenko, } & & \end{array}$

Finally, with the long literature record and various languages involved we came across some problems in spellings of geographical names and authors that we could not always resolve. Often, the transliteration of Russian names into French, German, and English literature resulted in different spellings, for example Ostroumoff/Ostroumov, Andrussoff/Andrussow/Andrusoff/Andrusov, and Apsheron/Absheron. We have followed the translations that are used by most of the Russianlanguage authors of this chapter but in some cases denote the different available spellings. 


\subsection{Systematic catalogue}

\subsubsection{Bivalvia}

Remarks. Within the endemic bivalve species groups, a general lack of combined molecular, morphological, and ecological approaches has led to partially unresolved taxonomy, especially within the genera Monodacna and Dreissena. Much of the bivalve taxonomy follows the latest review of Caspian bivalves by Kijashko in Bogutskaya et al. (2013), and we discuss deviations from his schedule. The list of Aral bivalves published by Vinarski and Kantor (2016) is based chiefly on Andreeva and Andreev (2003), and it is used here as a base with appropriate changes in nomenclature.

\section{Family Mytilidae Rafinesque, 1815}

\section{Mytilaster minimus (Poli, 1795)}

${ }^{\star} 1795$ Mytilus minimus Poli: 209-210, pl. 32, fig. 1.

1932 Mytilaster lineatus (Gmelin, 1790). - Bogachev: 38, pl. 1, figs 5-11 [non Mytilus lineatus

Gmelin, 1791.

1952 Mytilaster lineatus (Gmelin, 1789). - Zhadin: 285, fig. 248 [non Gmelin, 1791].

1969 Mytilaster lineatus (Gmel.). - Logvinenko \& Starobogatov: 311-312, figs 339a-b, pl. 5, figs 1-2

[non Gmelin, 1791].

1969 Mytilaster lineatus (Gmelin, 1790). - Vekilov: 155-157, pl. 35, figs 1-25 [non Gmelin, 1791].

2013 Mytilaster lineatus (Gmelin, 1791). - Kijashko in Bogutskaya et al.: 316, fig. 104 [non Gmelin, $1791]$.

Status. Native to Black Sea basin, invasive in Caspian Sea, introduced in Aral Sea but extinct there.

Type locality. Sicily, Italy.

Distribution. Native to the Mediterranean and Black Sea. Introduced in the Caspian Sea between 1917 and 1919 (Grigorovich et al. 2003).

Taxonomic notes. This species has commonly been mentioned as Mytilaster lineatus (Gmelin, 1791), but the Caspian-Aral species lacks the ribbing typical for that species. The attribution to $M$. minimus is based on shell morphology but confirmation from molecular analyses is required.

Remarks. Mytilaster minimus has successfully replaced Dreissena caspia and D. elata between 1938 and 1957 (Kostianoy et al., 2005) in the Caspian Sea. Logvinenko \& Starobogatov (1969) reported this species from the southern areas of the northern Caspian Sea, in the middle and the southern Caspian Sea down to 35-50 m water depth. Rarely, small individuals were found at depths 
down to $100 \mathrm{~m}$. The species does not tolerate salinities below 7-8 psu. This species was mentioned (as M. lineatus) from depths between 200 and $600 \mathrm{~m}$ in the South Caspian basin of Azerbaijan (Mirzoev and Alekperov, 2017). These deep records are unusual given other records and will require confirmation.

Conservation status. Not assessed.

\section{Family Cardiidae Lamarck, 1809}

Remarks. For the genus Cerastoderma, the species status of Pontocaspian material is subject of debate where morphological and increasingly molecular arguments show the possibility of sibling species occurrences (Sromek et al. 2016). The genus Didacna is relatively well established, however much uncertainty exists over distinction between the genera Monodacna, Adacna, and Hypanis. The generic concepts have shifted through time. Only lately, Kijashko in Bogutskaya et al. (2013) treated Monodacna as a subgenus of Adacna. Büyükmeriç and Wesselingh 2018 discussed the distinction between the three genera and considered Monodacna, Adacna, and Hypanis as valid.

\section{Adacna laeviuscula (Eichwald, 1829)}

${ }^{\star} 1829$ G. [lycymeris] laeviuscula Eichwald: 279, pl. 5, figs 1a-b.

1838 Adacna Laeviuscula m. - Eichwald: 170-171.

1841 Adacna laeviuscula. - Eichwald: 281-282, pl. 39, figs 1a-d.

1905 Adacna laeviuscula (Eichwald, 1829). - Ostroumov: pl. 2, fig. E.

1907 Adacna laeviuscula. - Ostroumov: 25, textfig., pl. 4, figs 6-8.

1952 Adacna (Adacna) laeviuscula (Eichwald, 1829). - Zhadin: 353-354, pl. 9, fig. 331.

1958 Adacna (Adacna) laeviuscula (Eichwald), 1829. - Nevesskaja: 49-50, pl. 9, figs 15-18.

1969 Hypanis laeviuscula laeviuscula (Eichw.). - Logvinenko \& Starobogatov: 337, fig. 353(5).

1973 Hypanis laeviuscula laeviuscula Eichwald, 1829. - Grossu: 144-145, textfig. 29.

2013 Adacna laeviuscula (Eichwald, 1829). - Kijashko in Bogutskaya et al.: 377, fig. 154, photo 48. 2016 Adacna (Adacna) laeviuscula (Eichwald, 1829). - Vinarski \& Kantor: 64.

Status. Pontocaspian species, endemic to Caspian Sea and possibly Black Sea basin.

Type locality. Azerbaijan, Caspian Sea, Gulf of Baku is the type locality given by Vinarski and Kantor (2016) and this is written on the label of the type material. However, the type description reads "Hab. australem ripam maris caspii, in sinu Astrabadensi" [southern border of the Caspian Sea, in bight of Astrabad (= Gorgan, Iran)]. Further research on the labels and documentation is required to assess whether a new lectotype or even neotype must be assigned for Adacna laeviuscula. 
Distribution. Caspian Sea; limans, coastal lakes, and Danube Delta in Black Sea basin (in case A. fragilis will be shown to be a synonym of A. laeviuscula).

Taxonomic notes. See discussion under A. fragilis.

Remarks. Kijashko in Bogutskaya et al. (2013) list the presence of this species at $30-60 \mathrm{~m}$ water depth in the Caspian Sea from muddy, sandy-mud, and rarely sandy bottoms. Logvinenko and Starobogatov (1969) reported the species from the northern, middle, and southern Caspian Sea basins down to 80-85 m water depth. In the Caspian Sea, the species has not been found in areas with salinities below 4 psu. However, the common occurrence of fresh (paired) specimens on beaches seen at Turali (Dagestan, Russia) and northern Azerbaijan indicates this species maintains viable populations in foreshore and possibly even shoreface habitats.

Conservation status. Not assessed.

\section{Adacna fragilis Milaschewitsch, 1908}

*1908 Adacna fragilis Milaschewitch: 992-993.

1973 Hypanis laeviuscula fragilis Milaschevitsch, 1916. - Grossu: 145.

?2006b Hypanis (Adacna) laeviuscula fragilis (Milachevitch, 1908). - Munasypova-Motyash: 522.

2009 Adacna (Adacna) fragilis Milaschevich, 1908. - Popa et al.: 13, fig. 5.

2016 Adacna (Adacna) fragilis Milaschewitsch, 1908. - Vinarski \& Kantor: 64.

Status. Pontocaspian species, Black Sea basin, status uncertain.

Type locality. Odessa region, Dniester liman and Katlabhuk Lake (Ukraine: Vinarski and Kantor, 2016).

Distribution. Danube Delta region and NW Black Sea basin coastal areas of Ukraine.

Taxonomic notes. We are uncertain about the status of Adacna fragilis Milaschewitch, 1908. The Black Sea basin material has a wide variety of shapes and often is thinner and sometimes more elliptical than the Caspian A. laeviuscula. Both forms were synonymised by Graf and Cummings (2018) and indicated as a possible synonym in MolluscaBase (2018b). However, the Black Sea basin occurrences are recorded from (coastal) lakes and small rivers suggesting little or only partial overlap in the ecological (and especially salinity) preferences of A. laeviuscula (e.g., MunasypovaMotyash 2006a, b, Popa et al. 2009). We are uncertain if A. fragilis might constitute a geographical subspecies (a status advocated by Grossu 1973), and further molecular analyses are needed to clarify the status of the Black Sea taxon.

Remarks. The species has been reported alive by Popa et al. (2009) from the Razim Lake complex on the Romanian Black Sea coast.

Conservation status. Not assessed. 


\section{Adacna minima Ostroumov, 1907}

*1907 Adacna minima Ostroumov: 23, textfig., pl. 4, figs 1-5.

1952 Adacna (Adacna) vitrea var. minima (Ostroumoff, 1907). - Zhadin: 353.

1967 Hypanis minima ostroumovi Logvinenko \& Starobogatov: 233.

1969 Hypanis minima ostroumovi Logv. et Star. - Logvinenko \& Starobogatov: 338, fig. 354(3).

1973 Hypanis minima ostroumovi Logvinenko et Starobogatov, 1968. - Grossu: 146, textfig. 31.

?1974 Hypanis minima sidorovi Starobogatov: 246, fig. 213.

2003 Hypanis minima minima (Ostroumov, 1907). - Andreeva \& Andreev: 88, fig. 5.1(3-4).

?2009 Hypania [sic] minima (Ostroumoff, 1907). - Filippov \& Riedel: 75, fig. 4s, t.

2013 Adacna minima ostroumovi (Logvinenko et Starobogatov, 1967). - Kijashko in Bogutskaya et

al.: 378, fig. 146.

2016 Adacna (Adacna) minima minima (Ostroumov, 1907). - Vinarski \& Kantor: 64.

2016 Adacna (Adacna) minima ostroumovi Logvinenko et Starobogatov, 1967. - Vinarski \& Kantor: 64.

Status. Pontocaspian species, endemic to Caspian Sea and Aral Sea; likely disappeared from the latter.

Type locality. The northern Caspian Sea and the Aral Sea (Vinarski and Kantor 2016)

Distribution. Aral Sea (probably extinct there; Andreeva and Andreev 2003), Caspian Sea.

Taxonomic notes. Graf and Cummings (2018) consider this species as a synonym of A. vitrea, but Kijashko in Bogutskaya et al. (2013) regards it as a valid species. The latter considers A. minima minima from the Aral Sea and A. minima ostroumovi from the Caspian Sea as distinct geographical subspecies. The likely disappearance of the species from the Aral Sea makes a molecular assessment of their distinctness very difficult and given the lack of other arguments we synonymise both. Furthermore, we are uncertain about the status of the subspecies Hypanis minima sidorovi Starobogatov, 1974 from the western Aral Sea. Without further data we assume it concerns a form that falls within the wide morphological variation of $A$. minima. We moreover are very uncertain as to the status of Hypanis minima from Holocene deposits of Aral Sea as illustrated by Filippov and Riedel (2009, fig. 4s, t). The juvenile specimen has relatively strong cardinal teeth, onset of clear ribs, and a general shape that more resembles Monodacna caspia.

Remarks. The species has been recorded mostly from the middle and southern Caspian Sea and more rarely from the eastern areas in the northern Caspian Sea down to $35 \mathrm{~m}$ water depth (Logvinenko and Starobogatov, 1969) as well as from the Aral Sea from where it may have disappeared.

Conservation status. Not assessed. 


\section{Adacna vitrea (Eichwald, 1829)}

${ }^{\star} 1829$ G. [lycymeris] vitrea Eichwald: 279, pl. 5, fig. 3.

1838 Adacna vitrea m. - Eichwald: 172-173.

1841 Adacna vitrea. - Eichwald: 282-283, pl. 39, figs 2a-b.

1905 Adacna glabra Ostroumov: 18-19.

1932a Adacna vitrea (Eichwald, 1829). - Bogachev: pl. 1, figs 3, 4, 11.

1932b Adacna vitrea (Eichwald, 1829). - Bogachev: 33, pl. 3, figs 13-16, 28-29.

1952 Adacna (Adacna) vitrea (Eichwald, 1829). - Zhadin: 352-353, fig. 330.

1958 Adacna (Adacna) vitrea (Eichwald), 1838. - Nevesskaja: 47-48, pl. 9, figs 19-22.

1969 Hypanis vitrea vitrea (Eichw.). - Logvinenko \& Starobogatov: 337, fig. 354(1), pl. 5, fig. 11.

1969 Hypanis vitrea glabra (Ostr.). - Logvinenko \& Starobogatov: 338, fig. 354(2).

1973 Hypanis vitrea vitrea Eichwald, 1829. - Grossu: 145-146, textfig. 30A.

1973 Hypanis vitrea glabra Ostroumoff, 1905. - Grossu: 146, textfig. 30B.

2003 Hypanis vitrea bergi Starobogatov, 1974. - Andreeva \& Andreev: 86, fig. 5.1(1-2).

2013 Adacna (Adacna) vitrea vitrea (Eichwald, 1829). - Kijashko in Bogutskaya et al.: 378, fig. 148.

2013 Adacna (Adacna) vitrea glabra Ostroumoff, 1905. - Kijashko in Bogutskaya et al.: 379, fig. 149.

2016 Adacna (Adacna) vitrea vitrea (Eichwald, 1829). - Vinarski \& Kantor: 65.

2016 Adacna (Adacna) vitrea glabra Ostroumov, 1905. - Vinarski \& Kantor: 65.

2016 Adacna (Adacna) vitrea bergi (Starobogatov, 1974). - Vinarski \& Kantor: 65.

Status. Pontocaspian species, endemic to Caspian Sea basin, Black Sea basin, and Aral Sea basin.

Type locality. "Australem oram caspii maris, Astrabadensem" [southern coast of Caspian Sea, near Astrabad (= Gorgan, Iran)].

Distribution. Black Sea basin (also in Azov Sea and adjacent lower Don River), Caspian Sea basin, and Aral Sea (including delta of Amu-Darya River). The Aral populations may have gone extinct in the 1980s (Andreeva and Andreev 2003).

Taxonomic notes. The species has been subdivided into three geographical subspecies which were not recognised by Graf and Cummings (2018). It concerns a species with thin shells that yield very few diagnostic characters that show overlap. Here, we synonymise the subspecies pending molecular assessments of their status.

Conservation status. Not assessed.

\section{Cerastoderma glaucum (Bruguière, 1789) s.l.}

*1789 Cardium glaucum Bruguière: 221-222.

1789 Cardium Glaucum Poiret: 13-15.

1869 Cardium isthmicus Issel: 74-76. 
1952 Cardium edule L., 1758. - Zhadin: 344-345, fig. 318 [non Cardium edule Linneaus, 1758]. 2003 Cerastoderma isthmicum (Issel, 1869). - Andreeva \& Andreev: 54, 62, fig. 6.1 (b), 6.7. 2013 Cerastoderma glaucum (Poiret, 1789). - Kijashko in Bogutskaya et al.: 342, fig. 126, photo 39. 2016 Cerastoderma glaucum (Bruguière, 1789). - Vinarski \& Kantor: 69. 2016 Cerastoderma isthmicus (Issel, 1869). - Vinarski \& Kantor: 70.

Status. Native Pontocaspian species (Black Sea basin), Holocene invasive in Caspian Sea and Aral Sea.

Type locality. French Mediterranean.

Distribution. NE Atlantic, Baltic Sea, Mediterranean, Black Sea basin, Caspian Sea basin, Aral Sea, isolated Saharan lakes (Plaziat, 1991).

Taxonomic notes. DNA studies have shown a strong structuring between Atlantic-western Mediterranean, Ionean, and Aegean-Pontocaspian populations of C. glaucum (Nikula and Väinölä, 2003; Sromek et al., 2016). According to Sromek et al. (2016: 515), the "strong genetic differentiation and the occurrence of private alleles may hint at the presence of cryptic species within C. glaucum". For a discussion on the authority of C. glaucum, see Vinarski and Kantor (2016: 69-70).

Remarks. The arrival of Cerastoderma glaucum in the Caspian Sea circa 8000 years ago has been linked to human settlement expansion through the Manych corridor (Fedorov, 1957; Yanina, 2009). It would be among the earliest human-mediated dispersal events for invertebrate species known to date.

Conservation status. Not assessed.

\section{Cerastoderma sp. A [non C. rhomboides (Lamarck, 1819)]}

1916 Cardium edule var. nuciformis Milaschewitch: 257-259, pl. 7, figs 7-8 [non Cardium nuciforme d'Orbigny, 1850].

2003 Cerastoderma rhomboides rhomboides (Lamarck, 1819). - Andreeva \& Andreev: 93, fig. 6.1 (A) [non Cardium rhomboides Lamarck, 1819].

2013 Cerastoderma rhomboides (Lamarck, 1819). - Kijashko in Bogutskaya et al.: 343, fig. 127, photo 40 [non Lamarck, 1819].

2016 Cerastoderma rhomboides (Lamarck, 1819). - Vinarski \& Kantor: 70 [non Lamarck, 1819].

Status. Native Pontocaspian species (Black Sea basin), introduced to Caspian Sea and Aral Sea.

Distribution. Black Sea (including Sea of Azov), Caspian Sea, Aral Sea, Aegean.

Taxonomic notes. This concerns a common rhomboid-shaped species in the Pontocaspian region whose name is uncertain. It has a short ligament in common with C. glaucum and the persistent occurrence of ribs on the posterior margin, the well-defined character of the ribs and the regular occurrence of scales in common with western European C. edule. This form has been 


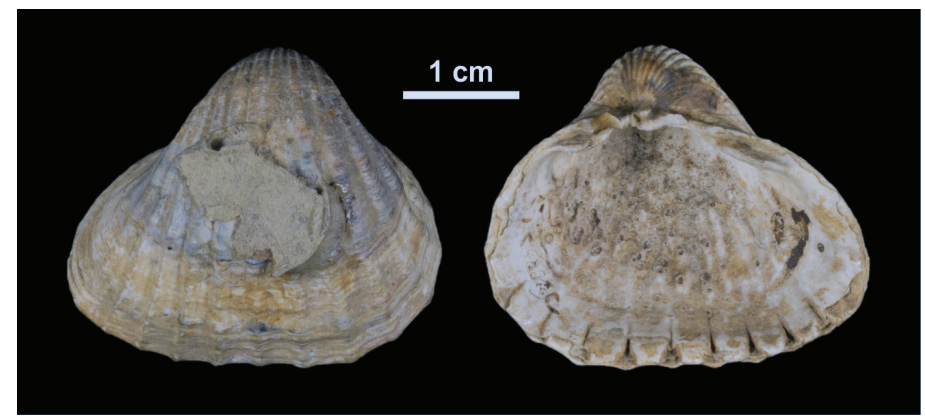

Fig 3.2: Syntype of Cerastoderma rhomboides (Lamarck, 1819), stored in the Muséum national d'Histoire naturelle Paris (MNHN.F.A50142), Pliocene, Tuscany, Italy. Photograph by E Porez. https://science.mnhn.fr/ institution/mnhn/collection/f/item/a50142?lang=fr_FR

often referred to as C. rhomboides (Lamarck, 1819) that has been described from the Italian Pliocene but that concerns a typical glaucum form (Fig. 3.2), not the rhomboid form of the Pontocaspian Cerastoderma. The species has been named Cardium edule var. nuciformis by Milaschewitch (1916), but that name is a junior primary homonym of Cardium nuciforme d'Orbigny, 1850. Even though some morphological features mentioned in the description of C. lamarcki (Reeve, 1845) may resemble those of the Pontocaspian species, the former has been traced to southern Great Britain (Nikula and Väinölä, 2003) from where molecular analyses only show the presence of C. glaucum.

Conservation status. Not assessed.

\section{Didacna baeri (Grimm, 1877)}

Fig. 3.3a

*1877 Cardium Baeri Grimm: 51-54, pl. 8, figs 2-3.

1914 Didacna Baeri (Grimm, 1877). - Nalivkin \& Anisimov: 4, pl. 1, figs 4-5.

1932 Didacna Baeri (Grimm, 1877). - Bogachev: 29, pl. 3, figs 1-7.

1933 Didacna Baeri (Grimm, 1877). - Zhizhchenko: 34, pl. 2, figs 5-8.

1952 Didacna baeri (Grimm, 1877). - Zhadin: 347-348, figs 321-322.

1953 Didacna baeri (Grimm, 1877). - Fedorov: 129, pl. 20, figs 10-11.

1968 Didacna baeri (Grimm, 1877). - Gadzhiev: 76-77, pl. 1, figs 1-2.

1969 Didacna baeri (Grimm). - Logvinenko \& Starobogatov: 324, fig. 344(2).

1969 Didacna baeri (Grimm, 1877). - Vekilov: 139-144, pl. 25, figs 1-8.

1973 Didacna baeri Grimm, 1877. - Grossu: 131, textfig. 7.

1983 Didacna baeri (Grimm, 1877). - Popov: 180, pl. 16, figs 20-23.

1988 Didacna baeri (Grimm, 1877). - Yanina \& Svitoch: 129, pl. 3, figs 7-13.

2005 Didacna baeri (Grimm, 1877). - Yanina: 242-244, pl. 14, figs 12-15.

2007 Didacna baeri (Grimm, 1877). - Nevesskaja: 940-941, pl. 23, figs 11-17. 
2013 Didacna baeri (Grimm, 1877). - Kijashko in Bogutskaya et al.: 352, fig. 136, photo 41 [pars, excluding synonymy of Didacna crassa].

2016 Didacna baeri (Grimm, 1877). - Vinarski \& Kantor: 71 [pars, excluding synonymy of Didacna crassa].

Status. Pontocaspian species, endemic to Caspian Sea.

Type locality. Caspian Sea, offshore Turkmenistan, station 132, 40³2’ N, 52²3’ E.

Distribution. Logvinenko and Starobogatov (1969) reported Didacna baeri from the southern basin (mostly on the eastern side) and from the middle basin down to $60 \mathrm{~m}$ water depth.

Taxonomic notes. In recent works (e.g., Kijashko in Bogutskaya et al. 2013), the species Didacna crassa (Eichwald, 1829) [= D. eichwaldi (Krynicki, 1837)] has been considered a synonym of $D$. baeri. However, both species can be distinguished. Didacna baeri has a less extended, more roundish shell, a less developed keel, and a low top with less projecting beak and in general more ribs than D. eichwaldi (Fig. 3.3). Didacna baeri occurred for the first time in the Novocaspian transgressive deposits whereas D. crassa already occurred in the late Khvalynian (Late Pleistocene). Both became very common during the Novocaspian.

Conservation status. Not assessed.

\section{Didacna barbotdemarnii (Grimm, 1877)}

${ }^{\star} 1877$ Cardium Barbot-de-Marnii Grimm: 56-58, pl. 8, figs 5-6.

1952 Didacna barbot-de-marnyi [sic] (Grimm, 1877). - Zhadin: 348, fig. 323.

1969 Didacna barbotdemarnyi [sic] (Grimm). - Logvinenko \& Starobogatov: 326-327, fig. 346, pl. 5, fig. 8.

1973 Didacna barbotdemarnyi [sic] Grimm, 1877. - Grossu: 133, textfig. 10.

2007 Didacna barbotdemarnyi [sic] (Grimm, 1877). - Nevesskaja: 941-943, pl. 24, figs 10-14.

2013 Didacna barbotdemarnii (Grimm, 1877). - Kijashko in Bogutskaya et al.: 353, fig. 139, photo

42.

2016 Didacna barbotdemarnii (Grimm, 1877). - Vinarski \& Kantor: 71.

Status. Pontocaspian species, endemic to Caspian Sea.

Type locality. Caspian Sea, station 116, $44^{\circ} 17^{\prime} \mathrm{N}, 50^{\circ} 22^{\prime}$ E.

Distribution. Southern, middle, and southern part of the northern Caspian Sea down to $40 \mathrm{~m}$ water depth preferentially on sandy sediments (Logvinenko and Starobogatov, 1969).

Conservation status. Not assessed. 


\section{Didacna eichwaldi (Krynicki, 1837)}

Fig. 3.3b

${ }^{\circ} 1829$ C.[ardium] crassum Eichwald: 283 [non Cardium crassum Gmelin, 1791].

${ }^{\star} 1837$ Cardium Eichwaldi Krynicki: 61 [nom. nov. pro C. crassum Eichwald, 1829, non Gmelin, $1791]$.

1841 Didacna crassa. - Eichwald: 273, pl. 39, figs 6a-b.

1876 Cardium crassum Eichwald, 1829. - Grimm: 136-138, pl. 6, fig. 3.

1905 Didacna crassa (Eichwald, 1829). - Ostroumov: 15, 69, pl. 2 (A).

1932 Didacna aff. crassa (Eichwald, 1829). - Bogachev: 27, pl. 2, figs 11-14.

1952 Didacna crassa Eichwald, 1841. - Zhadin: 349, fig. 325.

1953 Didacna crassa (Eichwald, 1829). - Fedorov: 130, pl. 20, figs 8-9, 12-13.

1958 Didacna crassa Eichwald, 1829. - Nevesskaja: 39-40, pl. 7, figs 8-9.

1969 Didacna crassa (Eichwald, 1829). - Vekilov: 134-139, pl. 24, figs 1-6, pl. 27, figs 1-2.

1988 Didacna crassa (Eichwald, 1829). - Yanina \& Svitoch: pl. 12, figs 8-9, pl. 13, figs 1-5.

2005 Didacna crassa (Eichwald, 1829). - Yanina: 242, pl. 14, figs 3-6.

2007 Didacna crassa (Eichwald, 1829). - Nevesskaja: 939-940, pl. 23, figs 1-5.

2013 Didacna baeri (Grimm, 1877). - Kijashko in Bogutskaya et al.: 352 [pars, non fig. 136, photo

41, non Cardium baeri Grimm, 1877].

2016 Didacna baeri (Grimm, 1877). - Vinarski \& Kantor: 71 [pars, non Grimm, 1877].

Status. Pontocaspian species, endemic to Caspian Sea.

Type locality. "Caspium mare” (Caspian Sea) (for C. crassum Eichwald, 1829).

Distribution. Caspian Sea. Didacna eichwaldi is known from the middle and southern Caspian Sea basins down to $35 \mathrm{~m}$ water depth and cannot tolerate lowered salinities.

Taxonomic notes. In recent works (Kijashko in Bogutskaya et al. 2013), the species Didacna crassa (Eichwald, 1829) [= D. eichwaldi (Krynicki, 1837)] has been considered a synonym of $D$. baeri. However, we see morphological discontinuities in our extensive material from the northern Caspian Sea basin that implies that D. eichwaldi with its protruding umbo and shouldered appearance is distinct from $D$. baeri that is characterized by a rounded umbo (see discussion above under D. baeri). Despite being in common usage, the name Didacna crassa is invalid as it is a junior homonym of Cardium crassum Gmelin, 1791; Krynicki (1837) introduced Cardium eichwaldi as replacement name.

Conservation status. Not assessed.

\section{Didacna longipes (Grimm, 1877)}

${ }^{\star} 1877$ Cardium longipes Grimm: 54-56, pl. 8, figs 4a-c. 


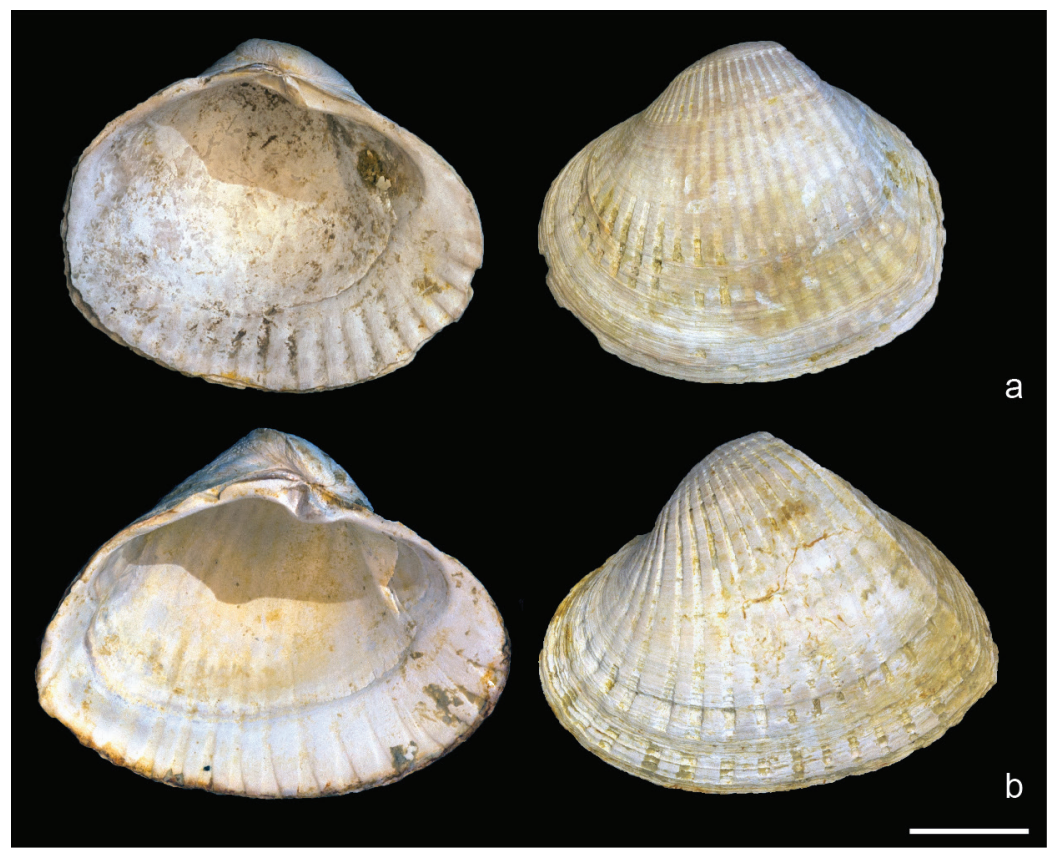

Fig. 3.3: Didacna baeri versus D. eichwaldi from Holocene (Novocaspian) deposits of Turali Lagoon (Dagestan, Russia). a RGM.961899, Didacna baeri (Grimm, 1877) b RGM.961900, Didacna eichwaldi (Krynicki, 1837), same locality. Scale bar: $1 \mathrm{~cm}$.

1952 Didacna longipes (Grimm, 1877). - Zhadin: 349-350, fig. 326.

1969 Didacna longipes (Grimm). - Logvinenko \& Starobogatov: 326, fig. 345.

1973 Didacna longipes Grimm, 1877. - Grossu: 132, textfig. 9, pl. 1, fig. 2.

?2007 Didacna carinata Nevesskaja: 943, pl. 24, figs 15-19.

2013 Didacna longipes (Grimm, 1877). - Kijashko in Bogutskaya et al.: 354, fig. 137, photo 43. 2016 Didacna longipes (Grimm, 1877). - Vinarski \& Kantor: 71.

Status. Pontocaspian species, endemic to Caspian Sea.

Type locality. Caspian Sea, offshore Azerbaijan, approximately $40^{\circ} 39^{\prime} \mathrm{N}, 50^{\circ} 26^{\prime} \mathrm{E}$.

Distribution. Southern and middle Caspian Sea basins and southern part of the northern Caspian Sea down to 30-40 m water depth. The species often co-occurs with D. barbotdemarnii.

Remarks. We are uncertain about the status of Didacna carinata Nevesskaja, 2007. The overall outline resembles that of $D$. barbotdemarnii, but the former species appears smaller and thinner. Kijashko in Bogutskaya et al. (2013) considered D. carinata as a synonym of D. longipes.

Conservation status. Not assessed.

\section{Didacna parallela Bogachev, 1932}


${ }^{\star}$ 1932b Didacna parallela Bogachev: pl. 2, figs 2-3.

1932a Didacna parallela Bogachev: 44, pl. 5, figs 1-7, 9.

1953 Didacna parallella [sic] Bogatchev, 1932. - Fedorov: 126, pl. 17, figs 1-11.

1969 Didacna parallella [sic] Bog. - Logvinenko \& Starobogatov: 324-325, fig. 344(3).

1969 Didacna parallella [sic] Bogatchev, 1932. - Vekilov: 117-120, pl. 21, figs 1-8.

1973 Didacna parallella [sic] Bogatchev, 1922 [sic]. - Grossu: 131, fig. 8, pl. 1, fig. 4.

2005 Didacna parallella [sic] Bogatchev, 1932. - Yanina: 237-238, pl. 12, figs 1-8.

2007 Didacna parallella [sic] Bogatchev, 1932. - Nevesskaja: 933-935, pl. 21, figs 1-5.

2013 Didacna parallela Bogachev, 1932. - Kijashko in Bogutskaya et al.: 355-356, fig. 138.

2016 Didacna parallela Bogachev, 1932. - Vinarski \& Kantor: 72.

Status. Pontocaspian species, endemic to Caspian Sea.

Type locality. Khala, Apsheron Peninsula, Azerbaijan (early Khvalynian, Late Pleistocene).

Distribution. Caspian Sea, southern basin and western part of middle basin between 50-85 $\mathrm{m}$ water depth (Logvinenko and Starobogatov, 1969). This species was mentioned from depths between 200 and $300 \mathrm{~m}$ in the South Caspian basin of Azerbaijan (Mirzoev and Alekperov, 2017), but we are not certain whether it concerns living specimens.

Remarks. Didacna parallela has been considered as extinct by Nevesskaja (2007) but was nevertheless treated in Kijashko in Bogutskaya et al. (2013). Live records are known at least until 1986 and we have no particular reason to assume it is extinct.

Conservation status. Not assessed.

\section{Didacna praetrigonoides Nalivkin \& Anisimov, 1914}

*1914 Didacna praetrigonoides Nalivkin \& Anisimov: 5-6, 16-17, pl. 1, figs 1-2.

1932b Didacna praetrigonoides Nalivkin \& Anisimov, 1914. - Bogachev: pl. 2, fig. 1.

1932a Didacna praetrigonoides Nalivkin \& Anisimov, 1914. - Bogachev: 42, pl. 4, figs 1-8, pl. 5, fig. 8.

1948 Didacna praetrigonoides Nal. - Fedorov: pl. 2, figs 10-13.

1953 Didacna praetrigonoides Nalivkin \& Anisimov, 1914. - Fedorov: 128, pl. 18, figs 1-6, pl. 19, figs 1-6.

1958 Didacna praetrigonoides Nalivkin et Anisimov, 1914. - Nevesskaja: 17-20, pl. 1, figs 1-14.

1969 Didacna trigonoides praetrigonoides Nal. et Anis. - Logvinenko \& Starobogatov: 324, fig. 343(2).

1969 Didacna praetrigonoides Nalivkin \& Anisimov, 1914. - Vekilov: 120-128, pl. 22, figs 1-9.

1973 Didacna trigonoides praetrigonoides Nalivkin et Anisimov, 1915. - Grossu: 129, textfig. 5.

1983 Didacna praetrigonoides praetrigonoides Nalivkin \& Anisimov, 1914. - Popov: 195, pl. 15, figs

1988 Didacna praetrigonoides Nalivkin \& Anisimov, 1914. - Yanina \& Svitoch: pl. 8, figs 4-7.

2005 Didacna praetrigonoides Nalivkin \& Anisimov, 1914. - Yanina: 241, pl. 14, figs 1-2. 
2007 Didacna praetrigonoides praetrigonoides Nalivkin \& Anisimov, 1914. - Nevesskaja: 927, pl. 19, figs 9-10.

Status. Pontocaspian species, endemic to Caspian Sea. Possibly extinct.

Type locality. Apsheron Peninsula, Azerbaijan, Quaternary.

Distribution. Caspian Sea. Logvinenko and Starobogatov (1969) reported the species from the southern Caspian Sea basin and the southern part of the middle Caspian Sea basin down to $60 \mathrm{~m}$ water depth. The species has been collected from Holocene deposits and beach occurrences the western part of the middle Caspian Sea basin as well (FW, pers. obs.). The species is reportedly extinct, not mentioned in Kijashko in Bogutskaya et al. (2013).

Remarks. The first appearance of Didacna praetrigonoides is in lower Khvalynian deposits, it became widespread during the late Khvalynian and was rare during the Novocaspian.

Conservation status. Not assessed. Didacna praetrigonoides has been reported to occur 'rarely in the modern Caspian Sea' (Nevesskaja 2007: 927), but material from recent assemblages has not been found.

\section{Didacna profundicola Logvinenko \& Starobogatov, 1966}

*1966a Didacna profundicola Logvinenko \& Starobogatov: 13-14, fig. 1.

1969 Didacna profundicola Logv. et Star. - Logvinenko \& Starobogatov: 328-329, fig. 349.

1973 Didacna profundicola Logvinenko et Starobogatov, 1966. - Grossu: 134, textfig. 13.

2007 Didacna profundicola Logvinenko et Starobogatov, 1966. - Nevesskaja: 944, pl. 20, figs 28a-c.

2013 Didacna profundicola Logvinenko et Starobogatov. - Kijashko in Bogutskaya et al.: 356, fig.

140 , photo 45.

2016 Didacna profundicola Logvinenko et Starobogatov. - Vinarski \& Kantor: 72.

Status. Pontocaspian species, endemic to Caspian Sea.

Type locality. Central part of the Caspian Sea.

Distribution. Middle and southern basins of Caspian Sea between 75 and $409 \mathrm{~m}$ water depth (Logvinenko and Starobogatov, 1969). This species was mentioned from depths between 200 and $600 \mathrm{~m}$ in the South Caspian basin of Azerbaijan (Mirzoev and Alekperov, 2017).

Conservation status. Not assessed.

\section{Didacna protracta (Eichwald, 1841)}

${ }^{\star} 1841$ Adacna protracta Eichwald: 280, pl. 40, figs 10-11 [non figs 9-10 as indicated in the text].

1877 Cardium catillus Eichw. - Grimm: 58, pl. 8, figs 7-8 [non Monodacna catillus Eichwald, 1841]. 1910 Didacna protracta (Eichwald, 1841). - Andrusov: 67, pl. 8, figs 22-33, pl. 9, figs 1-9. 
1952 Didacna protracta (Eichwald, 1841). - Zhadin: 348-349, fig. 324.

1953 Didacna protracta (Eichwald, 1829). - Fedorov: 127, pl. 14, figs 12-15, pl. 15, figs 1-16.

1967 Didacna protracta Eichwald, 1841. - Svitoch: 42-43, pl. 6, figs 6-9, pl. 7, figs 1-2.

1969 Didacna protracta protracta (Eichw.). - Logvinenko \& Starobogatov: 327, fig. 347.

1973 Didacna protracta protracta Eichwald, 1841. - Grossu: 133, textfig. 11.

1973 Didacna protracta submedia Andrusov, 1911. - Grossu: 133-134, textfig. 12.

1999 Didacna protracta (Eichwald, 1829). - Fedorov: pl. 12, figs 4-7.

2005 Didacna protracta (Eichwald, 1829). - Yanina: 238-239, pl. 12, figs 9-19.

2007 Didacna protracta protracta (Eichwald, 1829). - Nevesskaja: 938-939, pl. 22, figs 4-13.

2013 Didacna protracta (Eichwald, 1829). - Kijashko in Bogutskaya et al.: 356, fig. 141.

2013 Didacna protracta submedia Andrusov, 1910. - Kijashko in Bogutskaya et al.: 356, fig. 142.

2016 Didacna protracta (Eichwald, 1841). - Vinarski \& Kantor: 72.

Status. Pontocaspian species, endemic to Caspian Sea.

Type locality. The type series (?Recent, Caspian Sea) was reported as lost by Nevesskaja (2007) who introduced a neotype from the Elton Lake surroundings in the northern Caspian plains, Russia (early Khvalynian, Late Pleistocene).

Distribution. Middle and southern Caspian Sea basins; it is most common in the middle basin at 25-85 m water depth (Logvinenko and Starobogatov, 1969).

Taxonomic notes. According to Logvinenko and Starobogatov (1969), two subspecies occur in the Caspian Sea at different depth ranges: D. protracta protracta at 25-50 $\mathrm{m}$ and D. protracta submedia Andrusov, 1910 at 50-85 m. The latter differs from D. p. protracta by the relative posterior location of the umbo that is furthermore subdued. Both forms of Didacna protracta are widespread in the Khvalynian deposits of the Caspian Sea and Manych depression. According to Kijashko in Bogutskaya et al. (2013) morphological differences characteristic for the subspecies of Didacna protracta are due to allometric growth. The mere difference in depth distribution, with overlapping depths and intermediate forms, does not provide any argument to maintain these subspecies. Didacna protracta is the type species of the subgenus Protodidacna Logvinenko \& Starobogatov, 1966.

Remarks. The authorship attribution of this species to Eichwald (1829) as proposed by several authors was rejected in Vinarski and Kantor (2016). According to them, Cardium protractum Eichwald, 1829, described from the western Ukraine, probably refers to a different species.

Conservation status. Not assessed.

\section{Didacna pyramidata (Grimm, 1877)}

*1877 Cardium pyramidatum Grimm: 46-49, pl. 8, figs 1a-d.

1932 Didacna pyramidata (Grimm, 1877). - Bogachev: 28-29, pl. 2, figs 15-16. 
1952 Didacna pyramidata (Grimm, 1877). - Zhadin: 347, fig. 320.

1969 Didacna pyramidata (Grimm). - Logvinenko \& Starobogatov: 324, fig. 344(1).

1969 Didacna pyramidata (Grimm, 1877). - Vekilov: 144-147, pl. 26, figs 1-5.

1973 Didacna pyramidata Grimm, 1877. - Grossu: 130, textfig. 6, pl. 1, fig. 1.

2007 Didacna pyramidata (Grimm, 1877). - Nevesskaja: 940, pl. 23, figs 6-10.

2013 Didacna pyramidata (Grimm, 1877). - Kijashko in Bogutskaya et al.: 357, fig. 135, photo 47.

2016 Didacna pyramidata (Grimm, 1877). - Vinarski \& Kantor: 73.

Status. Pontocaspian species, endemic to Caspian Sea.

Type locality. Caspian Sea, offshore Azerbaijan, 3947’ N, 4959'30”'E (Kijashko in Bogutskaya et al. 2013).

Distribution. Caspian Sea: southern basin and southern part of the middle basin at depths between 30-100 m (Logvinenko and Starobogatov, 1969).

Conservation status. Not assessed.

\section{Didacna trigonoides (Pallas, 1771)}

${ }^{\star} 1771$ Cardium trigonoides Pallas: 478.

1831 Cardium trigonoides (Pallas, 1771). - Eichwald: 282.

1838 Didacna trigonoides n. - Eichwald: 166-167.

1841 Didacna trigonoides. - Eichwald: 271-272, pl. 39, figs 5a-c.

1876 Cardium trigonoides, Pall. - Grimm: 138-140, pl. 6, fig. 2.

1914 Didacna trigonoides (Pallas, 1771). - Kalitskiy: pl. 3, figs 1-2.

1914 Didacna trigonoides (Pallas, 1771). - Nalivkin \& Anisimov: 6, pl. 1, fig. 3.

1932b Didacna trigonoides (Pallas, 1771). - Bogachev: pl. 1, figs 5-6.

1932a Didacna trigonoides (Pallas, 1771). - Bogachev: 25, pl. 2, figs 1-9.

1933 Didacna trigonoides (Pallas, 1771). - Zhizhchenko: 35-36, pl. 2, figs 9-10.

1950 Didacna trigonoides (Pallas, 1771). - Pravoslavlev: 21-22, figs 1-4.

1952 Didacna trigonoides (Pallas, 1771). - Zhadin: 346, fig. 319.

1953 Didacna trigonoides (Pallas, 1771). - Fedorov: 129, pl. 20, figs 7-9.

1969 Didacna trigonoides trigonoides (Pall.). - Logvinenko \& Starobogatov: 323, fig. 343(1), pl. 5,

fig. 7.

1969 Didacna trigonoides (Pallas, 1771). - Vekilov: 128-134, pl. 23, figs 1-9, pl. 27, fig. 6.

1973 Didacna trigonoides trigonoides Pallas, 1771. - Grossu: 129, textfig. 4, pl. 1, fig. 3.

1977 Didacna trigonoides tuzetae Tadjalli-Pour: 97, pl. 1, fig. 3.

1983 Didacna trigonoides (Pallas, 1771). - Popov: 204, pl. 16, fig. 19.

1986 Didacna trigonoides (Pallas, 1771). - Yakhimovich et al.: 79, pl. 10, fig. 1.

1988 Didacna trigonoides (Pallas, 1771). - Yanina \& Svitoch: pl. 9, figs 7-12. 
2005 Didacna trigonoides (Pallas, 1771). - Yanina: 244-245, pl. 14, figs 7-11.

2007 Didacna trigonoides (Pallas, 1771). - Nevesskaja: 941, pl. 24, figs 1-9.

2013 Didacna trigonoides (Pallas, 1771). - Kijashko in Bogutskaya et al.: 358, fig. 134.

2016 Didacna trigonoides (Pallas, 1771). - Vinarski \& Kantor: 70.

Status. Pontocaspian species, endemic to Caspian Sea.

Type locality. Caspian Sea, a neotype has been designated based on a specimen from Chechen Island by Nevesskaja (2007, pl. 24, fig. 4).

Distribution. Caspian Sea, mostly eastern part of northern Caspian Sea basin (Logvinenko and Starobogatov, 1969). Furthermore, it is found in living position in Novocaspian deposits near Turali, Dagestan (western part middle basin; FW).

Remark. Genetic data are available through Albrecht et al. (2014).

Conservation status. Not assessed.

\section{Hypanis plicata (Eichwald, 1829)}

${ }^{\star} 1829$ G. [lycymeris] plicata Eichwald: 279, pl. 5, figs 2a-b.

1838 Adacne [sic] plicata m. - Eichwald: 171-172.

1916 Adacna relicta Milaschewitch: 274-276, pl. 8, figs 10-13 [non figs 10-12 as indicated in the text]. 1926 Adacna relicta var. dolosmiana Borcea: 468-469, pl. 18, figs 156-158, pl. 21, fig. 2.

1952 Adacna (Hypanis) plicata (Eichwald, 1829). - Zhadin: 354-355, fig. 332.

1958 Adacna (Hypanis) plicata (Eichwald), 1829. - Nevesskaja: 50-51, pl. 9, figs 9-14.

1969 Hypanis plicata plicata (Eichw.). - Logvinenko \& Starobogatov: 331-332, fig. 350.

1973 Hypanis plicata plicata Eichwald, 1829. - Grossu: 136, textfig. 14, pl. 1, fig. 5.

1973 Hypanis plicata relicta Milaschevitsch, 1916. - Grossu: 136, textfig. 15, pl. 1, figs. 6, 20-23.

1973 Hypanis dolosmaniana [sic] Borcea, 1826. - Grossu: 136, textfig. 16, pl. 1, figs 16-19.

1977 Hypanis plicata golbargae Tadjalli-Pour: 99, pl. 1, fig. 5.

2006a Hypanis plicata relicta (Milachevitch, 1916). - Munasypova-Motyash: 45-46.

2009 Adacna (Hypanis) plicata relicta Milaschevich, 1916. - Popa et al. 12, fig. 4.

2013 Hypanis plicata (Eichwald, 1829). - Kijashko in Bogutskaya et al.: 387, fig. 164, photo 56.

2016 Hypanis plicata plicata (Eichwald, 1829). - Vinarski \& Kantor: 73.

2016 Hypanis plicata relicta (Milaschewitsch, 1916). - Vinarski \& Kantor: 74.

Status. Pontocaspian species, endemic to Caspian Sea basin and Black Sea basin.

Type locality. "Sinum Astrabadensem" [Caspian Sea near Astrabad (= Gorgan, Iran)].

Distribution. Caspian Sea, western liman coast Black Sea basin.

Taxonomic notes. The Black Sea populations of $H$. plicata show a large range of morphological variation with elongated specimens that cannot be distinguished from Caspian $H$. plicata to severely 
stunted and irregularly shaped specimens that have been considered as a subspecies $(H$. plicata relicta) or as distinct species ( $H$. dolosmiana) (e.g., Munasypova-Motyash 2006a). These forms have intermediates indicating that the Black Sea basin specimens are a single species that should be attributed to $H$. plicata even though the latter appear to have lived under lower salinities than their Caspian counterparts. Molecular studies are required to elucidate the status of the Black Sea basin material.

Conservation status. Not assessed. Fresh shells (including paired specimens) have been found at several beaches around the Caspian Sea (Turali, Dagestan, Russia; Şuraabad, Azerbaijan; FW). The species has been reported alive from the Razim lake complex of the Romanian Black Sea coast by Popa et al. (2009).

\section{Monodacna acuticosta (Logvinenko \& Starobogatov, 1969)}

*1967 Hypanis acuticosta Logvinenko \& Starobogatov: 232.

1969 Hypanis angusticostata acuticosta Logvinenko \& Starobogatov: 334, fig. 353(1).

1973 Hypanis angusticostata acuticosta Logvinenko et Starobogatov, 1967. - Grossu: 141, fig. 23.

2013 Adacna (Monodacna) acuticosta (Logvinenko et Starobogatov, 1967). - Kijashko in Bogutskaya et al.: 379, fig. 160 , photo 50 .

2016 Adacna (Monodacna) acuticosta (Logvinenko et Starobogatov, 1967). - Vinarski \& Kantor: 66.

Status. Pontocaspian species, endemic to Caspian Sea.

Type locality. "Northern Caspian Sea on the central part of the slope" (Vinarski and Kantor 2016: 66), which likely refers to northern slope of the middle Caspian Sea basin.

Distribution. Caspian Sea (middle Caspian Sea basin).

Conservation status. Not assessed.

\section{Monodacna albida (Logvinenko and Starobogatov, 1967)}

*1967 Hypanis albida Logvinenko \& Starobogatov: 232.

1969 Hypanis albida Logv. et Star. - Logvinenko \& Starobogatov: 336, fig. 353(3).

1973 Hypanis albida Logvinenko et Starobogatov, 1967. - Grossu: 144, textfig. 28.

2013 Adacna (Monodacna) albida (Logvinenko et Starobogatov, 1967). - Kijashko in Bogutskaya et al.: 380, fig. 162 , photo 51 .

2016 Adacna (Monodacna) albida (Logvinenko et Starobogatov, 1967). - Vinarski \& Kantor: 66.

Status. Pontocaspian species, endemic to Caspian Sea.

Type locality. "Western Caspian Sea south-eastwards from Derbent" (Vinarski and Kantor 2016: $66)$. 
Distribution. Caspian Sea (middle and southern Caspian Sea basin). This species was mentioned (as Hypanis albida) from depths between 200 and $400 \mathrm{~m}$ in the South Caspian basin of Azerbaijan (Mirzoev and Alekperov, 2017).

Taxonomic notes. This species is part of a group of Caspian Monodacna with relative flat and wedge-shaped shells with low and sometimes poorly defined ribs (M. albida, M. polymorpha). Like for the Monodacna caspia group (see below), we are in need of studies to assess whether these taxa might form ecomorphs of a single species.

Conservation status. Not assessed.

\section{Monodacna caspia (Eichwald, 1829)}

${ }^{*} 1829$ C. [orbula] caspia Eichwald: 281, pl. 5, fig. 6.

1841 Monodacna caspia. - Eichwald: 274, pl. 39, figs 4a-c.

1905 Monodacna caspia (Eichwald, 1829). - Ostroumov: pl. 3, fig. C.

1932b Monodacna caspia (Eichwald, 1829). - Bogachev: pl. 1, figs 10, 13.

1932b Monodacna caspia (Eichwald, 1829). - Bogachev: 30, pl. 3, figs 21-27.

1952 Monodacna edentula (Pallas, 1771) var. caspia Eichwald, 1841. - Zhadin: 350, fig. 327B.

1958 Monodacna caspia (Eichwald), 1829. - Nevesskaja: 44-46, pl. 9, figs 1-8.

1963 Monodacna caspia caspia (Eichwald, 1829). - Nevesskaja: 66, pl. 8, figs 1-4.

1965 Monodacna caspia caspia (Eichwald). - Nevesskaja: 187-198, pl. 9, figs 6-15, 17-19, 23-26, 29.

1969 Monodacna caspia (Eichwald, 1829). - Vekilov: 147-150, pl. 31, figs 9-11.

1973 Hypanis caspia caspia Eichwald, 1829. - Grossu: 139, textfig. 19B.

1977 Hypanis caspia assalae Tadjalli-Pour: 99, pl. 1, fig. 4.

1977 Hypanis caspia nahali Tadjalli-Pour: 99, pl. 1, fig. 6.

2013 Adacna (Monodacna) caspia caspia (Eichwald, 1829). - Kijashko in Bogutskaya et al.: 380,

fig. 154.

2016 Adacna (Monodacna) caspia caspia (Eichwald, 1829). - Vinarski \& Kantor: 67.

Status. Pontocaspian species, endemic to Caspian Sea.

Type locality. "Caspium mare" [Caspian Sea].

Distribution. Caspian Sea.

Taxonomic notes. The Monodacna caspia group (M. caspia, M. filatovae, and M. knipowitschi) comprises three (sub-) species that all share the relatively convex and rounded shell and welldefined ribbing. These species have been described from different areas and habitats in the Caspian Sea and have been morphologically characterised by Kijashko in Bogutskaya et al. (2013). However, neither morphological analyses of intermediate populations nor genetic analyses have been performed to clarify if the three taxa are distinct or ecomorphs of a single species. We are therefore uncertain whether M. filatovae and M. knipowitschi should be maintained. 
Conservation status. Not assessed.

\section{Monodacna colorata (Eichwald, 1829)}

${ }^{\star} 1829$ G. [lycymeris] colorata Eichwald: 279-280, pl. 5, fig. 4.

1838 Adacna colorata m. - Eichwald: 169-170.

?1838 Monodacna pontica Eichwald: 168 .

1926 Monodacna colorata var. ialpugensis Borcea: 452, pl. 15, fig. 16.

1926 Monodacna colorata var. angusticostata Borcea: 452-453, pl. 15, figs 27-28, pl. 16, figs 90-91,

pl. 18, figs 143, 169, 173, pl. 21, fig. 7.

1926 Adacna Luciae Borcea: 469-471, pl. 18, figs 146, 148-149, 151-153, pl. 21, figs 8-9.

1952 Monodacna colorata (Eichwald, 1829). - Zhadin: 351, fig. 328.

?1972 Hypanis caspia grossui Scarlato \& Starobogatov: 214, pl. 4, figs 1a-b.

1973 Hypanis caspia grossui Scarlato et Starobogatov, 1971. - Grossu: 140, textfig. 21, pl. 1, fig. 8.

1973 Hypanis angusticostata angusticostata Borcea, 1926. - Grossu: 141, pl. 1, fig. 12.

1973 Hypanis luciae Borcea, 1926. - Grossu: 138, textfig. 18.

1973 Hypanis ialpugensis Borcea, 1926. - Grossu: 142, fig. 24, pl. 1, figs 9, 10.

1973 Hypanis colorata Eichwald, 1829. - Grossu: 142-143, fig. 25, pl. 1, figs 13-15.

1973 Hypanis pontica Eichwald, 1838. - Grossu: 143, fig. 26, pl. 1, fig. 11.

2006a Hypanis colorata (Eichwald, 1829). - Munasypova-Motyash: 42-43.

?2006a Hypanis pontica (Eichwald, 1838). - Munasypova-Motyash: 43-44.

?2006a Hypanis angusticostata angusticostata (Borcea, 1926). - Munasypova-Motyash: 44.

2009 Monodacna pontica Eichwald, 1838. - Popa et al.: 10, textfig. 2.

2009 Monodacna colorata Eichwald, 1829. - Popa et al.: 10-11, textfig. 3.

2012 Hypanis colorata (Eichwald, 1829). - Popa et al.: 153, 154.

2012 Hypanis angusticostata (Borcea, 1926). - Popa et al.: 153, 154.

2013 Adacna (Monodacna) colorata (Eichwald, 1829). - Kijashko in Bogutskaya et al.: 383, fig. 158.

2016 Adacna (Monodacna) angusticostata (Borcea, 1926). - Vinarski \& Kantor: 66.

2016 Adacna (Monodacna) grossui (Scarlato et Starobogatov, 1972). - Vinarski \& Kantor: 67.

2016 Adacna (Monodacna) ialpugensis (Borcea, 1926). - Vinarski \& Kantor: 68.

Status. Pontocaspian species, native to Black Sea basin (including lower Danube River), invasive in Caspian Sea and Volga River.

Type locality. "Hypanin fluvium, ad nigrum usque mare" [Lower course of the Yuzhnyi Bug River, all the way to the Black Sea, Ukraine].

Distribution. Native to all Black Sea basin Pontocaspian habitats and lower courses of adjacent rivers such as the Danube, Dnieper, and Dniester; invasive in Caspian Sea basin and lower Volga, as 
well as Lake Balkhash (Kazakhstan). Occurs hundreds of kilometres upstream in major tributaries (Danube: Popa et al. 2009; recent observations in Volga River upstream Volgograd by MV and AFS).

Taxonomic notes. Monodacna colorata appears to be a morphologically very variable species. Here, we propose to synonymise several local Black Sea species with this taxon. Given the difficulty to distinguish relatively flat shells typically associated with $M$. colorata from the more convex shells typically associated with M. pontica in, e.g., Lake Razim (Romania) and the apparent lack of genetic differentiation of convex specimens from $M$. colorata we assume that $M$. pontica is a synonym of $M$. colorata. Shell differences have been attributed to substrate differences. Further investigations to confirm the synonymy are required. Monodacna angusticostata was synonymised by Popa et al. (2012) based on molecular evidence, even though some morphological distinction was reported from M. colorata, which they attributed to differential habitat preference (sediment type).

Conservation status. Not assessed.

\section{Monodacna filatovae (Logvinenko \& Starobogatov, 1967)}

1876 Cardium caspium, Eichw. - Grimm: 134-136 [pars].

*1967 Hypanis caspia filatovae Logvinenko \& Starobogatov: 231.

1973 Hypanis caspia filatovae Logvinenko et Starobogatov, 1967. - Grossu: 139, textfig. 19a. 2013 Adacna (Monodacna) caspia filatovae Logvinenko et Starobogatov, 1967. - Kijashko in

Bogutskaya et al.: 381, fig. 155, photo 52.

2016 Adacna (Monodacna) caspia filatovae Logvinenko et Starobogatov, 1967. - Vinarski \& Kantor: 67.

Status. Pontocaspian species, endemic to Caspian Sea. Uncertain whether it concerns a morph of $M$. caspia.

Type locality. Gulf of Baku, Caspian Sea, Azerbaijan.

Distribution. Southern Caspian Sea basin.

Taxonomic notes. See remarks under Monodacna caspia above for uncertain status of $M$. filatovae.

Conservation status. Not assessed.

\section{Monodacna knipowitschi (Logvinenko \& Starobogatov, 1966)}

*1966a Hypanis caspia knipowitschi Logvinenko \& Starobogatov: 15, fig. 2.

1973 Hypanis caspia knipowitschi Logvinenko et Starobogatov, 1967. - Grossu: 140, textfig. 20. 2013 Adacna (Monodacna) caspia knipowitschi Logvinenko et Starobogatov, 1966. - Kijashko in Bogutskaya et al.: 381, figs 152, 153, photo 53. 
2016 Adacna (Monodacna) caspia knipowitschi Logvinenko et Starobogatov, 1966. - Vinarski \& Kantor: 67.

Status. Pontocaspian species, endemic to Caspian Sea. Uncertain whether it concerns a morph of $M$. caspia.

Type locality. Middle Caspian Sea basin.

Distribution. Caspian Sea (middle and southern basins). This species was mentioned (as Hypanis caspia knipowitchi) from depths between 200 and $300 \mathrm{~m}$ in the South Caspian basin of Azerbaijan (Mirzoev and Alekperov, 2017).

Taxonomic notes. See remarks under Monodacna caspia above for uncertain status of $M$. knipowitschi.

Conservation status. Not assessed.

\section{Monodacna polymorpha (Logvinenko \& Starobogatov, 1967)}

*1967 Hypanis angusticostata polymorpha Logvinenko \& Starobogatov, 1967: 232.

1973 Hypanis angusticostata polymorpha Logvinenko et Starobogatov, 1967. - Grossu: 141, fig. 22,

pl. 1 , fig. 7.

2013 Adacna (Monodacna) polymorpha Logvinenko et Starobogatov, 1967. - Kijashko in Bogutskaya et al.: 383, fig. 159, photo 54 .

2016 Adacna (Monodacna) polymorpha Logvinenko et Starobogatov, 1967. - Vinarski \& Kantor: 68.

Status. Pontocaspian species, endemic to Caspian Sea. Status uncertain.

Type locality. Central part of northern Caspian Sea.

Distribution. Northern Caspian Sea.

Taxonomic notes. See remarks under M. albida for uncertain species status.

Conservation status. Not assessed.

\section{Monodacna semipellucida (Logvinenko \& Starobogatov, 1967)}

*1967 Hypanis semipellucida Logvinenko \& Starobogatov: 232-233.

1973 Hypanis semipellucida Logvinenko et Starobogatov, 1967. - Grossu: 144, textfig. 27.

2013 Adacna (Monodacna) semipellucida Logvinenko et Starobogatov, 1967. - Kijashko in

Bogutskaya et al.: 384, fig. 161, photo 55 .

2016 Adacna (Monodacna) polymorpha Logvinenko et Starobogatov, 1967. - Vinarski \& Kantor: 68.

Status. Pontocaspian species, endemic to Caspian Sea.

Type locality. Off Tokmak Cape (also as Toqmaq Müyis), southern Kazakhstan, Caspian Sea. 
Distribution. Middle Caspian Sea.

Conservation status. Not assessed.

Family Semelidae Stoliczka, 1870

Abra segmentum (Récluz, 1843)

${ }^{\circ} 1836$ Erycina ovata Philippi: 13, pl. 1 fig. 13 [non Erycina ovata Gray, 1825].

*1843 Syndosmya segmentum Récluz: 365-366.

1969 Abra ovata (Phil.). - Logvinenko \& Starobogatov: 339, fig. 355, pl. 5, fig. 12.

2013 Abra segmenta (Récluz, 1843). - Kijashko in Bogutskaya et al.: 391, fig. 165.

2015 Abra ovata (Philippi, 1836). - Latypov: 240.

Status. Invasive Pontocaspian species.

Type locality. Mediterranean coast near Taranto (Italy).

Distribution. Mediterranean, Black Sea coastal regions, Sea of Azov, Caspian Sea, Aral Sea.

Taxonomic notes. This species has been reported in much of the $20^{\text {th }}$ century literature as Abra ovata (Philippi, 1836), which is invalid since the original name (Erycina ovata Philippi, 1836) represents a junior primary homonym of Erycina ovata Gray, 1825.

Remarks. The first transfer of Abra segmentum into the Caspian Sea occurred in 1947-1948, and the species was detected ever since 1955 (Latypov, 2015).

Conservation status. Not assessed.

Family Cyrenidae Gray, 1840

Corbicula fluminalis (Müller, 1774)

${ }^{\star} 1774$ Tellina fluminalis Müller: 205-206.

1952 Corbicula fluminalis (Müller, 1774). - Zhadin: 317, fig. 283.

2012 Corbicula fluminalis (Müller, 1774). - Welter-Schultes: 15, unnumbered textfigures.

2016 Corbicula fluminalis (O.F. Müller, 1774). - Nabozhenko \& Nabozhenko: 62, textfig. 1(3-4).

2016 Corbicula fluminalis (O.F. Müller, 1774). - Vinarski \& Kantor: 80.

Status. Native/Invasive Pontocaspian species.

Type locality. Euphrates River. 
Distribution. Native to large parts of western Asia (including southern Caspian river systems) and northern Africa, introduced in 1939 to southern North America and in 1980 from there to Europe (Seddon and Van Damme, 2016). The species has been recently recorded from the Caspian Dagestan coast (Nabozhenko and Nabozhenko, 2016).

Remarks. This species has been native to south Caspian rivers including the Kura river system (Zhadin 1952) and has expanded several times in the Late Pleistocene into the Caspian Sea, where in time intervals it survived in proximal lacustrine habitats. A recent introduction and expansion of the species has been recorded in the Kizlyarsky Gulf in Dagestan (Nabozhenko and Nabozhenko, 2016) and the strong increase in fresh material found around the gulf in subsequent years, including whole specimens (A.S. Gasanova, Makhachkala, pers. comm.) suggests the species may have established there.

Conservation status. Least Concern (Seddon and Van Damme, 2016).

\section{Family Dreissenidae Gray, 1840}

Remarks. Pontocaspian dreissenid taxonomy suffers from a lack of coordinated shell and DNA analyses. A large part of our considerations relies on the work of Rosenberg \& Ludyanskiy (1994) who examined and illustrated all type material of Pontocaspian Dreissena.

\section{Dreissena bugensis Andrusov, 1897}

${ }^{\star} 1897$ Dreissensia bugensis Andrusov: 285-286, pl. 15, figs 31-37.

1972 Dreissena rostriformis bugensis (Andrusov, 1897). - Scarlato \& Starobogatov: 232-233, pl. 6,

fig. 16.

1994 Dreissena bugensis (Andrusov, 1897). - Rosenberg \& Ludyanskiy: 1479-1480, figs 1a-e.

2013 Dreissena bugensis (Andrusov, 1897). - Kijashko in Bogutskaya et al.: 331, fig. 119.

2016 Dreissena bugensis (Andrusov, 1897). - Vinarski \& Kantor: 78.

Status. Until mid-20 $0^{\text {th }}$ century endemic to northern Black Sea liman coast, since then invasive elsewhere in Black Sea basin, Volga catchment, western Europe, and North America.

Type locality. Bug Liman near Nikolaev, Ukraine.

Distribution. Endemic to western Ukrainian liman coast, introduced in Danube Delta, Azov Sea, Volga catchment, western and central Europe, and North America (Coughlan et al., 2017; Orlova et al., 2004).

Taxonomic notes. This species has been considered as a subspecies of D. rostriformis (Deshayes, 1838) by some authors (e.g., Orlova et al. 2005), yet we follow the argumentation of Kijashko in Bogutskaya et al. (2013) to consider it as a distinct species. The proposed synonymy of Caspian 
D. rostriformis (= D. grimmi) and Black Sea D. bugensis by Stepien et al. (2013) is discussed below under D. grimmi.

Conservation status. Least Concern (von Rintelen and Van Damme, 2011a).

\section{Dreissena caspia Eichwald, 1855}

${ }^{\star} 1855$ Dreissena caspia Eichwald: 311-312, pl. 10, figs 19-21.

1969 Dreissena caspia (Eichw.). - Logvinenko \& Starobogatov: 316-318, fig. 341(2).

1994 Dreissena caspia Eichwald, 1855. - Rosenberg \& Ludyanskiy: 1482, figs 3e-f.

2013 Dreissena caspia Eichwald, 1855. - Kijashko in Bogutskaya et al.: fig. 109.

2016 Dreissena (Dreissena) caspia caspia Eichwald, 1855. - Vinarski \& Kantor: 76.

Status. Pontocaspian species, Caspian endemic, probably extinct.

Type locality. Chistyi Bank and Cheleken Island, Caspian Sea, Russia.

Distribution. Caspian Sea and Aral Sea, probably extinct.

Taxonomic notes. The species is commonly subdivided into a Caspian subspecies (D. caspia caspia) and an Aral Sea subspecies (D. caspia pallasi Andrusov, 1897). However, syntypes of the latter illustrated in Rosenberg and Ludyanskiy (1994, fig. 3f) show a broad and keeled Dreissena that has major morphological characters in common with $D$. polymorpha/elata rather than $D$. caspia. Filippov and Riedel (2009) reported Dreissena caspia from Holocene core deposits of Aral Sea, but given the juvenile status of their material they noted they were uncertain whether it might comprise D. polymorpha. Dreissena caspia was reported alive from the remaining "small Aral Sea" by Plotnikov et al. (2016). However, this latter record concerns more likely D. polymorpha and needs confirmation. Andreev and Andreeva (2003) mentioned that this subspecies has not been found in the Aral Sea since 1989.

Conservation status. Critically endangered, possibly extinct (von Rintelen and Van Damme, 2011b).

\section{Dreissena elata Andrusov, 1897}

${ }^{\star} 1897$ Dreissensia polymorpha var. elata Andrusov: 353, pl. 20, fig. 25.

1969 Dreissena elata (Andr.). - Logvinenko \& Starobogatov: 316, fig. 341(1).

1994 Dreissena elata Andrusov, 1897. - Rosenberg \& Ludyanskiy: 1482, fig. $3 g$.

2013 Dreissena elata (Andrusov, 1897). - Kijashko in Bogutskaya et al.: fig. 108.

2016 Dreissena (Dreissena) elata (Andrusov, 1897). - Vinarski \& Kantor: 76.

Status. Pontocaspian species, endemic to the Caspian Sea, probably extinct. Species status uncertain. 
Type locality. Kuuli Cape, Dazmyk, Apsheron Peninsula, Azerbaijan (Vinarski and Kantor 2016).

Distribution. Caspian Sea. Probably extinct.

Taxonomic notes. Dreissena elata has morphological features in common with D. polymorpha, including a relatively wide shell and a well-pronounced keel located close to the ventral margin. However, the $D$. elata shell is in general wider, flatter, and has a more rounded abapical margin even though shell characters are higly variable. Dreissena elata has been reported from areas in the Caspian Sea with salinities well over 5 psu, which is unusual for D. polymorpha elsewhere. We are uncertain whether $D$. elata might be a sibling species. Its apparently distinct morphology and autecological preferences suggest it is different from D. polymorpha, but it will require molecular comparison to investigate the possibility it concerns a mere morph that has undergone "ecological release" (Kohn, 1972). However, no living specimens of D. elata have been recorded since 1957 (Kostianoy et al., 2005) when its Caspian habitats were invaded by Mytilaster minimus.

Conservation status. Not assessed. It was reported as extinct by Kostianoy et al. (2005, and references therein). If $D$. elata is accepted as a valid species, it might qualify for the same conservation status as D. caspia (critically endangered, possibly extinct; von Rintelen and Van Damme, 2011b).

\section{Dreissena grimmi (Andrusov, 1890)}

Fig. $3.4 \mathrm{~b}$

1877 Dreyssena Brardii var. caspia Grimm: 74-75 [non Dreissena caspia Eichwald, 1855].

${ }^{\star} 1890$ Dr. [eissena] Grimmi Andrusov: 233 [nom. nov. pro Dreissena caspia Grimm, 1877, non

Eichwald, 1855].

1897 Dreissensia Grimmi Andrus. - Andrusov: 279-282, pl. 16, figs 16-18.

1897 Dreissensia rostriformis var. distincta Andrusov: 273-278, pl. 14, figs 18-24.

1897 Dreissensia Tschaudae var. pontocaspica Andrusov: 294-297, pl. 9, figs 27-32, pl. 15, figs 29-30.

1966a Dreissena rostriformis compressa Logvinenko \& Starobogatov: 15-16, fig. 3.

1969 Dreissena rostriformis grimmi Andr. - Logvinenko \& Starobogatov: 318, fig. 341(3).

1969 Dreissena rostriformis pontocaspica (Andr.). - Logvinenko \& Starobogatov: 319, fig. 341(6).

1994 Dreissena rostriformis (Deshayes, 1838). - Rosenberg \& Ludyanskiy: 1477-1479, figs 1f, $2 \mathrm{a}-\mathrm{j}$

[non Mytilus rostriformis Deshayes, 1838].

2013 Dreissena rostriformis (Deshayes, 1838). - Kijashko in Bogutskaya et al.: 330 [non Deshayes,

$1838]$.

2013 D. [reissena] rostriformis compressa Logvinenko et Starobogatov, 1966. - Kijashko in

Bogutskaya et al.: 331, fig. 117a, photo 38 .

2013 D. [reissena] rostriformis distincta (Andrusov, 1897). - Kijashko in Bogutskaya et al.: 331,

fig. 117c. 


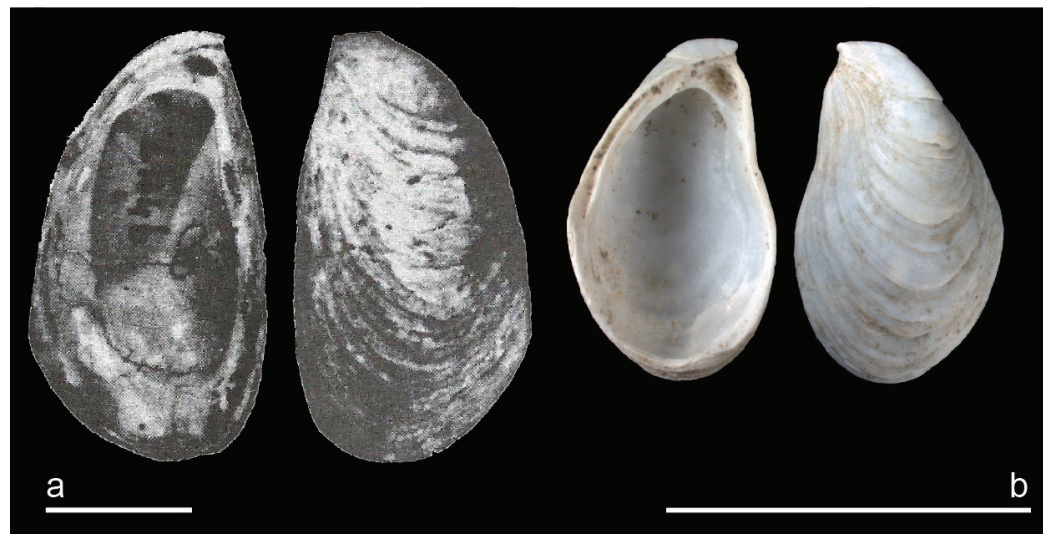

Fig. 3.4: Lectotype Dreissena rostriformis versus D. grimmi. a D. rostriformis Deshayes, 1838. Lectotype. Pliocene, Crimea. Reproduced from Archambault-Guezou (1976, pl. 6, fig 2a-2c) b RGM.961901, D. grimmi (Andrusov, 1890). Caspian Sea offshore Aktau, Kazakhstan, sample KAZ17-21, depth $44.3 \mathrm{~m}$. Scale bar: $1 \mathrm{~cm}$.

2013 D. [reissena] rostriformis grimmi (Andrusov, 1890). - Kijashko in Bogutskaya et al.: 331, fig. $117 \mathrm{~b}$.

2013 D. [reissena] rostriformis pontocaspica (Andrusov, 1897). - Kijashko in Bogutskaya et al.: 331, fig. $117 \mathrm{~d}$.

Status. Caspian Sea endemic.

Type locality. Caspian Sea.

Distribution. Middle to southern Caspian Sea basins. This species was mentioned (as D. rostriformis compressa) from depths between 200 and $400 \mathrm{~m}$ in the South Caspian basin of Azerbaijan (Mirzoev and Alekperov, 2017) and found living offshore Aktau (Kazakhstan) in 2017 below $20 \mathrm{~m}$ water depth.

Taxonomic notes. This Caspian species is very often cited as Dreissena rostriformis. Rosenberg and Ludyanskiy (1994: 1497) discuss the uncertainties of this attribution but state that “D. pontocaspica, D. distincta, D. compressa, and D. grimmi are synonyms of D. rostriformis" even though they find "some justification for maintaining a distinction between an extinct subspecies, D. rostriformis rostriformis and a living one, for which D. rostriformis grimmi is the oldest name". Their figure of the lectotype of D. rostriformis (Rosenberg and Ludyanskiy 1994: fig. 2a), which derives from Pliocene deposits of the Black Sea basin, concerns a relatively small, thick-shelled, and low Dreissena with a pointed beak and lacking a keel. On interior view, the shell area outside the pallial line is thick. Deshayes's lectotype has several characters in common with modern Caspian D. rostriformis and the closely related Black Sea basin D. bugensis. Yet, the Pliocene form has a broader umbonal area that results in a more subquadrangular shape, which is different from the modern Caspian Dreissena that have tear-drop to pear-shaped shells. The subquadrangular shape of 
Deshayes's material is even more pronounced in the pallial line on the shell's interior, a feature not seen in any modern Caspian material. The Pliocene Black Sea D. rostriformis has its general shape in common with Apsheronian (Early Pleistocene) Caspian dreissenids referred to as D. carinatocurvata as illustrated in Kolesnikov (1950, pl. 14, figs 14-16). Hence, we conclude that the recent Caspian species should be treated different from Pliocene D. rostriformis and the name D. grimmi should be applied instead.

Various subspecies have been attributed to Caspian Dreissena rostriformis (see, e.g., Kijashko in Bogutskaya et al. 2013 for a synonymy list). Even though morphological differences appear to be large, intermediates are known between the morphs. Stepien et al. (2013) reviewed molecular evidence for species boundaries within Dreissena. They concluded that (1) all Caspian Sea forms that have been mentioned in literature as (sub-) species of D. rostriformis (= D. grimmi) are one and the same species and (2) there is not enough molecular evidence and great difficulty in morphology to separate the Caspian species from the Black Sea basin D. bugensis. We agree with the first point made by Stepien et al. (2013); all forms reported from the middle and southern Caspian Sea basins appear to be mere morphs of a single species, a feature also noted by Rosenberg and Ludyanskiy (1994). However, we disagree with their second proposal. Dreissena bugensis and D. grimmi have non-overlapping ecological tolerances and are separated geographically (Rosenberg and Ludyanskiy, 1994). This fact together with the very limited but consistent genetic differentiation suggests that it may concern very recently evolved sister species. In the early 1980s, D. bugensis was introduced in the Volga (Zhulidov et al., 2005) and since then spread from there to central and western Europe and North America. So far, Dreissena bugensis has only been reported from the Volga itself and its delta but not from the northern Caspian Sea basin. If it would be conspecific with the middlesouthern Caspian species, which lives at higher salinities and deeper habitats, we would expect that the invasive populations in the north would have been blended with the Caspian population in the south. With no such intermediate populations found so far we consider both taxa as viable species.

Conservation status. Least Concern (for Dreissena rostriformis; von Rintelen and Van Damme, 2011c).

Dreissena polymorpha (Pallas, 1771) s.l.

${ }^{\star} 1771$ Mytilus polymorphus Pallas: 368, 435, 478.

1897 Dreissensia Andrusovi Andrusov: 374-376 pl. 18, figs 21-23.

1897 Dreissensia Pallasi Andrusov: 671-672, pl. 20, figs 33-35.

1897 Dreissensia polymorpha var. aralensis Andrusov: 354-355.

1897 Dreissensia polymorpha var. obtusecarinata Andrusov: 354.

1994 Dreissena polymorpha (Pallas, 1771). - Rosenberg \& Ludyanskiy: 1480-1482, figs 3a-b.

1994 Dreissena polymorpha aralensis Andrusov, 1897. - Rosenberg \& Ludyanskiy: 1480, fig. 3c.

1994 Dreissena polymorpha obtusecarinata Andrusov, 1897. - Rosenberg \& Ludyanskiy: 1481, fig. 3d. 
1994 Dreissena caspia pallasi Andrusov, 1897. - Rosenberg \& Ludyanskiy: 1482, fig. 3 f. 2003 Dreissena caspia pallasi (Andrusov, 1897). - Andreeva \& Andreev: 80, fig. 4.1(7-9). 2003 Dreissena polymorpha aralensis (Andrusov, 1897). - Andreeva \& Andreev: 79, fig. 4.1(1-3). 2003 Dreissena obtusecarinata (Andrusov, 1897). - Andreeva \& Andreev: 80, fig. 4.1(4-6).

2013 Dreissena (Dreissena) polymorpha (Andrusov, 1897). - Kijashko in Bogutskaya et al.: 328, fig 118a [pars, status fig. 118b uncertain]. 2016 Dreissena (Dreissena) polymorpha polymorpha (Andrusov, 1897). - Vinarski \& Kantor: 75. ?2016 Dreissena (Dreissena) polymorpha andrusovi (Brusina in Andrusov, 1897). - Vinarski \& Kantor: 75. ?2016 Dreissena (Dreissena) polymorpha aralensis (Andrusov, 1897). - Vinarski \& Kantor: 75. ?2016 Dreissena (Dreissena) polymorpha obtusecarinata (Andrusov, 1897). - Vinarski \& Kantor: 76. ?2016 Dreissena (Dreissena) caspia pallasi (Andrusov, 1897). - Vinarski \& Kantor: 7.

Status. Native Pontocaspian species.

Type locality. Volga and Yaik (nowadays Ural) rivers, Caspian Sea.

Distribution. Eurasian (native and invasive), North America (invasive) rivers, lakes, estuaries, deltas (Coughlan et al., 2017; Cummings and Graf, 2015; Rosenberg and Ludyanskiy, 1994). Several unique forms/species within this group reported from the Pontocaspian region.

Taxonomic notes. Dreissena polymorpha has been subject of intense DNA and ecological studies, but rarely Caspian communities were involved. Combined insights into the shell morphology, ecology, and molecular biology has to date not fully resolved several aspects of Pontocaspian records of this species. Occurrences in rivers and deltas of the Pontocaspian region are consistently attributed to Dreissena polymorpha. Yet, slightly deviating morphs exist(ed) in salinities typically not favoured by D. polymorpha elsewhere in the Caspian and Aral seas. A particular form of Dreissena polymorpha, documented by Kijashko in Bogutskaya et al. (2013), viz. D. polymorpha andrusovi (his figure 118b) will need further study as it has many morphological similarities with $D$. caspia (including general shape, location of semidiameter and broad flat shape of hinge platform).

Conservation status. Least Concern (Van Damme, 2014).

\section{Mytilopsis leucophaeata (Conrad, 1831)}

${ }^{\star} 1831$ Mytilus leucophaeatus Conrad: 263-264, pl. 11, fig. 13.

2013 Mytilopsis leucophaeata (Conrad, 1831). - Kijashko in Bogutskaya et al.: 320, fig. 107.

Status. Invasive Pontocaspian species.

Type locality. Southern coast of eastern United States.

Distribution. Black Sea basin, Caspian Sea, coasts of western Europe, Caribbean and northern South America. 
Remarks. The species, native to the southern coast of North America, was first introduced in Europe in 1835 (Heiler et al., 2010). In the Pontocaspian region, it first appeared in the northern Black Sea basin in 2002 and was first collected in the Caspian Sea in 2009 (Heiler et al., 2010). It is easily distinguished from Pontocaspian dreissenids by the presence of an aphophysis near the hinge.

Conservation status. Least Concern (Cummings, 2011).

\subsubsection{Gastropoda}

\section{Family Neritidae Rafinesque, 1815}

Theodoxus danubialis (Pfeiffer, 1828)

${ }^{*} 1828$ Nerita danubialis Pfeiffer: 48, pl. 8, figs 17-18.

2009 Theodoxus danubialis (C. Pfeiffer, 1828). - Fehér et al.: figs 2a-k, 4a-c, 5a-c.

2012 Theodoxus danubialis (Pfeiffer, 1828). - Welter-Schultes: 27, unnumbered textfigures.

2016 Theodoxus (Theodoxus) danubialis (Pfeiffer, 1828). - Vinarski \& Kantor: 156 [and synonyms

therein].

Status. Accepted native species.

Type locality. Danube River, Vienna, Austria.

Distribution. Danube River catchment, central to south-eastern Europe, as well as northern Italy (Fehér et al. 2009).

Taxonomic notes. The latest phylogenetic data supports a sister relationship between Theodoxus danubialis and the clade containing T. fluviatilis and T. velox (AFS, unpublished data). Some authors believe T. danubialis and T. prevostianus may represent different species given some level of genetic, ecological, and morphological differentiation (Fehér et al., 2009; Welter-Schultes, 2012; but see also Bandel 2001). More recent unpublished results may suggest that the genetic level of differentiation between these species is more indicative of intraspecific diversity within a single species (AFS, unpublished data).

Conservation status. Least Concern (Tomovic et al., 2010).

\section{Theodoxus fluviatilis (Linnaeus, 1758)}

${ }^{\star} 1758$ Nerita fluviatilis Linnaeus: 777.

1865 Theodoxus fluviatilis var. subthermalis Issel: 22-23.

1886 Neritina euxina Clessin: 55.

1908 Neritina danubialis var. danasteri Lindholm: 214-215. 
?1972 Theodoxus dniestroviensis Put': 80-82, textfig. 5.

?1999 Th. dniestroviensis Put', 1972. - Anistratenko et al.: 19, figs 4, 8.

1999 Th. fluviatilis (Linnaeus, 1758). - Anistratenko et al.: 13-15, figs 3-4.

2005 Theodoxus fluviatilis (Linnaeus, 1758). - Anistratenko: 7-8, textfigs 3-4.

2012 Theodoxus euxinus (Clessin, 1886). - Welter-Schultes: 27, unnumbered textfigures.

2012 Theodoxus fluviatilis (Linnaeus, 1758). - Welter-Schultes: 28, unnumbered textfigures.

2015 Theodoxus fluviatilis (Linnaeus, 1758). - Glöer and Pešić: 88-91, figs 1, 3-5, 9, 13-34.

2016 Theodoxus (Theodoxus) fluviatilis (Linnaeus, 1758). - Vinarski \& Kantor: 154-155 [pars, excluding synonyms sarmatica and velox].

2016 Theodoxus (Theodoxus) euxinus (Clessin, 1886). - Vinarski \& Kantor: 155.

2016 Theodoxus (Theodoxus) subthermalis (Bourguignat in Issel, 1865). - Vinarski \& Kantor:

157-158.

Status. Accepted native species.

Type locality. Near Uppsala, Sweden. The lectotype was designated by Anistratenko (2005).

Distribution. Widely distributed all over Europe, Anatolia, and north-western Africa. Within the Pontocaspian region, it is a common component of the lower reaches of Black and Azov Sea drainages (specifically in Bulgaria, Romania and Ukraine). Towards the east, the species extends at least as far as the Don River system in Russia and the coastal rivers of Georgia, but it is absent from the Caspian system. Records of this species from Iran and western Asia are likely misidentifications (AFS, unpublished data).

Taxonomic notes. Theodoxus fluviatilis exhibits considerable variation in shell colouration and shape (Glöer and Pešić, 2015). Unpublished molecular data confirm the synonymy of a number of taxa such as Theodoxus euxinus, T. danasteri, and T. subthermalis, and further suggest the inclusion of T. saulcyi and T. heldreichi (AFS, unpublished data). A final decision concerning the status of T. Aniestroviensis Put', 1972 described from the Dniester River (Rukhotyn village, Khotyn district, Chernivtsi region, Ukraine) is not possible at the moment. Despite appropriate efforts, we were unable to trace the type specimens of this species. Based on the original description and illustration (Put', 1972) it was considered as a junior synonym of T. fluviatilis by Anistratenko (1999) having an unusual colour pattern. Theodoxus milachevichi was described as a subfossil from the Crimean coast. It closely resembles morphotypes of both T. fluviatilis and T. velox V. Anistratenko in O. Anistratenko et al., 1999 and might be synonym of either species (compare type material illustrated in Kantor and Sysoev 2006). However, the morphological variability of the taxa involved, as well as the lacking possibility of acquiring genetic data for T. milachevichi, complicates a decision on the independence or synonymy of this species.

Conservation status. Least Concern (Kebapçı and Van Damme, 2012).

\section{Theodoxus pallasi Lindholm, 1924}


${ }^{\circ} 1838$ Neritina liturata Eichwald: 156-157 [non Neritina liturata Schultze, 1826].

${ }^{\star} 1924$ Theodoxus pallasi Lindholm: 33, 34 [nom. nov. pro Neritina liturata Eichwald, 1838, non

Schultze, 1826].

1947 Theodoxus (Theodoxus) pallasi var. nalivkini Kolesnikov: 106, 110.

1976 Theodoxus pallasi Lindholm, 1924. - Akramovskiy: 88, textfig. 23, pl. 1, figs 1-2.

1994 Theodoxus astrachanicus Starobogatov in Starobogatov, Filchakov, Antonova et Pirogov: 8-9,

fig. 1(1-2).

1994 Theodoxus astrachanicus Starobogatov et al.: 8-9, fig. 1(1-2).

2009 Theodoxus pallasi Lindholm, 1924. - Filippov \& Riedel: 70, 72, 74, 76, figs 4g-i.

2011 Theodoxus astrachanicus Starobogatov in Starobogatov, Filchakov, Antonova et Pirogov, 1994. -

Anistratenko et al.: 54-55, fig. 1 (6).

2012 Theodoxus pallasi Lindholm, 1924. - Welter-Schultes: 29, unnumbered textfigures.

2016 Theodoxus (Theodoxus) astrachanicus Starobogatov in Starobogatov, Filchakov, Antonova et

Pirogov, 1994. - Vinarski \& Kantor: 155-156.

2016 Theodoxus (Theodoxus) pallasi (Lindholm, 1924). - Vinarski \& Kantor: 156-157 [and

synonyms therein].

2017 Theodoxus pallasi Lindholm, 1924. - Anistratenko et al.: 221, figs 4, 7, $10,11$.

2018 Theodoxus pallasi Lindholm, 1924. - Neubauer et al.: 48-51, figs 4A-F.

Status. Accepted Pontocaspian species, name uncertain.

Type locality. "Inter Fucos littoris Derbendensis viva" (living among algae on the shores of Derbent), Dagestan, Russia.

Distribution. Present along the Caspian Sea shores, in the Volga River, and the Sea of Azov. Lived until the late 1980s in the Aral Sea but is possibly extinct there now (Aladin et al., 1998; Andreev et al., 1992; Micklin et al., 2014).

Taxonomic notes. Eichwald (1838) introduced the species Neritina liturata based on material from the shores of Derbent (Dagestan, Russia, northwestern Caspian Sea). That name is invalid as it is a junior primary homonym of $N$. liturata Schultze, 1826; it got replaced by Lindholm (1924) with Theodoxus pallasi (see also Anistratenko et al. 2017). Theodoxus pallasi is a widely used name, but a major nomenclatural change might be due. Unpublished molecular data suggest that all Theodoxus from the Caspian Sea, Azov Sea and Armenian lakes Sevan and Yerevan, as well as several mineral springs and streams in the Khorasan provinces of Iran, belong to a single species (AFS, unpublished results). The oldest name available for that group is Theodoxus major Issel, 1865, described from Lake Sevan in Armenia (originally as variety of the unavailable name T. schirazensis). Akramovskiy (1976) noted the similarity of T. pallasi and T. major and considered the latter as a morphotype of the former. Although he did not explicitly state it, he thereby suggested the two taxa to be synonymous. This view was adopted by Vinarski and Kantor (2016), who listed major in synonymy of pallasi, although Issel's (1865) name has priority. The potential synonymy also involves T. schultzii. 
Despite the characteristic appearance of the syntypes, the presence of intermediate morphologies in samples taken on shores of Azerbaijan and Kazakhstan in 2016 and 2017 (pers. obs. OA, VA, FW) indicate a close relationship with $T$. pallasi. Only, the radulae of these two species differ in the relative width of the central and marginal teeth (see Zettler 2007 and compare Anistratenko et al. 2017).

Unfortunately, the types of T. major, supposed to be in the Museo Regionale di Scienze Naturali, Torino, are inaccessible at the moment due to museum renovation (E. Gavetti, pers. comm., 10/2018). We refrain from a final conclusion on the synonymy of the species involved until information on the types of all taxa as well as published molecular data are available.

For details on the taxonomic relationship between T. pallasi and T. astrachanicus, see discussion in Anistratenko et al. (2017).

Conservation status. Data Deficient (Van Damme and Kebapçı, 2014).

\section{Theodoxus schultzii (Grimm, 1877)}

${ }^{\star} 1877$ Neritina Schultzii Grimm: 77-78, pl. 7, fig. 5, pl. 8, fig. 16.

1909 Neritina (Ninnia) Schultzei [sic] Grimm. - Andrusov: 106-107, pl. 6, fig. 38.

?1947 Theodoxus (Ninnia) schultzi [sic] var. jukovi Kolesnikov: 106, 110.

1950 Theodoxus (Ninnia) schultzei [sic] (Grimm). - Kolesnikov: 215-216, pl. 26, figs 12-13.

1969 Theodoxus schultzi [sic] (Grimm, 1877). - Logvinenko \& Starobogatov: 344, fig. 357.

?1974 Theodoxus zhukovi [sic] Kolesnikov, 1947. - Starobogatov: 255, textfig. 223.

2007 Theodoxus (Theodoxus) schultzii (Grimm, 1877). - Zettler: 249, figs 2-5.

2016 Theodoxus (Theodoxus) schultzii (Grimm, 1877). - Vinarski \& Kantor: 157.

Status. Pontocaspian species, status uncertain.

Type locality. Caspian Sea, in two localities, given by Grimm (1877) as $43^{\circ} 17^{\prime} \mathrm{N}, 01^{\circ} 03^{\prime} \mathrm{E}$, 40 fathoms, and $42^{\circ} 48^{\prime} \mathrm{N}, 01^{\circ} 22^{\prime} \mathrm{E}, 48$ fathoms. Since the longitude was calculated relative to the geographic position of Baku, situated approximately at $50^{\circ} \mathrm{E}$, the correct longitude should be about 5100’ E (Vinarski and Kantor 2016).

Distribution. Middle and southern Caspian Sea basins, between 15 and 100 m (Logvinenko and Starobogatov, 1969).

Taxonomic notes. See discussion of T. pallasi for notes on the potential synonymy with T. major Issel, 1865. The status of T. jukovi still requires confirmation (Vinarski and Kantor, 2016).

Conservation status. Not assessed.

Theodoxus velox V. Anistratenko in O. Anistratenko et al., 1999

${ }^{\star} 1999$ Th.[eodoxus] velox V. Anistratenko in O. Anistratenko et al.: 17-18, figs 4(7). 
Status. Pontocaspian species, name uncertain.

Type locality. Dnieper Delta, Zbur'ivka liman, Ukraine.

Distribution. This species was believed to be restricted to drainage systems of the northern Black Sea coast (even though the Oskol River lies far from the Black Sea coast), but unpublished molecular data suggest it may be distributed as far north as the eastern part of the Baltic Sea and as far south as Anatolia (AFS, unpublished data).

Taxonomic notes. The species was listed as junior synonym of T. fluviatilis by Vinarski and Kantor (2016). Theodoxus velox is indeed challenging to differentiate from some regional morphotypes of that species given the overlap in shell patterns. Unpublished molecular data indicate however that T. velox belongs to a different molecular clade (AFS, unpublished data). The distribution range of that clade overlaps with the range of T. sarmaticus (Lindholm, 1901), which is widely accepted as a junior synonym of T. fluviatilis in the literature (e.g., Vinarski and Kantor 2016). A revision of the taxa involved and study of the type material is required to solve the synonymy issues.

Conservation status. Not assessed.

\section{Family Cochliopidae Tryon, 1866}

\section{Eupaludestrina stagnorum (Gmelin, 1791)}

*1791 Helix stagnorum Gmelin: 3653.

1975 Falsihydrobia streletzkiensis Chukhchin: 121.

2012 Heleobia stagnorum (Gmelin, 1791). - Welter-Schultes: 39, unnumbered textfigures.

2012 Semisalsa stagnorum (Gemlin, 1791). - Kroll et al.: 1520.

Status. Accepted, native Pontocaspian or immigrant species.

Type locality. Kaasjeswater, Zierikzee, the Netherlands.

Distribution. Coastal areas of Europe and the Mediterranean region, extending to North Africa and east to Iran (Glöer, 2002). Occurrence in Black Sea according to, e.g., Chukhchin (1975) and in the Caspian Sea (TW, unpublished data).

Taxonomic notes. We find the attribution of this species to the genus Eupaludestrina unsatisfactory, yet a further revision is required to establish and stabilise the generic attribution. There is considerable confusion regarding the generic attribution of this species. It is commonly classified in the South American genus Heleobia (e.g., Prié), whereas Kroll et al. (2012) suggested that this species belongs to the genus Semisalsa, a group of European Cochliopidae distinct from Heleobia. However, Semisalsa is currently listed as junior synonym of Eupaludestrina Mabille, 1877 (type species: Hydrobia macei Paladilhe, 1867, by subsequent designation by Kadolsky 
2008). Following Kadolsky (2008), Eupaludestrina is currently ranked as subgenus of Heleobia in MolluscaBase (2018a), but both the phylogenetic and geographic distinction of the European and American species suggest separation on the genus level.

Remarks. It is unclear whether the species is native to the Pontocaspian area or a recent immigrant.

Conservation status. Least Concern (Prié, 2011).

\section{Family Hydrobiidae Stimpson, 1865}

Remarks. The Hydrobiidae form the most species-rich mollusc group in the Pontocaspian region. However, in general useful shell characters are few and highly variable (Wilke and Delicado, 2019). Descriptions in the past have often been very general, and illustrations of types are notably poor for several of the endemic taxa. A strong tendency of naming large numbers of species has developed throughout the $20^{\text {th }}$ century (e.g., Logvinenko and Starobogatov, 1969), but for some groups where morphological and genetic analyses could be performed (e.g., Caspiohydrobia spp.) it has been demonstrated that actual species numbers were much lower than the number of species described (Haase et al., 2010). For many of the endemic species, especially in the genus Turricaspia, the apparent loss of types, combined with the lack of living material makes it impossible to assess their taxonomic status. Currently, a number of taxonomic works is in progress on the endemic Pontocaspian hydrobiid groups. Some different insights on the genus-level classifications exist. Here, we adopt a conservative approach, mostly based on Neubauer et al. (2018).

\section{Subfamily Caspiinae Dybowski, 191)}

Remarks. The distinction of the genera Caspia, Ulskia, and Clathrocaspia follows Neubauer et al. (2018). The three taxa are differentiated based on details of the protoconch and the expression of teleoconch sculpture. Caspia s.s. is characterized by a single distinct but fine spiral keel below the suture. It is usually smooth, yet within the type species some reticulate ornament can be found. Species of Clathrocaspia expose a distinctive, reticulate pattern on the teleoconch and a malleate protoconch with faint spiral threads. The aperture of Clathrocaspia often develops a distinct flat base. The discinction of the two genera is subject of current research. Ulskia too has a malleate protoconch but with more distinct spiral threads; teleoconch sculpture is occasionally present as minute elongate nodules.

\section{Caspia baerii Clessin \& Dybowski in Dybowski, 1887}


${ }^{\star} 1887$ Caspia Baerii Clessin \& Dybowski in Dybowski: 36-37.

1888 [Caspia] Baerii n. sp. - Dybowski: 79, pl. 3, figs 4a-b.

1969 Pyrgula (Caspia) baerii (Cless. et Dyb.). - Logvinenko \& Starobogatov: 377, fig. 367(3).

2016 Caspia baerii Clessin et W. Dybowski in W. Dybowski, 1888. - Vinarski \& Kantor: 224.

Status. Accepted Pontocaspian species.

Type locality. Caspian Sea (no details).

Distribution. Caspian Sea and possibly Danube Delta (Romania). This species was mentioned (as Turricaspia baerii) from depths between 200 and $400 \mathrm{~m}$ in the South Caspian basin of Azerbaijan (Mirzoev and Alekperov, 2017).

Taxonomic notes. The type material is stored in the von Baer collection of Caspian Sea molluscs in the Zoological Museum of Lviv University (Ukraine) and comprises over a hundred syntypes (Anistratenko et al., 2018). The slender shell, the presence of a fine spiral keel below the suture, and the occasionally weakly reticulated surface distinguish this species from congeners.

Conservation status. Not assessed.

\section{Caspia valkanovi (Golikov \& Starobogatov, 1966)}

${ }^{\star} 1966$ P. [yrgula] (Caspia) baeri [sic] valkanovi Golikov \& Starobogatov: 354-355, fig. 1(9). 2006 Caspia valkanovi (Golikov et Starobogatov, 1966). - Kantor \& Sysoev: 88, pl. 41, fig. N.

Status. Pontocaspian species, identity uncertain.

Type locality. Off Crimea, station 18, sample 173.

Distribution. Endemic to the Black Sea basin.

Taxonomic notes. The identity and status of this subfossil taxon, described from phaseoline silt, are somewhat uncertain. The holotype illustrated in Kantor and Sysoev (2006) is poorly preserved and does not allow a proper assessment of its validity. The general shape and size are indicative of the genus Caspia and it looks like a variety and might be a synonym of $C$. baerii. Furthermore, we are not entirely certain as to the stratigraphic age of the stratigraphic origin of this species. The phaseoline silt is a marine Holocene unit, yet it contains reworked Late Pleistocene Neoeuxinian (Pontocaspian) species (FW, pers. obs.).

Conservation status. Not assessed.

\section{Clathrocaspia brotzkajae (Starobogatov in Anistratenko \& Prisjazhnjuk, 1992)}

*1992 Caspia (Clathrocaspia) brotzkajae Starobogatov in Anistratenko \& Prisjazhnjuk: 18-19, fig. 2a. 2016 Caspia brotzkajae Starobogatov in Anistratenko et Prisjazhnjuk, 1992. - Vinarski \&

Kantor: 224. 
Status. Accepted Pontocaspian species.

Type locality. Caspian Sea shores of Dagestan, Russia, at about $60 \mathrm{~m}$.

Distribution. Presently endemic to the Caspian Sea. The species was also recorded from the Holocene of Danube Delta, Ukraine (Anistratenko and Prisjazhnjuk 1992).

Taxonomic notes. The species differs from its congeners in the bulbous shape, with a ratio of body whorl height/shell height of about $3 / 4$, as well as regarding the expanded aperture.

Conservation status. Not assessed.

\section{Clathrocaspia gmelinii (Clessin \& Dybowski in Dybowski, 1887)}

*1887 Caspia Gmelinii Clessin \& Dybowski in Dybowski: 37-38.

1888 [Caspia] Gmelini [sic] n. sp. - Dybowski: 79, pl. 3, figs 7a-b.

1969 Pyrgula (Caspia) gmelinii (Cless. et W. Dyb.). - Logvinenko \& Starobogatov: 378, fig. 367(7).

?1969 Pyrgula (Caspia) sowinskyi Logvinenko \& Starobogatov: 378, fig. 367(4).

?1977 Pyrgula (Caspia) gaillardi Tadjalli-Pour: 107, pl. 2, fig. 8.

2015 Caspia gmelinii Clessin et W. Dybowski, 1887. - Boeters et al.: 178, figs 1-6.

2016 Caspia gmelinii Clessin et W. Dybowski in W. Dybowski, 1888. - Vinarski \& Kantor: 224.

Status. Accepted Pontocaspian species.

Type locality. Caspian Sea (no details).

Distribution. Endemic to the Caspian Sea, recorded from the middle and southern parts. This species was mentioned (as Turricaspia gmelinii) from depths between 200 and $300 \mathrm{~m}$ in the South Caspian basin of Azerbaijan (Mirzoev and Alekperov, 2017).

Taxonomic notes. The broad shell and the heavily reticulated surface distinguish this species from congeners. Pyrgula sowinskyi, from the middle and southern Caspian Sea, and P. gaillardi, from the Caspian Sea shore between Astara and Hashtpar (= Talesh), Iran, closely resemble C. gmelinii in terms of shell shape, the shape of the aperture, and the distinct reticulate teleoconch sculpture. Very likely, the two species are synonyms of C. gmelini. Since the type material of Logvinenko and Starobogatov (1969) has not be found, and the whereabouts of the material of Tadjalli-Pour (1977) is unknown, a re-examination of these species has to be postponed. Here, we suggest to treat them as nomina dubia until more information becomes available.

Conservation status. Data Deficient (same for P. sowinskyi; Son, 2011a; Vinarski, 2011a).

\section{Clathrocaspia isseli (Logvinenko \& Starobogatov, 1969)}

${ }^{\star} 1969$ Pyrgula (Caspia) isseli Logvinenko \& Starobogatov: 378, fig. 367(6).

2016 Pyrgula isseli Logvinenko et Starobogatov, 1968. - Vinarski \& Kantor: 239. 
Status. Pontocaspian species, identity uncertain.

Type locality. Southern Caspian Sea (no details), between 40-75 m water depth.

Distribution. Endemic to the Caspian Sea.

Taxonomic notes. This species hardly differs from $C$. pallasii and might be a junior synonym. Observations on Holocene material from the southern and northern Caspian Sea shores (VA, TN, FW) suggest that the minor differences range within intraspecific variability but further studies (preferentially involving DNA) are required to solve the identity of this taxon. The classification in Clathrocaspia is based on the reticulate sculpture typical of that genus.

Conservation status. Data Deficient (Vinarski, 2011b).

\section{Clathrocaspia knipowitschii (Makarov, 1938)}

*1938 Caspia gmelini [sic] var. Knipowitschii Makarov: 1058.

?1966 P. [yrgula] (Caspia) gmelini [sic] aluschtensis Golikov \& Starobogatov: 354, fig. 1(8).

1966 P. [yrgula] (Caspia) makarovi Golikov \& Starobogatov: 353-354, fig. 1(5).

?1987 Caspia gmelinii stanislavi Alexenko \& Starobogatov: 33, fig. 1.

1992 Caspia (Clathrocaspia) knipowitchi Makarov, 1938. - Anistratenko \& Prisjazhnjuk: 19, fig. 2 b.

2006 Caspia knipowitchi [sic] Makarov, 1938. - Kantor \& Sysoev: 87-88, pl. 41, fig. J.

2006 Caspia makarovi (Golikov et Starobogatov, 1966). - Kantor \& Sysoev: 88, pl. 41, fig. L.

2013 Caspia knipowitchii [sic] Makarov, 1938. - Anistratenko: 53-55, figs 1A-I, 3A-D, 5A-D.

2013 Caspia makarovi (Golikov and Starobogatov, 1966). - Anistratenko: 56-59, figs 2A-E, 3E.

2016 Caspia knipowitchi [sic] Makarov, 1938. - Vinarski \& Kantor: 224.

2016 Caspia makarovi (Golikov et Starobogatov, 1966). - Vinarski \& Kantor: 225.

?2016 Caspia stanislavi Alexenko et Starobogatov, 1987. - Vinarski \& Kantor: 225.

Status. Accepted Pontocaspian species.

Type locality. Ukraine, in the Dniester River (exact locality not specified).

Distribution. Azov Sea and northern Black Sea basin. Known from the Holocene of Danube Delta, Ukraine (Anistratenko and Prisjazhnjuk 1992).

Taxonomic notes. Clathrocaspia knipowitschii, C. makarovi, C. gmelini aluschtensis, and C. stanislavi were all described from the northern margin of the Black Sea. After detailed morphological comparison of C. knipowitschii and C. makarovi and preliminary genetic analyses (TW, unpublished data), we conclude that both taxa should be considered synonyms. Very likely, also C. gmelini aluschtensis and C. stanislavi are synonyms of C. knipowitschii, but a final decision on that matter requires investigation of the type material.

Conservation status. Least Concern (same for C. makarovi; (Son, 2011b, 2011c).

\section{Clathrocaspia logvinenkoi (Golikov \& Starobogatov, 1966)}


*1966 P. [yrgula] (Caspia) logvinenkoi Golikov \& Starobogatov: 354, fig. 1(7).

2006 Caspia logvinenkoi (Golikov et Starobogatov, 1966). - Kantor \& Sysoev: 88, pl. 41, fig. I.

2007b Caspia (Clathrocaspia) logvinenkoi (Golikov et Starobogatov, 1966). - Anistratenko: 25-26,

fig. 2.

2016 Caspia logvinenkoi (Golikov et Starobogatov, 1966). - Vinarski \& Kantor: 224-225.

Status. Accepted Pontocaspian species.

Type locality. Don Delta, Russia.

Distribution. Known only from the type locality.

Taxonomic notes. The species has distinctive shell characters: broad conical shape with a weak subsutural bulge and apically thickened peristome.

Remarks. The type material was collected by Mordukhai-Boltovskoi in 1937 and comprises two specimens - the holotype and the paratype. Three additional specimens were collected from the same region in 2006 (Anistratenko 2007b). The salinity at the type locality fluctuates between freshwater and ca. 1 psu.

Conservation status. Not assessed. In the fifty years since the description of this species five specimens have been collected; this is likely evidence of its rarity. Being known only from two close localities C. logvinenkoi appears to have an extremely narrow distributional range in the Azov-Black Sea basin, being endemic to the Taganrog province (e.g., Anistratenko 2007b).

\section{Clathrocaspia milae Boeters, Glöer \& Georgiev, 2015}

*2015 Caspia milae Boeters, Glöer \& Georgiev in Boeters et al.: 180-183, figs 9-21.

Status. Pontocaspian species, identity uncertain.

Type locality. Bulgaria, Danube Island Vardim $\left(43^{\circ} 37^{\prime} \mathrm{N}, 25^{\circ} 28^{\prime} \mathrm{E}\right)$

Distribution. Only known from type locality.

Taxonomic notes. This species closely resembles C. knipowitschii concerning shape, size, and sculpture. According to Boeters et al. (2015), the two species differ in the degree of cover of the umbilicus, the shape of the peristome and the size and number of whorls of the protoconch. Molecular and/or more in-depth morphological and anatomical studies are required to confirm that these apparently minor differences are sufficient to separate the species.

Remarks. If the species would be confirmed, it concerns a Pontocaspian species whose distribution currently is outside prime Pontocaspian habitat, yet Boeters et al. (2015) implied they would expect that several of the Caspia records from the lower Danube and Razim Lake complex might be attributed to C. milae as well. The Razim Lake complex is Pontocaspian habitat.

Conservation status. Not assessed. 


\section{Clathrocaspia pallasii (Clessin \& Dybowski in Dybowski, 1887)}

${ }^{\star} 1887$ Caspia Pallasii Clessin \& Dybowski in Dybowski: 37.

1888 Caspia Pallasii n. sp. - Dybowski: 79, pl. 3, figs 3a-b.

1969 Pyrgula (Caspia) pallasii (Cless. et W. Dyb.). - Logvinenko \& Starobogatov: 378, fig. 367(5). 2016 Pyrgula pallasii (Clessin et W. Dybowski in W. Dybowski, 1888). - Vinarski \& Kantor: 241.

Status. Accepted Pontocaspian species.

Type locality. Caspian Sea (no details).

Distribution. Endemic to the Caspian Sea.

Taxonomic notes. This species differs from the other Caspian species C. gmelinii in its very slender shape.

Conservation status. Not assessed.

\section{Ulskia behningi (Logvinenko \& Starobogatov, 1969)}

*1969 Pyrgula (Ulskia) behningi Logvinenko \& Starobogatov: 380, fig. 367(13).

2016 Pyrgula behningi Logvinenko et Starobogatov, 1968. - Vinarski \& Kantor: 236.

Status. Pontocaspian species, identity uncertain.

Type locality. Western part of the southern Caspian Sea, in the vicinity of the Kura River mouth, $39^{\circ} 05^{\prime} \mathrm{N}, 49^{\circ} 48^{\prime} \mathrm{E}, 120 \mathrm{~m}$.

Distribution. Type locality only.

Taxonomic notes. The drawings provided by Logvinenko and Starobogatov (1969) sketch a broad and conical shell. As such, it differs from the more elongate and ovoid Ulskia ulskii (Neubauer et al., 2018). A revision is required to clarify its taxonomic status.

Conservation status. Data Deficient (Vinarski, 2011c).

\section{?Ulskia derzhavini (Logvinenko \& Starobogatov, 1969)}

*1969 Pyrgula (Ulskia) derzhavini Logvinenko \& Starobogatov: 379, fig. 367(9).

2016 Pyrgula derzhavini Logvinenko et Starobogatov, 1968. - Vinarski \& Kantor: 237.

Status. Pontocaspian species, identity uncertain.

Type locality. Middle and southern Caspian Sea, 45-81 m.

Distribution. Type locality only. 
Taxonomic notes. The species differs from $U$. ulskii and $U$. behningi in the very slender elongate shape and the presence of a subsutural band; this suggests $P$. derzhavini might be likely a member of Caspia s.s. A revision is required to clarify its taxonomic status and generic placement.

Conservation status. Not assessed.

\section{Ulskia ulskii (Clessin \& Dybowski in Dybowski, 1887)}

${ }^{\star} 1887$ Caspia Ulskii Clessin \& Dybowski in Dybowski: 38-39.

1888 [Caspia] Ulskii n. sp. - Dybowski: 79, pl. 3, figs 8a-b.

1969 Pyrgula (Ulskia) nana Logvinenko \& Starobogatov: 379-380, fig. 367(12).

1969 Pyrgula (Ulskia) schorygini Logvinenko \& Starobogatov: 379, fig. 367(11).

2016 Pyrgula ulskii (Clessin et W. Dybowski in W. Dybowski, 1888). - Vinarski \& Kantor: 244.

2018 Ulskia ulskii (Clessin \& W. Dybowski in W. Dybowski, 1887). - Neubauer et al.: 52-54,

figs $5 \mathrm{~A}-\mathrm{K}$ [and synonyms therein].

Status. Accepted Pontocaspian species.

Type locality. Caspian Sea (no details).

Distribution. Western part of the Caspian Sea. This species was mentioned (as Turricaspia ulskii, T. schorgyni and T. nana) from depths between 200 and $400 \mathrm{~m}$ in the South Caspian basin of Azerbaijan (Mirzoev and Alekperov, 2017).

Taxonomic notes. This species was recently studied by Neubauer et al. (2018), who considered P. nana and P. schorygini as its junior synonyms.

Conservation status. Not assessed.

\section{Subfamily Hydrobiinae Stimpson, 1865}

Remarks. In addition to the taxa discussed below, the following species of Hydrobiinae have been mentioned from the Black Sea basin (updated statuses after MolluscaBase 2018a): Hydrobia aciculina (Bourguignat, 1876), H. acuta (Draparnaud, 1805), H. euryomphala (Bourguignat, 1876), H. mabilli (Bourguignat, 1876) [currently accepted as Peringia mabilli], H. macei Paladilhe, 1867 [currently accepted as Heleobia macei], H. procerula (Paladilhe, 1869) [currently considered a synonym of $H$. acuta] (Anistratenko et al., 2011). These species were described from the Western Mediterranean and their occurrence in the Black Sea region requires re-investigation; partly the records might be misidentifications of the species of Ecrobia listed below or Eupaludestrina (Cochliopidae) listed above. 
${ }^{\star} 1887$ Hydrobia grimmi Clessin in Dybowski: 55-56.

1888 [Hydrobia] grimmi Clessin. - Dybowski: 79, pl. 3, fig. 2.

2009 Caspiohydrobia grimmi (Clessin et Dybowski, 1888). - Filippov \& Riedel: 70-72, 74-76,

figs $4 \mathrm{a}-\mathrm{d}$.

Status. Accepted native Pontocaspian species.

Type locality. Caspian Sea (no details).

Distribution. Caspian Sea; Aral Sea; salt lakes near Chelyabinsk, Russia (Shishkoedova, 2010); Lake Sawa, Iraq (Haase et al., 2010); Arabian (Persian) Gulf (Glöer and Pešić, 2012); possibly also northern and central Kazakhstan and Tajikistan (Vinarski and Kantor, 2016), however, no molecular data are known to confirm the identity of the Central Asian snails. This species was mentioned (as Caspiohydrobia curta and C. gemma) from depths between 200 and $500 \mathrm{~m}$ in the South Caspian basin of Azerbaijan (Mirzoev and Alekperov, 2017).

Taxonomic notes. Most of the species that have been assigned to the genus Caspiohydrobia Starobogatov, 1970, including its type species, Pyrgohydrobia eichwaldiana Golikov \& Starobogatov, 1966, range within the morphological variability of E. grimmi. Previous examination of some Caspiohydrobia juvenile shells (Anistratenko, 2013; Filippov and Riedel, 2009; fig. 4A-C) as well as reproductive systems and radula did not find any criteria to support differentiation. Probably, all of the thirty Caspiohydrobia species listed by Kantor and Sysoev (2006) and Vinarski and Kantor (2016) for the Caspian Sea are morphotypes of a single species. Prelimary genetic analyses of Caspiohydrobia spp. from salt lakes near Chelyabinsk, Russia (TW, unpublished data) support this assumption.

Conservation status. Data Deficient (Vinarski, 2011d).

\section{Ecrobia maritima (Milaschewitch, 1916)}

${ }^{\star} 1916$ Hydrobia maritima Milaschewitch: 60-61, pl. 2, fig. 34.

1973 Hydrobia pontieuxini Radoman: 15-16.

1977 Ventrosia pontieuxini (Radoman, 1973). - Radoman: 210, pl. 21, figs 19-20.

1992 Pseudopaludinella cygnea Anistratenko in Anistratenko \& Prisjazhnjuk: 17, fig. 1a. 1992 Pseudopaludinella inflata Anistratenko in Anistratenko \& Prisjazhnjuk: 17-18, fig. 1 b. 1992 Pseudopaludinella ismailensis Anistratenko in Anistratenko \& Prisjazhnjuk: 18, fig. 1c. 2011 Pseudopaludinella pontieuxini (Radoman, 1973). - Anistratenko et al.: 78, pl. 3, fig. 4. 2015 Graecoanatolica yildirimi Glöer \& Pešić: 49-50, figs 10-14.

Status. Accepted, Pontocaspian species.

Type locality. Black Sea, at Feodosiya and Adler (Crimea, Ukraine). 
Distribution. Black Sea basin; northern Aegean Sea; Lake Sarikum, Turkey; northern Adriatic Sea.

Taxonomic notes. Hydrobia pontieuxini, described from the Black Sea coast in Mangalia, Romania, has been considered a synonym of E. maritima based on molecular data (Kevrekidis et al., 2005). Herein, we also consider the Pseudopaludinella species introduced by Anistratenko and Prisjazhnjuk (1992) as junior synonyms of E. maritima based on morphological similarities. A proper revision is still pending.

Conservation status. Not assessed.

\section{Ecrobia ventrosa (Montagu, 1803)}

${ }^{\star} 1803$ Turbo ventrosus Montagu: 317, pl. 12, fig. 13.

2012 Ecrobia ventrosa (Montagu 1803). - Kadolsky: 69-70.

2012 Hydrobia ventrosa (Montagu, 1803). - Welter-Schultes: 40, unnumbered textfigures.

Status. Accepted, immigrant species.

Type locality. On the Kent coast (United Kingdom), at Folkstone and Sandwich.

Distribution. Widespread along the coastal zones of northern and western Europe, the Mediterranean Sea, the Russia White Sea; introduced into the western Black Sea.

Taxonomic notes. Unpublished genetic data (TW) suggest that most previous records of E. ventrosa in the Black Sea are likely misidentifications of E. grimmi. A notable exception is a recent, genetically confirmed record from Constanța, Romania (Osikowski et al., 2016). Probably, the French species Paludestrina arenarum Bourguignat, 1876, P. leneumicra Bourguignat, 1876, P. paludinelliformis Bourguignat, 1876, and Ventrosia cissana Radoman, 1977, which have been listed for the Black Sea basin (Anistratenko, 1991; Anistratenko et al., 2011; Anistratenko and Prisyazhniuk, 1992), are junior synonyms or misidentifications of this species.

Conservation status. Least Concern (Van Damme, 2011a).

\section{Subfamily Pyrgulinae Brusina, 1882}

Remarks. The genus concepts of Pontocaspian Pyrgulinae follow the revision of Neubauer et al. (2018). Further change is expected in several of the keeled species here listed under?Turricaspia (?T. aenigma,?T. basalis,?T. dimidiata,?T. pseudobacuana, and?T. pseudodimiata) that may be grouped in an own genus for which the name Trachycaspia Dybowski \& Grochmalicki, 1917 (type species: Rissoa dimidiata Eichwald, 1838) is available. However, such a decision will require further documentation. 


\section{Clessiniola variabilis (Eichwald, 1838)}

${ }^{*} 1838$ Paludina variabilis Eichwald: 151-152.

1838 Paludina Triton Eichwald: 152.

1874 Bithynia? Eichwaldi Martens: 81.

?1887 Caspia Grimmi Clessin \& Dybowski in Dybowski: 39.

?1888 [Caspia] Grimmi n. sp. - Dybowski: 79, pl. 3, figs 5a-b.

1887 Clessinia Martensii Clessin \& Dybowski in Dybowski: 43.

1888 Clessinia Martensii n. sp. - Dybowski: 79, pl. 2, fig. 5.

1902a Clessinia ahngeri Westerlund: 45-46.

1966 P. [yrgula] (Clessiniola) pseudotriton Golikov \& Starobogatov: 356-357, fig. 2(3).

?1969 Pyrgula (Caspiella) derbentina Logvinenko \& Starobogatov: 374, fig. 366(8).

1969 Pyrgula (Caspiella) ovum Logvinenko \& Starobogatov: 374, fig. 366(9).

1969 Pyrgula (Caspiella) trivialis Logvinenko \& Starobogatov: 374-375, fig. 366(10).

1987 Turricaspia (Clessiniola) variabilis (Eichwald, 1838). - Alexenko \& Starobogatov: 34, textfig. 5.

1987 Turricaspia (Clessiniola) triton (Eichwald, 1838). - Alexenko \& Starobogatov: 34, textfig. 3.

1987 Turricaspia (Clessiniola) martensii (Clessin \& Dybowski in Dybowski, 1888). - Alexenko \&

Starobogatov: 34 , textfig. 4 .

1987 Turricaspia (Clessiniola) bogensis (Küster, 1852). - Alexenko \& Starobogatov: 34, not figured.

2006 Turricaspia variabilis (Eichwald, 1838). - Kantor \& Sysoev: 111, pl. 49, fig. J.

2011 Turricaspia martensii (Clessin et W. Dybowski in W. Dybowski, 1888). - Anistratenko et al.: 86,

fig. 3(17).

2011 Turricaspia triton (Eichwald, 1838). - Anistratenko et al.: 85-86, fig. 3(16).

2011 Turricaspia variabilis (Eichwald, 1838). - Anistratenko et al.: 85, fig. 3(15).

2014 Turricaspia variabilis. - Taviani et al.: 4, fig. 3b.

?2016 Turricaspia derbentina (Logvinenko et Starobogatov, 1968). - Vinarski \& Kantor: 247.

2016 Turricaspia martensii (Clessin et W. Dybowski in W. Dybowski, 1888). - Vinarski \&

Kantor: 248.

2016 Turricaspia ovum (Logvinenko et Starobogatov, 1968). - Vinarski \& Kantor: 248-249.

2016 Turricaspia pseudotriton (Golikov et Starobogatov, 1966). - Vinarski \& Kantor: 249.

2016 Turricaspia triton (Eichwald, 1838). - Vinarski \& Kantor: 250.

2016 Turricaspia trivialis (Logvinenko et Starobogatov, 1968). - Vinarski \& Kantor: 250-251.

2016 Turricaspia variabilis (Eichwald, 1838). - Vinarski \& Kantor: 251.

2018 Clessiniola variabilis (Eichwald, 1838). - Neubauer et al.: 60-63, figs 7A-I.

Status. Accepted Pontocaspian species.

Type locality. At the Volga River mouth near Astrakhan, and towards the Caspian Sea; also in recently lithified fossil limestone at the shores of Dagestan, Russia. 
Distribution. Caspian Sea, Azov Sea, and northern Black Sea region. This species was mentioned (as Turricaspia variabilis, T. derbentica and T. trivialis) in the South Caspian basin of Azerbaijan (Mirzoev and Alekperov, 2017).

Taxonomic notes. Neubauer et al. (2018) recently demonstrated the high variability of this species. Comparison of available illustrations and descriptions of the species listed in the synonymy list indicates that all of them range within this species' variability. Consequently, we consider all of them as junior synonyms of $C$. variabilis. A more in-depth review of the type material of the species involved is required to confirm this approach.

The status of Paludina bogensis Dubois in Küster (1852), which was listed as valid species of Turricaspia by Anistratenko and Stadnichenko (1995), is still unclear. That species was described from the Zapadnyi Bug River in Poland and closely resembles C. variabilis. It is, however, unlikely that a Pontocaspian species typical for oligohaline conditions occurs so far away in a pure freshwater environment. "Paludina eichwaldi Krynicki, 1837" found in the literature is a nomen nudum. Martens (1874) provided measurements and made the name thereby available, but he listed Paludina variabilis Eichwald, 1838 in synonymy, which has priority. Dybowski (1887) obviously overlooked this and considered Nematurella eichwaldi Krynicki a valid species. We follow Vinarski and Kantor (2016) and consider the species as a junior synonym of Clessiniola variabilis.

Conservation status. Least Concern (Cioboiu et al., 2011).

\section{Laevicaspia abichi (Logvinenko \& Starobogatov, 1969)}

*1969 Pyrgula (Caspiella) abichi Logvinenko \& Starobogatov: 372, fig. 366(3).

2016 Pyrgula abichi Logvinenko et Starobogatov, 1968. - Vinarski \& Kantor: 235.

Status. Accepted Pontocaspian species.

Type locality. Southern and western parts of the Middle Caspian Sea, 36-120 m.

Distribution. Middle and South Caspian basin. This species was mentioned (as Turricaspia abichi) from depths between 200 and $400 \mathrm{~m}$ in the South Caspian basin of Azerbaijan (Mirzoev and Alekperov, 2017).

Taxonomic notes. The species differs from the L. cincta in its much larger size, the conical shape, the narrower subsutural band and the larger aperture (compare Neubauer et al. 2018).

Conservation status. Data Deficient (Vinarski, 2011e).

\section{Laevicaspia caspia (Eichwald, 1838)}

${ }^{*} 1838$ Rissoa caspia Eichwald: 154-155.

non 1888 Micr.[omelania] caspia Eichw. sp. - Dybowski: 78, pl. 1, fig. 1.

?1896 B.[uliminus] (Napaeus?) goebeli Westerlund: 188. 
1915 Micromelania (?) curta Nalivkin: 21-22, 31, pl. 6, figs 1-2 [pars, non figs 3-4, 7, 9-14].

1915 [Micromelania (?) curta] var. plano-convexa Nalivkin: 22, 31, pl. 6, figs 15-18.

non 1915 Micromelania caspia Eichw. - Nalivkin: 22, 31, pl. 6, figs 5-6 [pars, non fig. 8].

non 1917 Micromelania (Turricaspia, Laevicaspia) caspia Eichw. - Dybowski \& Grochmalicki: 5-8,

36-38, pl. 1, figs 1-3.

non 1969 Pyrgula caspia (Eichw.). - Logvinenko \& Starobogatov: 369-370, fig. 364(1).

2006 Turricaspia caspia (Eichwald, 1838). - Kantor \& Sysoev: 106, pl. 49, fig. M.

2016 Turricaspia caspia (Eichwald, 1838). - Vinarski \& Kantor: 246.

2018 Laevicaspia caspia (Eichwald, 1838). - Neubauer et al.: 63-66, figs 8A-K [and

synonyms therein].

Status. Accepted Pontocaspian species.

Type locality. In fossil limestone of Dagestan, Russia.

Distribution. Endemic to the Caspian Sea. This species was mentioned (as Turricaspia caspia and T. curta) from depths between 200 and $500 \mathrm{~m}$ in the South Caspian basin of Azerbaijan (Mirzoev and Alekperov, 2017).

Taxonomic notes. For a detailed discussion about the identity of this species, its synonyms and former misidentifications, see Neubauer et al. (2018).

Conservation status. IUCN indicates "Least Concern" (Vinarski, 2012), but the true status of this species is highly uncertain.

\section{Laevicaspia cincta (Abich, 1859)}

${ }^{\star} 1859$ Rissoa cincta Abich: 57, pl. 2, fig. 6 .

?1887 Caspia Orthii Clessin \& Dybowski in Dybowski: 40.

?1888 [Caspia] Orthii n. sp. - Dybowski: 79, pl. 3, fig. 6.

1969 Pyrgula (Caspiella) cincta (Abich). - Logvinenko \& Starobogatov: 372, fig. 366(4).

2006 Pyrgula cincta (Abich, 1859). - Kantor \& Sysoev: 98, pl. 47, fig. L.

2016 Pyrgula cincta (Abich, 1859). - Vinarski \& Kantor: 236-237.

2018 Laevicaspia cincta (Abich, 1859). - Neubauer et al.: 66-68, figs 9A-H.

Status. Accepted Pontocaspian species.

Type locality. Gulf of Baku, Azerbaijan.

Distribution. Southern Caspian Sea (Logvinenko and Starobogatov 1969).

Taxonomic notes. For a detailed discussion about the identity of this species and its synonym, see Neubauer et al. (2018).

Conservation status. Data Deficient (Vinarski, 2011f). 


\section{Laevicaspia conus (Eichwald, 1838)}

${ }^{\star} 1838$ Rissoa Conus Eichwald: 155.

non 1876 Eulima conus, Eichw?. - Grimm: 154-156, pl. 6, fig. 14.

non 2006 Turricaspia conus conus (Eichwald, 1838). - Kantor \& Sysoev: 106, pl. 48, fig. J.

2016 Turricaspia conus conus (Eichwald, 1838). - Vinarski \& Kantor: 246-247.

2018 Laevicaspia conus (Eichwald, 1838). - Neubauer et al.: 69-71, figs 9I-P [and synonyms therein].

Status. Accepted Pontocaspian species.

Type locality. In fossil limestone of Dagestan, Russia.

Distribution. Endemic to the Caspian Sea (Logvinenko and Starobogatov 1969). This species was mentioned (as Turricaspia conus) from depths between 200 and $300 \mathrm{~m}$ in the South Caspian basin of Azerbaijan (Mirzoev and Alekperov, 2017).

Taxonomic notes. For a detailed discussion about the identity of this polymorphic species and previous misidentifications, see Neubauer et al. (2018).

Conservation status. Data Deficient (Vinarski, 2011g).

\section{?Laevicaspia ebersini (Logvinenko \& Starobogatov, 1969)}

*1969 Pyrgula (Oxypyrgula) ebersini Logvinenko \& Starobogatov: 368, fig. 363(7).

2016 Pyrgula ebersini Logvinenko et Starobogatov, 1968. - Vinarski \& Kantor: 238.

Status. Pontocaspian species, identity uncertain.

Type locality. Western part of the middle Caspian Sea, 0-50 m water depth.

Distribution. Type locality only.

Taxonomic notes. We cannot verify the status of this species given the inadequate descriptions and illustrations and its general resemblance to other species that were described earlier.

Conservation status. Data Deficient (Vinarski, 2011h).

\section{?Laevicaspia ismailensis (Golikov \& Starobogatov, 1966)}

${ }^{\star} 1966$ P. [yrgula] ismailensis Golikov \& Starobogatov: 358, fig. 2(11).

2006 Turricaspia ismailensis (Golikov et Starobogatov, 1966). - Kantor \& Sysoev: 108, pl. 50, fig. A.

2016 Turricaspia ismailensis (Golikov et Starobogatov, 1966). - Vinarski \& Kantor: 248.

Status. Accepted Pontocaspian species.

Type locality. Ukraine, Danube Delta, lakes Yalpug and Kugurlui.

Distribution. North-western Black Sea basin (Anistratenko and Stadnichenko 1995). 
Taxonomic notes. Based on the illustration of the holotype in Kantor and Sysoev (2006), we tentatively place the species in the genus Laevicaspia. A more detailed study is necessary to clarify its systematic position.

Conservation status. Vulnerable (Son and Cioboiu, 2011).

\section{Laevicaspia kolesnikoviana (Logvinenko \& Starobogatov in Golikov \& Starobogatov, 1966)}

*1966 P.[yrgula] (Caspiella) kolesnikoviana Golikov \& Starobogatov: 357-358, fig. 2(8-9).

1969 Pyrgula [(Caspiella)] kolesnikoviana Logv. et Star. - Logvinenko \& Starobogatov: 372,

fig. 366 (1).

2006 Pyrgula kolesnikoviana Logvinenko et Starobogatov in Golikov et Starobogatov, 1966. - Kantor

\& Sysoev: 100, pl. 47, fig. N.

2016 Pyrgula kolesnikoviana Logvinenko et Starobogatov in Golikov et Starobogatov, 1966. -

Vinarski \& Kantor: 239.

2018 Laevicaspia kolesnikoviana (Logvinenko \& Starobogatov in Golikov \& Starobogatov, 1966). -

Neubauer et al.: 71-73, figs 10A-E, K, N.

Status. Accepted Pontocaspian species.

Type locality. Caspian Sea, northward of Apsheron Peninsula, north-westward from Kamni Dva Brata Island, $40^{\circ} 47^{\prime} \mathrm{N}, 49^{\circ} 42^{\prime} \mathrm{E}, 30 \mathrm{~m}$ water depth.

Distribution. Endemic to the Caspian Sea. This species was mentioned (as Turricaspia kolesnikoviana) from depths between 200 and $400 \mathrm{~m}$ in the South Caspian basin of Azerbaijan (Mirzoev and Alekperov, 2017).

Taxonomic notes. For a detailed discussion about the identity of this species, see Neubauer et al. (2018).

Conservation status. Data Deficient (Vinarski, 2011i).

\section{Laevicaspia kowalewskii (Clessin \& Dybowski in Dybowski, 1887)}

${ }^{\star} 1887$ Caspia Kowalewskii Clessin \& Dybowski in Dybowski: 40-41.

1888 [Caspia] Kowalewskii n. sp. - Dybowski: 79, pl. 3, figs 9a-c.

2006 Pyrgula kowalewskii (Clessin et W. Dybowski in W. Dybowski, 1888). - Kantor \& Sysoev: 100, pl. 47, fig. M.

2016 Pyrgula kowalewskii (Clessin et W. Dybowski in W. Dybowski, 1888). - Vinarski \& Kantor:

239-240.

Status. Accepted Pontocaspian species.

Type locality. Caspian Sea (no details). 
Distribution. Caspian Sea, recorded from southern basin (Logvinenko and Starobogatov, 1969) and middle basin (personal observation based on material from Dagestan region, TAN, FW). This species was mentioned (as Turricaspia kowalewskii) from depths between 200 and $300 \mathrm{~m}$ in the South Caspian basin of Azerbaijan (Mirzoev and Alekperov, 2017).

Taxonomic notes. This species differs from L. kolesnikoviana in its bigger size, broader shape, and thinner peristome. Laevicaspia cincta can be distinguished based on the stouter shape and the presence of a narrow subsutural band.

Conservation status. Not assessed.

\section{Laevicaspia lencoranica (Logvinenko \& Starobogatov, 1969)}

*1969 Pyrgula (Eurycaspia) lencoranica Logvinenko \& Starobogatov: 357, fig. 358(14).

2016 Pyrgula lencoranica Logvinenko et Starobogatov, 1968. - Vinarski \& Kantor: 240.

Status. Pontocaspian species, identity uncertain.

Type locality. Caspian Sea (no details).

Distribution. Caspian Sea (Logvinenko and Starobogatov 1969).

Taxonomic notes. Based on the illustrations provided in Kantor and Sysoev (2006), this species differs from L. cincta and L. kowalewskii in the conical shape and large body whorl. A revision is required to assure its status as distinct species.

Conservation status. Not assessed.

\section{Laevicaspia lincta (Milaschewitch, 1908)}

*1908 Micromelania lincta Milaschewitch: 991.

?1966 P. [yrgula] (Caspiella) azovica Golikov \& Starobogatov: 357, fig. 2(7).

?1966 P.[yrgula] (Caspiella) boltovskoji Golikov \& Starobogatov: 357, fig. 2(4).

?1966 P.[yrgula] (Caspiella) crimeana Golikov \& Starobogatov: 358, fig. 2(10).

?1966 P.[yrgula] (Caspiella) limanica Golikov \& Starobogatov: 357, fig. 2(6).

?1966 P. [yrgula] (Caspiella) lindholmiana Golikov \& Starobogatov: 357, fig. 2(5).

?1966 P.[yrgula] (Laevicaspia) iljinae Golikov \& Starobogatov: 358-359, fig. 2(14).

?1966 P.[yrgula] (Laevicaspia) milachevitchi Golikov \& Starobogatov: 359, fig. 2(15).

?1966 P.[yrgula] (Laevicaspia) ostroumovi Golikov \& Starobogatov: 358, fig. 2(13).

?1966 P.[yrgula] (Turricaspia) borceana Golikov \& Starobogatov: 359, fig. 2(16).

?1966 P. [yrgula] (Turricaspia) nevesskae Golikov \& Starobogatov: 359, fig. 2(17).

?1987 Turricaspia abichi phaseolinica Alexenko \& Starobogatov: 33.

?1987 Turricaspia (Caspiella) derbentina borysthenica Alexenko \& Starobogatov: 34-35, fig. 6.

?1987 Turricaspia (Laevicaspia) grigorievi Alexenko \& Starobogatov: 35, fig. 7. 
?1987 Turricaspia (Laevicaspia) meneghiniana ukrainica Alexenko \& Starobogatov: 35, fig. 9.

?2006 Euxinipyrgula azovica (Golikov et Starobogatov, 1966). - Kantor \& Sysoev: 95, pl. 44, fig. K. ?2006 Euxinipyrgula borysthenica (Alexenko et Starobogatov, 1987). - Kantor \& Sysoev: 95,

pl. 44, fig. J.

?2006 Euxinipyrgula grigorievi (Alexenko et Starobogatov, 1987). - Kantor \& Sysoev: 95, pl. 44, fig. I. ?2006 Euxinipyrgula limanica (Golikov et Starobogatov, 1966). - Kantor \& Sysoev: 95, pl. 44, fig. H. 2006 Euxinipyrgula lincta (Milaschewitsch, 1908). - Kantor \& Sysoev: 95-96, pl. 45, fig. D.

?2006 Euxinipyrgula milachevitchi (Golikov et Starobogatov, 1966). - Kantor \& Sysoev: 96, pl. 45,

fig. C.

?2006 Euxinipyrgula ostroumovi (Golikov et Starobogatov, 1966). - Kantor \& Sysoev: 96, pl. 45, fig. B. ?2006 Euxinipyrgula ukrainica (Alexenko et Starobogatov, 1987). - Kantor \& Sysoev: 95, pl. 45, fig. A. ?2006 Turricaspia boltovskoji (Golikov et Starobogatov, 1966). - Kantor \& Sysoev: 105-106, pl. 48,

fig. K.

?2006 Turricaspia borceana (Golikov et Starobogatov, 1966). - Kantor \& Sysoev: 106, pl. 49, fig. B.

?2006 Turricaspia conus lindholmiana (Golikov et Starobogatov, 1966). - Kantor \& Sysoev: 107,

pl. 48 , fig. L.

?2006 Turricaspia crimeana (Golikov et Starobogatov, 1966). - Kantor \& Sysoev: 107, pl. 48, fig. C. ?2006 Turricaspia iljinae (Golikov et Starobogatov, 1966). - Kantor \& Sysoev: 108, pl. 49, fig. D. ?2006 Turricaspia nevesskae (Golikov et Starobogatov, 1966). - Kantor \& Sysoev: 109, pl. 49, fig. L.

Status. Accepted Pontocaspian species.

Type locality. Kotlabukh Lake, Odessa Region, Ukraine (approximately $45^{\circ} 25^{\prime} 35^{\prime \prime} \mathrm{N}$, $\left.28^{\circ} 59^{\prime} 41^{\prime \prime} \mathrm{E}\right)$.

Distribution. Limans and lower reaches of rivers Don, Dnieper, Dniester, and Southern Bug entering the northern Black Sea basin and the Azov Sea (Taganrog Bay), as well as in coastal lakes Kotlabukh and Yalpug (Vinarski and Kantor 2016). The record of an undescribed subspecies of T. boltovskoji from the Caspian Sea mentioned by Anistratenko and Stadnichenko (1995) is probably based on a misidentification.

Taxonomic notes. Golikov and Starobogatov (1966) and Alexenko and Starobogatov (1987) introduced a plethora of names for morphologically similar species from the northern Black Sea basin, partly deriving from subfossil horizons. They differ from Laevicaspia lincta slightly in the number of whorls and outline shape, but overall range within its morphological variability. Here, we consider them tentatively all junior synonyms of L. lincta. Since Starobogatov's type material is unknown, support for this approach requires collection of new material from the type localities of these taxa. Molecular data (Wilke et al., 2007) confirmed the conspecifity of L. lincta and L. milachevitchi.

Conservation status. Least Concern (Son, 2011d). 


\section{?Laevicaspia marginata (Westerlund, 1902)}

${ }^{\star}$ 1902a Nematurella marginata Westerlund: 45.

2013 Pyrgula marginata (Westerlund, 1902). - Vinarski et al.: 85, fig. 2F.

2016 Pyrgula marginata (Westerlund, 1902). - Vinarski \& Kantor: 240.

Status. Pontocaspian species, identity uncertain.

Type locality. Caspian Sea, "near Krasnojarsk" (Westerlund 1902a). This statement is clearly erroneous since Krasnojarsk is situated in Siberia. Most probably, Westerlund meant Krasnovodsk (nowadays Turkmenbashi) in Turkmenistan (Vinarski et al., 2013).

Distribution. Endemic to the Caspian Sea. This species was mentioned (as Turricaspia marginata) from depths between 200 and $300 \mathrm{~m}$ in the South Caspian basin of Azerbaijan (Mirzoev and Alekperov, 2017).

Taxonomic notes. The status of this species is uncertain. The illustrations of the type material by Vinarski et al. (2013) suggest a tentative placement in the genus Laevicaspia. It shows close similarities with L. sieversii (Clessin in Dybowski, 1887). A careful revision of the species is required to clarify its taxonomic status and systematic placement.

Conservation status. Not assessed.

\section{Laevicaspia sieversii (Clessin in Dybowski, 1887)}

${ }^{\star} 1887$ Nematurella Sieversii Clessin in Dybowski: 45-46.

1888 Nematurella Sieversi [sic] n. sp. - Dybowski: 78, pl. 2, fig. 1.

Status. Pontocaspian species, identity uncertain.

Type locality. Caspian Sea (no details).

Distribution. Endemic to the Caspian Sea.

Taxonomic notes. This species has not been found since its first description, its identity is unclear (Vinarski and Kantor, 2016). Judging from the description and drawing in Dybowski (1887), we suggest a systematic placement in Laevicaspia. It might be related to L. conus (Eichwald, 1838).

Conservation status. Not assessed.

\section{?Turricaspia aenigma (Logvinenko \& Starobogatov, 1969)}

*1969 Pyrgula (Celekenia) aenigma Logvinenko \& Starobogatov: 375, fig. 366(12).

2016 Pyrgula aenigma Logvinenko et Starobogatov, 1968. - Vinarski \& Kantor: 235.

Status. Pontocaspian species, identity uncertain. 
Type locality. Caspian Sea, northward of Apsheron Peninsula, 75 m.

Distribution. Type locality only.

Taxonomic notes. The identity of this species is unclear. The illustrations of the holotype in Kantor and Sysoev (2006) show a small shell with four whorls, of which the latter two bear a distinct keel. The small size and the relatively large protoconch suggest that the type specimen is a juvenile shell. More material (including adult specimens) are required to shed light on this species' identity.

Conservation status. Not assessed.

\section{Turricaspia andrussowi (Dybowski \& Grochmalicki, 1915)}

*1915 Micromelania (Turricaspia) andrussowi Dybowski \& Grochmalicki: 125-126, pl. 3, figs 31a-b. ?1969 Pyrgula (Oxypyrgula) dubia Logvinenko \& Starobogatov: 368, fig. 363(5).

?1969 Pyrgula (Oxypyrgula) turkmenica Logvinenko \& Starobogatov: 368, fig. 363(6).

2006 Turricaspia andrussowi (B. Dybowski et Grochmalicki, 1915). - Kantor \& Sysoev: 104-105,

pl. 48, fig. A [pars, excluding synonymy].

2016 Turricaspia andrussowi (B. Dybowski et Grochmalicki, 1915). - Vinarski \& Kantor: 245

[pars, excluding synonymy].

2018 Turricaspia andrussowi (B. Dybowski \& Grochmalicki, 1915). - Neubauer et al.: 74-76,

figs $11 \mathrm{~A}-\mathrm{B}$.

Status. Accepted Pontocaspian species.

Type locality. Caspian Sea (no details).

Distribution. Endemic to the Caspian Sea. The two tentative synonyms were recorded from the western part of the middle Caspian Sea and the eastern part of the southern Caspian Sea, respectively. This species was mentioned (as T. turkmenica, T. dubia and T. andrussowi) from depths between 200 and $500 \mathrm{~m}$ in the South Caspian basin of Azerbaijan (Mirzoev and Alekperov, 2017).

Taxonomic notes. The species was recently investigated by Neubauer et al. (2018). Pyrgula dubia and P. turkmenica are tentatively considered juveniles and thus junior synonyms of this species.

Conservation status. Not assessed.

\section{?Turricaspia basalis (Dybowski \& Grochmalicki, 1915)}

^1915 Micromelania dimidiata var. basalis Dybowski \& Grochmalicki: 131, pl. 3, figs 36a-b. 1969 Pyrgula (Trachycaspia) laticarinata Logvinenko \& Starobogatov: 359, fig. 359(3). 2006 Pyrgula basalis basalis (B. Dybowski \& J. Grochmalicki, 1915). - Kantor \& Sysoev: 97, pl. 46, fig. A. 
2006 Pyrgula basalis laticarinata Logvinenko et Starobogatov, 1968. - Kantor \& Sysoev: 97, pl. 46, fig. B.

2016 Pyrgula basalis basalis (B. Dybowski et Grochmalicki, 1915). - Vinarski \& Kantor: 236.

2016 Pyrgula basalis laticarinata Logvinenko et Starobogatov, 1968. - Vinarski \& Kantor: 236.

Status. Pontocaspian species, identity uncertain.

Type locality. Caspian Sea (no details).

Distribution. Middle and southern Caspian Sea (Logvinenko and Starobogatov 1969). This species was mentioned (as T. laticarinata) from depths between 200 and $400 \mathrm{~m}$ in the South Caspian basin of Azerbaijan (Mirzoev and Alekperov, 2017).

Taxonomic notes. The species is characterized by a massive keel near the lower suture.?Turricaspia dimidiata is distinguished based on its more centrally placed keel. This distinction is tentative and only based on comparison of available illustrations; we are aware of the possibility that these differences might not be diagnostic. Moreover, the keel seems to become stronger with increasing water depth (Starobogatov, 1968). Pyrgula laticarinata Logvinenko \& Starobogatov, 1969, which differs from T. basalis only in the strength of the keels, was considered a junior synonym by Neubauer et al. (2018).

Conservation status. Not assessed.

\section{?Turricaspia bogatscheviana (Logvinenko \& Starobogatov, 1969)}

*1969 Pyrgula (Oxypyrgula) bogatscheviana Logvinenko \& Starobogatov: 367, fig. 363(2).

2016 Turricaspia bogatscheviana (Logvinenko et Starobogatov, 1968). - Vinarski \& Kantor: 245.

Status. Pontocaspian species, identity uncertain.

Type locality. Western part of the Caspian Sea.

Distribution. Type locality only.

Taxonomic notes. The description and drawing of this species provided by Logvinenko and Starobogatov (1969) do not allow an evaluation whether it is a distinct species or synonym of a previously species.

Conservation status. Not assessed.

\section{Turricaspia chersonica Alexenko \& Starobogatov, 1987}

*1987 Turricaspia (Oxypyrgula) chersonica Alexenko \& Starobogatov: 35-36, fig. 10.

2016 Turricaspia chersonica Alexenko et Starobogatov, 1987. - Vinarski \& Kantor: 246.

Status. Pontocaspian species, identity uncertain. 
Type locality. Ukraine, in the Dnieper Delta.

Distribution. Type locality only.

Taxonomic notes. The status of this species is highly uncertain. The slender conical shell illustrated by Alexenko and Starobogatov (1987) suggest classification in the genus Turricaspia, which is otherwise only known from the Caspian Sea.

Conservation status. Data Deficient (Son, 2011e).

\section{Turricaspia columna (Logvinenko \& Starobogatov, 1969)}

*1969 Pyrgula (Oxypyrgula) columna Logvinenko \& Starobogatov: 368, fig. 363(8).

2016 Pyrgula columna Logvinenko et Starobogatov, 1968. - Vinarski \& Kantor: 237.

Status. Pontocaspian species, identity uncertain.

Type locality. Western part of the southern Caspian Sea.

Distribution. Type locality only.

Taxonomic notes. The species has not been found since its first description, and the whereabouts of the type material is unknown. Logvinenko and Starobogatov (1969) illustrate a small slender shell with convex whorls. It might well be a juvenile of another species.

Conservation status. Not assessed.

\section{Turricaspia concinna (Logvinenko \& Starobogatov, 1969)}

^1969 Pyrgula (Turricaspia) concinna Logvinenko \& Starobogatov: 365, fig. 362(3).

2016 Pyrgula concinna Logvinenko et Starobogatov, 1968. - Vinarski \& Kantor: 237.

Status. Pontocaspian species, identity uncertain.

Type locality. Middle Caspian Sea, 25-80 m.

Distribution. Type locality only.

Taxonomic notes. The illustrations provided by Logvinenko and Starobogatov (1969) indicate a large conical shell with nine convex whorls and a large, slightly inflated last whorl. These features are reminiscent of T. meneghiniana (Issel, 1865). However, T. concinna has not been found since its first description. The type material has been very recently detected in the collections of ZIN and awaits further study.

Conservation status. Not assessed.

Turricaspia dagestanica (Logvinenko \& Starobogatov, 1969)

*1969 Pyrgula (Turricaspia) dagestanica Logvinenko \& Starobogatov: 361, fig. 360(3). 
2016 Turricaspia dagestanica (Logvinenko et Starobogatov, 1968). - Vinarski \& Kantor: 247.

Status. Pontocaspian species, identity uncertain.

Type locality. Western shore of the middle Caspian Sea.

Distribution. Middle and south basin of Caspian Sea. This species was mentioned from depths between 200 and $300 \mathrm{~m}$ in the South Caspian basin of Azerbaijan (Mirzoev and Alekperov, 2017).

Taxonomic notes. The status of this species is highly uncertain. The illustrations of Logvinenko and Starobogatov (1969) show a slightly distorted shell with weakly convex whorls and a thin line below the suture. We are uncertain whether it might concern a growth aberration of a more common species.

Conservation status. Data Deficient (Vinarski, 2011j).

\section{Turricaspia dimidiata (Eichwald, 1838)}

*1838 Rissoa dimidiata Eichwald: 156.

?1947 Turricaspia bakuana Kolesnikov: 108, 112.

2006 Pyrgula dimidiata (Eichwald, 1838). - Kantor \& Sysoev: 99, pl. 46, fig. K.

?2006 Pyrgula bakuana (Kolesnikov, 1947). - Kantor \& Sysoev: 97, pl. 47, fig. C.

2016 Pyrgula dimidiata (Eichwald, 1838). - Vinarski \& Kantor: 238.

2016 Pyrgula bakuana (Kolesnikov, 1947). - Vinarski \& Kantor: 236-237.

Status. Accepted Pontocaspian species.

Type locality. In fossil limestone of Dagestan, Russia.

Distribution. Middle and southern Caspian Sea (Logvinenko and Starobogatov 1969). This species was mentioned from depths between 200 and $500 \mathrm{~m}$ in the South Caspian basin of Azerbaijan (Mirzoev and Alekperov, 2017).

Taxonomic notes. Although there is little doubt about the validity of this species, its true identity and possible synonyms are unclear. Eichwald's (1838) description clearly indicates a slender shell with median keel. His type material is unfortunately unknown. The high number of keeled species complicates an evaluation what is the "true" T. dimidiata and what are synonyms. We tentatively consider Turricaspia bakuana Kolesnikov, 1947 a junior synonym of this species, based on its slender shell with median keel matching Eichwald's description as well as the prevailing concept of T. dimidiata (compare Kantor and Sysoev 2006). More data are required to support this view.

Conservation status. Not assessed.

\section{Turricaspia eburnea (Logvinenko \& Starobogatov, 1969)}


*1969 Pyrgula (Laevicaspia) eburnea Logvinenko \& Starobogatov: 370, fig. 365(1).

2016 Turricaspia eburnea (Logvinenko et Starobogatov, 1968). - Vinarski \& Kantor: 247.

Status. Pontocaspian species, identity uncertain.

Type locality. Eastern part of the southern Caspian Sea.

Distribution. South Caspian basin. This species was mentioned from depths between 200 and $500 \mathrm{~m}$ in the South Caspian basin of Azerbaijan (Mirzoev and Alekperov, 2017).

Taxonomic notes. The identity of this species is unclear. Its shell resembles T. lyrata (Dybowski \& Grochmalicki, 1915) in terms of general shape and the large, flat protoconch; it differs from that species in the large size. The type material has been very recently found in the collection of ZIN and awaits further study. Until then, we refrain from a final decision on the species' status, but we have severe doubt that Pyrgula eburnea is a distinct species.

Conservation status. Not assessed.

\section{Turricaspia elegantula (Clessin \& Dybowski in Dybowski, 1887)}

${ }^{\star} 1887$ Micromelania elegantula Clessin \& Dybowski in Dybowski: 33.

1888 [Micromelania] elegantula n. sp. - Dybowski: 78, pl. 1, figs 7a-c.

2016 Turricaspia elegantula (Clessin et W. Dybowski in W. Dybowski, 1888). - Vinarski \& Kantor:

247-248.

Status. Pontocaspian species, identity uncertain.

Type locality. Caspian Sea (no details).

Distribution. Endemic to the Caspian Sea. This species was mentioned from depths between 200 and $300 \mathrm{~m}$ in the South Caspian basin of Azerbaijan (Mirzoev and Alekperov, 2017).

Taxonomic notes. There is considerable confusion about the identity of this species. Dybowski (1887) described and illustrated a very slender shell with a distinct whorl profile showing a straight-sided upper half and a convex lower half. In contrast, the illustrations in Logvinenko and Starobogatov (1969) suggest a similarly slender yet distorted shell with near almost sided whorls and expanded aperture. A restudy of the type material of T. elegantula show close similarities to T. spica. It differs from that species in the slenderer outline and flattened whorls.

Conservation status. Not assessed.

\section{Turricaspia eulimellula (Dybowski \& Grochmalicki, 1915)}

*1915 Micromelania (Turricaspia) eulimellula Dybowski \& Grochmalicki: 123-125, pl. 3, figs 27a-b. 2006 Pyrgula eulimellula (B. Dybowski et J. Grochmalicki, 1915). - Kantor \& Sysoev: 99-100, pl. 46, fig. L. 
2016 Pyrgula eulimellula (B. Dybowski et Grochmalicki, 1915). - Vinarski \& Kantor: 238-239.

Status. Accepted Pontocaspian species.

Type locality. Caspian Sea (no details).

Distribution. Middle Caspian Sea basin (Logvinenko and Starobogatov 1969). This species was mentioned from depths between 200 and $400 \mathrm{~m}$ in the South Caspian basin of Azerbaijan (Mirzoev and Alekperov, 2017).

Taxonomic notes. The near straight-sided, strongly attached whorls easily distinguish this species from most other Turricaspia species. Only Turricaspia grimmi (Clessin \& Dybowski in Dybowski, 1887) has a similar whorl arrangement, but its shell is slightly wider and the whorls are weakly stepped and bear a thin subsutural band.

Conservation status. Not assessed.

\section{Turricaspia fedorovi (Logvinenko \& Starobogatov, 1969)}

*1969 Pyrgula (Turricaspia) fedorovi Logvinenko \& Starobogatov: 362, fig. 360(2).

2016 Pyrgula fedorovi Logvinenko et Starobogatov, 1968. - Vinarski \& Kantor: 239.

Status. Pontocaspian species, identity uncertain.

Type locality. Western part of the middle Caspian Sea, $80 \mathrm{~m}$.

Distribution. Middle and South Caspian basin. This species was mentioned from depths between 200 and $400 \mathrm{~m}$ in the South Caspian basin of Azerbaijan (Mirzoev and Alekperov, 2017).

Taxonomic notes. The slender elongate shell with whorls slowly increasing in height distinguish this species from its congeners. However, a proper assessment of the species' status requires investigation. The whereabouts of the type material is unknown and no other records of this species are known. Currently, we are not able to verify the status of this species.

Conservation status. Not assessed.

\section{Turricaspia grimmi (Clessin \& Dybowski in Dybowski, 1887)}

*1887 Micromelania Grimmi Clessin \& Dybowski in Dybowski: 27-29.

1888 [Micromelania] Grimmi n. sp. - Dybowski: 78, pl. 1, figs 2a-c.

2006 Pyrgula grimmi (Clessin et W. Dybowski in W. Dybowski, 1888). - Kantor \& Sysoev: 100, pl. 46, fig. L.

2016 Pyrgula grimmi (Clessin et W. Dybowski in W. Dybowski, 1888). - Vinarski \& Kantor: 239.

Status. Accepted Pontocaspian species.

Type locality. Caspian Sea (no details). 
Distribution. Southern Caspian Sea basin (Logvinenko and Starobogatov, 1969). This species was mentioned from depths between 200 and $300 \mathrm{~m}$ in the South Caspian basin of Azerbaijan (Mirzoev and Alekperov, 2017).

Taxonomic notes. The peculiar morphology with straight-sided, weakly stepped whorls with a thin subsutural band is unique among Caspian Pyrgulinae. See above for a comparison with $T$. eulimellula.

Conservation status. Data Deficient (Vinarski, 2011k).

\section{Turricaspia lyrata (Dybowski \& Grochmalicki, 1915)}

*1915 Micromelania (Turricaspia) spica var. lyrata Dybowski \& Grochmalicki: 117, pl. 2, fig. 18. 2006 Pyrgula lirata [sic] (B. Dybowski et J. Grochmalicki, 1915). - Kantor \& Sysoev: 101, pl. 46,

fig. E.

2016 Pyrgula lirata [sic] (B. Dybowski et Grochmalicki, 1915). - Vinarski \& Kantor: 240.

2018 Turricaspia lyrata (B. Dybowski \& Grochmalicki, 1915). - Neubauer et al.: 77-79, figs 12A-K

[and synonyms therein].

Status. Accepted Pontocaspian species.

Type locality. Caspian Sea (no details).

Distribution. Endemic to the Caspian Sea (after Logvinenko and Starobogatov 1969); it occurs in the western part of the middle and southern Caspian Sea basins, but these authors used a slightly different concept of the species. This species was mentioned (as Turricaspia lirata) from depths between 200 and $300 \mathrm{~m}$ in the South Caspian basin of Azerbaijan (Mirzoev and Alekperov, 2017).

Taxonomic notes. See Neubauer et al. (2018) for a detailed discussion of the species and its synonyms.

Conservation status. Not assessed.

\section{Turricaspia marisnigri Starobogatov in Alexenko \& Starobogatov, 1987}

*1987 Turricaspia lirata marisnigri Starobogatov in Alexenko \& Starobogatov: 33.

Status. Pontocaspian species, identity uncertain.

Type locality. "Meotida" station 24, sample 229, near the coast of Crimea, in phaseoline silt (Holocene).

Distribution. Type locality only.

Taxonomic notes. The species can be distinguished based on its extremely slender shell with whorls slowly increasing. Still, clarification of its identity as well as its genus classification requires investigation of material. 
Conservation status. So far only known from Holocene deposits of the type locality; species might be extinct. Within Holocene deposits in the Black Sea small amounts of reworked Late Pleistocene "Neoeuxinian" faunas are found (FW, pers. obs.), and therefore the stratigraphic origin of such Pontocaspian species is uncertain.

\section{Turricaspia meneghiniana (Issel, 1865)}

${ }^{\star} 1865$ Bythinia Meneghiniana Issel: 21, pl. 1, figs 12-13.

1902a Micromelania subulata Westerlund: 47.

?1969 Pyrgula caspia (Eichw). - Logvinenko \& Starobogatov: 369-370, fig. 364(1) [non Rissoa caspia

Eichwald, 1838].

non 1987 T.[urricaspia] meneghiniana meneghiniana (Iss.). - Alexenko \& Starobogatov: 35, fig. 8.

2006 Turricaspia meneghiniana (Issel, 1865). - Kantor \& Sysoev: 109, pl. 49, fig. E.

2016 Turricaspia meneghiniana (Issel, 1865). - Vinarski \& Kantor: 248.

2018 Turricaspia meneghiniana (Issel, 1865). - Neubauer et al.: 79-81, figs 13A-K [and synonyms

therein].

Status. Accepted Pontocaspian species.

Type locality. Baku, Azerbaijan; (sub?)fossil.

Distribution. Middle and southern Caspian Sea (Logvinenko and Starobogatov, 1969).

Taxonomic notes. The species was recently discussed in detail by Neubauer et al. (2018), who discussed also previous misidentifications.

Conservation status. Not assessed.

\section{Turricaspia nossovi Kolesnikov, 1947}

*1947 Turricaspia nossovi Kolesnikov: 108, 111.

2006 Pyrgula nossovi (Kolesnikov, 1947). - Kantor \& Sysoev: 101, pl. 45, fig. G.

2016 Pyrgula nossovi (Kolesnikov, 1947). - Vinarski \& Kantor: 241.

Status. Accepted Pontocaspian species.

Type locality. Caspian Sea (no details).

Distribution. Southern Caspian Sea (Logvinenko and Starobogatov 1969). This species was mentioned from depths between 200 and $500 \mathrm{~m}$ in the South Caspian basin of Azerbaijan (Mirzoev and Alekperov, 2017).

Taxonomic notes. The very slender shape and the characteristic, highly convex whorls that slowly and regularly increase in height distinguish the species from most congeners. Pyrgula 
vinogradovi Logvinenko \& Starobogatov, 1969 and P. astrachanica Pirogov, 1971, which show very similar traits, might be junior synonyms. A more in-depth study is required to solve their statuses.

Conservation status. Data Deficient (Vinarski, 20111).

\section{?Turricaspia obventicia (Anistratenko in Anistratenko \& Prisjazhnjuk, 1992)}

${ }^{\star} 1992$ Caspia (Clathrocaspia) obventicia Anistratenko in Anistratenko \& Prisjazhnjuk: 19-20, fig. 2 b.

Status. Uncertain Pontocaspian species.

Type locality. Well 37 near Kiliya, Izmail district, Odessa region, Ukraine (from Holocene sediments).

Distribution. Type locality only.

Taxonomic notes. This species was originally attributed to the genus Caspia due to its small shell. A restudy of the holotype of this species, specifically its protoconch characteristics, suggest placement in the genus Turricaspia. Further studies are required to assure its validity.

Remarks. The species is known only from the holotype. The occurrence of Turricaspia in the Black Sea basin is unusual, as almost all other pyrguline Black Sea basin species (but see remark at $T$. spica for another unusual occurrence) are assigned to the genus Laevicaspia.

Conservation status. So far only known from Holocene deposits of the type locality; species might be extinct.

\section{?Turricaspia pseudobacuana (Logvinenko \& Starobogatov, 1969)}

*1969 Pyrgula (Eurycaspia) pseudobacuana Logvinenko \& Starobogatov: 358, fig. 358(16). 2016 Pyrgula pseudobacuana Logvinenko et Starobogatov, 1968. - Vinarski \& Kantor: 241.

Status. Pontocaspian species, probably junior synonym.

Type locality. Southern Caspian Sea, 50-80 m.

Distribution. South Caspian basin. This species was mentioned from depths between 200 and $300 \mathrm{~m}$ in the South Caspian basin of Azerbaijan (Mirzoev and Alekperov, 2017).

Taxonomic notes. The slender shell with a keel near the lower suture is reminiscent of T. basalis (Dybowski \& Grochmalicki, 1915). The short description and unspecified drawing precluded the verification of its status. The type material has been very recently detected in the collection of ZIN and awaits further study.

Conservation status. Not assessed. 
^1915 Micromelania (Turricaspia) pseudodimidiata Dybowski \& Grochmalicki: 126-128, pl. 3, figs 32a-b.

?1969 Pyrgula (Eurycaspia) pseudodimidiata (Dyb. et Gr.). - Logvinenko \& Starobogatov: 357, fig. 358(15).

?2006 Pyrgula pseudodimidiata (B. Dybowski et Grochmalicki, 1915). - Kantor \& Sysoev: 102, pl. 47, fig. G.

2016 Pyrgula pseudodimidiata (B. Dybowski et Grochmalicki, 1915). - Vinarski \& Kantor: 241.

Status. Pontocaspian species, identity uncertain.

Type locality. Caspian Sea (no details).

Distribution. Southern Caspian Sea (Logvinenko and Starobogatov, 1969). This species was mentioned from depths between 200 and $300 \mathrm{~m}$ in the South Caspian basin of Azerbaijan (Mirzoev and Alekperov, 2017).

Taxonomic notes. The identity of this species is uncertain. Dybowski and Grochmalicki (1915) describe and illustrate a shell with eight convex whorls bearing a weak, hardly protruding, irregular shaped keel near the lower suture. According to these authors, the keel varies considerably between a thin thread, a blunt bulge or a weak thickening at the suture. In contrast, the drawings provided by Logvinenko and Starobogatov (1969) and reproduced by Kantor and Sysoev (2006) suggest a shell with straight-sided whorls and a distinct keel. Inspection of the type material is required to clarify the status of this species.

Conservation status. Not assessed.

\section{Turricaspia pseudospica (Logvinenko \& Starobogatov, 1969)}

*1969 Pyrgula (Oxypyrgula) pseudospica Logvinenko \& Starobogatov: 366, fig. 363(1).

2016 Pyrgula pseudospica Logvinenko et Starobogatov, 1968. - Vinarski \& Kantor: 241-242.

Status. Pontocaspian species, identity uncertain.

Type locality. Middle and southern Caspian Sea, 15-75 m.

Distribution. Type locality only.

Taxonomic notes. The identity of this species is unclear. Judging from the drawing by Logvinenko and Starobogatov (1969), showing a small slender shell with about 6.5 convex whorls, the species might be based on a juvenile specimen. Moreover, it could be a junior synonym of the similarly shaped T. spica (Eichwald, 1855).

Conservation status. Not assessed.

\section{Turricaspia pulla (Dybowski \& Grochmalicki, 1915)}


${ }^{\star} 1915$ Micromelania (Turricaspia) caspia var. pulla Dybowski \& Grochmalicki: 111, pl. 1, fig. 6a. 1969 Pyrgula [(Turricaspia)] pulla (Dyb. et Gr.). - Logvinenko \& Starobogatov: 361-362, fig. 360 (8). 2006 Pyrgula pulla (B. Dybowski et Grochmalicki, 1915). - Kantor \& Sysoev: 102, pl. 46, fig. C. 2016 Pyrgula pulla (B. Dybowski et Grochmalicki, 1915). - Vinarski \& Kantor: 242.

2018 Turricaspia pulla (B. Dybowski \& Grochmalicki, 1915). - Neubauer et al.: 81-82, figs 14A-J.

Status. Accepted Pontocaspian species.

Type locality. Caspian Sea (no details).

Distribution. Endemic to the Caspian Sea, reported from the middle and southern Caspian Sea basins (Logvinenko and Starobogatov, 1969). This species was mentioned from depths between 200 and $300 \mathrm{~m}$ in the South Caspian basin of Azerbaijan (Mirzoev and Alekperov, 2017).

Taxonomic notes. The species can be easily distinguished from other Turricaspia species based on its relatively broad shell, the low-convex whorls, and its small size (Neubauer et al., 2018).

Conservation status. Data Deficient (Vinarski, 2011m).

\section{Turricaspia pullula (Dybowski \& Grochmalicki, 1915)}

${ }^{\star} 1915$ Micromelania (Turricaspia) caspia var. pullula Dybowski \& Grochmalicki: 111-112, pl. 1, fig. 7. 1969 Pyrgula [(Turricaspia)] pullula (Dyb. et Gr.). - Logvinenko \& Starobogatov: 366-367,

fig. 363 (3).

2006 Turricaspia pullula (B. Dybowski et Grochmalicki, 1915). - Kantor \& Sysoev: 109, pl. 50, fig. B. 2016 Turricaspia pullula (B. Dybowski et Grochmalicki, 1915). - Vinarski \& Kantor: 249.

2018 Turricaspia pullula (B. Dybowski \& Grochmalicki, 1915). - Neubauer et al.: 82-84, figs 14K-L.

Status. Accepted Pontocaspian species.

Type locality. Caspian Sea (no details).

Distribution. Endemic to the Caspian Sea, reported from the western part of the middle Caspian Sea (Logvinenko \& Starobogatov 1969).

Taxonomic notes. The very characteristic tripartite whorl profile allows an easy identification and discrimination from other Pontocaspian Pyrgulinae (Neubauer et al., 2018).

Conservation status. Data Deficient (Vinarski, 2011n).

\section{Turricaspia rudis (Logvinenko \& Starobogatov, 1969)}

${ }^{\star} 1969$ Pyrgula (Turricaspia) rudis Logvinenko \& Starobogatov: 362, fig. 360(5).

2016 Pyrgula rudis Logvinenko et Starobogatov, 1968. - Vinarski \& Kantor: 242.

Status. Pontocaspian species, identity uncertain. 
Type locality. Middle and southern Caspian Sea, 50-100 m.

Distribution. Type locality only.

Taxonomic notes. The status of this species is unclear. The drawing provided by Logvinenko and Starobogatov (1969) shows strong similarities to T. grimmi in terms of the near straight-sided whorls and the large aperture. Since the whereabouts of the type material is unknown, we refrain from a final conclusion on the potential synonymy.

Conservation status. Data Deficient (Vinarski, 2011o).

\section{Turricaspia sajenkovae (Logvinenko \& Starobogatov, 1969)}

${ }^{\star} 1969$ Pyrgula (Turricaspia) sajenkovae Logvinenko \& Starobogatov: 361, fig. 360(4).

2016 Turricaspia sajenkovae (Logvinenko et Starobogatov, 1968). - Vinarski \& Kantor: 249-250.

Status. Pontocaspian species, identity uncertain.

Type locality. Middle Caspian Sea.

Distribution. Type locality only.

Taxonomic notes. The available drawing of this species suggests a very slender shell with highly convex whorls bearing a subsutural band. The type material has not been found, and the identity of this species remains unclear.

Conservation status. Data Deficient (Vinarski, 2011p).

\section{Turricaspia similis (Logvinenko \& Starobogatov, 1969)}

*1969 Pyrgula (Caspiella) similis Logvinenko \& Starobogatov: 375, fig. 366(11).

2016 Pyrgula similis Logvinenko et Starobogatov, 1968. - Vinarski \& Kantor: 243.

Status. Pontocaspian species, identity uncertain.

Type locality. Eastern part of the middle Caspian Sea, 20-50 m.

Distribution. Middle and southern Caspian basin. This species was mentioned from depths between 200 and $300 \mathrm{~m}$ in the South Caspian basin of Azerbaijan (Mirzoev and Alekperov, 2017).

Taxonomic notes. Judging from the drawing in Logvinenko and Starobogatov (1969), presenting a small slender shell with about 5.5 highly convex whorls, the species might be based on a juvenile specimen. It might be a junior synonym of the similarly shaped T. meneghiniana (Issel, 1865). Without investigating the type material, which has not been found in the ZIN collection, the identity of this species remains unclear.

Conservation status. Not assessed.

Turricaspia simplex (Logvinenko \& Starobogatov, 1969) 
*1969 Pyrgula (Oxypyrgula) simplex Logvinenko \& Starobogatov: 367-368, fig. 363(4).

2016 Pyrgula simplex Logvinenko et Starobogatov, 1968. - Vinarski \& Kantor: 243.

Status. Pontocaspian species, identity uncertain.

Type locality. Middle Caspian Sea, 40-120 m.

Distribution. Middle and southern Caspian Sea. This species was mentioned from depths between 200 and $900 \mathrm{~m}$ in the South Caspian basin of Azerbaijan (Mirzoev and Alekperov, 2017).

Taxonomic notes. As for the previous species, it is highly uncertain whether this taxon is a distinct species. It might also be based on a juvenile and could be a synonym of an earlier described species, perhaps T. pulla or T. lyrata.

Conservation status. Not assessed.

\section{Turricaspia spasskii (Logvinenko \& Starobogatov, 1969)}

*1969 Pyrgula (Turricaspia) spasskii Logvinenko \& Starobogatov: 361, fig. 360(7).

2016 Turricaspia spasskii (Logvinenko et Starobogatov, 1968). - Vinarski \& Kantor: 250.

Status. Accepted Pontocaspian species.

Type locality. Western part of the middle Caspian Sea.

Distribution. Middle and southern Caspian Sea. This species was mentioned from depths between 200 and $300 \mathrm{~m}$ in the South Caspian basin of Azerbaijan (Mirzoev and Alekperov, 2017).

Taxonomic notes. The fast growing whorls terminating in a large body whorl with expanded aperture are characteristic for this species and facilitate discrimination from other Turricaspia species.

Conservation status. Data Deficient (Vinarski, 2011q).

\section{Turricaspia spica (Eichwald, 1855)}

${ }^{\star} 1855$ Paludina spica Eichwald: 303-304, pl. 10, figs 8-9.

?1992 Turricaspia spica (Eichw.). - Anistratenko \& Prisjazhnjuk: 18, fig. 2d.

2006 Turricaspia spica (Eichwald, 1855). - Kantor \& Sysoev: 110, pl. 49, fig. F.

2009 Turricaspia cf. spica (Eichwald, 1855). - Filippov \& Riedel: 70, 72, 74, 76, figs 4e-f.

2016 Turricaspia spica (Eichwald, 1855). - Vinarski \& Kantor: 250.

Status. Accepted Pontocaspian species.

Type locality. Ostrov Chechen' (island in NW Caspian Sea), Dagestan, Russia. 
Distribution. Endemic to the Caspian Sea. Occurred also in the Aral Sea during the Holocene (Filippov and Riedel 2009) but now extinct there. It has been reported from the Holocene of Danube Delta (Anistratenko and Prisjazhnjuk 1992) (see below).

Taxonomic notes. As the oldest described species presently attributed to Turricaspia, the validity of this species is without doubt. Its identity, however, is poorly known, given the limited information and poor drawing provided by Eichwald (1855), as well as the largely diverging concepts applied by later authors (see Neubauer et al. (2018) for a detailed discussion of the matter). We have furthermore a geographic record (Anistratenko and Prisjazhnjuk 1992) that is outside the Caspian-Aral distribution range of this genus. Comparison of the Danube material with Caspian specimens suggests the identification might be correct, yet further detail study is required to assess whether the Danube record might actucally not be an unusual form of Laevicaspia lincta.

Conservation status. Not assessed.

\section{Turricaspia turricula (Clessin \& Dybowski in Dybowski, 1887)}

${ }^{\star} 1887$ Micromelania turricula Clessin \& Dybowski in Dybowski: 34 .

1888 [Micromelania] turricula n. sp. - Dybowski: 78, pl. 1, figs 3a-c.

2006 Turricaspia turricula (Clessin et W. Dybowski in W. Dybowski, 1888). - Kantor \& Sysoev: 111, pl. 49 , fig. I.

2016 Turricaspia turricula (Clessin et W. Dybowski in W. Dybowski, 1888). - Vinarski \&

Kantor: 244.

Status. Accepted Pontocaspian species.

Type locality. Caspian Sea (no details).

Distribution. Middle and southern Caspian Sea. This species was mentioned from depths between 200 and $500 \mathrm{~m}$ in the South Caspian basin of Azerbaijan (Mirzoev and Alekperov, 2017).

Taxonomic notes. The species is characterised by a slender conical shell with weakly convex whorls with weak subsutural swelling and a slightly inflated body whorl with large aperture.

Conservation status. Not assessed.

\section{Turricaspia uralensis (Logvinenko \& Starobogatov, 1969)}

^1969 Pyrgula (Turricaspia) uralensis Logvinenko \& Starobogatov: 359, fig. 360(1).

2016 Pyrgula uralensis Logvinenko et Starobogatov, 1968. - Vinarski \& Kantor: 244.

Status. Pontocaspian species, identity uncertain.

Type locality. Eastern part of the northern Caspian Sea.

Distribution. Type locality only. 
Taxonomic notes. Logvinenko and Starobogatov (1969) illustrated a comparably small shell with eight highly convex whorls, large body whorl, and large aperture. Reliable assessment of the species' status requires investigation of the type material, which has only been discovered in ZIN in June 2018 and awaits further study.

Conservation status. Not assessed.

\section{Turricaspia vinogradovi (Logvinenko \& Starobogatov, 1969)}

*1969 Pyrgula (Oxypyrgula) vinogradovi Logvinenko \& Starobogatov: 368, fig. 363(9).

?1971 Pyrgula astrachanica Pirogov: 249-251, fig. 1.

?2006 Turricaspia astrachanica (Pirogov, 1971). - Kantor \& Sysoev: 105, pl. 48, fig. B.

2006 Turricaspia vinogradovi (Logvinenko et Starobogatov, 1968). - Kantor \& Sysoev: 111, pl. 50,

fig. C.

2016 Turricaspia vinogradovi (Logvinenko et Starobogatov, 1968). - Vinarski \& Kantor: 251.

Status. Pontocaspian species, identity uncertain.

Type locality. Northern Caspian Sea.

Distribution. Northern Caspian Sea and Volga Delta (Logvinenko and Starobogatov, 1969).

Taxonomic notes. The species as illustrated by Logvinenko and Starobogatov (1969) is based on a slender shell with highly convex whorls. The same traits are also typical for Pyrgula astrachanica. In fact, the type of T. vinogradovi could be a juvenile of that species. Moreover, both of them might be synonyms of Turricaspia nossovi Kolesnikov, 1947. Since a part of the type material of the species involved is lacking and some of the taxa are based on incomplete or presumably juvenile specimens, the identities of Pyrgula astrachanica and Turricaspia vinogradovi remain unresolved.

Conservation status. Turricaspia vinogradovi has not been assessed by the IUCN, T. astrachanica is marked as "Data Deficient" (Vinarski, 2011r).

\section{Hydrobiidae incertae sedis}

\section{Abeskunus brusinianus (Clessin \& Dybowski in Dybowski, 1887)}

${ }^{\star} 1887$ Zagrabica Brusiniana Clessin \& Dybowski in Dybowski: 52-53.

1888 Zagrabica Brusiniana n. sp. - Dybowski: 79, pl. 2, fig. 7.

2006 Pseudamnicola brusiniana (Clessin et W. Dybowski in W. Dybowski, 1888). - Kantor \& Sysoev:

114, pl. 51, fig. J.

2016 Pseudamnicola brusiniana (Clessin et W. Dybowski in W. Dybowski, 1888). - Vinarski \&

Kantor: 222. 
2018 Abeskunus brusinianus (Clessin \& W. Dybowski in W. Dybowski, 1887). - Neubauer et al.:

87-88, figs 16A-I.

Status. Accepted Pontocaspian species.

Type locality. Caspian Sea (no details).

Distribution. Middle and southern Caspian Sea (Logvinenko and Starobogatov 1969, Parr et al. 2007). Mirzoev and Alekperov (2017) mention Pseudamnicola brusinianus from depths between 200 and $400 \mathrm{~m}$ in the South Caspian basin of Azerbaijan but we are not entirely certain whether these records might include other Abeskunus species as well.

Taxonomic notes. For a detailed description and discussion, see Neubauer et al. (2018).

Conservation status. Least Concern (Vinarski, 2011s).

\section{Abeskunus depressispira (Logvinenko \& Starobogatov, 1969)}

*1969 Pseudamnicola (Abeskunus) depressispira Logvinenko \& Starobogatov: 381, fig. 367(14).

2016 Pseudamnicola depressispira Logvinenko et Starobogatov, 1968. - Vinarski \& Kantor: 222-223.

Status. Accepted Pontocaspian species.

Type locality. Western part of the southern Caspian Sea, northward of Kuraginsky Kamen' [= Kür Daş1] Island (approximately 3901'05”N, 49²0’02”E), $81 \mathrm{~m}$ water depth.

Distribution. In addition to the type locality, specimens have been found in Holocene material retrieved near the Kura Delta, a few kilometers north of the type locality.

Taxonomic notes. Current investigations on recently collected Holocene material from the south-western Caspian Sea confirm that this species belongs to the genus Abeskunus. The finely ribbed, low trochiform shell facilitates distinction from its congeners. The species epithet is based on the Latin noun "spira", spire, and is to be considered a noun in apposition (ICZN 1999, Art. 31.2.1.).

Conservation status. Data Deficient (Vinarski, 2011t).

\section{Abeskunus exiguus (Eichwald, 1838)}

${ }^{\circ} 1837$ Lithoclypus [sic] Caspius m. - Krynicki: 58 (nomen nudum).

${ }^{\star} 1838$ Paludina exigua Eichwald: 152-153.

1863 Bithinia sphaerion Mousson: 409-410.

1874 Lithoglyphus? Caspius Krynicki. - Martens: 80.

1877 Lithoglyphus caspius Grimm: 82-84, pl. 9, fig. 8.

1977 Pseudamnicola (Abeskunus) brusiniana michelae Tadjalli-Pour: 108, pl. 2, fig. 9.

2016 Pseudamnicola exigua (Eichwald, 1838). - Vinarski \& Kantor: 223.

2016 Pseudamnicola sphaerion (Mousson, 1863). - Vinarski \& Kantor: 223. 
Status. Accepted Pontocaspian species.

Type locality. In fossil (likely Pleistocene) limestone of Dagestan, Russia.

Distribution. Western Caspian Sea, known from northern and southern parts. Records from the eastern Caspian Sea by Logvinenko and Starobogatov (1969) could not be confirmed.

Taxonomic notes. An in-depth study of the literature suggests that the names Paludina exigua, Bithinia sphaerion, and Lithoglyphus caspius all refer to the same species. The name Lithoglyphus caspius was made available by Martens (1874) by referring to the description and illustration of Eichwald's species, rendering L. caspius a junior objective synonym of Abeskunus exiguus. All three taxa share the globular shape, the short spire, and the inflated last whorl. The subspecies Pseudamnicola brusiniana michelae from Iranian coasts of the Caspian Sea closely resembles $A$. exiguus and is herein considered a synonym as well. Abeskunus exiguus differs from A. brusinianus in the highly globular shell with small spire. A revision of the species is currently being prepared.

Conservation status. Not assessed.

\section{Andrusovia andrusovi Starobogatov, 2000}

*2000 Andrusovia andrusovi Starobogatov: 39-41, fig. 1B.

2016 Andrusovia andrusovi Starobogatov, 2000. - Vinarski \& Kantor: 214.

Status. Pontocaspian species, identity uncertain.

Type locality. Eastern part of the South Caspian Sea $\left(39^{\circ} 05^{\prime} \mathrm{N}, 52^{\circ} 35^{\prime} \mathrm{E}\right)$.

Distribution. Middle and southern Caspian Sea (Starobogatov, 2000).

Taxonomic notes. The species is very similar to the type species of Andrusovia, A. dybowskii, regarding the low spire. Investigation of the type material is required to clarify whether both taxa are distinct.

Remarks. Only recently, paratypes of this species were detected at the Zoological Museum of Moscow University. A study of the taxonomy of Andrusovia is currently under way.

Conservation status. Not assessed.

\section{Andrusovia brusinai Starobogatov, 2000}

*2000 Andrusovia brusinai Starobogatov: 41, fig. 1C.

2016 Andrusovia brusinai Starobogatov, 2000. - Vinarski \& Kantor: 214.

2018 Andrusovia brusinaiStarobogatov, 2000. - Neubauer et al.: 54-56, figs 6F-K, M-N.

Status. Pontocaspian species, identity uncertain.

Type locality. Eastern part of the middle Caspian Sea $\left(42^{\circ} 42.5^{\prime} \mathrm{N}, 51^{\circ} 32.5^{\prime} \mathrm{E}\right)$, at $80 \mathrm{~m}$ water depth. 
Distribution. Northern, middle, and southern Caspian Sea (Starobogatov 2000, Neubauer et al. 2018).

Taxonomic notes. The species was recently described in detail by Neubauer et al. (2018). The species was distinguished from A. dybowskii and A. andrusovi by the higher spire, but it is a variable character. Currently, the taxonomy of Andrusovia species is subject of further study.

Remarks. Starobogatov (2000) mentioned that the type material is housed in the ZIN collection, but we were unable to find the holotype and it is supposedly lost. Only recently, paratypes of this species were detected at the Zoological Museum of Moscow University and are currently being studied.

Conservation status. Not assessed.

\section{Andrusovia dybowskii Brusina in Westerlund, 1902b}

${ }^{*}$ 1902b Andrusovia Dybowskii Westerlund: 133.

? 2000 Andrusovia dybowskii Brusina in Westerlund, 1903. - Starobogatov: 39, fig. 1A.

2016 Andrusovia dybowskii Brusina in Westerlund, 1903. - Vinarski \& Kantor: 214.

Status. Accepted Pontocaspian species.

Type locality. Caspian Sea (no details).

Distribution. Middle and southern Caspian Sea (Starobogatov, 2000).

Taxonomic notes. Apparently, Brusina considered both the more conical and flatter shells ("conoidea vel discoidea") to belong to a single species. Starobogatov (2000) in turn referred only the flat type to as Andrusovia dybowskii and considered the conical ones to belong to separate species (A. brusinai and A. marina). The lately rediscovered type material represents the conico-globular type and is currently subject of study by Anistratenko et al.

Conservation status. Not assessed.

\section{Andrusovia marina (Logvinenko \& Starobogatov, 1969)}

${ }^{*} 1969$ Horatia (Caspiohoratia) marina Logvinenko \& Starobogatov: 382, fig. 367(18).

2000 Andrusovia marina (Logvinenko et Starobogatov, 1969). - Starobogatov: 41-42, fig. $1 \mathrm{D}$.

2016 Andrusovia marina (Logvinenko et Starobogatov, 1968). - Vinarski \& Kantor: 214-215.

Status. Pontocaspian species, identity uncertain.

Type locality. Northern slope of the middle Caspian Sea basin, $43^{\circ} 32.5^{\prime} \mathrm{N}, 49^{\circ} 17.5^{\prime} \mathrm{E}, 60 \mathrm{~m}$ water depth. 
Distribution. Middle and southern Caspian Sea (Starobogatov, 2000). This species was mentioned (as Horatia marina) from depths between 200 and $400 \mathrm{~m}$ in the South Caspian basin of Azerbaijan (Mirzoev and Alekperov, 2017).

Taxonomic notes. According to Neubauer et al. (2018), this species might be a senior synonym of A. brusinai Starobogatov, 2000. Inspection of recently discovered type material appears to support that view, but more in-depth studies are required to evaluate the status of this species.

Remarks. The holotype is not traced and supposedly lost. Only recently, paratypes of this species were detected at the Zoological Museum of Moscow University and are currently being studied.

Conservation status. Not assessed.

\section{Family Lithoglyphidae Tryon, 1866}

\section{Lithoglyphus naticoides (Pfeiffer, 1828)}

${ }^{\star} 1828$ Paludina naticoides Pfeiffer: 45-46, pl. 8, figs 1, 2, 4.

2012 Lithoglyphus naticoides (Pfeiffer, 1828). - Welter-Schultes: 41, unnumbered textfigures.

2016 Lithoglyphus naticoides (C. Pfeiffer, 1828). - Vinarski \& Kantor: 253.

Status. Accepted native species.

Type locality. In the Danube at Vienna, Austria, and at Pesth (today part of Budapest), Hungary.

Distribution. Originally only in rivers entering the Black Sea, in the Danube up to Regensburg (Germany). After 1800, also introduced to Elbe and Rhine regions by artificial canals, after 1900 in France (Welter-Schultes, 2012). Very common in the Volga Delta (Vinarski et al., 2018).

Conservation status. Least Concern (Van Damme, 2011b).

Family Tateidae Thiele, 1925

\section{Potamopyrgus antipodarum (Gray, 1843)}

*1843 Amnicola antipodarum Gray: 241.

1951 Potamopyrgus jenkinsi E. A. Smith 1889. - Grossu: 693-695, figs 1a-d.

1966 P.[yrgula] (Trachycaspia?) grossui Golikov \& Starobogatov: 359.

1991 Potamopyrgus polistchuki Anistratenko: 75, fig. 1(2).

1995 Potamopyrgus alexenkoae Anistratenko in Anistratenko \& Stadnichenko: 92-93, fig. 69.

2012 Potamopyrgus antipodarum (Gray, 1843). - Welter-Schultes: 40, unnumbered textfigures. 
Status. Accepted species, invasive.

Type locality. New Zealand (no details).

Distribution. Originally from New Zealand, probably introduced in 1859 to England, in 1872 to Tasmania, in 1895 to mainland Australia, in about 1900 to European mainland (Ponder, 1988) and in 1987 to North America (Zaranko et al., 1997).

Taxonomic notes. The two Black Sea species P. polistchuki and P. alexenkoae are here considered as junior synonyms of $P$. antipodarum, differing only very weakly in outline. Vinarski and Kantor (2016) listed Pyrgula (Trachycaspia?) grossui Golikov \& Starobogatov in synonymy of T. dimidiata (Eichwald, 1838). Golikov and Starobogatov (1966) introduced this species as new name for supposedly misidentified Potamopyrgus jenkinsi sensu Grossu (1951) from Razim Lake in Romania. The shell they later illustrate (Golikov and Starobogatov, 1972) indeed shows similarities with T. dimidiata. The shell illustrated in Grossu (1951), however, is completely different and shows a keeled form of $P$. antipodarum.

Conservation status. Least Concern (Van Damme, 2013).

\section{Family Planorbidae Rafinesque, 1815}

\section{Gyraulus eichwaldi (Clessin \& Dybowski in Dybowski, 1887)}

${ }^{\circ} 1876$ Pl.[anorbis] Eichwaldi. - Grimm: 157 (nomen nudum).

${ }^{*} 1887$ Planorbis Eichwaldi Clessin \& Dybowski in Dybowski: 49-52.

1888 Planorbis Eichwaldi Grimm. - Dybowski: 79, pl. 2, figs 11a-c, pl. 3, figs 10a-c.

?1966b Anisus (Andrusowia) [sic] eichwaldi infundibularis Logvinenko \& Starobogatov: 1472, fig. 4. ?1977 Anisus djalali Tadjalli-Pour: 109, pl. 2, fig. 10.

2016 Gyraulus (Gyraulus) eichwaldi (Grimm in W. Dybowski, 1888). - Vinarski \& Kantor, 2016: 378.

Status. Accepted Pontocaspian species.

Type locality. Caspian Sea (no details).

Distribution. Middle and southern Caspian Sea (Logvinenko and Starobogatov, 1969). This species was mentioned (as Anisus eichwaldi) from depths between 200 and $900 \mathrm{~m}$ in the South Caspian basin of Azerbaijan (Mirzoev and Alekperov, 2017).

Taxonomic notes. The species is characterized by a relatively large, asymmetrical shell. Anisus eichwaldi infundibularis is probably a morphotype of G. eichwaldi. We are uncertain about the status of Anisus djajali Tadjalli-Pour, 1977 as the description is very brief and the photographs are not very clear. It may well range within the morphological variability of G. eichwaldi.

Conservation status. Not assessed. 


\section{Gyraulus dybowskii (Kolesnikov, 1947)}

${ }^{\star} 1947$ Planorbis eichwaldi var. dybowskii Kolesnikov: 109, 112, fig. in tab. 1.

1966b Anisus (Andrusowia) [sic] kolesnikovi Logvinenko \& Starobogatov: 1473, fig. 5.

1966b Anisus (Andrusowia) [sic] kolesnikovi sublittoralis Logvinenko \& Starobogatov: 1472-1473, fig. 6.

2016 Gyraulus (Gyraulus) kolesnikovi (Logvinenko et Starobogatov, 1966). - Vinarski \& Kantor, 2016: 379 .

Status. Pontocaspian species, identity uncertain.

Type locality. Caspian Sea, $40^{\circ} 37^{\prime} \mathrm{N}, 50^{\circ} 52^{\prime} \mathrm{E}, 115 \mathrm{~m}$.

Distribution. Middle and southern Caspian Sea (Logvinenko and Starobogatov, 1969). This species was mentioned (as Anisus colesnikovi [sic]) from depths between 200 and $300 \mathrm{~m}$ in the South Caspian basin of Azerbaijan (Mirzoev and Alekperov, 2017).

Taxonomic notes. Logvinenko \& Starobogatov (1966b) considered this species and Andrusovia dybowskii Brusina in Westerlund, 1902b to belong in the same genus, Anisus (Andrusovia), rendering P. dybowskii Kolesnikov, 1947 a junior homonym. Therefore, they introduced A. kolesnikovi as replacement name. Since both taxa do clearly not belong to the same genus or even the same family, the replacement name is to be discarded.

The species resembles G. eichwaldi regarding the general habitus; it differs in the more pronounced angle at the transition between whorl flank and apical plane. A revision is required to investigate if the Caspian Gyraulus species are distinct species or morphotypes of G. eichwaldi. The generic placement follows Vinarski and Kantor (2016). Note that those authors listed the earlier described P. eichwaldi dybowskii Kolesnikov, 1947 in synonymy of G. kolesnikovi.

Conservation status. Least Concern (for Anisus kolesnikovi; Vinarski, 2011u).

\section{Gyraulus sulcatus (Logvinenko \& Starobogatov, 1966, non Hilgendorf, 1867)}

${ }^{\star}$ 1966b Anisus (Andrusowia) [sic] sulcatus Logvinenko \& Starobogatov: 1474, fig. 7.

2016 Gyraulus (Gyraulus) sulcatus (Logvinenko et Starobogatov, 1966). - Vinarski \& Kantor, 2016: 382.

Status. Pontocaspian species, identity uncertain, name invalid.

Type locality. Caspian Sea, $42^{\circ} 45^{`} \mathrm{~N}, 48^{\circ} 29^{\prime} \mathrm{E}, 79 \mathrm{~m}$.

Distribution. Middle Caspian Sea (Logvinenko and Starobogatov, 1969).

Taxonomic notes. The species in its present combination as Gyraulus sulcatus (following Vinarski and Kantor 2016) is invalid as it is a secondary homonym of the Miocene Gyraulus sulcatus (Hilgendorf, 1867). We refrain here from introducing a replacement name as the species' status 
is uncertain. It resembles G. eichwaldi and G. kolesnikovi in outline shape and differs only in the more pronounced angle between whorl flank and apical plane and the shallow furrow on the apical side. An in-depth revision is required to clarify if Gyraulus sulcatus is a distinct species or a mere morphotype of G. eichwaldi (Clessin \& Dybowski in Dybowski, 1887).

Conservation status. Not assessed.

\subsection{Discussion and conclusions}

The annotated check-list presented here is a first attempt to assess the species diversity of the Pontocaspian molluscs by experts working in different countries and fields (neontology, palaeontology, biogeography, phylogenetics). Hitherto, progress has been limited by a number of factors: (1) fresh material for genetic studies is available only for few nominal species, and (2) the type series of many species are lost or at least have not been found. It concerns not only the species described by Eichwald or Grimm in the $19^{\text {th }}$ century; the type specimens of many species established by Starobogatov and his co-workers in the 1960-2000s could not be traced in ZIN (Kantor and Sysoev, 2006; Vinarski and Kantor, 2016). Furthermore, progress has been limited by (3) a lack of representative shell samples to undertake quantitative statistical analyses of conchological variation, and (4) insufficient ecological and distribution data for many of the species.

Three species that have been reported from the Pontocaspian region are not included in this list. The bithyniid gastropod Alocinma caspica (Westerlund, 1902) has been described from the east side of the Caspian Sea (probably from the vicinity of Krasnovodsk, Turkmenistan; Beriozkina et al. 1995). However, Starobogatov et al. (2004) argued the species lives in waterbodies of Bol'shoy Balkhan (Turkmenistan) and probably not in the Caspian Sea itself (Vinarski et al. 2013, Vinarski and Kantor 2016). Furthermore, two Pseudamnicola species have been described from Lake Razim in Romania (P. leontina Grossu, 1986 and P. razelmiana Grossu, 1986) that is prime Pontocaspian habitat. Like bithyniids, Pseudamnicola has not been reported as a Pontocaspian group elsewhere, and probably they are freshwater species that live in the surrounding streams or in springs. For now, we have excluded these species from the Pontocaspian species list.

This list contains 55 accepted and a further 44 uncertain endemic Pontocaspian mollusc species (Table 3.2), here defined as species that are considered to be endemic for at least one of the Pontocaspian basins). There are 14 native and 3 immigrant species (at least in one of the Pontocaspian basins), even though some species may be native or endemic in one of the basins and have become invasive in another of the Pontocaspian basins. All species that have an uncertain status belong to the Pontocaspian category. The Caspian Sea basin has the highest number of accepted endemic Pontocaspian species (48) but also poses the greatest taxonomic challenges with a further 37 species whose status are unclear.

The species richness estimate reflects the current shift of molluscan systematics from morphology-based to integrated studies, with increasing contributions of molecular and statistical 
Table 3.2: Pontocaspian mollusc species list. Abbreviations: Status: A - accepted, U - uncertain. basins: AS - Aral Sea, BSB - Black Sea basin, CSB - Caspian Sea basin. Species are E - endemic, EX - extinct, IM immigrant, IN - invasive, $\mathrm{N}$ - Native (definitions in Table 3.1); ${ }^{\star}$ species encountered alive during the PRIDE program expeditions by participants; ${ }^{\dagger}$ very fresh material of species encountered, but not living specimens.

\begin{tabular}{|c|c|c|c|c|}
\hline Species & Status & BSB & CSB & AS \\
\hline Mytilaster minimus (Poli, 1795)* & A & $\mathrm{N}$ & IN & $\mathrm{IM} / \mathrm{EX}$ \\
\hline Adacna laeviuscula (Eichwald, 1829) & A & $?$ & $E$ & \\
\hline Adacna fragilis Milaschewitsch, 1908 & $\mathrm{U}$ & $\mathrm{E}$ & & \\
\hline Adacna minima Ostroumov, 1907 & A & & $\mathrm{E}$ & E/EX? \\
\hline Adacna minima ostroumovi (Logvinenko \& Starobogatov, 1967) & $\mathrm{U}$ & & $\mathrm{E}$ & \\
\hline Adacna vitrea (Eichwald, 1829) & A & $\mathrm{E}$ & $\mathrm{E}$ & E/EX? \\
\hline Adacna vitrea glabra Ostroumov, 1905 & $\mathrm{U}$ & E & $\mathrm{E}$ & \\
\hline Adacna vitrea bergi (Starobogatov, 1974) & $U$ & & & E/EX? \\
\hline Cerastoderma glaucum (Bruguière, 1789) s.l.** & A & $\mathrm{N}$ & IN & IN? \\
\hline Cerastoderma sp. A [non C. rhomboides (Lamarck, 1819)]* & A & $\mathrm{N}$ & IN & IN? \\
\hline Didacna baeri (Grimm, 1877) & A & & $E$ & \\
\hline Didacna barbotdemarnii (Grimm, 1877)* & A & & $\mathrm{E}$ & \\
\hline Didacna eichwaldi (Krynicki, 1837) & A & & $\mathrm{E}$ & \\
\hline Didacna longipes (Grimm, 1877)* & A & & $\mathrm{E}$ & \\
\hline Didacna parallela Bogachev, 1932 & A & & $\mathrm{E}$ & \\
\hline Didacna praetrigonoides Nalivkin \& Anisimov, 1914 & A & & E/EX & \\
\hline Didacna profundicola Logvinenko \& Starobogatov, $1966^{\dagger}$ & A & & $\mathrm{E}$ & \\
\hline Didacna protracta (Eichwald, 1841) & A & & $\mathrm{E}$ & \\
\hline Didacna pyramidata (Grimm, 1877) & A & & $\mathrm{E}$ & \\
\hline Didacna trigonoides (Pallas, 1771)* & A & & $\mathrm{E}$ & \\
\hline Hypanis plicata (Eichwald, 1829) & A & $\mathrm{E}$ & $\mathrm{E}$ & \\
\hline Monodacna acuticosta (Logvinenko \& Starobogatov, 1967) & A & & $\mathrm{E}$ & \\
\hline Monodacna albida (Logvinenko \& Starobogatov, 1967) & A & & $\mathrm{E}$ & \\
\hline Monodacna caspia (Eichwald, 1829) & A & & $E$ & $?$ \\
\hline Monodacna colorata (Eichwald, 1829)* & A & $\mathrm{E}$ & $\mathrm{IM}$ & \\
\hline Monodacna filatovae (Logvinenko \& Starobogatov, 1967) & U & & $\mathrm{E}$ & \\
\hline Monodacna knipowitschi (Logvinenko \& Starobogatov, 1966) & $U$ & & $\mathrm{E}$ & \\
\hline Monodacna polymorpha (Logvinenko \& Starobogatov, 1967) & $\mathrm{U}$ & & $\mathrm{E}$ & \\
\hline Monodacna semipellucida (Logvinenko \& Starobogatov, 1967) & A & & $\mathrm{E}$ & \\
\hline Abra segmentum (Récluz, 1843)* & A & $\mathrm{N}$ & IN & IN \\
\hline Corbicula fluminalis (Müller, 1774) & A & & $\mathrm{N} / \mathrm{IN}$ & \\
\hline Dreissena bugensis Andrussov, $189^{7} \dagger$ & A & $\mathrm{E} / \mathrm{IN}$ & IN & \\
\hline Dreissena caspia Eichwald, 1855 & A & & E/EX & E/EX \\
\hline Dreissena elata Andrusov, 1897 & $U$ & & E/EX & \\
\hline Dreissena grimmi (Andrusov, 1890)* & A & & E & \\
\hline Dreissena polymorpha (Pallas, 1771) s.l..* & A & $\mathrm{N}$ & $\mathrm{N}$ & $\mathrm{N}$ \\
\hline Mytilopsis leucophaeata (Conrad, 1831)* & A & IN & IN & \\
\hline Theodoxus danubialis (Pfeiffer, 1828)* & A & $\mathrm{N}$ & & \\
\hline Theodoxus fluviatilis (Linnaeus, 1758) & A & $\mathrm{N}$ & & \\
\hline Theodoxus pallasi Lindholm, 1924* & A & $\mathrm{N}$ & $\mathrm{N}$ & N/EX? \\
\hline Theodoxus schultzii (Grimm, 1877)* & $\mathrm{U}$ & & $\mathrm{E}$ & \\
\hline Theodoxus velox V. Anistratenko in O. Anistratenko et al., 1999 & A & $\mathrm{N}$ & & \\
\hline Eupaludestrina stagnorum (Gmelin, 1791) & A & $\mathrm{N} / \mathrm{IM}$ & $\mathrm{N} / \mathrm{IM}$ & \\
\hline Caspia baerii Clessin \& Dybowski in Dybowski, 1887 & A & E? & E & \\
\hline ?Caspia valkanovi (Golikov \& Starobogatov, 1966) & $\mathrm{U}$ & $\mathrm{E}$ & & \\
\hline Clathrocaspia brotzkajae (Starobogatov in Anistratenko \& Prisyazhniuk, 1992) & A & ?E & $\mathrm{E}$ & \\
\hline
\end{tabular}




\section{CHAPTER 3}

\begin{tabular}{|c|c|c|c|c|}
\hline Species & Status & BSB & CSB & AS \\
\hline Clathrocaspia gmelinii (Clessin \& Dybowski in Dybowski, 1887) & A & & $\mathrm{E}$ & \\
\hline Clathrocaspia isseli (Logvinenko \& Starobogatov, 1969) & $\mathrm{U}$ & & $\mathrm{E}$ & \\
\hline Clathrocaspia knipowitschii (Makarov, 1938) & A & $\mathrm{E}$ & & \\
\hline Clathrocaspia logvinenkoi (Golikov \& Starobogatov, 1966) & A & $\mathrm{E}$ & & \\
\hline Clathrocaspia milae Boeters, Glöer \& Georgiev, 2015 & $\mathrm{U}$ & $\mathrm{E}$ & & \\
\hline Clathrocaspia pallasii (Clessin \& Dybowski in Dybowski, 1887) & $A$ & & $\mathrm{E}$ & \\
\hline Ulskia behningi (Logvinenko \& Starobogatov, 1969) & $\mathrm{U}$ & & $\mathrm{E}$ & \\
\hline ?Ulskia derzhavini (Logvinenko \& Starobogatov, 1969) & $\mathrm{U}$ & & E & \\
\hline Ulskia ulskii (Clessin \& Dybowski in Dybowski, 1887) & $A$ & & $\mathrm{E}$ & \\
\hline Ecrobia grimmi (Clessin in Dybowski, 1887)* & A & & $\mathrm{N}$ & $\mathrm{N}$ \\
\hline Ecrobia maritima (Milaschewitsch, 1916)* & A & $\mathrm{N}$ & & \\
\hline Ecrobia ventrosa (Montagu, 1803) & A & IM & & \\
\hline Clessiniola variabilis (Eichwald, 1838) & A & $\mathrm{E}$ & $\mathrm{E}$ & \\
\hline Laevicaspia abichi (Logvinenko \& Starobogatov, 1969) & A & & $\mathrm{E}$ & \\
\hline Laevicaspia caspia (Eichwald, 1838) & A & & $\mathrm{E}$ & \\
\hline Laevicaspia cincta (Abich, 1859) & $A$ & & $\mathrm{E}$ & \\
\hline Laevicaspia conus (Eichwald, 1838) & A & & $\mathrm{E}$ & \\
\hline ?Laevicaspia ebersini (Logvinenko \& Starobogatov, 1969) & $\mathrm{U}$ & & $\mathrm{E}$ & \\
\hline ?Laevicaspia ismailensis (Golikov \& Starobogatov, 1966) & $A$ & $\mathrm{E}$ & & \\
\hline Laevicaspia kolesnikoviana (Logvinenko \& Starobogatov in Golikov \& & A & & $\mathrm{E}$ & \\
\hline
\end{tabular}

Starobogatov, 1966)

Laevicaspia kowalewskii (Clessin \& Dybowski in Dybowski, 1887)

Laevicaspia lencoranica (Logvinenko \& Starobogatov, 1969)

Laevicaspia lincta (Milaschewitsch, 1908)

?Laevicaspia marginata (Westerlund, 1902)

Laevicaspia sieversi (Clessin in Dybowski, 1887)

?Turricaspia aenigma (Logvinenko \& Starobogatov, 1969)

Turricaspia andrussowi (Dybowski \& Grochmalicki, 1915)

?Turricaspia basalis (Dybowski \& Grochmalicki, 1915)

?Turricaspia bogatscheviana (Logvinenko \& Starobogatov, 1969)

Turricaspia chersonica Alexenko \& Starobogatov, 1987

Turricaspia columna (Logvinenko \& Starobogatov, 1969)

Turricaspia concinna (Logvinenko \& Starobogatov, 1969)

Turricaspia dagestanica (Logvinenko \& Starobogatov, 1969)

Turricaspia dimidiata (Eichwald, 1838)

Turricaspia eburnea (Logvinenko \& Starobogatov, 1969)

Turricaspia elegantula (Clessin \& Dybowski in Dybowski, 1887)

Turricaspia eulimellula (Dybowski \& Grochmalicki, 1915)

Turricaspia fedorovi (Logvinenko \& Starobogatov, 1969)

Turricaspia grimmi (Clessin \& Dybowski in Dybowski, 1887)

Turricaspia lyrata (Dybowski \& Grochmalicki, 1915)

Turricaspia marisnigri Starobogatov in Alexenko \& Starobogatov, 1987

Turricaspia meneghiniana (Issel, 1865)

Turricaspia nossovi Kolesnikov, 1947

?Turricaspia obventicia (Anistratenko in Anistratenko \& Prisjazhnjuk, 1992)

?Turricaspia pseudobacuana (Logvinenko \& Starobogatov, 1969)

?Turricaspia pseudodimidiata (Dybowski \& Grochmalicki, 1915)

Turricaspia pseudospica (Logvinenko \& Starobogatov, 1969)

Turricaspia pulla (Dybowski \& Grochmalicki, 1915)

Turricaspia pullula (Dybowski \& Grochmalicki, 1915)

Turricaspia rudis (Logvinenko \& Starobogatov, 1969)

Turricaspia sajenkovae (Logvinenko \& Starobogatov, 1969)

E 


\begin{tabular}{|c|c|c|c|c|}
\hline Species & Status & BSB & CSB & AS \\
\hline Turricaspia similis (Logvinenko \& Starobogatov, 1969) & $\mathrm{U}$ & & $\mathrm{E}$ & \\
\hline Turricaspia simplex (Logvinenko \& Starobogatov, 1969) & $\mathrm{U}$ & & $\mathrm{E}$ & \\
\hline Turricaspia spasskii (Logvinenko \& Starobogatov, 1969) & A & & $\mathrm{E}$ & \\
\hline Turricaspia spica (Eichwald, 1855) & A & ?E & $\mathrm{E}$ & ?E \\
\hline Turricaspia turricula (Clessin \& Dybowski in Dybowski, 1887) & A & & $\mathrm{E}$ & \\
\hline Turricaspia uralensis (Logvinenko \& Starobogatov, 1969) & U & & $\mathrm{E}$ & \\
\hline Turricaspia vinogradovi (Logvinenko \& Starobogatov, 1969) & $\mathrm{U}$ & & $\mathrm{E}$ & \\
\hline Abeskunus brusinianus (Clessin \& Dybowski in Dybowski, 1887) & A & & $\mathrm{E}$ & \\
\hline Abeskunus depressispira (Logvinenko \& Starobogatov, 1969) & A & & $\mathrm{E}$ & \\
\hline Abeskunus exiguus (Eichwald, 1838) & $A$ & & $\mathrm{E}$ & \\
\hline Andrusovia andrusovi Starobogatov, 2000 & $\mathrm{U}$ & & $\mathrm{E}$ & \\
\hline Andrusovia brusinai Starobogatov, 2000 & U & & $\mathrm{E}$ & \\
\hline Andrusovia dybowskii Brusina in Westerlund, 1902 & A & & $\mathrm{E}$ & \\
\hline Andrusovia marina (Logvinenko \& Starobogatov, 1969) & $\mathrm{U}$ & & $E$ & \\
\hline Lithoglyphus naticoides (Pfeiffer, 1828)* & A & $\mathrm{N}$ & $\mathrm{IM} ?$ & \\
\hline Potamopyrgus antipodarum (Gray, 1843)* & A & IM & & \\
\hline Gyraulus eichwaldi (Clessin \& Dybowski in Dybowski, 1887) $^{\dagger}$ & A & & $\mathrm{E}$ & \\
\hline Gyraulus dybowskii (Kolesnikov, 1947) & U & & $\mathrm{E}$ & \\
\hline Gyraulus sulcatus (Logvinenko \& Starobogatov, 1966) & $U$ & & $\mathrm{E}$ & \\
\hline
\end{tabular}

species delineation approaches (Vinarski, 2018). It has recently been shown that many nominal taxa of fresh- and brackish-water snails and mussels described on the basis of their shell characters (the Pontocaspian molluscs rarely were described on the base of anatomical studies) lack a genetic support (with few exceptions such as e.g., Popa et al. 2012, Stepien et al. 2013) and thus do not represent evolutionary meaningful units. On the other hand, cryptic speciation is known within many taxa of molluscs in long-lived lakes (Albrecht et al., 2006), and the Pontocaspian biota may include some previously unrecognized species. Thus, we consider our check-list rather as a starting point for further integrated research, not a definitive and fixed inventarization of the Pontocaspian molluscs.

Anyone who reads this list or works such as Logvinenko and Starobogatov (1969) or Vinarski and Kantor (2016) may think that the Caspian Sea still maintains its unique and species-rich mollusc fauna. However, the actual state of affairs is problematic as many species thought to be endemic to this large saline lake have not been found since their description, and recent attempts to obtain fresh material for genetic studies mostly failed. Clearly, the conservation status of Pontocaspian species is insufficiently known. With our working list we aim to assist in the necessary follow-up conservation assessments.

Most taxonomic difficulties we encounter for the bivalve genera Monodacna and Dreissena and the Pyrgulinae gastropods (especially genera Turricaspia and Laevicaspia). Furthermore, there is an urgent need to assess whether representatives of species complexes in the three main Pontocaspian basins (Aral Sea, Caspian Sea, Black Sea) concern separate species as several of these regional populations are in immediate danger of extinction or already extinct (for example with the disappearance of the Aral Sea). Combined methodological efforts will enable us to estimate the 
extent and characterise the nature of Pontocaspian faunal turnover, and this species list is a first attempt in the required uniform taxonomic base.

\section{Acknowledgments}

We thank Ana Bianca Pavel (Geoecomar, Constanța, Romania) and A.S. Gasanova (Makhachkala, Russia) for additional observations on living species occurrences. We are furthermore grateful to Dietrich Kadolsky and Mathias Harzhauser, as well as to the editor Eike Neubert, for constructive comments.

\section{Funding}

The PRIDE program has received funding from the European Union's Horizon 2020 research and innovation programme under the Marie Sklodowska-Curie grant agreement No. 642973. TAN was supported by an Alexander-von-Humboldt Scholarship. Further support came from the German Research Foundation (DFG, grant no. WI1902/14) to TW. MV has financial support from the Russian Ministry of Higher Education and Science (project no. 6.1352.2017/4.6). TY was supported by the Russian Science Foundation (grant no. 16-17-10103). 
MOLLUSC SPECIES LIST 
teristist

25

(2)

$(x+3)+3$

thas

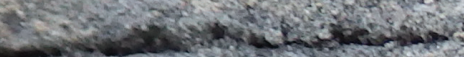

ser 150 :

nitentso

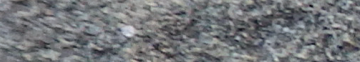

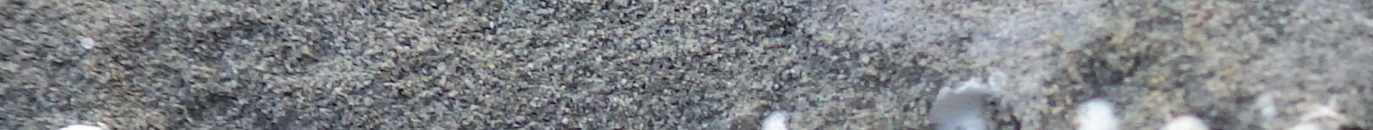

4.

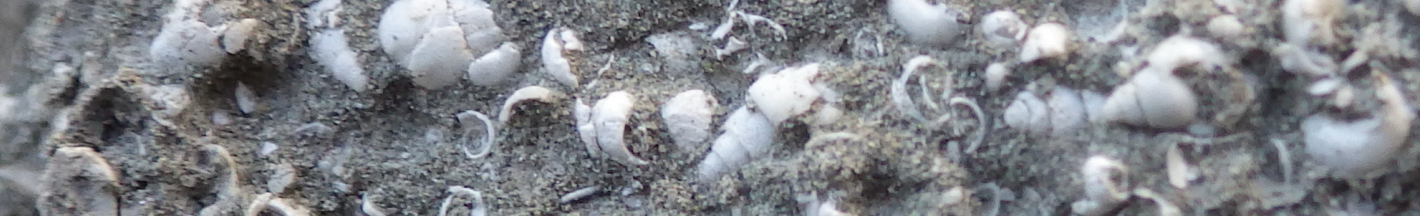

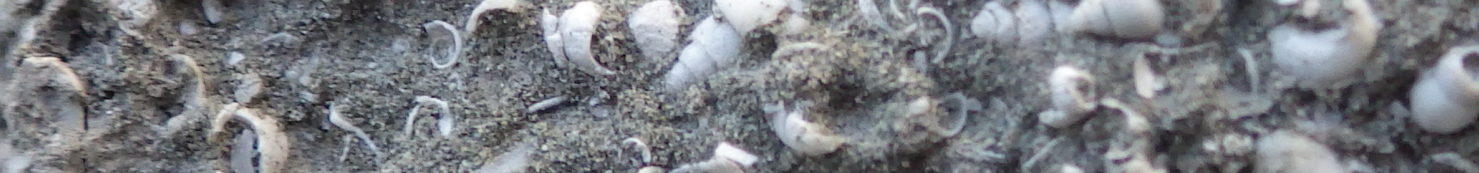

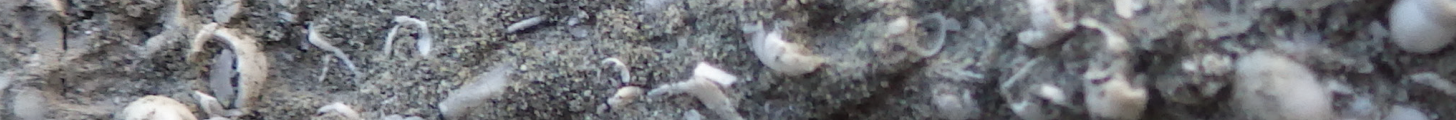

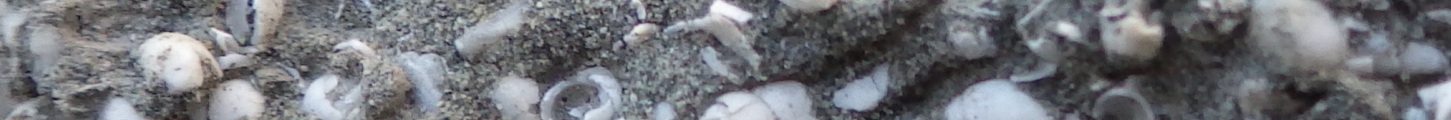

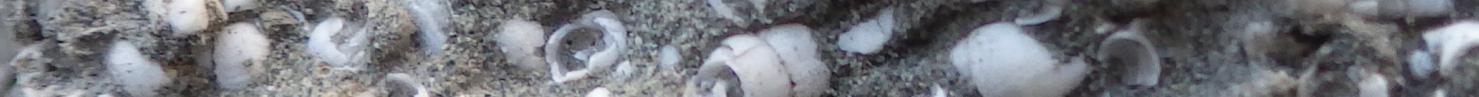

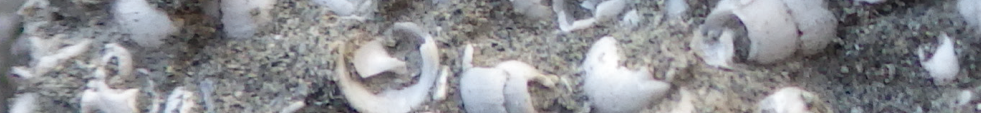

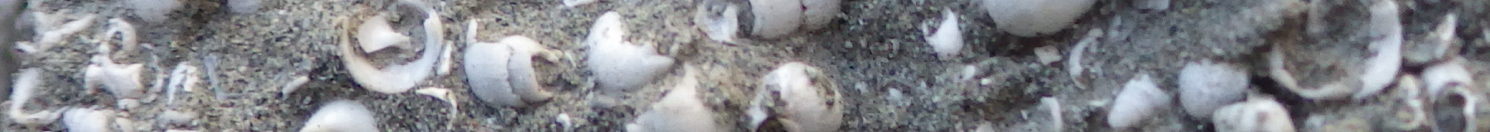

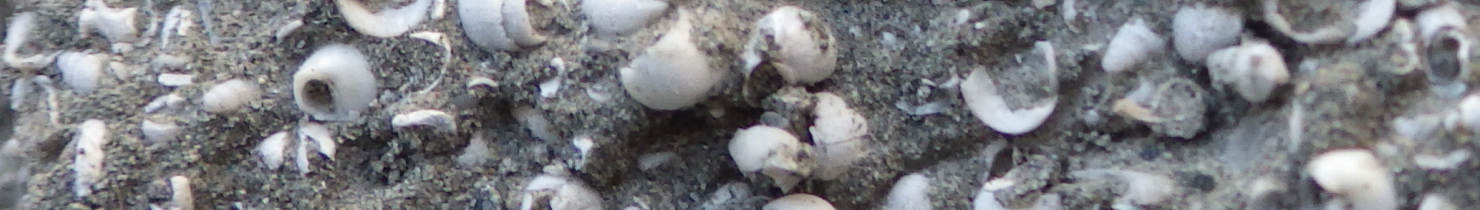

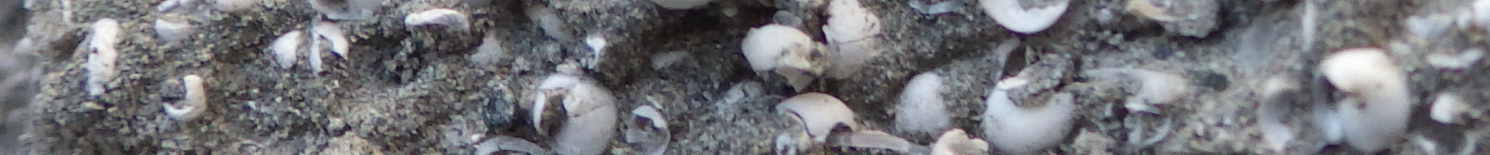

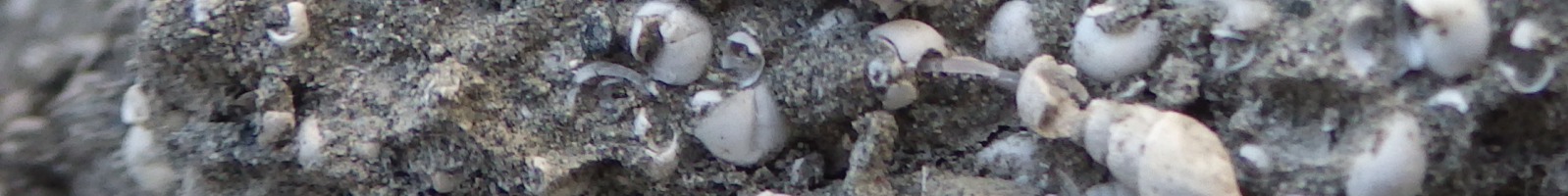
(3.15) 


\title{
4
}

\section{Late Pleistocene Caspian gastropod DiVERSITY (SELITRENNOYE, RUSSIA)}

\section{Published as:}

Neubauer, T.A., van de Velde, S., Yanina, T.A., Wesselingh, F.P., 2018. A late Pleistocene gastropod fauna from the northern Caspian Sea with implications for Pontocaspian gastropod taxonomy. ZooKeys 770, 43-103. http://doi.org/10.3897/zookeys.770.25365

\begin{abstract}
The presented chapter details a very diverse non-marine gastropod fauna retrieved from Caspian Pleistocene deposits along the Volga River north of Astrakhan (Russia). During time of deposition (early Late Pleistocene, late Khazarian regional substage), the area was situated in shallow water of the greatly expanded Caspian Sea. The fauna contains 24 species, of which 16 are endemic to the Pontocaspian region and 15 to the Caspian Sea. The majority of the species (13) belongs to the Pyrgulinae (Hydrobiidae), a group famous for its huge morphological variability in the Pontocaspian region. The phenotypic diversity has led to an inflation of genus and species names in the literature. New concepts are proposed for many of the genera and species found in the present material, with implications for the systematics and taxonomy of the entire Pontocaspian gastropod fauna. Laevicaspia vinarskii sp. $\mathrm{n}$. is described as a new species. This contribution is considered a first step in revising the Pontocaspian gastropod fauna.
\end{abstract}

\subsection{Introduction}

The Caspian Sea is Earth's largest inland water body. With an area of $378,100 \mathrm{~km}^{2}$ it covers about $40 \%$ of the world's continental surface water (Dumont, 1998; Lehner and Döll, 2004). The endorheic Caspian basin is situated at the crossroads between Europe and Asia and borders Azerbaijan, Iran, Kazakhstan, Russia, and Turkmenistan. Today, its water balance is strongly controlled by the rivers Volga (Russia) and Ural (Kazakhstan) entering from the north and the Kura River (Azerbaijan) flowing in from the southwest and by evaporation from the sea and the adjacent Kara Bogaz Gol (Dumont, 1998). The Caspian Sea is a mesohaline lake with an average salinity of about 12.8 psu. Steep salinity gradients exist in the northern Caspian Sea from near freshwater conditions at the Volga River delta in the north to a maximum of 13.8 psu in the southeast (Dumont, 1998). 
During the Pleistocene, several major transgressive-regressive cycles caused recurrent connections between Black Sea and Caspian basins, which were accompanied by dramatic changes in lake size, salinity and biotic assemblages (e.g., Dumont, 1998; Forte and Cowgill, 2013; Shkatova, 2010; Svitoch, 2012, 2008b; Taviani et al., 2014; Van Baak et al., 2013; Yanina, 2014, 2013; YankoHombach et al., 2007). In spite of the major environmental fluctuations over the geological past, the Caspian Sea basin hosted a succession of anomalohaline to freshwater lakes since the late Pontian (late Messinian, late Miocene; Popov et al., 2006; Van Baak et al., 2013). The extensive duration of the fluctuations since the Early Pleistocene facilitated the accumulation of diverse and highly endemic ("Pontocaspian") biota in this long-lived lake (sensu Gorthner, 1994). As to the recent mollusk fauna, 92 species of gastropods and 35 species of bivalves are listed in latest systematic catalogues (e.g., Kantor et al., 2010; Kantor and Sysoev, 2006, 2005; Vinarski and Kantor, 2016). As for the gastropods, which are dominated by small-sized Hydrobiidae, 92.4\% of them are endemic to the Caspian Sea (Neubauer et al., 2016a). Because of its high diversity, the Caspian Sea has been classified as a major biodiversity hotspot for anomalohaline gastropods (Neubauer et al., 2015a). However, the endemic mollusk fauna is at present severely suffering from the expansion of a number of invasive species (Albrecht et al., 2014; Grigorovich et al., 2003; Heiler et al., 2010; Kosarev and Yablonskaya, 1994; Orlova et al., 2004; Riedel et al., 2006; Therriault et al., 2004). Since the early $20^{\text {th }}$ century, human activity has led to a massive increase in the rate of establishment of non-indigenous aquatic species compared to preceding natural colonization (Grigorovich et al., 2003). Additional environmental pressure is exerted on the resident fauna by the increasing concentrations of heavy metals and pesticides (e.g., Agusa et al., 2004; Anan et al., 2005).

In order to predict future biodiversity loss as a response to natural or anthropogenically induced environmental change, it is vital to document and understand the species richness and development of the endemic fauna over longer temporal scales. For this purpose, a sound taxonomic framework is required. The extreme morphological variability of many of the described species complicates taxonomy and, thereby, hampers reliably diversity assessments. Preceding taxonomic studies carried out in the 19th and $20^{\text {th }}$ century have produced a plethora of available species names, partly based on minor morphological deviations. Taxonomic works are hampered by (1) the inadequate nature of descriptions and illustrations, (2) the apparent loss of much of the material, (3) the few and hugely variable morphological characters in some of the groups, and (4) the apparent recent loss of many of the species, which makes combined morphological and molecular approaches impossible. Presently, the statuses of most Caspian endemic gastropods, especially of the numerous representatives of the Pyrgulinae (Hydrobiidae), are poorly resolved.

The present contribution details a diverse gastropod fauna from upper Khazarian (Upper Pleistocene) deposits from the northwestern part of the Caspian basin, at that time witnessing a major transgressive event (Svitoch 2012; Fig. 4.1). We provide descriptions, illustrations and comparisons of the so far mostly poorly known species, and suggest nomenclatural and taxonomic rectifications. Since we could examine little of the type material of the discussed species (mostly 


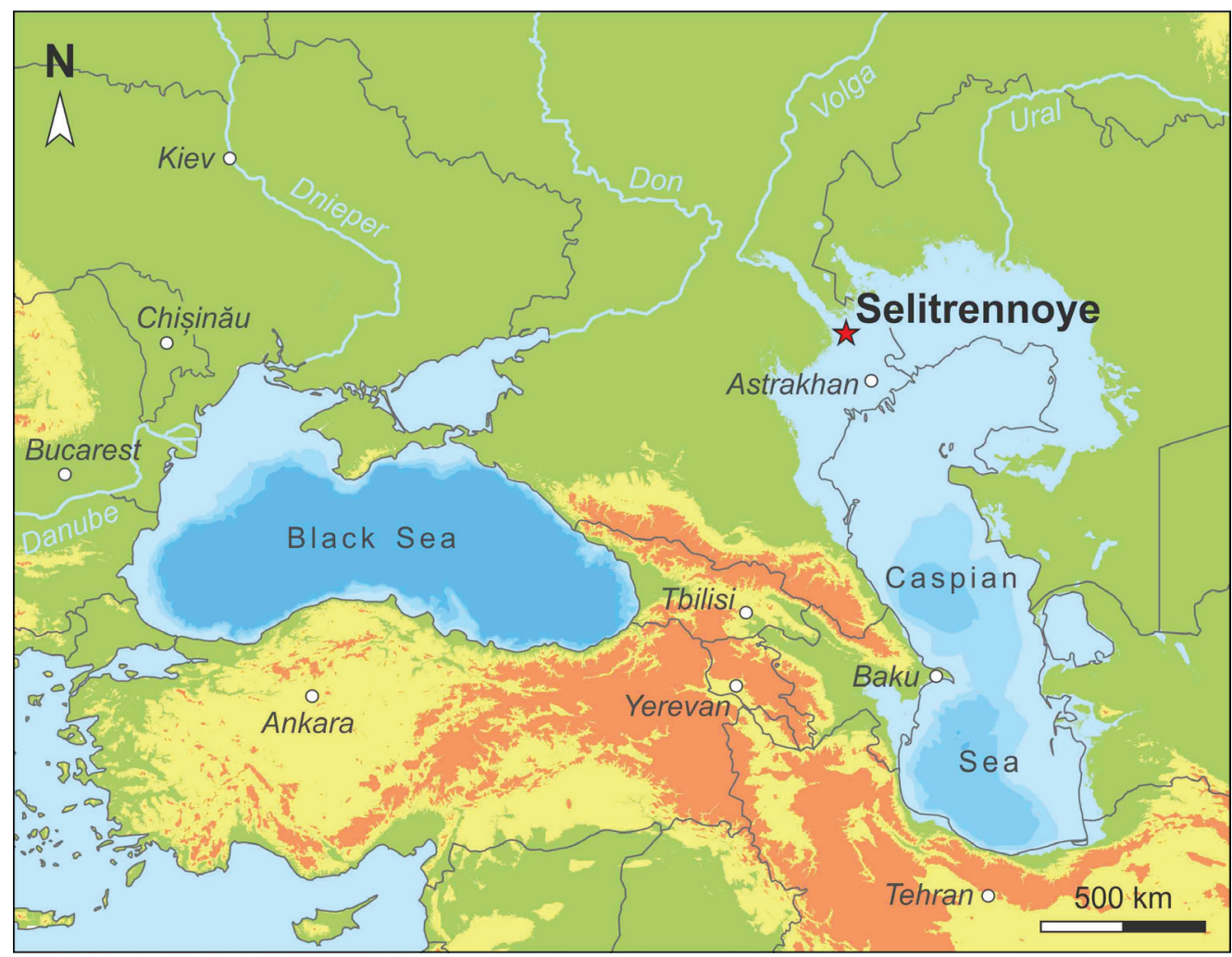

Fig. 4.1: Geographic overview of the Pontocaspian region, with indication of the extent of the late Khazarian (early Late Pleistocene) transgression. The star marks Selitrennoye. Paleo-lake level was modeled in ESRI ArcGIS 10.4 based on Yanina (2014), who suggested an absolute lake level of $10 \mathrm{~m}$ b.s.l. at that time.

Considering the present Caspian base level of $27 \mathrm{~m}$ b.s.l., this estimate corresponds to a lake level rise of $17 \mathrm{~m}$. (Note that the model is restricted to the Pontocaspian catchment area and disregards potential topographic differences.) The bathymetry ranges are based on the GEBCO_2014 model (version 20150318) for present-day (Weatherall et al., 2015); shown isobaths equal to 100, 500 and $1000 \mathrm{~m}$ below current lake level.

because the whereabouts are unknown), we limit our conclusions on former concepts and potential synonymies to taxa that have been thoroughly described and/or adequately illustrated (e.g., Kantor and Sysoev 2006). One particular focus of the present work is the revision of genus concepts that have been applied to Pontocaspian Hydrobiidae.

\subsection{Materials and methods}

The studied mollusk fauna derives from deposits exposed near the small village of Selitrennoye (also as Selitrennoe; Russ. Селитренное) along the left bank of the Akhtuba River, a distributary of the Volga River (Russia) (Fig. 4.1). The locality is situated about $100 \mathrm{~km}$ NNW of the city of Astrakhan 


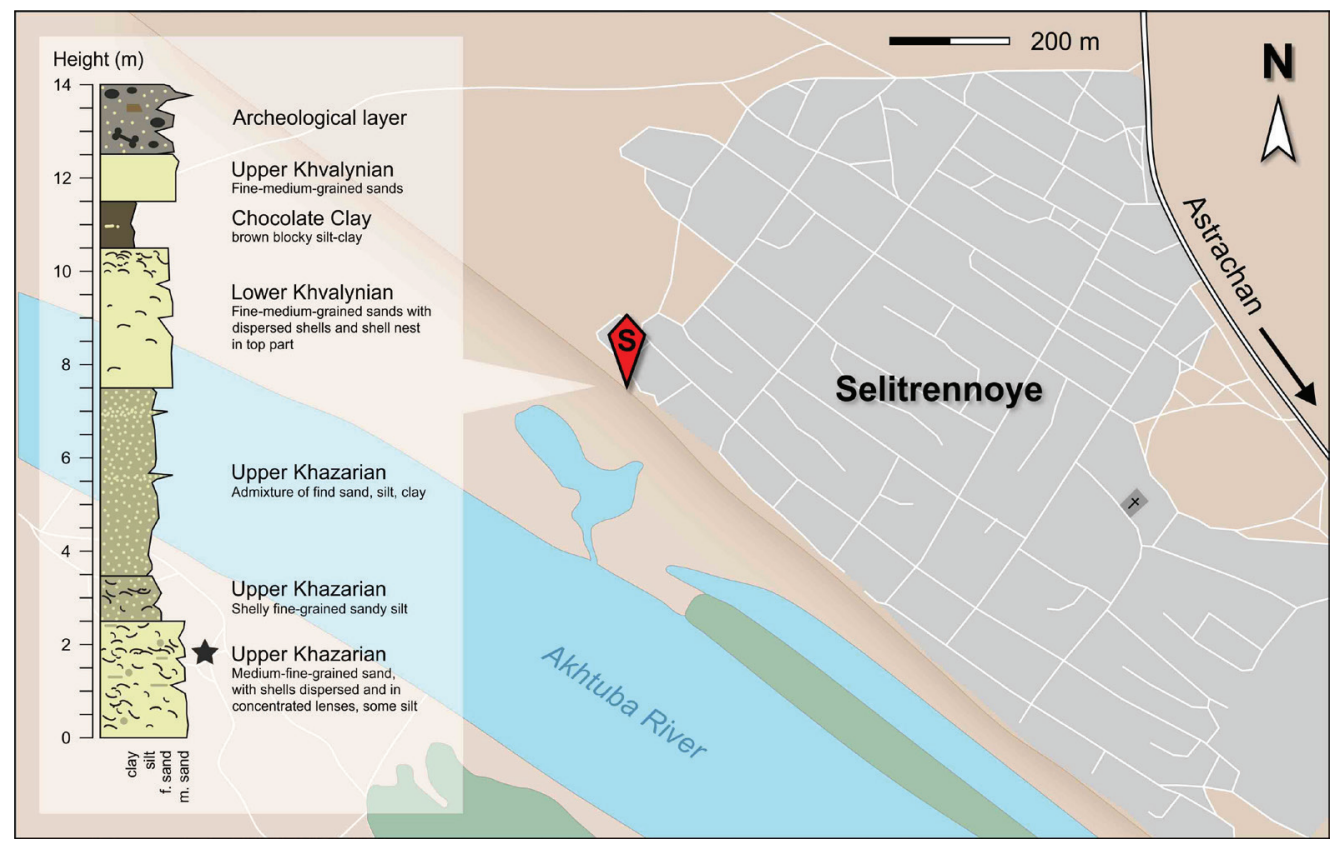

Fig. 4.2: Geographic position and log of the sampled section at Selitrennoye village. The star marks the layer of which the fauna derives. The stratigraphy was established based on the occurrence of Lymnocardiinae bivalves, following the biostratigraphic scheme of Yanina (2013).

in the administrative division of the same name $\left(47^{\circ} 10^{\prime} 21.19^{\prime \prime} \mathrm{N}, 47^{\circ} 26^{\prime} 25.41^{\prime \prime} \mathrm{E}\right.$, WGS84). The investigated section of $14 \mathrm{~m}$ height spans the upper Khazarian to Khvalynian regional substages, which correlates to the early Late Pleistocene (Svitoch, 2012; Yanina, 2013a, 2014). The base of the Quaternary outcrop, which lies $19 \mathrm{~m}$ below sea level, is formed by $2.5 \mathrm{~m}$ of upper Khazarian sands with common dispersed shells, including shell lenses (Fig. 4.2). This layer contains the here described gastropod fauna and several species of Lymnocardiinae bivalves. Upsection follows a 1-m-thick interval of horizontally alternating sandy and silty layers containing a diverse assemblage of bivalves of the genera Monodacna, Didacna, and Dreissena. Above it, $4 \mathrm{~m}$ of clays containing siltstones and sand layers were deposited. Overlying the interval, $3 \mathrm{~m}$ of lower Khvalynian sands are present, containing species of Didacna and Dreissena, followed by $1 \mathrm{~m}$ of brown silty clays ("chocolate clays"). The top of the Pleistocene deposits is marked by $1 \mathrm{~m}$ of upper Khvalynian sands and sandy loams barren of fossils, topped by a late Holocene soil complex rich in archeological remains.

Approximately $5 \mathrm{~kg}$ of sediment were collected by F.W. in September 2015 and has been washed over a $0.5 \mathrm{~mm}$ sieve before sorting. All material is stored at the Faculty of Geography of the Moscow State University under collection numbers LV 201501-201530 and 201731-201750 and at the 


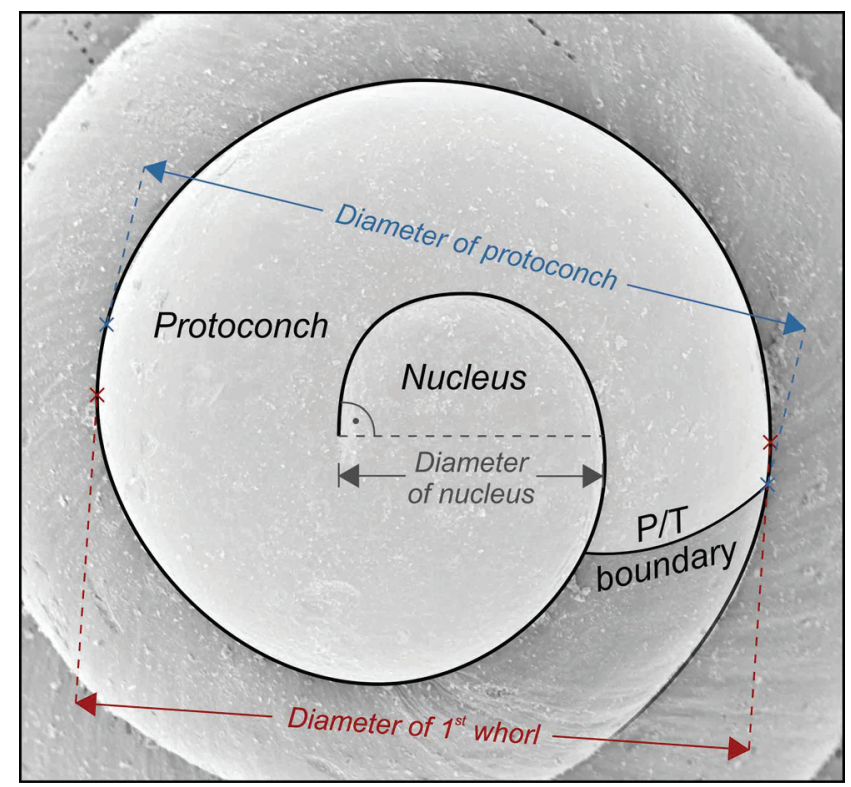

Fig. 4.3: Sketch of the measurements made on the protoconch. The method for counting whorls follows Verduin (1977).

Naturalis Biodiversity Center, Leiden, the Netherlands, under collection numbers RGM 13097841309793, 1309797-1309856, 1310190-1310249, and 1310252-1310258.

Macro-photographs of the specimens were taken with a Leica M165 C stereomicroscope with attached DFC420 camera, using the focus stacking function of the Leica Application Suite software v. 4.4.0 at the Naturalis Biodiversity Center, Leiden. SEM images were acquired on a JEOL JSM$6480 \mathrm{LV}$ at the same institute. Specimens were coated with a $20 \mathrm{~nm}$ thick platinum-palladium alloy in a Quorum Q150T S coater.

For every species, a number of specimens was measured as representatives of its morphological spectrum. Shell measurements for Theodoxus are given as height $\mathrm{x}$ largest width (perpendicular to height) $\mathrm{x}$ second-largest width (perpendicular to both other axes); for all other species, measurements are given as height $\mathrm{x}$ width. Counting of protoconch whorls follows the method used by Verduin (1977) (Fig. 4.3). Descriptions and information on the whereabouts of type material are only indicated for Pontocaspian species; a brief account on the non-indigenous species detected herein is provided at the end of the Systematic Paleontology section. Synonymy lists comprise original descriptions, records providing illustrations and entries in systematic catalogues referring to Caspian records (e.g., Kantor and Sysoev, 2006; Vinarski and Kantor, 2016). The systematic classification follows Bouchet et al. (2017) and MolluscaBase (2017).

Abbreviations used are: 
P/Tprotoconch/teleoconch;

MSU Moscow State University, Moscow, Russia, Faculty of Geography;

RGM Naturalis Biodiversity Center, Leiden, the Netherlands, coll. Fossil Mollusca (formerly Rijksmuseum van Geologie en Mineralogie);

ZIN Zoological Institute of the Russian Academy of Sciences, St. Petersburg, Russia.

\subsection{Systematic paleontology}

We tried to locate the depository of type specimens for all identified species, but this was successful only for a part of the fauna. In particular, much of the type material of the species described by Logvinenko and Starobogatov (1969) could not be located, since these authors did not provide information on the depository of the types or the localities they were retrieved at. According to Kantor et al. (2010), the types should be stored in ZIN but few have been found, since large parts of Starobogatov's collection have not been entirely inventoried as yet.

Class Gastropoda (Cuvier, 1795)Cuvier, 1795

Subclass Neritimorpha Golikov and Starobogatov, 1975

Order Cycloneritimorpha Frýda, 1998

Superfamily Neritoidea Rafinesque, 1815

Family Neritidae Rafinesque, 1815

Subfamily Neritininae Poey, 1852

\section{Genus Theodoxus Montfort, 1810}

Type species. Theodoxus lutetianus Montfort, 1810 [currently considered as a synonym of Theodoxus fluviatilis (Linneaus, 1758)]; by original designation. Recent; Europe.

\section{Theodoxus pallasi Lindholm, 1924}

Fig. 4.4A-F

1838 Neritina liturata m. Eichwald: 156-157 [non Neritina liturata Schultze, 1826].

1841 Neritina liturata m. - Eichwald: 258-260, pl. 38, figs 18-19 [non Schultze, 1826].

1855 Neritina liturata m. - Eichwald: 307-308 [non Schultze, 1826].

1887 Neritina liturata Eichw. sp. - W. Dybowski: 56-60 [non Schultze, 1826].

1888 [Neritina] liturata Eichw. - W. Dybowski: 79, pl. 2, fig. 10 [non Schultze, 1826].

* 1924 Theodoxus pallasi nom. nov.; Lindholm: 33, 34.

1952 Theodoxus pallasi Lindh. - Zhadin: 208-209, fig. 124.

1969 Theodoxus pallasi Ldh. - Logvinenko \& Starobogatov: 343, pl. 5, figs 5-6, textfig. 356.

1994 Theodoxus atrachanicus Starobogatov in Starobogatov et al..: 8-9, fig. 1 (1-2). 
1994 Th.[eodoxus] pallasi Ldn. - Starobogatov et al.: 8-9, fig. 1 (3-4).

2006 Theodoxus pallasi Lindholm, 1924. - Kantor and Sysoev: 45, pl. 20, fig. C.

2006 Theodoxus atrachanicus Starobogatov in Starobogatov et al., 1994. - Kantor \& Sysoev: 44,

pl. 21, fig. C

2009 Theodoxus pallasi Lindholm, 1924. - Filippov \& Riedel: 70, 72, 74, 76, figs 4g-i.

2011 Theodoxus astrachanicus Starobogatov in Starobogatov, Filchakov, Antonova et Pirogov, 1994. -

Anistratenko et al. et al.: 54-55, fig. 1 (6).

2012 Theodoxus pallasi Lindholm, 1924. - Welter-Schultes: 29, unnumbered textfig.

2016 Theodoxus (Theodoxus) astrachanicus Starobogatov in Starobogatov et al., 1994. - Vinarski and

Kantor: 155-156.

2016 Theodoxus (Theodoxus) pallasi (Lindholm, 1924). - Vinarski \& Kantor: 156-157.

2017 Theodoxus pallasi Lindholm, 1924. - Anistratenko et al.: 221, figs 4, 7, 10, 11 [cum syn.].

Material. 294 specimens (RGM 1309841, RGM 1309843, RGM 1310190-1310193, LV 201510).

Type material. Lectotype: ZIN 54547/63, designated by Starobogatov et al. (1994).

Type locality. "Inter Fucos littoris Derbendensis viva" (living among algae on the shores of Derbent), Dagestan, Russia.

Dimensions. 5.95 x $6.62 \times 4.81 \mathrm{~mm}$ (RGM 1310191, Figs 4.4A-C); 4.52 × 5.59 x $4.05 \mathrm{~mm}$ (LV 201510, Figs 4.4D-F); 6.62 × 7.31 x 5.30 mm (RGM 1310192, Fig. 4.4I); 6.63 x 7.53 x 4.99 mm (RGM 1310190).

Description. Near globular shell with up to 2.7 whorls. Protoconch consists of about half a whorl; diameter of about $570 \mu \mathrm{m}$; nucleus measures ca. $250 \mu \mathrm{m}$ in diameter; surface mostly corroded; P/T transition indistinct, marked by onset of growth lines. Apex weakly raised. Last whorl passes from upper suture over weakly inclined ramp with shallow concavity into broadly, regularly rounded flank that is near semicircular in profile; relative length of ramp increases with ontogeny. Aperture inclined, regularly semicircular. Callus moderately thickened, glossy, edentate; right margin bulging, symmetrically sinuate, with near straight-sided lower and upper thirds and broad, shallow indentation in central third; left margin extends sinuate over base of penultimate whorl, with small adapical indentation, formed by slightly protruding peristome margin. Peristome sharply edged throughout ontogeny from adapical tip to where it passes into callus margin at base of penultimate whorl. Adapically, peristome margin forms steep crest towards callus, sometimes accompanied by thin, shallow furrow at the transition. Color pattern already starts on early teleoconch as widely spaced, dark yellow to brown curved lines, which pass into slightly irregular zigzag lines with partly dichotomizing branches on last whorl; line width, density, amplitude, color and raggedness varies among specimens and partly within the same individual.

Discussion. The regular, widely spaced zigzag pattern is characteristic of the species. Comparable patterns occur in T. danubialis (Pfeiffer, 1828) and occasionally in T. fluviatilis (Linneaus, 1758), but in these species lines are finer and more closely spaced. They furthermore 


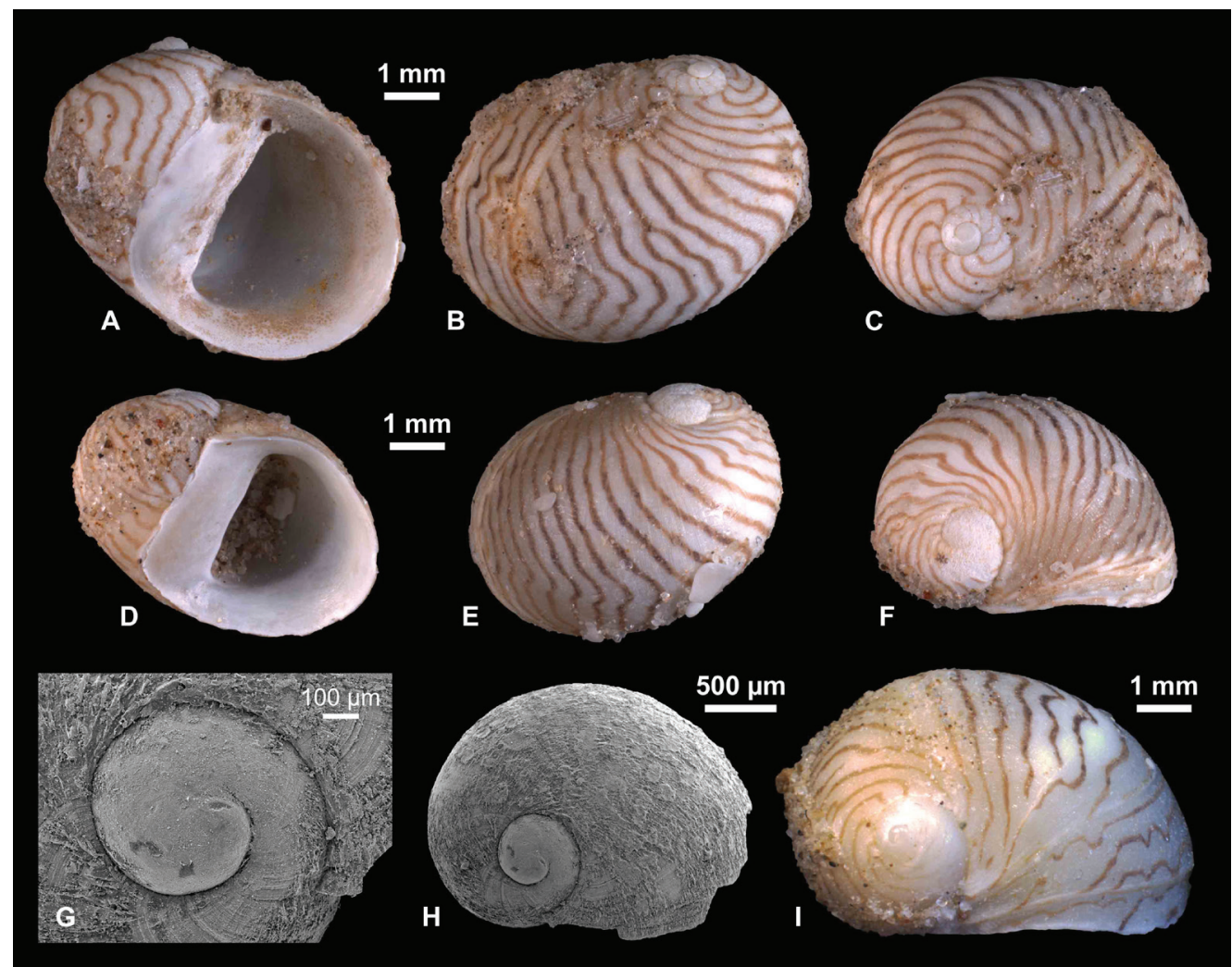

Fig. 4.4: Neritidae. A-C Theodoxus pallasi Lindholm, 1924, RGM 1310191 D-F T. pallasi, LV 201510 G, H T. pallasi, RGM 1309843 I T. pallasi, RGM 1310192.

differ in their less elongated shells. Similarly, T. euxinus (Clessin, 1886) from the Black Sea is more globular and shows a much denser and finer color pattern (Kantor and Sysoev, 2005; WelterSchultes, 2012). Theodoxus schultzii (Grimm, 1877) has traditionally been distinguished from T. pallasi by its rounder shell and the massively expanded aperture (Zettler, 2007). Currently, the whole group is under study using genetic data. Preliminary results suggest that both T. pallasi and T. schultzii may be grouped with the Iranian species T. pallidus (Dunker, 1861), and possibly a major name change for T. pallasi is due (A.F. Sands, pers. commun. 01/2018).

Theodoxus astrachanicus Starobogatov in Starobogatov et al., 1994 from the Azov Sea and Volga delta is claimed to differ from T. pallasi in size and rate of whorl expansion (Starobogatov et al., 1994). However, both species correspond well in terms of shell shape and, in particular, the typical zigzag pattern (see also Kantor \& Sysoev 2006). We therefore agree with Anistratenko et al. (2017) to treat T. astrachanicus as a junior synonym of T. pallasi.

Distribution. Presently living in the Caspian Sea, the Sea of Azov and the Aral Sea; records from Armenia and the Ural River need confirmation (Anistratenko et al., 2017). In the Pleistocene, 
the species also dwelled in river deltas entering the Black Sea, where it probably became extinct during the Neoeuxinian/Late Pleistocene (Anistratenko et al., 2017).

\author{
Subclass Caenogastropoda Cox, 1960 \\ Order Littorinimorpha Golikov \& Starobogatov, 1975 \\ Superfamily Truncatelloidea Gray, 1840 \\ Family Hydrobiidae Stimpson, 1865
}

\title{
Subfamily Caspiinae B. Dybowski, 1913
}

Discussion. The genus Caspia has been widely used for species with small ovoid shells, occasionally with spiral or reticulate teleoconch sculpture. Based on the expression of sculpture, some authors have divided the species among the (sub)genera Caspia s.s., with a single spiral line below the suture, and Clathrocaspia Lindholm, 1930, exposing a reticulate pattern (e.g., Anistratenko, 2013; Anistratenko and Prisyazhniuk, 1992; Boeters et al., 2015; Büyükmeriç and Wesselingh, 2018). Species lacking teleoconch sculpture were grouped under the new taxon Ulskia by Logvinenko \& Starobogatov (1969). While those authors considered it a subgenus of Pyrgula, W. Dybowski (1887) originally treated its type species (Caspia ulskii Clessin \& W. Dybowski in W. Dybowski, 1887, see below) as a sculpture-less form of Caspia.

Ulskia ulskii is available in the present material, and we have investigated the type species of Clathrocaspia (Caspia pallasii Clessin \& W. Dybowski in W. Dybowski, 1887) obtained from Holocene deposits of the northern and southern Caspian Sea. However, the type species of Caspia, Caspia baerii Clessin \& W. Dybowski in W. Dybowski, 1887, is unknown to us. The original description suggests that it is similar to Ulskia and Clathrocaspia in terms of size and shape, yet to differ in the presence of a single line below to suture, demarcating a narrow subsutural ramp. All three genera are probably closely related, which is also suggested by the similar protoconchs of Ulskia and Clathrocaspia (pers. obs. T.A.N.). Since Ulskia and Clathrocaspia can be easily distinguished based on the presence of sculpture, we propose to treat them as distinct genera. The status of Caspia remains doubtful until the type species is properly re-investigated.

The Caspia - Clathrocaspia - Ulskia species group can be well delimited from the larger, elongate-conical or - ovoid Turricaspia auct. and Pyrgula auct. Moreover, unpublished molecular data suggest that the group is unrelated to Pyrgulinae (T. Wilke, pers. comm. 04/2018). We follow Anistratenko (2013) and Bouchet et al. (2017), who listed the Caspiinae as separate subfamily.

\section{Genus Ulskia Logvinenko \& Starobogatov, 1969}

Type species. Caspia ulskii Clessin \& W. Dybowski in W. Dybowski, 1887; by original designation. Caspian Sea, Recent. 


\section{Ulskia ulskii (Clessin \& W. Dybowski in W. Dybowski, 1887)}

Fig. $4.5 \mathrm{~A}-\mathrm{K}$

* 1887 Caspia Ulskii nob.; W. Dybowski: 38-39.

1888 [Caspia] Ulskii n. sp. - W. Dybowski: 79, pl. 3, fig. 8.

1952 Caspia ulskii W. Dyb., 1888. - Zhadin: 205, fig. 205.

1969 Pyrgula [(Ulskia)] nana Logvinenko \& Starobogatov: 379, fig. 367 (12).

1969 Pyrgula [(Ulskia)] schorygini Logv. et Star. sp. n.; Logvinenko \& Starobogatov: 379, fig. 367 (11).

1969 Pyrgula [(Ulskia)] ulskii (Cless. et W. Dyb.). - Logvinenko \& Starobogatov: 379, figs 367 (10).

2006 Pyrgula nana Logvinenko et Starobogatov, 1968. - Kantor \& Sysoev: 101, pl. 47, fig. D.

2006 Pyrgula schorygini Logvinenko et Starobogatov, 1968. - Kantor \& Sysoev: 103, pl. 45, fig. E.

2006 Pyrgula ulskii (Clessin et W. Dybowski in W. Dybowski, 1888). - Kantor \& Sysoev: 104, pl. 45,

fig. F.

2016 Pyrgula nana Logvinenko et Starobogatov, 1968. - Vinarski \& Kantor: 240-241.

2016 Pyrgula schorygini Logvinenko et Starobogatov, 1968. - Vinarski \& Kantor: 242.

2016 Pyrgula ulskii (Clessin et W. Dybowski in W. Dybowski, 1888). - Vinarski \& Kantor: 244.

Material. 19 specimens (RGM 1309790, RGM 1309810, RGM 1309856, RGM 1310208, LV 201506).

Type material. "Probable syntype": ZIN 4608/1. Holotype of P. schorygini: ZIN 4357/1. Holotype of P. nana not traced.

Type locality. "Kaspi-See" (Caspian Sea, no further details mentioned). Type locality of $P$. schorygini: Caspian Sea; off Apsheron Peninsula, $40^{\circ} 07.5^{\prime} \mathrm{N}, 50^{\circ} 57.5^{\prime} \mathrm{E}$, WGS84, $88 \mathrm{~m}$ (after Vinarski \& Kantor 2016). Type locality of P. nana: western part of the Caspian Sea, 70-120 m.

Dimensions. 2.05 x 1.13 mm (RGM 1309810, Figs 4.5A, F, H, I); 2.16 x 1.16 mm (LV 201506, Figs 4.5B, C, G); 2.12 x 1.10 mm (RGM 1309856, Figs 4.5D, E); 2.12 x 1.23 mm (RGM 1309790, Figs 4.5J, K).

Description. Slender ovoid shell with up to 4.7 whorls. Protoconch broad, low dome-shaped, comprising 1.25 whorls that measure $365 \mu \mathrm{m}$; nucleus is ca. $105 \mu \mathrm{m}$ wide; protoconch surface finely but strongly malleate; pattern irregular on initial part and only partly present on nucleus; $\mathrm{P} / \mathrm{T}$ transition marked by thin axial line and slight step in the upper suture. Teleoconch whorls slightly ton-shaped, weakly convex in abapical half and straight-sided or almost so in adapical half, followed by pronounced convexity at upper suture, producing slightly stepped spire. Last whorl attains ca. 61-66\%, descends into steep, straight base. Aperture slender ovoid, slightly inclined, with faint adapical notch at contact to penultimate whorl. Peristome slightly thickened and expanded. In lateral view, outer lip exposes marked adapical indentation and very weak abapical indentation; columellar lip straight. Umbilicus narrow but always open. Growth lines weak but distinctly sigmoidal, with opisthocyrt upper half and prosocline lower half. In addition, faint spiral threads are visible on some shells. 


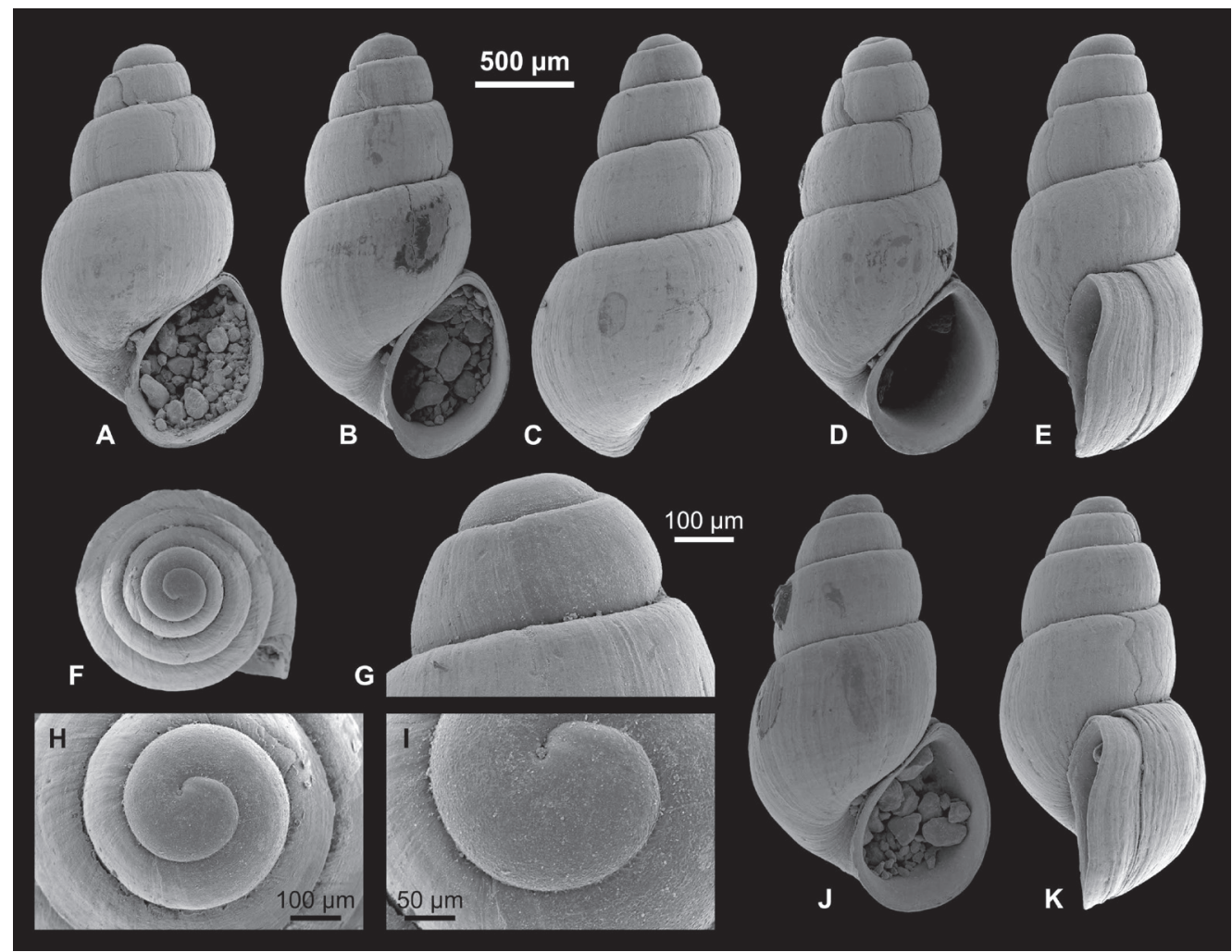

Fig. 4.5: Caspiinae. A, F, H, I Ulskia ulskii (Clessin \& W. Dybowski in W. Dybowski, 1887), RGM 1309810 B, C, G U. ulskii, LV 201506 D, E U. ulskii, RGM 1309856 J, K U. ulskii, RGM 1309790.

Discussion. Pyrgula schorygini Logvinenko \& Starobogatov, 1969 and P. nana Logvinenko \& Starobogatov, 1969, both of which were also originally included in the subgenus Ulskia, closely resemble this species. Logvinenko \& Starobogatov (1969) did not discuss similarities or differences among the species involved, but their descriptions suggest they considered minor differences in whorl profile and suture depth sufficient to discriminate species. A similar range of variability is present in our sample as well and might rather reflect intraspecific variation. We thus consider the three species synonymous.

Two more species were attributed to the subgenus Ulskia by Logvinenko \& Starobogatov (1969). The shell of Caspia derzhavini (Logvinenko \& Starobogatov, 1969) is more slender and has more whorls. Caspia behningi (Logvinenko \& Starobogatov, 1969) differs in its broader and distinctly conical shape.

Distribution. Endemic to the Caspian Sea, reported from water depths between 45 and $120 \mathrm{~m}$ (Logvinenko \& Starobogatov 1969). 


\section{? Subfamily Horatiinae Taylor, 1966}

\section{Genus Andrusovia Brusina in Westerlund, 1902a}

Type species. Andrusovia dybowskii Brusina in Westerlund, 1902a; by original designation. Caspian Sea, Recent.

Discussion. The subfamily placement of the genus follows Vinarski \& Kantor (2016: 214) and is based on the resemblance with species of the genus Horatia Bourguignat, 1887 (see also discussion in Starobogatov 2000). A recent molecular phylogeny including the Hydrobiidae suggests the Horatiinae to be distinct from the Belgrandiinae (Wilke et al., 2013; see also Bank 2017). We follow Starobogatov (2000) and regard Caspiohoratia Logvinenko \& Starobogatov, 1969 as a junior synonym of Andrusovia.

\section{Andrusovia brusinai Starobogatov, 2000}

Fig. 4.6F-K, M-N

* 2000 Andrusovia brusinai Starobogatov, sp. nov.; Starobogatov: 41, fig. 1C.

2006 Andrusovia brusinai Starobogatov, 2000. - Kantor \& Sysoev: 83, pl. 40, fig. C.

2016 Andrusovia brusinai Starobogatov, 2000. - Vinarski \& Kantor: 214.

Material. 39 specimens (RGM 1309839, RGM 1309840, RGM 1310206, LV 201509).

Type material. Holotype: ZIN (no number).

Type locality. Eastern part of the middle Caspian Sea ( $42^{\circ} 42.5^{\prime} \mathrm{N}, 51^{\circ} 32.5^{\prime} \mathrm{E}$, WGS84), at $80 \mathrm{~m}$.

Dimensions. 1.52 x 1.44 mm (RGM 1309840, Figs 4.6F, G); 1.54 x 1.55 mm (LV 201509, Figs 4.6H, K, N); 1.81 x 1.80 mm (RGM 1309839, Figs 4.6I, J, M); 1.71 x 1.52 mm; 1.67 x 1.69 mm; 1.83 x $1.55 \mathrm{~mm} ; 1.64 \times 1.51 \mathrm{~mm}$.

Description. Shell broad trochiform, about as high as wide, with up to 4 whorls. Rarely specimens with slightly elevated spire occur. Protoconch high domical, about semicircular in profile; initial part immersed; consists of 1.1 whorls, measures $300 \mu \mathrm{m}$ in diameter; nucleus about $90 \mu \mathrm{m}$ wide; protoconch surface finely but strongly malleate near lower suture, rest appears to be irregularly granulate, but that might be due to poor preservation; $\mathrm{P} / \mathrm{T}$ boundary sharp, marked by massive growth constrictions near lower suture. Teleoconch whorls highly convex, with maximum convexity in adapical half, producing slightly stepped spire. Last whorl attains $74-81 \%$ of shell height. Aperture broadly drop-shaped, slightly inclined, with faint adapical notch at contact to penultimate whorl. Peristome slightly thickened and expanded at columella and base; sinuate in lateral view, with weakly protruding central part and weak adapical indentation. Umbilicus wide, deep. Fine prosocline growth lines cover shell. On one specimen, traces of spiral threads occur on base. 


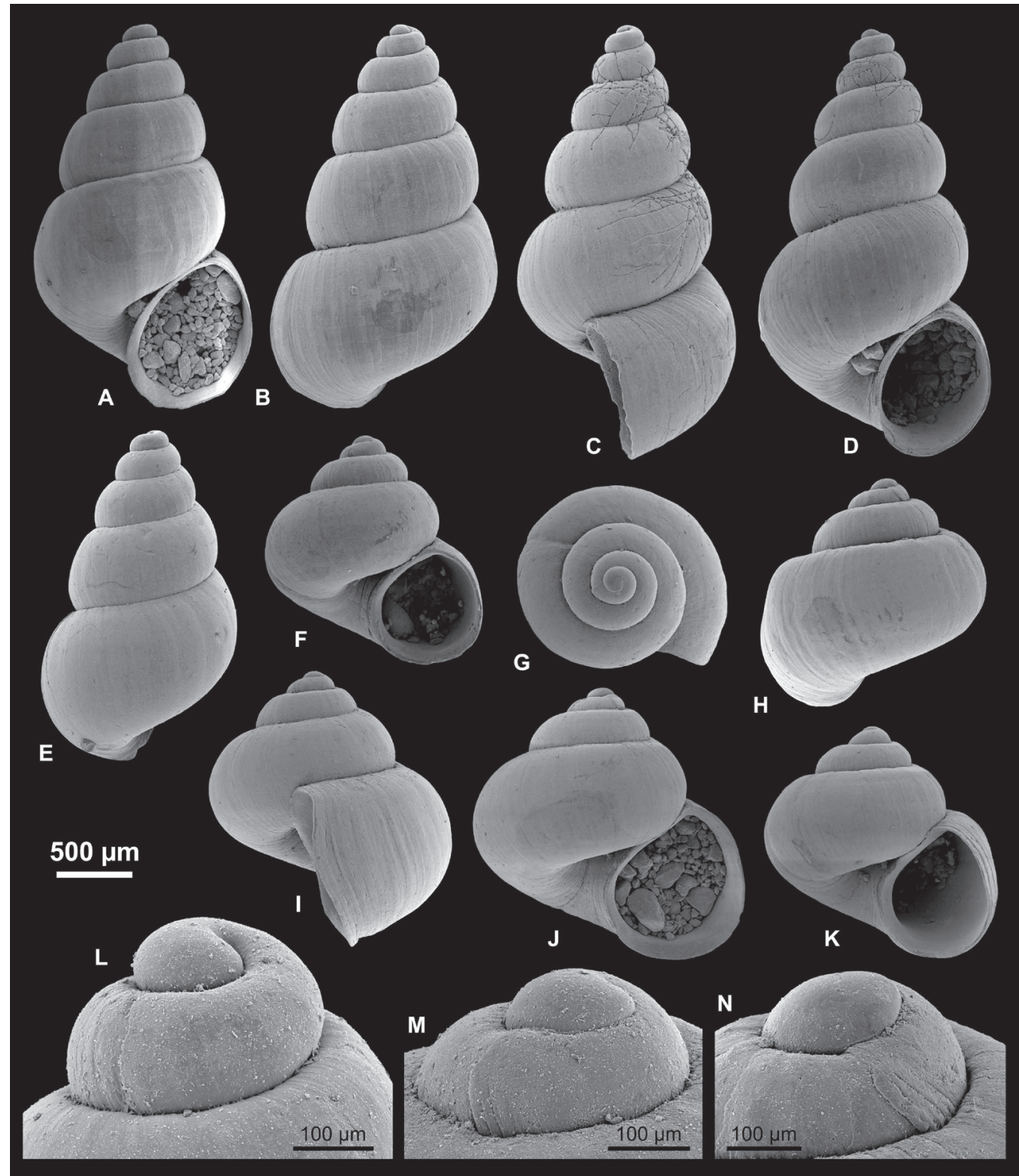

Fig. 4.6: Hydrobiinae and Horatiinae. A, B, L Ecrobia cf. grimmi (Clessin in W. Dybowski, 1887), LV 201508 C, D E. cf. grimmi, RGM 1309845 E E. cf. grimmi, RGM 1309847 F, G Andrusovia brusinai Starobogatov, 2000, RGM 1309840 H, K, N A. brusinai, LV 201509 I, J, M A. brusinai, RGM 1309839.

Discussion. The Caspian congeners Andrusovia dybowskii Brusina in Westerlund, 1902a (sensu Starobogatov 2000) and A. andrusovi Starobogatov, 2000 differ from the present species in their much lower spires. Andrusovia marina (Logvinenko \& Starobogatov, 1969) is smaller and has a 
shorter spire. Starobogatov (2000) based the distinction from A. brusinai on minor differences in shell ratios but these are strongly affected by the varying number of whorls and shell size; it might well be that A. marina and A. brusinai are just different growth stages of the same species. Since we have not seen the type material of Logvinenko \& Starobogatov (1969), we tentatively accept the distinction of both taxa by Starobogatov (2000). Further comparison with the Logvinenko \& Starobogatov material is essential to assess whether the two names refer indeed to distinct species.

Andrusovia brusinai resembles several recent species of Horatia Bourguignat, 1887, Hauffenia Pollonera, 1898 and Islamia Radoman, 1973 in terms of shell shape and protoconch surface. These differ from the present species in the either straight-sided (Hauffenia, Islamia; Arconada and Ramos, 2006; Erőss and Petró, 2008) or abapically (instead of adapically) sinuated peristome (Horatia; Szarowska, 2006; Szarowska and Falniowski, 2014). Shells of several species of Pontohoratia Vinarski, Palatov \& Glöer, 2015 and Motsametia Vinarski, Palatov \& Glöer, 2015 resemble Andrusovia species in terms of size and shape. They all differ in the more regularly shaped protoconchs, which show large nuclei and lack the massive growth constrictions.

Distribution. Endemic to the Caspian Sea, reported from middle and south Caspian Sea at depths between 47 and $311 \mathrm{~m}$ (Starobogatov 2000).

\section{Subfamily Hydrobiinae Stimpson, 1865}

\section{Genus Ecrobia Stimpson, 1865}

Type species. Turbo minutus Totten, 1834; by original description. United States, Recent.

\section{Ecrobia cf. grimmi (Clessin in W. Dybowski, 1887)}

Fig. 4.6A-E, L

cf. * 1887 Hydrobia Grimmi Cless.; W. Dybowski: 55-56.

cf. 1888 [Hydrobia] Grimmi Clessin. - W. Dybowski: 79, pl. 3, fig. 2.

cf. 1952 Hydrobia grimmi (Clessin) W. Dyb., 1888. - Zhadin: 225, fig. 147.

cf. 1969 Pyrgohydrobia grimmi (Cless. et W. Dyb.) - Logvinenko \& Starobogatov: 249, fig. 358 (11).

cf. 2006 Caspiohydrobia grimmi (Clessin in W. Dybowski, 1888). - Kantor \& Sysoev, 91-92, pl. 43,

fig. E.

cf. 2009 Caspiohydrobia grimmi (Clessin et Dybowski, 1888). - Filippov \& Riedel: 70-72, 74-76,

figs $4 \mathrm{a}-\mathrm{d}$.

cf. 2016 Caspiohydrobia grimmi (Clessin et W. Dybowski in W. Dybowski, 1888). - Vinarski \&

Kantor: 229. 
Material. 345 specimens (RGM 1309845, RGM 1309847, RGM 1310207, LV 201508).

Type material. Not traced.

Type locality. "Kaspi-See” (Caspian Sea, no further details mentioned).

Dimensions. 2.56 x 1.45 mm (LV 201508, Figs 4.6A, B, L); 2.83 x 1.54 mm (RGM 1309845, Figs 4.6C, D); 2.19 x 1.30 mm (RGM 1309847, Fig. 4.6E); 3.88 x 2.26 mm; 3.48 x 1.97 mm; 3.77 x 1.99 m; $3.50 \times 1.89 \mathrm{~mm} ; 3.26 \times 1.79 \mathrm{~mm} ; 3.33 \times 1.66 \mathrm{~mm}$.

Description. Shell shape highly variable, ranging from broad ovoid to slender conical, comprising up to 6.5 whorls. Protoconch consisting of about one whorl, with nucleus immersed; initial part slightly raised, producing acute apex; surface weakly granular to malleate; $\mathrm{P} / \mathrm{T}$ transition clear. Protoconch and teleoconch whorls highly convex, sometimes slightly flattened centrally in later whorls; suture deep. Size of last whorl varies between 55-62\%, descends into straight-sided base. Aperture regularly ovoid, slightly inclined, touching base of penultimate whorl, leaving wide umbilicus. Peristome simple, sometimes weakly expanded. Surface smooth expect for very fine prosocline growth lines.

Discussion. The shells of Ecrobia can only be reliably identified on the species-level using molecular data (Haase et al., 2010). Therefore, we tentatively assign the detected specimens to Ecrobia grimmi, which is the only Ecrobia species occurring in the Caspian Sea today (Haase et al., 2010).

Most of the species presently assigned to Caspiohydrobia Starobogatov, 1970, including its type species, Pyrgohydrobia eichwaldiana Golikov \& Starobogatov, 1966, range within the morphological variability of this species. Previous examination of both reproductive systems (Sitnikova et al., 1992) and juvenile shells (Filippov \& Riedel, 2009) did not yield criteria supporting interspecific differentiation. Very likely all of the thirty Caspiohydrobia species listed by Kantor \& Sysoev (2006) are morphotypes of a single species, probably E. grimmi. Given the problems of using shell morphology to identify Ecrobia, taxonomic conclusions on the synonymy of the Caspiohydrobia species require molecular data.

Note on species authority. W. Dybowski (1887: 7) noted that all diagnoses were drafted by Clessin and himself and most new species were therefore marked with "nob." (Lat. nobis, "us"). However, W. Dybowski obviously made exceptions. In case of the new genus Clessinia, he marked the authority with "m." (Lat. meus, "mine"). For Hydrobia grimmi, the authority is clearly indicated with "Cless.", making Clessin the sole author of the species (unlike indicated by several authors).

Distribution. Caspian Sea; Lake Sawa, Iraq (Haase et al., 2010); salt lakes near Chelyabinsk, Russia (Shishkoedova, 2010). Fossil records derive from Holocene deposits of the Aral Sea (Filippov \& Riedel, 2009).

\section{Subfamily Pyrgulinae Brusina, 1882}


1882 Pyrgulinae Brusina: 230.

1914 Micromelaniidae B. Dybowski \& Grochmalicki: 276.

1915 Turricaspiinae B. Dybowski \& Grochmalicki: 103.

2017 Pyrgulinae Brusina, 1882. - Bouchet et al.: 212, 346 [cum syn.].

Discussion. The Caspian Pyrgulinae (sensu lato) encompasses 64 species that are considered accepted in the current literature (Vinarski \& Kantor 2016). However, most of them are poorly known, documented by insufficient descriptions and drawings; for many, the type material has not been found (Kantor \& Sysoev 2006, Vinarski \& Kantor 2016). The extreme morphological variability of several representatives, such as those detected in the material from Selitrennoye, led previous authors to introduce numerous species based on shells with only minor deviations in shape, size or whorl outline. The Caspian Pyrgulinae therefore requires careful revision using molecular and anatomical data as far as available.

In addition to the problems associated with distinguishing species, genus-level classification is poorly resolved as well. Several attempts have been made to categorize this vast variability, and genus concepts have changed tremendously (e.g., B. Dybowski \& Grochmalicki 1915, 1917, Zhadin 1952, Logvinenko \& Starobogatov 1969, Kantor \& Sysoev 2006, Vinarski \& Kantor 2016). Twelve genus names have been described for members of the Caspian Pyrgulinae, based on quite different concepts of traits considered diagnostic. Currently, all species are classified within Caspia Clessin \& W. Dybowski, 1887, Pyrgula De Cristofori and Jan, 1932 and Turricaspia B. Dybowski \& Grochmalicki, 1915 (Kantor \& Sysoev 2006, Vinarski \& Kantor 2016). This scheme unites quite a variety of different morphologies under the same genus names, while at the same time similar species were assigned to different genera (e.g., Kantor \& Sysoev 2006). Unfortunately, hardly any previous study provided explanations for their genus classifications or systematic concepts in general.

A thorough revision of all Caspian Pyrgulinae is beyond the scope of this study, but we discuss and revise the concepts that have been applied to the species studied herein.

Vinarski \& Kantor (2016) listed 38 species of the genus Pyrgula for the Caspian Sea. The type species of Pyrgula De Cristofori \& Jan, 1832, P. annulata (Linnaeus, 1758), lives in freshwater lakes and springs in Italy and Dalmatia (Welter-Schultes 2012). Shell morphology, anatomy and protoconch characteristics are very similar to Pontocaspian Pyrgulinae, e.g., some species of Turricaspia (compare also discussion in Riedel et al. 2001). However, molecular evidence suggests that Pyrgula annulata is only distantly related to the Pontocaspian species flock within the Pyrgulinae, with the last common ancestor dating back to the late Miocene (Wilke et al., 2007). Therefore, Pontocaspian species should not be attributed to Pyrgula, despite apparent morphological congruence, especially of some of the keeled Pontocaspian Pyrgulinae. A separation on subfamily level as proposed by B. Dybowski and Grochmalicki (1915) is opposed by the latest phylogeny of rissooidean gastropods, which suggests a rather close relationship (Wilke et al., 2013). 
Turricaspia B. Dybowski \& Grochmalicki, 1915 (type species: Micromelania turricula B. Dybowski \& Grochmalicki, 1915) was introduced for species with turriform, elongate shells with numerous whorls. Presently, the genus includes 22 Caspian species, encompassing elongate and broad, conical and ovoid, and sculptured and smooth species (Kantor \& Sysoev 2006, Vinarski \& Kantor 2016). Many species assigned to Pyrgula by Kantor \& Sysoev (2006) and Vinarski \& Kantor (2016) actually resemble Turricaspia turricula with respect to the turriform, conical shell. This similarity also regards the type species of the genera Caspiopyrgula Logvinenko \& Starobogatov, 1969 (type species: Turricaspia nossovi Kolesnikov, 1947), Eurycaspia Logvinenko \& Starobogatov, 1969 (Micromelania pseudodimidiata B. Dybowski \& Grochmalicki, 1917), Oxypyrgula Logvinenko \& Starobogatov, 1969 (Pyrgula pseudospica Logvinenko \& Starobogatov, 1969), and Trachycaspia B. Dybowski \& Grochmalicki, 1917 (Rissoa dimidiata Eichwald, 1838). After examination of descriptions and illustrations of the type species (e.g., Kantor \& Sysoev 2006), we conclude that these genera should be considered as junior synonyms of Turricaspia.

Some of the species classified as Turricaspia by Kantor \& Sysoev (2006) and Vinarski \& Kantor (2016) differ considerably from Turricaspia s.s. in shell shape. This contains the type species of the genera Caspiella Thiele, 1928 (Rissoa conus Eichwald, 1838), Clessiniola Lindholm, 1924 (Paludina variabilis Eichwald, 1838), and Laevicaspia B. Dybowski \& Grochmalicki, 1917 (Rissoa caspia Eichwald, 1838). In turn, some species presently attributed to the genus Euxinipyrgula Sitnikova \& Starobogatov, 1999 (type species: Pyrgula milachevitchi Golikov \& Starobogatov, 1966) closely resemble species of the Laevicaspia - Caspiella group (compare Anistratenko et al. 2011).

Based on a review of the Pontocaspian species formerly attributed to these genera and illustrated in the literature (Alexenko and Starobogatov, 1987; Anistratenko, 2008; Golikov and Starobogatov, 1966; Kantor and Sysoev, 2006; Logvinenko and Starobogatov, 1969), we propose to distinguish the genera Clessiniola and Laevicaspia from Turricaspia, and to treat Caspiella and Euxinipyrgula as junior synonyms of Laevicaspia.

Clessiniola species can be easily distinguished from species attributed to other genera based on their broad shells with a large body whorl and aperture. The situation for the Laevicaspia Caspiella - Euxinipyrgula is more difficult. The three type species (see above) share the ovoid shape with cyrtoconoid spire, the high whorl accretion rate, the shape, inclination, lateral sinuation and thickening of the aperture, and the extent and sculpture of the protoconch (e.g., Anistratenko 2008, Kantor and Sysoev 2006, and this study). The only differences are shell size and whorl convexity, which we do not consider sufficient to distinguish genera. The adapical thickening of the aperture resulting from downward growing of the shell in late ontogeny as stated in the diagnosis of the genus Euxinipyrgula by Sitnikova \& Starobogatov (1999) is also shown for species that have been attributed to Caspiella (see below). The features of the soft-part anatomy considered diagnostic by these authors need to be rechecked and compared to live material from the Caspian Sea to reevaluate the position of Euxinipyrgula. Sitnikova \& Starobogatov (1999) also discussed the similarities between Caspiella and Euxinipyrgula, concluding that Caspiella should 
perhaps be included in the genus Euxinipyrgula, possibly as a separate subgenus (which would be nomenclaturally invalid however).

The ovoid shape, lateral sinuation and thickening of the aperture typical for the Laevicaspia Caspiella - Euxinipyrgula group are also found among species of the genus Prososthenia Neumayr, 1869 from the middle Miocene of the Dinaride Lake System (e.g., Neubauer et al. 2015b). These species, however, differ in the granulate protoconch making up less than one whorl.

Species of Turricaspia differ from Laevicaspia in the slower, regular whorl accretion, producing a conical spire and a higher number of whorls at the same size. In addition, Turricaspia species have usually more fragile shells, thinner peristomes and often more strongly sinuate growth lines.

The genus Caspia is listed among Pyrgulinae in latest catalogues (Kantor \& Sysoev 2006, Vinarski \& Kantor 2016), but it has been shown to be unrelated to that subfamily (Anistratenko 2013, Bouchet et al. 2017; see discussion of the Caspiinae above).

Finally, several Pontocaspian Pyrgulinae have been previously assigned to the genus Micromelania Brusina, 1874 (e.g., W. Dybowski 1887, B. Dybowski \& Grochmalicki 1917). Its type species, Micromelania cerithiopsis Brusina, 1874 (subsequent designation by Dollfus, 1912), derives from late Miocene deposits of Lake Pannon. It differs considerably from Pontocaspian Pyrgulinae regarding the presence of 2-4 noded keels and the small size (4.5 x $1.33 \mathrm{~mm}$ after Brusina, 1874) compared to the rather high number of eight whorls.

\section{Genus Clessiniola Lindholm, 1924}

1887 Clessinia W. Dybowski: 41 [non Doering, 1875].

1924 Clessiniola Lindholm: 32-33, 34.

1928 Clessinola Strand: 68 [junior objective synonym of Clessiniola].

Type species. Paludina variabilis Eichwald, 1838; by typification of replaced name (Clessinia W. Dybowski, 1887). Volga delta and Caspian Sea, Quaternary to Recent.

\section{Clessiniola variabilis (Eichwald, 1838)}

Fig. 4.7A-I

* 1838 Paludina variabilis m.; Eichwald: 151-152.

1841 Paludina variabilis m. - Eichwald: 253-254, pl. 38, figs 6-7.

1853 Pal.[udina] variabilis m. - Eichwald: 285.

1887 Clessinia variabilis Eichw. sp. - W. Dybowski: 41-42.

1888 [Clessinia] variabilis Eichw. sp. - W. Dybowski: 79, pl. 2, fig. 6.

1952 Clessiniola variabilis (Eichwald, 1841). - Zhadin: 255, fig. 199.

1966 P.[yrgula] (Clessiniola) variabilis. - Golikov \& Starobogatov: 356, fig. 2 (2). 
1969 Pyrgula [(Clessiniola)] variabilis (Eichw.) - Logvinenko \& Starobogatov: 377, fig. 367 (1).

1987 T.[urricaspia] variabilis (Eichw.). - Alexenko \& Starobogatov: 34, fig. 5.

2006 Turricaspia variabilis (Eichwald, 1838). - Kantor \& Sysoev: 111, pl. 49, fig. J.

2011 Turricaspia variabilis (Eichwald, 1838). - Anistratenko et al.: 85, fig. 3 (15).

2014 Turricaspia variabilis. - Taviani et al.: 4, fig. 3 b.

2016 Turricaspia variabilis (Eichwald, 1838). - Vinarski \& Kantor: 251.

Material. 4867 specimens (RGM 1309815, RGM 1309826, RGM 1309827, RGM 1309831, RGM 1310243-1310247, LV 201507).

Type material. Not traced.

Type locality. "In Volgae ostio prope Astrachanum, et versus mare Caspium; etiam fossili in calcatio lapide conglutinato recentissimo Dagesthanici littoris" (at the Volga river mouth near Astrakhan, and towards the Caspian Sea; also in recently lithified fossil limestone at the shores of Dagestan).

Dimensions. $5.91 \times 3.31 \mathrm{~mm}$ (LV 201507, Figs 4.7A-C); 6.31 x 3.59 mm (RGM 1310246, Fig. 4.7D); 4.60 x 2.35 mm (RGM 1310245, Fig. 4.7E); 6.08 x 3.18 mm (RGM 1310243, Figs 4.7F-H); 6.85 x $3.89 \mathrm{~mm}$ (RGM 1310244).

Description. Broadly drop-shaped to rarely conical shell of up to six whorls. Protoconch insufficiently preserved to specify extent and surface sculpture; P/T transition indistinct; first whorl measures ca. $340 \mu \mathrm{m}$ in diameter. Teleoconch whorls moderately and regularly convex; sometimes, spire is very faintly stepped; suture narrow. In many specimens, shells start to grow stronger in abapical direction in course of last (two) whorl(s), producing non-parallel suture and relatively higher penultimate whorl. Rarely, forms with comparatively slender shape and regularly increasing whorls (and thus relatively smaller last and penultimate whorls) occur. Both types are linked via intermediates. Aperture regularly ovoid, inclined; inner lip glossy, weakly to sometimes more prominently thickened; strongly adnate, sheet-like expanded over base of penultimate whorl and columella, rarely leaving very narrow umbilicus; broad, shallow spout occurs at transition between columella and base; outer lip mainly thin, sometimes weakly thickened at anterior notch. Growth lines very faint, with prosocline upper third and near orthocline lower two-thirds.

Discussion. This species displays a large morphological variability within our ample material. Shell shape ranges between slender conical to broadly ovoid, sometimes with weakly irregular growth. Likewise, shell size, whorl convexity, and number of whorls vary considerably. Yet, these features intergrade without clear boundary, rendering a distinction of species unreasonable.

The morphological variability is not restricted to our material but a general feature of Clessiniola. It was documented by several previous authors, partly for specimens from the same localities (e.g., Alexenko and Starobogatov, 1987; Anistratenko et al., 2011; Dybowski, 1887; Eichwald, 1838; Golikov and Starobogatov, 1966; Issel, 1865; Logvinenko and Starobogatov, 1969). The species concepts applied by the different authors, however, varied greatly. The present material 
includes shells that have been variably attributed to the species C. variabilis (Eichwald, 1838), C. triton (Eichwald, 1838) and C. martensii (Clessin \& W. Dybowski in W. Dybowski, 1887). The tritonmorphotype sensu Eichwald characterizes broad specimens with slightly detached aperture (see also Kantor \& Sysoev 2006); these forms are rarely represented in our material. Eichwald $(1838,1841)$ himself confirmed the rarity of the form, also stating that he did not find a living representative (in contrast to C. variabilis). The martensii-morphotype was introduced for similarly broad morphologies. (Note that Clessin \& W. Dybowski used a different concept of $C$. triton, there having a rather elongate conical shell.)

Because of the fluent morphological transition between forms traditionally referred to as C. variabilis, C. triton and C. martensii, as well as their joint occurrence in several localities in the Pontocaspian region, one might consider all of them synonymous. Personal observations on Holocene material from Dagestan area, however, indicate indeed distinguishable morphotypes without intermediates. Moreover, frequent shell repair found in most of the Selitrennoye specimens additionally complicates an unbiased view on morphological diversity. A more in-depth investigation comparing un-damaged material from different sites is thus required.

Given the large variability, the Caspian species Clessiniola ovum (Logvinenko \& Starobogatov, 1969) and C. trivialis (Logvinenko \& Starobogatov, 1969), as well as C. pseudotriton (Golikov \& Starobogatov, 1966) from the Dniester River mouth (compare Kantor \& Sysoev 2006), might too be considered as synonyms of $C$. variabilis. However, the original descriptions and drawings provided impede clarification of their statuses.

Clessinia ahngeri Westerlund, 1902 is often listed as junior synonym of C. variabilis, but without discussion (e.g., Logvinenko \& Starobogatov 1969, Vinarski \& Kantor 2016). The original description of C. ahngeri suggests close similarities indeed between both species claiming, however, that it differs from other congeners in the much larger spire $(11 \times 5 \mathrm{~mm})$ and the slightly sinuate outer lip. Examination of Westerlund's (1902b) material is required to ascertain the alleged synonymy.

The record of "Paludina Eichwaldi Kryn." Eichwald (1841) lists in synonymy of C. variabilis refers to a nomen nudum mentioned in a species list by Krynicki (1837).

Distribution. Endemic to the Pontocaspian region. Found in the Caspian Sea and the lower courses of rivers and freshwater parts of the Azov and Black seas (Anistratenko et al., 2011; Vinarski and Kantor, 2016). Also reported from Neoeuxinian (Late Pleistocene) deposits of the Marmara Sea (Taviani et al. 2014).

\section{Genus Laevicaspia B. Dybowski \& Grochmalicki, 1917}

? 1902a Thaumasia Westerlund: 104 [non Perty, 1833; non Albers, 1850].

1917 Laevicaspia B. Dybowski \& Grochmalicki: 5.

1928 Caspiella Thiele: 353, 381. 


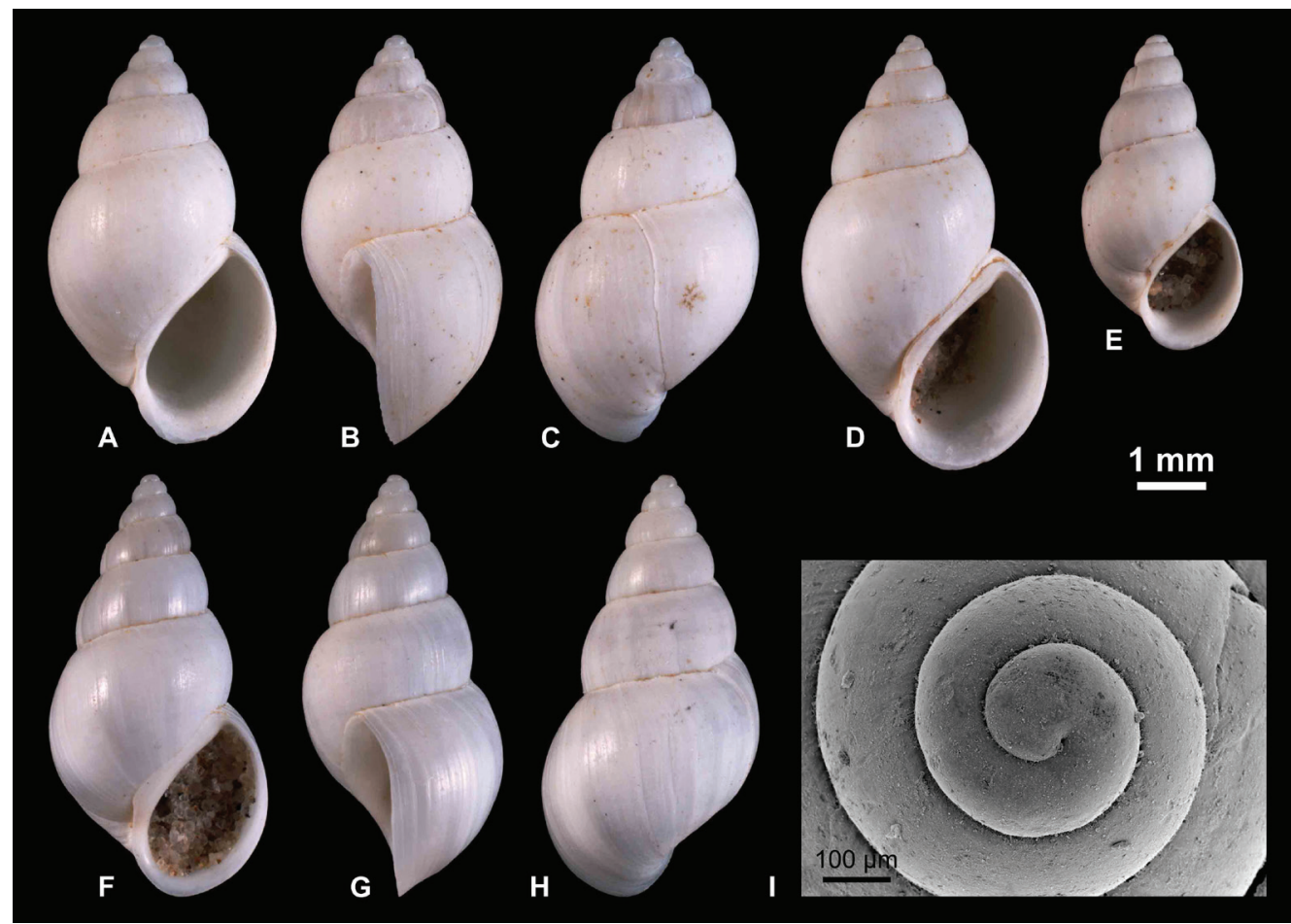

Fig. 4.7: Pyrgulinae. A-C Clessiniola variabilis (Eichwald, 1838), LV 201507, broad morphotype D C. variabilis, RGM 1310246, broad morphotype E C. variabilis, RGM 1310245, slender morphotype F-H C. variabilis, RGM 1310243, slender morphotype I C. variabilis, RGM 1309827.

1999 Euxinipyrgula Sitnikova \& Starobogatov: 158, 162.

Type species. Rissoa caspia Eichwald, 1838; by subsequent designation by Logvinenko \& Starobogatov (1969). Caspian Sea, Pleistocene.

Discussion. Lindholm (1922) studied the type material of Buliminus goebeli Westerlund, 1896 from Mangyschlak (Mangystau Peninsula, Kazakhstan) and concluded that is a junior synonym of "Micromelania" caspia (Eichwald, 1838). Westerlund (1902a), considering Buliminus goebeli as a member of terrestrial "Bulimoidea" (= Enidae), introduced the new genus Thaumasia, which - given synonymy of the type species involved - would take precedence over Laevicaspia B. Dybowski \& Grochmalicki, 1917. However, Thaumasia Westerlund, 1902 is invalid as a junior homonym of Thaumasia Perty, 1833 (Arachnida) and Thaumasia Albers, 1850 (Gastropoda, Subulinidae) (see also Lindholm (1925).

\section{Laevicaspia caspia (Eichwald, 1838)}

Fig. $4.8 \mathrm{~A}-\mathrm{K}$ 
* 1838 Rissoa caspia m.; Eichwald: 154-155.

1841 Rissoa caspia - Eichwald: 256-257, pl. 38, figs 14-15.

1853 Riss.[oa] caspia m. - Eichwald: 273.

non 1876 Hydrobia caspia, Eichw. - Grimm: 150-153, pl. 6, fig. 15.

non 1877 Hydrobia caspia, Eichw. - Grimm: 79-80, pl. 7, figs 3a-d.

non 1887 Micromelania caspia Eichw. sp. - W. Dybowski: 21.

non 1888 Micr.[omelania] caspia Eichw. sp. - W. Dybowski: 78, pl. 1, fig. 1.

? 1896 B.[uliminus] (Napaeus?) goebeli Westerlund: 188.

1914 Micromelania (?) curta Nalivkin: 21-22, 31, pl. 6, figs 1-2 [partim; non figs 3-4, 7, 9-14].

1914 [Micromelania (?) curta] var. plano-convexa Nalivkin: 22, 31, pl. 6, figs 15-18.

non 1914 Micromelania caspia Eichw. - Nalivkin: 22, 31, pl. 6, figs 5-6 [partim; non fig. 8].

non 1917 Micromelania (Turricaspia, Laevicaspia) caspia Eichw. - B. Dybowski \& Grochmalicki:

5-8, 36-38, pl. 1, figs 1-3.

non 1969 Pyrgula caspia (Eichw.). - Logvinenko \& Starobogatov: 369-370, fig. 364 (1).

1987 T.[urricaspia] caspia (Eichw.). - Alexenko \& Starobogatov: 33, fig. 2.

2006 Turricaspia caspia (Eichwald, 1838). - Kantor \& Sysoev: 106, pl. 49, fig. M.

2014 Euxinipyrgula lincta. - Taviani et al.: 4, fig. 3c [non Micromelania lincta Milashevich, 1908].

2016 Turricaspia caspia (Eichwald, 1838). - Vinarski \& Kantor: 246.

Material. 300 specimens (RGM 1309788, RGM 1309789, 1309797, RGM 1309798, RGM 1310196, RGM 1310257, RGM 1310258, LV 201511).

Type material. Lectotype: ZIN (No. 1 in systematic catalogue), designated by Alexenko \& Starobogatov (1987).

Type locality. "In eodem lapide calcario Dagesthanico, fossilis" (in the same limestone of Dagestan [referring to the previous species, also found in Dagestan], fossil).

Dimensions. 9.01 x $3.31 \mathrm{~mm}$ (RGM 1310257, Figs 4.8A-C); 7.88 x $3.31 \mathrm{~mm}$ (RGM 1310258, Figs 4.8D-F); 10.33 x $3.92 \mathrm{~mm}$ (LV 201511, Figs 4.8I-K); $9.92 \times 3.83 \mathrm{~mm} ; 10.21$ x $3.88 \mathrm{~mm}$; $9.52 \times$ $3.54 \mathrm{~mm} ; 9.69 \times 3.61 \mathrm{~mm}$.

Description. Large, slender ovoid shell comprising up to 8.3 whorls. Protoconch large, measuring 535-600 $\mu \mathrm{m}$ at 1.15-1.2 whorls, with initial part inflated; nucleus almost immersed, 190$230 \mu \mathrm{m}$ wide; nucleus and early protoconch bear intentions of malleate sculpture, which passes into granular surface after half a whorl accompanied by onset of spiral striae; P/T boundary indistinct. Whorl convexity decreasing rapidly: first teleoconch whorl moderately convex, second to last whorl low convex, sometimes almost straight-sided; maximum convexity is in lower half; whorls closely attached, suture narrow; a very small but marked convexity appears at upper suture, producing a faintly stepped spire; occasionally, it is accompanied by shallow abapical concavity. Last whorl makes up 46-50\% of shell height, passing over regular but weakly convex to near straight-sided to slightly concave base. Aperture slender ovoid, inclined, closely attached to preceding whorl; in latest 
ontogeny, shell growth is more abapically directed, resulting in marked thickening at adapical tip. Peristome simple, thin, slightly expanded and indented at base; distinctly and regularly sigmoidal in lateral view, with upper half broadly indented and lower half broadly protruding; inner lip protrudes in lateral view, extending sheet-like over base of penultimate whorl; umbilicus mostly closed, rarely very narrow, slit-like. Growth lines weakly sigmoidal: strongly prosocline in upper half, weakly opisthocline in lower half. Several specimens show faint spiral threads on last and penultimate whorls.

Discussion. Different concepts of this species previously applied have led to considerable confusion about its real identity. This is partly rooted in the description and illustration provided by Eichwald $(1838,1841)$ that were insufficient to allow safe discrimination from similar species. For instance, Micromelania caspia sensu Grimm (1876, 1877), W. Dybowski (1887-1888) and B. Dybowski \& Grochmalicki (1917) differs from the present species in the acute apex, the moderately convex whorls, the deep suture and the thin peristome. As already noted by Alexenko \& Starobogatov (1987), it represents a different species, i.e., Laevicaspia lincta (Milaschewitch, 1908). That species was described from Lake Katlabukh near the Danube delta in Ukraine (lectotype, which matches Milashevich's description, is illustrated in Kantor \& Sysoev 2006: 95, pl. 45, fig. D; as Euxinipyrgula lincta). Specimens from the Neoeuxinian (Late Pleistocene) of the Marmara Sea identified as E. cf. lincta by Taviani et al. (2014) differ from that species in the near straight-sided whorls and thickened peristome; in fact, the material corresponds well to L. caspia.

Micromelania caspia sensu Nalivkin (1914) comprises at least two species, both being more elongate, having more whorls and relatively smaller last whorls than $L$. caspia. In turn, some of the illustrated syntypes of "Micromelania" curta Nalivkin, 1914 and the variety "Micromelania" curta var. planoconvexa Nalivkin, 1914 from Bakunian deposits of Shikhovo, Apsheron Peninsula, Azerbaijan, closely resemble the present species and are thus (partly) considered synonymous. "Micromelania" curta encompasses a great variability of shapes, ranging from slender, elongate (caspia-type) to broad, conical shells. Since no holotype or lectotype have been designated, the status of this species is unresolved at present. Note that Pyrgula curta sensu Logvinenko \& Starobogatov (1969) and Kantor \& Sysoev (2006) does not correspond to Nalivkin's species but rather to the specimens Nalivkin (1914) misidentified as Micromelania caspia.

Similarly, Pyrgula caspia sensu Logvinenko \& Starobogatov (1969) is a quite different species, showing highly convex whorls and an inflated last whorl. It rather ranges within the morphological variability of Turricaspia meneghiniana (see below).

Alexenko \& Starobogatov (1987) finally brought stability to the identity of L. caspia by designating a lectotype (see Kantor \& Sysoev 2006: 106, pl. 49, fig. A; as Turricaspia caspia), which matches well our specimens. The label accompanying their specimen reads "Kaspiyskoye more" ("Caspian Sea"), which differs from the information provided by Eichwald (Dagestan) (see also discussion in Vinarski \& Kantor 2016: 246). Inspection of the catalogue of the Zoological Institute, 


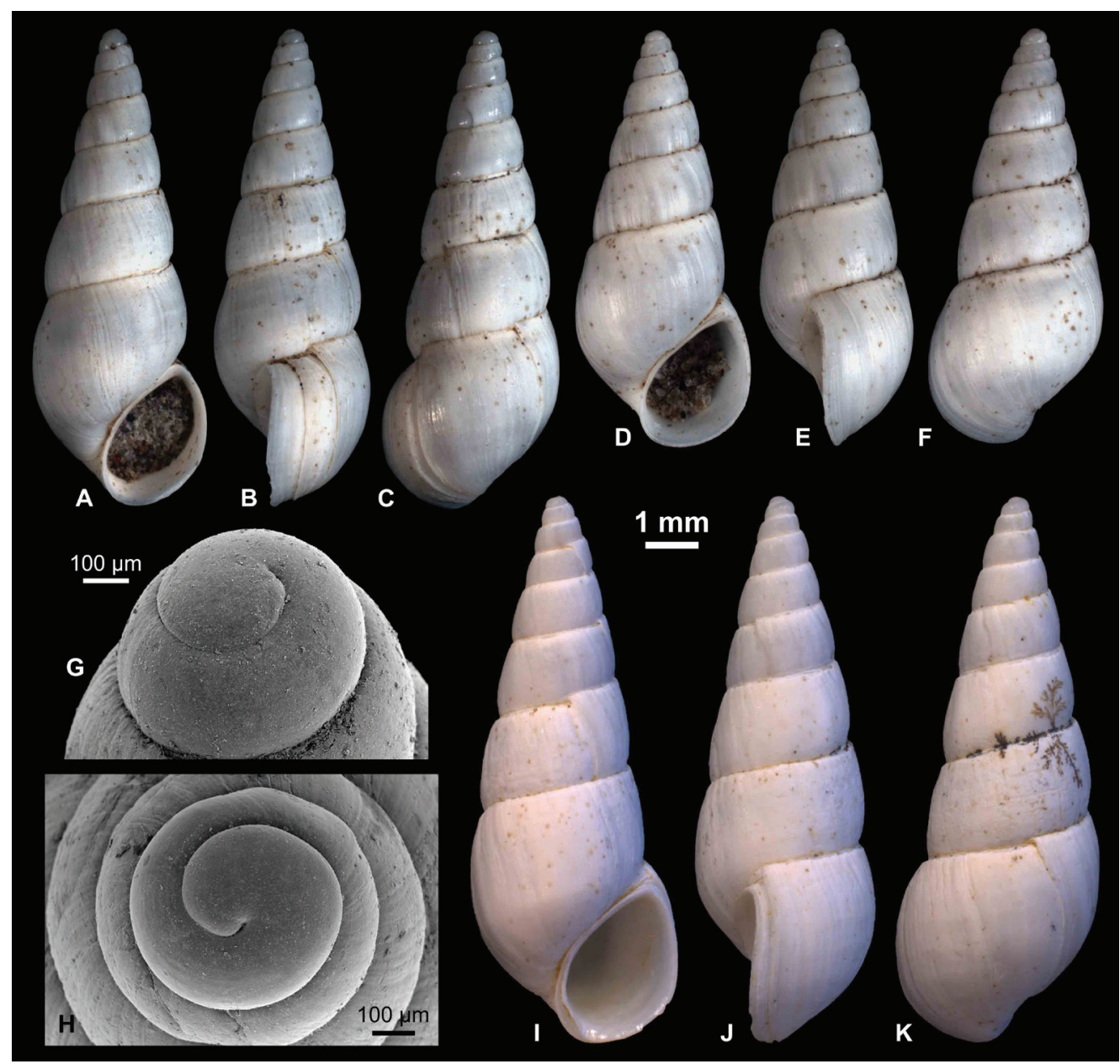

Fig. 4.8: Pyrgulinae. A-C Laevicaspia caspia (Eichwald, 1838), RGM 1310257 D-F L. caspia, RGM 1310258 G L. caspia, RGM 1310197 H L. caspia, RGM 1310198 I-K L. caspia, LV 201511.

Russian Academy of Sciences, St. Petersburg (ZIN), however, confirmed that the lectotype is based on Eichwald's original material.

The similar Laevicaspia iljinae (Golikov \& Starobogatov, 1966) from Holocene deposits of the Crimean Peninsula can be distinguished in its slenderer shape and the spruce-like whorl outline (i.e., steep, straight-sided upper two-thirds passing over convexity into flatter, convex lower third; see also Kantor \& Sysoev 2006: 108, pl. 49, fig. D).

Distribution. Endemic to the Caspian Sea (Logvinenko \& Starobogatov 1969 stated that the species occurs at a depth of 30-150 m in the middle and southern Caspian Sea, but these data have to be revised given their incorrect concept of L. caspia). 


\section{Laevicaspia cincta (Abich, 1859) comb. $\mathbf{n}$.}

Fig. 4.9A-H

* 1859 Rissoa cincta; Abich: 57, pl. 2, fig. 6 .

? 1887 Caspia Orthii Clessin \& W. Dybowski in W. Dybowski: 40.

? 1888 [Caspia] Orthii n. sp. - W. Dybowski: 79, pl. 3, fig. 6.

1969 Pyrgula [(Caspiella)] cincta (Abich). - Logvinenko \& Starobogatov: 372, fig. 366 (4).

2006 Pyrgula cincta (Abich, 1859). - Kantor \& Sysoev: 98, pl. 47, fig. L.

2016 Pyrgula cincta (Abich, 1859). - Vinarski \& Kantor: 236.

Material. 174 specimens (RGM 1309806, RGM 1309807, RGM 1310200, LV 201514).

Type material. Not traced.

Type locality. Abich (1859) specified the type locality on p. 12-13 as "Gulf of Baku".

Dimensions. 3.83 x 1.93 mm (LV 201514, Figs 4.9A, B); 4.05 x 1.89 mm (RGM 1309807, Figs 4.9C-E); 4.41 x 2.10 mm (RGM 1309806, Figs 4.9F-H); 4.73 x $2.11 \mathrm{~mm} ; 4.59$ x $2.10 \mathrm{~mm} ; 4.58$ x 2.17 $\mathrm{mm}$.

Description. Slender ovoid shell with up to 6.5 whorls. Protoconch broad, low dome-shaped, consists of 1.2 whorls that measure $415 \mu \mathrm{m}$ in diameter, with slightly inflated initial part; nucleus $150 \mu \mathrm{m}$ wide; protoconch surface weakly granulate, with intentions of striae on second half; P/T transition distinct, formed by sharp, thin axial line. Whorl convexity decreases steadily during ontogeny, with early teleoconch whorls being moderately convex and penultimate and last whorl low convex to almost straight-sided. On third teleoconch whorl, weak subsutural band emerges that slightly enhances during ontogeny; band forms weak bulge throughout, with maximum convexity in its lower half and steep, almost straight-sided ramp in upper half; abapical demarcation clear, sometimes accompanied by thin groove. Last whorl attains 54-65\% of shell height, passing from flattened whorl flank over marked convexity into steep, straight-sided base. Aperture near dropshaped, inclined, with acute adapical angle, straight parietal margin, obtuse angle between parietal and columellar margins, sometimes slightly expanded palatal margin. Peristome not thickened, weakly expanded at columella and base; regularly sinuate in lateral view, with broad adapical indentation and about equally broad and high abapical protrusion. Umbilicus closed or very narrow. Growth lines weakly prosocline in upper half, near orthocline in lower half.

Discussion. The Selitrennoye specimens match with the original description in terms of size (shell height: 3-4 mm), the ovoid shell shape, the number of whorls, the rounded last whorl and the simple peristome margin; they differ in the expression of the subsutural band, which Abich indicated to be "weakly keeled". We consider these differences to range within the intraspecific variability of this species.

Laevicaspia cincta can be readily distinguished from other Pontocaspian Pyrgulinae by its ovoid, slightly stepped shell with broad, blunt apex, subsutural band and flattened whorls in later 

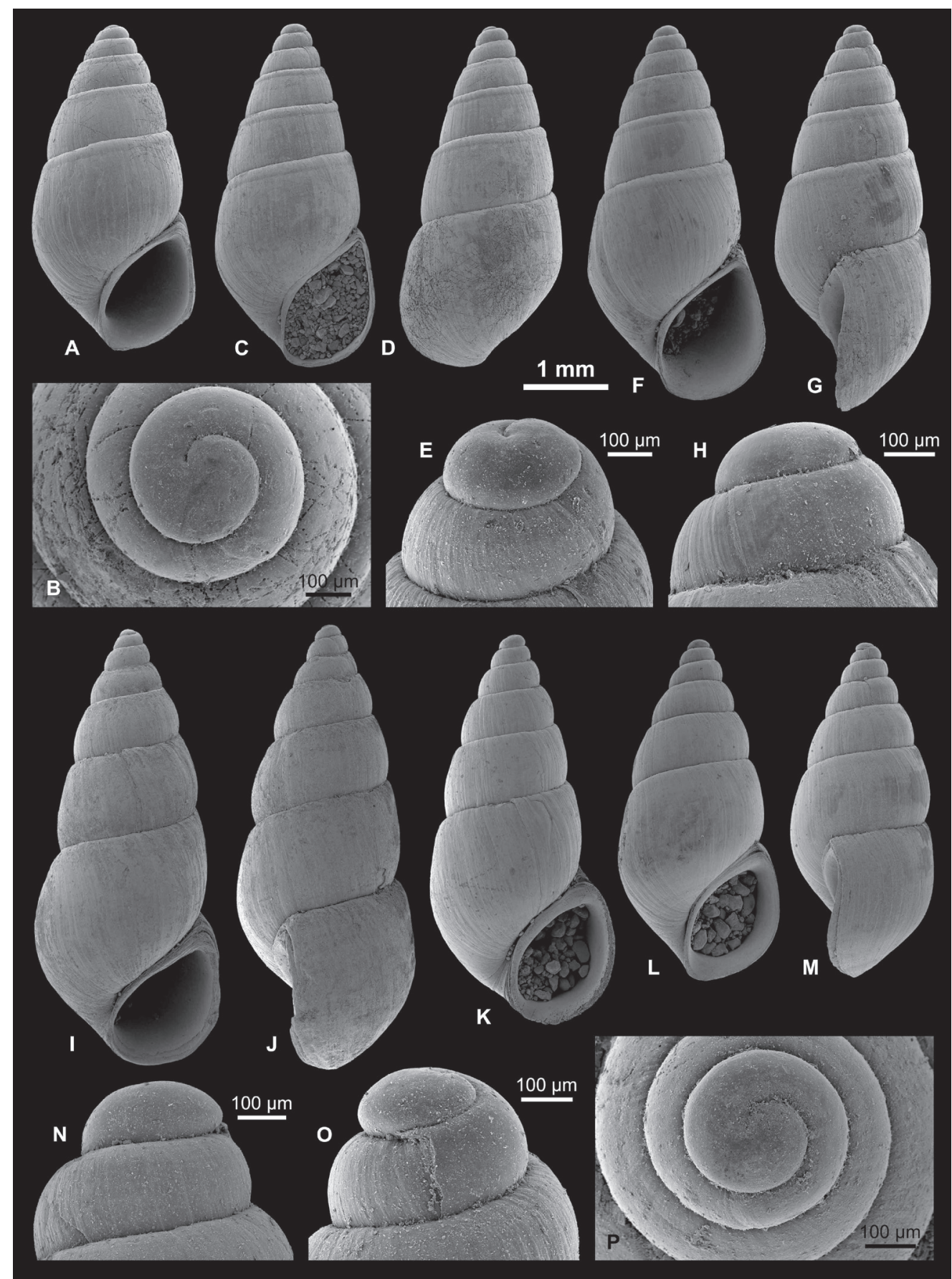

Fig. 4.9: Pyrgulinae. A, B Laevicaspia cincta (Abich, 1859), LV 201514 C-E L. cincta, RGM 1309807 F-H L. cincta, RGM 1309806 I, J L. cincta, RGM 1309830 K Laevicaspia conus (Eichwald, 1838), LV 201515 L-O L. conus, RGM 1309829 P L. conus, RGM 1309828. 
ontogeny. Laevicaspia abichi (Logvinenko \& Starobogatov, 1969) from the middle Caspian Sea, differs in the much larger size $(6.8 \times 3 \mathrm{~mm})$, the conical shape, the narrower subsutural band and the larger aperture. The Caspian endemic species Laevicaspia kowalewskii (Clessin \& W. Dybowski in W. Dybowski, 1887) resembles L. cincta very closely in terms of the slender ovoid shape with near straight-sided whorls, the closely attached aperture with thin peristome, and the lacking umbilicus; it differs in the lack of a subsutural band and the more elongate shape.

Caspia orthii Clessin \& W. Dybowski in W. Dybowski, 1887 was synonymized with the present species by previous authors (e.g., Logvinenko \& Starobogatov 1969, Kantor \& Sysoev 2006, Vinarski \& Kantor 2016). The original description matches well our specimens in terms of size $(4.8 \times 1.9$ $\mathrm{mm}$ ), number of whorls, expression of the subsutural band and shape of the aperture; the only difference is the "elongated-conical" shape compared to the ovoid shells of L. cincta described by Abich (1859) and represent by our material. Although not having seen W. Dybowski's type material, we tentatively follow the previous assessment and consider Caspia orthii a junior synonym of Laevicaspia cincta.

Note that Rissoa cincta Deshayes, 1861 (p. 404, pl. 24, figs 4-6), described from the Eocene (Bartonian) of the Paris basin, is a junior primary homonym of this species. At present, this species is classified in the genus Pseudotaphrus Cossmann, 1888 (Ponder 1984: 96).

Distribution. Endemic to the Caspian Sea, in the southern part at a depth of up to $>250 \mathrm{~m}$ (Parr et al., 2007). 2007).

\section{Laevicaspia conus (Eichwald, 1838) comb. $\mathbf{n}$.}

Fig. 4.9I-P

\section{* 1838 Rissoa Conus m.; Eichwald: 155.}

1841 Rissoa Conus m. - Eichwald: 257, pl. 38, figs 16a-b [wrongly given as “figs 16-17” on p. 257;

see also corrigendum at the end of Eichwald's work].

1853 Riss.[oa] conus m. - Eichwald: 273.

non 1876 Eulima conus, Eichw?. - Grimm: 154-156, pl. 6, fig. 14.

1887 Nematurella conus Eichw. sp. (non Grimm). - W. Dybowski: 45.

1888 [Nematurella] conus Eichw. sp. - W. Dybowski: 78, pl. 2, fig. 3.

? 1896 Prosostenia [sic] conus Eichw. - Sinzov: 49-50, pl. 1, figs 30-33.

1926?Nematurella conus (Eichwald). - Wenz: 2007.

1952 Caspiella conus (Eichwald, 1841). - Zhadin: 259, fig. 211.

1969 Pyrgula [(Caspiella)] conus (Eichw). - Logvinenko \& Starobogatov: 374, fig. 366 (5-6).

non 2006 Turricaspia conus conus (Eichwald, 1838). - Kantor \& Sysoev: 106, pl. 48, fig. J.

2016 Turricaspia conus conus (Eichwald, 1838). - Vinarski \& Kantor: 246-247. 
Material. 1135 specimens (RGM 1309828, RGM 1309829, RGM 1309830, RGM 1310199, RGM 1310226-1310228, LV 201515).

Type material. Not traced.

Type locality. "In eodem lapide calcareo, fossilis" (in the same limestone [referring to previous species, found in Dagestan], fossil).

Dimensions. 5.14 x 2.19 mm (RGM 1309830, Figs 4.9I, J); 4.60 x 2.18 mm (LV 201515, Fig. 4.9K); 4.02 x $1.91 \mathrm{~mm}$ (RGM 1309829, Figs 4.9L-O); 3.87 x 1.87 mm (RGM 1309828, Fig. 4.9P); 4.60 x $2.23 \mathrm{~mm}$ (RGM 1310226); 5.12 x $2.37 \mathrm{~mm}$ (RGM 1310227); 4.17 x $2.14 \mathrm{~mm}$ (RGM 1310228).

Description. Ovoid, glossy shell with up to 6.8 whorls. Shell outline variable, depending on growth stage: shells with up to 5 whorls are rather broad, nearly conical; in late ontogeny, shell growth is directed adapically, producing more elongate shapes with narrow, high last whorl; sometimes, these slender elongate morphotypes have slightly irregular shape. Protoconch consists of 1.2 whorls with $355 \mu \mathrm{m}$ in diameter; nucleus almost immersed, $125 \mu \mathrm{m}$ wide; surface faintly malleate or granulate, with intentions of spiral sculpture detected in some specimens; P/T boundary very distinct, marked by sharp, thin axial line. Teleoconch whorls weakly to moderately convex, sometimes adapically flattened. Last whorl attains between 55-63\% of total height, grades into straight-sided or weakly convex base. Aperture drop-shaped, inclined, closely attached to base of preceding whorl, usually covering or rarely leaving slit-like umbilicus. Peristome slightly expanded, thin or thickened all around, especially at adapical tip; regularly sinuate in lateral view, with broad adapical indentation and about equally broad and high abapical protrusion. Growth lines weak, prosocline in upper half, orthocline in lower half.

Discussion. Logvinenko \& Starobogatov (1969) listed "Rissoa conus Eichwald, 1841, partim" in synonymy of Pyrgula kolesnikoviana Logvinenko \& Starobogatov in Golikov \& Starobogatov, 1966 (now classified in Laevicaspia; see below), but without any explanation. The synonymy list was expanded as "Rissoa conus sensu Eichwald, 1841, partim, non Eichwald, 1838" by Kantor \& Sysoev (2006) and Vinarski \& Kantor (2016), yet again without discussion. The synonymy is not mentioned in the original description of Laevicaspia kolesnikoviana in Golikov \& Starobogatov (1966). Very likely, the synonymy roots in the ambiguous description of Eichwald $(1838,1841)$, summarizing two different morphologies. Eichwald referred to the typical form as having a conical shell with seven, gently increasing whorls, whereas the last two are much broader; the size was indicated as $2 \times 1$ lin., which corresponds to $4.2 \times 2.1 \mathrm{~mm}$ (given Eichwald used the Russian liniya). In addition, he mentioned rarer, slightly longer (3 lin.) specimens, with deeper suture and straight-sided whorls. In 1841, Eichwald illustrated one of these rare specimens. The description in the 1841-work, however, is almost identical to the original description. In this light, it remains unclear why Kantor \& Sysoev (2006) and Vinarski \& Kantor (2016) referred to as "Rissoa conus sensu Eichwald, 1841, partim, non Eichwald, 1838" in their synonymy lists of L. kolesnikoviana. To complete confusion, the specimen illustrated in Kantor \& Sysoev (2006) is not L. conus, differing in the broad, blunt apex and the near 
straight-sided whorls; it rather resembles L. kowalewskii (Clessin \& W. Dybowski in W. Dybowski, 1887).

The holotype of L. kolesnikoviana illustrated by Kantor \& Sysoev (2006, pl. 47, fig. N) corresponds to the description and illustration of the rare, slender morphology of Laevicaspia conus sensu Eichwald in terms of the number of whorls and the near straight-sided whorls; it differs only in the considerably smaller size $(3.7 \mathrm{~mm}$ vs. $6.3 \mathrm{~mm}$ ). Yet, Golikov \& Starobogatov (1966) and Logvinenko \& Starobogatov (1969) indicate larger sizes for L. kolesnikoviana (5.5 $\mathrm{mm}$ and 6.5 $\mathrm{mm}$, respectively), suggesting a great variability in size. On the other hand, the two morphologies delineated by Eichwald also match our own observations on L. conus. In late ontogeny, growth is directed almost entirely abapically, resulting in more elongate shells with an additional whorl. These larger morphologies correspond completely to the smaller, relatively bulkier shells in all other aspects, which is why we consider them as morphotypes rather than species-group taxa. Without Eichwald's material at hand it is difficult to arrive at a conclusion on this matter.

The species has affinities with several representatives of the Azov and Black seas. Pyrgula (Caspiella) lindholmiana Golikov \& Starobogatov, 1966, today considered as a subspecies of L. conus (e.g., Vinarski \& Kantor 2016), has a larger and broader shell. Similarly, Laevicaspia milachevitchi (Golikov \& Starobogatov, 1966) and Laevicaspia boltovskoji (Golikov \& Starobogatov, 1966) are broader than L. conus, while Laevicaspia lincta (Milaschewitch, 1908) and Laevicaspia limanica (Golikov \& Starobogatov, 1966) are more slender and larger.

"Eulima conus Eichwald" as described and illustrated by Grimm (1876, 1877) has little resemblance to actual $L$. conus. He illustrated a very elongate, conical shell with many more and almost perfectly straight-sided whorls. This fact was already noticed by Clessin \& W. Dybowski a few years later, and they introduced Micromelania grimmi Clessin \& W. Dybowski in W. Dybowski, 1887 for the misidentified species.

The illustrations of specimens from the Kuyalnikian (late Pliocene to early Pleistocene) of the Odessa region identified as Prososthenia conus by Sinzov (1896) show shells with similar shape, proportions and whorl convexity. A more detailed examination of material from the region is required to assess whether it is indeed conspecific with $L$. conus.

Distribution. Endemic to the Caspian Sea, reported from depths between 0 and $120 \mathrm{~m}$ (Logvinenko \& Starobogatov 1969).

\section{Laevicaspia kolesnikoviana (Logvinenko \& Starobogatov in Golikov \& Starobogatov, 1966) comb. $n$.}

Fig. 4.10A-E, K, N

* 1966 P. [yrgula] (Caspiella) kolesnikoviana Logvinenko et Starobogatov; Golikov \& Starobogatov:

357, fig. 2 (8-9).

1969 Pyrgula [(Caspiella)] kolesnikoviana Logv. et Star. - Logvinenko \& Starobogatov: 372, 


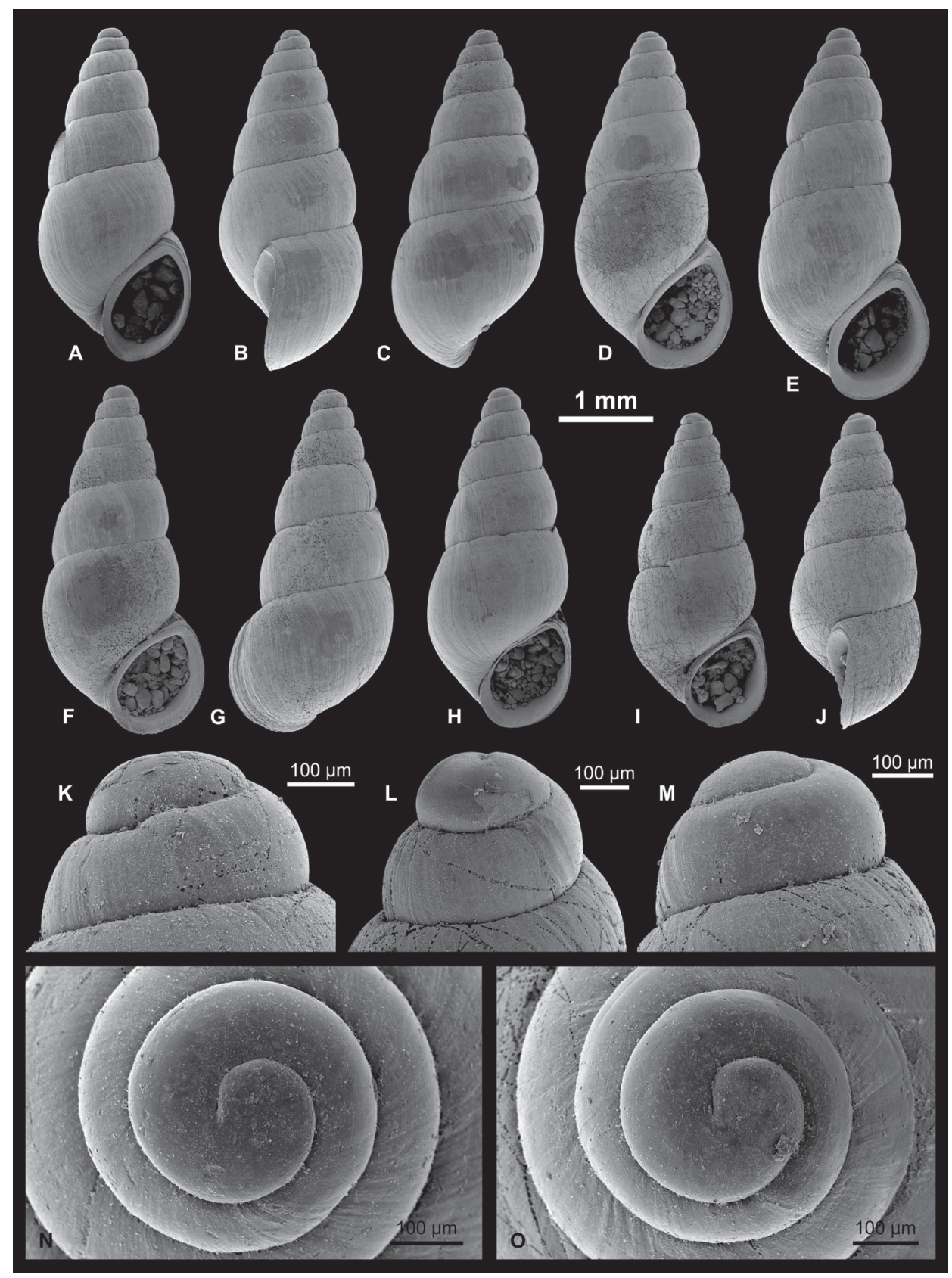

Fig. 4.10: Pyrgulinae. A-C, K Laevicaspia kolesnikoviana (Logvinenko \& Starobogatov in Golikov \& Starobogatov, 1966), RGM 1309816 D L. kolesnikoviana, LV 201516 E, N L. kolesnikoviana, RGM 1309819 F, G Laevicaspia vinarskii sp. n., holotype, LV 201517 H, O L. vinarskii sp. n., RGM paratype, 1309805 I, J, L, M L. vinarskii sp. n., paratype, RGM 1309821. 
fig. 366 (1).

2006 Pyrgula kolesnikoviana Logvinenko et Starobogatov in Golikov et Starobogatov, 1966. - Kantor \& Sysoev: 100, pl. 47, fig. N.

2016 Pyrgula kolesnikoviana Logvinenko et Starobogatov in Golikov et Starobogatov, 1966. -

Vinarski \& Kantor: 239.

Material. 514 specimens (RGM 1309816, RGM 1309818, RGM 1309819, RGM 1310212, RGM 1310221-1310225, LV 201516).

Type material. Holotype: ZIN 4462/1.

Type locality. Caspian Sea, N of Apsheron peninsula, NW from Kamni Dva Brata Island, $40^{\circ} 47^{\prime} \mathrm{N}, 49^{\circ} 42^{\prime} \mathrm{E}, 30 \mathrm{~m}$ (Vinarski \& Kantor 2016).

Dimensions. 3.55 x 1.63 mm (RGM 1309816, Figs 4.10A-C, K); 3.59 x 1.67 mm (LV 201516, Fig. 4.10D); 3.95 x 1.82 mm (RGM 1309819, Figs 4.10E, N); 3.90 x 1.77 mm (RGM 1309818); 4.04 x 1.96 mm (RGM 1310222); 4.49 x 1.99 mm (RGM 1310223); 3.54 x 1.72 mm (RGM 1310224).

Description. Small, slender ovoid, shiny shell with up to 6.9 whorls. Protoconch consists of 1.2 whorls, measuring $355 \mu \mathrm{m}$ in diameter; nucleus rather long, ca. $130 \mu \mathrm{m}$ wide; surface finely granulate (maybe due to preservation; traces of finely malleate to irregularly striate pattern occurs on margins of nucleus and initial part); faint striae on last third; P/T boundary distinct. Whorl convexity of teleoconch whorls decreasing: first to second whorl moderately to highly convex, last whorl low to moderately convex. Faint subsutural band appears on later teleoconch whorls in some specimens, sometimes accompanied by weak concavity below. Last whorl attains $50-57 \%$ of shell height, passing via broad, regular convexity in to weakly convex base. Aperture ovoid, inclined, closely attached to preceding whorl; in latest ontogeny, shell growth is more abapically directed, resulting in marked thickening at adapical angle. Peristome thin or thickened all around, with parietal margin sometimes slightly expanded; weakly but regularly sinuate in lateral view, with broad adapical indentation and about equally broad and high abapical protrusion. Umbilicus usually closed or very narrow, slit-like. Growth lines weak, prosocline in upper half, orthocline in lower half. In addition, faint spiral furrows appear in some specimens.

Discussion. Co-occurring Laevicaspia vinarskii sp. n. differs in the consistently lower whorl expansion rate at the same size and the smaller aperture. Laevicaspia kowalewskii (Clessin \& W. Dybowski in W. Dybowski, 1887) can be distinguished by its broader and larger shell.

Distribution. Endemic to the Caspian Sea, reported from depths between 25 and $180 \mathrm{~m}$ (Kolesnikov 1947, Logvinenko \& Starobogatov 1969).

\section{Laevicaspia vinarskii sp. $\mathrm{n}$.}

http://zoobank.org/8399A902-945D-444A-A8AD-136592F8E527

Fig. 4.10F-J, L-M, O 
Type material. Holotype: LV 201517; 3.70 x 1.72 mm (Figs 4.10F-G). Paratypes: RGM 1309821; 3.34 x 1.48 mm (Figs 4.10I, J, L, M). RGM 1309805; 3.61 x 1.54 mm (Figs 4.10H, O). LV 201731; 4.14 x $1.93 \mathrm{~mm}$.

Additional material. 5 specimens (RGM 1309793, LV 201732).

Type locality. Selitrennoye, Astrakhan, Russia; northern Caspian basin; GPS coordinates: $47^{\circ} 10^{\prime} 21.19^{\prime \prime} \mathrm{N}, 47^{\circ} 26^{\prime} 25.41^{\prime \prime} \mathrm{E}$ (WGS84).

Age. Early Late Pleistocene (late Khazarian, MIS 5).

Etymology. In honor of Maxim Vinarski (Saint Petersburg State University) for his contributions to Malacology.

Diagnosis. Slender ovoid, imperforate shell with up to 6.5 moderately convex whorls, narrow suture, granulate-striate protoconch, high whorl expansion rate and small, adnate, inclined aperture.

Description. Slender ovoid shell with up to 6.5 whorls. Protoconch consists of 1.2 whorls measuring $375 \mu \mathrm{m}$; nucleus is $140 \mu \mathrm{m}$ wide; surface strongly granulate on nucleus, less so on remaining protoconch, striae appear on last 0.25 whorls; $\mathrm{P} / \mathrm{T}$ transition marked by distinct growth rim. Teleoconch whorls moderately convex, separated by narrow suture; whorls increase slowly in height, with the last attaining $53-57 \%$ of shell height, passing into weakly convex base. Weak subsutural band is observed in one specimen. Aperture small, inclined, closely attached to base of preceding whorl, leaving no or slit-like umbilicus. Peristome slightly thickened, especially at adapical tip; regularly sinuate in lateral view, with broad adapical indentation and about equally broad and high abapical protrusion. Distinct spiral furrows occur in well preserved specimens. Growth lines weak, prosocline in upper half, orthocline in lower half.

Discussion. The new species differs from co-occurring Laevicaspia kolesnikoviana in the higher whorl expansion rate at about the same size and the larger aperture. Laevicaspia? ismailensis (Golikov \& Starobogatov, 1966) from lakes Yalpug and Kugurlu in the Danube river delta is more slender and larger $(5.6 \mathrm{~mm})$ at the same number of whorls and has a less inclined, rounder aperture (see holotype illustrated by Kantor \& Sysoev 2006: pl. 50, fig. A).

Distribution. Endemic to the Caspian Sea Pleistocene, so far only known from Selitrennoye

\section{Genus Turricaspia B. Dybowski \& Grochmalicki, 1915}

1915 Turricaspia B. Dybowski \& Grochmalicki: 105.

1917 Trachycaspia B. Dybowski \& Grochmalicki: 22.

1969 Pyrgula (Caspiopyrgula) Logvinenko \& Starobogatov: 366.

1969 Pyrgula (Eurycaspia) Logvinenko \& Starobogatov: 357.

1969 Pyrgula (Oxypyrgula) Logvinenko \& Starobogatov: 366.

Type species. Micromelania turricula B. Dybowski \& Grochmalicki, 1915; by subsequent designation by Wenz, (1939). Caspian Sea, Recent. 


\section{Turricaspia andrussowi (B. Dybowski \& Grochmalicki, 1915)}

Fig. $4.11 \mathrm{~A}, \mathrm{~B}$

* 1915 Micromelania (Turricaspia) Andrussowi nov. sp.; B. Dybowski \& Grochmalicki: 125-126, pl. 3, figs 31a-b.

1917 Micromelania (Turricaspia, Trachycaspia) Andrussowi nov. sp. - B. Dybowski \& Grochmalicki: 26-27, pl. 4, fig. 39.

1969 Pyrgula [(Turricaspia)] andrusovi [sic] (Dyb. et Gr.). - Logvinenko \& Starobogatov: 365-366, fig. 362 (4) [partim].

2006 Turricaspia andrussowi (B. Dybowski et Grochmalicki, 1915). - Kantor \& Sysoev: 104-105,

pl. 48, fig. A [partim].

2016 Turricaspia andrussowi (B. Dybowski et Grochmalicki, 1915). - Vinarski \& Kantor:

245 [partim].

Material. 3 spire fragments (RGM 1309814, RGM 1310205).

Type material. Lectotype: ZIN 4355/1 (specimen illustrated by B. Dybowski \& Grochmalicki 1915, 1917), designated by Logvinenko \& Starobogatov (1969), illustrated by Kantor \& Sysoev (2006: pl. 48, fig. A).

Type locality. Caspian Sea (no locality specified).

Description. Available fragments indicate very slender, conical shell. Apex broad, blunt, bulbous. Whorl profile flattened, very weakly spruce-like, with straight-sided upper two-thirds passing over convexity into weakly convex lower third; in addition, broad, flat subsutural band appears, sometimes accompanied by very narrow concavity below. Umbilicus seems fully closed. Aperture not preserved in any specimen.

Discussion. The identification of the three spire fragments rests upon the strongly adpressed whorls with very narrow suture and the flattened, spruce-like whorl profile, and the large, bulbous protoconch. Turricaspia eulimellula (B. Dybowski \& Grochmalicki, 1915) has a similarly slender spire with adpressed whorls, but it bears a basal keel and the maximum whorl convexity is around mid-height instead of in the lower third. Turricaspia grimmi (Clessin \& W. Dybowski in W. Dybowski, 1887) differs in its perfectly straight-sided, rectangular, very weakly stepped whorl profile (see also B. Dybowski and Grochmalicki 1917, pl. 3, figs 34-35; Kantor \& Sysoev 2006, pl. 46, fig. L).

A very similar species is Pyrgula dubia Logvinenko \& Starobogatov, 1969 from the middle Caspian Sea, matching the present one in the weakly spruce-like whorl profile; in fact, it might just be a juvenile specimen of T. andrussowi. Similarly, Pyrgula turkmenica Logvinenko \& Starobogatov, 1969, from the eastern part of southern Caspian Sea, corresponds to T. andrussowi in the weak subsutural band accompanied by an abapical concavity; it might as well be a juvenile representative of T. andrussowi. 


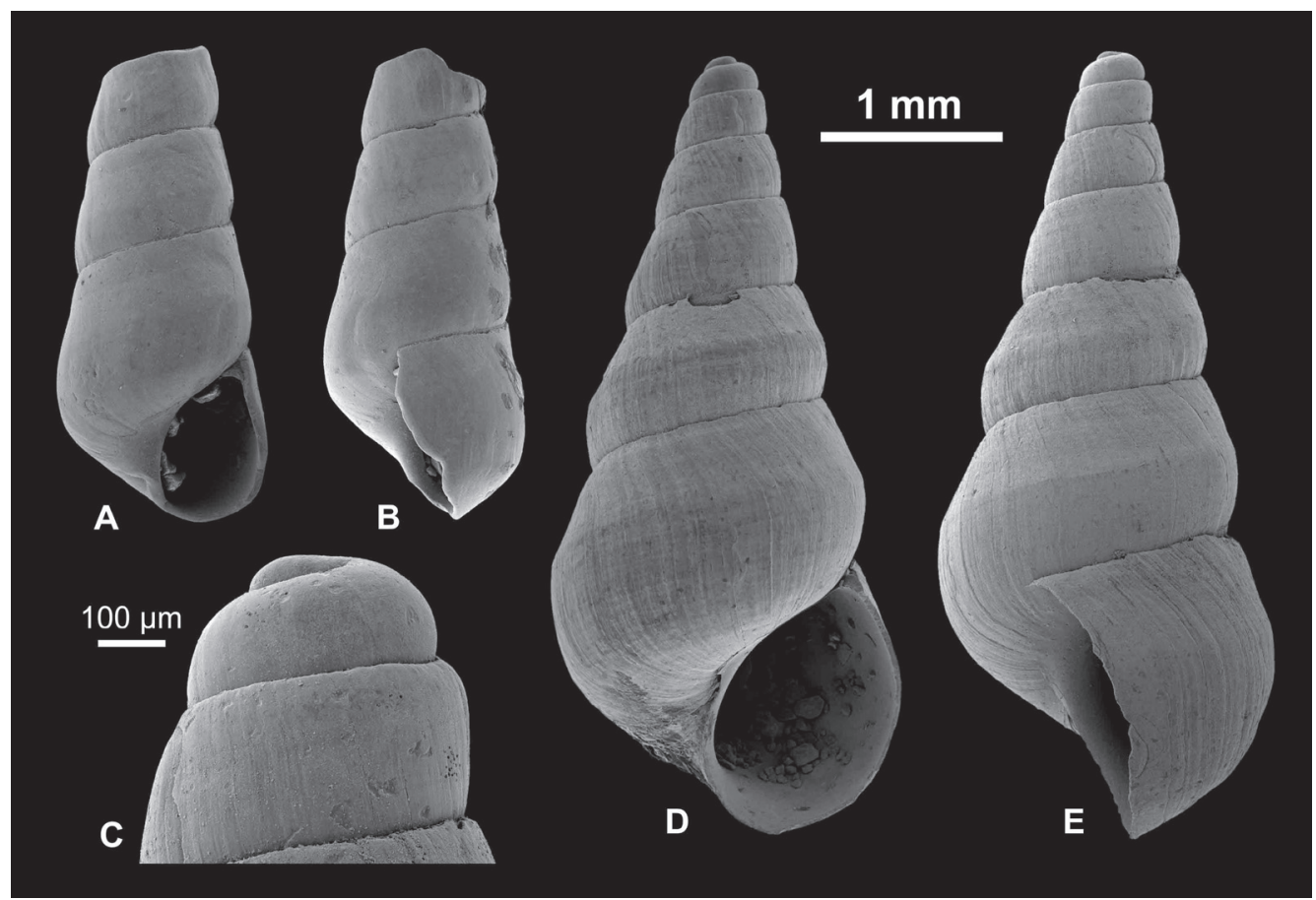

Fig. 4.11: Pyrgulinae. A-B Turricaspia andrussowi (B. Dybowski \& Grochmalicki, 1915), RGM 1309814, C-E

Turricaspia? dimidiata (Eichwald, 1838), RGM 1309787

Logvinenko \& Starobogatov (1969) synonymized without discussion Hydrobia spica sensu Grimm, 1876, Turricaspia elegantula (B. Dybowski \& Grochmalicki, 1915), T. brusinae (B. Dybowski \& Grochmalicki, 1915), as well as several varieties of T. spica and T. turricula described by B. Dybowski \& Grochmalicki (1915) in synonymy of T. andrussowi (see also Kantor \& Sysoev 2006, Vinarski \& Kantor 2016). However, none of these taxa actually resembles T. andrussowi. This species can be well delimited from these alleged synonyms in its bulbous protoconch and the characteristic, weakly spruce-like whorl profile. (Note that the drawing provided by Logvinenko \& Starobogatov 1969 shows a rather broad shell with acute apex; it has little in common with the lectotype designated by them).

Distribution. Endemic to the Caspian Sea (Logvinenko \& Starobogatov 1969 indicated occurrences for the middle and southern Caspian Sea at depths of 25-80 m, but based on a much wider concept of the species).

\section{Turricaspia? dimidiata (Eichwald, 1838)}

Fig. 4.11C-E

? ${ }^{\star} 1838$ Rissoa dimidiata m.; Eichwald: 156. 
? 1841 Rissoa dimidiata m. - Eichwald: 258, pl. 38, figs 17a-b [wrongly given as "figs 16-17" on p. 258; see also corrigendum at the end of Eichwald's work].

? 1853 Pal.[udina] dimidiata m. - Eichwald: 285-286.

? 1887 Micromelania dimidiata Eichw. sp. - W. Dybowski: 31 [partim].

? 1888 Micromelania dimidiata Eichw. sp. - W. Dybowski: 78, pl. 1, figs 4a-f, 5 [partim].

? 1917 Micromelania (Turricaspia) dimidiata Eichw. - B. Dybowski \& Grochmalicki: 32-33, pl. 4, figs 44-47 [partim].

? 1969 Pyrgula dimidiata (Eichw.). - Logvinenko \& Starobogatov: 358-359, fig. 359 (1).

? 2006 Pyrgula dimidiata (Eichwald, 1838). - Kantor \& Sysoev: 99, pl. 46, fig. K.

? 2016 Pyrgula dimidiata (Eichwald, 1838). - Vinarski \& Kantor: 238.

Material. 1 subadult specimen (RGM 1309787).

Type material. Not traced.

Type locality. "In eodem lapide calcareo, fossilis" (in the same limestone [referring to the previous species, found in Dagestan], fossil).

Dimensions. $4.29 \times 1.93 \mathrm{~mm}$.

Description. Slender elongate shell with ca. 6.5 whorls preserved. Protoconch granulate, originally perhaps densely malleate. First teleoconch whorl straight-sided in profile, passing into weakly convex outline on $2^{\text {nd }}-3^{\text {rd }}$ whorl. Between $3^{\text {rd }}$ and $4^{\text {th }}$ whorl, broad, blunt central swelling emerges, grading into thin angulation on $5^{\text {th }}$ whorl; no keel is developed. Whorl portion above swelling/angulation straight-sided, below weakly convex; directly above it, weak concavity is formed locally. Aperture ovoid, strongly adnate, leaving no umbilicus, with thin peristome. Growth lines rather distinct, with prosocline upper half and near orthocline lower half.

Discussion. A single subadult shell containing ca. 6.5 whorls (including the protoconch) is available. Size and number of whorls as well as the centrally placed angulation correspond well to Eichwald's $(1838,1841)$ description and illustration of T. dimidiata. However, the central keel is very weakly expressed in our specimen and it starts not before the fourth whorl, which is why we only tentatively attribute it to this species.

Kantor \& Sysoev (2006) illustrate a much more elongate specimen with cyrtoconoid spire and more abapically placed keel; it might represent a different species. Turricaspia bakuana (Kolesnikov, 1947), likewise described from Caspian Sea, too has a central keel, but differs in the much more slender shell and consistently strong keel from the second teleoconch whorl onwards (cf. Kantor \& Sysoev 2006). Turricaspia basalis (B. Dybowski \& Grochmalicki, 1915) has a broader conical habitus and the keel is placed near the lower suture. The subspecies T. b. laticarinata (Logvinenko \& Starobogatov, 1969) only differs from T. basalis in the thickness of the keel and is herein considered a junior synonym of the nominal species.

Distribution. Endemic to the Caspian Sea, reported from middle and south Caspian Sea at depths between 35 and 200 m (Logvinenko \& Starobogatov 1969). 


\section{Turricaspia lyrata (B. Dybowski \& Grochmalicki, 1915)}

Fig. 4.12A-K

* 1915 Micromelania (Turricaspia) spica Eichw. var. lyrata nov. var.; B. Dybowski \& Grochmalicki:

117, pl. 2, fig. 18.

1915 Micromelania (Turricaspia) spica Eichw. var. incisata nov. var.; B. Dybowski \& Grochmalicki:

117, pl. 2, fig. 19.

1915 Micromelania (Turricaspia) spica Eichw. var. striata nov. var.; B. Dybowski \& Grochmalicki:

117, pl. 2, fig. 20.

1917 Micromelania (Turricaspia) spica Eichw. var. lyrata nov. var. - B. Dybowski \& Grochmalicki: 17, pl. 3, fig. 25.

1917 Micromelania (Turricaspia) spica Eichw. var. incisata nov. var. - B. Dybowski \& Grochmalicki:

18 , pl. 3, fig. 26.

1917 Micromelania (Turricaspia) spica Eichw. var. striata nov. var. - B. Dybowski \& Grochmalicki:

18, pl. 3, fig. 27.

1969 Pyrgula [(Turricaspia)] lirata [sic] (Dyb. et Gr.). - Logvinenko \& Starobogatov: 365,

fig. 362 (2).

2006 Pyrgula lirata [sic] (B. Dybowski et Grochmalicki, 1915). - Kantor \& Sysoev: 101, pl. 46, fig. E. 2016 Pyrgula lirata [sic] (B. Dybowski et Grochmalicki, 1915). - Vinarski \& Kantor: 240.

Material. 562 specimens (RGM 1309802, RGM 1309825, RGM 1310209, RGM 1310213, RGM 1310214, RGM 1310216, RGM 1310218-1310220, LV 201512, LV 201513).

Type material. Lectotype: ZIN 4552/1 (specimen illustrated by B. Dybowski \& Grochmalicki 1915, 1917), designated by Logvinenko \& Starobogatov (1969), illustrated by Kantor \& Sysoev (2006: pl. 46, fig. E).

Type locality. Caspian Sea (no locality specified).

Dimensions. 7.68 x 2.59 mm (RGM 1310213, Figs 4.12A-C); 7.99 x 2.42 mm (RGM 1310220, Fig. 4.12D); 7.34 x $2.28 \mathrm{~mm}$ (RGM 1310214, Fig. 4.12E); 7.54 x $2.50 \mathrm{~mm}$ (LV 201512, Fig. 4.12F); 6.87 x 2.43 mm (LV 201513, Figs 4.12G-I); 7 x 2.52 mm (RGM 1310218, Fig. 4.12J).

Description. Slender elongate shell of up to 9 whorls. Protoconch large, measuring about 485 $\mu \mathrm{m}$ in diameter; it forms bulbous cap on top of shell and comprises 1.25 whorls; surface weakly granulate, with striae on last 0.25 whorls; nucleus low, broad, ca. $170 \mu \mathrm{m}$ in diameter; $\mathrm{P} / \mathrm{T}$ transition very distinct, marked by sharp growth cessation. Teleoconch whorls low to moderately convex, often flattened or with straight-sided upper half, which creates spruce-like morphology. Sometimes, very weak and thin bulge appears below suture, producing faintly stepped spire. Most shells bear very low and somewhat irregular spirals, but expression varies considerably concerning its onset (mainly starts on lower whorls), strength (faint traces to distinct but blunt keels) and number of elements (one keel near base to several keels spread across whorl profile). Expression of sculpture 


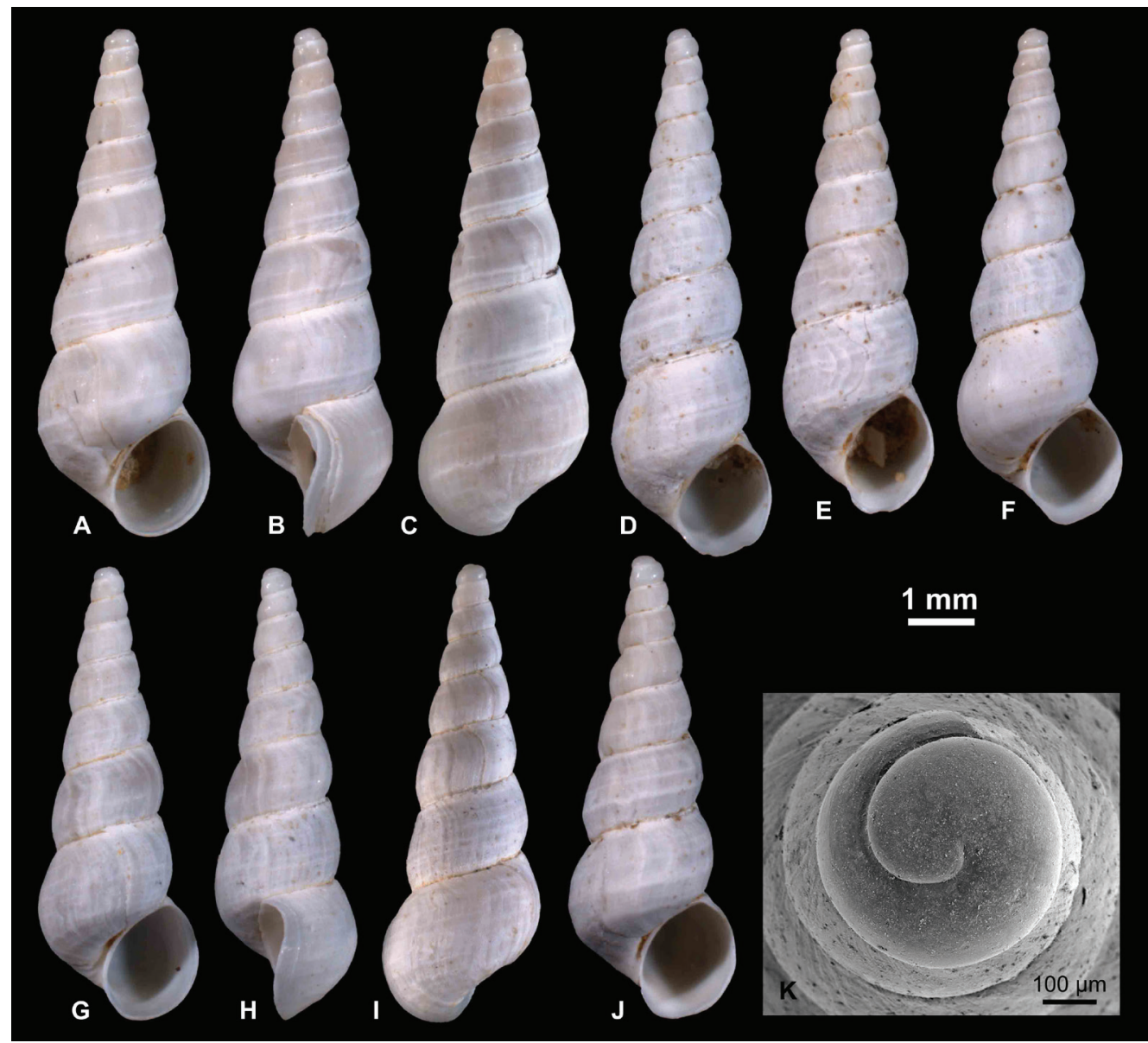

Fig. 4.12: Pyrgulinae. A-C Turricaspia lyrata (B. Dybowski \& Grochmalicki, 1915), RGM 1310213 D T. lyrata, RGM 1310220 E T. lyrata, RGM 1310214 F T. lyrata, LV 201512 G-I T. lyrata, LV 201513 J T. lyrata, RGM 1310218 K T. lyrata, RGM 1309802.

varies in most specimens throughout ontogeny, which creates uneven, rugged appearance. Aperture comparatively small, in most cases regularly ovoid and weakly inclined, covering up umbilicus entirely or leaving very thin opening; peristome simple. Growth lines strongly sigmoidal, with prosocline upper third and opisthocline lower two-thirds.

Discussion. This species can be distinguished from its congeners in its large, bulbous protoconch and the typical, somewhat irregular sculpture. It is consistently larger, more massive and on average bears much stronger sculpture than co-occurring T? spica. The varieties "Micromelania (Turricaspia) spica var. incisata" and "M. (T.) spica var. striata" introduced by B. Dybowski \& Grochmalicki (1915) only differ in the depth of the suture and the expression of the teleoconch sculpture, respectively. Given the variability of these features, we consider both of them synonymous 
with T. lyrata. Already Logvinenko \& Starobogatov (1969) considered incisata and lyrata synonymous and, as first revisers, chose lyrata as the valid name of the species. The variety " $M$. (T.) spica var. lordosa" B. Dybowski \& Grochmalicki, 1915 might also be a synonym of this species. However, the apex of the specimen illustrated in B. Dybowski \& Grochmalicki $(1915,1917)$, which contains diagnostic characters, is not preserved. Nevertheless, striata and lordosa are certainly not synonymous with T. andrussowi as suggested by Logvinenko \& Starobogatov (1969). That species differs from $T$. lyrata in the much slender whorls with spruce-like, near straight-sided profile.

Distribution. Endemic to the Caspian Sea (after Logvinenko \& Starobogatov 1969, it occurs in the western part of the middle and southern Caspian Sea at a depth of 25-50 m; mind however that these authors used a slightly different concept of the species).

\section{Turricaspia meneghiniana (Issel, 1865)}

Fig. 4.13A-K

* 1865 Bythinia Meneghiniana, Issel; Issel: 21, pl. 1, figs 12-13.

1866 Bythinia Meneghiniana, Issel. - Issel: 405, pl. 1, figs 12-13.

1917 Micromelania (Turricaspia) caspia Eichw. var. inflata nov. var. - B. Dybowski \& Grochmalicki:

9, pl. 1, fig. 5.

? 1969 Pyrgula caspia (Eichw). - Logvinenko \& Starobogatov: 369-370, fig. 364 (1).

? 1969 Pyrgula meneghiniana (Issel). - Logvinenko \& Starobogatov: 370, fig. 365 (2).

non 1987 T.[urricaspia] meneghiniana meneghiniana (Iss.). - Alexenko \& Starobogatov: 35, fig. 8.

2006 Turricaspia meneghiniana (Issel, 1865). - Kantor \& Sysoev: 109, pl. 49, fig. E.

2016 Turricaspia meneghiniana (Issel, 1865). - Vinarski \& Kantor: 248.

Material. 248 specimens (RGM 1309799, RGM 1309800, RGM 1310197, RGM 1310198, RGM 1310256, LV 201518).

Type material. Not traced.

Type locality. "Nei giacimenti fossiliferi di Baku" (from fossil deposits in Baku).

Dimensions. 10.86 x 4.27 mm (RGM 1310256, Figs 4.13A-C); 10.91 x 4.36 mm (LV 201518, Figs 4.13D, E, I); 11.17 x 4.50 mm (RGM 1310197, Figs 4.13F-H); 10.82 x 4.14 mm; 11.23 x 4.40 mm; $11.65 \times 4.49 \mathrm{~mm}$.

Description. Conical shell with up to 9.3 whorls. Protoconch comprises 1.3 whorls, measuring $440 \mu \mathrm{m}$ in diameter, with slightly inflated initial part; nucleus measures $150 \mu \mathrm{m}$ in diameter; entire protoconch surface weakly granulate; indistinct spiral striae appear on second half; P/T transition distinct, formed by sharp, thin axial line. Teleoconch whorls increase slowly but regularly in height and width; whorls moderately convex, whereas convexity slightly decreases with ontogeny. Last whorl attains $45-48 \%$ of shell height, passes over perfect convexity into slightly convex base. Aperture ovoid, inclined, closely attached to base of preceding whorl across almost entire parietal 

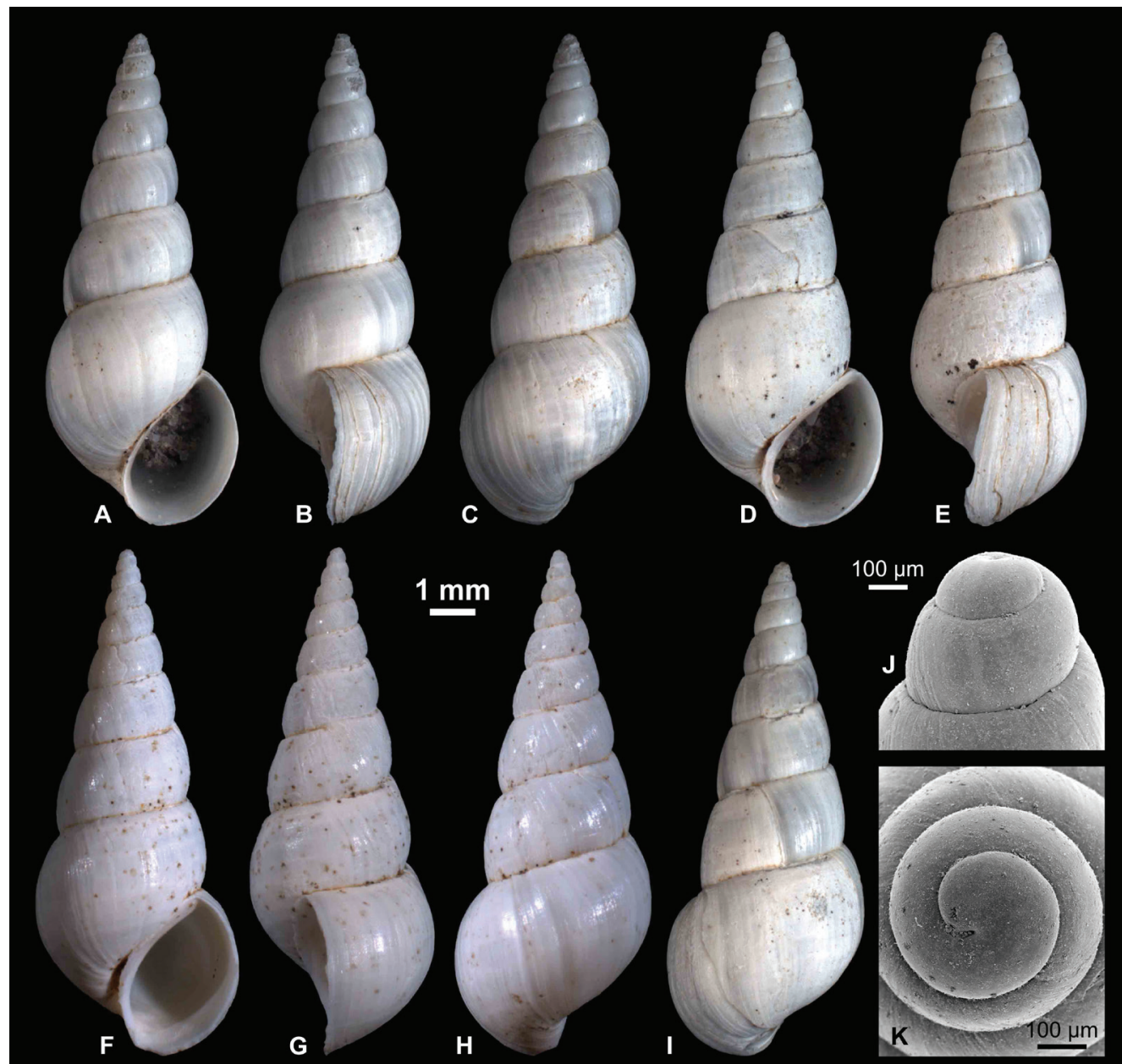

C

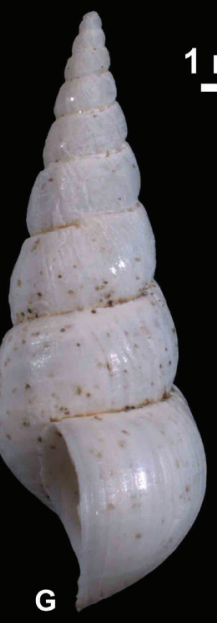

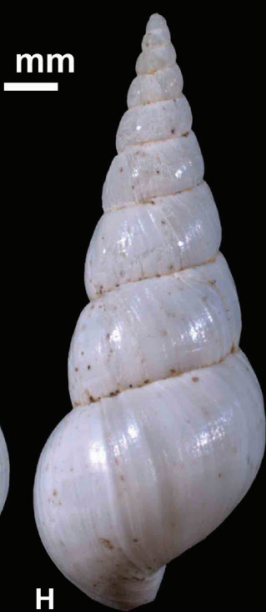

D

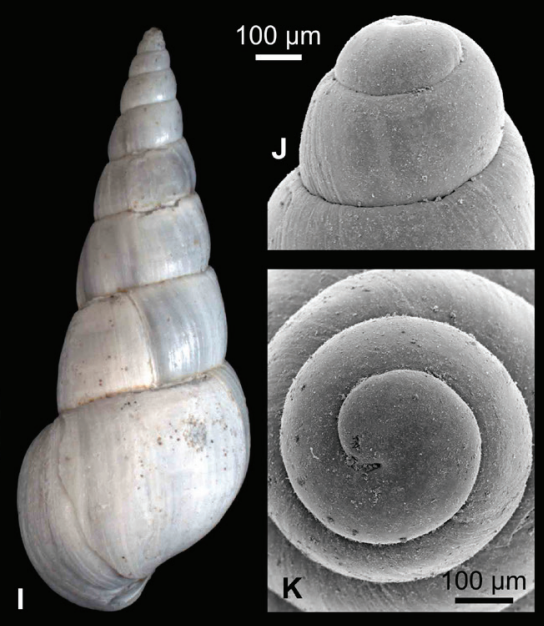

Fig. 4.13: Pyrgulinae. A-C Turricaspia meneghiniana (Issel, 1865), RGM 1310256 D, E, I T. meneghiniana, LV 201518 F-H T. meneghiniana, RGM 1310197 J, K T. meneghiniana, RGM1309799.

margin. Peristome thin, not thickened, little expanded; weakly sigmoidal in lateral view, with broad, shallow indentation in upper half and broad, weak protrusion in lower half; inner lip protrudes in lateral view, extending sheet-like over base of penultimate whorl; umbilicus very narrow, slit-like. Growth lines weakly sigmoidal: strongly prosocline in upper half, weakly opisthocline in lower half. Several specimens show faint spiral threads on last and penultimate whorls.

Discussion. Our material matches well to the description of Issel (1865), corresponding in the conical shell shape, the regularly increasing whorls, the rounded last whorl with faint spiral striae, and the ovate, adapically angulated aperture; only his specimens $(13.5 \times 5 \mathrm{~mm})$ are larger than ours and consist of more whorls. Compared to his description, Issel's illustration seem to overemphasize 
the relative height of the last whorl and underrepresent the pronounced whorl convexity. However, variability as to these characteristics is discernible also in our material.

Micromelania subulata Westerlund, 1902 is commonly listed as junior synonym of this species but always without discussion (e.g., Kantor and Sysoev, 2006; Logvinenko and Starobogatov, 1969; Vinarski and Kantor, 2016). Westerlund's (1902b) description refers to a large (15 mm), very long, elongate shell with 9.5-10 whorls and a thickened callus connecting the peristome margins. These features partly oppose Issel's description, which is why we tend to consider both taxa as separate, in contrast to most previous authors. Unfortunately, Westerlund's (1902b) type material of this species could not be traced, neither in the Göteborg Natural History Museum nor the Swedish Museum of Natural History in Stockholm, where the largest parts of Westerlund's material is stored (Vinarski et al., 2013).

Another commonly cited synonym is Micromelania caspia var. inflata B. Dybowski \& Grochmalicki, 1915, which indeed matches both Issel's description and our material.

Turricaspia meneghiniana differs from the similarly large Laevicaspia caspia (Eichwald, 1838) in its regularly conical profile, the higher number of whorls, and the higher whorl convexity. The drawings of "Pyrgula meneghiniana (Issel)" provided by Logvinenko \& Starobogatov (1969) indicate a broader shell with low whorl convexity and might represent a different species. In contrast, Pyrgula caspia sensu Logvinenko \& Starobogatov (1969) (non Eichwald 1838) resembles the present species in terms of the high shell convexity and regular growth rate and might be conspecific. Turricaspia meneghiniana sensu Alexenko \& Starobogatov (1987), with few, low convex whorls and an angled base, is clearly a different species.

Distribution. Endemic to the Caspian Sea, reported from middle and south Caspian Sea at depths between 0 and $35 \mathrm{~m}$ (Logvinenko \& Starobogatov 1969).

\section{Turricaspia pulla (B. Dybowski \& Grochmalicki, 1915)}

Fig. 4.14A-J

* 1915 Micromelania (Turricaspia) caspia Eichw. var. pulla nov. var.; B. Dybowski \& Grochmalicki:

111, pl. 1, fig. 6a.

1917 Micromelania (Turricaspia) caspia Eichw. var. pulla nov. var. - B. Dybowski \& Grochmalicki:

10, pl. 1, fig. 7.

1969 Pyrgula [(Turricaspia)] pulla (Dyb. et Gr.). - Logvinenko \& Starobogatov: 361-362, fig. 360 (8). 2006 Pyrgula pulla (B. Dybowski et Grochmalicki, 1915). - Kantor \& Sysoev: 102, pl. 46, fig. C. 2016 Pyrgula pulla (B. Dybowski et Grochmalicki, 1915). - Vinarski \& Kantor: 242.

Material. 186 specimens (RGM 1309803, RGM 1309804, RGM 1309820, RGM 1310211, RGM 1310253-1310254, LV 201519). 
Type material. Lectotype: ZIN 4422/1 (specimen illustrated by B. Dybowski \& Grochmalicki 1915, 1917), designated by Logvinenko \& Starobogatov (1969), illustrated by Kantor \& Sysoev (2006: pl. 46, fig. C).

Type locality. Caspian Sea (no locality specified).

Dimensions. 4.88 x 2.10 mm (LV 201519, Figs 4.14A-C); 5.17 x 2.11 mm (RGM 1310254, Figs 4.14D, I, J); 4.77 x 1.90 mm (RGM 1310253, Figs 4.14E-G); 5.84 x 2.16 mm (RGM 1309803); 5.54 x 1.97 mm (RGM 1309804).

Description. Slender conical shell with up to 8 whorls. Protoconch bulbous, weakly granulate, with striae on second half; diameter $410 \mu \mathrm{m}$, consists of 1.25 whorls; nucleus low, broad, $140 \mu \mathrm{m}$ wide; transition to teleoconch distinct. Teleoconch whorls weakly convex, with maximum convexity at or slightly below midline of whorl profile; portion above maximum convexity almost straightsided, portion below weakly convex. Whorls are separated by deep suture. Height of last whorl amounts $45 \%$ of total shell. Sometimes intentions of spiral lines appear on lower half of last whorl. Aperture ovoid, oblique, with weakly thickened and slightly expanded peristome; in lateral view, peristome is distinctly sigmoidal, with broad, shallow indentation in upper half and broad, weak protrusion in lower half. Umbilicus very narrow or closed. Growth lines sigmoidal, markedly prosocline in upper half, weakly opisthocline in lower half.

Discussion. The species can be easily distinguished from most other species of Turricaspia by its comparably broad conical shape, the low-convex whorls, and its small size. Juvenile specimens of T. meneghiniana remind of T. pulla but the former have broader shells with more convex whorls. Turricaspia pullula is likewise broader and exposes a characteristic tripartite whorl profile (see below).

Distribution. Endemic to the Caspian Sea, reported from middle and south Caspian Sea at depths between 15 and 75 m (Logvinenko \& Starobogatov 1969).

\section{Turricaspia pullula (B. Dybowski \& Grochmalicki, 1915)}

Fig. $4.14 \mathrm{~K}, \mathrm{~L}$

* 1915 Micromelania (Turricaspia) caspia Eichw. var. pullula nov. var.; B. Dybowski \& Grochmalicki: 111-112, pl. 1, fig. 7.

1917 Micromelania (Turricaspia) caspia Eichw. var. pullula nov. var. - B. Dybowski \& Grochmalicki: 10-11, pl. 1, fig. 8.

1969 Pyrgula [(Turricaspia)] pullula (Dyb. et Gr.). - Logvinenko \& Starobogatov: 366-367,

fig. 363 (3).

2006 Turricaspia pullula (B. Dybowski et Grochmalicki, 1915). - Kantor \& Sysoev: 109, pl. 50, fig. B. 2016 Turricaspia pullula (B. Dybowski et Grochmalicki, 1915). - Vinarski \& Kantor: 249.

Material. 1 damaged specimen (RGM 1310210). 


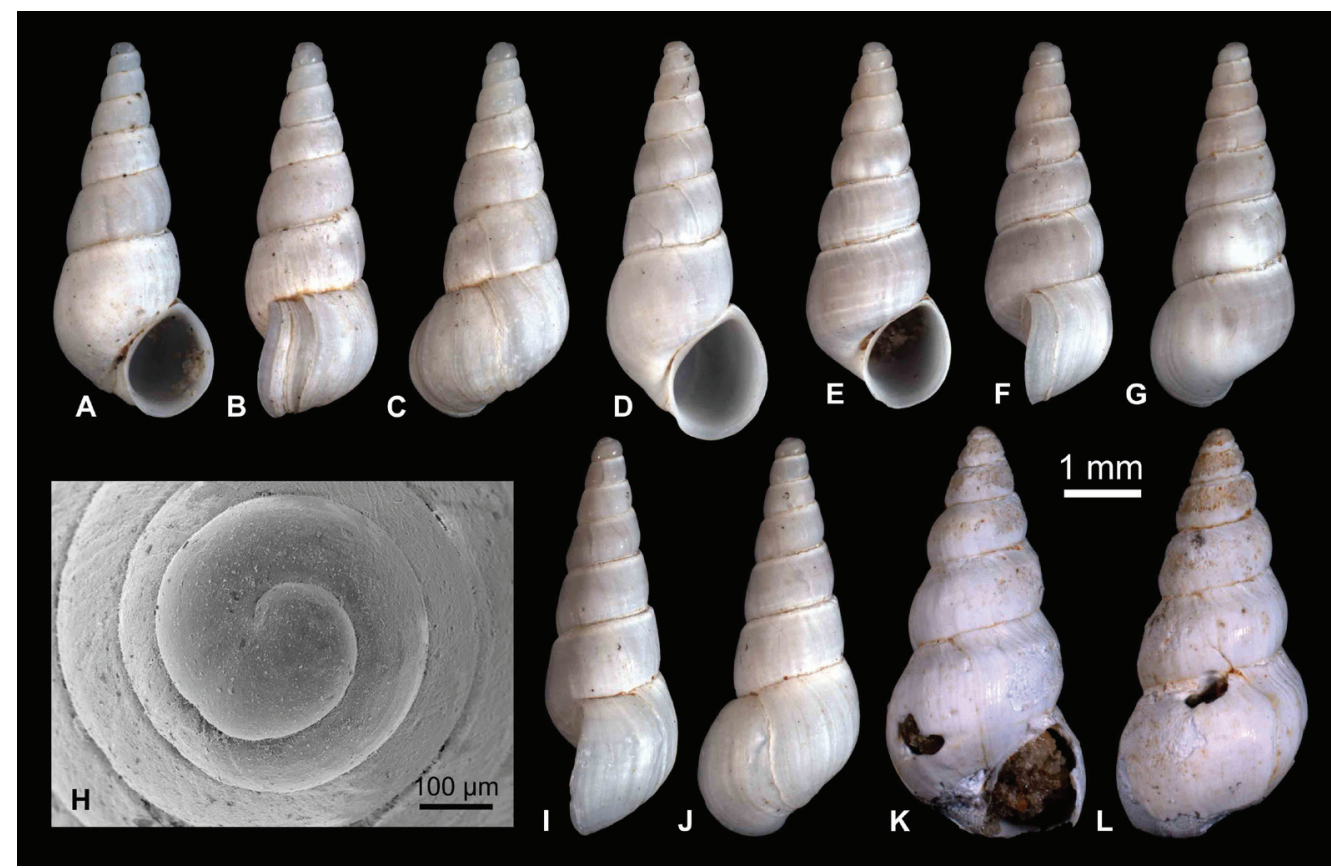

Fig. 4.14: Pyrgulinae. A-C Turricaspia pulla (B. Dybowski \& Grochmalicki, 1915), LV 201519 D, I, J T. pulla, RGM 1310254 E-G T. pulla, RGM 1310253 H T. pulla, RGM 1309820 K, L Turricaspia pullula (B. Dybowski \& Grochmalicki, 1915), RGM 1310210.

Type material. Lectotype: ZIN 4423/1 (specimen illustrated by B. Dybowski \& Grochmalicki 1915, 1917), designated by Logvinenko \& Starobogatov (1969), illustrated by Kantor \& Sysoev (2006: pl. 50, fig. B).

Type locality. Caspian Sea (no locality specified).

Dimensions. $5.36 \times 2.62 \mathrm{~mm}$.

Description. A single incomplete specimen of about 6 whorls is preserved. Protoconch is corroded beyond recognition. Early teleoconch whorls are poorly convex to centrally flattened. Convexity strongly increases on about $3^{\text {rd }}$ whorl. From $4^{\text {th }}$ whorl onwards, whorl surface is partitioned into three zones: two lower zones are roughly straight-sided in profile, upper one slightly concave; middle zone slightly wider than other two; zones are separated by blunt angulations, whose expression varies between very faint to distinct (but no keel is formed). Aperture not preserved, but the tight coiling of the last preserved whorl suggests that umbilicus is absent. Growth lines strongly prosocline in upper third, near orthocline in lower two-thirds; transition coincides with boundary between upper and middle zone.

Discussion. The available specimen corresponds well to the lectotype as illustrated by Kantor \& Sysoev (2006). The very characteristic tripartite whorl profile is only discernible on the penultimate whorl of their specimen. Such a pattern is unknown for any other Pontocaspian Pyrgulinae. 
Distribution. Endemic to the Caspian Sea, reported from the western part of the middle Caspian Sea at a depth of $60 \mathrm{~m}$ (Logvinenko \& Starobogatov 1969).

\section{Turricaspia? spica (Eichwald, 1855)}

Fig. 4.15A-R

cf. ${ }^{\star} 1855$ Paludina spica m.; Eichwald: 303-304, pl. 10, figs 8-9.

cf. 1887 Micromelania spica Eichw. sp. - W. Dybowski: 29-31.

cf. 1888 Micr.[omelania] spica Eichw. sp. - W. Dybowski: 78, pl. 1, figs 6a-c, pl. 3, figs 11a-d.

cf. 1917 Micromelania (Turricaspia) spica Eichw. - B. Dybowski \& Grochmalicki: 16-17, pl. 3,

figs 22-27.

cf. 1952 Micromelania spica (Eichwald, 1855). - Zhadin: 252-253, fig. 194.

cf. 1992 Turricaspia spica. - Anistratenko \& Prisyazhniuk: 19, fig. 2 d.

cf. 2006 Turricaspia spica (Eichwald, 1855). - Kantor \& Sysoev: 110, pl. 49, fig. F.

cf. 2009 Turricaspia cf. spica (Eichwald, 1855). - Filippov \& Riedel: 70, 72, 74, 76, figs 4e-f.

cf. 2016 Turricaspia spica (Eichwald, 1855). - Vinarski \& Kantor: 250.

Material. 1420 specimens (RGM 1309784, RGM 1309785, RGM 1309786, RGM 1309811, RGM 1309812, RGM 1309813, RGM 1310229-1310231, RGM 1310233-1310237, RGM 1310239, RGM 1310240, LV 201501, LV 201502).

Type material. Not traced, most probably in ZIN (Vinarski \& Kantor 2016).

Type locality. "Im kapischen Meere, am Ufer der Insel Tschetschnja, vorzüglich nordostwärs von der Insel im Meeresgrunde" (in the Caspian Sea, at the shores of Ostrov Chechen', especially on the seafloor northeast of the island).

Dimensions. 6.40 x 2.18 mm (RGM 1310237, Figs 4.15A-C); 5.93 x 2.27 mm (LV 201501, Figs 4.15D-F); 6.13 x 2.19 mm (LV 201502, Figs 4.15G-I); 6.36 x 2.21 mm (RGM 1310230, Figs 4.15J-L); $6.01 \times 1.90$ mm (RGM 1310231, Figs 4.15M-O); 5.88 x 2.00 mm (RGM 1310233, Fig. 4.15P); 5.55 x 1.97 mm (RGM 1310236, Fig. 4.15Q).

Description. Slender elongate shell, with up to nine convex whorls. Protoconch forms small bulbous cap, consisting of 1.3 whorls that measure $365 \mu \mathrm{m}$ in diameter; surface weakly granulate, spiral striae set in after 0.5 whorls; nucleus is $140 \mu \mathrm{m}$ wide; $\mathrm{P} / \mathrm{T}$ boundary marked by thin, sharp axial line. Early teleoconch whorls have low convex profile. Two morphotypes are present: Form $\mathrm{A}$ is broader, with whorls increasing slightly more in height (thus producing relatively larger last whorl) and little convex whorls; Form B is more slender, whorls increase less fast in height in relation to width and whorl profile is stronger and more regularly convex. Both types are linked via intermediates. Generally, whorl profile varies between regularly convex (of varying strength), laterally flattened or bipartite (with near straight-sided upper half and convex lower half; rarely, transition between halves coincides with spiral thread). Suture is narrow. In some specimens, last 


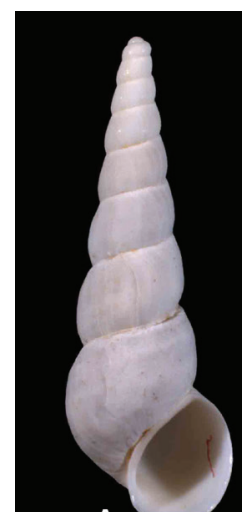

A
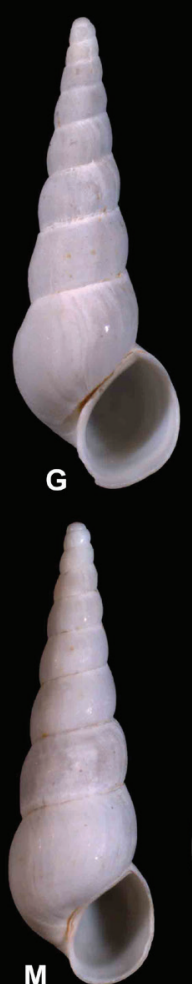

B

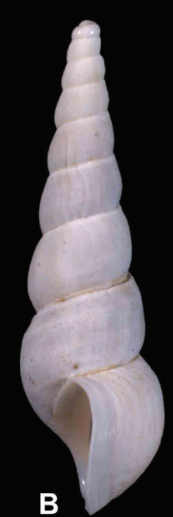

C

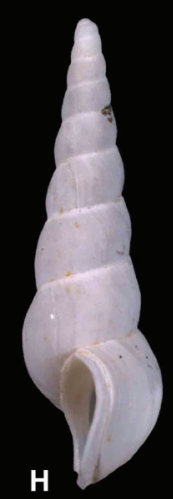

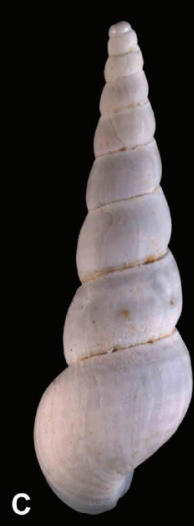
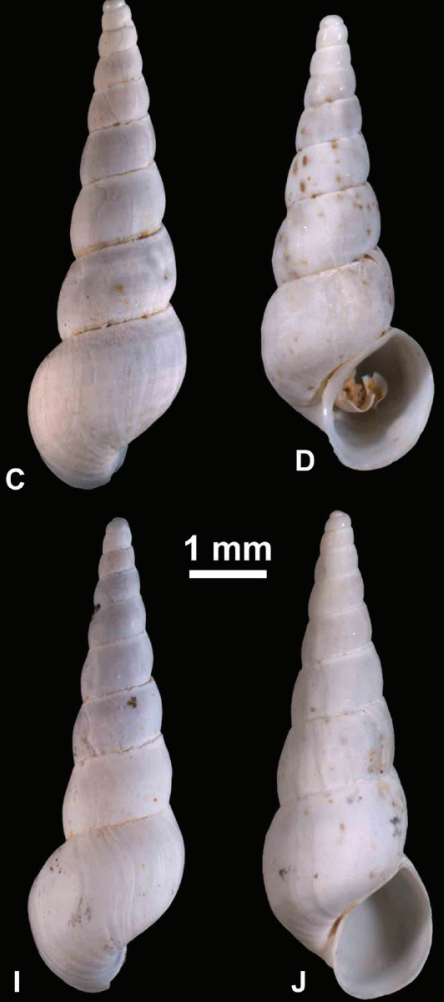
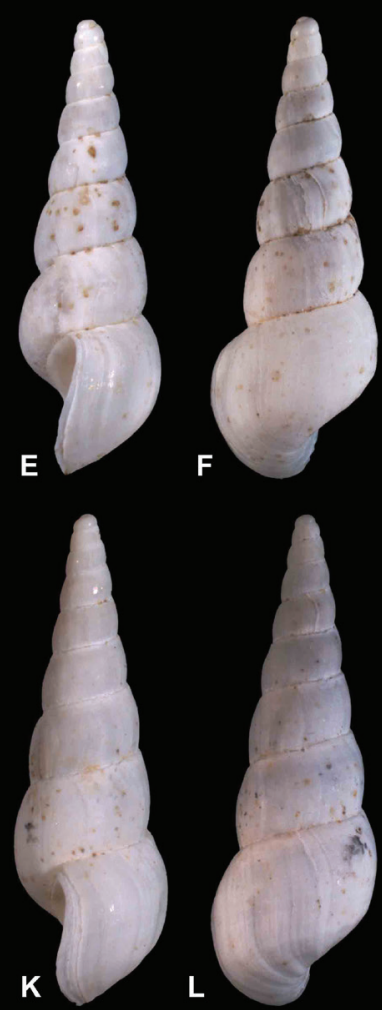
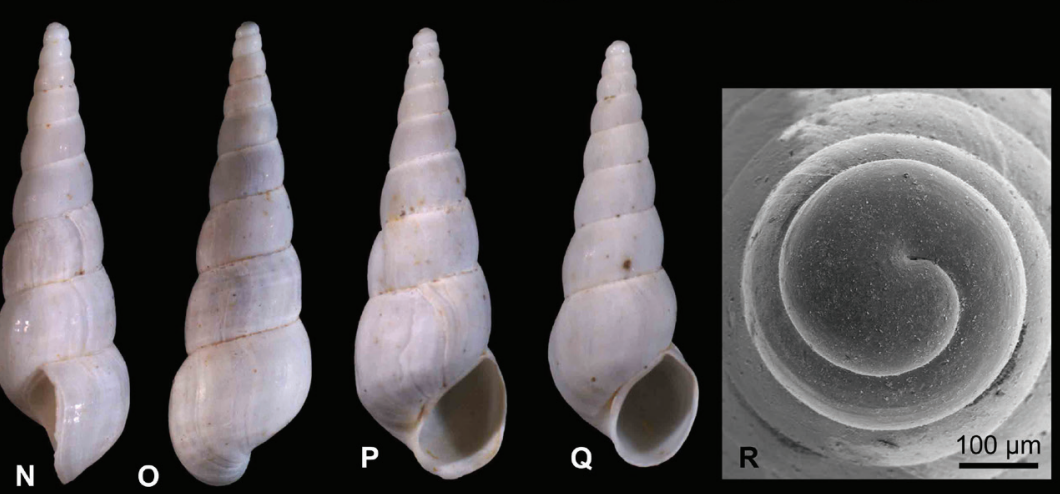

Fig. 4.15: Pyrgulinae. A-C Turricaspia? spica (Eichwald, 1855), form B, RGM 1310237 D-F T.? spica, transitional form, LV 201501 G-I T.? spica, form B, LV 201502 J-L T.? spica, form A, RGM 1310230 M-O T.? spica, form B, RGM 1310231 P T.? spica, form A, RGM 1310233 Q T.? spica, transitional form, RGM 1310236 R T.? spica, RGM 1309813.

whorl is slightly inflated and aperture is expanded. Traces of spiral sculpture, ranging from faint lines to blunt keels of variable number occur on several shells. Aperture expansion and sculpture 
are found on both morphotypes, as well as in intermediates. Umbilicus mostly covered by inner lip; if open, it is very narrow. Growth lines markedly sigmoidal, with prosocline upper third and opisthocline lower two-thirds.

Discussion. The huge morphological variability with intergrading morphotypes complicates reasonable taxonomic distinctions within this taxon. Moreover, much of the shape variation (especially in later whorls) seems to be a result of shell repair after predator-induced damage.

The variability also hampers linking our material to an existing name. Several species (and varieties) have been introduced for slender elongate, multi-whorled shells from the Caspian Sea. While the sculptured representatives can be fairly well delimited, the smooth-shelled taxa have caused considerable confusion. Particularly challenging are the many small, slender species with pointy apex, moderately to strongly convex whorls and thin peristome. The group includes (aside from T. spica): T. elegantula (B. Dybowski \& Grochmalicki, 1915), T. turricula (B. Dybowski \& Grochmalicki, 1915), T. nossovi (Kolesnikov, 1947), T. concinna (Logvinenko \& Starobogatov, 1969), T. spasskii (Logvinenko \& Starobogatov, 1969), T. uralensis (Logvinenko \& Starobogatov, 1969) and T. astrachanica (Pirogov, 1971). Turricaspia lyrata (B. Dybowski \& Grochmalicki, 1915), which was originally introduced as subspecies of T. spica, can be well delimited from that group because of its much larger, blunt apex.

A major problem in identifying and discriminating those species is that the concepts applied by later authors occasionally diverge largely from the original perceptions. This especially regards T. spica and the species described by B. Dybowski \& Grochmalicki (1915). Unfortunately, the types for these species are not known for sure (Kantor \& Sysoev 2006, Vinarski \& Kantor 2016) and the original descriptions, drawings, and illustrations are mostly insufficient to allow distinction. Beyond that, different traits have been considered as diagnostic by different authors when describing new species, and morphological variability was hardly considered at all.

The identity of Turricaspia spica (sensu Eichwald) is dubious. The original description and illustration do not allow distinction from other similar species. The present specimens differ slightly from T. spica sensu Kantor \& Sysoev, 2006, which is characterized by a faster whorl accretion rate and relatively higher whorls (including the last whorl). In contrast, our material largely fits the concept of T. spica as used by B. Dybowski \& Grochmalicki (1917). We tentatively classify the Selitrennoye specimens in Turricaspia spica, being the oldest available name of the group. Many of the later proposed names might turn out to be junior synonyms. A more in-depth study is required to solve this problematic case.

Distribution. Turricaspia spica is endemic to the Caspian Sea. After Logvinenko \& Starobogatov (1969), it occurs at a water depth between 0 and $30 \mathrm{~m}$, but those authors applied a different concept of the species.

\section{Hydrobiidae incertae sedis}




\section{Genus Abeskunus Kolesnikov in Logvinenko \& Starobogatov, 1969}

Type species. Paludina exigua Eichwald, 1838; by original designation. Caspian Sea, Pleistocene.

Discussion. The genus Abeskunus and the species that have been attributed to it have caused considerable confusion. A detailed discussion of the taxonomic and nomenclatural problems associated with Abeskunus, considerations on its systematic placement, as well as a description of the type species will be provided in a forthcoming study. Preliminary work confirms classification of the species described below in Abeskunus.

\section{Abeskunus brusinianus (Clessin \& W. Dybowski in W. Dybowski, 1887)}

Fig. 4.16A-I

* 1887 Zagrabica Brusiniana nob.; W. Dybowski: 52-53.

1888 Zagrabica Brusiniana n. sp. - W. Dybowski: 79, pl. 2, fig. 7.

1952 Zagrabica brusiniana W. Dyb., 1888. - Zhadin: 235, fig. 166 [partim].

1969 Pseudamnicola [(Abeskunus)] brusiniana (Cless. et W. Dyb.). - Logvinenko \& Starobogatov:

381, fig. 367 (15).

2006 Pseudamnicola brusiniana (Clessin et W. Dybowski in W. Dybowski, 1888). - Kantor \& Sysoev:

114, pl. 51, fig. J.

2016 Pseudamnicola brusiniana (Clessin et W. Dybowski in W. Dybowski, 1888). - Vinarski \&

Kantor: 222.

Material. 489 specimens (RGM 1309834, RGM 1309842, RGM 1310194, LV 201505).

Type material. Not traced.

Type locality. "Kaspi-See" (Caspian Sea, no further details mentioned).

Dimensions. 4.12 x 3.82 mm (RGM 1309834, Figs 4.16A, F); 4.15 x 3.65 mm (LV 201505, Figs 4.16B, C, I); 3.00 x 2.74 mm (RGM 1309842, Figs 4.16D, E, G, H); 4.14 × 3.42 mm; 4.15 x 3.53 mm; $4.34 \times 3.79 \mathrm{~mm} ; 4.39 \times 3.87 \mathrm{~mm} ; 4.59 \times 3.68 \mathrm{~mm}$.

Description. Shell broadly conical, comprising up to 4.5 whorls. Protoconch broadly domical, with almost immersed initial part; consists of 1.25 whorls, measures $525 \mu \mathrm{m}$ in diameter; nucleus is ca. $160 \mu \mathrm{m}$ wide; nucleus surface covered with irregular elongated wrinkles; protoconch surface wrinkled, bearing thin, irregular spiral grooves on first third, passing over irregular pattern of faint spiral grooves and wrinkles into numerous, regularly parallel spiral furrows on last third; $\mathrm{P} / \mathrm{T}$ transition without growth rim, marked by onset of growth lines. Teleoconch whorls highly convex, with maximum convexity in adapical half, producing slightly stepped spire. Last whorl attains 77-85\% of shell height. Aperture drop-shaped, slightly inclined, with marked adapical notch at contact to penultimate whorl. Outer peristome margin not or slightly thickened, columellar and parietal margins weakly thickened; peristome slightly expanded towards columella (protruding 


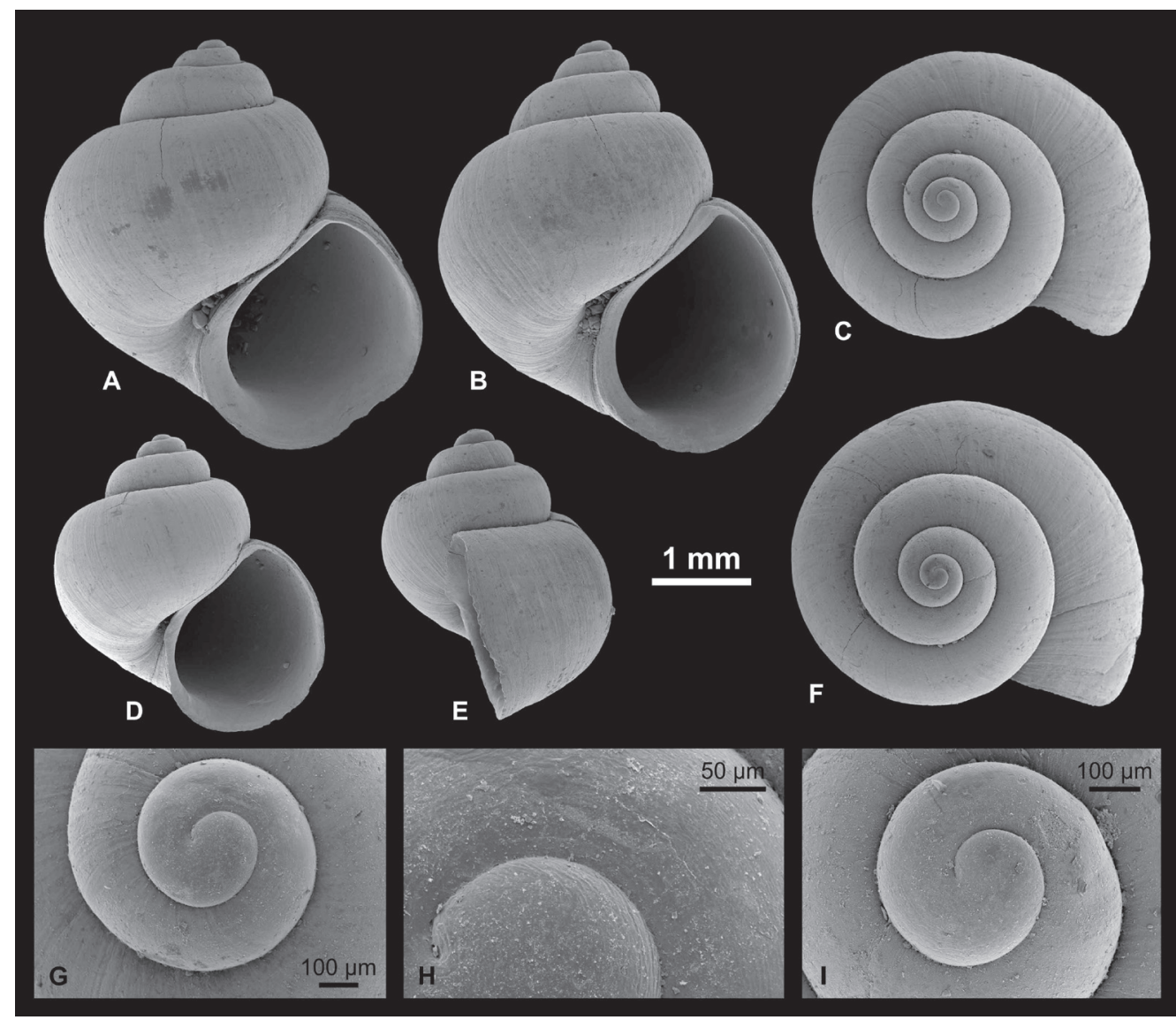

Fig. 4.16: Hydrobiidae incertae sedis. A, F Abeskunus brusinianus (Clessin \& W. Dybowski in W. Dybowski, 1887), RGM 1309834 B, C, I A. brusinianus, LV 201505 D, E, G, H A. brusinianus, RGM 1309842.

towards umbilicus in lateral view) and strongly towards base; weakly sinuate in lateral view, with broad but weak adapical protrusion and straight-sided abapical part. Umbilicus narrow, slit-like. Prosocline growth lines cover shell surface.

Discussion. The species differs from the type species A. exiguus (Eichwald, 1838) in the conical shell, the taller spire, the less inflated last whorl, and the distinct umbilicus. Abeskunus brusinianus michelae Tadjalli-Pour, 1977 is much more globular than A. brusinianus. The latter species strongly reminds of and might be conspecific with A. exiguus. Pseudamnicola depressispira Logvinenko \& Starobogatov, 1969, which these authors also included in the subgenus Abeskunus, differs from the presumed congeners in the valvatoid shape with very wide umbilicus and small but distinct riblets.

Pseudamnicola? brusiniana Pavlović, 1903 is a junior secondary homonym of this species, for which Neubauer et al. (2015b) introduced Pseudamnicola? babindolensis as replacement 
name. Because of the revised classification, P.? brusiniana Pavlović is reinstated as valid, with P.? babindolensis as its junior objective synonym (ICZN 1999, Art. 59.4).

Distribution. Endemic to the Caspian Sea, in the southern and middle part up to a depth of $>250 \mathrm{~m}$ (Logvinenko \& Starobogatov 1969, Parr et al. 2007).

\section{Non-indigenous species}

In addition to the Pontocaspian elements, six taxa including ubiquitous Palearctic species were identified. They all occur in low numbers and differ from Pontocaspian species in their preservation state. Shells of larger taxa (Valvata, Esperiana, and Lithoglyphus) are eroded and suggest transport. The smaller planorbids are better preserved but differ in their orange color indicating that they were not deposited along with the whitish shells of the Pontocaspian residents. Moreover, all six taxa are typical freshwater dwellers (e.g., Welter-Schultes 2012). They probably derive from rivers flowing into the northern Caspian Sea (Fig. 4.1).

Anisus cf. spirorbis (Linnaeus, 1758) (Figs 4.17A-F). - 13 juvenile to semi-adult specimens have been found. They match A. spirorbis as depicted by Glöer (2002) and Welter-Schultes (2012) in size, the regularly striated surface, the slightly overlapping whorls, and the weakly asymmetrical lateral profile. However, whorls expand in relative width a bit more rapidly in the Selitrennoye specimens, which is why we only tentatively assign our material to this species.

Planorbis cf. planorbis (Linnaeus, 1758) (Figs 4.17G-L). - Two juvenile specimens and one semi-adult are available, showing either a distinct or intentions of a keel on the periphery of the apical side, a feature typical of P. planorbis (Glöer, 2002; Welter-Schultes, 2012). In addition, shell size, whorl expansion and lateral profile fit well to this species. Since no adult specimen with fully developed keel have been found, we attribute our specimens to this species provisionally.

Bithynia sp. (Fig. 4.17M). - Four juvenile specimens are available, consisting of the protoconch and about one teleoconch whorl; the operculum is in-situ preserved in all specimens. The classification is based on the presence and shape of the operculum, the characteristics of the protoconch, as well as the shape of the aperture, all of which are features typical of the genus Bithynia (compare Glöer et al. 2005; Neubauer et al., 2015c).

Esperiana esperi (Férussac, 1823) (Fig. 4.17N). - The single fragmentary specimen matches well the specimens illustrated by Welter-Schultes (2012). The similar and often co-occurring Microcolpia daudebartii acicularis (Férussac, 1823) is more elongate and lacks the color pattern (Glöer 2002, Welter-Schultes 2012). In the Russian literature, E. esperi is commonly listed as member of the genus Fagotia Bourguignat, 1884 (e.g., Starobogatov et al. 2004, Vinarski \& Kantor 2016), which is, however, invalid as a junior objective synonym of Esperiana. Starobogatov et al. $(1992,2004)$ listed numerous species of Fagotia for extant European water bodies and categorized them into several subgenera. All of them are presently considered junior synonyms of Esperiana and E. esperi, respectively (for a complete synonymy list, see Vinarski \& Kantor, 2016). Fagotia roseni Starobogatov 


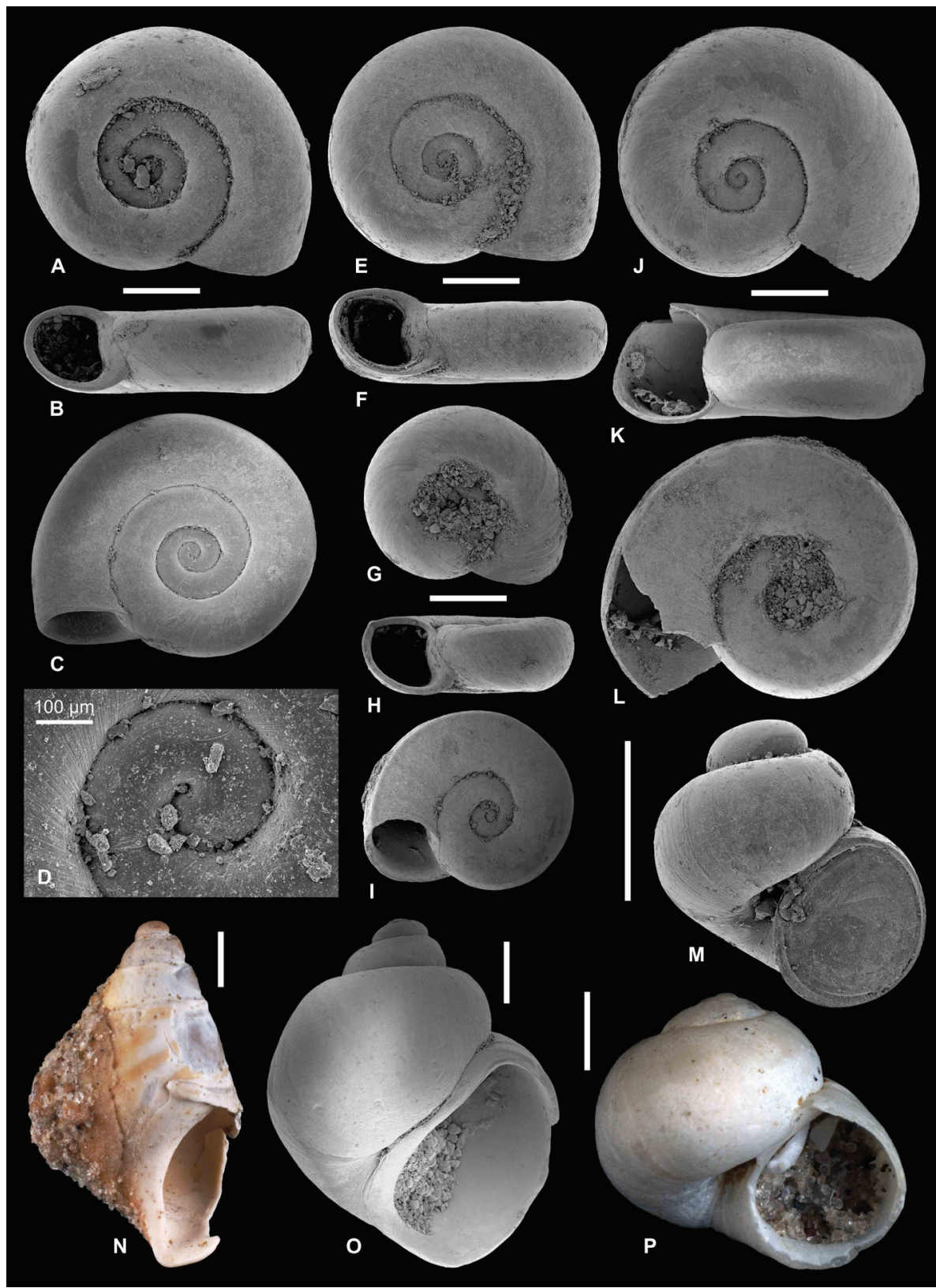

Fig. 4.17: Non-indigenous species. A-D Anisus cf. spirorbis (Linnaeus, 1758), LV 201503 E-F A. cf. spirorbis, RGM 1309801 G-I Planorbis cf. planorbis (Linnaeus, 1758), LV 201504 J-L P. cf. planorbis, RGM 1309835 M Bithynia sp., juvenile, RGM 1309853 N Esperiana esperi (Férussac, 1823), RGM 1309792 O Lithoglyphus naticoides (Pfeiffer, 1828), RGM 1309832 P Valvata piscinalis (Müller, 1774), RGM 1310249. Scale bar equals 1 $\mathrm{mm}$ unless indicated otherwise. Note that all Planorbidae are figured at the same scale to facilitate comparison. 
Table 4.1: List of species recovered from the late Khazarian deposits at Selitrennoye, with indication of their status as endemic to the Caspian Sea and the Pontocaspian region as a whole.

\begin{tabular}{|c|c|c|c|c|}
\hline Species & Family & $\begin{array}{l}\text { No. of } \\
\text { specimens }\end{array}$ & $\begin{array}{l}\text { Caspian } \\
\text { endemic }\end{array}$ & $\begin{array}{l}\text { Pontocaspian } \\
\text { endemic }\end{array}$ \\
\hline Theodoxus pallasi Lindholm, 1924 & Neritidae & 294 & & \\
\hline Ulskia ulskii (W. Dybowski \& Clessin in W. Dybowski, 1888) & Hydrobiidae & 19 & $\mathrm{x}$ & $\mathrm{x}$ \\
\hline Andrusovia brusinai Starobogatov, 2000 & Hydrobiidae & 39 & $\mathrm{x}$ & $\mathrm{x}$ \\
\hline Ecrobia cf. grimmi (Clessin in W. Dybowski, 1888) & Hydrobiidae & 345 & & \\
\hline Clessiniola variabilis (Eichwald, 1838) & Hydrobiidae & 4867 & & $\mathrm{x}$ \\
\hline Laevicaspia caspia (Eichwald, 1838) & Hydrobiidae & 300 & $x$ & $x$ \\
\hline Laevicaspia cincta (Abich, 1859) & Hydrobiidae & 174 & $x$ & $\mathrm{x}$ \\
\hline Laevicaspia conus (Eichwald, 1838) & Hydrobiidae & 1135 & $x$ & $x$ \\
\hline $\begin{array}{l}\text { Laevicaspia kolesnikoviana (Logvinenko \& Starobogatov in } \\
\text { Golikov \& Starobogatov, 1966) }\end{array}$ & Hydrobiidae & 514 & $\mathrm{x}$ & $\mathrm{x}$ \\
\hline Laevicaspia vinarskii sp. $\mathrm{n}$. & Hydrobiidae & 9 & $x$ & $\mathrm{x}$ \\
\hline Turricaspia andrussowi (B. Dybowski \& Grochmalicki, 1915) & Hydrobiidae & 3 & $x$ & $\mathrm{x}$ \\
\hline Turricaspia? dimidiata (Eichwald, 1838) & Hydrobiidae & 1 & $x$ & $x$ \\
\hline Turricaspia lyrata (B. Dybowski \& Grochmalicki, 1915) & Hydrobiidae & 562 & $\mathrm{x}$ & $\mathrm{x}$ \\
\hline Turricaspia meneghiniana (Issel, 1865) & Hydrobiidae & 248 & $x$ & $x$ \\
\hline Turricaspia pulla (B. Dybowski \& Grochmalicki, 1915) & Hydrobiidae & 186 & $x$ & $x$ \\
\hline Turricaspia pullula (B. Dybowski \& Grochmalicki, 1915) & Hydrobiidae & 1 & $x$ & $x$ \\
\hline Turricaspia? spica (Eichwald, 1855) & Hydrobiidae & 1420 & $x$ & $x$ \\
\hline $\begin{array}{l}\text { Abeskunus brusinianus (W. Dybowski \& Clessin in W. Dybowski, } \\
\text { 1888) }\end{array}$ & , Hydrobiidae & 489 & $x$ & $x$ \\
\hline Valvata piscinalis (Müller, 1774) & Valvatidae & 8 & & \\
\hline Esperiana esperi (Férussac, 1823) & Melanopsidae & 1 & & \\
\hline Bithynia sp. & Bithyniidae & 4 & & \\
\hline Lithoglyphus naticoides (Pfeiffer, 1828) & Lithoglyphidae & 1 & & \\
\hline Anisus cf. spirorbis (Linnaeus, 1758) & Planorbidae & 13 & & \\
\hline Planorbis cf. planorbis (Linnaeus, 1758) & Planorbidae & 3 & & \\
\hline
\end{tabular}

in Starobogatov et al., 1992 from Quaternary deposits of Georgia also ranges within the variability of E. esperi and is herewith considered synonymous.

Lithoglyphus naticoides (Pfeiffer, 1828) (Fig. 4.17O). - The shape of the sole specimen ranges well within the large morphological variability of Recent L. naticoides (e.g., Glöer 2002). Late Pleistocene Lithoglyphus jahni Urbański, 1975 has a relatively taller conical shell and elevated spire (Kondrashov, 2007). Coeval Lithoglyphus pyramidatus Möllendorf, 1873 is more elongate and lacks the stepped spire (Glöer 2002).

Valvata piscinalis (Müller, 1774) (Fig. 4.17P). - The eight, partly fragmented and corroded shells correspond well to Recent representatives of the species (Glöer 2002, Welter-Schultes 2012). Several of the Valvata species listed for the Volga delta region by Starobogatov et al. (1994, fig. 2) might be synonymous with this species. A conclusion on that matter requires examination of the material, which is unavailable to us. 


\subsection{Discussion}

The current work provides a first insight into the magnitude of endemic Caspian gastropod biodiversity. The gastropod fauna of Selitrennoye is composed of 24 species, 16 of which are Pontocaspian endemic species and 15 exclusively Caspian. Six species are considered to be nonindigenous based on the combination of a truly freshwater autecology, a general wide spread palearctic distribution and a slightly different preservation from the bulk of the well preserved Caspian lacustrine species in the material. The non-Caspian gastropods are low in numbers, and we suspect they may have either floated into the Caspian Sea during periods of high river discharge or more likely were mixed in from underlying sediment layers through bioturbation. The Selitrennoye fauna was deposited in open lacustrine settings at a paleosalinity of approximately 10-11 psu as suggested by the general composition of the mollusk fauna (Yanina 2012). The presence of paired bivalves in the same sample indicates the in-situ character of the fauna. The shelly levels are located around $17 \mathrm{~m}$ b.s.l., and late Khazarian maximum sea levels are estimated as $10 \mathrm{~m}$ b.s.l. The presence of very sandy sediments with lenses suggests deposition above storm wave base. Altogether, this might translate into a sea floor at about $7 \mathrm{~m}$ water depth. The settings can be best compared with the present-day southermost part of the northern Caspian basin.

The taxonomy and systematics of Caspian gastropods is very much in need of an update. The abundant and well-preserved material presented here has given an indication about the generic placements of species and the magnitude of species richness. When compared to the latest inventory of Caspian gastropods by Vinarski \& Kantor (2016), who presented 92 species for the entire Caspian Sea, our numbers (that represent a single locality) are still rather low. The synonymization of species we propose does in general point to lower species numbers for Caspian gastropod faunas as reported before. However, the possibility exists that some of species considered synonyms are sibling species. In order to test for that, we will require extensive new living material to perform combined genetic and morphometric analyses. In recent expeditions in the coastal areas of Azerbaijan and in the Caspian territory of Kazakhstan, we failed to detect living endemic Pyrgulinae gastropod species. All Caspian endemics are suffering badly from invasive species that have caused a total turnover of the fauna during the $20^{\text {th }}$ century (Albrecht et al., 2014; Grigorovich et al., 2003; Heiler et al., 2010; Kosarev and Yablonskaya, 1994; Orlova et al., 2004; Riedel et al., 2006; Therriault et al., 2004). This situation appears to complicate or even make it impossible to follow such an integrated approach. Especially for the genera Clessiniola, Laevicaspia, and Turricaspia, we think devoted taxonomic revisions will be required to assess the number of species and potential presence of siblings. The present revision does elucidate generic concepts. Even though it is open for further improvement, it will provide a basis for the establishment of evolutionary relationships within genera by comparison with older (Bakunian/Apsheronian) and younger Caspian faunas. By understanding species richness and evolutionary relationships of Caspian faunas, we will be able to document the nature and severity of the Anthropocene biodiversity crisis in this long-lived lake. 


\section{Author contributions}

FPW and TY conducted field work and collected the material; SV and FPW processed the material; TAN, SV, and FPW identified the species; TAN and FPW wrote the manuscript.

\section{Acknowledgements}

We are grateful to Vitaliy V. Anistratenko, Maxim Vinarski, Jan Johan ter Poorten, Anita Eschner, and Yuri Kantor for support during literature research. Maxim Vinarski is moreover thanked for inspection of the collection catalogue of the Zoological Institute of the Russian Academy of Sciences in St. Petersburg. We thank Ronald Pouwer and Marjan Helwerda (Naturalis Biodiversity Center, Leiden) for assistance in sample sorting. Our sincere thanks also go to Dietrich Kadolsky, Mathias Harzhauser, Peter Glöer, Diana Delicado, and Daniela Esu for sharing taxonomic considerations. Tom Wilke shared information on unpublished molecular data of the Caspian hydrobiids. Ted von Proschwitz and Anna Persson are thanked for their effort in trying to locate Westerlund's type material. Thomas Nichterl helped with Latin translations. The careful reviews by Vitaliy V. Anistratenko and Frank Riedel greatly improved the quality of this work.

\section{Funding}

This chapter contributes to the PRIDE Project ("Drivers of Pontocaspian Biodiversity Rise \& Demise") funded by the European Union's Horizon 2020 research and innovation programme under the Marie Sklodowska-Curie grant agreement No. 642973. It also contributes to the FreshGEN Project ("Freshwater systems in the Neogene and Quaternary of Europe: Gastropod biodiversity, provinciality, and faunal gradients") funded by the Austrian Science Fund FWF (project no. P25365-B25). T.A.N. was supported by an Alexander-von-Humboldt Scholarship and a Martin Fellowship granted by Naturalis Biodiversity Center. T.Y. was supported by the Russian Science Foundation (grant no. 16-17-10103).

\section{References note}

After Anistratenko (2013), the publication dates of W. Dybowski's "Die Gasteropoden-Fauna des Kaspischen Meeres" is not 1888 as indicated in the respective journal volume. Issue 1 (pp. 1-64, containing all descriptions) was published in 1887; issues 2 (pp. 65-79, summary and plate captions) and 3 (pls. 1-3) appeared in 1888.

B. Dybowski \& Grochmalicki (1917) is a slightly altered version of B. Dybowski \& Grochmalicki (1915). That work is a preprint initially destined to be published in the "Annuaire du Musée Zoologique de l'Académie impériale des Sciences de St Petersbourg", vol. 20, but it was withdrawn from the volume by the editors. It is nonetheless nomenclaturally available. Since the authors thought their work had remained unpublished, they slightly emended it and re-published it in 1917, re-describing most of the taxa they introduced in 1915 as new and adding new ones. Despite considerable effort, we were unable to obtain a copy of that rare work. 
The publication date of Birshtein et al's comprehensive systematic account of the Caspian fauna, including the catalogue of Caspian mollusks by Logvinenko \& Starobogatov, is usually given as "1968" and so it says in the book itself. According to Sysoev \& Kantor (1992); however, the book was published in April 1969. 

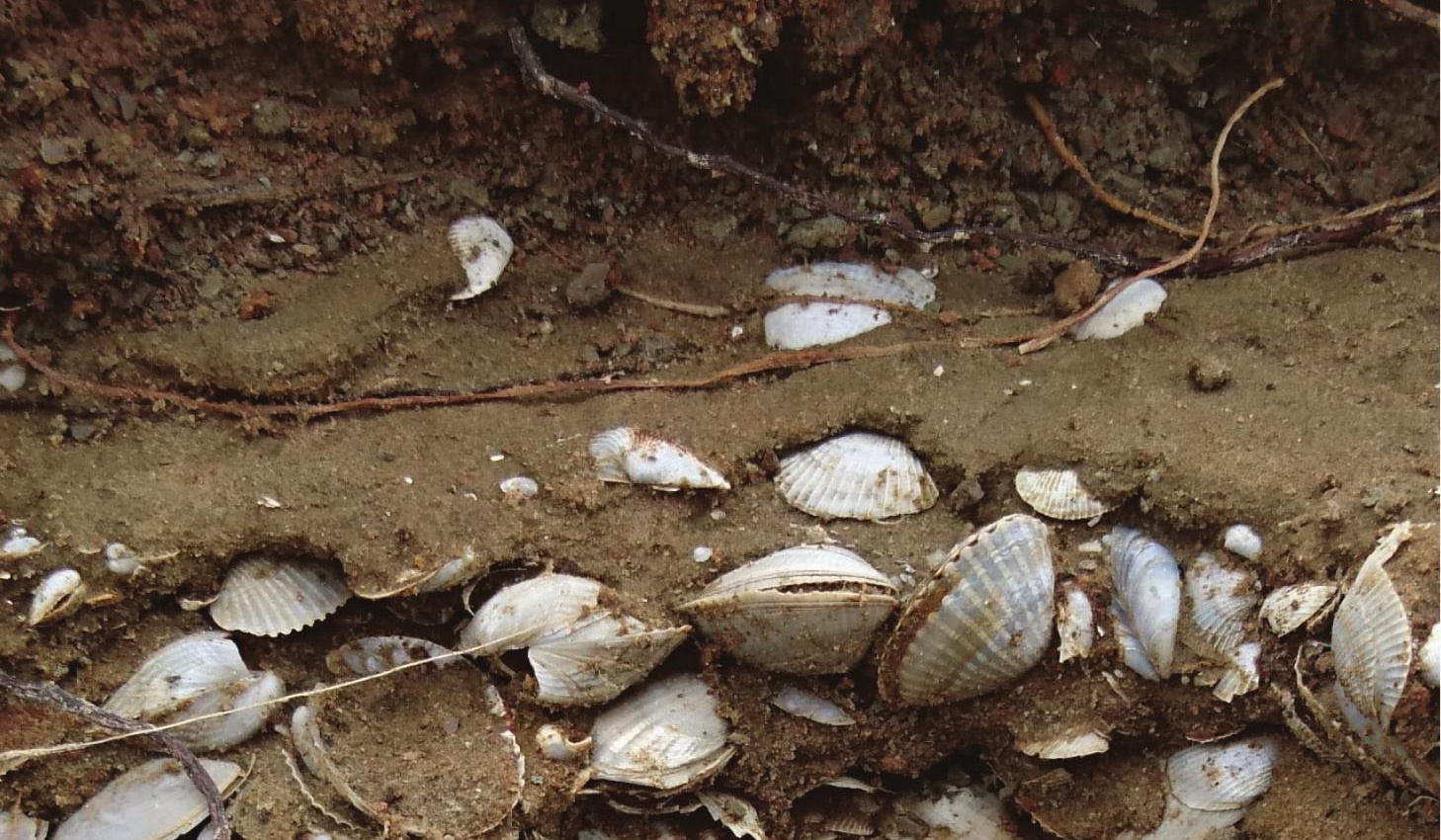

2)

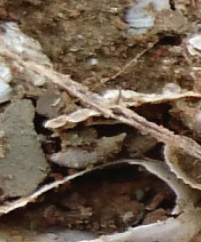

in
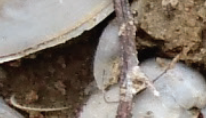

bis

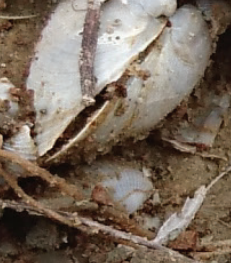

(3)
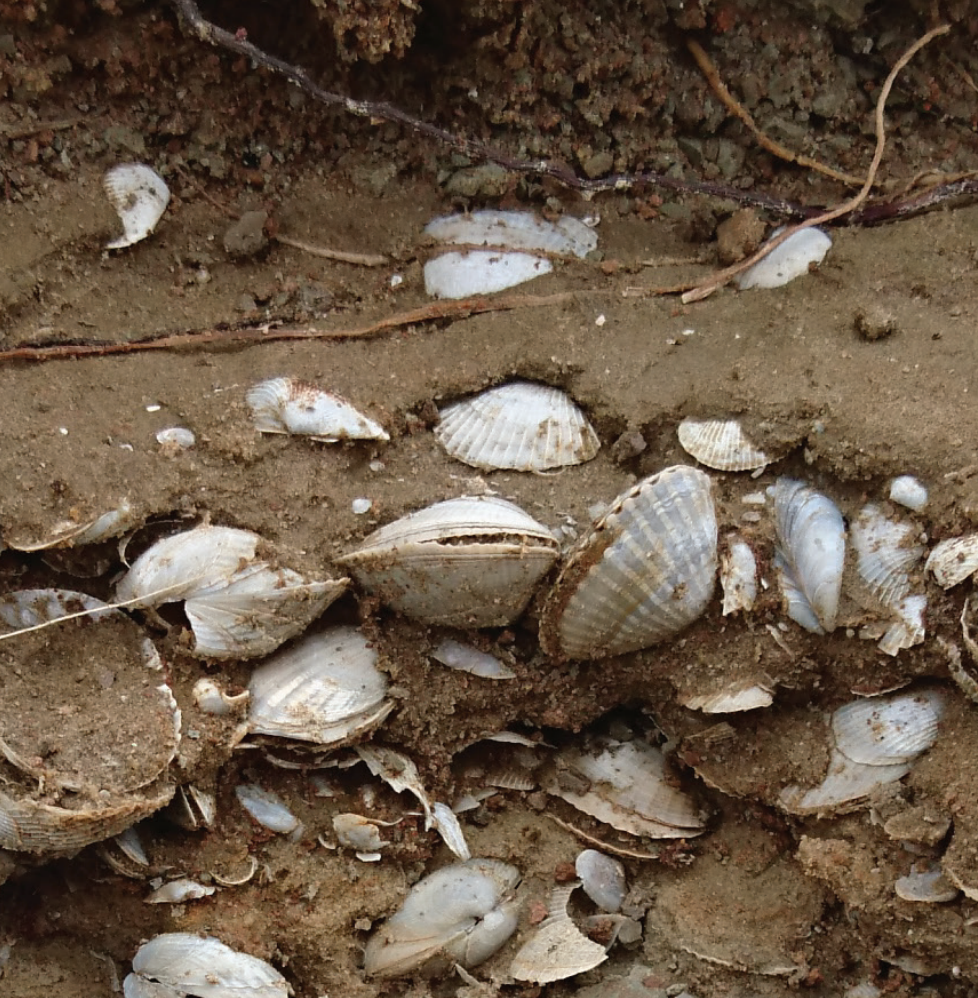

62

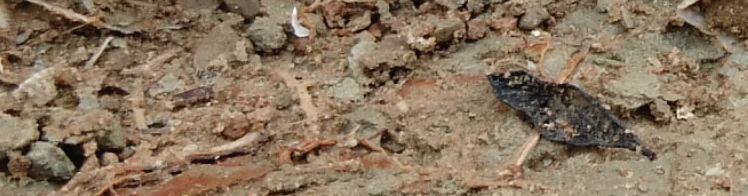

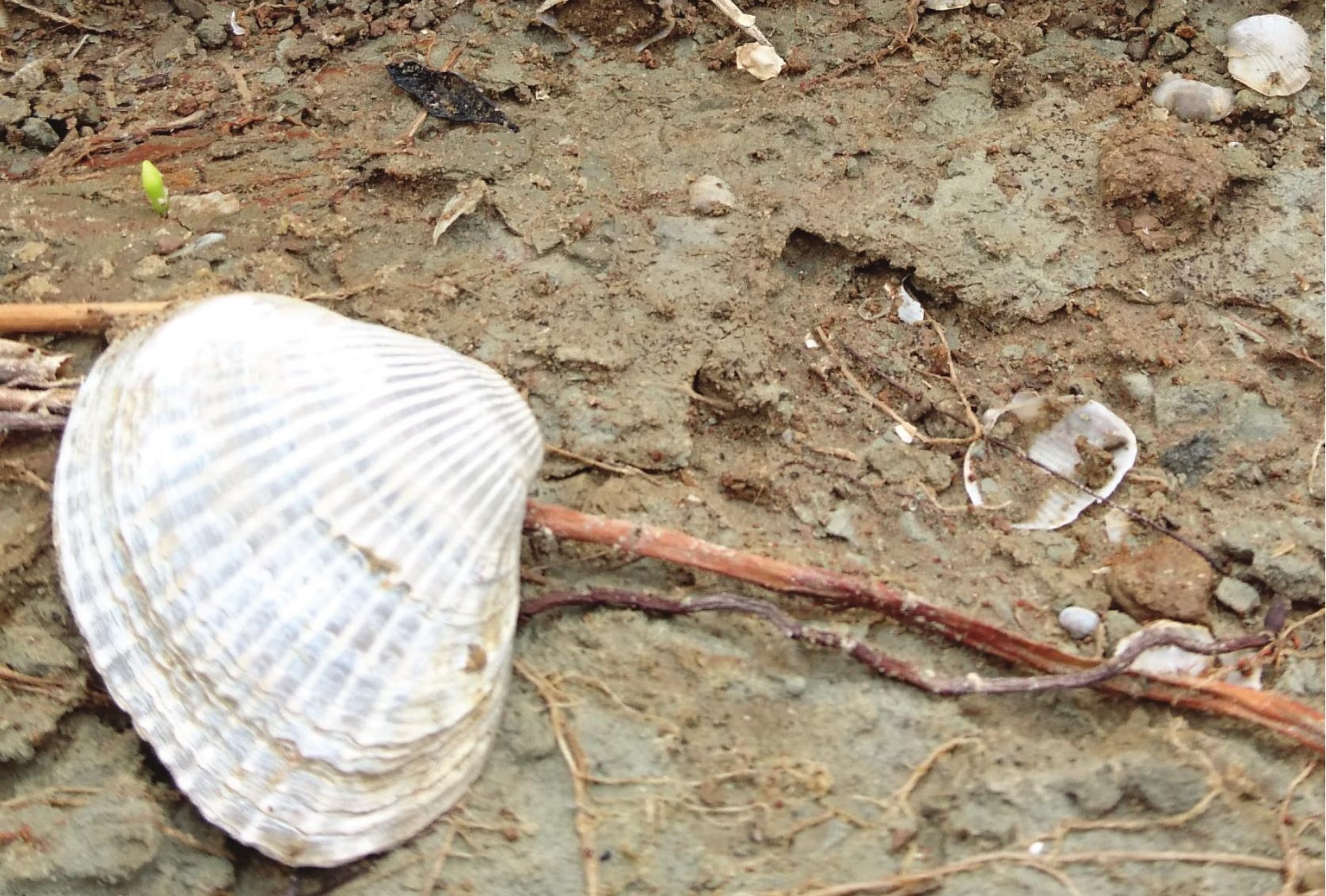




\title{
Late Pleistocene Caspian mollusc diversity (SELitrenNOYe, Russia)
}

\section{Published as:}

van de Velde, S., Yanina, T.A., Neubauer, T.A., Wesselingh, F.P., 2019. The Late Pleistocene mollusk fauna of Selitrennoye (Astrakhan province, Russia): A natural baseline for endemic Caspian Sea faunas. J. Great Lakes Res., 1-13. http://doi.org/10.1016/j.jglr.2019.04.001

\begin{abstract}
The native Caspian Sea fauna underwent severe changes since the early $20^{\text {th }}$ century, mostly due to anthropogenic activities. However, the nature, magnitude and rate of biodiversity change can only be assessed by comparison with natural baseline settings. A mostly in-situ mollusk fauna retrieved from Late Pleistocene (Hyrcanian, $107 \pm 7 \mathrm{ka}$ ) deposits at Selitrennoye (Astrakhan province, Russia) provides a snapshot of a natural Caspian assemblage. In total, 24 gastropod and 13 bivalve species were identified. The fauna is predominantly endemic/native ( $94 \%$ in species numbers and $99 \%$ in abundance) and is dominated by three families (Cardiidae, Dreissenidae and Hydrobiidae). The Selitrennoye assemblage is a natural baseline of a pre-invasive Caspian Sea fauna living in a shallow (15-25 m), lower mesohaline (5-8 psu) open lake environment. The species-rich Selitrennoye fauna contrasts the largely depleted and invasive-dominated fauna that nowadays occupies similar habitats in the Caspian Sea and underlines the magnitude of the current biodiversity crisis.
\end{abstract}

\subsection{Introduction}

The Caspian Sea is Earth's largest inland water body. During the Quaternary, it has had a dynamic history of transgression and regression events (Forte \& Cowgill, 2013; Krijgsman et al., 2019 and references therein; Yanina, 2014). While during large parts of the Quaternary it was an isolated sea, such as today, it had episodic connections to the Black Sea. During such high stands, it was considerably larger than today and extended to the North and occasionally to the Aral Sea. In contrast, the Caspian Sea was a restricted and partly much smaller water body during lowstands (Krijgsman et al., 2019). In reponse to the dynamic history of the basin, the Caspian Sea fauna has a long history of diversification and turnover events. Throughout the Quaternary, the fauna was subjected to a constant variation in salinity regimes (Kosarev and Yablonskaya, 1994) and is now characterized by a high degree of endemism (Kostianoy et al., 2005). The estimated number of 
accepted non-invasive mollusk species living in the Caspian Sea today stands at 65, of which 55 are endemic (Wesselingh et al., 2019).

Since the early $20^{\text {th }}$ century, native Caspian faunas have undergone dramatic turnover (Karpinsky, 2010a, 2010b; Kosarev and Yablonskaya, 1994; Latypov, 2015). Specifically endemic species were marginalized mostly by human activities, such as introduction of invasive species, chemical and agricultural pollution and poaching (Dumont, 1995; Grigorovich et al., 2003; Kosarev and Yablonskaya, 1994; Kostianoy and Kosarev, 2010; Rekacewicz and Dejouhanet, 2002; Rodionov, 1994; Stolberg et al., 2013). In many areas, the benthic communities have been almost completely replaced by communities dominated by invasive species (Grigorovich et al., 2003; Karpinsky, 2010b; Kosarev and Yablonskaya, 1994; Latypov, 2015; Leroy et al., 2018; Orlova et al., 2005; Rekacewicz and Dejouhanet, 2002; Stolberg et al., 2013; Therriault et al., 2004). Some species were deliberately introduced, such as Abra segmentum; others, such as Mytilaster minimus and Mytilopsis leucophaeata, were accidentally introduced and caused widespread changes in benthic communities (Chepalyga and Tarasov, 1997; Grigorovich et al., 2003; Kosarev and Yablonskaya, 1994; Latypov, 2015). These invasives triggered the demise and, in some cases, the extinction of endemic species (Wesselingh et al., 2019 and references therein).

Understanding the nature and severity of the modern Caspian Sea biodiversity crisis is hampered by a lack of comparison with natural baseline data (Kostianoy et al., 2005; Rekacewicz and Dejouhanet, 2002), as well as a poorly resolved taxonomy (Wesselingh et al., 2019). A baseline dataset ideally contains a well preserved in situ fauna together with a characterization of the habitat in order to allow comparison with faunas from similar habitats of today. However, no long-term (pre-impact) standardized data sets exist for the Caspian Sea that allow us to document the nature and severity of biodiversity change of today. Hence, we need alternative approaches to establish a biodiversity baseline for the anthropogenic biodiversity crisis.

A very well-preserved Late Pleistocene mollusk fauna encountered along a tributary of the lower Volga River in Astrakhan province (Russia) provides the opportunity to establish a natural baseline for $20^{\text {th }}$ century biodiversity change. The fauna derives from an outcrop below the village of Selitrennoye from an interval attributed to the regional Late Khazarian epoch (Neubauer et al., 2018; Sedaikin, 1988; Svitoch and Yanina, 1997). In the present study, we specify the stage as Hyrcanian. According to the most recent dates based on optically stimulated luminescence, the age of the Hyrcanian transgression is estimated at $107 \pm 7 \mathrm{ky}$ (Kurbanov et al., 2018), corresponding to the early Late Pleistocene. The presence of paired bivalves and the excellent preservation status imply a largely in-situ fauna. The fauna and sediment characteristics permit to constrain paleoecological properties. The gastropod taxonomy was addressed by revision of the fauna by Neubauer et al., (2018); here, we investigate the bivalve fauna.

Here, we (1) document mollusk species composition and richness of the Selitrennoye fauna along with taxonomic remarks, (2) assess the taphonomic fidelity of the fauna, and (3) characterize the paleoenvironment of the fauna. The established baseline enables comparison with 


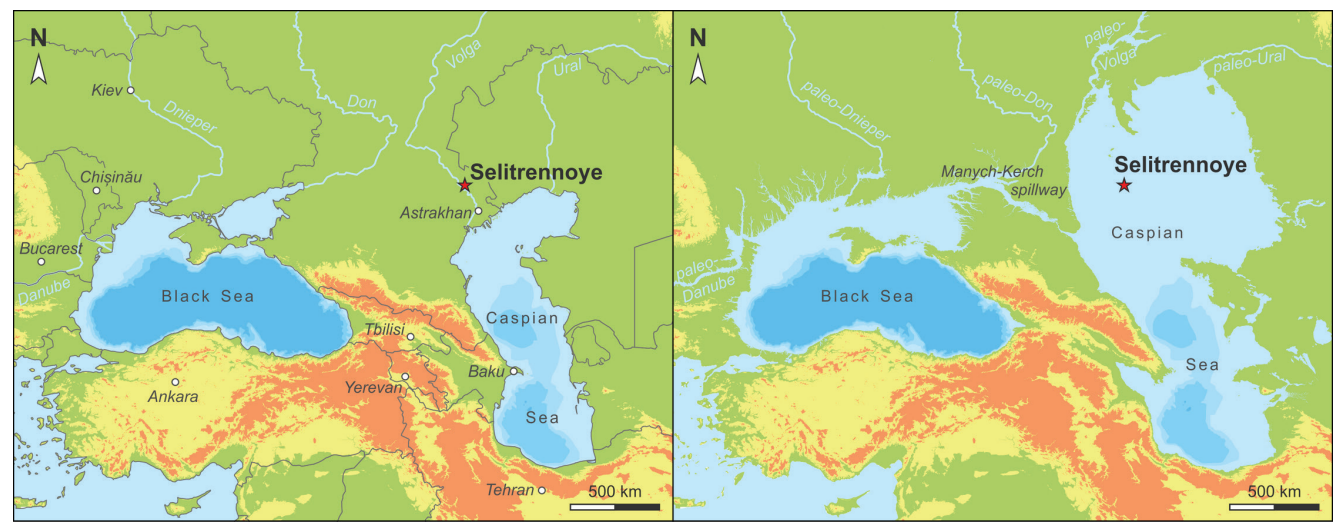

Fig. 5.1: Caspian Sea today (left panel) and during the Late Pleistocene Hyrcanian regional stage (right panel) (modified after Neubauer et al. 2018). The study site of Selitrennoye is indicated with a red star. Hyrcanian lake level was modeled in ESRI ArcGIS 10.4 based on Krijgsman et al. (2019), who suggested an absolute lake level of $30 \mathrm{~m}$ above sea level. (i.e., $57 \mathrm{~m}$ higher than today) at that time, following Popov, 1983).

anthropogenically affected Caspian Sea faunas living in similar environments today, a prerequisite to investigate past and present biodiversity change.

\subsection{Environmental setting}

Today, the Caspian Sea is an isolated, endorheic anomalohaline lake (Fig. 5.1). Its lake level (currently at around $27 \mathrm{~m}$ below oceanic level) reflects a balance between runoff, precipitation and evaporation (Arpe et al. 2018; Krijgsman et al., 2018). The Caspian Sea is subdivided into three subbasins. The northern Caspian basin is a shallow shelf area where major rivers such as Volga and Ural strongly determine water properties. Salinities range from 0 psu (practical salinity unit) at river mouths to approximately $10 \mathrm{psu}$ at the transition to the Middle Caspian basin (Kosarev and Yablonskaya, 1994; Kostianoy et al., 2005). The Middle and South Caspian basins are deep, and salinities range from about 10 to 13 psu (Kostianoy et al., 2005). The Caspian Sea benthic community is dominated by bivalve mollusks and crustaceans (Kostianoy et al., 2005). Although bivalves have fewer species numbers, they represent $>90 \%$ of the total benthic biomass (Kosarev and Yablonskaya, 1994; Kostianoy et al., 2005).

During the previous interglacial (MIS5), Caspian Sea lake levels fluctuated between -50 and +30 m (Krijgsman et al., 2019) and episodically spilled over into the Black Sea (Yanina, 2012a). During highstands, the northern Caspian Sea was much larger and the average salinity in the Caspian Sea was slightly lower, because of the influence of fresh water from the Volga, Terek and other smaller rivers (Yanina, 2012a). The Late Khazarian epoch (MIS5) can be subdivided into the late Khazarian stage and the Hyrcanian (or Girkanian) stage. The latter marked the end of two transgressions that occurred during the last interglacial. At the onset of the Hyrcanian, Caspian Sea water level was above the threshold (around $26 \mathrm{~m}$ above sea level) of the Manych-Kerch spillway north of the 


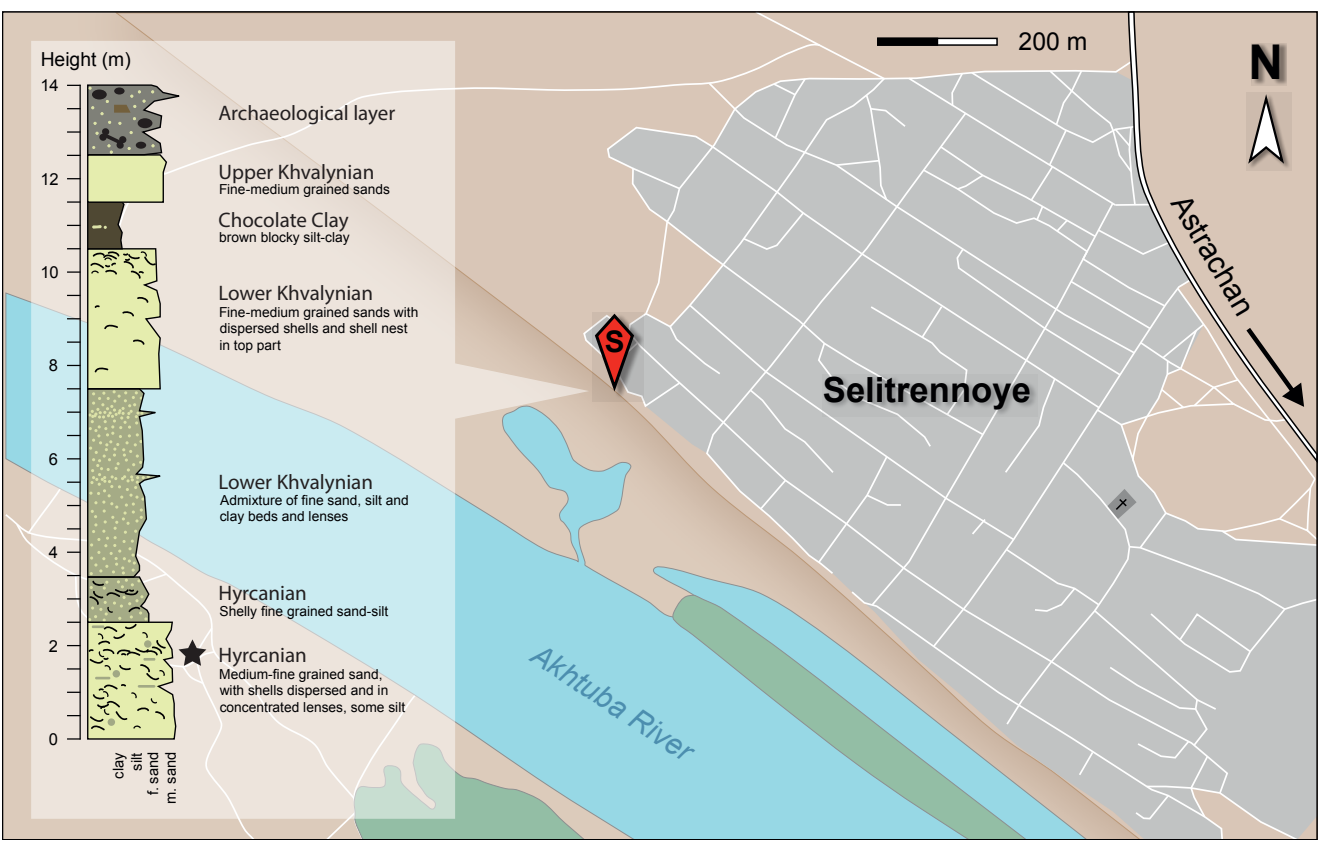

Fig. 5.2: Location and section of the Selitrennoye outcrop next to Akhtuba river. Updated from Neubauer et al. (2018) to show new allocation of stratigraphic units.

Caucasus (Fig. 5.1), and water flooded from the Caspian Sea into the Black Sea. The Hyrcanian ended with the MIS4 Atelian regression when Caspian Sea lake level dropped to about $130 \mathrm{~m}$ below oceanic levels (Krijgsman et al., 2019). Although the late Khazarian and the Hyrcanian were two warm-water transgressive basins, climate was already cooling down at the end of the Hyrcanian (Yanina, 2012a). Conditions were cooler than today, with smaller seasonal contrasts (Kurbanov et al., 2018).

\subsection{Material and methods}

\subsubsection{Study site and geological context}

The study site Selitrennoye $\left(47^{\circ} 10^{\prime} 21.19^{\prime \prime} \mathrm{N}, 47^{\circ} 26^{\prime} 25.41^{\prime \prime} \mathrm{E}\right)$ is located at the eastern margin of the lower Volga valley (Fig. 5.1). The $14 \mathrm{~m}$ thick cliff section (Fig. 5.2) is located next to the Akhtuba River, the eastern branch of the Volga River. During summer, low water levels expose the full outcrop, which consists of a succession of fine sand, silt and clay intervals with variable fossil content. The Hyrcanian level that yielded the mollusk fauna studied herein is located within the basal unit of the outcrop. This $2.5 \mathrm{~m}$ thick interval is composed of mostly well sorted, fine-grained sands with dispersed shells and lenses of shells. The presence of wavy bedding and some fine-scale 
cross-stratification indicates deposition above storm wave base, yet the presence of paired bivalves implies relatively low-energy conditions.

\subsubsection{Taphonomy}

We washed approximately $5 \mathrm{~kg}$ of sediment over a sieve with a mesh size of $0.5 \mathrm{~mm}$. The residue was checked for five different taphonomic criteria: color mixing, fragmentation, dissolution, abrasion, and predation/bio-erosion intensity. Color mixing measures the percentage of shells with colors other than the dominant color. Fragmentation describes the percentage of fragments and broken shells. Dissolution concerns the shells' majority state of dissolution, including pits or shell layers that have become softened. Abrasion relates to the total percentage of fine details preserved. Predation and bioerosion involves the percentages affected by encrustation (the formation of a crust/hardcoating) or (predatory) borings. The taphonomic signatures were used to assess the fidelity of the Selitrennoye sample, and percentages always concern the whole assemblage. The presence of paired bivalves and the occurrence of juveniles were specifically noted. Necessary

\subsubsection{Mollusks community}

Mollusks were identified to the species level and the number of individuals per species was counted. The gastropod fauna was already treated by Neubauer et al. (2018), here we provide details on the bivalves. We discuss morphological variation, taxonomic issues and available ecological data for each species identified. All valves and fragments containing more than half the hinge were counted. Each valve accounted for a half individual and numbers were rounded up to the next integer. Selected specimens were photographed with a Zeiss SteREO Discovery.V20 inverted Axiomat microscope using the stacking function for thoroughly focused images. Mollusks that were too big to fit the microscope vision were photographed with a Nikon D70. Shell measurements and abbreviations included: $\mathrm{H}$-maximum height in $\mathrm{mm}$ (measured from dorsal margin to ventral margin), L-maximum length in $\mathrm{mm}$ (from posterior to anterior margin), LV-left valve, and RV-right valve.

The systematic classification of Didacna species follows mostly Nevesskaja (2007); for other bivalve species, we used Bogutskaya et al. (2013), Latypov (2015), Wesselingh et al. (2019). Synonymy lists provide first descriptions and records with illustrations (Bogutskaya et al., 2013; Kantor and Sysoev, 2006; Nevesskaja, 2007; Wesselingh et al., 2019); further synonymy can be found in Vinarski and Kantor (2016) and Wesselingh et al. (2019).

For the analysis of the mollusk community structure, we combined the data of gastropods (Neubauer et al., 2018) and bivalves. We used R version 3.5.2 (R Core Team 2018) and the package 'iNext' 2.0.19 (Chao et al., 2014; Hsieh et al., 2016) to perform a rarefaction analysis to estimate the representativeness of the sample (Raup, 1975). 


\subsubsection{Paleoecology}

We used published data on salinity, depth ranges, and habitat substrate available to reconstruct the paleoenvironment (Andreev and Andreeva, 2003; Bogutskaya et al., 2013; Chukhchin, 1984; Glöer, 2002; Grigorovich et al., 2003; Logvinenko and Starobogatov, 1969; Mirzoev and Alekperov, 2017; Mordukhai-Boltovskoi, 1974; Neubauer et al., 2018; Nevesskaja, 2007; Parr et al., 2007; Starobogatov, 1994, 2000; Yanina, 1981). Published information was supplemented with personal observations. For the extinct Didacna species, salinity estimates could only be inferred. Today, the salinity range for Didacna species is 3-14 psu (Bogutskaya et al., 2013); hence we estimated salinity ranges for all extinct species accordingly. The depth range of most currently living Didacna species is established from 0 to $50 \mathrm{~m}$. Because only few exceptions are known of species living deeper than $70 \mathrm{~m}$ (Bogutskaya et al., 2013), we estimated depth ranges for extinct Didacna between 0-50 m. The estimated maximum salinity for species nowadays living in the Middle and Southern Caspian Sea basins is 12-13 psu, which relates to the current average salinity in those basins (Kosarev and Yablonskaya, 1994).

\section{$5.4 \quad$ Results}

\subsubsection{Taphonomy}

The Selitrennoye mollusk fauna is exceptionally well preserved. The dominating shell color is white, with little admixture of other colors (5\%). The fragmentation rate is low (20\%). Individual species with a fragile shell such Adacna spp. are mostly broken, but breakage appears to be the result of sample processing. Within the outcrop, these shells were found often complete but with cracks. Overall dissolution density is as low as $5 \%$, with no pits visible, but some of the shells have a rough outer surface that either may result from dissolution, abrasion or both. However, visible abrasion was encountered in $<1 \%$ of the specimens only. Few individuals with signs of predation or bioerosion were found $(<5 \%)$. Of the bivalve species $50 \%$ contained paired individuals, which indicates an in-situ fauna. Gastropods altered by taphonomy were very rarely encountered. The preservation of the six non-endemic species (Esperiana esperi, Bithynia sp., Lithoglyphus naticoides, Valvata piscinalis, Anisus cf. spirorbis, Planorbis cf. planorbis) differs from the endemic Caspian species (Neubauer et al., 2018). They are typical Palearctic fresh water species and were excluded from further analyses (Neubauer et al., 2018).

\subsubsection{Fauna composition}

We encountered 14 bivalve and 24 gastropod species in the 20.569 counted specimens (Table 5.1). Ten species in the sample are represented by less than ten individuals. The six non-endemic gastropod species with a different preservation are taken out of the analysis of the baseline composition. Both adult and juvenile shells are preserved. The mollusk assemblage is almost fully endemic Pontocaspian (>99\% of individuals; Table 5.1). The majority of the species $(90 \%)$ are 
Table 5.1: Mollusks species list of Selitrennoye. Gastropod data from Neubauer et al., 2018. Asterisks mark ex-situ species that have been admixed to the fauna.

\begin{tabular}{|c|c|c|c|}
\hline Species & Family & Status & Number \\
\hline Adacna laeviuscula (Eichwald, 1829) & Cardiidae & endemic & 30 \\
\hline Adacna minima Ostroumov, 1907 & Cardiidae & endemic & 4678 \\
\hline Didacna cristata Bogachev, 1932 & Cardiidae & endemic & 14 \\
\hline Didacna ebersini Fedorov, 1953 & Cardiidae & endemic & 27 \\
\hline Didacna emendata (Popov, 1983) & Cardiidae & endemic & 37 \\
\hline Didacna subcatillus Andrussov, 1910 & Cardiidae & endemic & 1888 \\
\hline Didacna subcrassa (Pravoslavlev, 1939) & Cardiidae & endemic & 34 \\
\hline Didacna subpyramidata Pravoslavlev, 1939 & Cardiidae & endemic & 10 \\
\hline Hypanis plicata (Eichwald, 1829) & Cardiidae & endemic & 37 \\
\hline Monodacna caspia (Eichwald, 1829) s.l. & Cardiidae & endemic & 867 \\
\hline Monodacna semipellucida (Logvinenko \& Starobogatov, 1967) & Cardiidae & endemic & 1 \\
\hline Dreissena caspia Eichwald, 1855 & Dreissenidae & endemic & 1620 \\
\hline Dreissena elata Andrusov, 1897 & Dreissenidae & endemic & 588 \\
\hline Dreissena grimmi Eichwald, 1855 & Dreissenidae & endemic & 105 \\
\hline Theodoxus pallasi Lindholm, 1924 & Neritidae & native & 294 \\
\hline Abeskunus brusinianus (Dybowski \& Clessin in Dybowski, 1888) & Hydrobiidae & endemic & 489 \\
\hline Andrusovia brusinai Starobogatov, 2000 & Hydrobiidae & endemic & 39 \\
\hline Clessiniola variabilis (Eichwald, 1838) & Hydrobiidae & endemic & 4867 \\
\hline Ecrobia cf. grimmi (Clessin in Dybowski, 1888) & Hydrobiidae & native & 345 \\
\hline Ulskia ulskii (Dybowski \& Clessin in Dybowski, 1888) & Hydrobiidae & endemic & 19 \\
\hline Laevicaspia caspia (Eichwald, 1838) & Hydrobiidae & endemic & 300 \\
\hline Laevicaspia cincta (Abich, 1859) & Hydrobiidae & endemic & 174 \\
\hline Laevicaspia conus (Eichwald, 1838) & Hydrobiidae & endemic & 1135 \\
\hline $\begin{array}{l}\text { Laevicaspia kolesnikoviana (Logvinenko \& Starobogatov in Golikov \& } \\
\text { Starobogatov, 1966) }\end{array}$ & Hydrobiidae & endemic & 514 \\
\hline Laevicaspia vinarskii Neubauer et al., 2018 & Hydrobiidae & endemic & 9 \\
\hline Turricaspia andrussowi (Dybowski \& Grochmalicki, 1915) & Hydrobiidae & endemic & 3 \\
\hline Turricaspia? dimidiata (Eichwald, 1838) & Hydrobiidae & endemic & 1 \\
\hline Turricaspia lyrata (Dybowski \& Grochmalicki, 1915) & Hydrobiidae & endemic & 562 \\
\hline Turricaspia meneghiniana (Issel, 1865) & Hydrobiidae & endemic & 248 \\
\hline Turricaspia pulla (Dybowski \& Grochmalicki, 1915) & Hydrobiidae & endemic & 186 \\
\hline Turricaspia pullula (Dybowski \& Grochmalicki, 1915) & Hydrobiidae & endemic & 1 \\
\hline Turricaspia? spica (Eichwald, 1855) & Hydrobiidae & endemic & 1420 \\
\hline Bithynia sp. & Bithyniidae & $*$ & 4 \\
\hline Lithoglyphus naticoides (Pfeiffer, 1828) & Lithoglyphidae & * & 1 \\
\hline Esperiana esperi (Férussac, 1823) & Melanopsidae & * & 1 \\
\hline Anisus cf. spirorbis (Linnaeus, 1758) & Planorbidae & * & 13 \\
\hline Planorbis cf. planorbis (Linnaeus, 1758) & Planorbidae & * & 3 \\
\hline Valvata piscinalis (Müller, 1774) & Valvatidae & * & 8 \\
\hline
\end{tabular}

represented by three families: Dreissenidae (3 species), Cardiidae (10 species), and the Hydrobiidae (17 species: see Neubauer et al. 2018). The most abundant bivalve species is Adacna minima (4678 individuals) and the most abundant gastropod is Clessiniola variabilis (4867 individuals). Thirty of the 32 species are Pontocaspian endemics (sensu Wesselingh et al., 2019), the other two are native to 
Table 5.2: Selitrennoye species list and paleoecological indications from literature. References: ${ }^{1}$ Andreev and Andreeva (2003) ${ }^{2}$ Bogutskaya et al. (2013) ${ }^{3}$ Glöer (2002) ${ }^{4}$ Grigorovich, Therriault, and MacIsaac (2003) ${ }^{5}$ Logvinenko and Starobogatov (1969) ${ }^{6}$ Mirzoev and Alekperov (2017) ${ }^{7}$ Nevesskaja (2007) ${ }^{8}$ Neubauer et al. (2018) ${ }^{9}$ Parr et al. (2007) ${ }^{10}$ Mordukhay-Boltovskoy (1974) ${ }^{11}$ Starobogatov (1994) ${ }^{12}$ Starobogatov (2000), ${ }^{13}$ Yanina (1981), ${ }^{14}$ Wesselingh et al. (2019) ${ }^{15}$ Chukhchin (1984).

\begin{tabular}{|c|c|c|c|}
\hline Species & Natural salinity ranges (psu) & Environment & Depth (m) \\
\hline Adacna laeviuscula & $\min .5-8^{2}, 4-14^{2}, \min .4^{5}$ & $\begin{array}{l}\text { Caspian Sea. }{ }^{2} \text { Muddy, sandy-mud and, rarely, } \\
\text { sandy bottoms. }{ }^{2}\end{array}$ & $30-100^{2,5}$ \\
\hline Adacna minima & $\min .5-8^{2}, 14-26^{1}$ & $\begin{array}{l}\text { Middle and South Caspian Sea. }{ }^{2} \text { Muddy and } \\
\text { sandy bottoms. }{ }^{1}\end{array}$ & $0-35^{2}$ \\
\hline Didacna cristata & $\min .3, \max .14$ & Caspian Sea. ${ }^{7}$ & $0-50 ?$ \\
\hline Didacna ebersini & $\min .3, \max .14$ & Caspian Sea.7 & $0-50 ?$ \\
\hline Didacna emendata & $\min .3, \max .14$ & Caspian Sea. ${ }^{7}$ & $0-50 ?$ \\
\hline Didacna subcatillus & $\min .3, \max .14$ & Caspian Sea. ${ }^{7}$ & $0-50 ?$ \\
\hline Didacna subcrassa & $\min .3, \max .14$ & Caspian Sea.? & $0-50 ?$ \\
\hline Didacna subpyramidata & $\min .3, \max .14$ & Caspian Sea. ${ }^{7}$ & $0-50 ?$ \\
\hline Hypanis plicata & $4-8^{2,5}, \max 12-13$ & $\begin{array}{l}\text { Caspian Sea. }{ }^{2} \text { Silty-sandy, clayey soils, hard } \\
\text { aleurites with shell rock. }{ }^{2}\end{array}$ & $0-40^{2}$ \\
\hline Monodacna caspia & $\min .2^{2}, \max .8^{2}$ & $\begin{array}{l}\text { Northern Caspian Sea. }{ }^{2} \text { Muddy and sandy-mud } \\
\text { substrates. }{ }^{2}\end{array}$ & $0-200^{2,5}$ \\
\hline Monodacna semipellucida & $\min .5-8^{2}, \max .12-13$ & Middle Caspian Sea. ${ }^{14}$ & $0-40^{2,5}$ \\
\hline Dreissena caspia & optimum 2-82, max. 12-13 & Caspian Sea. ${ }^{2,5}$ & $0-40^{2,5}$ \\
\hline Dreissena elata & optimum 2-82, max. 12-13 & Middle and Southern Caspian Sea. ${ }^{2}$ & $0-40^{2,5,14}$ \\
\hline Dreissena grimmi & optimum 2-8 ${ }^{2}$, max. $12-13$ & Middle Caspian Sea. ${ }^{2,11}$ & $35-100^{2,11}$ \\
\hline Theodoxus pallasi & optimum $0-8^{2}$, max. $12-13$ & $\begin{array}{l}\text { Caspian Sea. }{ }^{2} \text { Low salinity seas and large lakes, } \\
\text { limans and estuaries. } .^{5,10}\end{array}$ & $0-40^{2,5,10}$ \\
\hline Abeskunus brusinianus & $\min .5-8^{2}, \max .12-13$ & Middle and South Caspian Sea. ${ }^{2}$ & $0-250^{2,5}$ \\
\hline Andrusovia brusinai & $\min .5-8^{2}, \max .12-13$ & Middle and South Caspian Sea. ${ }^{2,12}$ & $45-311^{2,12}$ \\
\hline Clessiniola variabilis & optimum $0-8^{2}, 5-7^{15}$, max. $12-13$ & Caspian Sea., & $0-300^{2,5,6}$ \\
\hline Ecrobia cf. grimmi & $\min 2-8^{2}, \max .12-13$ & Southern Caspian Sea., ${ }^{2,6}$ & $25-40^{2,5}$ \\
\hline Laevicaspia caspia & $\min .5-8^{2}, \max .12-13$ & Middle and Southern Caspian Sea. ${ }^{2}$ & $30-500^{2,5,6}$ \\
\hline Laevicaspia cincta & $\min .5-8^{2}, \max .12-13$ & Southern Caspian Sea. ${ }^{2}$ & $20->250^{2,9}$ \\
\hline Laevicaspia conus & $\min .5-8^{2}, \max .12-13$ & Caspian Sea. ${ }^{2,6}$ & $0-300^{2,5,6}$ \\
\hline Laevicaspia kolesnikoviana & $\min .5-8^{2}, \max .12-13$ & Southern Caspian Sea. ${ }^{2}$ & $25-400^{2,5,6}$ \\
\hline Laevicaspia vinarskii & Unknown & Northern Caspian Sea. ${ }^{8}$ & unknown \\
\hline Turricaspia andrussowi & $\min .5-8^{2}, \max .12-13$ & Middle and Southern Caspian Sea. ${ }^{2,6}$ & $25-500^{2,5,6}$ \\
\hline Turricaspia? dimidiata & $\min .5-8^{2}, \max .12-13$ & Middle and Southern Caspian Sea. ${ }^{2,6}$ & $35-500^{2,5,6}$ \\
\hline Turricaspia lyrata & $\min .5-8^{2}, \max .12-13$ & Middle and Southern Caspian Sea., 6 & $25-50^{2,5}$ \\
\hline Turricaspia meneghiniana & $\min .5-8^{2}, \max .12-13$ & Middle and Southern Caspian Sea. ${ }^{2}$ & $0-40^{2,5}$ \\
\hline Turricaspia pulla & $\min .5-8^{2}, \max .12-13$ & Middle and Southern Caspian Sea. ${ }^{2}$ & $15-300^{2,5,6}$ \\
\hline Turricaspia pullula & $\min .5-8^{2}, \max .12-13$ & Middle Caspian Sea. ${ }^{2}$ & $35-100^{2,5}$ \\
\hline Turricaspia? spica & $\min .5-8^{2}, \max .12-13$ & Northern and Middle Caspian Sea. ${ }^{2}$ & $0-40^{2,5}$ \\
\hline Ulskia ulskii & $\min .5-8^{2}, \max .12-13$ & Southern Caspian Sea. ${ }^{2}$ & $35-300^{2,5,6}$ \\
\hline
\end{tabular}

the region (Theodoxus pallasi and Ecrobia cf. grimmi). The rarefaction curve is nearly saturated, suggesting that our sample represents an appropriate estimate of the true richness (Fig. 5.3). 


\subsubsection{Paleoenvironment}

The fauna from Selitrennoye lived in the open northern Caspian Sea (Fig. 5.1). Autecological data for the mollusk species are listed in Table 5.2. The gastropod fauna reflects mesohaline (5-13 psu) conditions. Although the majority of bivalves give a similar signal (5-13 psu), a few species show restrictions for their optimal living conditions. Monodacna caspia has a maximum salinity preference of 8 psu. Based on current living Didacna species a paleosalinity around 8-13 psu is estimated for all Didacna species. Though, it is known that in general trigonoid Didacna species prefer somewhat less saline waters (Yanina, 2012a). Also D. subcatillus is reported to have lived in lower saline conditions than most Didacna species (Yanina, 2012a). Although the preferred salinity ranges of the 31 analyzed in-situ species overlap between 5-13 psu, we estimate paleosalinity around 5-8 psu, limited by the salinity preferences of Monodacna and Didacna. All other species are able to survive under those conditions as well. In general, the fauna lived on a sandy lake floor. The depth ranges of the most common species overlap between 0 and $45 \mathrm{~m}$. The abundance of the grazing snail Theodoxus indicates photic conditions, and sedimentological features indicate current flows and possible winnowing, which suggests a location just above the storm wave base. By taking approximately half the wave length, the wave base can be calculated (Stoker, 1947). Currently the wave lengths in the Caspian Sea fluctuate between $14 \mathrm{~m}$ and $50 \mathrm{~m}$, with an average value of $32 \mathrm{~m}$ (Hartgerink, 2005). We therefore estimate fair weather wave base at $16 \mathrm{~m}$. The limiting minimum depths for the gastropod species are between $15 \mathrm{~m}$ (Turricaspia pulla) and $25 \mathrm{~m}$ (Laevicaspia kolesnikoviana, Turricaspia andrussowi and T. lyrata). We therefore estimate paleo-water depths at Selitrennoye to be around 15-25 m.

\subsubsection{Systematic paleontology}

This section provides information on bivalves only; see Neubauer et al. (2018) for notes on the gastropods.

\section{Family Cardiidae}

Adacna laeviuscula (Eichwald, 1829)

Fig. 5.4: 1

${ }^{\star} 1829$ G.[lycymeris] laeviuscula Eichwald: 279, pl. 5, fig. 1.

1986 Adacna (Adacna) laeviuscula (Eichwald, 1831). - Yakhimovich et al.: 85, pl. 11, fig. 8.

2013 Adacna laeviuscula (Eichwald, 1829). - Bogutskaya: 377, fig. 154, photo 48.

Dimensions - max. L $32 \mathrm{~mm}$, H $21 \mathrm{~mm}$.

Characterization - Large, subquadrate to subtrigonal thin-shelled flat cardiid with strong posterior and slight anterior gape; dorsal margins relatively straight; relatively few ribs that are thin 


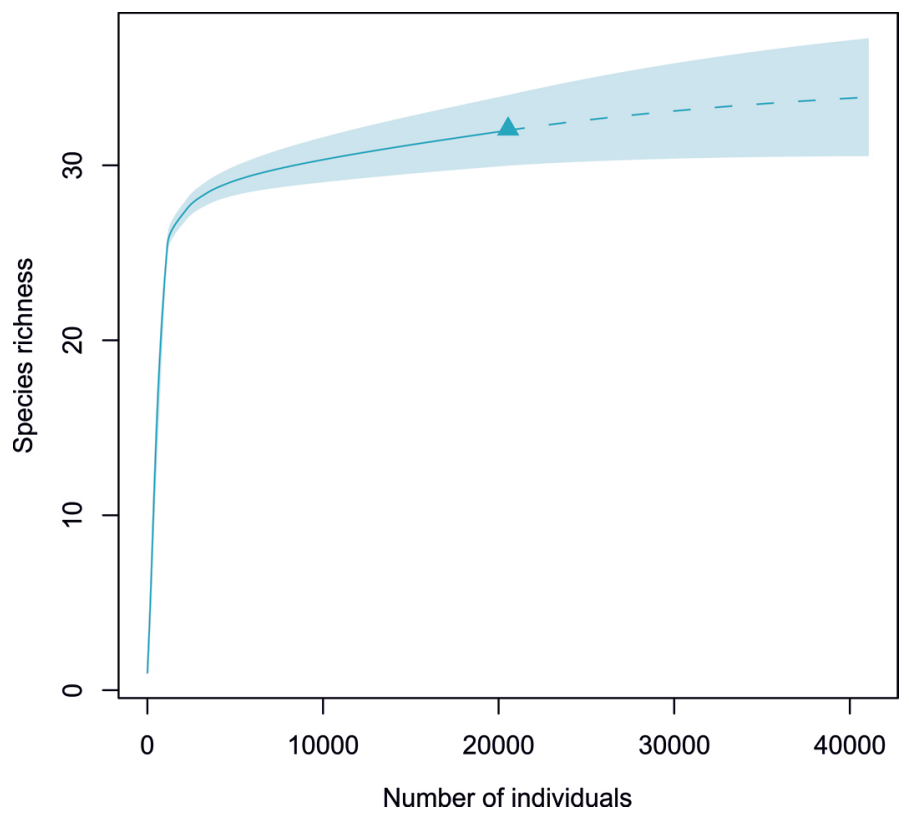

Fig. 5.3: Rarefaction curve of Selitrennoye diversity with $95 \%$ confidence interval and extrapolated richness. The triangle indicates the observed richness.

in juvenile stages and become very flat and separated by barely perceptible grooves in adult stages; hinge is a mostly edentulous, straight and flat ridge; in juvenile specimens a small cardinal tooth may be present that disappears in adult stages.

Ecology - This species has been listed from the entire Caspian Sea from water depths between 35 and $100 \mathrm{~m}$ in salinities of at least 4 psu (Bogutskaya et al., 2013; Logvinenko and Starobogatov, 1969). The common occurrence of fresh, paired specimens on exposed beaches of the middle Caspian (Turali, Russia; Sirvan, Azerbaijan: pers. observ. FW) demonstrates that A. laeviuscula has viable populations in foreshore settings above storm wave base indicating shallower habitats than previously reported.

Adacna minima Ostroumov, 1907

Fig. 5.4: 2

${ }^{\star} 1907$ Adacna minima Ostroumov: 23, pl. 4, fig. 1-5.

1969 Adacna minima ostroumovi Logvinenko and Starobogatov: 338, fig. 354, 3.

2013 Adacna minima ostroumovi Logvinenko \& Starobogatov, 1969 - Bogutskaya et al.: 378, fig. 146.

Dimensions - max. L 16.5 mm, H 12.7 mm. 


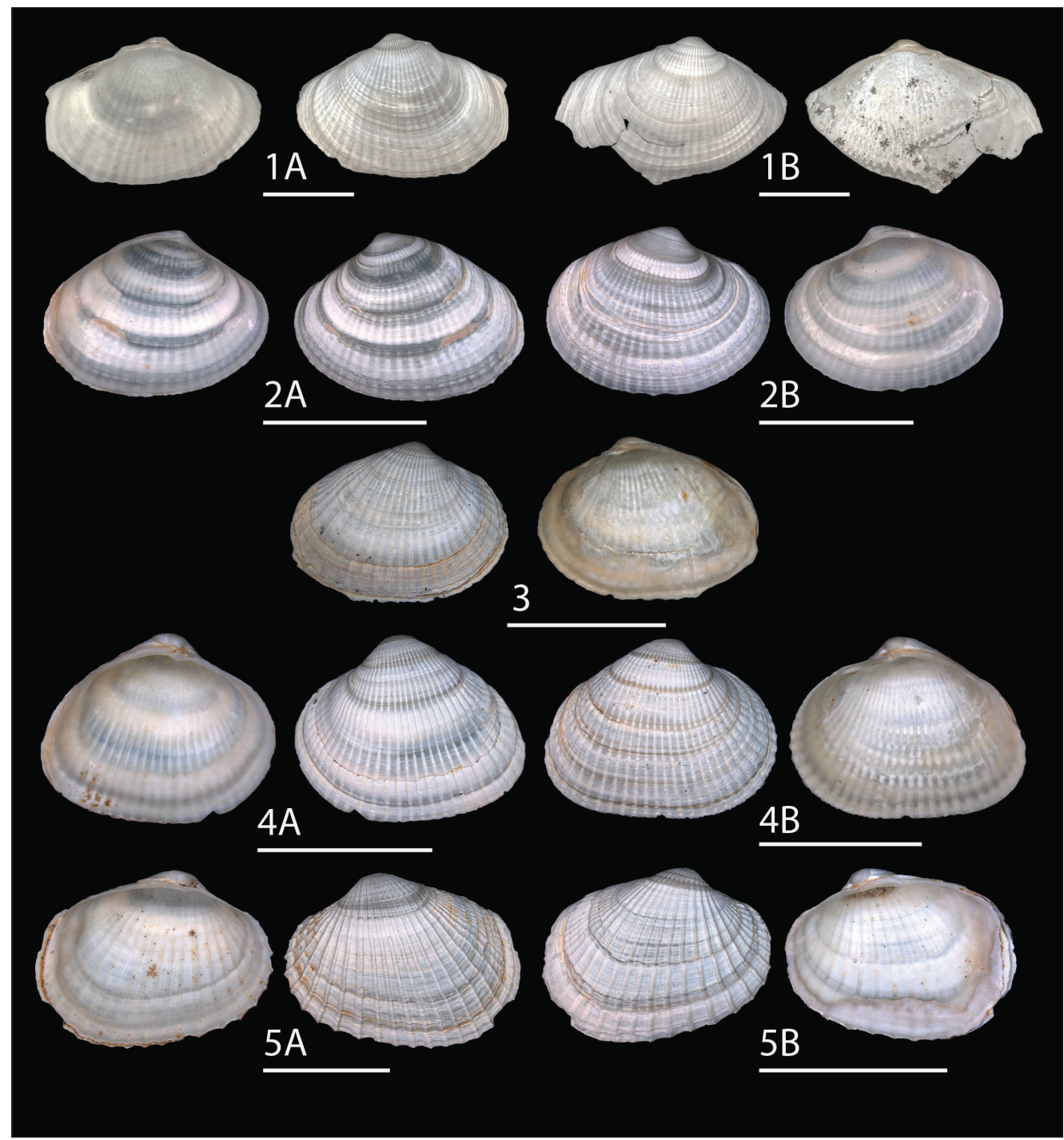

Fig. 5.4: Cardiidae. (1) Adacna laeviuscula; (a) RGM.1309812 LV; (b) RGM.1309813 RV. (2) Adacna minima; (A) RGM.1309811 LV; (b) RGM.1309810 RV. (3) Monodacna semipellucida, RGM.1309802 RV; (4) Monodacna caspia s.l. (a) RGM.1309803 LV; (b) RGM.1309804 RV. (5) Hypanis plicata; (a) RGM.1309808 LV (b) RGM.1309809 RV. Scale bars $=1 \mathrm{~cm}$.

Characterization - Relatively small subtriangular to subrounded Adacna; shell thin, slightly more convex than other Adacna species and in outline resembling some Monodacna species, but hinge plate very thin, edentulous with the exception of juvenile stages where a small cardinal tooth in LV can be present that disappears in adult stages; dorsal margins usually more or less straight; 
ribs low, flat regularly spaced and fading toward anterior and posterior margins; in our material specimens with relatively well developed low ribs to almost smooth specimens and intermediates occur; well-developed growth bands in our material.

Ecology - Species occurs mainly in the middle and south-east of the Caspian Sea, less often in the north Caspian Sea (Logvinenko and Starobogatov, 1969). Endemic species living in water with a salinity of at least 5-8 psu, preferably muddy, sandy-muddy and, rarely, sandy bottoms, mainly in the middle and south Caspian Sea at depths of $<40 \mathrm{~m}$ (Bogutskaya et al., 2013).

Didacna cristata Bogachev, 1932

Fig. 5.4: 6

${ }^{\star} 1932$ Didacna praetrigonoides var. cristata Bogachev: 44, pl. 4, fig. 9-14.

1948 Didacna cristata Bogachev - Fedorov: 19, pl. 1, fig. 4-6, pl. 2, fig. 4-8.

1953 Didacna cristata Bogachev - Fedorov: 127, pl. 16, fig. 1-11.

1983 Didacna cristata Bogachev, 1932 - Popov: 201, pl. 12, fig. 9-22.

Dimensions - max. L 19.8 mm, H $16.3 \mathrm{~mm}$.

Characterization - Medium-sized, relatively high, subtrigonate to subovate convex and robust Didacna. Beak clearly defined. Posterodorsal margin steep, thin, well delimited. Semidiameter located on posterior ridge that is well developed and sharp. In about half of the specimens two elevated ribs form the posterior ridge. Posterior margin rounded angular. Between 15-21 posterior ribs that are wide and flat and about three times as wide as the interspaces. Juveniles have a wide trapezoid outline with a rounded lower margin and a subtruncate posterior margin. The hinge plate and cardinal teeth are robust.

Taxonomic notes: Bogachev (1932b) distinguished the new variety D. praetrigonoides var. cristata from typical $D$. praetrigonoides by its smaller size, more triangular outline and sharper keel. Fedorov (1953) showed that the variety not only differs in shape and size from $D$. praetrigonoides but also in its stratigraphic position. While $D$. praetrigonoides is characteristic for the upper Khvalynian deposits, $D$. praetrigonoides var. cristata is an index fossil of the lower Khvalynian of the east coast of the Caspian Sea. Fedorov (1953) mentioned that the juvenile D. praetrigonoides forms are similar to D. cristata. Nevesskaja (1958) disagreed with Fedorov while studying a collection of mollusks from the Khvalynian deposits of West Turkmenistan. She stated that the Khvalynian beds of Turkmenistan yielded relatively small shells (up to $50 \mathrm{~mm}$ long), with a well-developed plate like a keel and a small number of ribs (23-27). Nevesskaja (1958) concluded that the variety should not be regarded as a distinct taxon, since it only shows the plasticity of the species but cannot be well delineated in time or space (see also Nevesskaja (2007). In contrast, Popov (1983a) supported the opinion of Fedorov (1953) based on a comparative statistical analysis of shell dimensions of $D$. cristata and D. praetrigonoides (Table 41 in Popov, 1983a)). He demonstrated that the differences 
between $D$. cristata and D. praetrigonides were bigger than between many others Quaternary Didacna species. Here, we follow the view of Fedorov (1953) and Popov (1983a).

Ecology - Unknown (extinct). In general trigonoid Didacna species prefer low salinities (Yanina, 2012a), but since $D$. cristata is extinct the paleosalinities can only be inferred.

Didacna ebersini Fedorov, 1953

Fig. 5.5: 5

${ }^{\star} 1953$ Didacna ebersini Fedorov: 125, pl. 14, fig. 2, fig. 5, and fig. 6 (? non fig. 1, 3, 4).

1999 Didacna ebersini Fedorov - Fedorov: pl. 12, fig. 1.

1983 Didacna ebersini Fedorov - Popov: 203, pl. 16, fig. 1-16.

2007 Didacna ebersini Fedorov, 1953 - Nevesskaja: 931, pl. 20, fig. 6-16.

Dimensions - max. L 19.0 mm, H 14.9 mm.

Characterization - Intermediate-sized, flat and thin shelled broad trigonate Didacna with flat ribs; posterodorsal margin is low and in adult stages not well delimited. The posterior ridge is low and subangular and fading during growth. The species have 16-22 posterior ribs. Rib width is somewhat irregular but ribs are about as wide as interspaces. In cross-section they are markedly low. Juvenile outline is trigonate with a distinct often double keel forming the posterior ridge. The base of the juveniles is flat to somewhat concave just before the posterior ridge. Ecology - Unknown (extinct).

Didacna emendata (Popov, 1983)

Fig. 5.5: 4

${ }^{\star} 1983$ Didacna delenda emendata Popov: 174, pl. 6, fig. 8-20.

2007 Didacna emendata Popov, 1983 - Nevesskaja: 915, pl. 15, fig. 22-23.

Dimensions - L $21.2 \mathrm{~mm}, \mathrm{H} 18.3 \mathrm{~mm}$.

Characterization - Medium-sized, subrounded-subtrigonate relatively flat to semiconvex, high and thin-shelled Didacna. Beak clearly defined but low. Posterodorsal margin steep, broad, well delimited. Semidiameter located on posterior ridge that is well developed and subrounded. Only few of the specimens develop two elevated ribs that form the posterior ridge. Posterior margin subangular to angular. Individuals show $22-28$ posterior ribs that are thin and flat and about two times as wide as the interspaces. Juveniles have a high subtrigonate outline with a rounded lower margin and a straight acute posterior ridge resembling the outline of Parvicardium species. The hinge plate is narrow, cardinal tooth well developed.

Ecology - Unknown (extinct). 
Didacna subcatillus Andrusov, 1910

Fig. 5.5: 3

${ }^{\star} 1910$ Didacna catillus var. subcatillus Andrusov: 78, pl. 9, fig. 22-23.

1953 Didacna subcatillus Andrussov - Fedorov: 127, pl. 14, fig. 16-20

1958 Didacna subcatillus Andrussov - Nevesskaja: 24, pl. 3, fig. 1-6.

1986 Didacna subcatillus Andrussov, 1910 - Yakhimovich et al.: 84, pl. 4, fig. 3, 4. 2007

Didacna subcatillus subcatillus Andrussoff, 1910 - Nevesskaja: 935, pl. 21, fig. 6-14.

Dimensions - max. L 43.4 mm, H 33.8 mm.

Characterization - Didacna subcatillus is a broad trapezoid highly variable species that does harbor several specific forms that we could link through intermediates forms in the studied material (Fig. 5.6: 1-3). The posterodorsal keel is usually low, the posterior margin is rounded. The posterior ridge is pronounced and mostly angular in juvenile stages and can become more subrounded in adult stages. The posterior ribs range between 18-25. Interspaces are narrow (about $40-60 \%$ of the width of the ribs). Towards the anterior margin ribs become often less pronounced and the posterior rib width and prominence increases towards the posterodorsal ridge. The rib cross-section is irregular, usually flat or subrounded. The location of the semidiameter is on the posterior ridge in juveniles and close to the center of the shell in adults. The ventral half of the shell is typically straight and dipping. Juvenile shells have already a trapezoid to low trigonate outline with a barely rounded lower margin and a well-developed posterodorsal keel. We found strong variations in shell shapes and sizes and investigated the possible presence of sibling (sub-) species. Some individuals grow as large as $43.4 \mathrm{~mm}(\mathrm{~L})$ x $33.8 \mathrm{~mm}(\mathrm{H})$, while $95 \%$ of individuals show maximum dimensions of $15 \mathrm{~mm}(\mathrm{~L}) \times 12 \mathrm{~mm}(\mathrm{H})$. One particular phenotype is small, has a thick shell that is somewhat convex and has markedly thick hinge plate and teeth and regularly developed ribs that have a more or less rounded cross-section (Fig. 5.6: 1a, 2a). This form however is connected via intermediates (Fig. 5.6: 1b, 1c, 2b, 2c) with thin-shelled forms that are less convex and have thinner hinge features (Fig. 5.6: 1d, 2d).

Taxonomic notes - The various forms of Didacna subcatillus have been attributed to a number of species and forms in the past, to which Nevesskaja (2007) attributed biostratigraphic value. However, we were unable to delimit these forms in our variable material (Fig. 5.8) and consider them synonyms.

Ecology - Unknown (extinct). Didacna subcatillus preferred lower saline waters than most Didacna species (Yanina, 2012a).

Didacna subcrassa (Pravoslavlev, 1939)

Fig. 5.5: 1 


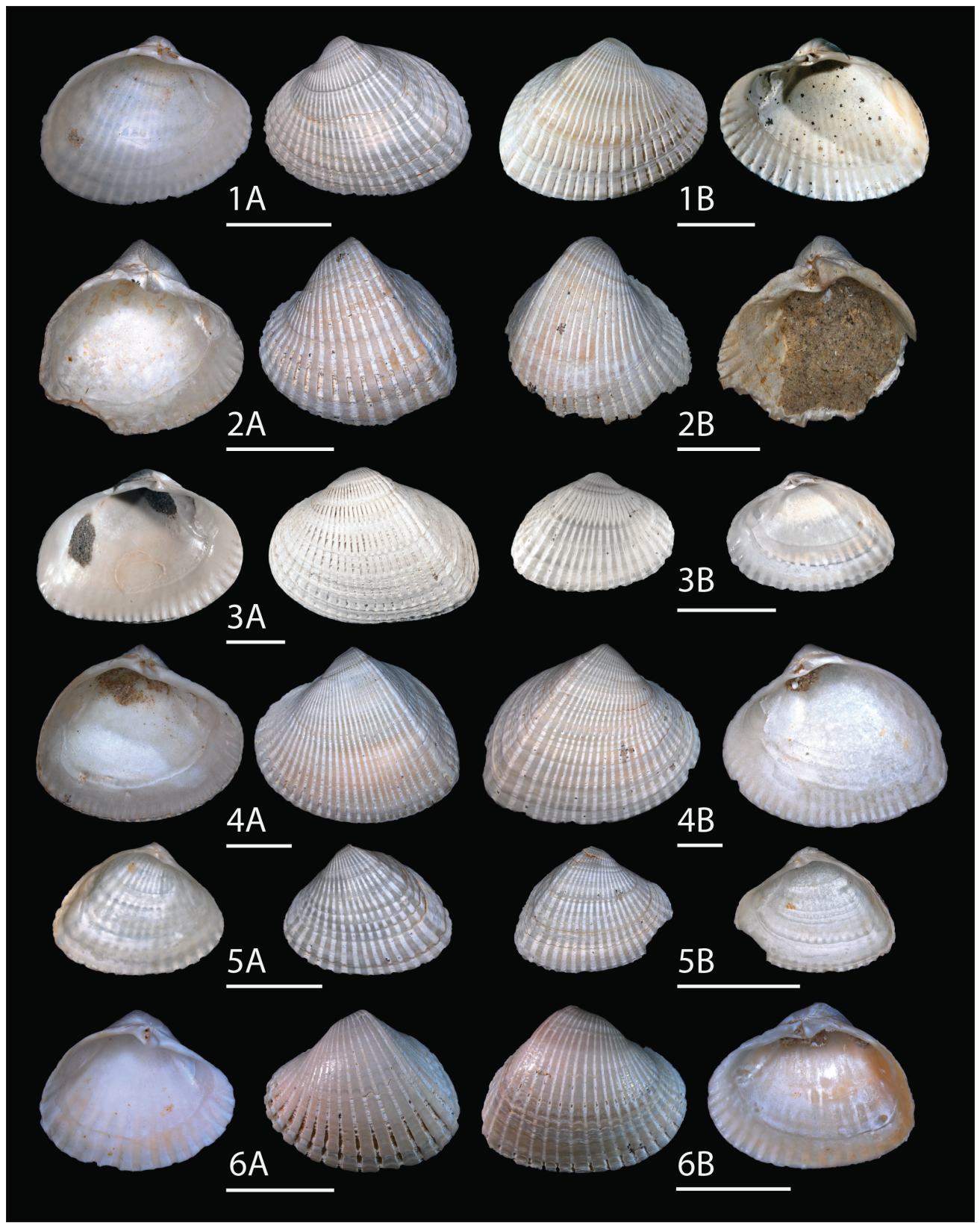

Fig. 5.5: Overview of the Cardiidae. (1) Didacna subcrassa; (a) RGM-1309816 LV; (b) RGM-1309815 RV. (2) Didacna subpyramidata; (a) RGM-1309797 LV; (b) RGM-1309814 RV. (3) Didacna subcatillus; (a) RMG1309819 LV; (b) RMG-1309820 RV. (4) Didacna emendata; (a) RGM-1309799 LV; (b) RGM-1309798 RV. (5) Didacna ebersini; A (a) RGM-1309817 LV; (b) RGM-1309818 RV. (6) Didacna cristata; (a) RGM.1309800 LV; (b) RGM.1309801 RV. Scale bars $1 \mathrm{~cm}$. 
${ }^{*} 1939$ Didacna subcrassa Pravoslavlev: 227, pl. 4, fig. 6-11.

1983 Didacna subcrassa Pravoslavlev, 1939 - Popov: 199, pl, 8, fig. 11-16.

2007 Didacna subcrassa subcrassa Pravoslavlev, 1939 - Nevesskaja: 920, pl. 16, fig. 14-18.

Dimensions - max. L $32.5 \mathrm{~mm}, \mathrm{H} 25.5 \mathrm{~mm}$.

Characterization - Thin-shelled subtrapezoid to subovate to subtrigonate species, usually flat and trigonoid in juvenile stages. The posterodorsal keel is poorly delimited, the low angle posterior bend is rounded. The posterior ridge is subrounded. It is more pronounced in juvenile stages and fading in adult stages. The species has 19-26 posterior ribs. Interspaces are about half to equal width of the ribs. Anterior ribs are sometimes poorly developed and rib width increases towards the posterior keel. Beak is protruding, the hinge is thin. The location of the semidiameter in juveniles is on the posterior ridge but in adults becomes located towards the center of the shell.

Ecology - Unknown (extinct).

Didacna subpyramidata Pravoslavlev, 1939

Fig. 5.5: 2

${ }^{\star} 1939$ Didacna subpyramidata Pravoslavlev: 212, pl. 1, fig. 7-8.

1953 Didacna subpyramidata Pravoslavlev, 1939 - Fedorov: 122, pl. 9, fig. 4, 8, pl. 10, fig. 7-10.

1969 Didacna subpyramidata Pravoslavlev, 1939 - Vekilov: 83, pl. 14, fig. 1-4.

1983 Didacna subpyramidata Pravoslavlev, 1939 - Popov: 198, pl. 7, fig. 1-6.

2007 Didacna subpyramidata Pravoslavlev, 1939 - Nevesskaja: 908, pl. 13, fig. 13-18.

Dimensions - max. L 43.8 mm, H 39.5 mm.

Characterization - Large, high, trigonate-convex species with protruding beak; posterodorsal margin very steep and clearly delimited; the posterior ridge is sharp and massive. The species show 17-21 posterior ribs that are typically 2-3 times as wide as the interspaces. The ribs have a subangular to flat-square cross section. Shells are thick and robust as is the hinge. Outline of juvenile shells is trigonate and very similar as Didacna emendata but with fewer ribs.

Ecology - Unknown (extinct).

Hypanis plicata (Eichwald, 1829)

Fig. 5.4: 5

${ }^{\star} 1829$ G. [lycymeris] plicata Eichwald: 279, pl. 5, fig. 2a-d.

1986 Adacna (Hypanis) plicata (Eichwald, 1829) - Yakhimovich et al.: 85, pl. 7, fig. 2.

2013 Hypanis plicata (Eichwald, 1829) - Bogutskaya et al.: 387, fig. 164, photo 56. 


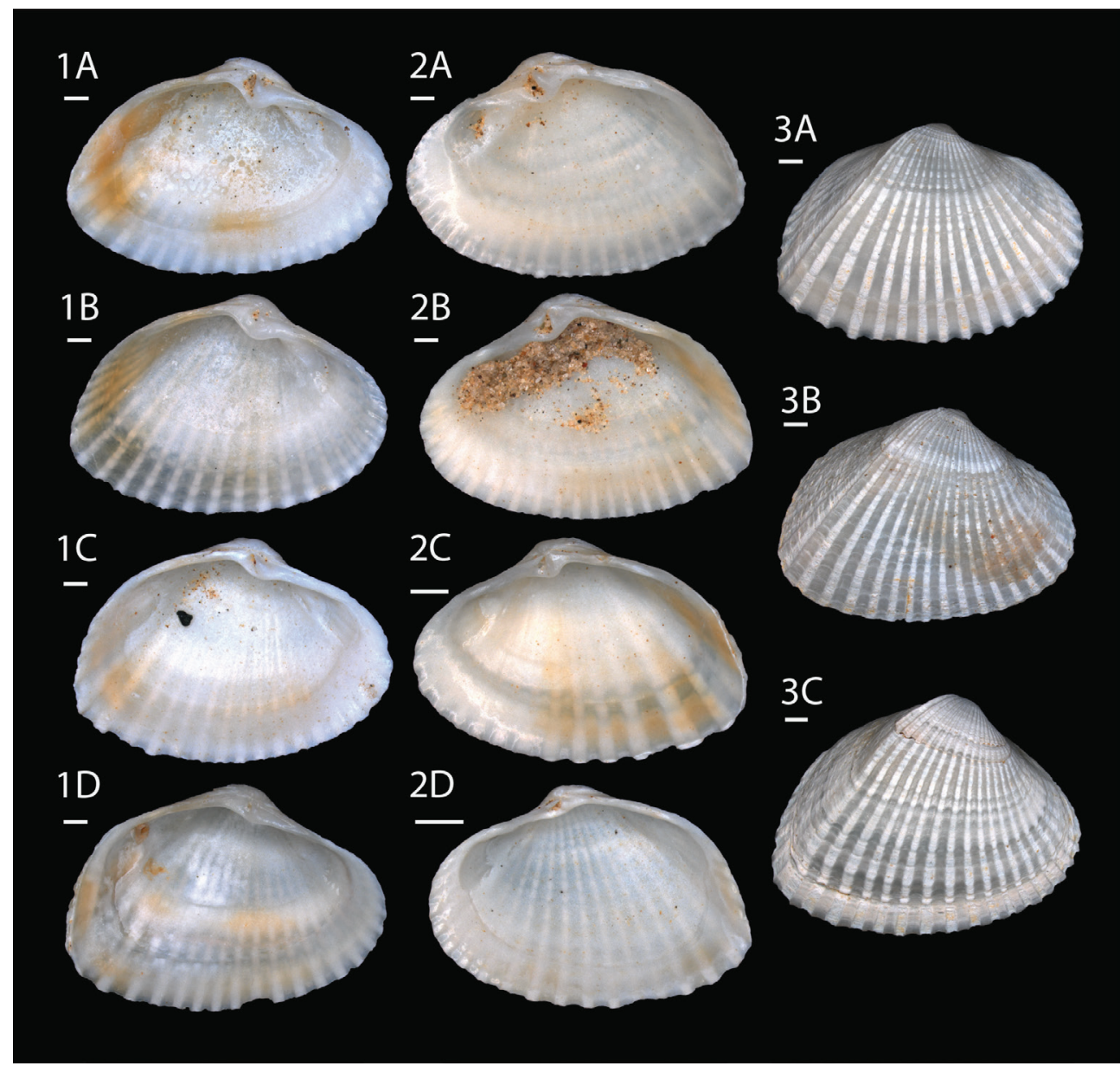

Fig. 5.6: Shape variation in Didacna subcatillus RGM.1310272. (1) Variability of dentition in LV: (a) thick hinge, to (d) thin hinge. (2) Variability of dentition in RV: (a) thick hinge, to (d) thin hinge. (3) Shape variability of LV (a) oval (b) oval/triangular, (c) triangular. Scale bars $=1 \mathrm{~mm}$.

Dimensions - Estimated max. L $19.5 \mathrm{~mm}, \mathrm{H} 14 \mathrm{~mm}$ (all larger shells in the sample are broken). Logvinenko and Starobogatov (1969) reported L $35 \mathrm{~mm}$ and H $26 \mathrm{~mm}$ for this species.

Characterization - Thin-shelled, subquadrangular to subelliptical intermediate convex shell with edentulous hinge; shell flattened; ribs are thin, erect and separated by wide concave interspaces.

Taxonomic notes - In the northern Caspian, there are sometimes smaller individuals that can resemble somewhat the outline of Adacna vitrea forma glabra, from which they differ by their welldeveloped ribs (Logvinenko and Starobogatov, 1969).

Ecology - The species occurs on muddy to sandy-muddy lake floors and shelly firm grounds in the north, middle and south Caspian Sea (Bogutskaya et al., 2013). Lives down to $30 \mathrm{~m}$ water 
depth in salinities between 4-8 psu (Bogutskaya et al., 2013; Logvinenko and Starobogatov, 1969). However, our own observations of Hypanis washed ashore along coasts of the Middle and South Caspian basins suggest they may have lived in slightly higher salinities as well.

Monodacna caspia (Eichwald, 1829) s.l.

Fig. 5.4: 4

${ }^{\star} 1829$ C. [orbula] caspia Eichwald: 281, pl. 5, fig. 6.

2013 Adacna (Monodacna) caspia caspia (Eichwald, 1829) - Bogutskaya et al.: 380, fig. 154.

1986 Monodacna caspia (Eichwald), 1938 - Yakhimovich et al.: 84, pl. 12, fig. 12.

Dimensions - max. L $23.3 \mathrm{~mm}, \mathrm{H} 18.6 \mathrm{~mm}$.

Characterization - The small-sized cardiid shows a variety of shapes and sizes in our Selitrennoye material. The presence of a series of intermediate morphologies (Fig. 5.7: 1a-e) suggests a single polymorphic species. All specimens have a single cardinal tooth and lack the lateral tooth that typifies Monodacna, yet the thickness and expression of the hinge is extremely variable. A common form is thin-shelled, relatively convex with straight posterior margin and relatively well developed, regularly spaced but thin ribs (Fig. 5.7: 1c). This shape conforms to shells of $M$. caspia illustrated in Bogutskaya et al. (2013). Another form is flatter, in general slightly thicker shelled and has a distinct wedge-shape (Fig. 5.7: 1a). Its ribs are lower and slightly more irregular than in the previous form. This wedge-shaped form conforms to several modern Monodacna species as reported in Bogutskaya et al. (2013) such as Monodacna albida (Logvinenko and Starobogatov, 1967) and M. polymorpha (Logvinenko and Starobogatov, 1967) that have been tentatively grouped into one species by Wesselingh et al. (2019).

Taxonomic notes - Our findings of a large morphological variation in Monodacna, with typical forms conforming to modern species but also with all kind of intermediates, either shows that (1) we are dealing with an ancestral species of all or most of the present-day Caspian Monodacna species or (2) that several of the present-day species should be regarded as a single species. A combined morphological-molecular approach is required to assess the species delimitations within living faunas.

Ecology - Caspian Monodacna species occur in a wide range of habitats today, and given the uncertainty of the identity of these species, it is difficult to report the ecological characteristics. Species live mainly in northern Caspian Sea on muddy and sandy-muddy substrates at a maximum depth of $40 \mathrm{~m}$ (Bogutskaya et al., 2013). Monodacna species are filter feeders whose salinity preferences range mostly from 2 to 8 psu (Bogutskaya et al., 2013).

Monodacna semipellucida (Logvinenko \& Starobogatov, 1967)

Fig. 5.4: 3 
*1967 Hypanis semipellucida Logvinenko and Starobogatov: 232-233.

1973 Hypanis semipellucida Logvinenko et Starobogatov, 1967 - Grossu: 144, fig. 27.

2013 Adacna (Monodacna) semipellucida Logvinenko et Starobogatov, 1967 - Kijashko in

Bogutskaya et al.: 384, fig. 161, photo 55.

Dimensions - max. L 23 mm, H 16 mm.

Characterization - This species is relatively thin-walled and low, often has an elliptical outline in adult stages with low, broad and smooth ribs and narrow interspaces. The ribs and interspaces are well visible on the shell's interior. The most distinct character is the cardinal tooth that is a very narrow but well delimited knob that is located well towards the base of the hinge platform.

Ecology - Monodacna semipellucida lives in the Middle Caspian Sea (Bogutskaya et al., 2013; Logvinenko and Starobogatov, 1969; Wesselingh et al., 2019), down to $40 \mathrm{~m}$ water depth and minimum salinities of 5-8 psu (Bogutskaya et al., 2013; Logvinenko and Starobogatov, 1969).

\section{Family Dreissenidae}

Dreissena caspia Eichwald, 1855

Fig. 5.8: 1-3

${ }^{\star} 1855$ Dreissena caspia Eichwald: 311-312, pl. 10, fig. 19-21.

2013 Dreissena caspia Eichwald, 1855 - Bogutskaya et al.: 321, fig. 109.

Dimensions - max. L $7.4 \mathrm{~mm}, \mathrm{H} 22.7 \mathrm{~mm}$.

Characterization - Elongate, somewhat flat Dreissena with rounded margins; keel low or absent resulting in rounded cross-profile. The semidiameter is initially located at the dorsal margin but in sub adult stages crosses to the ventral margin. In adult stages, the semidiameter becomes less pronounced and is located in the middle of the shell. The posterodorsal margin is broadly rounded (and not subangular as in D. elata), the posterior margin is rounded and the anterior margin is straight to slightly round. The hinge platform is flat and solid.

Ecology - Dreissena caspia is a filter feeder that used to be common all over the Caspian Sea but is now possibly extinct (Bogutskaya et al., 2013). The species seems to be completely outcompeted by Mytilaster minimus (Logvinenko and Starobogatov, 1969). The species was most abundant at depths up to $40 \mathrm{~m}$ (Logvinenko and Starobogatov, 1969), and in a salinity range between 2 and 8 psu (Bogutskaya et al., 2013).

Dreissena elata Andrusov, 1897

Fig. 5.8: 4-5 
*1897 Dreissensia [sic] polymorpha var. elata Andrusov: 353, pl. 20, fig. 25.

2013 Dreissena elata (Andrusov, 1897) - Bogutskayaet al.: 321, fig. 108.

Dimensions - max. L 9 mm, H 19.4 mm. Logvinenko and Starobogatov (1969) reported H up to 30 $\mathrm{mm}$.

Characterization - Medium- to thick-shelled triangular-shaped Dreissena with a wide range of morphologies, ranging from an elongated form (Fig. 5.8: 4) to a short form (Fig. 5.8: 5). In general, the valves have a well-developed keel that runs close to the posteroventral margin; the latter is straight or can be concave in its upper half. The initial part of the dorsal margin is flaring and the inflection towards the lower dorsal margin is usually well developed. Adult shells can be somewhat flaring. The overall shell is broad and the lower margin is rounded.

Taxonomic notes - The systematics and taxonomy of this species are not resolved. Dreissena elata has several characteristics in common with the widespread Eurasian D. polymorpha Pallas, 1771 (whose distribution nowadays also includes North America). The Caspian material resembles D. polymorpha, especially with regard to shape of the keel, but it is broader, thicker and somewhat flatter. However, also very slender forms exist together with intermediates in the studied material (Fig. 5.7: 2). Molecular studies would be required to assess whether D. elata and D. polymorpha are conspecific.

Ecology - Before the introduction of Mytilaster minimus, D. elata was abundant in the South and Middle Caspian basins at depths of up to $35 \mathrm{~m}$ mainly on firm ground and shelly/stony substrate. By now, it is probably extinct (Logvinenko and Starobogatov, 1969). The species occurred in salinities between 2 and 8 psu (Bogutskaya et al., 2013).

Dreissena grimmi Andrusov, 1890

Fig. 5.8: 6-7

${ }^{\star} 1890$ Dr.[eissena] Grimmi Andrusov: 233.2013 Dreissena rostriformis (Deshayes, 1838) Bogutskaya et al.: 330, fig. 117b.

Dimensions - Max. L 9.9 mm, H 22.5 mm.

Characterization - Relatively flat comma- to tear-shaped Dreissena lacking a keel; the ventral margin is somewhat concave in its upper half; often a byssate depression is developed; the line of semidiameter runs in the middle of the shell; the hinge platform is flat, wide and robust.

Taxonomic notes - This species is commonly known as Dreissena rostriformis (Deshayes, 1838), a species originally described from Pliocene deposits of Crimea in the Black Sea basin. Its lectotype (as illustrated in Rosenberg and Ludyanskiy, 1994) shows a different shell shape with almost parallel sides that result in a subquadrangular overall outline. This shape is mirrored by the pallial line on the interior and has not been seen in the drop-shaped outlines of late Quaternary Caspian Dreissena. 


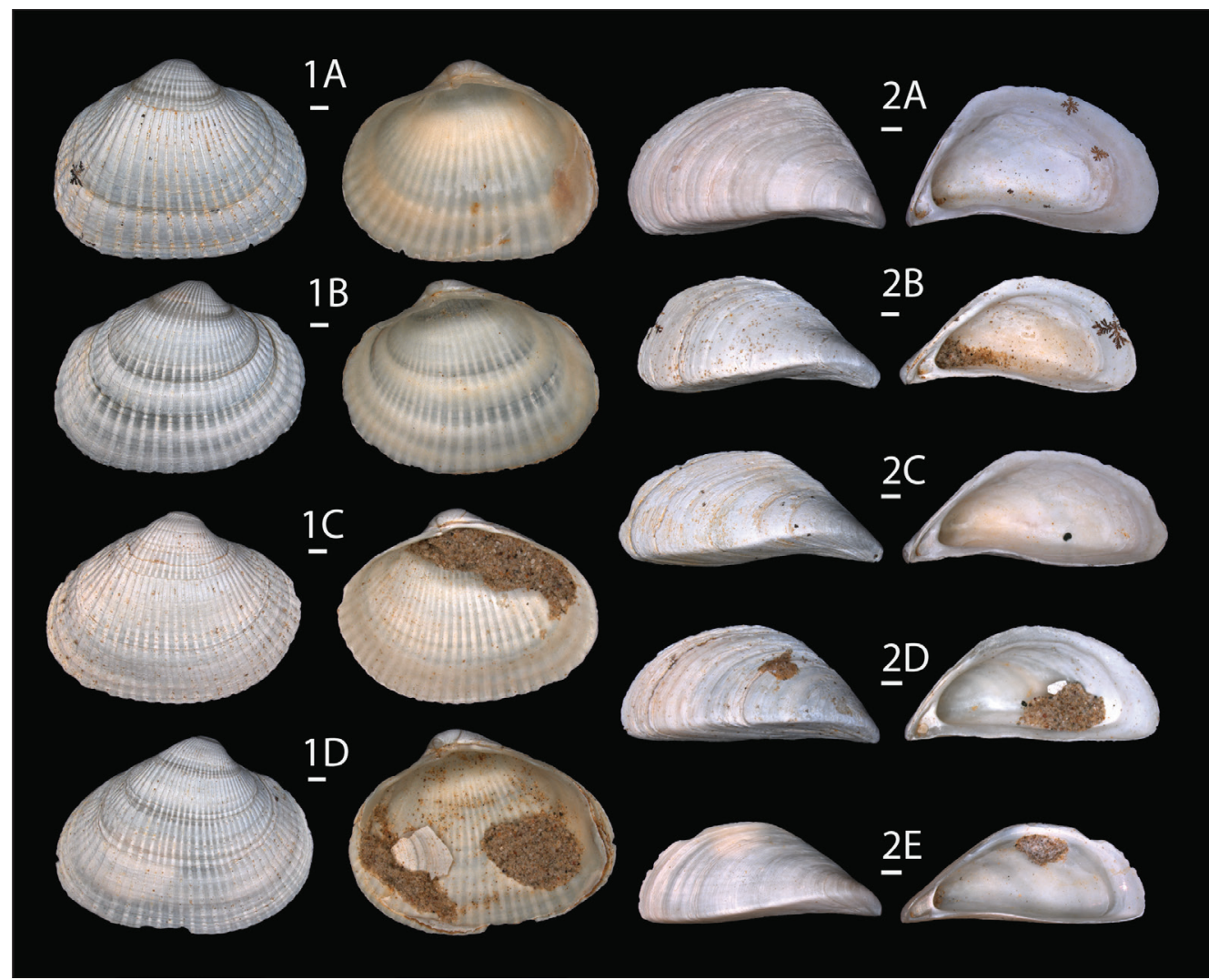

Fig. 5.7: Plasticity (shape variability) of (1) Monodacna caspia RGM.1309807. (a) umbo in the middle, more square (b) umbo not in middle, more round (c) umbo in the middle, oval (d) umbo not in middle, more oval shape. (2) Dreissena elata. (a) RGM.1310278 short, curved (b) RGM.1310280 medium, curved (c) RGM.1310280 long, curved (d) RGM.1310280 medium, straight (e) RGM.1310282 long, straight. Scale bars under figure numbers are $1 \mathrm{~mm}$.

Hence, the name D. rostriformis should be abandoned for late Quaternary Caspian material; the next available name is D. grimmi (Wesselingh et al., 2019). In addition, the four subspecies described from the Caspian Sea (Bogutskaya et al., 2013) are likely synonyms as indicated by molecular analyses (Stepien et al., 2013). The latter authors however argue for synonymy with the Black Sea D. bugensis Andrusov, 1897. That species has a slight but consistent genetic differentiation but incompatible ecological preferences in the Black Sea basin compared to the Caspian mussels (e.g. salinity preferences of 0-2 psu versus 7-12 psu; Stepien et al., 2013). The introduction of D. bugensis in the Volga catchment in the 1980s has not yet led to reconnection of Caspian population of $D$. grimmi (pers. obs.), hence we consider these species as separate species. 


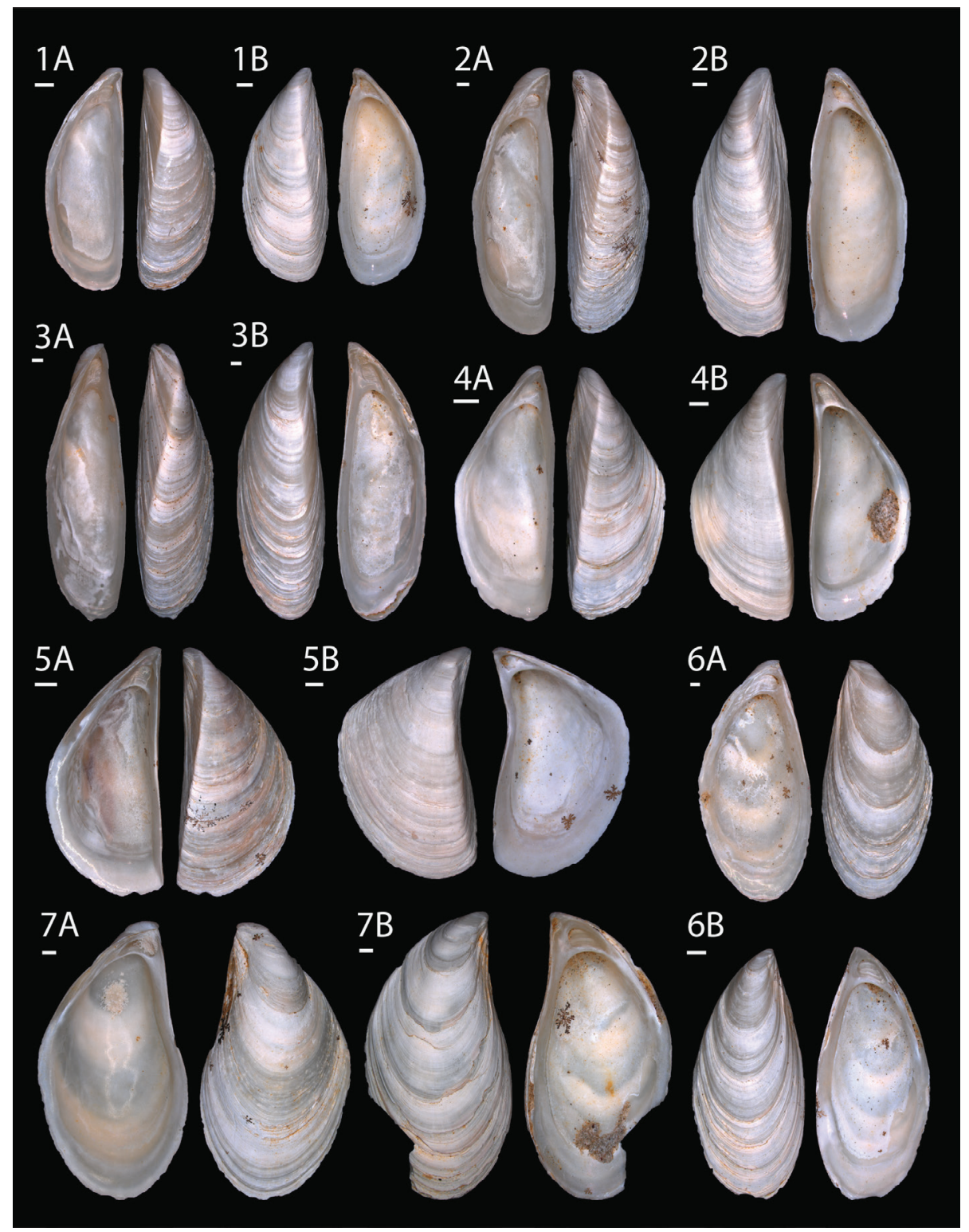

Fig. 5.8: Dreissenidae. (1-3) Dreissena caspia Eichwald, 1855: (1a) RGM.1310289 short type, LV; (1b) RGM.1310288 short type, RV; (2a) RGM.1310286 medium/curved type, LV; (2b) RGM.1310287 medium/ curved type, RV; (3a) RGM.1310285 elongated type, LV; (3b) RGM.1310284 elongated type, RV. (4-5) Dreissena elata (Andrusov, 1897): (4a) RGM.1310283 elongated type, LV; (4b) RGM.1310282 elongated type, RV; (5a) RGM.1310279 short type, LV; (5b) RGM.1310278 short type, RV). (6-7) Dreissena grimmi (Andrusov, 1890): (6a) RGM.1310276 straight type, LV; (6b) RGM.1310275 straight type, RV; (7a) RGM.1310274 curved type, LV; (7b) RGM.1310273 curved type, RV. Scale bars $=1 \mathrm{~mm}$. 
Ecology - Dreissena grimmi lives in the Middle and South Caspian basin at depths between 15 and $300 \mathrm{~m}$ water depth and salinities between 7-12 psu (Bogutskaya et al., 2013).

\subsection{Discussion}

The taphonomic assessment of the Selitrennoye fauna indicates a very well preserved community that is fit to be used as a natural baseline. The few, rare gastropods that differ in their preservation state represent a different, probably true freshwater habitat and were likely reworked (through bioturbation) from underlying strata or transported to the site by currents. Overall, the taphonomic criteria indicate rapid deposition, little time averaging and little physical disturbance.

The sedimentology, taphonomy and autecology of the fauna permits us to reconstruct the paleoenvironments; the studied fauna represents a sandy lake floor assemblage of filter feeders, particle feeders and one herbivore that lived within the photic zone in approximately 15-25 $\mathrm{m}$ water depth and lower mesohaline conditions (5-8 psu). During the Hyrcanian stage, the Caspian Sea level rose, exceeding the Caspian Sea level of the preceding late Khazarian stage (Kurbanov et al., 2018; Yanina et al., 2017a). The climate was slightly cooler and wetter than during the previous regressive epoch (Yanina et al., 2017a). Our salinity approximation matches with the estimated 7-8 psu in the Kerch-Manych strait, where water from the northern Caspian Sea flowed into the Black Sea (Kurbanov et al., 2018).

Comparison of faunas between Selitrennoye and those of similar environments in the Caspian Sea today give an indication of the magnitude of biodiversity change. Water depths around 15-25 $\mathrm{m}$ and salinities around 8 psu occur today at the transition of the northern and middle Caspian basin, even though the setting is more open towards the deep Middle Caspian basin and wave induced disturbance of the Caspian Sea floor may reach deeper than in Selitrennoye. However, Holocene shelly faunas from these modern environments are different in composition and diversity compared to the Late Pleistocene fauna studied here. A shelly residue from the Caspian Sea floor on the north-middle Caspian basin transition was obtained offshore Kazakhstan during a field campaign 2017 (Fig. 5.9). The sample is dominated by fresh material of the invasive species Abra segmentum, Cerastoderma glaucum, and Mytilaster minimus, while only very few fresh specimens of very few species of the Pontocaspian endemic complex are present. Similar dominance of Holocene immigrant species and almost entire lack of endemic species has been documented from various localities in the Middle and South Caspian basins (Kosarev and Yablonskaya, 1994; Latypov, 2015; Leroy et al., 2018).

In addition to changing abundances, Late Pleistocene and Holocene Caspian faunas differ in their species compositions, yet with considerable variation among systematic groups. The gastropod fauna and parts of the bivalve fauna (species of Dreissena, Adacna and Hypanis) found in the Late Pleistocene appear the same as those living in the Caspian Sea until the early $20^{\text {th }}$ century (Yanina, 2012a). On the contrary, the Late Pleistocene Didacna fauna does not contain any species that extends into the Holocene. The complete turnover within the genus Didacna has been traditionally 


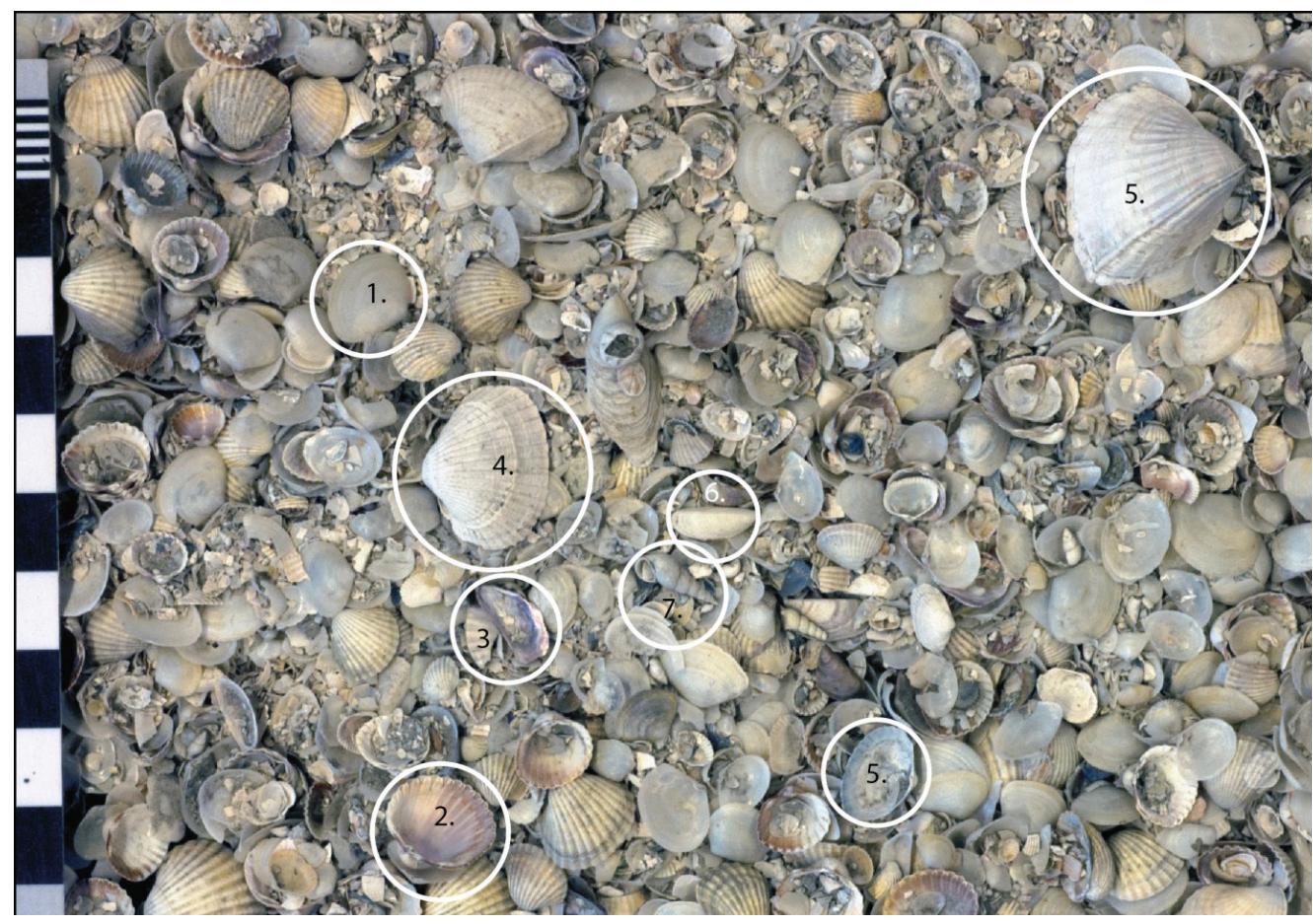

Fig. 5.9: Shelly residue from the Caspian Sea floor on the North-Middle Caspian basin transition offshore Kazakhstan $\left(44^{\circ} 43.4 \mathrm{~N}, 50^{\circ} 13.2 \mathrm{E}\right.$; water depth $\left.8 \mathrm{~m}\right)$. The soft bottom fauna is dominated by Holocene invasives such as (1) Abra segmentum, (2) Cerastoderma spec. A sensu Wesselingh et al., 2019, and (3) Mytilaster minimus. Pontocaspian endemics occur in this sample (4) Monodacna albida s.l., (5) Didacna spp, (6) Dreissena caspia and (7) Turricaspia meneghiniana, yet these all are discolored and presumably pre-20 $0^{\text {th }}$ century).

used for a detailed biozonation of Quaternary Caspian deposits (Nevesskaja, 2007), yet the apparent stability of all other species is new and in marked contrast.

The stratigraphic age of the Selitrennoye fauna is revised here: the fauna is attributed to the regional Hyrcanian stage (Late Pleistocene, Marine Isotope Stage MIS5d-c). The sample contains a typical Middle-Late Pleistocene Caspian fauna; all genera are known from Khazarian, Hyrcanian and Khvalynian deposits (Krijgsman et al., 2019; Popov, 1983b; Yanina, 2014). Previously, the fauna was attributed to the Late Pleistocene (MIS5) Late Khazarian regional stage (Neubauer et al., 2018; Yanina, 2013a), but the lack of crassoidal Didacna indicator species (Didacna nalivkini, D. delenda, D. ovalis, D. karabugasica, D. subovalis, D. ovatocrassa, D. schuraosenica) is at odds with such an attribution. The index species of the Late Khazarian, Didacna surachanica (Fedorov, 1957; Nevesskaja, 2007; Yanina, 2005), is also lacking in the material. Of species characteristic of the early Khvalynian (Didacna ebersini, D. parallella, D. protracta, D. praetrigonoides, D. delenda and D. zhukovi) only Didacna ebersini is present in the Selitrennoye sample. The Hyrcanian 
faunas have been reported to contain the following Didacna species: D. subcatillus, D. cristata, D. schuraosenica, D. pallasi and D. subcrassa (Popov, 1983b; Yanina, 2014), fitting the fauna reported here very well. Especially the occurrence of $D$. cristata together with $D$. subcatillus is typical for the Hyrcanian period (Popov, 1983b). In the literature, it is mentioned that Hyrcanian faunas are often accompanied by the freshwater species Corbicula fluminalis (Yanina, 2012a). That species however favors fresh water and very low salinities, well below those reconstructed for the Selitrennoye assemblage.

\subsection{Outlook}

Our approach to characterize composition and diversity in a fossil fauna to establish a baseline for comparison with biodiversity today will need to be extended to other habitats. So far, the Selitrennoye assemblage is the only completely documented Late Pleistocene in-situ fauna from the Caspian Sea. Also, Holocene faunas require documentation and characterization for such comparisons. A well-resolved taxonomy is paramount for such studies, which is complicated by the paucity of suitable assemblages and the difficulties in determining species (Neubauer et al., 2018; Wesselingh et al., 2019). Establishing species boundaries is moreover hindered by the lack of life material of many of the modern endemic Caspian species that are necessary for combined molecular, anatomical and morphological analyses (Wesselingh et al., 2019). Shelly assemblages like the one documented here, whose taphonomic fidelity and depositional environment are wellconstrained, offer a way forward to document biodiversity change and investigate its drivers. Taphonomic characterization of assemblages is an essential step to identify in-situ assemblages and allow for comparison with (pre-) Holocene baseline samples.

\section{Author contributions}

F.P.W., T.Y. and S.V. conducted field work and collected the material; S.V. and F.P.W. processed the material; S.V., T.Y., F.P.W. and T.A.N. identified the species; S.V. and T.A.N. performed the analysis; S.V. and F.P.W. wrote the manuscript.

\section{Acknowledgements}

We thank Ronald Pouwer and Marjan Helwerda (Naturalis Biodiversity Center, Leiden) for assistance in sample sorting. We are grateful for the constructive comments of two anonymous reviewers. Funding: This work was supported by the European Union's Horizon 2020 research and innovation program [Marie Sklodowska-Curie grant agreement No 642973, 2015-2019]; and an Alexander-von-Humboldt scholarship. 


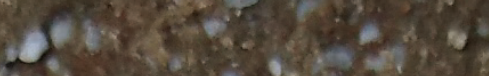

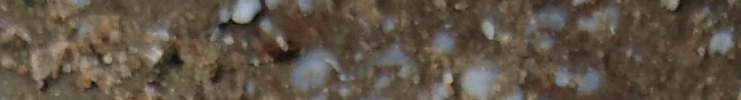

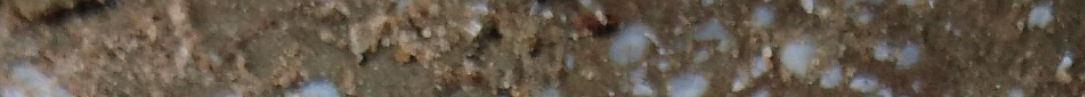

3004 and

4. 42

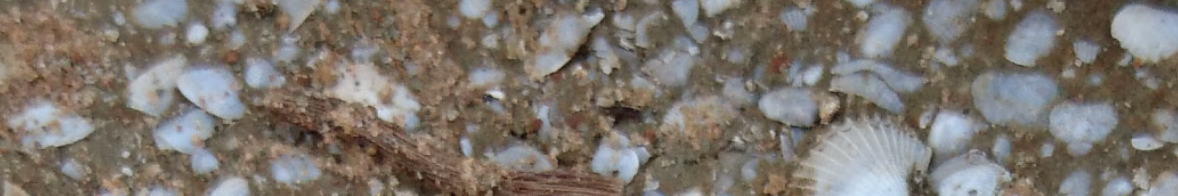

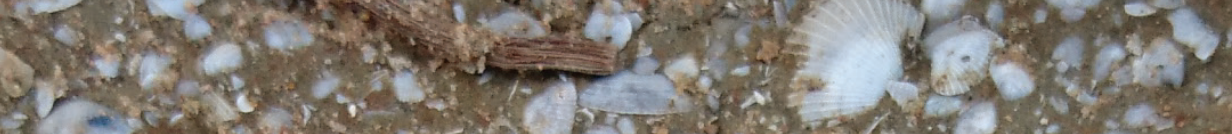

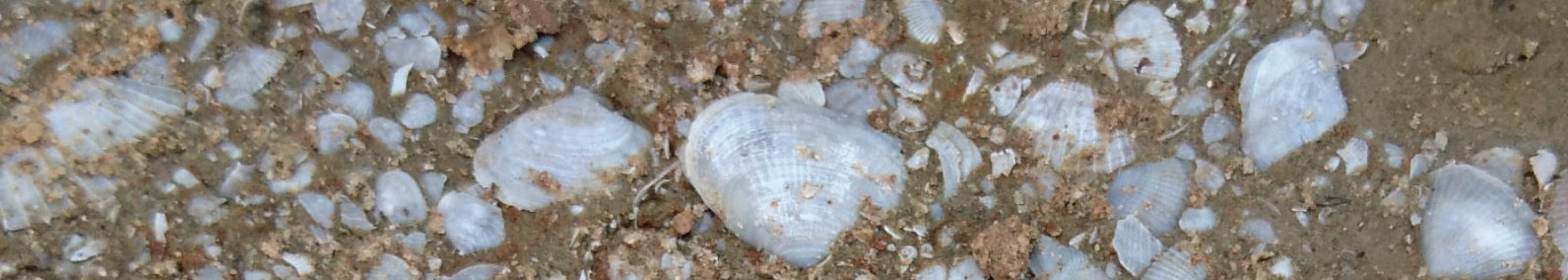
(20) - $x$. 2.

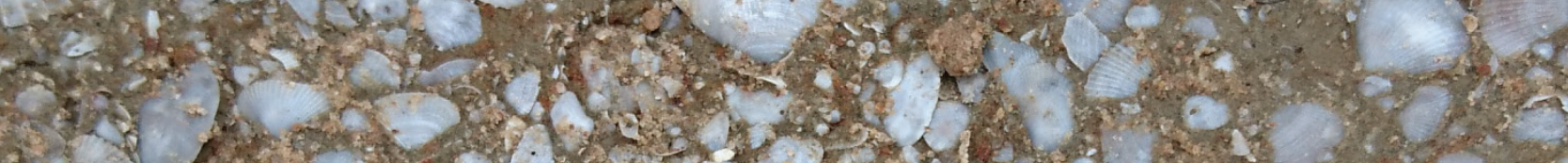

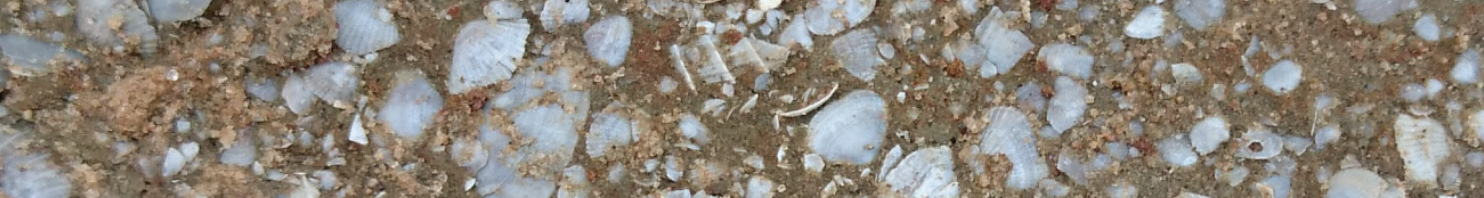

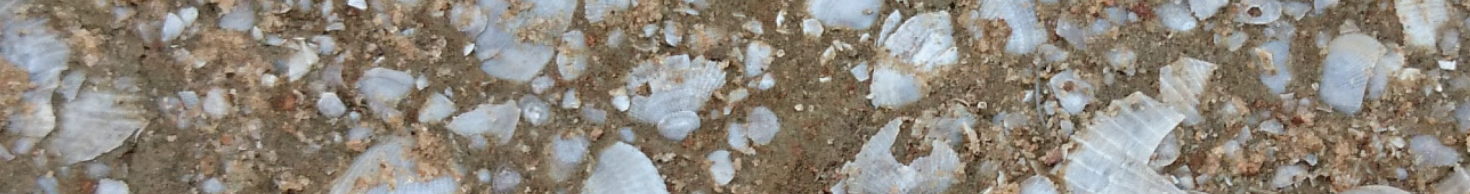
1. $-20 y=8$ $2+67^{3}$

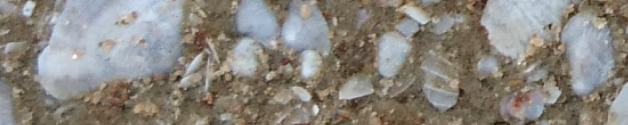




\title{
Holocene Caspian mollusc diversity (Turali, Russia)
}

\section{Published as:}

van de Velde, S., Wesselingh, F.P., Yanina, T.A., Anistratenko, V.V., Neubauer, T.A., ter Poorten, J.J., Vonhof, H.B., Kroonenberg, S.B., 2019. Mollusc biodiversity in late Holocene nearshore environments of the Caspian Sea: A baseline for the current biodiversity crisis. Palaeogeogr. Palaeoclimatol. Palaeoecol. 109364. http://doi.org/10.1016/j.palaeo.2019.109364

\begin{abstract}
The Caspian Sea is an evolutionary island whose rich and endemic fauna have evolved in partial isolation over the past two million years. Baseline studies of pre- $20^{\text {th }}$ century communities are needed in order to assess the severity of the current Caspian biodiversity crisis, which mostly involves invasive species. An inventory of late Holocene shelly assemblages (c. 2000-2500 cal yrs BP) from outcrops in and around Great Turali Lake (Dagestan, Russia) shows a diverse nearshore community consisting of 24 endemic Caspian species, two invasive species and two Caspian native species that lived in a shallow embayment with mesohaline salinities of circa 5-13 psu (parts per thousands). This pre-crisis Holocene Caspian mollusc community serves as a baseline against which modern mollusc diversity measurements can be evaluated. Examination of faunas from similar environments living today and, in the past, illustrates the dramatic changes in nearshore communities during the $20^{\text {th }}$ century. Our study identifies a habitat that may have served as a refuge, but that is currently under threat from invasive species. The severity of the Caspian biodiversity crisis is comparable with other well-known biodiversity crises in semi-isolated ecosystems such as the cichlid fish communities of Lake Victoria, Africa.
\end{abstract}

\subsection{Introduction}

The biggest inland water body on Earth is the Caspian Sea, with a surface area of $371,000 \mathrm{~km}^{2}$. It is an anomalohaline lake, whose water level and salinity regimes are determined by a balance of runoff and evaporation (Kosarev and Yablonskaya, 1994; Krijgsman et al., 2019). The Caspian Sea can be subdivided into three basins: the northern, middle and southern Caspian basin. Each basin is characterized by its own temperature, depth, salinity and ecology features and faunas. The Caspian Sea is disconnected from the open ocean, and various rivers contribute to the inflow of fresh water 
to the basin. Most of the water (80\%) derives from the Volga River, resulting in a strong north-south salinity gradient in the lake (Kostianoy et al., 2005). Near the mouth of the river the salinity is 0 psu, the average of the rest of the basin is around 11-13 psu. Currently, the Caspian Sea water level is 27 m below global sea level (Arpe et al., 2018).

The Caspian Sea has a volatile history of large-scale and rapid lake level change (Badyukova and Kalashnikov, 2009; Fedorov, 1978; Ignatov et al., 1993; Kaplin and Selivanov, 1995; Kosarev and Yablonskaya, 1994; Kroonenberg et al., 2000, 2007; Rychagov, 2002; Svitoch, 2014; Van Baak et al., 2019; Varuschenko et al., 1987; Yanina, 2012c), which greatly affected the extent of the lake. During the last major high-stand in the Late Pleistocene lake levels rose up to 50m above global sea level (77 $\mathrm{m}$ above current Caspian Sea water level), and an overflow gateway existed north of the Caucasus towards the Black Sea (early Khvalynian transgression: Chepalyga, 2007; Yanina, 2014). The major cause of the transgression event was the surface runoff increase from the catchment area during the period of deglaciation (Arslanov et al., 2016; Sorokin et al., 2018). In contrast, at the time of the last big regression in the early Holocene (the Mangyshlak regression: Bezrodnykh and Sorokin, 2016; Yanina, 2014) the level of the Caspian Sea was about 100m below the global sea level (73 m below the current Caspian Sea water level). The extreme lowstand of the Mangyshlak has been ascribed to the colder, more continental climatic conditions during the Boreal (Arslanov et al., 2016). During the late Holocene two additional minor highstands were reached; $-25 \mathrm{~m}$ (compare to $-27 \mathrm{~m}$ of present-day Caspian Sea) around $2600 \mathrm{cal}$ yrs BP, and $-26 \mathrm{~m}$ during the Little Ice Age (Kroonenberg et al., 2007). The Derbant regression during the Warm Medieval period corresponded to a lowstand of around 32m (Kroonenberg et al., 2007).

Coinciding with those huge changes, the Caspian endemic fauna has undergone a protracted series of diversifications and extinctions during the Quaternary, including several major turnover events (Krijgsman et al., 2019; Nevesskaja, 2007; Svitoch and Yanina, 2001; Yanina, 2014). The last natural turnover event of the Caspian Sea biota concurred in the early Holocene during the Mangyshlak regression (Krijgsman et al., 2019: 10-8 ka) when the Khvalynian fauna became replaced by the late Holocene Novocaspian fauna. The pre- $20^{\text {th }}$ century Novocaspian faunas $(<7$ ka) are characterized by the abundance of endemic cardiid and dreissenid bivalve species (of the genera Didacna, Monodacna, Adacna, Hypanis and Dreissena) and endemic hydrobiid gastropod species (Clathrocaspia, Laevicaspia, Turricaspia and Abeskunus) (Logvinenko and Starobogatov, 1969; Sorokin et al., 2018; Svitoch, 2014; Svitoch and Yanina, 2001; Wesselingh et al., 2019; Yanina, 2011). Three species (Cerastoderma glaucum, Cerastoderma sp. A [non C. rhomboides] and Ecrobia grimmi; nomenclature after Wesselingh et al., 2019) established in early Holocene times and lived alongside the endemic Caspian species ever since. Cerastoderma glaucum and C. sp. A were probably introduced by humans and are still considered invasive in the Caspian Sea basin, but Ecrobia grimmi is considered native (Wesselingh et al., 2019).

During the $20^{\text {th }}$ century a major biodiversity crisis unfolded in the Caspian Sea (Kosarev and Yablonskaya, 1994; Latypov, 2015). The introduction of a number of euryhaline marine invasive 
species impacted the Caspian fauna profoundly as shown by observational time series (Kosarev and Yablonskaya, 1994) and boxcore data (Leroy et al., 2018). Highly adaptive and competitive marine species, which were in part introduced as food source for fish stock, thrived in the mesohaline Caspian environment and outcompeted most endemic species (Karpinsky, 2010b). As a result, the diverse endemic Caspian mollusc communities became replaced by species-poor communities dominated by invasive species (Latypov, 2015; Leroy et al., 2018; Wesselingh et al., 2019). Dense populations of invasive species like Mytilaster minimus, Abra segmentum and Cerastoderma spp. and the native species Ecrobia grimmi now dominate the coastal faunas (Karpinsky et al., 2005; Latypov, 2015; Leroy et al., 2018; Mamaev, 2002). Several species of the endemic Caspian fauna are presently considered extinct, and for several other species presumed to be alive no living specimens have been recorded in the past decades (examples in Kosarev and Yablonskaya, 1994; Wesselingh et al., 2019). Beach collecting around the middle Caspian basin at the Great Turali Lake (Russia, 2003), Sarvan (northern Azerbaijan, 2015) and Bautino (Kazakhstan, 2017) yielded fresh material of only a limited number of Caspian endemic species, such as Theodoxus pallasi, Didacna baeri, D. trigonoides, D. parallela, Adacna laeviuscula, A. vitrea and Hypanis plicata (personal observations: FPW, SV and VA). Although this suggests that some endemic species still live in the coastal zone, the restricted amount of living endemic species implies a major decline in diversity.

A proper insight into the severity of the Caspian biodiversity crisis is hampered because (1) the taxonomy of Caspian groups is poorly resolved (Neubauer et al., 2018; van de Velde et al., 2019c; Wesselingh et al., 2019), (2) recent expeditions failed to recover living material for the majority of the species, and (3) a lack of pre- $20^{\text {th }}$ century baseline inventories. Here, we report a fauna from shallow-water Novocaspian (Holocene) deposits from several outcrops around the Great Turali Lake (Fig. 6.1) located south of Makhachkala along the middle Caspian coast of Dagestan (Russia). The Turali fauna provides a baseline for the pre-crisis nearshore Caspian community, which serves as a reference point for comparison with present-day communities. By investigating the depositional environment and documenting the composition of the fauna, we aim to provide a habitatconstrained biodiversity baseline for the composition of shallow-water mollusc faunas prior to the drastic alterations that took place in the $20^{\text {th }}$ century.

\subsection{Study area}

\subsubsection{Geographical context}

The middle Caspian basin is a deep (maximum depth $788 \mathrm{~m}$ ), well-mixed basin with only minor summer water stratification resulting in rather uniform salinities across the entire depth range. Salinities are typically about 11-13 psu, apart from deltaic areas of rivers draining the north-eastern Caucasus where salinities can be locally depressed. The coastal morphology of the western shore of the middle Caspian basin is largely determined by wave-action, rapid sea-level change, tectonic uplift, as well as local input of terrigenous erosive products from the Caucasian hinterlands. 

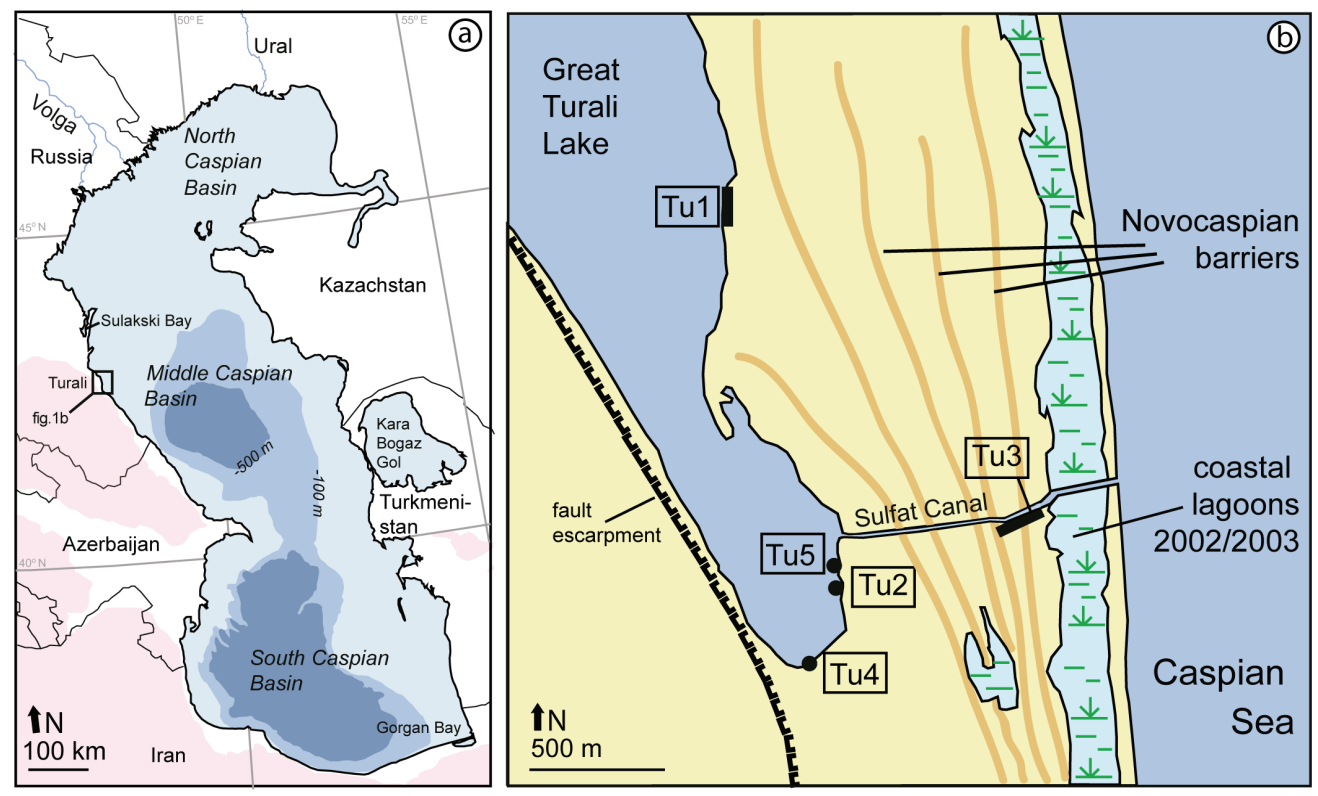

Fig. 6.1: Geographic context of study site. (a) Map of the Caspian Sea. Source bathymetry: Kostianoy et al.

(2005): Fig. 1 (p. 7). (b) Location of the outcrops treated in this chapter. Tu1-Tu5 represent outcrops Turali 1-5. Brown ridges are Holocene Novocaspian beach barriers (see Kroonenberg et al., 2007).

During the Novocaspian stage the Caspian Sea-level rose several meters above the current level twice; approximately $2600 \mathrm{cal}$ yrs BP and during the Little Ice Age (Kroonenberg et al., 2007). These highstands produced extensive coastal deposits along the entire Caspian Sea, including the record treated herein. Our material was collected in and around the Great Turali Lake, which was a bay on the west coast of the middle Caspian basin at the time (Kroonenberg et al., 2007, 2000). During the 2600 cal yrs BP highstand the bay became gradually more isolated from the sea by an eastward growing series of barriers, fed by episodic northwards longshore drift and extensive wave action. After an intervening lowstand the final closure occurred during the Little Ice Age highstand (Kroonenberg et al., 2007).

\subsubsection{Sample sites}

Nine samples from five localities are treated in this chapter (Figs 6.1, 6.2). Four of these localities are positioned along the Great Turali Lake (Ozero Bol'shoye Turali in Russian) and one at the Sulfat Canal that links the lake with the Caspian Sea. The localities are situated on a coastal strip some $25 \mathrm{~km}$ southeast of the city of Makhachkala. Locality Turali-1 (47 $\left.41^{\prime} 20^{\prime \prime} \mathrm{E}, 42^{\circ} 49^{\prime} 54^{\prime \prime} \mathrm{N}\right)$ is an approximately $50 \mathrm{~m}$ long cliff exposure along the east bank of the Great Turali Lake. Sample M0222 was taken there. Locality Turali-2 $\left(47^{\circ} 41^{\prime} 43^{\prime \prime} \mathrm{E}, 42^{\circ} 49^{\prime} 04^{\prime \prime} \mathrm{N}\right)$ consists of a number of very slightly westward-dipping layers that are exposed in the shore zone and just below the water table on the 


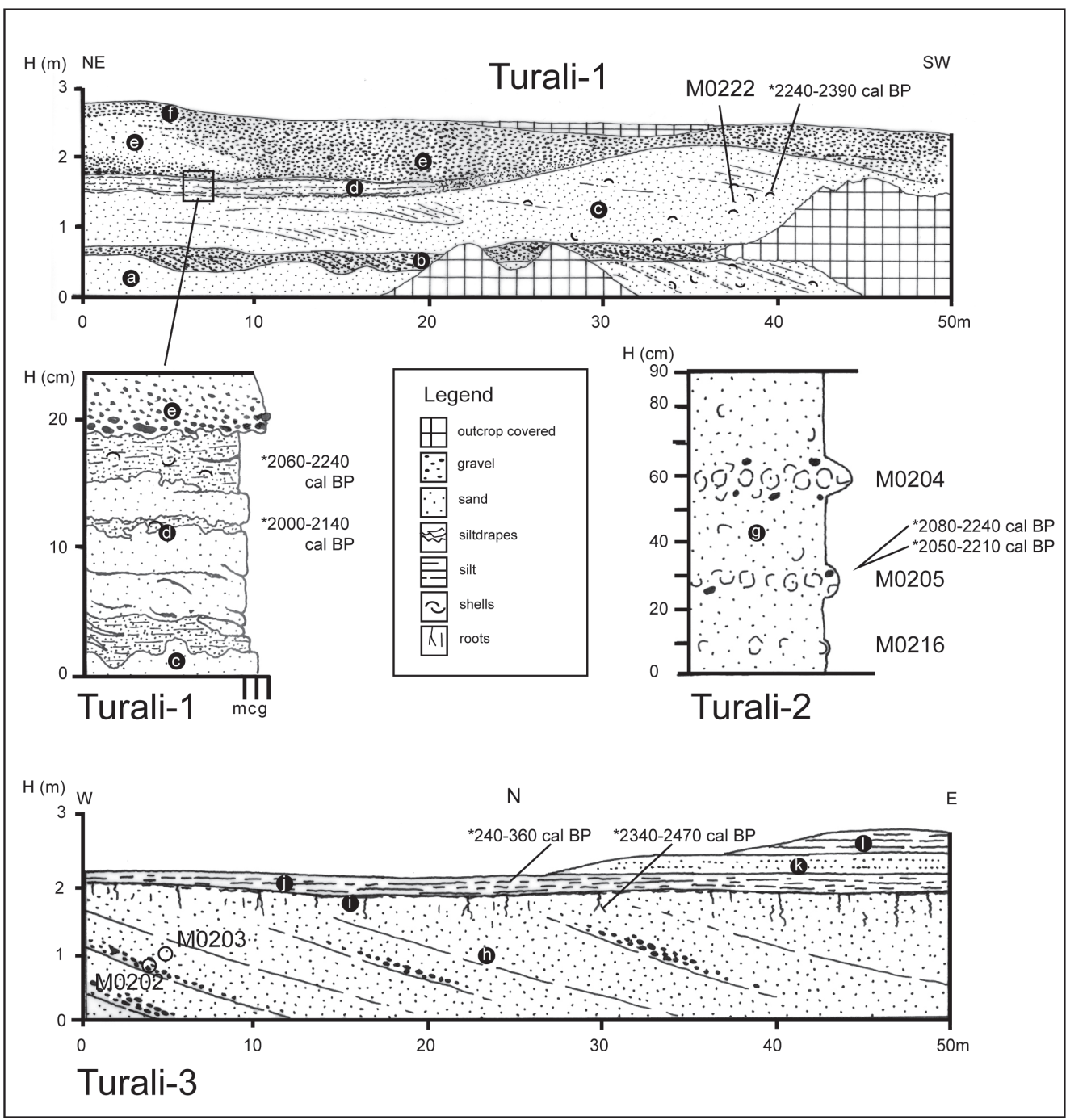

Fig. 6.2: Schematic representation of sections Turali 1-3. Asterisks $\left(^{*}\right)$ denote calibrated ${ }^{14} \mathrm{C}$ ages yrs BP. Small case letters refer to sedimentary units: a. eastwards-dipping bay fill, b. eastwards-dipping bay fill, c. sand with shells along eastward-dipping foresets, $d$. deformed laminated silts and sands, e. massive gravel beds, f. coarsegrained pebble lag, g. slightly dipping sand layers with shells, h. low-angle clinoforms with pebbles and shells, i. stratified silt stone, lagoonal, j. silt layer with shells, k. Aeolian interval, l. stratified silt stone, lagoonal.

south-eastern margin of the Great Turali Lake, south of the Sulfat Canal outlet. Samples M0204,

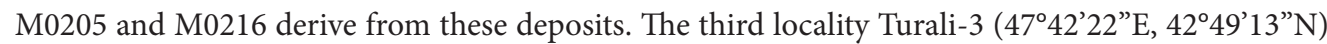
comprises a series of outcrops along the south bank of the Sulfat Canal. Samples M0202 and M0203 were collected there. Turali-4 and Turali-5 represent single sediment layers and these are 
not illustrated in Fig. 6.2. Turali-4 (47 $\left.41^{\prime} 33^{\prime \prime} \mathrm{E}, 42^{\circ} 48^{\prime} 51^{\prime \prime} \mathrm{N}\right)$ is a flat grey-yellow silt layer of at least $50 \mathrm{~cm}$ thickness with molluscs outcropping on the southern beach of the Great Turali Lake. Samples M0220 and M0221 were collected there within a few meters from each other. Turali-5 (47'41'43"E, $42^{\circ} 49^{\prime} 08^{\prime \prime} \mathrm{N}$ ) is a single shell-bearing sand layer exposed in the shore zone, just below the water table, 100 meter north of Turali-2. Sample M0215 was taken there.

\subsection{Material and methods}

For each sample about $1 \mathrm{~kg}$ of sediment was washed through a $1 \mathrm{~mm}$-sieve. Molluscs were identified to the species level and the total of individuals for each species was counted. For bivalves, all valves and fragments containing a hinge were counted. One valve was counted as half an individual, whereas for gastropods, a fragment with a protoconch was considered one individual. Final counts were rounded up to the next integer. We follow the gastropod taxonomy of Neubauer et al. (2018) and Wesselingh et al. (2019). The generic classification of Pontocaspian hydrobiids is subject of current studies and nomenclature might further be updated as a result in the near future. For bivalves, we used Kijashko in Bogutskaya et al. (2013), Wesselingh et al. (2019) and van de Velde et al. (2019). Cases in which we deviate are argued below.

To assess the taphonomic fidelity of the fauna, we examined preservation characteristics of the molluscs. Samples were checked for dissolution, abrasion, coloration and fragmentation. Paired bivalves, which indicate in-situ samples, were noted. To reconstruct the Holocene environment of Turali, we used the published information on species' preferred environmental conditions (salinity ranges, habitat and depth ranges) collected by van de Velde et al. (2019). Additional ecological characteristics were assembled from literature data and personal observations for Adacna vitrea, Cerastoderma cf. glaucum, Cerastoderma sp. A and Monodacna albida, Didacna baeri, D. eichwaldi, D. parallela, D. protracta, D. pyramidata, D. trigonoides, Abeskunus exiguus, Laevicaspia conus and Clathrocaspia gmelinii.

Stable isotope data derive from Vonhof et al. (2004). Radiocarbon data were previously published by Kroonenberg et al. (2007). The software Calib version 5 was used to calibrate ${ }^{14} \mathrm{C}$ ages to calendar years BP. To correct for reservoir ages, the marine calibration curve Marine 04 was used (Hughen et al., 2004). We used R version 3.5.2 (R Core Team, 2018) and the package 'iNext' 2.0.19 (Chao et al., 2014; Hsieh et al., 2016) to perform rarefaction analyses to estimate the representativeness of the samples (Raup, 1975). Land snails and reworked species were excluded from this analysis.

The following abbreviations are used: $\mathrm{LV}=$ left valve, $\mathrm{RV}=$ right valve, $\mathrm{RGM}=$ collections of Fossil Mollusca, Naturalis Biodiversity Center collection, formerly Rijksmuseum Geologie en Mineralogie, Leiden, the Netherlands. 


\subsection{Results}

\subsubsection{Geology and age}

Five facies are described in the studied outcrops (Table 6.1). Facies I (beach-berm shingle) and II (highstand/regressive shoreface and bay fill) dominate the sections. Other facies include lagoonal (Facies III), lagoonal to restricted embayment (Facies IV) and paleosol (Facies V).

Section Turali-1 contains two successive coarsening-up units, with beach settings migrating over bay fill deposits. A lagoonal interval is found in between the two coarsening-up units. The lower unit comprises a lower interval of eastwards-dipping bay fill (facies IIb, Fig. 6.2-a) overlain by beach-berm shingle (facies I, Fig. 6.2-b). Although the contact between the two intervals appears to be sharp, increasing pebble lines along the clinoforms at the top of the lower interval in the southern part of the outcrop indicate that the contact may become gradual laterally. The upper unit comprises three intervals. The lower interval (facies IIb, Fig. 6.2-c) is a body of sand with shells, including paired Didacna trigonoides and Adacna laeviuscula, dispersed or lined along eastward-dipping foresets. This sand layer has an undulating top, forming a palaeo-relief with height differences of about $70 \mathrm{~cm}$. A single ${ }^{14} \mathrm{C}$ age of $2240-2390 \mathrm{cal}$ yrs BP was measured from a paired Didacna trigonoides (specimen HV\#10a; Table 6.2). Within a depression in the northern half of the outcrop a $20 \mathrm{~cm}$-thick succession (Fig. 6.2-d) of deformed laminated silts and sands is found (attributed to facies III, Iva and IVb, lagoonal deposits). In the silts and silty sands small paired Cerastoderma are common. The ${ }^{14} \mathrm{C}$ ages of Cerastoderma from two silt layers (2000-2140 cal yrs BP and 2060-2240 cal yrs BP) indicate that the different lagoonal layers are of approximately the same age and only a few hundred years younger than the top of underlying sequence I. The lagoonal interval grades laterally into the base of massive gravel beds (Fig. 6.2-e) assigned to facies I (beach-berm shingle). The shingle grades laterally into more sand-dominated deposits, possibly a gradation into facies IIb (fill), which overlays the the lagoonal interval. Finally, a coarsegrained pebble lag (Fig. 6.2-f) is found on top of the section that may represent ablation of and soil formation in the underlying gravel interval.

Section Turali-2 is formed by slightly dipping layers outcropping on the floor of the lake. The stratigraphic thickness is only $90 \mathrm{~cm}$, and the succession is assigned to facies IIb (Fig. 6.2-g). The sands and shell layers have a very low-angle westward dip $\left(<5^{\circ}\right)$. The shell beds yield abundant paired, in-situ bivalves dominated by Didacna eichwaldi. The lower boundary of the shelly intervals is not sharply delimited. The fauna is comparatively diverse and well-preserved, but minor amounts of abraded specimens and fragments as well as some pebbles indicate the proximity of physical disturbance. These specimens and fragments either originated from proximal wash-over events or are the result of reworking of an underlying transgressive layer by bioturbation. Two paired $D$. eichwaldi specimens in the lower shell bed yield ${ }^{14} \mathrm{C}$ ages of $2080-2240 \mathrm{cal}$ yrs BP and 2050-2210 cal yrs BP, respectively. The section in Turali-2 may therefore be the lateral equivalent of the upper sequence of Turali-1. 


\section{CHAPTER 6}

Table 6.1: Sedimentary facies in the Novocaspian (Holocene) deposits near Turali.

\begin{tabular}{|c|c|c|c|c|c|}
\hline Facies & Color & Lithology & Sedimentary structures & Details & Interpretation \\
\hline I & $\begin{array}{l}\text { grey- } \\
\text { yellow }\end{array}$ & $\begin{array}{l}\text { poorly sorted gravel } \\
\text { with variable amounts } \\
\text { of coarse-grained } \\
\text { sands }\end{array}$ & $\begin{array}{l}\text { sediment can be matrix or clast- } \\
\text { supported, bedding poorly and } \\
\text { irregularly developed }\end{array}$ & $\begin{array}{l}\text { pebbles }(1-8 \mathrm{~cm}) \text {, grey to } \\
\text { orange brown durable } \\
\text { calcilutite, flattened, } \\
\text { irregularly oriented or } \\
\text { slightly imbricate }\end{array}$ & beach-berm shingle \\
\hline II & yellowish & $\begin{array}{l}\text { fine to coarse grained } \\
\text { poorly to reasonably } \\
\text { sorted sand }\end{array}$ & $\begin{array}{l}\text { low-angle dipping foresets } \\
\text { with sometimes imbricated } \\
\text { gravel and shell accumulations } \\
\text { present, top sets and bottom } \\
\text { sets rarely found }\end{array}$ & $\begin{array}{l}\text { dispersed shells and } \\
\text { pebbles }\end{array}$ & \\
\hline Ila & yellowish & $\begin{array}{l}\text { sands medium-coarse } \\
\text { grained }\end{array}$ & $\begin{array}{l}\text { foresets dipping seaward, well } \\
\text { defined }\end{array}$ & $\begin{array}{l}\text { abraded shells and } \\
\text { shell fragments, often } \\
\text { with a mixture of } \\
\text { colours, dispersed and } \\
\text { concentrated along } \\
\text { clinoforms, plugs of flat } \\
(\varnothing<2 \mathrm{~cm}), \text { imbricate } \\
\text { carbonate pebbles occur }\end{array}$ & $\begin{array}{l}\text { eastward prograding } \\
\text { shore face during } \\
\text { lake-level fall }\end{array}$ \\
\hline Ilb & yellowish & $\begin{array}{l}\text { sands mostly fine to } \\
\text { medium grained }\end{array}$ & $\begin{array}{l}\text { foresets dipping landwards or } \\
\text { undulating (possibly including } \\
\text { hummocky cross stratification), } \\
\text { somewhat irregularly } \\
\text { developed, locally stacked } \\
\text { low-angle dipping foresets with } \\
\text { cross stratification, foresets } \\
\text { grade laterally into Facies Ilc }\end{array}$ & $\begin{array}{l}\text { shells and shell fragments } \\
\text { on foresets or dispersed } \\
\text { in sediment, sometimes } \\
\text { abraded but well- } \\
\text { preserved, include paired } \\
\text { bivalves (sometimes in } \\
\text { butterfly preservation) }\end{array}$ & $\begin{array}{l}\text { washover lobes } \\
\text { of beach barriers } \\
\text { formed by storms } \\
\text { during lake-level } \\
\text { rise and highstand } \\
\text { interfingering with } \\
\text { bay floor successions }\end{array}$ \\
\hline IIc & $\begin{array}{l}\text { grey- } \\
\text { yellow }\end{array}$ & $\begin{array}{l}\text { fine-grained sand } \\
\text { to silt }\end{array}$ & $\begin{array}{l}\text { subhorizontal massive or } \\
\text { poorly stratified }\end{array}$ & $\begin{array}{l}\text { dispersed well-preserved } \\
\text { molluscs, including pairs of } \\
\text { Monodacna and Dreissena, } \\
\text { shell beds with in-situ } \\
\text { Didacna dominated faunas }\end{array}$ & shallow bay floor \\
\hline III & $\begin{array}{l}\text { yellowish- } \\
\text { white }\end{array}$ & $\begin{array}{l}\text { fine to medium } \\
\text { grained, well sorted } \\
\text { sand }\end{array}$ & more or less horizontal layering & & $\begin{array}{l}\text { lagoon, possibly with } \\
\text { substantial input of } \\
\text { windblown sands. }\end{array}$ \\
\hline IV & & $\begin{array}{l}\text { silt to fine grained } \\
\text { silty sand }\end{array}$ & & $\begin{array}{l}\text { paired subadult and } \\
\text { juvenile Cerastoderma }\end{array}$ & \\
\hline $\mathrm{IVa}$ & & $\begin{array}{l}\text { silt to medium } \\
\text { grained sand }\end{array}$ & $\begin{array}{l}\text { massive silt to slightly } \\
\text { irregularly layered silt-medium } \\
\text { grained sand laminae }\end{array}$ & $\begin{array}{l}\text { shells, mostly well- } \\
\text { preserved, paired subadult } \\
\text { and juvenile Cerastoderma } \\
\text { and Ecrobia grimmi }\end{array}$ & $\begin{array}{l}\text { restricted embayment } \\
\text { or lagoon with storm- } \\
\text { induced sand layers }\end{array}$ \\
\hline $\mathrm{IVb}$ & & $\begin{array}{l}\text { fine-medium grained } \\
\text { silty sands }\end{array}$ & $\begin{array}{l}\text { silt drapes, sometimes } \\
\text { overlaying wave ripples }\end{array}$ & $\begin{array}{l}\text { few dispersed shells, } \\
\text { mostly of Cerastoderma }\end{array}$ & $\begin{array}{l}\text { restricted embayment } \\
\text { or lagoon lacking } \\
\text { storm-induced sand } \\
\text { layers }\end{array}$ \\
\hline v & $\begin{array}{l}\text { grey- } \\
\text { purple- } \\
\text { black }\end{array}$ & $\begin{array}{l}\text { sand or partially flat- } \\
\text { lying gravel with loam }\end{array}$ & & $\begin{array}{l}\text { sand with root fragments } \\
\text { and dispersed organic } \\
\text { matter, gravel with } \\
\text { root traces and some } \\
\text { organic matter, dispersed } \\
\text { pulmonate (terrestrial) } \\
\text { snails }\end{array}$ & $\begin{array}{l}\text { soil developed } \\
\text { in sandy/gravelly } \\
\text { substrate }\end{array}$ \\
\hline
\end{tabular}

Section Turali-3 (Sulfat Canal) contains two units. The lower circa two-meter unit is a single unit assigned to facies IIb (shoreface, Fig. 6.2-h). Low-angle clinoforms with occasional pebbles and often abraded shells and shell fragments are present. Some concentrations of worn Dreissena elata 
Table 6.2: Radiocarbon ages (compiled from Kroonenberg et al., 2007).

\begin{tabular}{llccc}
\hline Sample & Species & Sample site & 14C age (yrs uncal. BP) & Calendar age (cal. yrs BP) \\
\hline HV\#06 & Cerastoderma sp. A & Turali-3 & $525 \pm 33$ & $240-360$ \\
HV\#08 & indet. pulmonate terrestrial snail & Turali-3 & $2603 \pm 33$ & $2340-2470$ \\
HV\#09 & Cerastoderma sp. A & Turali-1 & $2370 \pm 40$ & $2060-2240$ \\
HV\#10a & Didacna trigonoides & Turali-1 & $2517 \pm 41$ & $2240-2390$ \\
HV\#11 & Cerastoderma sp. A & Turali-1 & $2322 \pm 37$ & $2000-2140$ \\
M0205\#1 & Didacna eichwaldi & Turali-2 & $2373 \pm 38$ & $2080-2240$ \\
M0205\#2 & Didacna eichwaldi & Turali-2 & $2366 \pm 30$ & $2050-2210$ \\
\hline
\end{tabular}

and Clessiniola variabilis are present. Root traces, dispersed organic matter as well as dispersed, slightly decalcified terrestrial snails are found in the upper $30-50 \mathrm{~cm}$ indicating soil formation after deposition $(<2600 \mathrm{cal}$ yrs BP). This lower unit is overlain by three thin layers, assigned to facies IV, II and IV, respectively. The lower silt layer of the upper interval (Fig. 6.2-j) contains abundant and well-preserved paired subadult Cerastoderma as well as Ecrobia grimmi. A shell of the former yielded a ${ }^{14} \mathrm{C}$ age of 240-360 cal yrs BP. The three upper beds appear to represent mostly lagoonal facies with possibly a short Aeolian interval (Fig. 6.2-k) developed in the Middle Ages and thus overlie the older Novocaspian deposits with a hiatus comprising approximately $1800 \mathrm{yrs}$.

Turali- 4 and Turali-5 are single layers cropping out along the banks of the Great Turali Lake for which no age data are available. Locality Turali-4 comprises a single fine-grained sandy silt layer with dispersed molluscs. The layer contains very poorly developed bedding planes. Given the location farthest from the shore and close to the escarpment that bounded the landward side of the Novocaspian deposits, this layer may be among the oldest Novocaspian intervals. It is considered to represent a (relatively shallow) bay floor infill. Locality Turali-5 is a poorly delimited shelly sand layer, and like Turali-2 located below the water table.

\subsubsection{Taphonomy}

The degree of preservation varies within the samples. Samples M0202 and M0203 are dominated by abraded (polished) fragments and specimens. Within most other samples the majority of shells have retained fine sculptural details, and paired bivalves were observed (Fig. 6.3), but a few abraded specimens were found too. These abraded specimens were either induced by storm events or result from reworking by bioturbation from underlying layers. In rare cases Late Pleistocene fossil species were found in these samples. Both Khvalynian and Khazarian (Late Pleistocene) units crop out very close to the study site. The land snails were either introduced in the layers during post-depositional soil formation or reworked floating material.

\subsubsection{Faunal composition and taxonomy}

All studied material is listed in Table 6.3. The samples represents 28 identifiable aquatic mollusc species, of which two (Cerastoderma cf. glaucum, Cerastoderma sp. A) are invasive, and two (Ecrobia 


\section{CHAPTER 6}

Table 6.3: Turali species list with mollusc counts per sample. Species indicated with (n) are native species, (i) are invasive, and species indicated with (r) are reworked.

\begin{tabular}{|c|c|c|c|c|c|c|c|c|c|}
\hline Species & M0202 & M0203 & M0204 & M0205 & M0215 & M0216 & M0220 & M0221 & M0222 \\
\hline $\begin{array}{l}\text { Cerastoderma cf. glaucum (Bruguière, } \\
\text { 1789) (i) }\end{array}$ & 2.5 & 1.0 & 1.5 & 0.5 & 1.0 & 2.0 & 0.0 & 1.5 & 59.0 \\
\hline $\begin{array}{l}\text { Cerastoderma sp. A [non C. rhomboides } \\
\text { (Lamarck, 1819)] (i) }\end{array}$ & 14.5 & 6.5 & 752.0 & 73.5 & 32.5 & 263.0 & 1.0 & 3.0 & 36.5 \\
\hline Adacna laeviuscula (Eichwald, 1829) & 29.0 & 0.5 & 22.5 & 0.0 & 0.5 & 4.0 & 0.0 & 5.0 & 15.5 \\
\hline Adacna vitrea (Eichwald, 1829) & 115.5 & 5.5 & 42.0 & 2.5 & 0.0 & 11.0 & 5.5 & 64.5 & 18.0 \\
\hline Hypanis plicata (Eichwald, 1829) & 29.0 & 3.0 & 93.5 & 2.0 & 0.5 & 13.0 & 1.0 & 8.5 & 2.5 \\
\hline $\begin{array}{l}\text { Monodacna albida (Logvinenko \& } \\
\text { Starobogatov, 1967) }\end{array}$ & 11.0 & 26.0 & 57.0 & 10.5 & 4.0 & 20.0 & 1.5 & 7.0 & 4.0 \\
\hline Monodacna caspia (Eichwald, 1829) & 14.5 & 7.0 & 27.0 & 2.5 & 2.0 & 7.0 & 0.0 & 2.0 & 2.0 \\
\hline $\begin{array}{l}\text { Monodacna semipellucida (Logvinenko \& } \\
\text { Starobogatov, 1967) }\end{array}$ & 7.5 & 3.0 & 6.5 & 6.0 & 0.0 & 4.5 & 0.0 & 0.5 & 11.5 \\
\hline Didacna eichwaldi (Krynicki, 1837) & 178.5 & 11.5 & 332.0 & 9.5 & 2.5 & 96.0 & 0.5 & 0.0 & 0.0 \\
\hline Didacna baeri (Grimm, 1877) & 12.5 & 5.5 & 18.0 & 7.0 & 1.0 & 7.5 & 0.0 & 0.0 & 0.0 \\
\hline Didacna barbotdemarnii (Grimm, 1877) & 2.5 & 0.0 & 1.0 & 0.0 & 0.0 & 0.0 & 0.0 & 9.0 & 9.5 \\
\hline Didacna parallela Bogachev, 1932 & 17.0 & 0.0 & 18.5 & 0.0 & 0.0 & 4.0 & 0.0 & 0.0 & 3.5 \\
\hline Didacna protracta (Eichwald, 1841) (r) & 1.0 & 0.0 & 0.0 & 1.0 & 0.0 & 0.5 & 0.0 & 0.0 & 0.5 \\
\hline Didacna pyramidata (Grimm, 1877) & 3.5 & 0.0 & 0.0 & 0.0 & 1.5 & 2.0 & 0.0 & 0.5 & 1.0 \\
\hline Didacna trigonoides (Pallas, 1771) & 13.5 & 1.5 & 32.0 & 2.0 & 10.0 & 8.5 & 0.0 & 2.5 & 17.5 \\
\hline Dreissena caspia Eichwald, 1855 & 215.0 & 53.5 & 15.5 & 5.5 & 5.0 & 24.5 & 2.0 & 14.5 & 51.0 \\
\hline Dreissena elata Andrusov, 1897 & 1598.0 & 248.5 & 3089.0 & 83.5 & 38.5 & 1313.0 & 37.5 & 251.0 & 174.0 \\
\hline Dreissena grimmi (Andrusov, 1890) & 7.5 & 3.5 & 0.0 & 0.0 & 0.0 & 1.0 & 0.0 & 0.0 & 0.0 \\
\hline Theodoxus pallasi Lindholm, 1924 (n) & 104.0 & 7.0 & 663.0 & 51.0 & 35.0 & 244.0 & 1.0 & 12.0 & 49.0 \\
\hline $\begin{array}{l}\text { Abeskunus brusinianus (Clessin \& } \\
\text { Dybowski in Dybowski, 1887) }\end{array}$ & 11.0 & 0.0 & 75.0 & 0.0 & 1.0 & 28.0 & 0.0 & 0.0 & 0.0 \\
\hline Abeskunus exiguus (Eichwald, 1838) & 25.0 & 0.0 & 26.0 & 1.0 & 0.0 & 16.0 & 0.0 & 0.0 & 1.0 \\
\hline Abeskunus sp. indet. & 5.0 & 0.0 & 0.0 & 0.0 & 0.0 & 2.0 & 0.0 & 0.0 & 0.0 \\
\hline Clessiniola variabilis (Eichwald, 1838) & 61.0 & 18.0 & 300.0 & 16.0 & 12.0 & 110.0 & 3.0 & 2.0 & 26.0 \\
\hline $\begin{array}{l}\text { Ecrobia grimmi (Clessin in Dybowski, } \\
1887)(\mathrm{n})\end{array}$ & 126.0 & 57.0 & 65.0 & 15.0 & 3.0 & 33.0 & 2.0 & 89.0 & 55.0 \\
\hline $\begin{array}{l}\text { Laevicaspia sieversii (Clessin in Dybowski, } \\
\text { 1887) }\end{array}$ & 1.0 & 0.0 & 1.0 & 0.0 & 0.0 & 0.0 & 0.0 & 0.0 & 0.0 \\
\hline $\begin{array}{l}\text { Laevicaspia kolesnikoviana (Logvinenko \& } \\
\text { Starobogatov in Golikov \& Starobogatov, } \\
\text { 1966) }\end{array}$ & 1.0 & 3.0 & 0.0 & 0.0 & 0.0 & 0.0 & 0.0 & 1.0 & 0.0 \\
\hline Laevicaspia conus (Eichwald, 1838) & 9.0 & 0.0 & 9.0 & 0.0 & 0.0 & 2.0 & 0.0 & 1.0 & 0.0 \\
\hline $\begin{array}{l}\text { Clathrocaspia gmelinii (Clessin \& Dybowski } \\
\text { in Dybowski, 1887) (r) }\end{array}$ & 0.0 & 1.0 & 0.0 & 0.0 & 0.0 & 0.0 & 0.0 & 0.0 & 0.0 \\
\hline Turricaspia spica (Eichwald, 1855) & 553.0 & 88.0 & 33.0 & 0.0 & 4.0 & 5.0 & 2.0 & 13.0 & 17.0 \\
\hline Turricaspia sp. indet & 0.0 & 0.0 & 0.0 & 0.0 & 0.0 & 0.0 & 0.0 & 0.0 & 1.0 \\
\hline Pulmonata sp. indet. & 14.0 & 2.0 & 9.0 & 1.0 & 3.0 & 2.0 & 0.0 & 4.0 & 2.0 \\
\hline
\end{tabular}

grimmi and Theodoxus pallasi) are native species sensu Wesselingh et al. (2019); the remainder are endemic Caspian species. The rarefaction curve is nearly saturated for the largest three samples, 
suggesting that our samples represent an appropriate estimate of the true richness (Fig. 6.4). Pictures of all species are shown in Figs 6.5-6.7.

The endemic Caspian fauna contains several endemic species complexes (Logvinenko and Starobogatov, 1969; Neubauer et al., 2018), and identifications can be difficult. This is mainly caused by the poorly studied variability of mollusc characteristics (Anistratenko et al., 2017) and by the lack of data concerning the type material of almost all Caspian species (Anistratenko et al., 2019, 2018; Vinarski and Kantor, 2016). First steps in revising the Pontocaspian gastropod fauna are in progress (Neubauer et al., 2018; van de Velde et al., 2019c; Wesselingh et al., 2019). Here, we discuss some of the taxonomic uncertainties in the Turali fauna

\subsubsection{Bivalves}

We are not entirely certain about the distinction and identity of the two Cerastoderma species in the Turali samples (Fig. 6.5A-D). Two forms that coincide with the species as reported by Wesselingh et al. (2019) are C. glaucum (Fig. 6.5C-D) and Cerastoderma sp. A (Fig. 6.5A-B). The latter species is typically more convex, thick-shelled, has more regularly spaced ribs often with regularly developed scales and these ribs usually extend well to the anterior and posterior margins. Cerastoderma glaucum in the Turali samples is much thinner shelled, ribs are lower and fade towards the edges of the shells. A marked difference exists in the degree of symmetry of the shell, with C. glaucum being stronger inequilateral. Also, the number of ribs differs slightly. The length/height $(\mathrm{L} / \mathrm{H})$ ratio also differs, but that may (partly) result from differences in the shell size of the measured specimens (all C. glaucum valves being larger than C. sp. A). Without conducting more elaborate morphometric analyses based on a broader range of Pontocaspian material, we feel it premature to introduce a new name. Several names have been used for specimens similar to C. sp. A as reported here (see Wesselingh et al., 2019).

The common Didacna species (D. trigonoides, D. eichwaldi, D. baeri and D. barbotdemarnii) in the Turali material have closely resembling morphologies and a large shell shape variability. The distinguishing characters proposed by Nevesskaja (2007) were found to apply to the studied material with slight modifications (Supplementary Table S6.1). Didacna trigonoides is convex, thin-shelled, high and has an acute posterior ridge (often a double ridge on juvenile stages) and flat, relatively few ribs (12-20 anterior ribs). Didacna baeri has a rounded shape, relative low shell with more numerous ribs (19-22 anterior ribs). The posterior keel is not well developed and distinct only near the umbo. The general shell shape resembles that of D. eichwaldi, but the latter species has slightly fewer ribs (typically 18-20 anterior ribs), is more convex, has a more projecting beak and a more distinct posterior ridge. Finally, D. barbotdemarnii can resemble juvenile and subadult specimens of $D$. trigonoides but the former has slightly more ribs (16-20+ anterior ribs versus 12-20 on $D$. trigonoides) that are low and broad, is broader and flatter with a relatively low beak and the posterior ridge is poorly pronounced. 


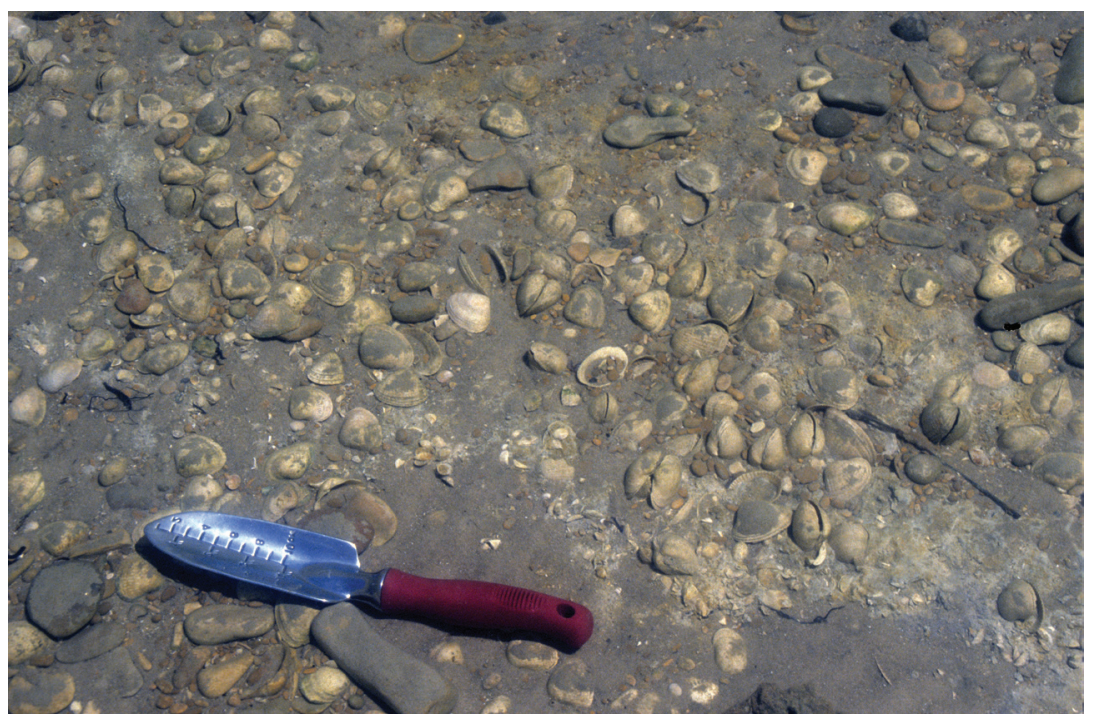

Fig. 6.3: Paired Didacna eichwaldi (Turali-2, sample M0205) exposed just below the water table of the Great Turali Lake. Width of the shells approximately $2 \mathrm{~cm}$. Photograph SBK, 2002.

There still exists uncertainty about the amount and definition of species within the genus of Monodacna (Wesselingh et al., 2019). In our material we distinguish three types: Monodacna albida, M. caspia and M. semipellucida (Fig. 6.6; G-L). They can all be recognized as Monodacna species by their single cardinal tooth and lack of a posterior keel. Monodacna caspia (Fig. 6.6; I-J) is a highly variable species, but can be identified by the thick, sturdy, relatively convex shell and the regularly spaced, almost flat ribs. Interspaces are narrower than the ribs. The beak is almost centrally located and slightly curved towards the anterior margin. Monodacna albida (Fig. 6.6; G-H) can be distinguished by its wedge-shape shell outline and its low flat ribs that are irregularly spaced. The location of the beak is in the centre of the shell. Monodacna semipellucida (Fig. 6.6; K-L) can be distinguished from M. albida by being relatively thin-walled. Moreover, the shell is lower, often elliptical and bears a very characteristic, very thin, tuberculate cardinal tooth. The ribbing is weak and the beak is located towards the anterior margin.

We are uncertain about the identity of Dreissena elata (Fig. 6.6; O-P). The shells are morphologically similar to the Palearctic D. polymorpha, even though Caspian shells are in general lower, thicker and are often wider. The habitats of genuine D. polymorpha and the Caspian D. elata are apparently non-overlapping, with the former restricted to habitats of fresh water up to 2 psu in the Volga delta and adjacent rivers, while the latter occurred in the coast of the Caspian Sea in salinities of 7-13 psu (Orlova et al., 2005). However, the D. elata populations disappeared in the second half of the $20^{\text {th }}$ century. They were outcompeted by Mytilaster minimus, thereby impeding a molecular taxonomic assessment. If $D$. elata is confirmed as a separate species, it might well be extinct. 


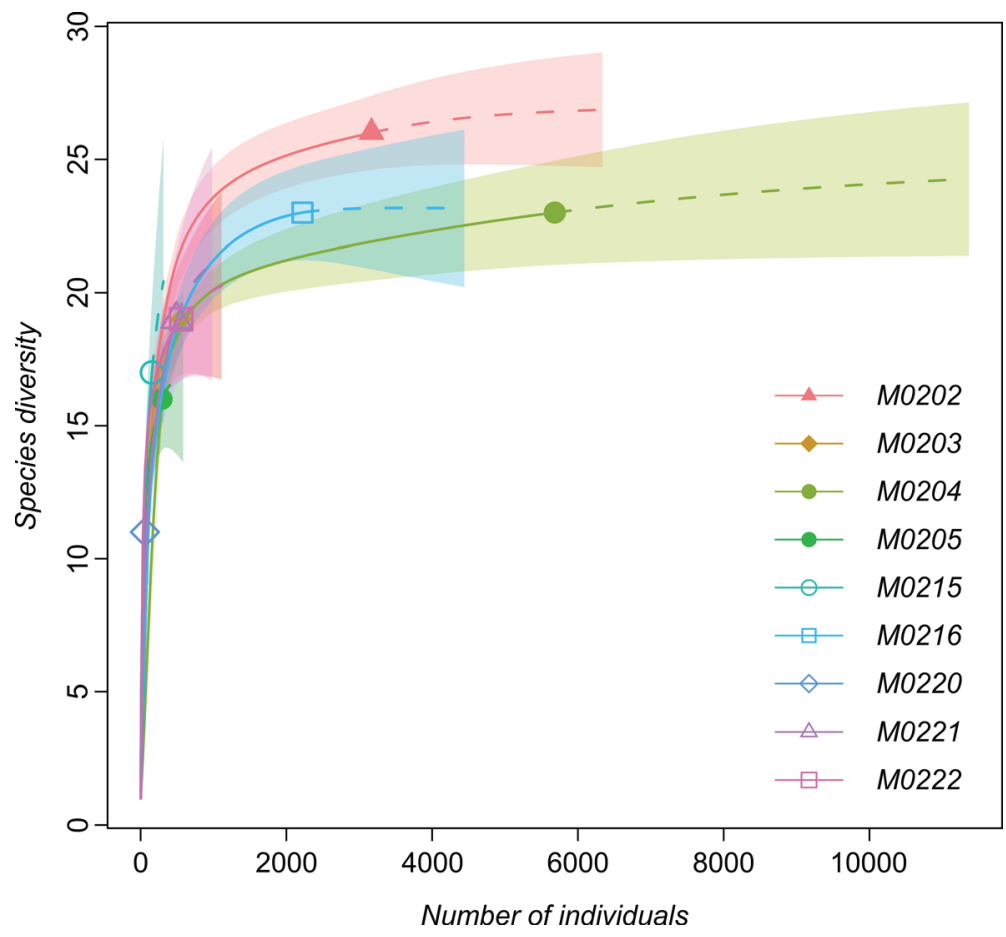

Fig. 6.4: Rarefaction curves of the Turali samples with $95 \%$ confidence interval and extrapolated species richness for double sample size.

\subsubsection{Gastropoda}

The Turali sample of Theodoxus pallasi contains a remarkable variation of colour patterns and shapes (Fig. 6.7; K, L). Colour varieties range from dotted specimens to zig-zag coloured specimens, and the general shape varies from ovate to elongate. The latter shape is often attributed to T. schultzii (Fig. 6.7; L), but in our material we see intermediate forms as well. A recent molecular approach suggests that all forms from the Caspian Sea might be conspecific with the Armenian T. major Issel, 1865 (Sands et al., 2019b).

The identification of Abeskunus species was difficult because different species concepts have been proposed (Logvinenko and Starobogatov, 1969; Neubauer et al., 2018). Here, we distinguish two species, Abeskunus brusinianus (Fig. 6.7I-J) and Abeskunus exiguus (Fig. 6.7M). The former species involves a considerable morphological variability as to the height of the spire and two morphs were found (Fig. 6.7I-J). Further taxonomic study is required to assess whether the two shapes of A. brusinianus represent ecomorphs or distinct species.

Shells of Clessiniola variabilis, Ecrobia grimmi, Laevicaspia conus and L. sieversii contain a wide range of variability too. Sometimes it is difficult to distinguish one species from other, e.g. $L$. conus and L. sieversii, and molecular and/or more in-depth morphological and anatomical studies 
CHAPTER 6

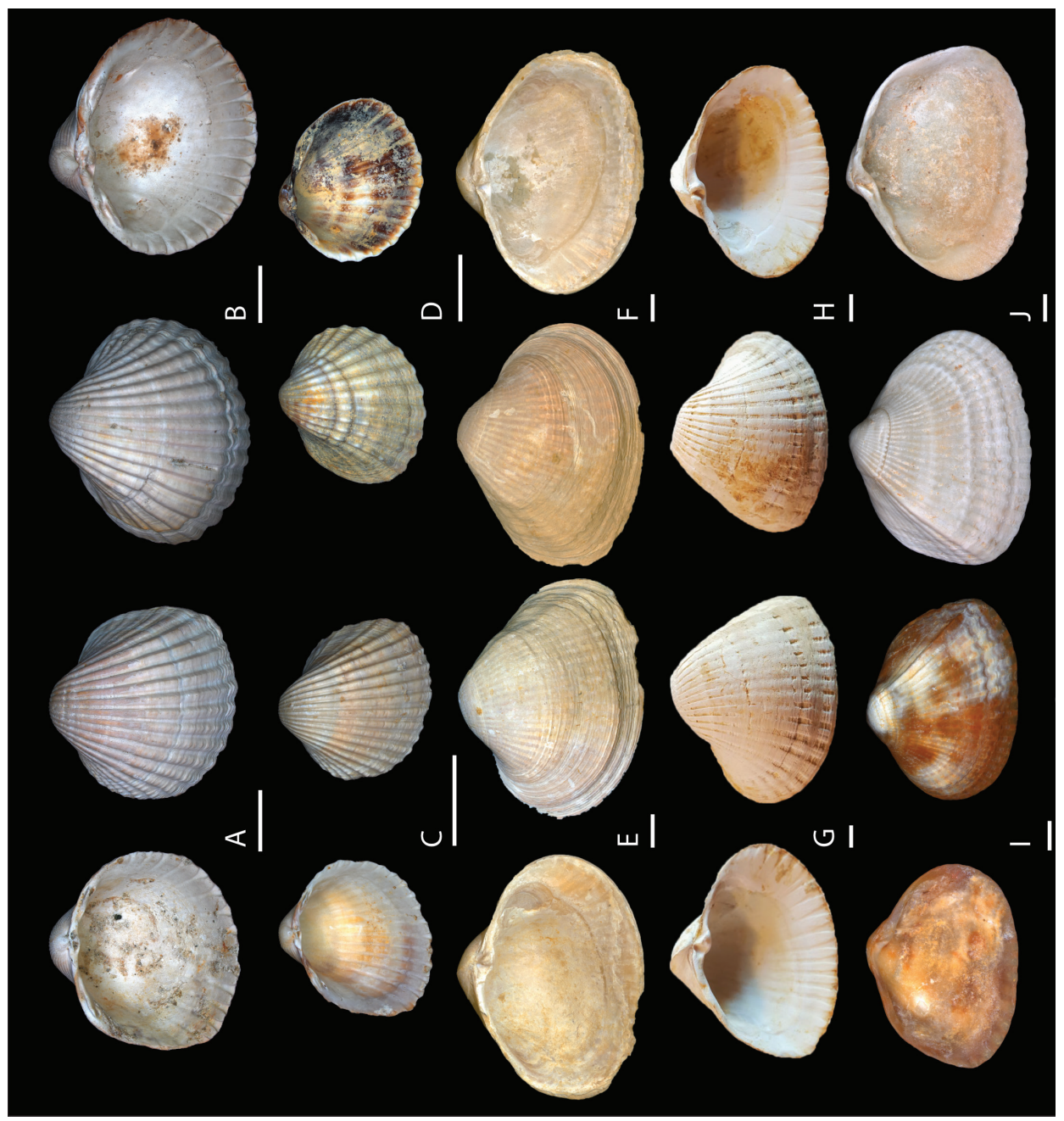



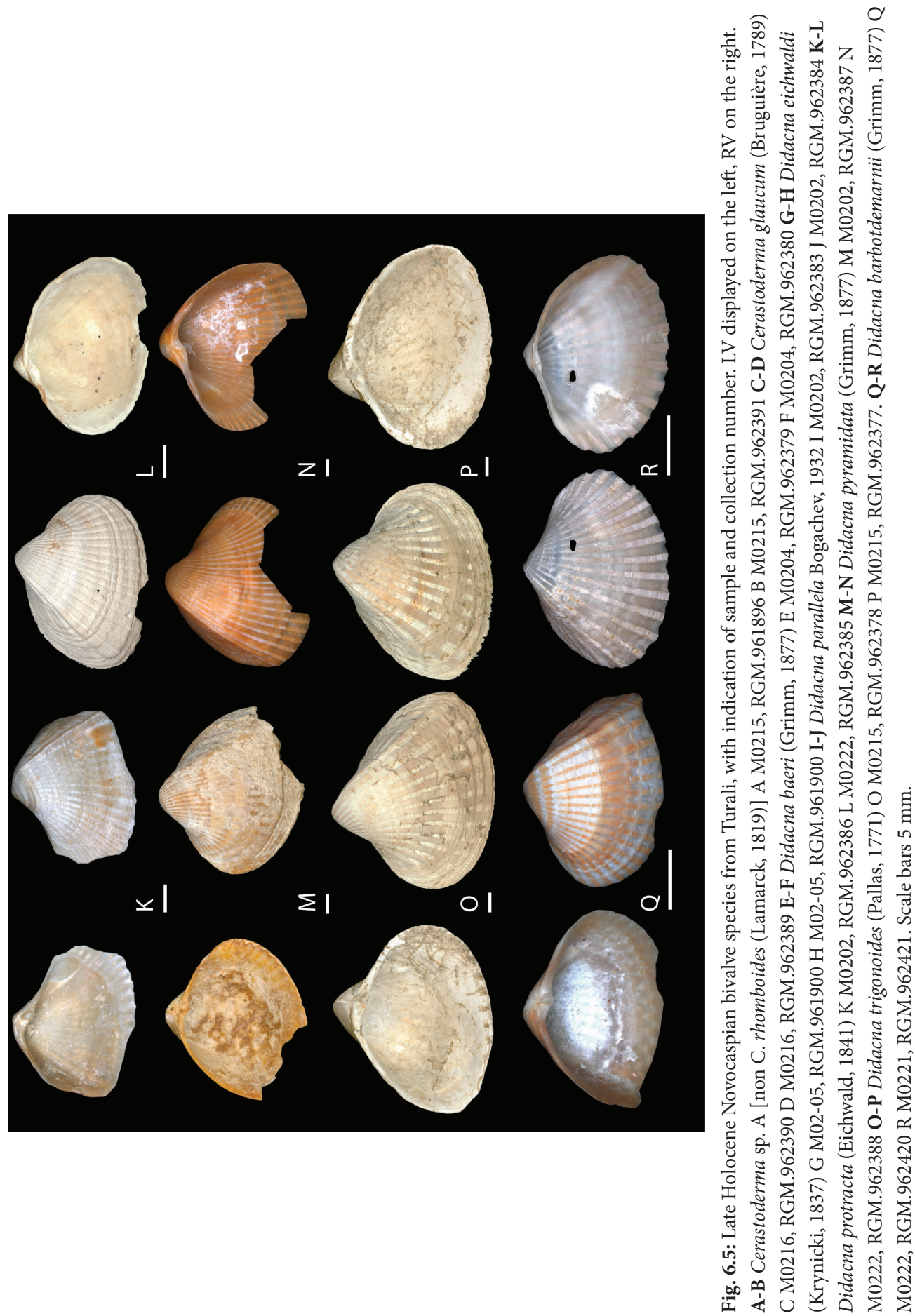


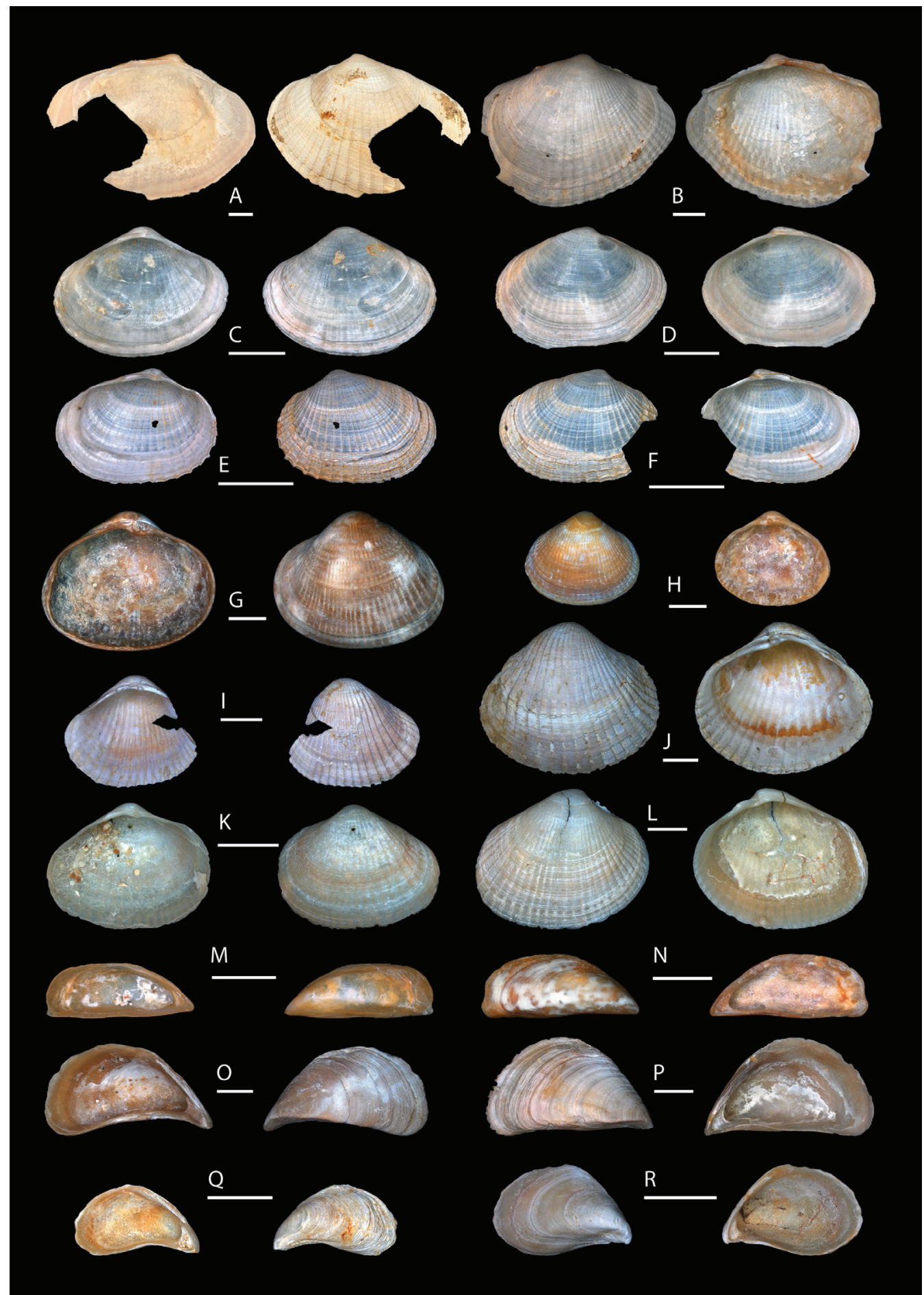


Fig. 6.6 (opposite page): Late Holocene Novocaspian bivalve species from Turali, with indication of sample and collection number. LV displayed on the left, RV on the right. A-B Adacna laeviuscula (Eichwald, 1829). A M0222, RGM.962359 B M0222, RGM.962358 C-D Adacna vitrea (Eichwald, 1829) C M0221, RGM.962360 D M0221, RGM.962361 E-F Hypanis plicata (Eichwald, 1829) E M0221, RGM.962362 F M0221, RGM.962363 G-H Monodacna albida (Logvinenko \& Starobogatov, 1967) G M0202, RGM.962364 H M0202, RGM.962365 I-J Monodacna caspia (Eichwald, 1829) I M0204, RGM.962367 J M0205, RGM.962368 K-L Monodacna semipellucida (Logvinenko \& Starobogatov, 1967) K M0222, RGM.962369 L M0222, RGM.962370 M-N Dreissena caspia Eichwald, 1855 M M0222, RGM.962371 N M0202, RGM.962372 O-P Dreissena elata Andrusov, 1897 O M0203, RGM.962375 P M0221, RGM.962376 Q-R Dreissena grimmi Andrusov, 1890 Q M0203, RGM.962374 R M0202, RGM.962373. Scale bars 5 mm.

are required. In some cases, morphological variation seems to be very well defined. For example, modern specimens of Turricaspia spica fit well in shape and size with the extensive specimens from Turali (Fig. 6.7; G).

\subsubsection{Palaeoecology}

Ecological data for mollusc species is given in Table 6.4. The majority of the Turali fauna represents salinities between 5 and 13 psu, indicating a lower to upper mesohaline environment. The upper salinity tolerance of Monodacna caspia has previously been reported as 8 psu (van de Velde et al., 2019c), but personal observations of species present in the middle and southern Caspian Sea indicate an upper salinity tolerance of 12-13 psu instead. All species are able to live within the depth range of 0 to $50 \mathrm{~m}$ on a silty sandy to muddy lake floor. The abundance of Theodoxus, a grazer of microalgae, confirms the fauna lived within the photic zone. Direct evaluation of vertical distribution of species inhabiting the Caspian Sea (Kolesnikov, 1947; Tarasov, 1996; Tarasov and Chepalyga, 1996) supports the conclusion about a shallow environment for the Novocaspian Turali molluscs. A similar composition of faunal communities (the absence of deep-dwelling forms) can be observed along the Dagestan shore today. This corresponds well with shallow bay and barrier facies from where the faunas were collected. No species that inhabit depths over $30 \mathrm{~m}$ such as Didacna profundicola, Clathrocaspia spp., Ulskia ulskii, Turricaspia elegantula, T. dimidiata and Andrusovia spp. were found.

The samples represent washover-bay floor transitions between 2000 and $2400 \mathrm{cal}$ yrs BP and the presence of paired bivalves in almost all samples shows that these faunas were mostly in situ. The faunal composition (species group ratios) is similar in the samples. The most abundant species is Dreissena elata (52\% of all individuals, the species occurs in all samples), followed by Cerastoderma sp. A, Theodoxus pallasi (each accounts for $9 \%$ of the total abundance, both occur in all samples). The common occurrence of the grazing gastropod T. pallasi in all samples indicates shallow environments in the photic zone. 


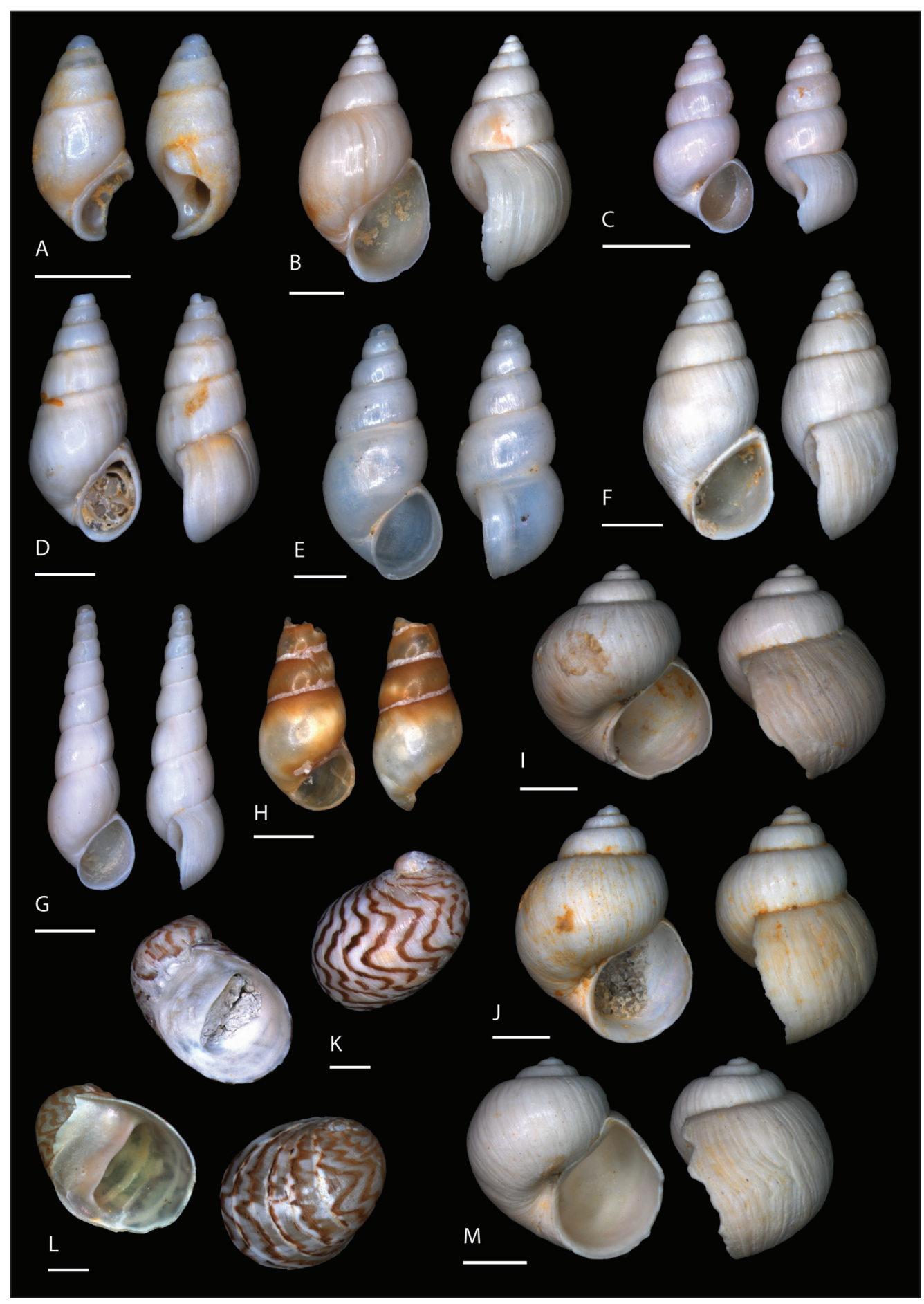


Fig. 6.7 (opposite page): Late Holocene Novocaspian gastropod species from Turali, with indication of sample and collection number. A Clathrocaspia gmelinii: M0203, RGM.1309848 B Clessiniola variabilis: M0204, RGM.1309864 C Ecrobia grimmi: M0202, RGM.1309863 D Laevicaspia sieversii: M0204, RGM.1309849 E Laevicaspia kolesnikoviana: M0221, RGM.1309850 F Laevicaspia conus: M0204, RGM.1309851 G Turricaspia spica: M0202, RGM.1309858 H Turricaspia sp. indet. M0222, RGM.962401. I Abeskunus brusinianus: low morph, M0204, RGM.962355 J Abeskunus brusinianus: high morph, M0204, RGM.962355 K Theodoxus pallasi: M0204, RGM.130985, L. Theodoxus pallasi: M0220, RGM.1309862, M Abeskunus exiguus, M0204, RGM.962357. Scale bars $1 \mathrm{~mm}$.

\subsection{Discussion}

\subsubsection{Novocaspian mollusc biodiversity and palaeoenvironment}

The Turali fauna contains a snapshot of a pre- $20^{\text {th }}$ century mollusc fauna from shore and shallow bay environments in the western-middle Caspian basin. The palaeoenvironment (depth, depositional energy, temperature) is constrained by the sedimentary facies and ecological preferences of the species. The Turali setting represents a semi-open shallow bay with beach ridges partially isolating the bay from the main Caspian Sea (Fig. 6.8). The differences in the palaeoenvironment are minimal between individual sites and there are no strong dissimilarities regarding facies, age, mollusc diversity and palaeoenvironment that are not in concordance with the general results. The sedimentary succession represents mostly transitional settings between beach barriers and bay floor environments of around 2000-2400 cal yrs BP and the palaeoecology of the mollusc faunas fits with such environments. Sclerochronological analyses of stable isotope ratios in the molluscs shows strong seasonal changes in oxygen and carbon isotope values, which are generally in line with seasonal changes in temperature and salinity in the nearby Caspian Sea today (Vonhof et al., 2004). The setting resembles that of the Sulaksky Bay north of Makhachkala (Dagestan).

In total, we encountered 28 identifiable species: 24 are Pontocaspian endemics, two species are native, and two are invasive. Of the 24 endemics, only two species were found as reworked species. The Turali fauna is dominated by Dreissena elata, Cerastoderma sp. A and Theodoxus pallasi. Common species are Turricaspia spica, Didacna eichwaldi, Clessiniola variabilis, Dreissena caspia, Ecrobia grimmi, Adacna vitrea, Monodacna albida, Hypanis plicata and Abeskunus brusinianus. The invasive species (Cerastoderma spp.) are common but not dominant.

The species composition indicates a palaeo-water depth between 0 and $50 \mathrm{~m}$, even though the majority of species prefer the shallowest parts of these depths and sedimentary structures indicate very shallow depositional depths. The salinity range varies between 5 and 13 psu. These estimated salinity ranges overlap with the current salinity in the middle Caspian basin (11-13 psu). Caspian Sea levels around 2600 cal yr BP were very similar to today's Caspian Sea level (around $-25 \mathrm{~m}$ versus $-27 \mathrm{~m}$ today: Kroonenberg 


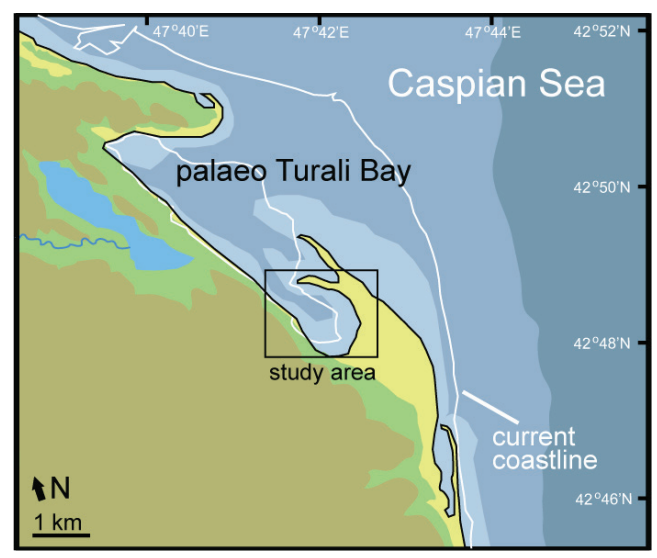

Fig. 6.8: Reconstruction of Turali Bay, c. $2300 \mathrm{cal}$ yr BP. The palaeocoastline is approximately based on the estimated lake level reconstructed for the time of deposition.

et al., 2008), hence it is likely that salinity regimes were similar to today's salinity.

\subsubsection{Holocene versus Pleistocene faunas}

The Turali faunas have aspects in common with other Late Pleistocene Caspian communities. Thirteen bivalve species and 24 gastropod species were identified at a Hyrcanian (c. $107 \mathrm{ka}$ ) outcrop at Selitrennoye (Russia): 99\% of the individuals belong to endemic species (van de Velde et al., 2019c). The Selitrennoye assemblage is dominated by the same three families as the Turali assemblages: Cardiidae, Dreissenidae and Hydrobiidae. The authors estimated palaeosalinities between 5 and 8 psu (it might be slightly higher as the estimate was partially based on an erroneous upper salinity tolerance of 8 psu for Monodacna caspia, while our current observations show a limit of 12-13 psu instead). Half of the species (14 out of 28) found at Turali are also found at Selitrennoye. The genus Didacna shows a completely different species composition on both sites, illustrative for the rapid turnover of Didacna species in particular (Nevesskaja, 2007).

\subsubsection{Comparison with Caspian biodiversity of today}

Latypov (2015) studied invertebrates from the Sulaksky Bay, where a number of stations down to $4 \mathrm{~m}$ water depth were sampled during 1994-2001. He did not report salinities, but these may have been slightly lower than in the adjacent Caspian Sea because the bay itself borders on the Terek River delta. Otherwise Sulaksky Bay yields an almost identical environment as the Turali settings (shallow open bay in the proximity of beach barriers). Latypov (2015) reported a predominant Abra-Cerastoderma community dominated by three invasive species A. segmentum, M. minimus as well as C. glaucum (which likely includes C. sp. A). He only reported seven Pontocaspian species from extensive sampling efforts. The sampling design is not entirely clear and differs from our Turali 
Table 6.4: Environmental indicators: optimal living conditions of Turali species. References: ${ }^{1}$ Bogutskaya et al., 2013, ${ }^{2}$ Logvinenko and Starobogatov, $1969,{ }^{3}$ Mirzoev and Alekperov, 2017, ${ }^{4}$ Nevesskaja, 2007, ${ }^{5}$ Starobogatov, 1994, ${ }^{6}$ Yanina, 1981, ${ }^{7}$ Wesselingh et al., 2019, ${ }^{8}$ Chukhchin, $1984,{ }^{9}$ Vinarski and Kantor, 2016. ${ }^{*}$ Our findings point towards shallow foreshore environments.

\begin{tabular}{|c|c|c|c|c|}
\hline Species & Origin & $\begin{array}{l}\text { Natural salinity ranges } \\
\text { (psu) }\end{array}$ & Environment & Depth (m) \\
\hline Cerastoderma cf. glaucum & Invasive 7 & Min. $5-8^{1}, 10-23^{6}$ & Caspian Sea. ${ }^{1}$ & $10-50^{1}, 5-40^{6}$ \\
\hline $\begin{array}{l}\text { Cerastoderma sp. A [non } \\
\text { C. rhomboides] }\end{array}$ & Invasive $^{7}$ & Min. $5-8^{1}, \max 12-13$ & Caspian Sea. ${ }^{1}$ & $0-40^{1}$ \\
\hline Adacna laeviuscula & Endemic $^{1}$ & Min. $5-8^{1}, 4-14^{1}, \min .4^{2}$ & $\begin{array}{l}\text { Caspian Sea. }{ }^{1} \text { Muddy, sandy-mud and, } \\
\text { rarely, sandy bottoms. }{ }^{1}\end{array}$ & $30-100^{1}, \max .80-85^{2 *}$ \\
\hline Adacna vitrea & Endemic $^{1}$ & Min. 5-8', max 12-13 & Caspian Sea. ${ }^{1,2}$ & $0-40^{1}, 20$ rarely $30^{2}$ \\
\hline Hypanis plicata & Endemic $^{7}$ & $4-8^{1,2}, \max 12-13$ & $\begin{array}{l}\text { Caspian Sea. }{ }^{1} \text { Silty-sandy, clayey soils, } \\
\text { hard aleurites with shell rock. }\end{array}$ & $0-40^{1}, 0.5-30^{1,2}$ \\
\hline Monodacna albida & Endemic $^{1}$ & Min. 5-8 ${ }^{1}, \max 12-13$ & Middle and southern Caspian Sea. ${ }^{1,2}$ & $0-150^{1,2}, 200-400^{3}$ \\
\hline Monodacna caspia & Endemic $^{1}$ & $2-8, \max 12-13$ & $\begin{array}{l}\text { Northern Caspian Sea. }{ }^{1} \text { Middle \& } \\
\text { southern Caspian Sea } \text { Muddy and } \\
\text { sandy-mud substrates. }{ }^{1}\end{array}$ & $0-40^{1}, 0-200^{2}$ \\
\hline Monodacna semipellucida & Endemic ${ }^{1}$ & Min. $5-8^{1}, \max 12-13$ & Middle Caspian Sea. ${ }^{1}$ & $0-40^{1}, 0-30^{2}$ \\
\hline Didacna eichwaldi & Endemic $^{9}$ & Min. 3 , max. $14^{1}$ & $\begin{array}{l}\text { Middle and southern Caspian Sea. }{ }^{1} \\
\text { Western and eastern Caspian Sea. }{ }^{4}\end{array}$ & $7.5-60^{1}$ \\
\hline Didacna baeri & Endemic $^{1}$ & Min. 3 , max. $14^{1}$ & $\begin{array}{l}\text { Southern Caspian Sea. }{ }^{1} \text { Southern } \\
\text { Caspian Sea and southern part of the } \\
\text { middle Caspian Sea., }\end{array}$ & $0-50^{1,6}, 0-60^{2}$ \\
\hline Didacna barbotdemarnii & Endemic ${ }^{1}$ & Min. 3 , max. $14^{1}$ & Middle and southern Caspian Sea. ${ }^{1}$ & $0-40^{1}$ \\
\hline Didacna parallela & Endemic $^{1}$ & Min. 3 , max. $14^{1}$ & Middle and southern Caspian Sea. ${ }^{1}$ & $\begin{array}{l}50-100^{1}, 50-85^{2,6} \\
200-300^{3}\end{array}$ \\
\hline Didacna protracta & Endemic $^{1}$ & Min. 3 , max. $14^{1}$ & Middle and southern Caspian Sea. ${ }^{1,2,4}$ & $25-50^{1,2}, 25-75^{6}$ \\
\hline Didacna pyramidata & Endemic $^{1}$ & Min. 3 , max. $14^{1}$ & $\begin{array}{l}\text { South Caspian Sea', Southern and } \\
\text { middle Caspian Sea. }\end{array}$ & $35-130^{1}, 30-100$ \\
\hline Didacna trigonoides & Endemic $^{1}$ & Min. 3 , max. $14^{1}$ & Caspian Sea. ${ }^{1}$ Northern Caspian Sea. ${ }^{2}$ & $5-60^{1}$ \\
\hline Dreissena caspia & Endemic $^{1}$ & Opt. $2-8^{1}, \max 12-13$ & Caspian Sea. ${ }^{1,2}$ & $0-40 ?^{1}, 0-35^{2}$ \\
\hline Dreissena elata & Endemic $^{1}$ & Opt. 2-8', $\max 12-13$ & Middle and southern Caspian Sea. ${ }^{1}$ & $0-40 ?^{1}, 0-35^{2}, 0-30^{7}$ \\
\hline Dreissena grimmi & Endemic $^{1}$ & Opt. 2-8', $\max 12-13$ & Middle Caspian Sea. ${ }^{1,5,2}$ & $\begin{array}{l}35-100^{1}, 45-80^{2,5} \\
200-400^{3}\end{array}$ \\
\hline Theodoxus pallasi & Native $^{7}$ & Opt. 0-8', max 12-13 & $\begin{array}{l}\text { Caspian Sea.' Low salinity seas and large } \\
\text { lakes, limans and estuaries. }^{2}\end{array}$ & $0-40^{1}, 0-35^{2}$ \\
\hline Abeskunus brusinianus & Endemic ${ }^{1}$ & Min. 5-8 ${ }^{1}, \max 12-13$ & Middle and southern Caspian Sea. ${ }^{1}$ & $0-200^{1}$ \\
\hline Abeskunus exiguus & Endemic $^{1}$ & Min. 5-8', $\max 12-13$ & Northern Caspian Sea. ${ }^{1}$ & $0-40^{1}$ \\
\hline Clessiniola variabilis & Endemic $^{1}$ & Opt. $0-8^{1}, 5-7^{8}, \max 12-13$ & Caspian Sea. ${ }^{1,3}$ & $0-25^{2},>20^{1}, 200-300^{3}$ \\
\hline Ecrobia grimmi & Native $^{7}$ & Opt. 2-8', $\max 12-13$ & Southern Caspian Sea. ${ }^{1,3}$ & $>25^{1}, 25-40^{2}$ \\
\hline Laevicaspia sieversii & Endemic $^{1}$ & Min. 5-8 ${ }^{1}, \max 12-13$ & Caspian Sea. ${ }^{1,3}$ & $0-120^{1,2}, 200-300^{3}$ \\
\hline $\begin{array}{l}\text { Laevicaspia } \\
\text { kolesnikoviana }\end{array}$ & Endemic $^{1}$ & Min. 5-8 ${ }^{1}, \max 12-13$ & Southern Caspian Sea. ${ }^{1}$ & $\begin{array}{l}25-120^{1}, 25-180^{2} \\
200-400^{3}\end{array}$ \\
\hline Laevicaspia conus & Endemic $^{1}$ & Min. $5-8^{1}, \max 12-13$ & Caspian Sea. ${ }^{1,3}$ & $25-50^{1,2}, 200-300^{3}$ \\
\hline Clathrocaspia gmelinii & Endemic $^{1}$ & Min. $5-8^{1}, \max 12-13$ & Middle and southern Caspian Sea. ${ }^{1,2}$ & $\begin{array}{l}35-100^{1}, 30-81^{2}, 200- \\
300^{3}\end{array}$ \\
\hline Turricaspia spica & Endemic $^{1}$ & Min. 5-8 ${ }^{1}, \max 12-13$ & Northern and middle Caspian Sea., 2 & $0-40^{1}, 0-30^{2}$ \\
\hline
\end{tabular}




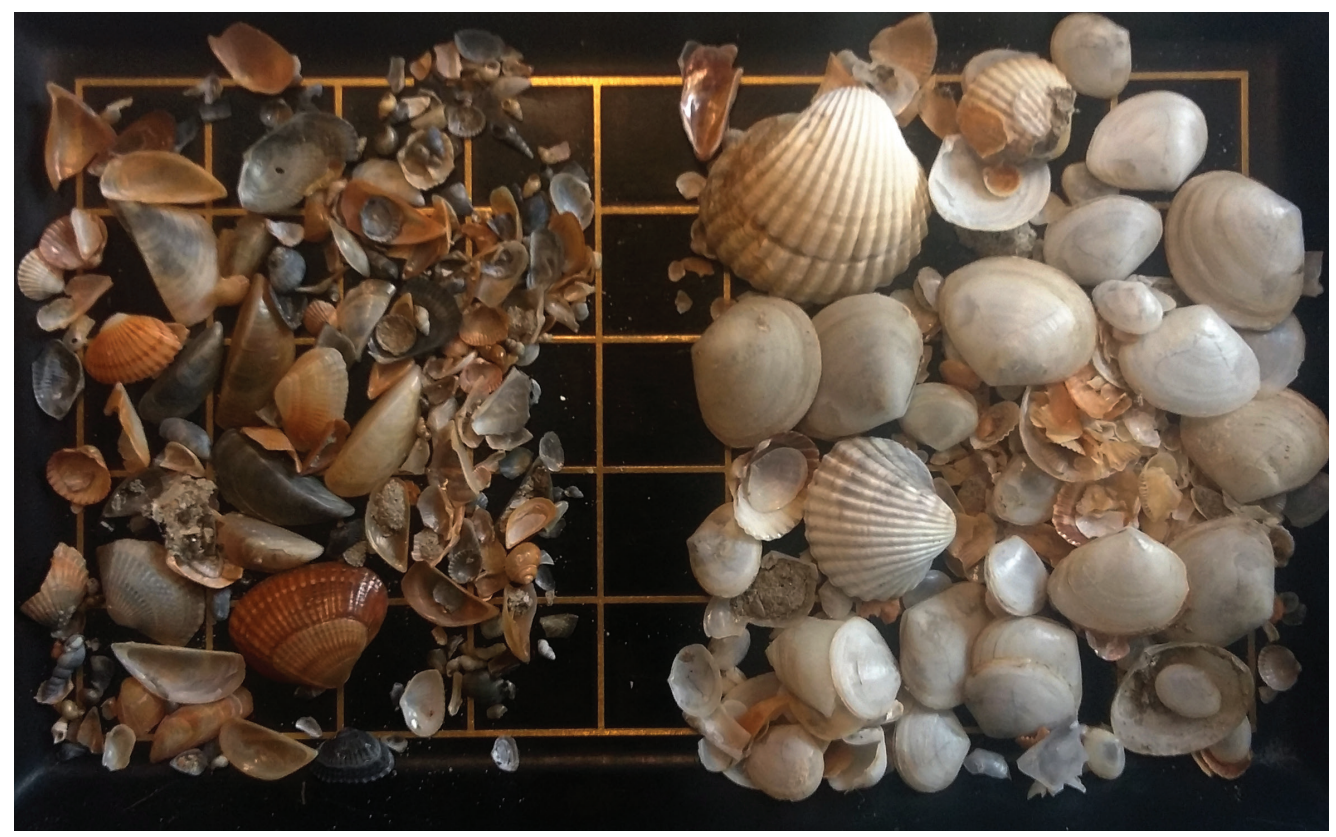

Fig. 6.9: Box core residue (sample M0267, c. $2 \mathrm{~km}$ off shore Turali at a water depth of $9.4 \mathrm{~m}$ ) separated into the dark Novocaspian (left) and light $20^{\text {th }}$ century (right) fractions defined in the text. Largest shell $\mathrm{c} 1.5 \mathrm{~cm}$ across.

approach, yet the numbers reported and the presence of small amounts of species in Latypov's analyses indicate that today's richness is more than three times as low and that communities now are dominated by invasive species and natives instead of endemic species.

A similar division has been observed in grab samples taken offshore Turali (samples taken by FPW): (1) Novocaspian shells and fragments with darker grey-blue-brown colour and extensive surface wear and (2) light coloured specimens with preservation of fine surface details and often presence of colouration and/or organic remains representing the $20^{\text {th }}$ century assemblage (Fig. 6.9). The separation of the shelly residue allows a basic comparison. The fresh-looking fauna component there is dominated by the native C. sp. A and E. grimmi and the invasive A. ovata and M. minimus. Only some fresh specimens of the Pontocaspian Clessiniola variabilis were found. The older fraction of the sample represents pre- $20^{\text {th }}$ century Novocaspian species such as Dreissena caspia and D. elata, Didacna baeri, D. barbotdemarnii as well as Caspian hydrobiid species.

The dominance by invasive species in modern assemblages is not restricted to the middle Caspian basin as is shown by a faunal inventory from nearshore settings in Gorgan Bay in Iran (Leroy et al., 2018) in the southern basin. Three samples taken between $5.2 \mathrm{~m}$ and $8.6 \mathrm{~m}$ water depth contained only nine species $(\mathrm{n}=226)$. The samples are also dominated by the native species Ecrobia grimmi, ancient invasive Cerastoderma glaucum/C. sp. A and the $20^{\text {th }}$ century invasive Abra 
Table 6.5: Overview of mollusc species biomass abundances $\left(\mathrm{mg} / \mathrm{m}^{2}\right)$, collected at the environmental monitoring programme of the north-east Caspian Sea (2005-2016). ${ }^{\star}$ Status based on Wesselingh et al (2019). Macrozoobenthos samples were taken with van Veen grab sampler $\left(0.1 \mathrm{~m}^{2}\right)$, Petersen Dredger $\left(0.025 \mathrm{~m}^{2}\right)$ and tubular dredger $\left(0.002 \mathrm{~m}^{2}\right)$ along four sites: Kashagan, Aktote, Kalamkas sites and the oild field pipe route in the north-east Caspian Sea. From: North Caspian Operating Company et al (2018).

\begin{tabular}{|c|c|c|c|c|c|c|c|c|c|c|c|}
\hline Species & 2006 & 2007 & 2008 & 2009 & 2010 & 2011 & 2012 & 2013 & 2014 & 2015 & 2016 \\
\hline Theodoxus pallasi Lindholm, 1924 & 0.00 & 0.00 & 0.25 & 0.00 & 0.00 & 0.00 & 0.00 & 0.00 & 0.00 & 0.09 & 0.15 \\
\hline $\begin{array}{l}\text { Clathrocaspia gmelinii (Clessin \& Dybowski } \\
\text { in Dybowski, 1887) }\end{array}$ & 0.00 & 0.00 & 0.00 & 0.00 & 0.00 & 0.00 & 0.00 & 0.00 & 0.00 & 0.09 & 0.00 \\
\hline Clathrocaspia sp. & 8.95 & 0.00 & 0.00 & 5.16 & 3.36 & 6.68 & 6.52 & 5.94 & 3.30 & 3.18 & 4.97 \\
\hline Laevicaspia conus (Eichwald, 1838) & 0.00 & 0.00 & 0.00 & 0.79 & 0.52 & 0.00 & 0.00 & 0.00 & 0.00 & 0.00 & 0.00 \\
\hline $\begin{array}{l}\text { Turricaspia andrussowi (Dybowski \& } \\
\text { Grochmalicki, 1915) }\end{array}$ & 0.00 & 0.00 & 0.00 & 0.00 & 0.00 & 0.00 & 0.00 & 0.00 & 0.00 & 0.09 & 0.00 \\
\hline $\begin{array}{l}\text { Turricaspia uralensis (Logvinenko \& } \\
\text { Starobogatov, 1969) }\end{array}$ & 0.00 & 0.00 & 0.00 & 0.00 & 0.00 & 0.00 & 0.00 & 0.00 & 0.00 & 0.00 & 0.15 \\
\hline $\begin{array}{l}\text { anus (Clessin \& Dybowski } \\
\text { 7) }\end{array}$ & 0.00 & 0.00 & 0.00 & 0.00 & 0.00 & 0.00 & 0.28 & 0.00 & 0.00 & 0.00 & 0.00 \\
\hline Abeskunus sp. & 0.00 & 0.00 & 0.00 & 0.00 & 0.00 & 0.00 & 0.00 & 0.17 & 0.00 & 0.00 & 0.00 \\
\hline $\begin{array}{l}\text { Gyraulus eichwaldi (Clessin \& Dybowski in } \\
\text { Dybowski, 1887) }\end{array}$ & 0.00 & 0.00 & 0.00 & 0.00 & 0.00 & 0.00 & 0.00 & 0.00 & 0.00 & 0.09 & 0.00 \\
\hline Mytilaster minimus (Poli, 1795) & 0.00 & 0.00 & 0.99 & 3.28 & 1.29 & 0.53 & 0.00 & 0.09 & 0.00 & 0.00 & 0.15 \\
\hline Adacna minima Ostrc & 0.00 & 0.00 & 0.00 & 0.00 & 0.00 & 0.00 & 0.00 & 0.00 & 0.00 & 0.00 & 0.15 \\
\hline vitrea (Eichwald, 1829) & 23.64 & 9.52 & 17.82 & 24.60 & 5.94 & 1.34 & 0.28 & 4.28 & 7.49 & 5.51 & 12.13 \\
\hline $\begin{array}{l}\text { Cerastoderma glaucum (Bruguière, 1789)/ } \\
\text { C. sp. A* }\end{array}$ & 0.00 & 0.00 & 0.74 & 2.38 & 3.88 & 29.95 & 58.92 & 81.12 & 59.71 & 78.83 & 71.49 \\
\hline Didacna trigonoides (Pallas, 1771) & 60.06 & 28.57 & 49.50 & 67.86 & 63.31 & 32.35 & 20.11 & 18.44 & 22.99 & 21.69 & 25.88 \\
\hline Didacna protracta (Eichwald, 1841) & 0.00 & 0.00 & 0.25 & 0.00 & 0.00 & 0.00 & 0.00 & 0.00 & 0.00 & 0.17 & 0.58 \\
\hline Didacna pyramidata (Grimm, 1877) & 0.00 & 0.00 & 0.00 & 0.00 & 2.33 & 0.00 & 0.00 & 0.00 & 0.00 & 0.00 & 0.00 \\
\hline Didacna sp. & 0.64 & 0.00 & 0.50 & 0.40 & 0.00 & 0.00 & 0.00 & 0.00 & 0.00 & 0.09 & 0.44 \\
\hline $\begin{array}{l}\text { Monodacna albida (Logvinenko \& } \\
\text { Starobogatov, 1967) }\end{array}$ & 0.00 & 0.00 & 0.00 & 0.00 & 0.00 & 0.00 & 0.00 & 0.00 & 0.00 & 0.17 & 0.15 \\
\hline Monodacna colorata (Eichwald, 1829) & 58.79 & 61.90 & 75.74 & 90.48 & 67.70 & 26.47 & 11.90 & 21.59 & 38.06 & 31.93 & 42.98 \\
\hline Monodacna caspia (Eichwald, 1829) & 7.99 & 0.79 & 25 & 0.00 & 0.00 & 0.00 & 0.00 & 0.00 & 0.00 & 0.52 & 0.00 \\
\hline Monodacna sp.? & 0.32 & 0.00 & 6.93 & 0.00 & 0.26 & 0.27 & 0.57 & 0.61 & 0.00 & 0.09 & 1.61 \\
\hline Abra segmentum (Récluz, 1843) & 38.98 & 75.40 & 77.48 & 89.29 & 91.21 & 96.52 & 96.03 & 92.92 & 86.72 & 89.76 & 95.32 \\
\hline Dreissena caspia Eichwald, 1855 & 0.00 & 0.00 & 0.00 & 0.40 & 0.00 & 0.00 & 0.00 & 0.00 & 0.00 & 0.00 & 0.00 \\
\hline Dreissena polymorpha s.l. (Pallas, 1771) & 61.02 & 29.37 & 19.06 & 58.73 & 52.45 & 11.76 & 0.00 & 0.44 & 0.00 & 0.09 & 0.29 \\
\hline Bivalvia gen. et sp. indet. & 16.61 & 0.00 & 0.00 & 0.00 & 0.00 & 0.00 & 0.00 & 0.00 & 0.00 & 0.00 & 0.15 \\
\hline
\end{tabular}

segmentum that make up $97 \%$ of the total abundance. Fresh-looking shells of endemic species (five species) made up only $3 \%$.

The impact of recent invasions on the Caspian fauna is shown in observational time series such as those of the environmental monitoring programme (2005-2016) of the North Caspian Operating Company (NCOC, 2018). It shows the species richness and biomass of the north-eastern Caspian Sea benthic communities (NCOC, 2018; summary in Table 6.5) as well as the current distribution of native and foreign mollusc species. In total, the NCOC monitoring provided 21 endemic Pontocaspian mollusc species and 3 marine invasive species (Mytilaster minimus, Cerastoderma 
glaucum [which likely includes C. sp. A] and Abra segmentum). The marine invasive species of this ten year record make up half the biomass (49\%), and Monodacna colorata, which originated in the Black Sea basin, accounts for another 20\%, leaving 29\% of the biomass for endemic Caspian species. Abra segmentum, which accounts for $34 \%$ of the total biomass, was introduced as a food source for fish (Malinovskaya and Zinchenko, 2011). As opportunistic euryhaline species A. segmentum outcompeted the native Pontocaspian species (Karpinsky, 2010b). Invasive species make up 10\% of the specimen numbers in the Turali faunas while they represent almost $70 \%$ of the biomass in the modern north-eastern Caspian assemblage. The endemic Pontocaspian fauna has formed over a long period of time and never had to face competition of marine species before (Kostianoy et al., 2005). The introduction of new marine invasive species, intentionally or accidentally, is expected to have a very strong and adverse impact on the native Pontocaspian fauna.

\subsubsection{Refuges}

Beach collections from the Great Turali Lake and later at Sirvan (Azerbaijan) and Bautino (Kazakhstan: all alongside the middle Caspian basin) delivered fresh material of a number of Pontocaspian endemic bivalves: Adacna vitrea, A. laeviuscula, Didacna protracta, D. trigonoides, D. barbotdemarnii and Hypanis plicata. It concerns specimens with often paired valves, preserved colour patterns and organic remnants. This indicates that these bivalve species still live alongside the. invasive species within the foreshore habitats. For several of the species only deeper habitats have been mentioned before: for example, Adacna laeviuscula, has been reported from depths ranging between $35 \mathrm{~m}$ and $100 \mathrm{~m}$ (Bogutskaya et al., 2013; Logvinenko and Starobogatov, 1969). The foreshore habitats merit further exploration as they may comprise a refuge for a particular set of Pontocaspian species. Within the Black Sea similar foreshore habitats have been invaded by Anadara inaequivalvis/kagoshimensis, Mya arenaria and Rapana venosa. Such species may have the ability to seriously impact the Caspian foreshore assemblages and further marginalize endemic species in case they might be introduced there.

\subsection{Conclusions}

The studied Holocene Turali fauna represents a snapshot of a pre- $20^{\text {th }}$ century crisis middle Caspian open bay to shoreface mollusc community. Comparisons with present-day data are qualitative, but indicate the loss of many endemic Caspian species and a very large turnover in such communities. However, it is likely that a foreshore community still exists where alongside immigrant species a number of endemic Caspian species still thrive. This foreshore habitat is in need of further investigations as it may be threatened by further invasive species.

\section{Author contributions}

SV wrote the chapter. SV and FPW analysed Monodacna, Abeskunus and Dreissena material, performed statistical analyses. FPW co-wrote the chapter, collected material and made field 
observations and drafted the chapter outline. FPW, JJP and TAY analysed Didacna material and TAY provided stratigraphic and ecological data. VVA and TAN analysed gastropod species, TAN and SV statistical analyses and TAN co-wrote the chapter, JJP checked cardiids in general and Cerastoderma species in particular, HBV provided the geochemical context; SBK initiated the Turali research and provided stratigraphic and sedimentological context.

\section{Acknowledgements}

Suzanne Leroy is thanked for making available material from Iran for comparison. Charles Barnard assisted with sample processing. This work was supported by the European Union's Horizon 2020 research and innovation program [Marie Sklodowska-Curie grant agreement No 642973, 20152019]. TAN was supported by an Alexander-von-Humboldt Scholarship and a Martin Fellowship granted by Naturalis Biodiversity Center. TAY was supported by Russian Science Foundation (Grant 16-17-10103). We are grateful for the constructive comments of Frank Riedel and an anonymous reviewer. This chapter is dedicated to the memory of our host in Dagestan, Gayirbeg Magomedovich Abdurakhmanov, Director of the Institute of Ecology of Dagestan State University. 


\section{CHAPTER 6}

Supplementary Table S6.1. Morphological and morphometric data of Didacna species. Slightly modified from Nevesskaja (2007). ${ }^{\star}$ Didacna crassa in Nevesskaja (2007).

\begin{tabular}{|c|c|c|c|c|}
\hline & Rib number & $\begin{array}{l}\text { Convexity (Width/ } \\
\text { Length) }\end{array}$ & $\begin{array}{l}\text { Beaks projecting } \\
\text { (Height beak/Height) }\end{array}$ & Keel bend \\
\hline Didacna trigonoides & $\begin{array}{l}12-20 \text { anterior } \\
5-8 \text { posterior }\end{array}$ & $\begin{array}{l}\text { Convex to very } \\
\text { convex } \\
0.27-0.37 \text { average } \\
0.32-0.34\end{array}$ & $\begin{array}{l}\text { Moderately or } \\
\text { significantly projecting } \\
0.12-0.19 \text { average } \\
0.15-0.16\end{array}$ & $\begin{array}{l}\text { Very sharp at the beak, becoming } \\
\text { g smoother downwards }\end{array}$ \\
\hline Didacna baeri & $\begin{array}{l}\text { 19-22 anterior } \\
\text { 6-8 posterior }\end{array}$ & $\begin{array}{l}\text { Moderately convex } \\
0.25-0.35 \text { average } \\
0.28-0.30\end{array}$ & $\begin{array}{l}\text { Relatively low or } \\
\text { moderately projecting } \\
0.06-0.13 \text { average } \\
0.08-0.11\end{array}$ & $\begin{array}{l}\text { Distinct only at the beak, } \\
\text { becoming smooth downwards }\end{array}$ \\
\hline Didacna eichwaldi * & $\begin{array}{l}18-20 \text { anterior } \\
5-8 \text { posterior }\end{array}$ & $\begin{array}{l}\text { Moderately to very } \\
\text { convex } \\
0.24-0.37 \text { average } \\
0.28-0.33\end{array}$ & $\begin{array}{l}\text { Moderately or } \\
\text { significantly projecting } \\
0.10-0.17 \text { average } \\
0.12-0.15\end{array}$ & $\begin{array}{l}\text { Rather sharp at the beak, } \\
\text { becoming smooth downwards }\end{array}$ \\
\hline Didacna barbotdemarnii & $\begin{array}{l}\text { Poorly developed, } \\
\text { difficult to count } \\
16->20 \text { anterior }\end{array}$ & $\begin{array}{l}\text { Slightly convex } \\
0.15-0.23 \text { average } \\
0.18-0.20\end{array}$ & $\begin{array}{l}\text { Relatively low } \\
0.06-0.09 \text { average } 0.08\end{array}$ & $\begin{array}{l}\text { Distinct only at the beak, } \\
\text { becoming poorly pronounced/ } \\
\text { smooth below }\end{array}$ \\
\hline & Beak & Apical angle & Length & Height/Length \\
\hline Didacna trigonoides & Acute triangular & $\begin{array}{l}85^{\circ}-118^{\circ} \\
\text { average } 104^{\circ}-107^{\circ}\end{array}$ & $\begin{array}{l}\text { Up to } 60 \mathrm{~mm} \text {; } \\
\text { occasionally } 65 \mathrm{~mm}\end{array}$ & $\begin{array}{l}0.72-0.96 \\
\text { average } 0.80-0.84\end{array}$ \\
\hline Didacna baeri & $\begin{array}{l}\text { Blunt or slightly } \\
\text { carinate }\end{array}$ & $\begin{array}{l}95^{\circ}-120^{\circ} \\
\text { average } 110^{\circ}-115^{\circ}\end{array}$ & Up to $40-50 \mathrm{~mm}$ & $\begin{array}{l}0.70-0.88 \\
\text { average } 0.75-0.80\end{array}$ \\
\hline Didacna eichwaldi* & $\begin{array}{l}\text { Carinate to greater } \\
\text { or lesser extent }\end{array}$ & $\begin{array}{l}90^{\circ}-120^{\circ} \\
\text { average } 105^{\circ}-115^{\circ}\end{array}$ & Up to $55 \mathrm{~mm}$ & $\begin{array}{l}0.69-0.88 \\
\text { average } 0.74-0.84\end{array}$ \\
\hline Didacna barbotdemarnii & $\begin{array}{l}\text { Blunt or poorly } \\
\text { carinate }\end{array}$ & $\begin{array}{l}116^{\circ}-130^{\circ} \\
\text { average } 123^{\circ}-126^{\circ}\end{array}$ & Up to $20 \mathrm{~mm}$ & $\begin{array}{l}0.66-0.72 \\
\text { average } 0.68-0.70\end{array}$ \\
\hline
\end{tabular}


HOLOCENE CASPIAN SEA: TURALI 


\section{APPENDIX: \\ DATA REPORT ON MOLLUSC ASSEMBLAGES FROM LATE QUATERNARY BOREHOLE OF THE NORTHERN CASPIAN SEA}

\section{In preparation:}

van de Velde, S., Yanina, T.A., Neubauer, T.A., Berdnikova, A., Garova, E., Wesselingh, F.P. Evolution of northern Caspian Sea mollusc faunas during the Late Quaternary.

\subsection{Introduction}

The Caspian Sea has a very dynamic history of regressions and transgressions and salinity gradients (Krijgsman et al., 2019; Yanina, 2014). The biota inhabiting the Caspian Sea adapted to these fluctuating environmental conditions, resulting in a unique species diversity and a high endemism up to $100 \%$ in some faunal groups (Dumont, 2000). No research has been done on the development of faunal assemblages through time even though some groups are well known to have experienced major periods of turnover (e.g. Didacna species: Nevesskaja, 2007; Yanina and Khomchenko, 2014). In this data report, the mollusc diversity of five regional stratigraphic stages covering the last 120 kyr (late Khazarian, Hyrcanian, early Khvalynian, late Khvalynian, Novocaspian) is analysed from a $67.8 \mathrm{~m}$ core taken in the northern Caspian Sea. The aim of the study in preparation is to examine the change in species richness and relative abundance through time and assess the potential factors driving these changes. In this Appendix data report, we show snapshots of northern Caspian Sea mollusc diversity through time prior to human impact, to characterise successive faunas in terms of composition and diversity in order to allow comparison with modern mollusc diversity. By putting the mollusc composition changes in a wider time frame the severity of the current rate of anthropogenic-driven biodiversity decline (compare Lattuada et al., 2019b) becomes explicit.

\subsection{Material and methods}

A $67.8 \mathrm{~m}$ long core was taken in the northern Caspian Sea shelf at a water depth of around $11.9 \mathrm{~m}$. The approximate location of the core is around $44^{\circ} 55^{\prime} 8.0^{\prime \prime} \mathrm{N}, 48^{\circ} 51^{\prime} 51.6^{\prime \prime} \mathrm{E}$ (Sorokin et al., 2018: Fig. 7.1B, locality 3), but precise locality data are confidential. The preliminary stratigraphic framework is based on stratigraphic mollusc marker species, a series of dating and correlation techniques using seismic profiles which enabled us to assign the borehole intervals to regional Caspian stratigraphic stages (Krijgsman et al., 2019; Sorokin et al., 2018). Twelve sediment samples 
Table 7.1: Mollusc abundances (number of individuals per species per sample depth) of the northern Caspian Sea borehole \#5. The time periods abbreviations stand for: $\mathrm{Nc}=$ Novocaspian, LKhv $=$ Late Khvalynian, Ekhv $=$ early Khvalynian, $\mathrm{Hyr}=$ Hyrcanian, $\mathrm{LKhz}=$ Late Khazarian, EKhz $=$ early Khazarian.

\begin{tabular}{|c|c|c|c|c|c|c|c|c|c|c|c|c|c|c|c|}
\hline 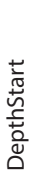 & 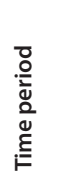 & 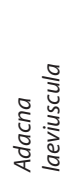 & 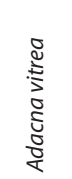 & $\begin{array}{l}\dot{0} \\
0 \\
\vdots \\
\vdots \\
\dot{0} \\
\dot{0}\end{array}$ & $\begin{array}{l}\bar{\Xi} \\
\bar{\Xi} \\
0 \\
\bar{\Xi} \\
\bar{\Xi} \\
0\end{array}$ & 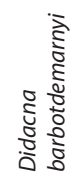 & 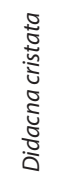 & 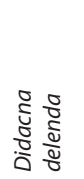 & 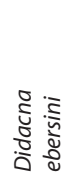 & 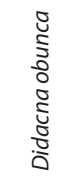 & 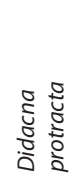 & 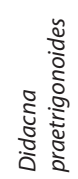 & 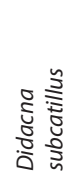 & 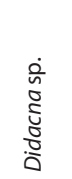 & 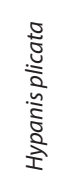 \\
\hline 1,05 & $\mathrm{Nc}$ & 30 & 23 & & & 45 & & & & & & & & & \\
\hline 7 & LKhv & 10 & 12 & & & & 19 & & & & & & 64 & 10 & 9 \\
\hline 14,7 & LKhv & & & & & & & & & & & & 1 & & $1 ?$ \\
\hline 15,1 & LKhv & & 12 & 2 & & & 7 & & & & & & 26 & 11 & \\
\hline 16 & EKhv & 1 & 3 & & & & & & & 35 & 1 & & 53 & & \\
\hline 17,6 & EKhv & & & & & & & & & & & & & 27 & \\
\hline 19,1 & EKhv & & & & & & & 4 & 2 & & & & 22 & & \\
\hline 34,6 & Hyr & & & & & & & 9 & & & & & 11 & & \\
\hline 35 & Hyr & & & & 1 & & & & & & & & 43 & 6 & \\
\hline 36,5 & LKhz & & 4 & & & & & & & & & & 38 & 15 & \\
\hline 44,2 & LKhz & & & & & & & & & & & & & & \\
\hline 65,4 & EKhz & & 1 & & 1 & & & & & & & 2 & & & 4 \\
\hline 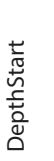 & 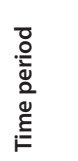 & 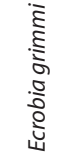 & 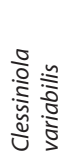 & 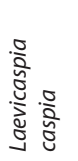 & 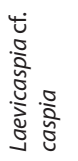 & 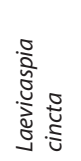 & 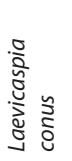 & 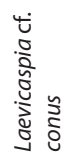 & 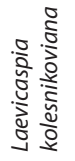 & 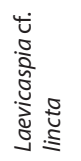 & 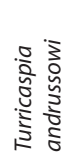 & 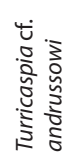 & 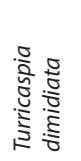 & 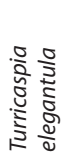 & 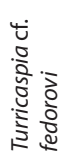 \\
\hline 1,05 & $\mathrm{Nc}$ & 3 & 2 & & & & & & & & & & & & \\
\hline 7 & LKhv & & 15 & & & & & & & & & & & & \\
\hline 14,7 & LKhv & 9 & & & & & & & & & & & & & \\
\hline 15,1 & LKhv & & & & & & & & 2 & & & 3 & & & \\
\hline 16 & EKhv & 39 & & 1 & & & & & 2 & & & & & & \\
\hline 17,6 & EKhv & & & & 1 & 3 & 2 & 6 & 88 & & & & & & \\
\hline 19,1 & EKhv & & & 14 & & 3 & 8 & & 5 & $1 ?$ & 36 & & & 23 & \\
\hline 34,6 & Hyr & & & 2 & & & & & & & & & 6 & & \\
\hline 35 & Hyr & & 1 & 1 & & & & & & & & & & & \\
\hline 36,5 & LKhz & & 14 & & & & & & 3 & & & & & & 2 \\
\hline 44,2 & LKhz & & & & & & & & & & & & & & \\
\hline 65,4 & EKhz & & & & & & & & & & & & & & \\
\hline
\end{tabular}




\begin{tabular}{|c|c|c|c|c|c|c|c|c|c|c|c|c|c|c|c|}
\hline 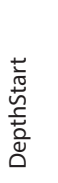 & 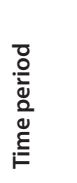 & 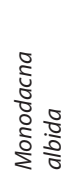 & 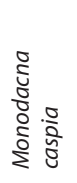 & 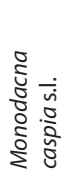 & 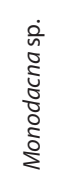 & 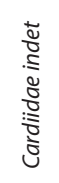 & 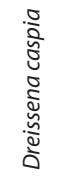 & 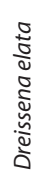 & 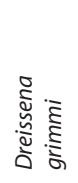 & 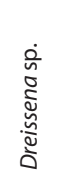 & 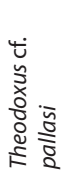 & 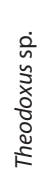 & $\begin{array}{l}: \bar{z} \\
\bar{z} \\
0 \\
\frac{0}{0} \\
\bar{z} \\
0\end{array}$ & 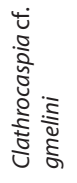 & 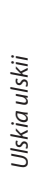 \\
\hline 1,05 & $\mathrm{Nc}$ & & 134 & & 316 & & 110 & 16 & & 304 & 4 & & & & \\
\hline 7 & LKhv & 26 & & 71 & 33 & & 7 & 45 & & & 4 & & & & \\
\hline 14,7 & LKhv & 1 & 4 & & & & 5 & & 2 & & & 1 & & & \\
\hline 15,1 & LKhv & & 35 & & 79 & 100 & 7 & 9 & 2 & 23 & & & 3 & & \\
\hline 16 & EKhv & & 20 & & & 140 & 10 & 9 & 19 & & & 3 & & & \\
\hline 17,6 & EKhv & & & & & 4 & 7 & 8 & 111 & 336 & 29 & & & 4 & \\
\hline 19,1 & EKhv & & 71 & & & 4 & & 91 & 232 & & & 15 & & 25 & \\
\hline 34,6 & Hyr & 34 & 18 & & & & 10 & & 202 & & & 1 & & 17 & 4 \\
\hline 35 & Hyr & 95 & 50 & & & & 6 & 8 & 96 & & & 1 & & & \\
\hline 36,5 & LKhz & 25 & 20 & & & & 239 & & 22 & & 19 & 19 & & & \\
\hline 44,2 & LKhz & & & & & 1 & 2 & & 3 & & & & & & \\
\hline 65,4 & EKhz & 7 & 2 & & & 1 & & 4 & 1 & & & & & & \\
\hline
\end{tabular}

\begin{tabular}{|c|c|c|c|c|c|c|c|c|c|c|c|c|c|c|c|}
\hline 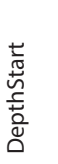 & 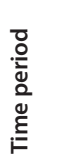 & 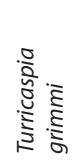 & 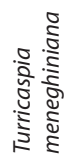 & 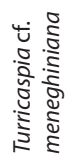 & 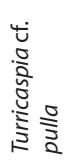 & 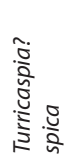 & 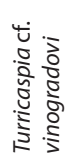 & 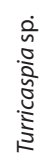 & 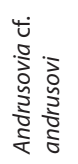 & 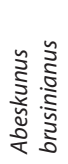 & 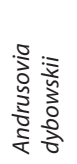 & $\begin{array}{l}\frac{n}{0} \\
\frac{0}{2} \\
\frac{0}{2} \\
\frac{5}{2} \\
\frac{2}{4}\end{array}$ & 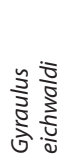 & 题 & \\
\hline 1,05 & $\mathrm{Nc}$ & & & & & & 6 & & & & & & & 982 & \\
\hline 7 & LKhv & & & & & & & 1 & & 3 & & 1 & & 310 & \\
\hline 14,7 & LKhv & & & & & & & 1 & & & & & & 14 & \\
\hline 15,1 & LKhv & & 8 & & 1 & 219 & & 1 & & 4 & & & & 316 & \\
\hline 16 & EKhv & & & 1 & & 39 & & & & 2 & & & & 294 & \\
\hline 17,6 & EKhv & & & & 5 & 52 & & & & & & & & 526 & \\
\hline 19,1 & EKhv & & 8 & & & & & & 10 & & & & 1 & 466 & \\
\hline 34,6 & Hyr & & & & & & & 3 & & & 10 & & 1 & 302 & \\
\hline 35 & Hyr & 1 & 1 & & & 6 & & 1 & & 1 & & & & 306 & \\
\hline 36,5 & LKhz & & & & & & & 19 & & & & & & 401 & \\
\hline 44,2 & LKhz & & & & & & & & & & & & & 6 & \\
\hline 65,4 & EKhz & & & & & & & & & & & & & & 23 \\
\hline
\end{tabular}




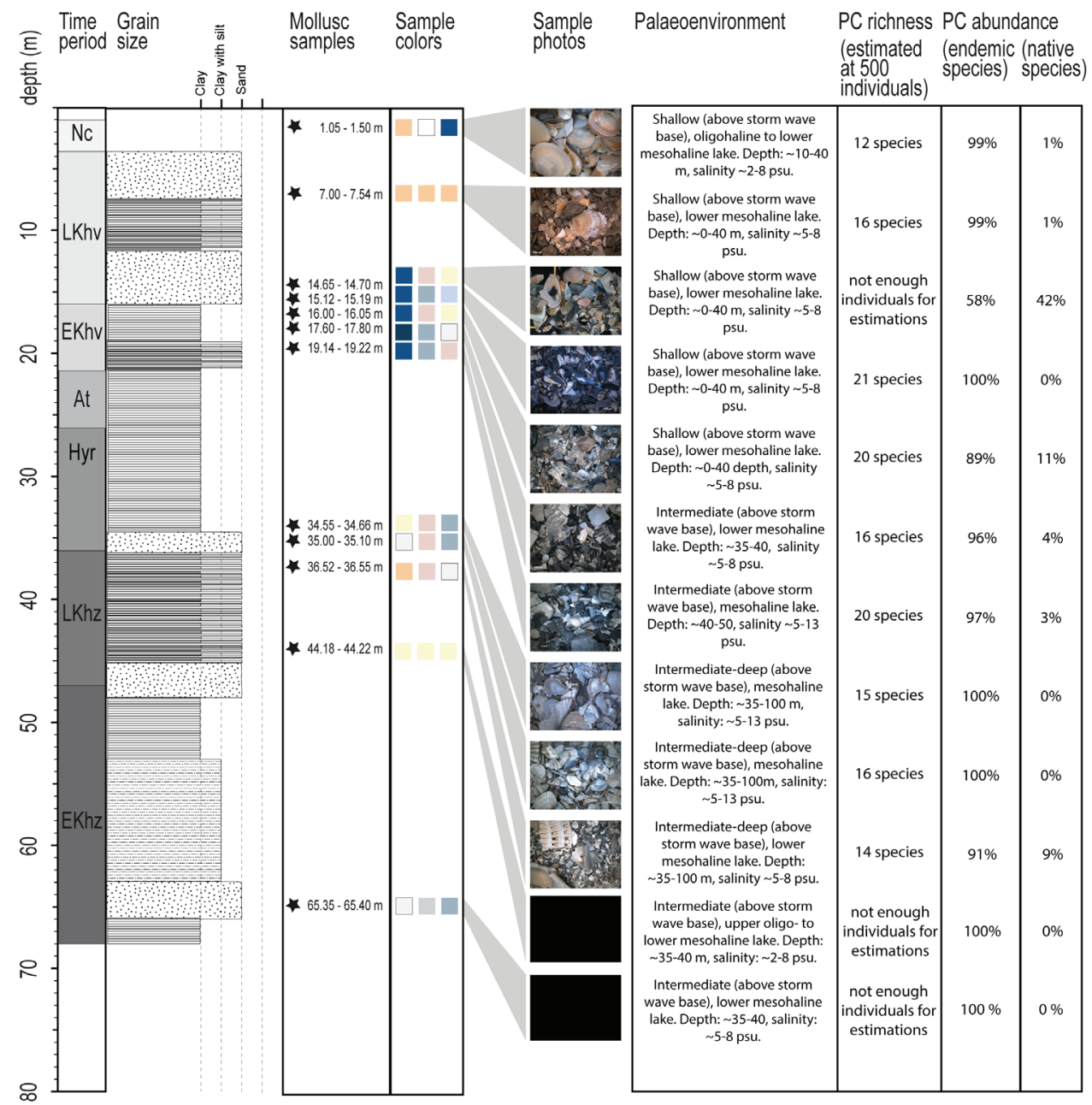

Fig. 7.1: Core data, paleoenvironmental and mollusc faunal indications of the northern Caspian Sea borehole \#5. From left to right: core depth (in $\mathrm{m}$ ), time period, sedimentology (grain size), mollusc sample depth, sample colours, sample photos, palaeoenvironment, Pontocaspian richness estimate at 500 specimens, percentage of Caspian endemic species and native species. The time periods abbreviations stand for: Nc $=$ Novocaspian, $\mathrm{LKhv}$ $=$ Late Khvalynian, Ekhv = early Khvalynian, At = Atelian, Hyr = Hyrcanian, LKhz = Late Khazarian, EKhz = early Khazarian.

were taken for mollusc analysis and analysed following methods in van de Velde et al. (2019). Molluscs were identified to the lowest possible taxonomic level and counted. A rarefaction analysis was performed using R version 3.5.2 (R Core Team, 2018) with package 'iNEXT' v. 2.0.19 (Hsieh et 
Table 7.2: Summary of mollusc biomass $\left(\mathrm{mg} / \mathrm{m}^{2}\right)$ encountered during environmental monitoring programme of the north-east Caspian Sea (2005-2016). From: North Caspian Operating Company et al. (2018). ${ }^{\star}$ According to Wesselingh et al. (2019) it is likely this species concerns two sibling species; C. glaucum and C. spec. A.

\begin{tabular}{|c|c|c|c|c|c|c|c|c|c|c|c|c|c|}
\hline Family & Species & 2006 & 2007 & 2008 & 2009 & 2010 & 2011 & 2012 & 2013 & 2014 & 2015 & 2016 & Total \\
\hline Mytilidae & Mytilaster minimus & 0 & 0 & 1,0 & 3,3 & 1,3 & 0,5 & 0 & 0,1 & 0 & 0 & 0,2 & 6,3 \\
\hline Cardiidae & Adacna minima & 0 & 0 & 0 & 0 & 0 & 0 & 0 & 0 & 0 & 0 & 0,2 & 0,2 \\
\hline Cardiidae & Adacna vitrea & 23,6 & 9,5 & 17,8 & 24,6 & 5,9 & 1,3 & 0,3 & 4,3 & 7,5 & 5,5 & 12,1 & 112,6 \\
\hline Cardiidae & Cerastoderma glaucum * & 0 & 0 & 0,7 & 2,4 & 3,9 & 30,0 & 58,9 & 81,1 & 59,7 & 78,8 & 71,5 & 387,0 \\
\hline Cardiidae & Didacna trigonoides & 60,1 & 28,6 & 49,5 & 67,9 & 63,3 & 32,4 & 20,1 & 18,4 & 23,0 & 21,7 & 25,9 & 410,8 \\
\hline Cardiidae & Didacna protracta & 0 & 0 & 0,3 & 0 & 0 & 0 & 0 & 0 & 0 & 0,2 & 0,6 & 1,0 \\
\hline Cardiidae & Didacna pyramidata & 0 & 0 & 0 & 0 & 2,3 & 0 & 0 & 0 & 0 & 0 & 0 & 2,3 \\
\hline Cardiidae & Didacna sp. & 0,6 & 0 & 0,5 & 0,4 & 0 & 0 & 0 & 0 & 0 & 0,1 & 0,4 & 2,1 \\
\hline Cardiidae & Monodacna albida & 0 & 0 & 0 & 0 & 0 & 0 & 0 & 0 & 0 & 0,2 & 0,2 & 0,3 \\
\hline Cardiidae & Monodacna caspia & 8,0 & 0,8 & 0,3 & 0 & 0 & 0 & 0 & 0 & 0 & 0,5 & 0 & 9,6 \\
\hline Cardiidae & Monodacna colorata & 58,8 & 61,9 & 75,7 & 90,5 & 67,7 & 26,5 & 11,9 & 21,6 & 38,1 & 31,9 & 43,0 & 527,5 \\
\hline Cardiidae & Mondacna sp? & 0,3 & 0 & 6,9 & 0 & 0,3 & 0,3 & 0,6 & 0,6 & 0 & 0,1 & 1,6 & 10,7 \\
\hline Semelidae & Abra segmentum & 39,0 & 75,4 & 77,5 & 89,3 & 91,2 & 96,5 & 96,0 & 92,9 & 86,7 & 89,8 & 95,3 & 929,6 \\
\hline Dreissenidae & Dreissena caspia & 0 & 0 & 0 & 0,4 & 0 & 0 & 0 & 0 & 0 & 0 & 0 & 0,4 \\
\hline Dreissenidae & Dreissena cf. elata & 61,0 & 29,4 & 19,1 & 58,7 & 52,5 & 11,8 & 0,0 & 0,4 & 0 & 0,1 & 0,3 & 233,2 \\
\hline Neritidae & Theodoxus pallasi & 0 & 0 & 0,3 & 0 & 0 & 0 & 0 & 0 & 0 & 0,1 & 0,2 & 0,5 \\
\hline Hydrobiidae & Clathrocaspia gmelinii & 0 & 0 & 0 & 0 & 0 & 0 & 0 & 0 & 0 & 0,1 & 0 & 0,1 \\
\hline Hydrobiidae & Clathrocaspia sp. & 9,0 & 0 & 0 & 5,2 & 3,4 & 6,7 & 6,5 & 5,9 & 3,3 & 3,2 & 5,0 & 48,1 \\
\hline Hydrobiidae & Laevicaspia conus & 0 & 0 & 0 & 0,8 & 0,5 & 0 & 0 & 0 & 0 & 0 & 0 & 1,3 \\
\hline Hydrobiidae & Turricaspia andrussowi & 0 & 0 & 0 & 0 & 0 & 0 & 0 & 0 & 0 & 0,1 & 0 & 0,1 \\
\hline Hydrobiidae & Turricaspia uralensis & 0 & 0 & 0 & 0 & 0 & 0 & 0 & 0 & 0 & 0 & 0,2 & 0,2 \\
\hline Hydrobiidae & Abeskunus brusinianus & 0 & 0 & 0 & 0 & 0 & 0 & 0,3 & 0 & 0 & 0 & 0 & 0,3 \\
\hline Hydrobiidae & Abeskunus sp. & 0 & 0 & 0 & 0 & 0 & 0 & 0 & 0,2 & 0 & 0 & 0 & 0,2 \\
\hline \multirow{2}{*}{ Planorbidae } & Gyraulus eichwaldi & 0 & 0 & 0 & 0 & 0 & 0 & 0 & 0 & 0 & 0,1 & 0 & 0,1 \\
\hline & Bivalvia indet. & 16,6 & 0 & 0 & 0 & 0 & 0 & 0 & 0 & 0 & 0 & 0,2 & 16,8 \\
\hline
\end{tabular}

al., 2019) to estimate the species richness and the representativeness of the samples for each time period. All species have been illustrated. Palaeoecological indications of the species has been derived from multiple literature resources and summarized in Table 7.3. Data on the current (2005-2016) living species have been taken from the literature for comparison and show mollusc species biomass collected during an 11-year monitoring period by the North Caspian Operating Company (NCOC, 2018), Table 7.2

\subsection{Results}

In total 45 species were recognised within the twelve samples (Table 7.1). The samples represent Novocaspian (1 sample), late Khvalynian (3 samples), early Khvalynian (3 samples), Hyrcanian (2 samples), late Khazarian (2 samples), and early Khazarian (1 sample) regional stratigraphic stages (Table 7.1, Fig. 7.1.). The rarefaction analysis shows that for each time period we have at least one sample with near-saturated richness, implying sample size to be adequate for richness estimates 
Table 7.3: Palaeoecological indications as derived from the literature. ${ }^{1}$ Bogutskaya et al. (2013), ${ }^{2}$ Logvinenko and Starobogatov (1969), ${ }^{3}$ Mirzoev and Alekperov (2017), ${ }^{4}$ Nevesskaja (2007), ${ }^{5}$ Starobogatov (1994), ${ }^{6}$ Glöer (2002), ${ }^{7}$ Wesselingh et al. (2019) ${ }^{8}$ Chukhchin (1984), ${ }^{9}$ Vinarski and Kantor (2016), ${ }^{10}$ Andreev and Andreeva (2003), ${ }^{11}$ Parr et al. (2007), ${ }^{12}$ Gittenberger et al. (2004). CS = Caspian Sea.

\begin{tabular}{|c|c|c|c|c|}
\hline Species & Family & Status & Natural salinity range (psu) & Depth \\
\hline Mytilaster minimus (Poli, 1795) & Mytilidae & invasive $^{7}$ & $\min .5-8^{1}$, max. 38 (Med. Sea) & $0-60^{1}$ \\
\hline Adacna laeviuscula (Eichwald, 1829) & Cardiidae & $\mathrm{CS}$ endemic ${ }^{7}$ & $4-14^{1,2}$ & $30-100^{1,4}$ \\
\hline Adacna vitrea (Eichwald, 1829) & Cardiidae & $\mathrm{CS}$ endemic ${ }^{7}$ & $\min .5-8^{1}, \max .12-13$ & $0-40^{1}$ \\
\hline Cerastoderma glaucum (Bruguière, 1789) & Cardiidae & invasive $^{7}$ & $\min .5-8^{1}$, max. 38 (Med. Sea) & $10-50^{1}$ \\
\hline Didacna baeri (Grimm, 1877) & Cardiidae & $\mathrm{CS}_{\text {endemic }}{ }^{7}$ & $3-14^{1}$ & $7.5-60^{1}, 17-49^{2}$ \\
\hline Didacna barbotdemarnii (Grimm, 1877) & Cardiidae & $\mathrm{CS}_{\text {endemic }}{ }^{7}$ & $3-14^{1}$ & $30-42^{1} 0-42^{2}$ \\
\hline Didacna cristata Bogachev, 1932 & Cardiidae & CS endemic ${ }^{4}$ & $3-14^{1}$ & $0-50^{1}$ \\
\hline Didacna delenda Bogachev, 1932 & Cardiidae & CS endemic ${ }^{4}$ & $3-14^{1}$ & $0-50^{1}$ \\
\hline Didacna ebersini Fedorov, 1953 & Cardiidae & $\mathrm{CS}_{\text {endemic }}{ }^{4}$ & $3-14^{1}$ & $0-50^{1}$ \\
\hline Didacna obunca Popov, 1983 & Cardiidae & CS endemic ${ }^{4}$ & $3-14^{1}$ & $0-50^{1}$ \\
\hline Didacna protracta (Eichwald, 1841) & Cardiidae & $\mathrm{CS}$ endemic ${ }^{7}$ & $3-14^{1}$ & $25-50^{2}, 25-80^{1}$ \\
\hline $\begin{array}{l}\text { Didacna praetrigonoides Nalivkin \& } \\
\text { Anisimov, } 1914\end{array}$ & Cardiidae & CS endemic ${ }^{7}$ & $3-14^{1}$ & $6-43^{2}$ \\
\hline Didacna pyramidata (Grimm, 1877) & Cardiidae & $\mathrm{CS}$ endemic ${ }^{7}$ & $3-14^{1}$ & $30-130^{1}, 42-130^{2}$ \\
\hline Didacna subcatillus Andrussoff, 1910 & Cardiidae & CS endemic ${ }^{4}$ & $3-14^{1}$ & $0-50^{1}$ \\
\hline Didacna trigonoides (Pallas, 1771) & Cardiidae & $\mathrm{CS}$ endemic ${ }^{7}$ & $3-14^{1}$ & $5-40^{1}$ \\
\hline Hypanis plicata (Eichwald, 1829) & Cardiidae & $\mathrm{CS}$ endemic ${ }^{7}$ & $4-8^{1,2}, \max .12-13$ & $0-40^{1}$ \\
\hline $\begin{array}{l}\text { Monodacna albida (Logvinenko \& } \\
\text { Starobogatov, 1967) }\end{array}$ & Cardiidae & CS endemic ${ }^{7}$ & $\min 5-8^{1,2}, \max .12-13$ & $0-150^{1}$ \\
\hline Monodacna caspia (Eichwald, 1829) & Cardiidae & $\mathrm{CS}_{\text {endemic }}{ }^{7}$ & $2-8^{1}, \max .12-13$ & $0-200^{1,2}$ \\
\hline Abra segmentum (Récluz, 1843) & Semelidae & invasive $^{7}$ & $\min .5-8^{1}$, max. 38 (Med. Sea) & $0-40^{1}$ \\
\hline Dreissena caspia Eichwald, 1855 & Dreissenidae & CS endemic $^{7}$ & opt. $2-8^{1}$, max. $12-13$ & $0-40^{1,2}$ \\
\hline Dreissena cf. elata Andrusov, 1897 & Dreissenidae & $\mathrm{CS}$ endemic ${ }^{7}$ & opt. 2-8 ${ }^{1}$, max. $12-13$ & $0-40^{1,2,7}$ \\
\hline Dreissena grimmi (Andrusov, 1890) & Dreissenidae & $\mathrm{CS}_{\text {endemic }}{ }^{7}$ & opt. 2-8 ${ }^{1}$, max. $12-13$ & $35-100^{1,5}$ \\
\hline Theodoxus cf. pallasi Lindholm, 1924 & Neritidae & CS native ${ }^{7}$ & opt. 0-8 ${ }^{1}$, max. $12-13$ & $0-40^{1,2}$ \\
\hline $\begin{array}{l}\text { Caspia baerii Clessin \& Dybowski in } \\
\text { Dybowski, } 1887\end{array}$ & Hydrobiidae & CS endemic ${ }^{7}$ & $\min .5-8^{1}, \max .12-13$ & $35-80^{1}$ \\
\hline $\begin{array}{l}\text { Clathrocaspia cf. gmelini (Clessin \& } \\
\text { Dybowski in Dybowski, 1887) }\end{array}$ & Hydrobiidae & CS endemic $^{7}$ & $\min .5-8^{1}, \max .12-13$ & $35-100^{1}$ \\
\hline $\begin{array}{l}\text { Ulskia ulskii (Clessin \& Dybowski in } \\
\text { Dybowski, 1887) }\end{array}$ & Hydrobiidae & CS endemic ${ }^{7}$ & $\min .5-8^{1}, \max .12-13$ & $35-300^{1,2,3}$ \\
\hline Ecrobia grimmi (Clessin in Dybowski, 1887) & Hydrobiidae & CS native $^{7}$ & opt. 2-8 ${ }^{1}$, max. $12-13$ & $25-40^{1,2}$ \\
\hline Clessiniola variabilis (Eichwald, 1838) & Hydrobiidae & $\mathrm{CS}_{\text {endemic }}{ }^{7}$ & opt. $0-8^{1}, 5-7^{8}, \max .12-13$ & $0-300^{1,2,3}$ \\
\hline Laevicaspia caspia (Eichwald, 1838) & Hydrobiidae & $\mathrm{CS}_{\text {endemic }}{ }^{7}$ & $\min .5-8^{1}, \max .12-13$ & $30-500^{1,2,3}$ \\
\hline Laevicaspia cincta (Abich, 1859) & Hydrobiidae & $\mathrm{CS}_{\text {endemic }}{ }^{7}$ & $\min .5-8^{1}, \max .12-13$ & $20->250^{1,11}$ \\
\hline Laevicaspia conus (Eichwald, 1838) & Hydrobiidae & $\mathrm{CS}_{\text {endemic }}{ }^{7}$ & $\min .5-8^{1}, \max .12-13$ & $0-300^{1,2,3}$ \\
\hline $\begin{array}{l}\text { Laevicaspia kolesnikoviana (Logvinenko \& } \\
\text { Starobogatov in Golikov \& Starobogatov, } \\
\text { 1966) }\end{array}$ & Hydrobiidae & CS endemic ${ }^{7}$ & $\min .5-8^{1}, \max \cdot 12-13$ & $25-400^{1,2,3}$ \\
\hline Laevicaspia cf. lincta (Milaschewitsch, 1908) & Hydrobiidae & BS endemic ${ }^{7}$ & fresh $^{9}$ & \\
\hline $\begin{array}{l}\text { Turricaspia andrussowi (Dybowski \& } \\
\text { Grochmalicki, 1915) }\end{array}$ & Hydrobiidae & $\mathrm{CS}$ endemic ${ }^{7}$ & $\min .5-8^{1}, \max .12-13$ & $25-500^{1,2,3}$ \\
\hline Turricaspia dimidiata (Eichwald, 1838) & Hydrobiidae & CS endemic ${ }^{7}$ & $\min .5-8^{1}, \max .12-13$ & $35-500^{1,2,3}$ \\
\hline $\begin{array}{l}\text { Turricaspia elegantula (Clessin \& Dybowski } \\
\text { in Dybowski, 1887) }\end{array}$ & Hydrobiidae & $\mathrm{CS}_{\text {endemic }}{ }^{7}$ & $\min .5-8^{1}, \max .12-13$ & $40-100^{1}$ \\
\hline $\begin{array}{l}\text { Turricaspia cf. fedorovi (Logvinenko \& } \\
\text { Starobogatov, 1969) }\end{array}$ & Hydrobiidae & CS endemic ${ }^{7}$ & $\min .5-8^{1}, \max .12-13$ & $35-100^{1}$ \\
\hline
\end{tabular}




\begin{tabular}{|c|c|c|c|c|}
\hline $\begin{array}{l}\text { Turricaspia grimmi (Clessin \& Dybowski in } \\
\text { Dybowski, 1887) }\end{array}$ & Hydrobiidae & CS endemic $^{7}$ & $\min .5-8^{1}, \max .12-13$ & $70-200^{1}$ \\
\hline Turricaspia meneghiniana (Issel, 1865) & Hydrobiidae & CS endemic $^{7}$ & $\min .5-8^{1}, \max .12-13$ & $0-40^{1,2}$ \\
\hline $\begin{array}{l}\text { Turricaspia cf. pulla (Dybowski \& } \\
\text { Grochmalicki, 1915) }\end{array}$ & Hydrobiidae & $\mathrm{CS}_{\text {endemic }}{ }^{7}$ & $\min .5-8^{1}, \max .12-13$ & $15-300^{1,2,}$ \\
\hline Turricaspia cf. spica (Eichwald, 1855) & Hydrobiidae & $\mathrm{CS}_{\text {endemic }}{ }^{7}$ & $\min .5-8^{1}, \max .12-13$ & $0-40^{1,2}$ \\
\hline $\begin{array}{l}\text { Turricaspia uralensis (Logvinenko \& } \\
\text { Starobogatov, 1969) }\end{array}$ & Hydrobiidae & $\mathrm{CS}_{\text {endemic }}{ }^{7}$ & $\min .5-8^{1}, \max .12-13$ & $0-40^{1}$ \\
\hline $\begin{array}{l}\text { Turricaspia cf. vinogradovi (Logvinenko \& } \\
\text { Starobogatov, 1969) }\end{array}$ & Hydrobiidae & $\mathrm{CS}_{\text {endemic }}{ }^{7}$ & $\min .5-8^{1}, \max .12-13$ & $0-10^{1}$ \\
\hline $\begin{array}{l}\text { Abeskunus brusinianus (Clessin \& Dybowski } \\
\text { in Dybowski, 1887) }\end{array}$ & Hydrobiidae & CS endemic $^{7}$ & $\min .5-8^{1}, \max .12-13$ & $0-250^{1,2}$ \\
\hline $\begin{array}{l}\text { Andrusovia cf. andrusovi Starobogatov, } \\
2000\end{array}$ & Hydrobiidae & $\mathrm{CS}_{\text {endemic }}{ }^{7}$ & $\min .5-8^{1}, \max .12-13$ & $20-100^{1}$ \\
\hline $\begin{array}{l}\text { Andrusovia dybowskii Brusina in } \\
\text { Westerlund, } 1902\end{array}$ & Hydrobiidae & $\mathrm{CS}_{\text {endemic }}{ }^{7}$ & $\min .5-8^{1}, \max .12-13$ & $35-115^{1}$ \\
\hline $\begin{array}{l}\text { Gyraulus eichwaldi (Clessin \& Dybowski in } \\
\text { Dybowski, 1887) }\end{array}$ & Planorbidae & $\mathrm{CS}_{\text {endemic }}{ }^{7}$ & $\min .5-8^{1}, \max .12-13$ & $35-200^{1}$ \\
\hline Anisus spirorbis (Linnaeus, 1758) & Planorbidae & & fresh $^{9}$ & \\
\hline Valvata goldfussiana (Wüst, 1901) & Valvatidae & & fresh $^{12}$ & \\
\hline Valvata piscinalis (Müller, 1774) & Valvatidae & & $0-5^{6}$, fresh $^{9}$ & \\
\hline
\end{tabular}

(Fig. 7.2). The exception is the early Khazarian assemblage whose single sample is composed of too few individuals to give an indication of richness. An overview of the modern species taken from North Caspian Operating Company (NCOC, 2018) can be found in Table 7.2.

The molluscs of the late Khazarian substage include 10 anomalohaline and two freshwater (Valvata spp.) species (Table 7.1, Fig. 7.3). Of the total late Khazarian assemblage 100\% of the individuals are Pontocaspian (91\% endemic and 9\% native). The fauna suggests deposition in the lower photic zone at around 0-40 m water depth (Table 7.3 and references therein). Salinity optima range from 5-8 psu, with the exception of the freshwater species Borysthenia goldfussiana and Valvata piscinalis. These two very abraded mollusc species were found in very low amounts and were probably washed in or reworked from underlying strata.

The fauna of the Hyrcanian stage is composed of 19 anomalohaline species (Table 7.1, Fig. 7.4) and comprises of $100 \%$ Pontocaspian endemics. The majority of specimens belong to Dreissena grimmi, Clathrocaspia gmelinii, Monodacna albida and M. caspia, and the extinct Didacna subcatillus. The extant species live down to $100 \mathrm{~m}$ depth. Salinity optima range from 5-8 psu.

The early Khvalynian fauna contains 27 species (Table 7.1, Fig. 7.5), which are typical of anomalohaline environments; they are all Pontocaspian (95\% endemic, 5\% native). The overall assemblage is representative of the lower photic zone at around $35-40 \mathrm{~m}$ water depth. The majority of species can live up to hundreds of meter depth (Dreissena grimmi, Monodacna albida, Monodacna caspia, Clathrocaspia gmelinii, Laevicaspia kolesnikoviana, Turricaspia andrussowi and Turricaspia elegantula), but the depth estimates are restricted by occurrences of Theodoxus pallasi, Turricaspia spica and Dreissena elata which live at a maximum of $40 \mathrm{~m}$ depth. Salinities are estimated at 5-8 psu. 


\section{CHAPTER 7}

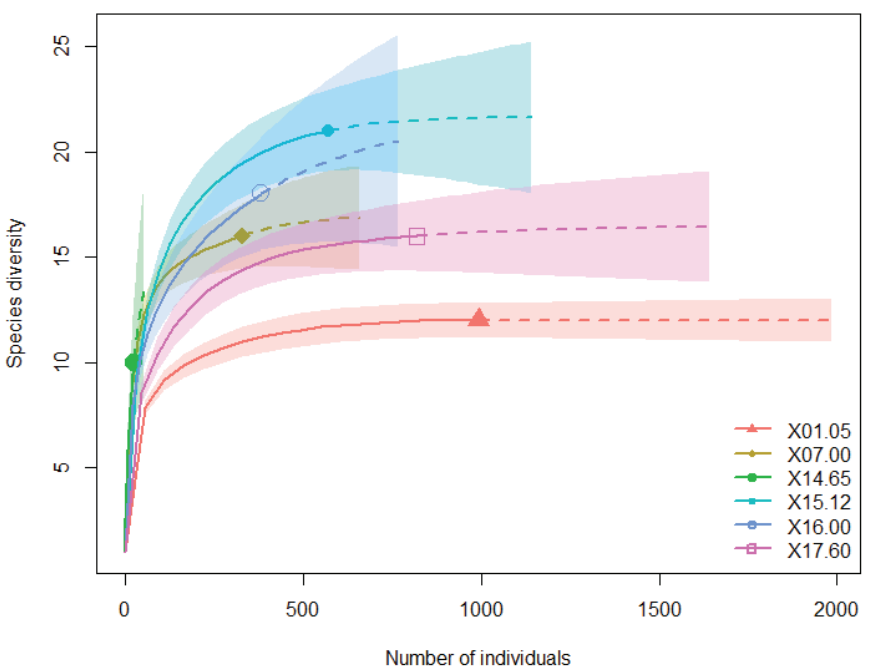

Fig. 7.2a: Rarefaction curves for the upper six mollusc assemblages. Species diversity stands for the number of species. Representative samples: 1.05 (Novocaspian), 7.00 (late Khvalynian), 15.12 (late Khvalynian), 17.6 (early Khvalynian). Not enough individuals for a true representation of richness: 14.65 (late Khvalynian), 16.00 (early Khvalynian).

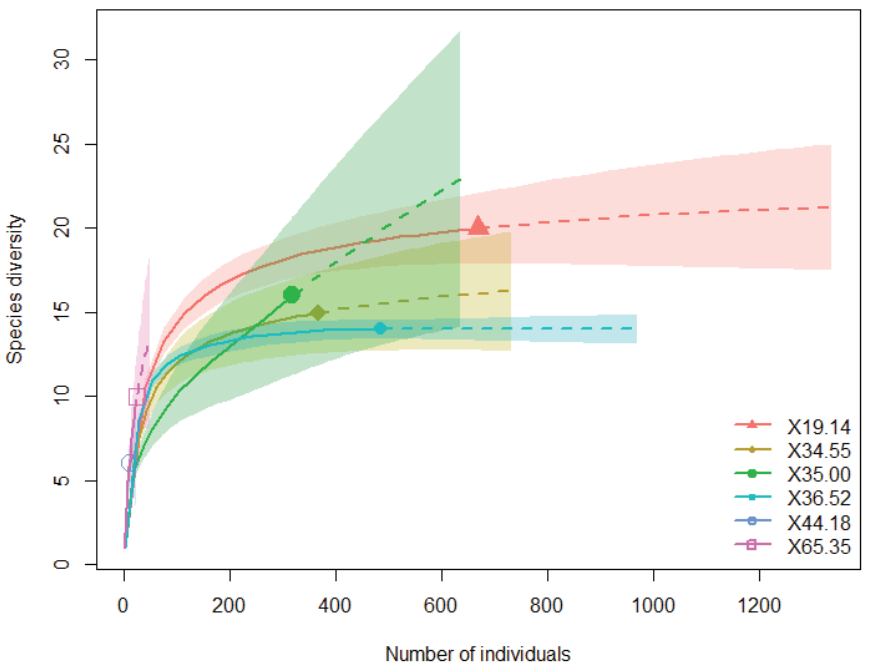

Fig. 7.2b: Rarefaction curves for the lower six mollusc assemblages. Species diversity stands for the number of species. Representative samples: 19.14 (early Khvalynian), 34.55 (Hyrcanian), 36.52 (late Khazarian). Not enough individuals for a true representation of richness: 35.00 (Hyrcanian), 44.18 (late Khazarian), 65.35 (early Khazarian). For each time period, except for the early Khazarian, there is at least one sample with enough individuals to give a good estimate of species diversity. 
The Late Khvalynian mollusc fauna contains 22 species (Table 7.1, Fig. 7.6) of which 21 are anomalohaline species and one is fresh water (Anisus spirorbis); the former are all of Pontocaspian origin (98\% endemic, $2 \%$ native). The majority of species (Turricaspia spica, Clessiniola variabilis, Dreissena elata, Monodacna caspia, and Didacna subcatillus) are able to live much deeper than -40 $\mathrm{m}$, but the presence of the grazing snail Theodoxus indicates the molluscs lived in the photic zone. Salinities are estimated at 5-8 psu based on the preference of the majority of species, but they all can live in salinities of up to 13 psu. The species that prefer deeper waters are represented only by very few individuals (Dreissena grimmi, Caspia baerii, Laevicaspia kolesnikoviana, Turricaspia andrussowi).

The Novocaspian sample includes 10 Pontocaspian species (Table 7.1, Fig. 7.7). Of these species 8 are endemic and 2 are native (Theodoxus pallasi and Ecrobia grimmi). The depth distribution of most species (Monodacna caspia, Dreissena. caspia, Adacna vitrea, Didacna barbotdemarnii, Theodoxus pallasi) ranges between 0-40 $\mathrm{m}$, whereas the presence of Turricaspia vinogradovi implies a maximum depth of only $10 \mathrm{~m}$. Salinity ranges are estimated at 2-8 psu, which are the optima for the majority of species. Theodoxus indicates conditions in the photic zone.

The modern mollusc assemblages of the NCOC monitoring project consist of 19 species (Table 7.2), of which 16 species are endemic to the Caspian Sea, two species are native, and three are marine invasive species. Of the total collected biomass of molluscs $\left(\mathrm{mg} / \mathrm{m}^{2}\right)$ collected over 11 years 31\% are Caspian Sea endemic, 20\% native Pontocaspian species that derive from the Black Sea region (Monodacna colorata) and 49\% belong to marine invasive species: Mytilaster minimus, Abra segmentum and Cerastoderma glaucum.

\section{Acknowledgements}

This research was part of the PRIDE (Pontocaspian RIse and DEmise) project, which has received funding from the European Union's Horizon 2020 research and innovation program, under the Marie Sklodowska-Curie [grant agreement No 642973]. We thank the University of Moscow for making the samples available. Many thanks go to Marjan Helwerda (Naturalis Biodiversity Center, Leiden) for assisting with mollusc samplessorting. 


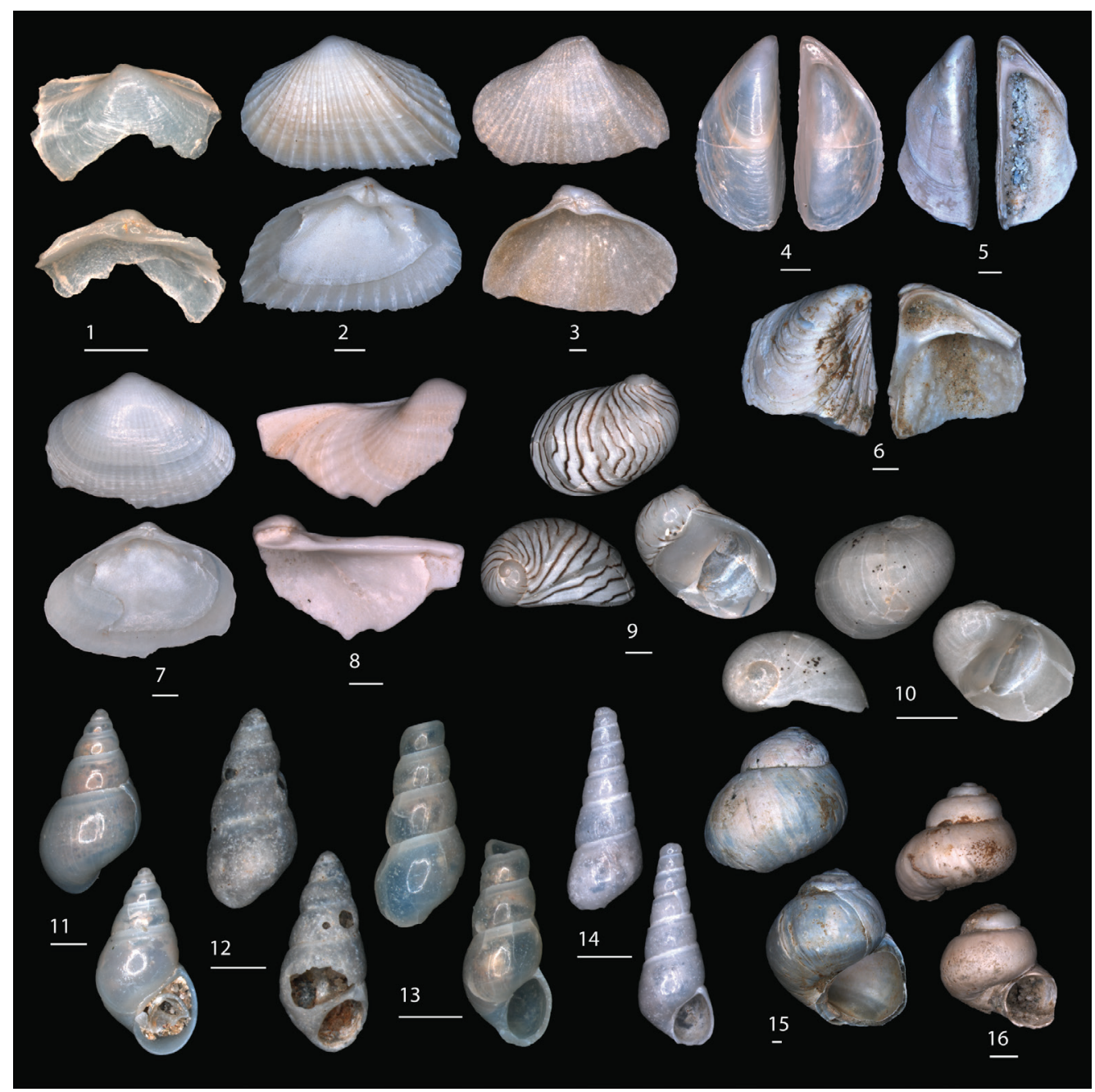

Fig. 7.3: Overview of late Khazarian Pontocaspian molluscs + two fresh water mollusc (15. \& 16.). 1. Adacna vitrea (depth 36.52-36.55 m, RGM.962422), 2. Didacna subcatillus (depth 36.52-36.55 m, RGM.962423), 3. Didacna sp. (depth 36.52-36.55 m, RGM.962424), 4. Dreissena caspia (depth 36.52-36.55 m, RGM.962425), 5. Dreissena cf. elata (depth 44.18-44.22 m, RGM.962434), 6. Dreissena grimmi (depth 44.18-44.22 m, RGM.962435), 7. Monodacna albida (depth 36.52-36.55 m, RGM.962426), 8. Monodacna caspia (depth 36.5236.55 m, RGM.962427), 9. Theodoxus cf. pallasi (depth 36.52-36.55 m, RGM.962428), 10. Theodoxus sp. (depth 36.52-36.55 m, RGM.962429), 11. Clessiniola variabilis (depth 36.52-36.55 m, RGM.962430), 12. Laevicaspia kolesnikoviana (depth 36.52-36.55 m, RGM.962431), 13. Turricaspia cf. fedorovi (depth 36.52-36.55 m, RGM.962432), 14. Turricaspia sp. (depth 36.52-36.55 m, RGM.962433), 15. Valvata goldfussiana (depth 44.1844.22 m, RGM.962436), 16. Valvata piscinalis (depth 44.18-44.22 m, RGM.962437). Scale bars $=1 \mathrm{~mm}$. 


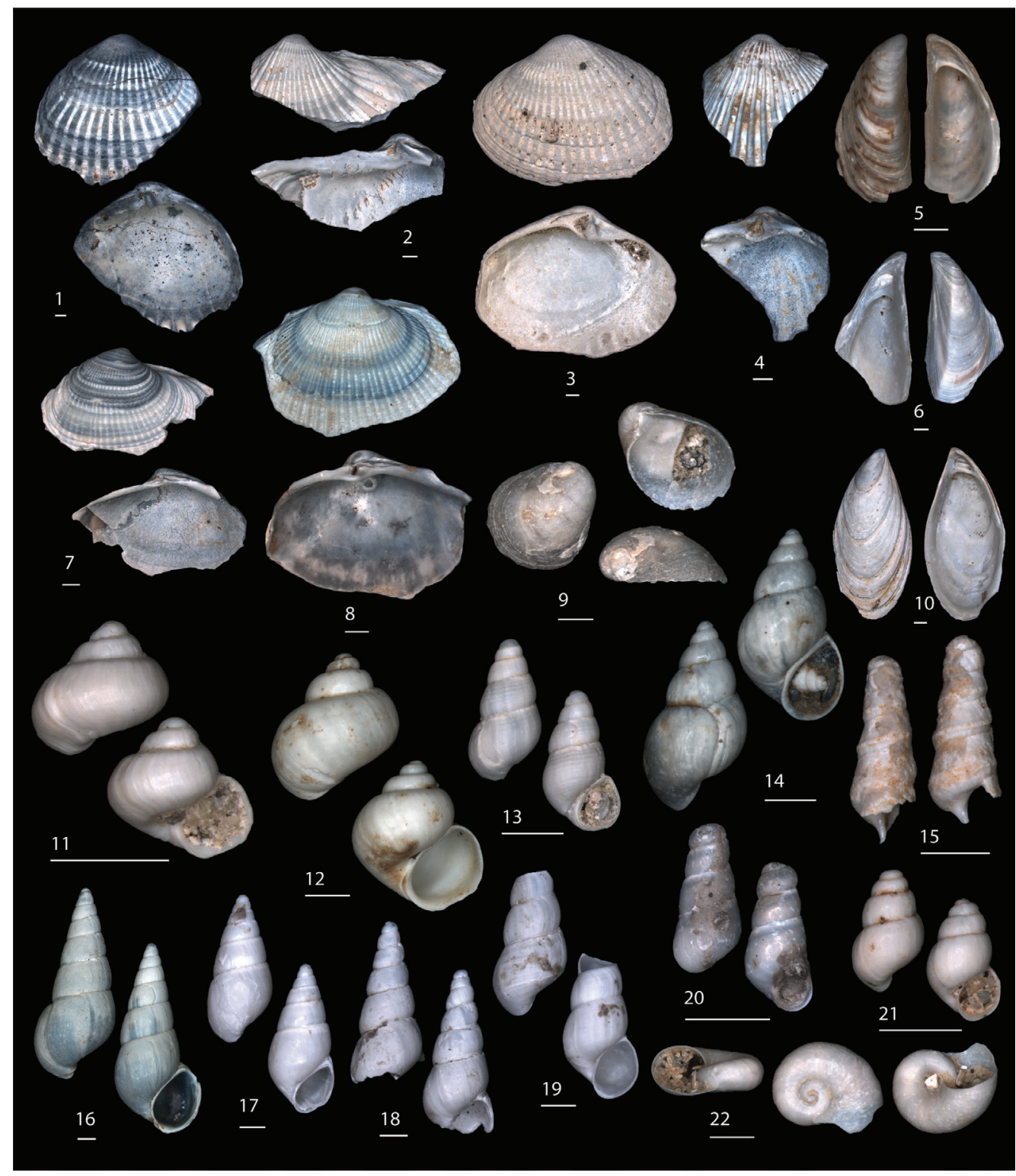

Fig. 7.4: Overview of the molluscs of the Hyrcanian stage. 1. Didacna baeri (depth 35.00-35.10 m, RGM.962446), 2. Didacna delenda (depth 34.55-34.60 m, RGM.962438), 3. Didacna subcatillus (depth 34.5534.60 m, RGM.962439), 4. Didacna sp. (depth 35.00-35.10 m, RGM.962447), 5. Dreissena caspia (depth 35.0035.10 m, RGM.962448), 6. Dreissena cf. elata (depth 35.00-35.10 m, RGM.962449), 7. Monodacna albida (depth 35.00-35.10 m, RGM.962450), 8. Monodacna caspia (depth 35.00-35.10 m, RGM.962451), 9. Theodoxus sp. (depth 34.55-34.60 m, RGM.962440), 10. Dreissena grimmi (depth 35.00-35.10 m, RGM.962452), 11. Andrusovia dybowskii (depth 34.55-34.60 m, RGM.962441), 12. Abeskunus brusinianus (depth 35.00-35.10 m, RGM.962454), 13. Clathrocaspia cf. gmelini (depth 34.55-34.60 m, RGM.962442), 14. Clessiniola variabilis 


\section{(continuation previous page)}

(depth 35.00-35.10 m, RGM.962455), 15. Turricaspia dimidiata (depth 34.55-34.60 m, RGM.962443), 16. Laevicaspia caspia (depth 35.00-35.10 m, RGM.962456), 17. Turricaspia grimmi (depth 35.00-35.10 m, RGM.962457), 18. Turricaspia meneghiniana (depth 35.00-35.10 m, RGM.962458), 19. Turricaspia? spica (depth 35.00-35.10 m, RGM.962459), 20. Turricaspia sp. (depth 35.00-35.10 m, RGM.962453), 21. Ulskia ulskii. (depth 34.55-34.60 m, RGM.962444), 22. Gyraulus eichwaldi (depth 34.55-34.60 m, RGM.962445). Scale bars = $1 \mathrm{~mm}$.

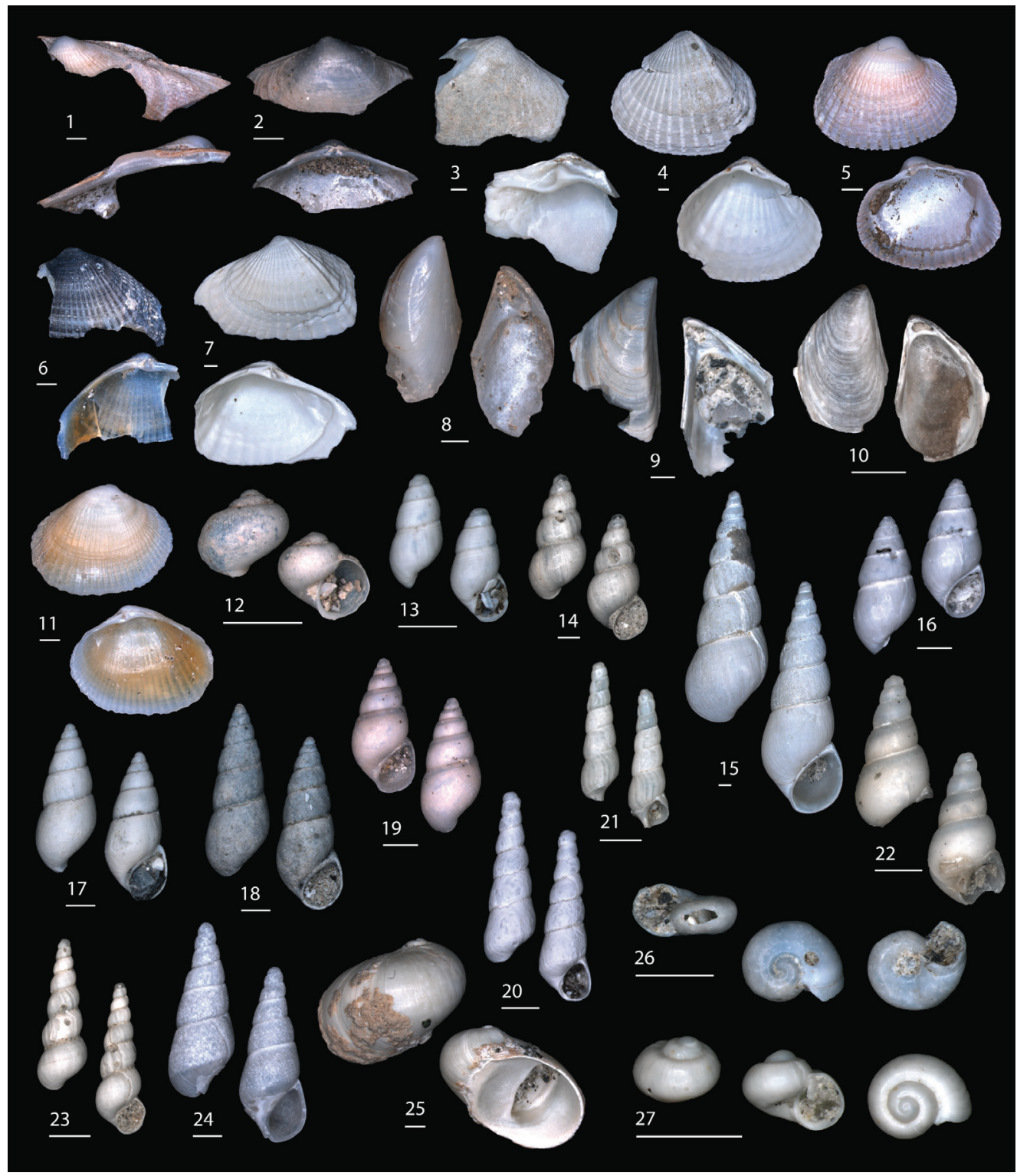


Fig. 7.5 (opposite page): Overview of the molluscs of the Early Khvalynian stage: 1. Adacna laeviuscula (depth 16.00-16.05 m, RGM.962460), 2. Adacna vitrea (depth 16.00-16.05 m, RGM.962461), 3. Didacna delenda (depth 19.14-19.22 m, RGM.962475), 4. Didacna ebersini (depth 19.14-19.22 m, RGM.962476), 5. Didacna obunca (depth 16.00-16.05 m, RGM.962462), 6. Didacna protracta (depth 16.00-16.05 m, RGM.962463), 7. Didacna subcatillus (depth 19.14-19.22 m, RGM.962477), 8. Dreissena caspia (depth 16.00-16.05 m, RGM.962464), 9. Dreissena cf. elata (depth 17.60-17.80 m, RGM.962472), 10. Dreissena grimmi (depth 16.00-16.05 m, RGM.962465), 11. Monodacna caspia (depth 16.00-16.05 m, RGM.962466), 12 Abeskunus brusinianus (depth 16.00-16.05 m RGM.962467), 13. Clathrocaspia cf. gmelini (depth 19.14-19.22 m, RGM.962478), 14. Ecrobia grimmi (depth 16.00-16.05 m, RGM.962468), 15. Laevicaspia caspia (depth 19.14-19.22 m, RGM.962479), 16. Laevicaspia cincta (depth 17.60-17.80 m, RGM.962473), 17. Laevicaspia conus (depth 19.14-19.22 m, RGM.962480), 18. Laevicaspia cf. lincta (depth 19.14-19.22 m, RGM.962481), 19. Laevicaspia kolesnikoviana (depth 16.00-16.05 m, RGM.962469), 20. Turricaspia andrussowi (depth 19.14-19.22 m, RGM.962483), 21. Turricaspia elegantula (depth 19.14-19.22 m, RGM.962482), 22. Turricaspia meneghiniana (depth 16.00-16.05 m, RGM.962470), 23. Turricaspia? spica (depth 16.00-16.05 m, RGM.962471), 24. Turricaspia cf. pulla (depth 17.60-17.80 m, RGM.962474), 25. Theodoxus sp. (depth 19.14-19.22 m, RGM.962484), 26. Gyraulus eichwaldi (depth 19.14-19.22 m, RGM.962485), 27. Andrusovia cf. andrusovi (depth 19.14-19.22 m, RGM.962486). Scale bars $=1 \mathrm{~mm}$.

Fig. 7.6 (next page): Overview of the molluscs of the Late Khvalynian stage: 1. Adacna laeviuscula (depth 07.00-07.54 m, RGM.962487), 2. Adacna vitrea (depth 15.12-15.19 m, RGM.962495), 3. Didacna cristata (depth 15.12-15.19 m, RGM.962496), 4. Didacna subcatillus (depth 15.12-15.19 m, RGM.962497), 5. Dreissena caspia (depth 15.12-15.19 m, RGM.962498), 6. Dreissena cf. elata (depth 15.12-15.19 m, RGM.962499), 7. Dreissena grimmi (depth 15.12-15.19 m, RGM.962500), 8. Hypanis plicata (depth 07.00-07.54 m, RGM.962488), 9. Monodacna albida (depth 07.00-07.54 m, RGM.962489), 10. Monodacna caspia (depth 07.00-07.54 m, RGM.962490), 11. Abeskunus brusinianus (depth 15.12-15.19 m, RGM.962501), 12. Caspia baerii (depth 15.1215.19 m, RGM.962502), 13. Clessiniola variabilis (depth 07.00-07.54 m, RGM.962491), 14. Ecrobia grimmi (depth 14.65-14.70 m, RGM.962494), 15. Laevicaspia kolesnikoviana (depth 15.12-15.19 m, RGM.962503), 16. Turricaspia sp. (depth 15.12-15.19 m, RGM.962504), 17. Turricaspia cf. andrussowi (depth 15.12-15.19 m, RGM.962505), 18. Turricaspia meneghiniana (depth 15.12-15.19 m, RGM.962506), 19. Turricaspia cf. pulla (depth 15.12-15.19 m, RGM.962507), 20. Turricaspia? spica (depth 15.12-15.19 m, RGM.962508), 21. Theodoxus cf. pallasi (depth 07.00-07.54 m, RGM.962492), 22. Anisus spirorbis (depth 07.00-07.54 m, RGM.962493). Scale bars $=1 \mathrm{~mm}$. 


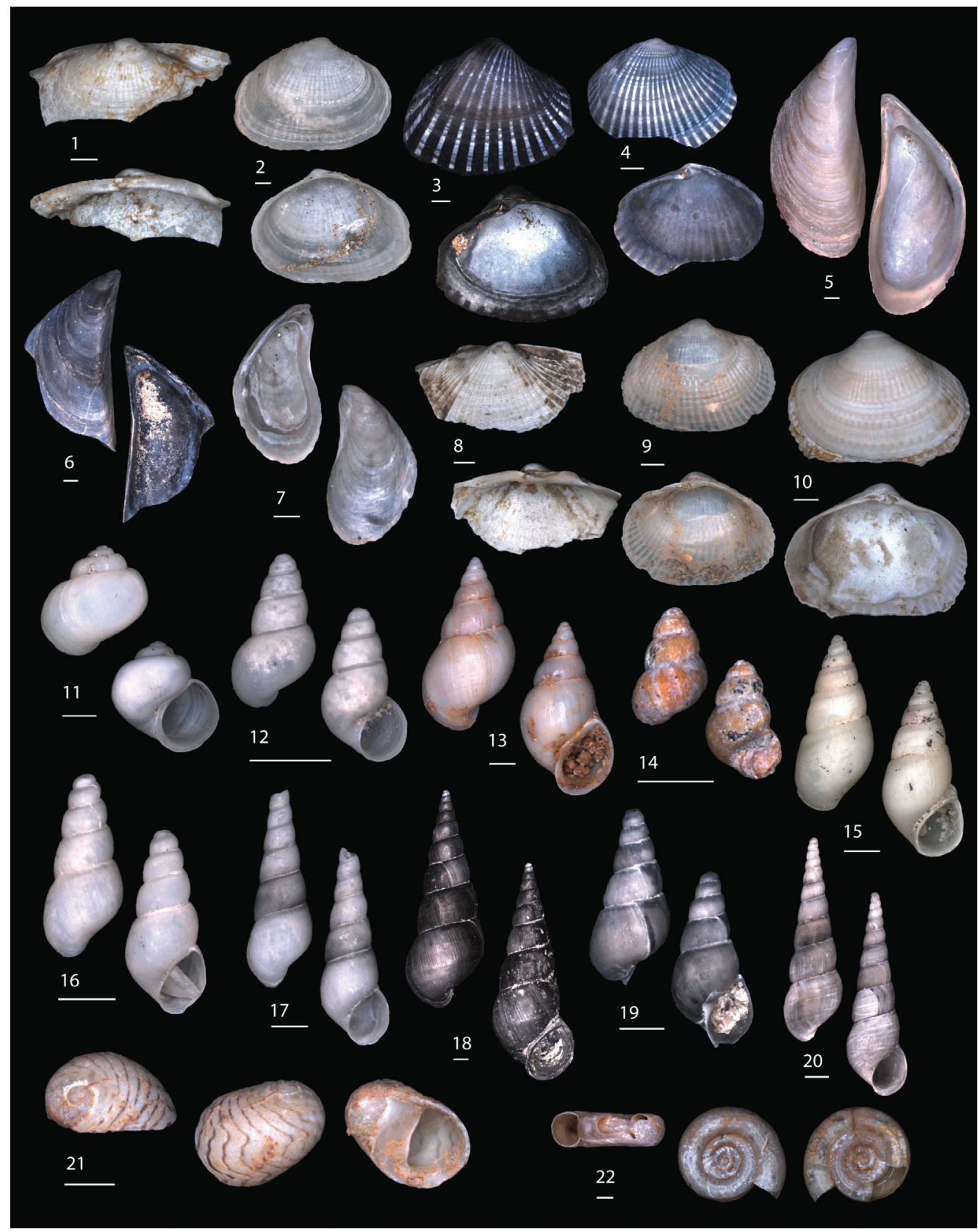

(Fig. 7.6: description on previous page) 


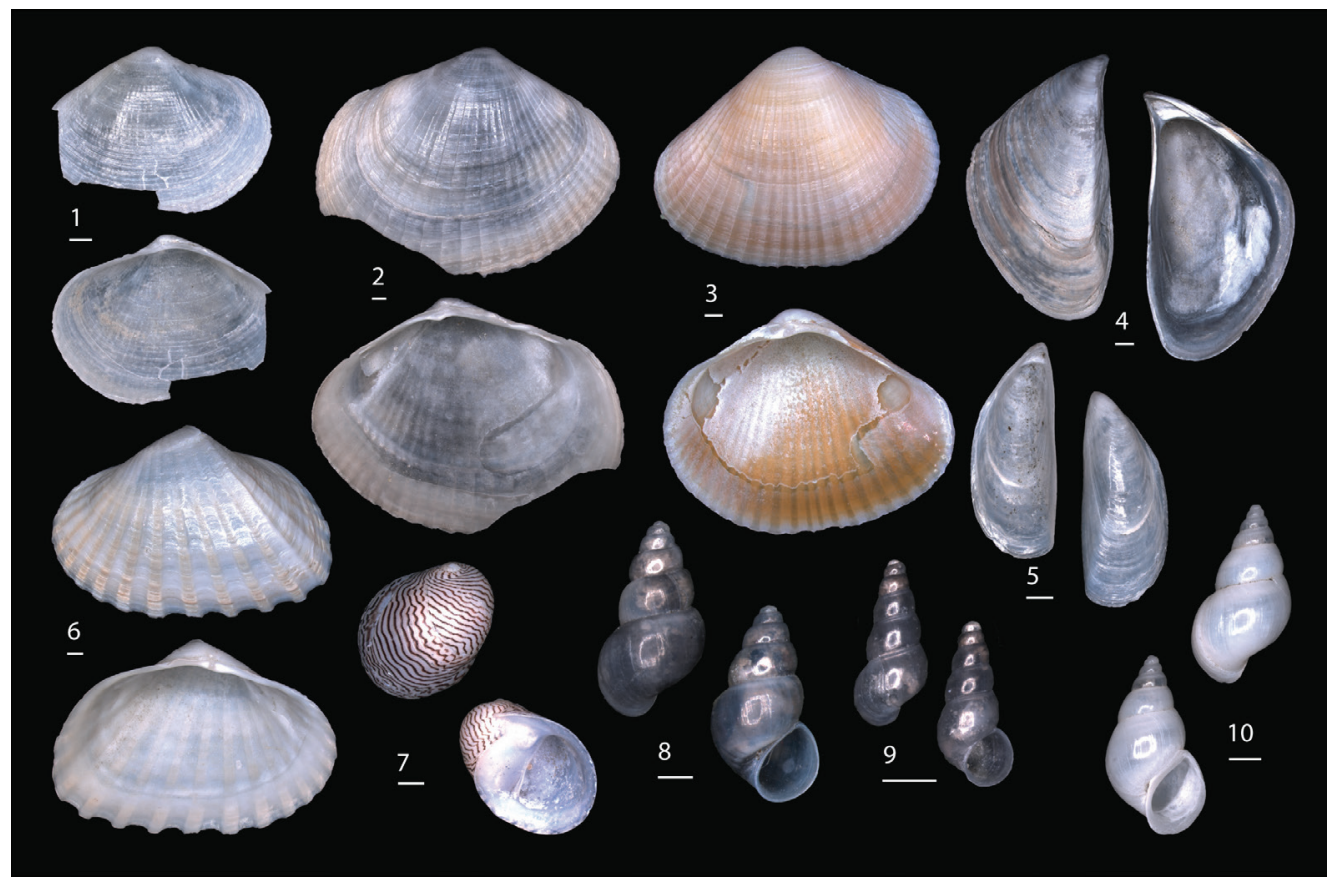

Fig. 7.7: Overview of the molluscs of the Novocaspian stage: 1. Adacna vitrea (depth 01.05-01.50 m,

RGM.962510), 2. Adacna laeviuscula (depth 01.05-01.50 m, RGM.962511), 3. Monodacna caspia (depth 01.0501.50 m, RGM.962509), 4. Dreissena cf. elata (depth 01.05-01.50 m, RGM.962512), 5. Dreissena caspia (depth 07.00-07.54 m, RGM.962513), 6. Didacna barbotdemarnii (depth 01.05-01.50 m, RGM.962514), 7. Theodoxus cf. pallasi (depth 01.05-01.50 m, RGM.962515), 8. Ecrobia grimmi (depth 01.05-01.50 m, RGM.962516), 9. Turricaspia cf. vinogradovi (depth 01.05-01.50 m, RGM.962517), 10. Clessiniola variabilis (depth 01.05-01.50 m, RGM.962518). Scale bars $=1 \mathrm{~mm}$. 


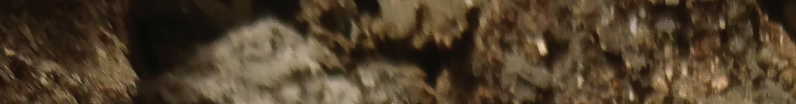

\section{$9 u^{4}, f^{-2}+9$}

$5+20+2$.

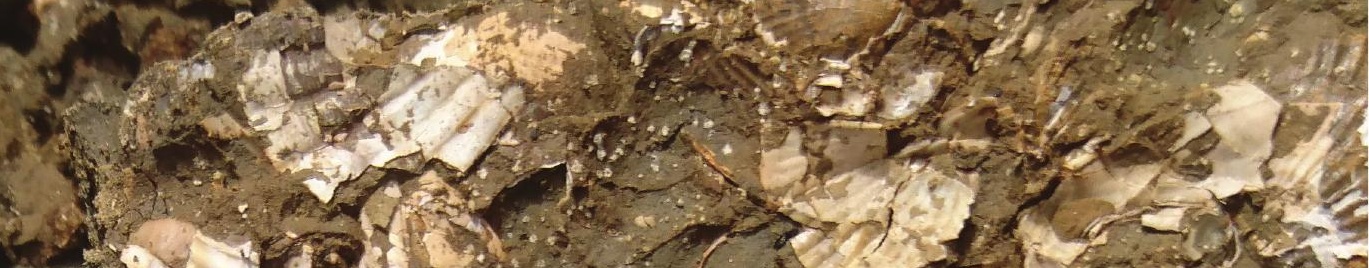

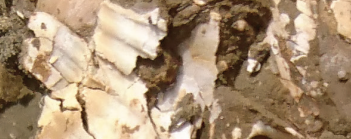
- ind

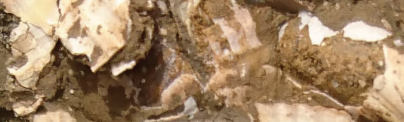

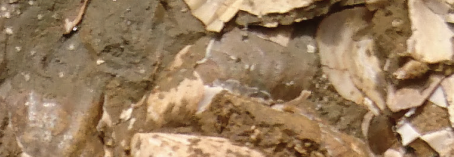

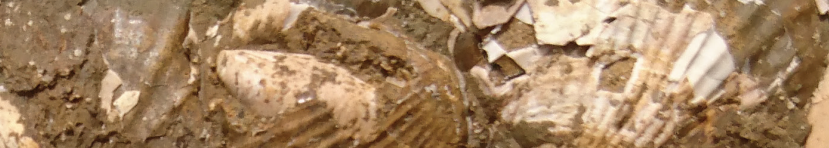

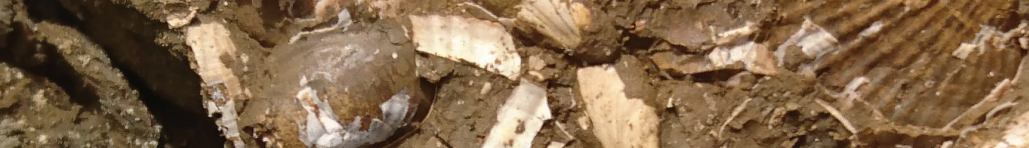

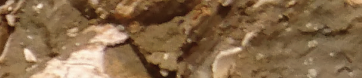

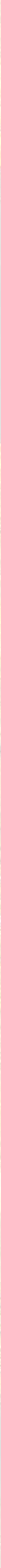




\title{
LATE Holocene MOLLUSC BIODIVERSITY OF THE WESTERN BLACK SEA (RAZIM-SiNOIE LAKE, ROMANIA)
}

\section{Published as:}

van de Velde, S., Jorissen, E.L., Neubauer, T.A., Radan, S., Pavel, A.B., Stoica, M., Van Baak, C.G.C., Martínez Gándara, A., Popa, L.O., de Stigter, H., Abels, H.A., Krijgsman, W., Wesselingh, F.P., 2019. A conservation palaeobiological approach to assess faunal response of threatened biota under natural and anthropogenic environmental change. Biogeoscience 16, 2423-2442. http://doi.org/10.5194/ bg-2019-2423-2019

\begin{abstract}
Palaeoecological records are required to test ecological hypotheses necessary for conservation strategies as short-term observations can insufficiently capture natural variability and identify drivers of biotic change. Here, we demonstrate the importance of an integrated conservation palaeobiology approach when making validated decisions for conservation and mitigating action. Our model system is the Razim-Sinoie lake complex (RSL) in the Danube Delta (Black Sea coast, Romania), a dynamic coastal lake system hosting unique Pontocaspian mollusc species that are now severely under threat. The Pontocaspians refer to an endemic species group that evolved in the Black Sea and Caspian Sea basins under reduced salinity settings over the past few million years. The natural, pre-industrial RSL contained a salinity gradient from fresh to mesohaline (18 ppm) until human intervention reduced the inflow of mesohaline Black Sea water into the lake system. We reconstruct the evolution of the RSL over the past 2000 years from integrated sedimentary facies and faunal analyses based on 11 age-dated sediment cores and investigate the response of mollusc species and communities to those past environmental changes. Three species associations ("marine", "Pontocaspian" and "freshwater") exist and their spatio-temporal shifts through the system are documented. Variable salinity gradients developed, with marine settings (and faunas) dominating in the southern part of the system and freshwater conditions (and faunas) in the northern and western parts. Pontocaspian species have mostly occurred in the centre of the RSL within the marinefreshwater salinity gradient. Today, freshwater species dominate the entire system, and only a single Pontocaspian species (Monodacna colorata) is found alive. We show that the human-induced reduced marine influence in the system has been a major driver of the decline of the endemic
\end{abstract}


Pontocaspian biota. It urges improved conservation action by re-establishing a salinity gradient in the lake system to preserve these unique species.

\subsection{Introduction}

The emerging field of conservation palaeobiology aims to evaluate palaeobiological records to make informed contributions to biodiversity conservation. A spectrum of conservation palaeobiology studies exists covering different time scales as well as biota (Birks, 2012; Dietl and Flessa, 2011; Kosnik and Kowalewski, 2016; Vegas-Vilarrubia et al., 2011). These provide important insights into resilience of species and communities under environmental change. Yet, few studies provide longterm observations, quantitative and environmental data, as well as direct guidance to conservation of threatened habitats and communities today (Cramer et al., 2017). A relevant conservation palaeobiology model system should ideally include species and communities that are currently under threat, together with a high spatio-temporal resolution geological record of past habitat dynamics, and should contain both natural variation and anthropogenic influence. Altogether the data should not only focus on scientific observations and understanding, but also contribute to conservation policies with relevant proposals for ecosystem management (Albano et al., 2016; Helama et al., 2007; Kosnik and Kowalewski, 2016; Martinelli et al., 2017; Vegas-Vilarrubia et al., 2011).

Here, we report a unique conservation palaeobiology model system that combines a detailed historical record of environmental and faunal change with relevant proposals for conservation. The Razim-Sinoie lake complex (RSL) consists of a set of coastal lakes and lagoons located in the south of Danube Delta along the Black Sea in Romania (Fig. 8.1). The system has a dynamic late Holocene history of lake and barrier formation and of connectivity with the Danube River, as well as the Black Sea, that affected salinity gradients (Gâştescu, 2009; Giosan et al., 2006; Panin et al., 2016; Panin and Jipa, 2002; Romanescu, 2013; Vespremeanu-Stroe et al., 2017). Since ancient Greek times, shipping ports have been present in the RSL (Bony et al., 2015; Breţcan et al., 2008; Romanescu, 2013), and from 1800 onwards, active human modification of the river and marine outlets shaped the system towards its present state (Breţcan et al., 2009, 2008). The RSL is known as prime habitat for currently threatened Pontocaspian species (Grossu, 1973; Popa et al., 2010, 2009). Within the area of the Danube Delta, a strong reduction of Pontocaspian species occurrences has been documented for the past decades (Alexandrov et al., 2004; Popa et al., 2009). Before 1956, about 70\% of the species living in the benthic zone had a Pontocaspian origin, and remaining species belonged to other brackish or freshwater species (Teodorescu-Leonte et al., 1956). After 2000, this relationship shifted completely and the dominant forms seem to be freshwater species (Catianis et al., 2018).

We aim to build a palaeobiological record from sediment cores in the RSL that shows faunal responses to past natural and human-induced environmental variations. Insight into faunal development and resilience has direct relevance for outlining conservation strategies for Pontocaspian biota. The RSL is uniquely equipped for this study as it is one of the largest areas 

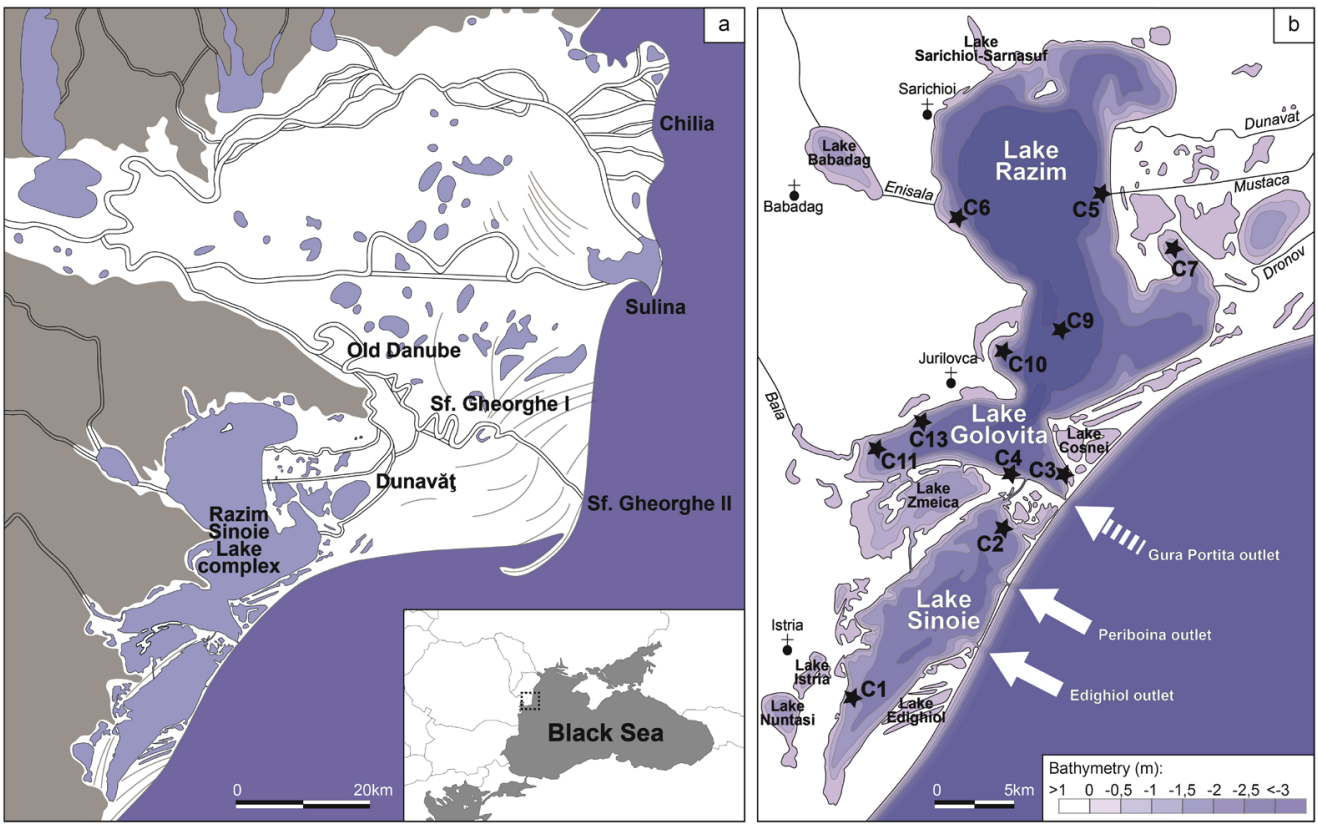

Fig. 8.1: Location of study area along the Romanian Black Sea coast with core locations indicated by black stars. (a) Danube Delta and RSL (modified after Vespremeanu-Stroe et al., 2017). (b) RSL bathymetry with location of study cores (modified after Dimitriu et al., 2008). Two current marine outlets are indicated by white arrows; a third outlet (Gura Portita) was closed in the 1970s and is indicated by a dashed white arrow.

where threatened Pontocaspian biota still occur in the Black Sea basin and contains a detailed late Holocene geological record of faunal and environmental change.

\subsection{Regional setting}

Over the past millennia, the RSL has evolved from a restricted marine embayment south of the Danube Delta into the highly restricted lake system of today (Vespremeanu-Stroe et al., 2017) (Fig. 8.1a). Much of the restriction has been attributed to prograding beach-barriers that were fed by sediments brought by longshore currents from eroding Danubian deltaic lobes in the north (Dan et al., 2009; Giosan et al., 2006; Panin, 1997, 1989; Panin and Jipa, 2002; Ștefănescu, 1981; Vespremeanu-Stroe et al., 2013). Today, the RSL contains several large and many small shallow lakes of a maximum depth of $3.5 \mathrm{~m}$ and is supplied with fresh water and sediments from the Dunavăţ Branch (Rădan et al., 1999).

Small-scale human modifications have occurred in the system since the ancient Greeks dredged and modified access from the Black Sea to the ports of Istros (Histria) and Orgame (Argamum) (Bony et al., 2015; Breţcan et al., 2008; Romanescu, 2013). Major anthropogenic modifications impacted the system in the $20^{\text {th }}$ century to increase freshwater aquaculture production. The digging 
of two channels between the RSL and the southern Danube branch during the first three decades of the $20^{\text {th }}$ century and seven additional channels around 1950 (Breţcan et al., 2009; Romanescu and Cojocaru, 2010) increased river influence in the RSL. At the same time, access to the Black Sea became restricted by the closure of the Gura Portiţa outlet around 1960-1970 (Breţcan et al., 2009; Breţcan and Tâmpu, 2008). Today, the Periboina and Edighiol channels remain the only (and highly restricted) connections between Lake Sinoie and the marine realm. As a result, the RSL has considerably freshened over the past 100 years (Catianis et al., 2018; Stănică, 2011).

Prior to major anthropogenic modifications, the RSL contained a salinity gradient between the northern-central parts, dominated by fresh water, and the southern part, where elevated salinities occurred (Breţcan et al., 2009). The northern-central part consists of the three main lakes Razim (or Razelm), Golovița and Zmeica, and several marginal lakes such as Agighiol, Babadag, Coșna and Leahova. Salinities in this part of the system were reported between 0.4 and $2.5 \mathrm{~g} / \mathrm{L}$ (Vadineanu et al., 1997). The southern part comprises the main lake, Sinoie (also known as Sinoe), and a number of shallow and smaller lakes such as Istria, Nuntași and Edighiol. Here, salinities ranged between 0.5 and $6.5 \mathrm{~g} / \mathrm{L}$ in the late $20^{\text {th }}$ century (Vadineanu et al., 1997). Over the past decade, the entire system has become almost entirely fresh water: expeditions led by GeoEcoMar in 2017 estimated 0 psu in the northern-central parts based on mollusc species salinity tolerances and measured 0.1$0.6 \mathrm{psu}$ in the southern part (Table S1 in the Supplement). Salinity may vary seasonally depending on freshwater input from the Danube and through variations in storm activity over the Black Sea, causing additional mesohaline water to enter the RSL through the marine outlets (Breţcan et al., 2008; Dinu et al., 2015).

The RSL has been reported as prime habitat area for Pontocaspian species (Grossu, 1973; Popa et al., 2010, 2009), including endemic molluscs, ostracods, dinoflagellates, fish and crustaceans. Pontocaspian biota are a unique group of aquatic species that evolved within the Caspian Sea and Black Sea basins, as well as surrounding rivers and lakes, over the past few million years (Krijgsman et al., 2019). The basins experienced strong base-level changes and periods of isolation and connection from the open ocean, characterised by variable, anomalohaline ("brackish") conditions (Grigorovich et al., 2003; Kosarev and Yablonskaya, 1994; Kurbanov et al., 2014; Yanina, 2014). Ever since the Middle Pleistocene, during times of interglacial sea-level highstands (similar to present day), marine conditions and faunas occupied the main Black Sea basin and pushed Pontocaspian species into coastal habitats such as deltas, lagoons and estuaries. During glacial lowstands, the Black Sea became isolated from the open ocean, freshened, and Pontocaspian biota occupied the entire basin (Krijgsman et al., 2019). Today, Pontocaspian biota in the Black Sea basin are restricted to relatively small areas in lagoons, estuaries and deltas with salinity gradients along the coasts of Romania, Ukraine and Russia (including the Sea of Azov; Anistratenko, Khaliman, \& Anistratenko, 2011; Mordukhai-Boltovskoi, 1979). Of these restricted areas, the RSL offers the largest area of Pontocaspian habitat. Pontocaspian species are currently under threat through habitat modification, pollution, poaching and invasive species (Popa et al., 2009; Shiganova, 2010; Zarbaliyeva et al., 2016) 


\subsection{Material and methods}

We performed facies and fauna analyses on 11 shallow sediment cores. Because the RSL lakes are very shallow they do not allow for boats with piston core facilities. We manually took PVC cores with a diameter of $7.5 \mathrm{~cm}$ and lengths between $0.5 \mathrm{~m}$ and $1.95 \mathrm{~m}$ at water depths of 1.0 to $3.5 \mathrm{~m}$ during two expeditions in October 2015 and July 2016 (Fig. 8.1b; Table 8.1). By pushing the pipes in the soft sediment and ensuring they were sealed, we were able to create a vacuum when retrieving the cores. Deformation along the core edges was minimal. Sedimentary structures like horizontal beddings were conserved within the sediments proving that the sampling method was successful and representative of changes through time and space of the depositional environment. The cores were cut lengthwise in half back in the laboratory. Analyses were performed on one half; the other half was archived in a cold room at Utrecht University.

An age model was constructed using a variety of dating methods, including ${ }^{14} \mathrm{C}$ measurements, analysis of downcore distribution of ${ }^{210} \mathrm{~Pb}$, palaeomagnetic secular variations and a known first occurrence date of an invasive species. Five samples were dated with ${ }^{14} \mathrm{C}$ measurements in the Center for Isotope Research at Groningen University. Dating results were calibrated based on a time range with a $95 \%$ probability obtained from two reservoir ages. The ${ }^{14} \mathrm{C}$ ages have been calibrated to calendar years with the software program OxCal version 4.3 (Ramsey, 2017), using the calibration curve IntCal13 (Reimer et al., 2013). For the late Holocene, reservoir ages have been estimated at approximately 450 to 550 years in the Danube Delta (Bonsall et al., 2004) and between 250 and 500 years in the Black Sea (Kwiecien et al., 2008). For more information on the ${ }^{14} \mathrm{C}$ dated species see Table S9.

The downcore distribution of ${ }^{210} \mathrm{~Pb}$ was assessed on four cores in the Ocean Systems Department of NIOZ, Texel. Isotopic decay of ${ }^{210} \mathrm{~Pb}$ (half-life 22.3 years) was measured via its granddaughter radionuclide ${ }^{210} \mathrm{Po}$. We applied a sampling resolution of $6 \mathrm{~cm}$ in the upper $14 \mathrm{~cm}$ of each core, and a sampling resolution of $12 \mathrm{~cm}$ below. Measurements were performed on wet-sieved $<63 \mu \mathrm{m}$ sediment fractions. Sediments were spiked with $1000 \mu \mathrm{l}$ of a standard solution of ${ }^{209} \mathrm{Po}$ and leached at $105^{\circ} \mathrm{C}$ for $6 \mathrm{~h}$ in a $10 \mathrm{ml}$ solution of concentrated hydrochloric acid. After diluting with $40 \mathrm{ml}$ of demineralized water and $5 \mathrm{ml}$ of ascorbic acid, silver platelets were immersed and left in the solution at $80^{\circ} \mathrm{C}$ for $15 \mathrm{~h}$ in order to collect the natural ${ }^{210} \mathrm{Po}$ and the added ${ }^{209} \mathrm{Po}$ by spontaneous electrochemical deposition. The Po radionuclides were then counted by a Canberra alpha detector. The sediment depths with excess ${ }^{210} \mathrm{~Pb}$ decayed to below detection level were used as age tie point of 150 yrs BP.

We performed palaeomagnetic analyses on core C3 at the Palaeomagnetic Laboratory Fort Hoofddijk at Utrecht University. Oriented $0.5 \mathrm{~cm}^{3}$ plastic cubes were pushed in the sediment core in two overlapping rows giving an average sampling resolution of $0.5 \mathrm{~cm}$. The sediments in these cubes were then stepwise demagnetized using alternating fields (AFs) up to a maximum of $100 \mathrm{mT}$ on a robotized sample handler controller attached to a horizontal 2G Enterprises DC SQUID cryogenic 
Table 8.1: Core data.

\begin{tabular}{|c|c|c|c|c|c|c|}
\hline Expedition & Core & Latitude & Longitude & Lake & Water depth (m) & Core length $(\mathrm{m})$ \\
\hline 2015 & $\mathrm{C} 1$ & $44.538111^{\circ} \mathrm{N}$ & $28.778583^{\circ} \mathrm{E}$ & Sinoie & 1.10 & 0.97 \\
\hline 2015 & $\mathrm{C} 2$ & $44.665944^{\circ} \mathrm{N}$ & $28.937139^{\circ} \mathrm{E}$ & Sinoie & 1.90 & 1.20 \\
\hline 2015 & $\mathrm{C} 3$ & $44.694194^{\circ} \mathrm{N}$ & $28.995028^{\circ} \mathrm{E}$ & Golovița & 0.80 & 1.19 \\
\hline 2015 & $\mathrm{C} 4$ & $44.698000^{\circ} \mathrm{N}$ & $28.937167^{\circ} \mathrm{E}$ & Golovița & 0.50 & 1.10 \\
\hline 2015 & $\mathrm{C} 5$ & $44.893472^{\circ} \mathrm{N}$ & $29.036167^{\circ} \mathrm{E}$ & Razim & 2.40 & 0.59 \\
\hline 2015 & $\mathrm{C} 6$ & $44.872722^{\circ} \mathrm{N}$ & $28.874194^{\circ} \mathrm{E}$ & Razim & 1.50 & 1.20 \\
\hline 2016 & $\mathrm{C} 7$ & $44.863889^{\circ} \mathrm{N}$ & $29.096944^{\circ} \mathrm{E}$ & Razim & 1.30 & 1.16 \\
\hline 2016 & $\mathrm{C} 9$ & $44.800000^{\circ} \mathrm{N}$ & $28.987778^{\circ} \mathrm{E}$ & Razim & 3.50 & 0.60 \\
\hline 2016 & $\mathrm{C} 10$ & $44.789167^{\circ} \mathrm{N}$ & $28.918056^{\circ} \mathrm{E}$ & Razim & 1.70 & 1.60 \\
\hline 2016 & $\mathrm{C} 11$ & $44.714444^{\circ} \mathrm{N}$ & $28.786111^{\circ} \mathrm{E}$ & Golovița & 1.50 & 1.92 \\
\hline 2016 & $\mathrm{C} 13$ & $44.736667^{\circ} \mathrm{N}$ & $28.844444^{\circ} \mathrm{E}$ & Golovița & 1.50 & 1.95 \\
\hline
\end{tabular}

magnetometer (Mullender et al., 2016). Changes in the magnetisation direction were recorded along the core and compared with regional archaeomagnetic data (Kovacheva et al., 2014, 1998).

Finally, the first arrival of the invasive snail Potamopyrgus antipodarum in Europe in 1859 (Ponder, 1988) provided an additional maximum age tie point. The species is originally from New Zealand, and the chronology of its introduction in other parts of the world is well known. It was introduced around 1859 to England, in 1872 to Tasmania, in 1895 to mainland Australia, in ca. 1900 to the European mainland (Ponder, 1988), and in 1987 to North America (Zaranko et al, 1997). The first reports of $P$. antipodarum from sites closest to the RLS come from Romania in 1951 (Son, 2008) and the Black Sea in 1952 (Gomoiu et al, 2002). As the first detection of an alien species possibly post-dates the timing of its true arrival (Albano et al, 2018; Crooks, 2005), we use the earliest known arrival date of 1859 in Europe and not the first report of arrival in the Black Sea. We checked the consistency of the age model by recalculating the model with the Black Sea arrival date to see if a possible time lag would severely affect our model and conclusions. We calculated sedimentation rates for all cores with dates available and extended the results to the remaining cores through correlation of sedimentary facies.

Sedimentary facies were characterized using lithological and sedimentological criteria and used to develop a facies model. Cores were digitally photographed and logged at a millimetre-scale. Sediment colours were defined using the Munsell Soil Color Charts. Sedimentary features such as grain size variations, laminations and cross-stratification were described. Various types of inclusions were documented, such as the presence of shells, organic material and trace fossils. Detailed sedimentological observations permitted the understanding of variations in depositional energy regimes and sedimentary processes and helped to track palaeoenvironments through time.

Mollusc samples, consisting of a block of sediment of $1 \mathrm{~cm}$ thickness and $5 \mathrm{~cm}$ diameter, were taken at $6 \mathrm{~cm}$ intervals. Samples were washed and wet-sieved over a $0.5 \mathrm{~mm}$ sieve. Samples rich in fauna (estimated $>300$ specimens) were split to facilitate counting. Molluscs were identified to species level and the number of individuals for each species was counted. For bivalves, one valve was 
counted as half an individual, whereas for gastropods, a fragment with a protoconch was considered one individual. Final counts were rounded up to the next integer. Species were classified into groups with different salinity requirements corresponding to their different evolutionary origins (i.e. freshwater, Pontocaspian and marine), to be able to follow the threatened Pontocaspian species through time and space (Table S2).

For the current species distribution within the RSL, we used qualitative data of three expeditions carried out in 2015, 2016 and 2017 (Table S1). Van Veen grab samples and dredge samples from 77 stations obtained during a 2017 survey of GeoEcoMar (the National Institute for Research and Development of Marine Geology and Geoecology, Romania), were investigated for living molluscs. Together with the data from two surveys in 2015 and 2016 by members of the team of authors specifically in search for living Pontocaspian molluscs in the RSL, a distribution map of species was made.

We used three taphonomic criteria on the mollusc faunas to score for the fidelity of samples, i.e. fragmentation, dissolution and abrasion (details in Table S3). These characters yield information about transport, energy and post-burial processes like compaction and dissolution and may point to reworking or time-averaging of a sample (Erthal et al., 2011; Kidwell, 2013). Samples with high taphonomic alteration (any of the three taphonomic scores higher than 3; Table S3) were excluded from statistical analyses as they are likely to represent time-averaged or mixed assemblages.

For palaeosalinity estimates, we used published autecological tolerances of species (Table S2). However, published upper salinity tolerances are often laboratory-based or derive from the unique Baltic Sea (Zhadin, 1952) and are not very informative as to the actual preferences of species in the RSL. We therefore assigned species to their optimum salinity habitat within the system: freshwater, lower or upper oligohaline and lower or upper mesohaline (sensu Strydom, Whitfield and Wooldridge, 2003, Table S2). The Black Sea has a salinity of $18 \mathrm{psu}$, which is used as the maximum salinity in our classification, although the salinity in the southern portion of the RSL is occasionally higher due to extensive summer evaporation (Dinu et al., 2015).

We performed a variety of multivariate analyses and statistical tests to explore the spatiotemporal species distribution and associations and test for potential associations with environmental variables. Samples with fewer than 30 specimens were excluded from the analyses to avoid the effect of small sample size on species richness.

The similarity among species compositions of individual samples was explored by means of a non-metric multidimensional scaling (nMDS). Data were square rooted and subjected to Wisconsin double standardisation, where species are first standardised by maxima and then the samples by sample totals. The nMDS was computed from a Bray-Curtis dissimilarity matrix. Salinity (i.e. weighted average of species' optimum salinity per sample) and grain size (using the upper bound of each category following the Wentworth scale) were fitted as 2D surfaces to the nMDS ordination plot to test if differences in species compositions are related to these parameters (compare Hauffe et al., 2011; Neubauer, Harzhauser, Mandic, Kroh, \& Georgopoulou, 2016). The applied surface fitting 

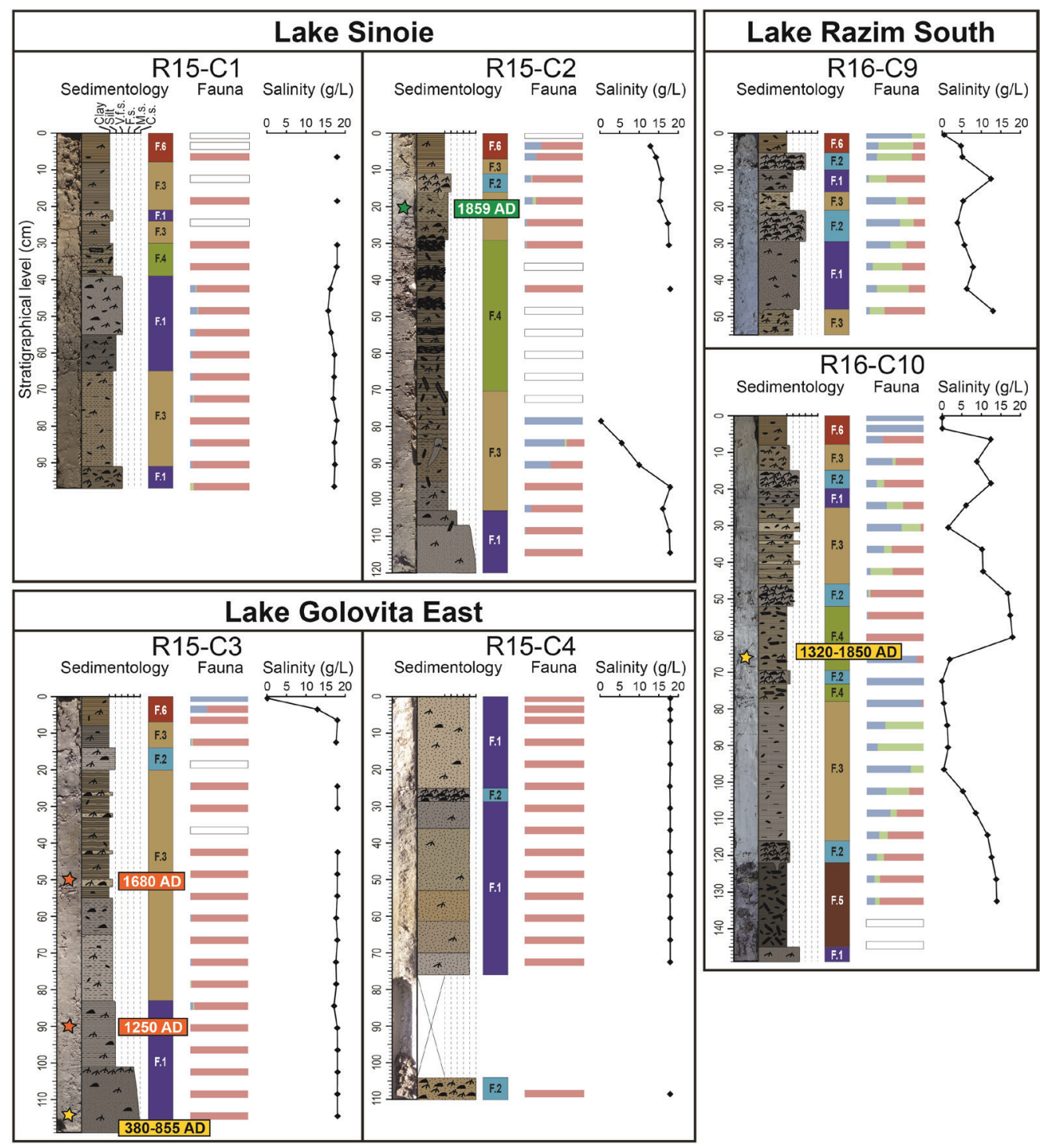

Fig. 8.2a: Overview of core data. From left to right each core: core photograph, sedimentology (lithology), facies, fauna relative abundance per species group based on origin \& evolution and estimated palaeosalinities.

uses restricted maximum likelihood estimation and an isotropic smoother employing thin-plate regression splines. For visualization purposes, the nMDS plot was rotated so that the first axis is parallel to the salinity gradient and the second to grain size.

$K$-means partitioning was used to determine if the three evolutionary species groups correspond to ecological communities (Legendre, 2005). The data were Hellinger-transformed, i.e. 

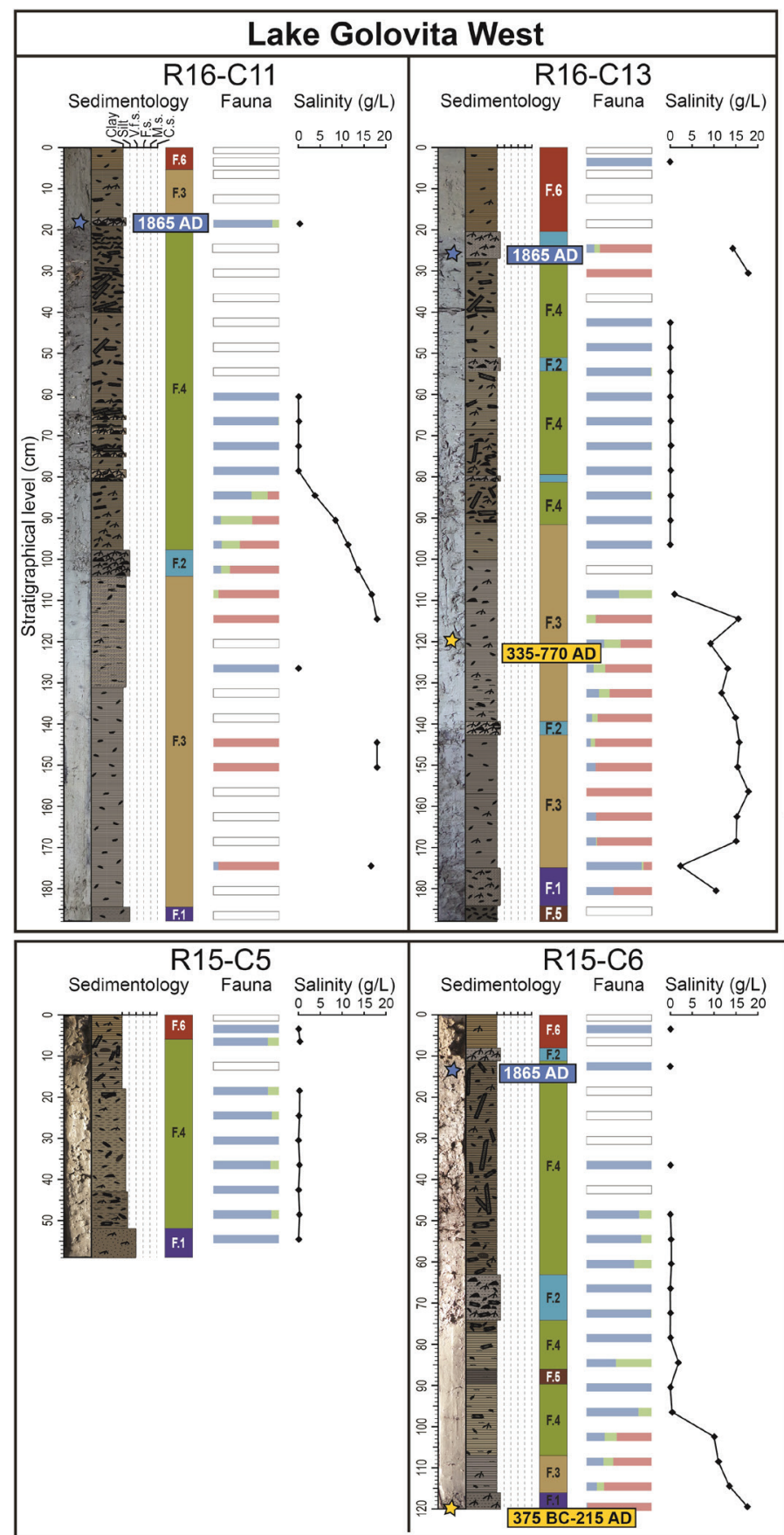

LEGEND:

SEDIMENTARY FACIES

F.1 Facies 1: sands

F.2 Facies 2: shell-rich sands

F.3 Facies 3: laminated clays/silts

F.4 Facies 4: organic-rich clays/silts

F.5 Facies 5: organic-rich black clays

7.6 Facies 6: oxidized clays

DATING METHODS

\) Stable isotopes ${ }^{14} \mathrm{C}$

Stable isotopes ${ }^{210} \mathrm{~Pb}$

六 Magnetostratigraphy

Introduction of Potamopyrgus

\section{FAUNA INDICATION}

\section{$\square$ Freshwater species}

Marine species

Pontocaspian species

No data

\section{Lake Razim North} R16-C7

Sedimentology Fauna Salinity $(\mathrm{g} / \mathrm{L})$

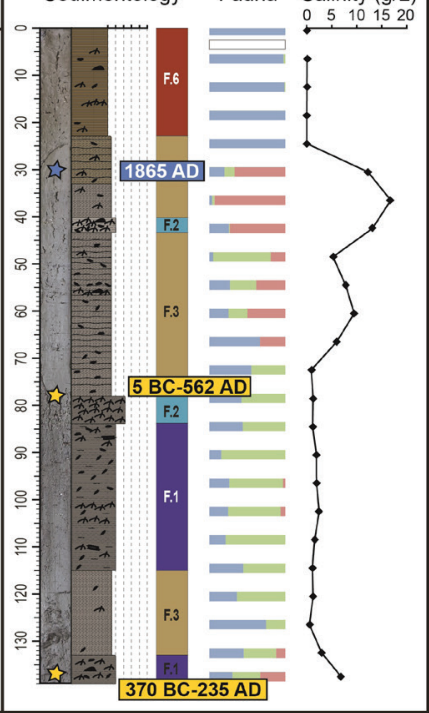

Fig. 8.2b: Overview of core data. From left to right each core: core photograph, sedimentology (lithology), facies, fauna relative abundance per species group based on origin \& evolution and estimated palaeosalinities. 
square-rooting the relative abundances of count data, and standardized by subtracting the mean and dividing by the standard deviation (Borcard et al., 2011; Legendre and Gallagher, 2001). This procedure has been recommended for clustering of species abundance data because it limits the influence of high abundance values (Legendre and Gallagher, 2001; Rao, 1995). We used the 20 most abundant species to avoid a bias from rare species (Borcard et al., 2011). We chose $k$ to range between 2 and 10 in order to find appropriate groups representing different environmental types. To find significant species associations, we calculated Kendall's $W$ coefficient of concordance for each of the partitioned datasets (Legendre, 2005). This method tests for the most encompassing assemblages, hence the smallest number of clusters with the largest number of positively and significantly associated species (Borcard et al., 2011). For each $k$, a global Kendall's $W$ test was run to estimate if the identified species groups were significantly associated. An a posteriori test was conducted to evaluate the contribution of each species to the groups (Borcard et al., 2011; Legendre, 2005). Species groups that were not globally significant, as well as species that were negatively or not significantly associated, were excluded. For the definition of species associations, we chose the solution with $k$ being smallest and yielding groupings that reflect ecologically consistent units.

Finally, we tested for differences between the relative abundances of each of the above-defined ecological associations per sample across facies type. A Shapiro-Wilk test was conducted to test for normality of the relative abundances per association. Since normality was rejected in all cases, we performed for each association a Kruskal-Wallis rank sum test to assess whether the medians of relative abundances differ globally across facies types. In addition, pairwise Wilcoxon rank sum tests were computed to test for differences in median relative abundances between individual facies.

All analyses were performed in R v. 3.3.3 (R Core Team 2017), using package "vegan” v. 2.4-4 (Oksanen et al., 2015)

\subsection{Results}

\subsubsection{Age model}

We obtained 13 age tie points showing that the RSL record covers slightly over 2000 years (Fig. 8.2, Table S4, S9). An average sedimentation rate of $0.108 \mathrm{~cm} /$ years across the entire lake system was deduced (Table S5). Sedimentation rates are estimated as $0.083 \mathrm{~cm} /$ years for the lower parts of the cores and at $0.126 \mathrm{~cm} /$ years for the upper parts. Sedimentation rates in the RSL are high in comparison to other regional examples of Miocene-Pliocene deltaic and lacustrine environments (De Leeuw et al., 2013; Jorissen et al., 2018), which may be explained by a lack of post-depositional compaction of the sediments in these young lagoon and lacustrine sediments. We excluded admixed reworked faunas (high taphonomic scores) to reduce a possible bias in our age model. Any other bias from reworking through bioturbation and time-averaging is very unlikely given the consistency of assemblages and observed trends. Moreover, our age model was little affected (1-5 
years difference) by the use of the first arrival date of $P$. antipodarum in Europe (1859) compared to the first documented Black Sea region occurrence in 1952.

\subsubsection{Facies model}

We identified six facies that represent specific sedimentary processes and depositional environments (Fig. 8.2; Table S6). Facies F1 consists of medium-grey (GLEY 2-4/5B) silts to coarse-grained sands with many reworked millimetre-scale shell fragments. We interpret this facies as deposited under high energies in lagoon environments exposed to open marine conditions. Facies F2 is made of medium-grey (GLEY 2-5/5B) shell-rich silty clays to coarse-grained sands, with many millimetreto centimetre-scale reworked shell fragments and complete shells. This facies is interpreted as sediments washing over sand barriers during storms or after human interventions and that have been deposited in lagoon environments. Facies 3 consists of greenish-grey (GLEY 1-5/10Y) to olive grey (5Y-5/2) silts or clays with some millimetre-scale horizontal laminations. We interpret this facies to be deposited under fluctuating energy regimes, as a combination of suspension deposits and flood events within shallow lagoon to lacustrine environments. Facies 4 is made of olive grey (5Y-5/2) organic-rich silts and clays. Many millimetre- to centimetre-scale terrestrial organic material fragments, including many reeds incorporated vertically or horizontally into the sediments. This facies is considered to represent low depositional energies in shallow lacustrine environments. Facies 5 consists of dark olive grey (5Y-3/2) to black (5Y-2.5/2) organic-rich clays. These sediments contain abundant millimetre- to centimetre-scale terrestrial organic fragments, forming peat layers. We interpret this facies to represent very low energy stagnant water bodies in swamp areas. Finally, facies 6 is made of olive-brown $(2.5 \mathrm{Y}-4 / 3)$ to brown $(10 \mathrm{YR}-4 / 3)$ clays without structures. We interpret this facies to be deposited under flocculation of clay particles in very low energy environments, affected by sediment oxidation. These deposits represent the most recent sediments deposited in the lacustrine system (the active layer). The six facies highlight various depositional energies in the system. Dynamic sedimentary processes are dominant in lagoon environments with preferential deposition of shelly sands, whereas more stable sedimentary processes are prevalent in lacustrine environments with preferential deposition of organic-rich clays.

\subsubsection{Mollusc composition and palaeosalinity}

A total of 235 samples yielded 16,587 mollusc specimens belonging to 44 species (Table S7).

Most species are typical for freshwater environments (24 species), 12 species are of marine origin, and eight species have a Pontocaspian character (Table S2). Salinity tolerances of the latter group typically include a range from freshwater to oligohaline settings. The three species groups are present in all cores, showing variable presence through time and space (Fig. 8.2). The freshwater group is dominated by Dreissena polymorpha, Valvata piscinalis and Gyraulus crista. Marine species are mainly opportunistic species that live in mesohaline conditions and include Lentidium mediterraneum, Ecrobia maritima and Abra segmentum. The Pontocaspian group consists of Adacna 


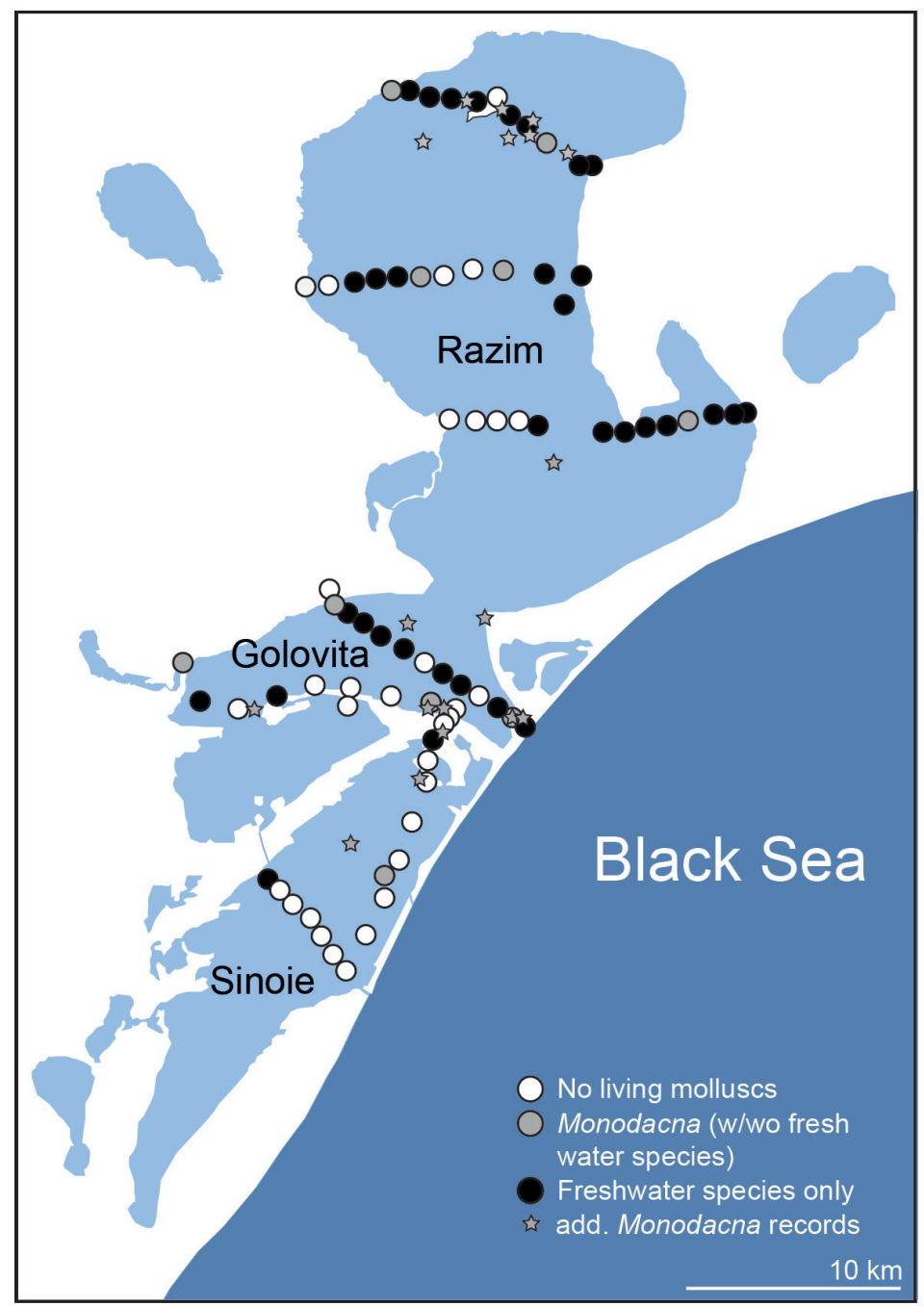

Fig. 8.3: Sampling locations of three expeditions in 2015-2017. The first (September-October 2015) and second expedition (July 2016) were searching for living Pontocaspian molluscs. The third expedition consisted of six transects sampled by GeoEcoMar in 2017 in search of any living mollusc. In the legend w/wo means with or without.

fragilis, Clathrocaspia knipowitschii, Dreissena bugensis, Hypanis plicata, Monodacna colorata and Theodoxus spp. Most often, individual samples include a mix of the three salinity groups, while some show a $100 \%$ domination of fresh or marine species. Pontocaspian species rarely dominate a whole sample (only twice: $\mathrm{C} 10$ at $83 \mathrm{~cm}$ and $\mathrm{C} 13$ at $42 \mathrm{~cm}$ ).

The distribution data of extant species show an almost complete domination by freshwater species in the entire RSL (Fig. 8.3, Table S1). In Lake Razim, Lake Golovița, Lake Zmeica, as 


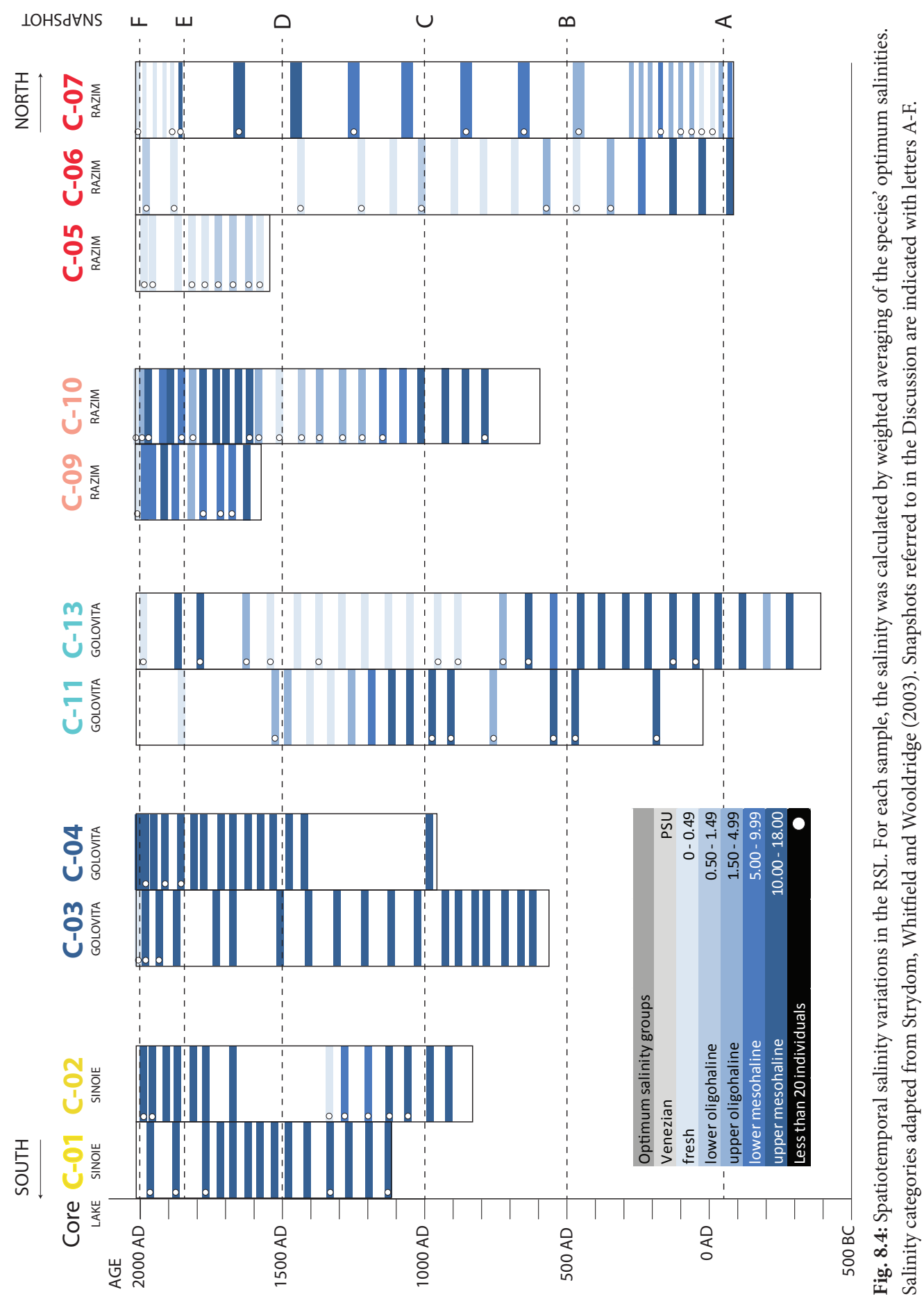


well as along the Jurilovca Canal, the main species found alive are freshwater species. The only Pontocaspian species we found in the RSL system is Monodacna colorata, and in very low numbers (1-5 individuals per station). In Lake Sinoie, very few living species were found in 2 out of 15 stations, all of which were freshwater taxa. The two field trips in 2015 and 2016 that specifically focused on finding living Pontocaspian Lymnocardiinae resulted in a few additional locations for living Monodacna colorata (Fig. 8.3). During our expeditions in the RSL in search for living molluscs, no other living Pontocaspian species besides Monodacna colorata were found, nor any marine species.

Our age-dated environment model shows that the salinity gradients have dynamically shifted through the system over time (Fig. 8.4). The southern part (cores C01-C02-C03-C04) has maintained mesohaline conditions almost during the entire time interval. The northern part (C05C06-C07) has been freshwater to oligohaline with intervals of increased salinities. Core 7 contains unusual high salinity associations between $500 \mathrm{AD}$ and $1900 \mathrm{AD}$ compared to the surrounding cores. The cores taken in the centre of the system (C09-C10-C11-C13) show several oscillations between freshwater and mesohaline conditions. The majority of the cores indicate mesohaline conditions at the base.

\subsubsection{Statistical analyses}

The nMDS shows that in the 2000-year record most freshwater species lived in the northern part of the system (Razim), while the centre and south (Golovița and Sinoie) were dominated by species that tolerate higher salinities (nMDS stress $=0.173$ ) (Fig. 8.5, Table S8). More precisely, the southern lakes have been almost permanently occupied by mesohaline species, and freshwater species dominated the northern part of Lake Razim and western Lake Golovița most of the time. Pontocaspian species occurred in various parts of the system through time, yet they were almost always present in the central-northern parts and almost entirely lacking in the southern part. The surface fitting revealed a strong association between species composition and salinity $\left(\mathrm{R}_{\text {adj }}^{2}=0.945\right.$, deviance explained $=95.1 \%, \mathrm{P}<0.001)$ and, to a lesser extent, grain size $\left(\mathrm{R}_{\text {adj }}^{2}=0.533\right.$, deviance explained $=57.6 \%, \mathrm{P}<0.001)($ Table S8).

The $k$-means partitioning for two, three, four and five groups yields significant results for Kendall's $W$ coefficient of concordance; higher $k$ produced groups partly consisting of single species, which do not allow testing for concordant groups. Only for $k=2$, all groups were globally concordant; for each of $k=3$ through to $k=5$, one group was not concordant (Table S8). The a posteriori test for $k=2$ generally distinguished between a marine group (but including Potamopyrgus antipodarum and Theodoxus danubialis) and a freshwater-Pontocaspian group (Table S8). The two concordant groups identified for $k=3$ both consist of a mixed composition: one cluster was dominated by marine species, including again the freshwater species $P$. antipodarum and $T$. danubialis, the other one was composed of Pontocaspian species along with freshwater Dreissena polymorpha and marine Rissoa membranacea. The a posteriori test for $k=4$ identified three 


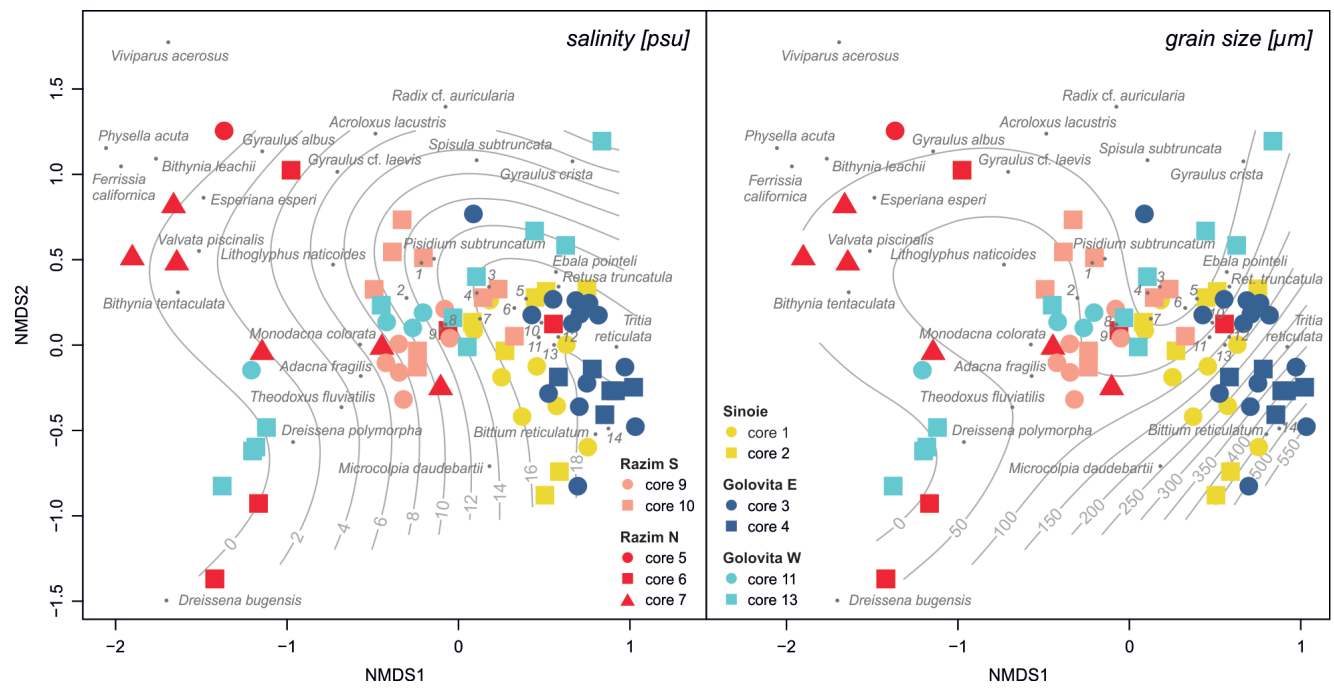

Fig. 8.5: NMDS ordination plot of species compositions across samples grouped into lake regions (stress $=0.173)$. Optimum salinity and grain size were fitted as two-dimensional smooth surfaces to illustrate the associations with species composition. Species marked with numbers: 1 - Planorbis planorbis, 2 - Clathrocaspia knipowitschii, 3 - Potamopyrgus antipodarum, 4 - Theodoxus danubialis, 5 - Planorbarius corneus, 6 - Abra segmentum, 7 - Rissoa membranacea, 8 - Valvata macrostoma, 9 - Hypanis plicata, 10 - Mytilaster minimus, 11 Ecrobia maritima, 12 - Parthenina interstincta, 13 - Cerastoderma glaucum, 14 - Lentidium mediterraneum.

groups that match the groups based on species origin, with the only exceptions that the marine R. membranacea clustered with the Pontocaspian group (Table 8.2). For $k=5$, the Pontocaspian group was split up into bivalves (including the freshwater D. polymorpha) and a mixed gastropod group including Clathrocaspia, Rissoa and T. danubialis. While the marine group was still clearly demarcated, hardly any of the freshwater species were significantly associated.

Of all the clustering levels tested for, $k=4$ yielded the ecologically most consistent groupings (Fig. 8.6). Indicator species for Association I are Dreissena polymorpha, D. bugensis and Valvata piscinalis. The Dreissena species are filter feeding mussels that require hard/firm substrates such as shells or sticks (Gittenberger et al., 2004). Valvata piscinalis is a herbivore species that occurs on muddy bottoms in standing to slowly moving waters rich in plants (Glöer, 2002). All three species are common freshwater species but are able to tolerate salinities up to 5 psu (Glöer, 2002).

Association II is characterized by mainly Pontocaspian species, i.e. Adacna fragilis, Monodacna colorata, Hypanis plicata and Clathrocaspia knipowitschii. In general, Adacna spp. occur on muddy, rarely sandy bottoms. In the Caspian Sea, they can tolerate salinities between 4-14 psu (Bogutskaya et al., 2013). Monodacna colorata inhabits muddy and sandy-muddy substrates and has its optimum habitat between 0.03-4 psu, but can tolerate higher salinities (Bogutskaya et al., 2013). Hypanis 
Table 8.2: Results of the a posteriori test of the contributions of individual species to the overall concordance of the four groups identified by $k$-means clustering at $k=4$. Provided are the mean Spearman correlation between a species and all other species in the respective group, its contribution to the overall concordance statistic $W$ for that group, the permutational probability corrected using Holm's method and the group it is associated with. Species belonging to the non-concordant group and those not significantly associated $(\mathrm{P}>0.05)$ are marked with an asterisk. Note that, except for the outlier Rissoa membranacea, groups 1-3 correlate well with the three defined salinity groups.

\begin{tabular}{|c|c|c|c|c|}
\hline Species & Spearman mean & W per species & Corrected P & Group \\
\hline Dreissena polymorpha & 0.187 & 0.35 & 0.032 & 1 \\
\hline Dreissena bugensis & 0.226 & 0.381 & 0.03 & 1 \\
\hline Gyraulus crista* & 0.13 & 0.304 & 0.23 & 1 \\
\hline Lithoglyphus naticoides* & 0.16 & 0.328 & 0.175 & 1 \\
\hline Valvata piscinalis & 0.222 & 0.378 & 0.029 & 1 \\
\hline Adacna fragilis & 0.451 & 0.561 & 0.002 & 2 \\
\hline Clathrocaspia knipowitschii & 0.435 & 0.548 & 0.002 & 2 \\
\hline Hypanis plicata & 0.423 & 0.538 & 0.002 & 2 \\
\hline Monodacna colorata & 0.434 & 0.547 & 0.002 & 2 \\
\hline Rissoa membranacea & 0.36 & 0.488 & 0.002 & 2 \\
\hline Abra segmentum & 0.495 & 0.596 & 0.002 & 3 \\
\hline Cerastoderma glaucum & 0.452 & 0.561 & 0.002 & 3 \\
\hline Ecrobia maritima & 0.534 & 0.627 & 0.002 & 3 \\
\hline Mytilaster minimus & 0.336 & 0.469 & 0.002 & 3 \\
\hline Parthenina interstincta & 0.35 & 0.48 & 0.002 & 3 \\
\hline Lentidium mediterraneum* & -0.064 & 0.149 & 0.83 & 4 \\
\hline Potamopyrgus antipodarum* & 0.138 & 0.311 & 0.113 & 4 \\
\hline Retusa truncatula* & 0.08 & 0.264 & 0.299 & 4 \\
\hline Theodoxus danubialis* & 0.104 & 0.283 & 0.23 & 4 \\
\hline Theodoxus fluviatilis* & 0.019 & 0.216 & 0.729 & 4 \\
\hline
\end{tabular}

plicata is a filter feeder that prefers silty-sandy to clayey bottoms between 0.5 and $30 \mathrm{~m}$ (Bogutskaya et al., 2013). In the Caspian Sea, it prefers salinities between 4 and 8 psu (Bogutskaya et al., 2013), yet in the Black Sea, populations occur in lower salinities (Popa et al., 2009). They have also been observed in the freshwater Volga Delta (Yanina et al., 2010). Clathrocaspia knipowitschii is a herbivore gastropod that has been found at depths of 1.5-3 $\mathrm{m}$ in deltaic areas with salinities of 0-1.5 psu (Boeters et al., 2015). In addition to the Pontocaspian species, the marine grazing gastropod Rissoa membranacea clusters with this association. This species prefers 15-19 psu but can tolerate salinities below 15 psu (Rehfeldt, 1968).

Association III is defined by marine species: Mytilaster minimus, Ecrobia maritima, Cerastoderma glaucum, Abra segmentum and Parthenina interstincta. Abra, Cerastoderma and Ecrobia are capable of withstanding extreme variations in temperature and salinities between oligohaline and hypersaline (Gontikaki et al., 2003; Kevrekidis et al., 2009; Kevrekidis and Wilke, 2005). Parthenina and Mytilaster are mesohaline taxa that prefer salinities above 15 psu (Table S2). 

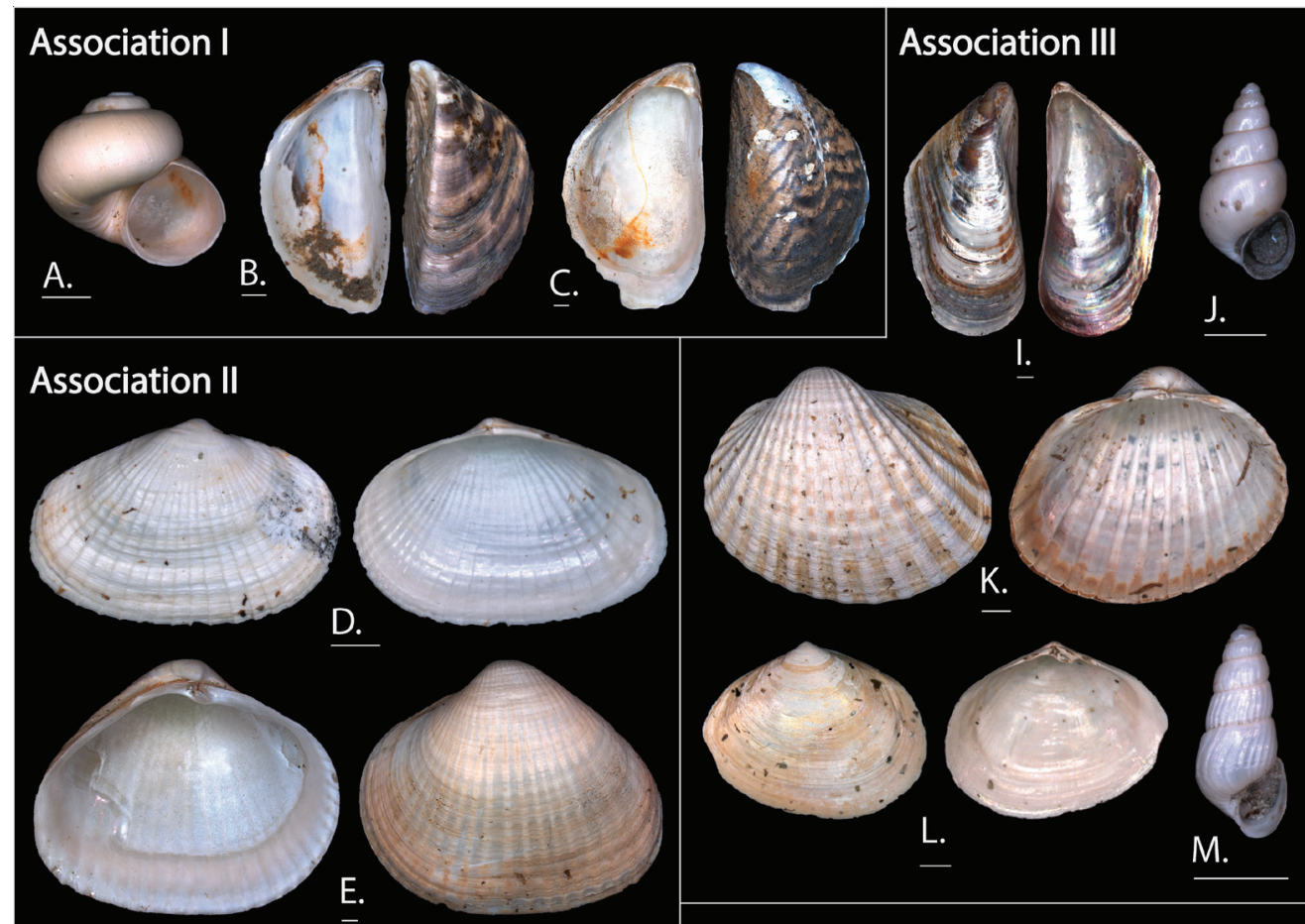

Association III
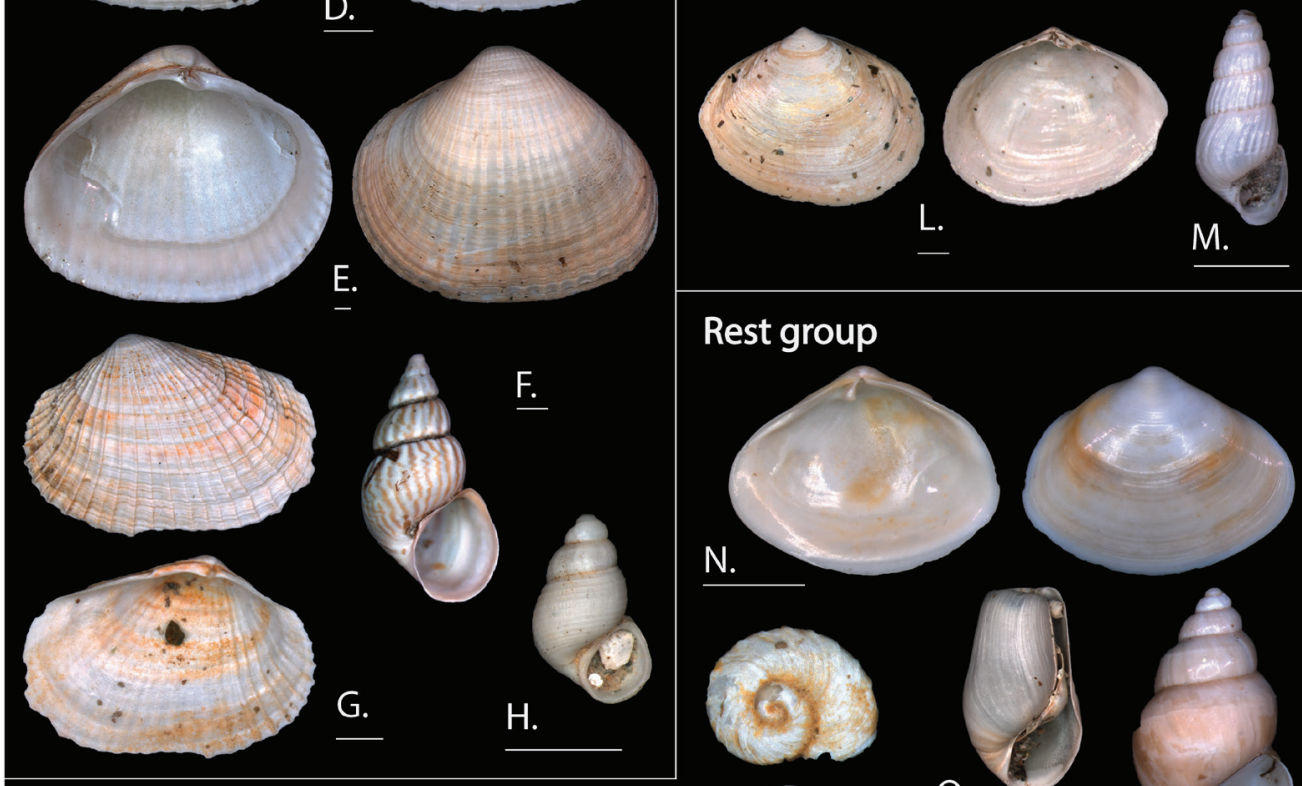

\section{Rest group}
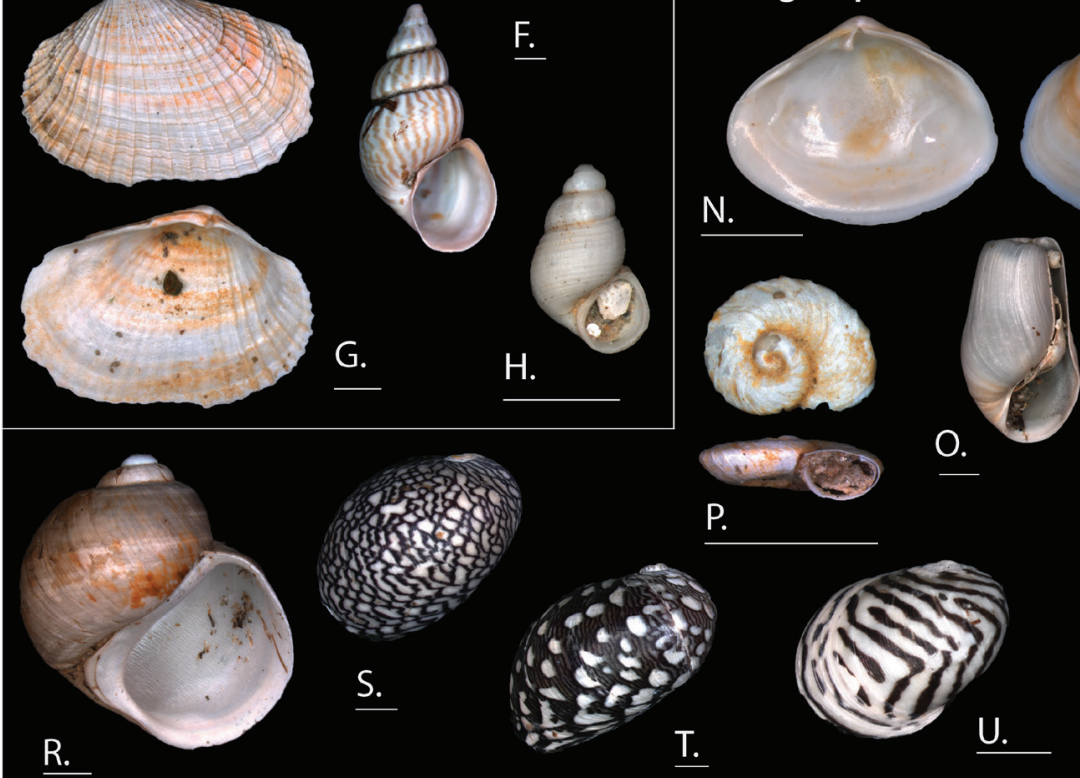

P.

Q.

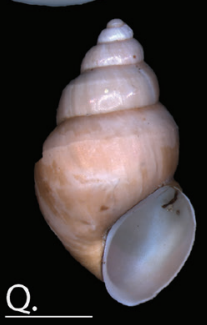

Fig. 8.6 (description next page) 
Fig. 8.6 (previous page): Overview of the twenty most abundant mollusc species grouped according to the results of Kendall's $W$ coefficient of concordance (for $k=4$ ). A. Valvata piscinalis (RGM.1309841, Core C7, depth $6 \mathrm{~cm}$ ). B. Dreissena polymorpha (RGM.1309827, C7-6 cm). C. Dreissena bugensis (RGM.1309846, C5-18 cm). D. Adacna fragilis (RGM.1309835, C2-18 cm). E. Monodacna colorata s.l. (RGM.1309823, C7-14 cm). F. Rissoa membranacea (RGM.1309830, C3-48 cm). G. Hypanis plicata (RGM.1309845, C9-3 cm). H. Clathrocaspia knipowitschii (RGM.1309843, C11-102 cm). I. Mytilaster minimus (RGM.1309838, C3-24 cm). J. Ecrobia maritima (RGM.1309831, C3-48 cm). K. Cerastoderma glaucum (RGM.1309844, C13-24 cm). L. Abra segmentum (RGM.1309821, C1-48 cm). M. Parthenina interstincta (RGM.1309832, C3-48 cm). N. Lentidium mediterraneum (RGM.1309837, C4-12 cm). O. Retusa truncatula (RGM.1309828, C2-42 cm). P. Gyraulus crista (RGM.1309840, C5-54 cm). Q. Potamopyrgus antipodarum (RGM.1309836, C2-18 cm). R. Lithoglyphus naticoides (RGM.1309842, C5-18 cm). S. Theodoxus fluviatilis (RGM.1309826, C11-66 cm). T. T. fluviatilis (RGM.1309824, C11-78 cm). U. Theodoxus danubialis (RGM.1309839, C3-24 cm). V. T. danubialis (RGM.1309834, C2-30 cm). Scale bars are $1 \mathrm{~mm}$.

The remaining 7 of the 20 most abundant species are either assigned to a non-concordant group or are not significantly associated. This outgroup contains a mixture of ecological types, including strictly marine taxa like Lentidium mediterraneum and Retusa truncatula, as well as typical freshwater species (Lithoglyphus naticoides, Gyraulus crista) and species that can tolerate a broad range of salinities (Theodoxus danubialis, T. fluviatilis, Potamopyrgus antipodarum). These species are variably assigned to different clusters in other solutions of the $k$-means clustering (Table S8), which suggests that they might not be characteristic of a specific environment or belong to ecological groups that could not be identified by our analyses.

The relative abundances of the three associations are partly related to facies type (Fig. 8.7). Association I is dominant in the low-energy lacustrine facies F4 and F6, the latter of which is typical of the modern setting. The marine Association III is most common in facies F3, characteristic for shallow lagoon to lacustrine environments, and F5, typical of stagnant swampy areas. In contrast, the Pontocaspian-dominated Association II is evenly distributed across all facies types. This result is also confirmed by the Kruskal-Wallis rank sum tests: Association I $\left(\chi^{2}=37.367, \mathrm{P}<0.001\right)$ and Association III $\left(\chi^{2}=23.431, \mathrm{P}<0.001\right)$ show significant differences of the median relative abundances across facies types, while Association II does not $\left(\chi^{2}=7.751, \mathrm{P}=0.101\right)$. Pairwise Wilcoxon tests yielded six significant differences for Association I (F1-F2, F1-F4, F1-F6, F2-F3, F3-F4, F3-F6) and three for Association III (F1-F3, F3-F4, F3-F6) (Table S8).

\subsection{Discussion}

\subsubsection{Evolution of the RSL}

We subdivided the Late Holocene evolution of the RSL into six phases, represented by snapshots A-F (Fig. 8.4, Fig. 8.8). The phases are strongly related to the development of the Danube Delta 

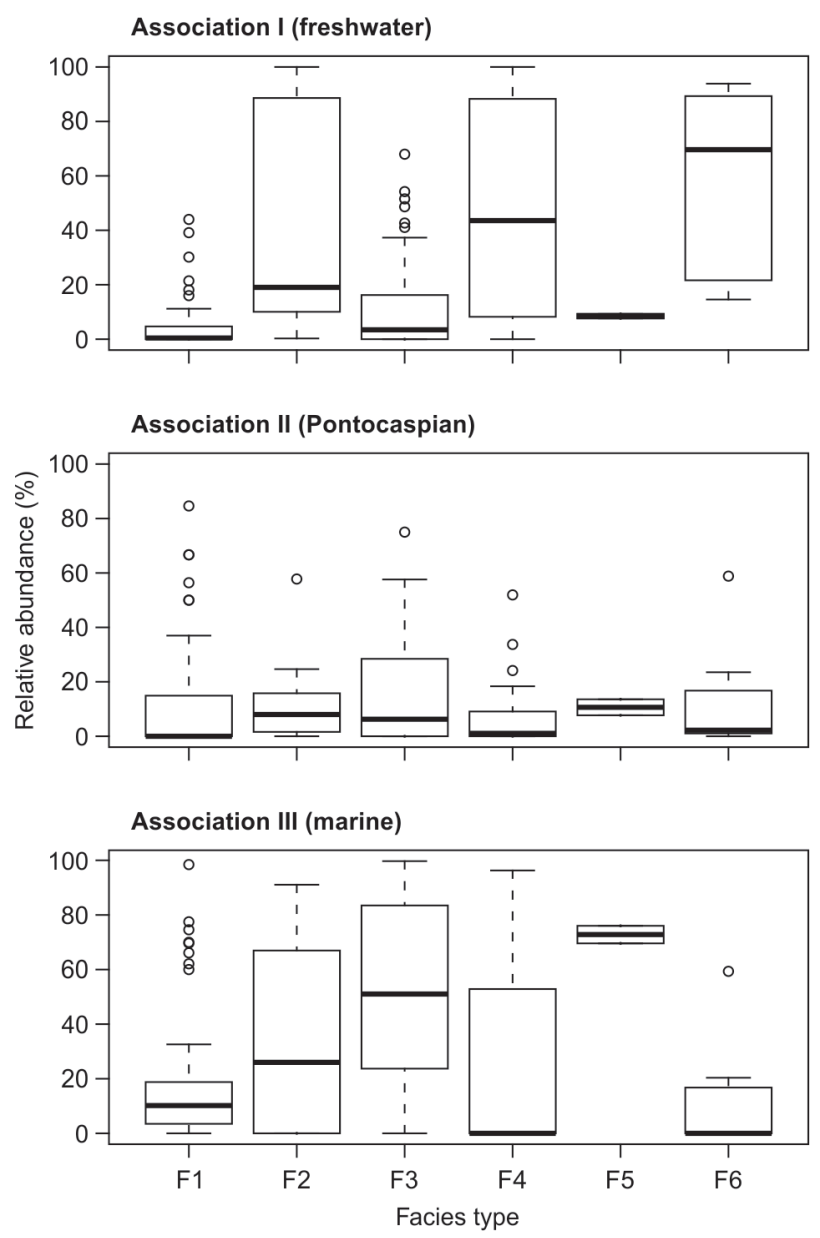

Fig. 8.7: Boxplots show the distribution of relative abundances of the associations across the six facies types.

(Giosan et al., 2006; Panin, 1997, 1989; Panin et al., 2003; Ștefănescu, 1981; Vespremeanu-Stroe et al., 2017), as well as modern human modifications of the RSL (Breţcan et al., 2009; Romanescu and Cojocaru, 2010).

Around $50 \mathrm{BC}$, the RSL was a restricted embayment west of the Black Sea, formed by a barrier complex south of the Danube Delta (Fig. 8.8A). At that time, the Sf. Gheorghe I lobe was no longer active for the benefit of the southern Old Dunavăţ (D1) lobe (Vespremeanu-Stroe et al., 2017), equivalent to the old Coșna Delta described earlier (Panin, 1997, 1989). Erosion of the deltaic lobes by strong longshore currents (Dan et al., 2009) had shaped an asymmetric wave-dominated delta in the north (Bhattacharya and Giosan, 2003; Preoteasa et al., 2016). Sediment drifting had created the Zmeica, Istria and Pahane sand barriers (Bony et al., 2015; Giosan et al., 2006; Vespremeanu-Stroe et al., 2017). The analysed facies show the separation of a protected marine bay in the west and an 

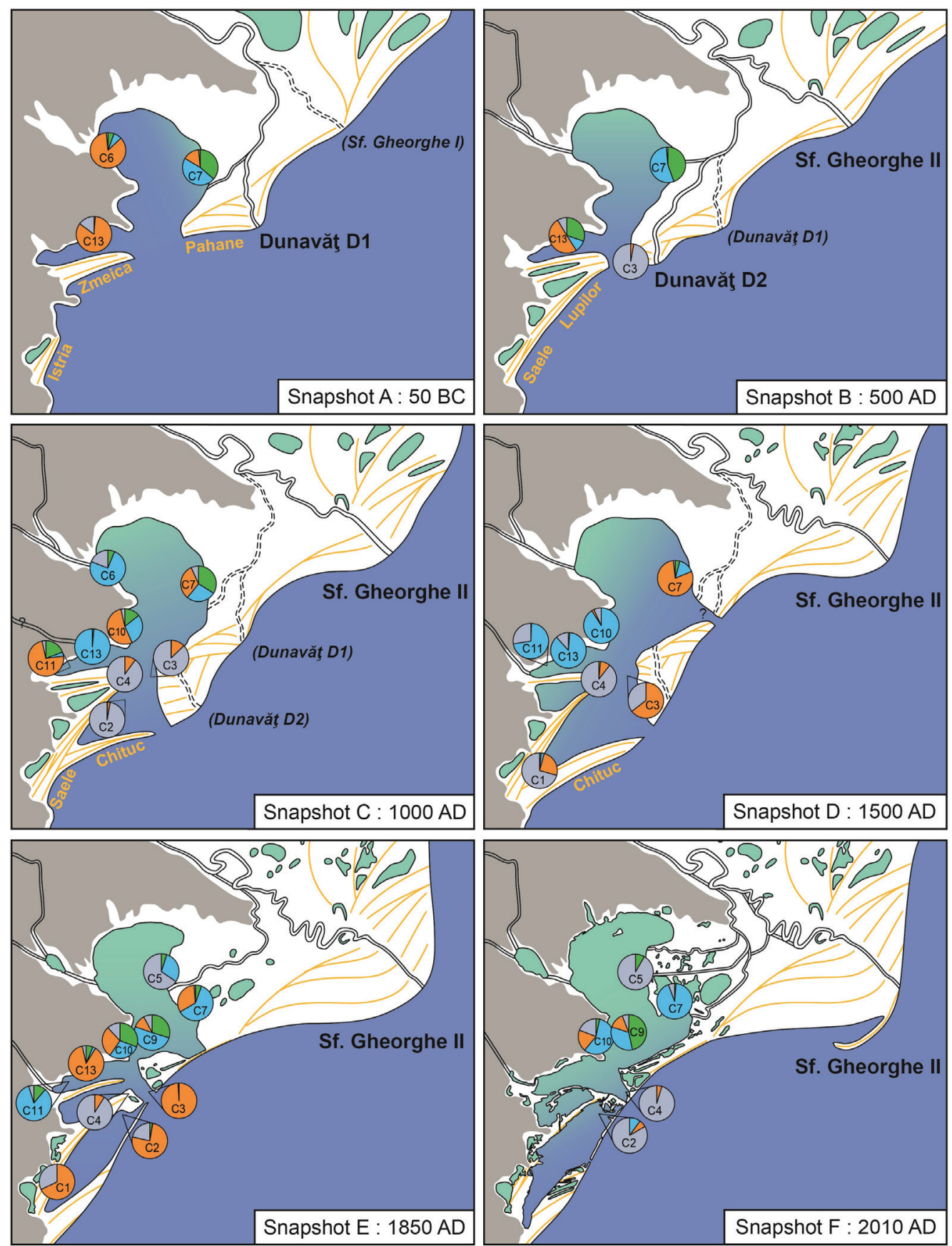

Fig. 8.8: Snapshot reconstructions of the evolution of the RSL and their mollusc biota. The names of major sand barriers are indicated in yellow, while those of deltaic lobes are in black. The names in parentheses and italic font are currently inactive lobes. Pie charts indicate the relative abundance of the three associations in the 
(Fig. 8.8: continuation of opposite page) time interval of \pm 50 years of the indicated snapshot: blue Association I (freshwater); green - Association II (Pontocaspian), orange - Association III (marine), grey - rest group. Water colours indicate a salinity gradient: blue is Black Sea influence (18 psu); green is river influence $(0 \mathrm{psu})$. Note the freshening of the system and according changes in species associations with the decreasing influence of mesohaline waters from the Black Sea.

exposed lagoon in the north (Fig. 8.2). Both the presence of marine Association III species in all cores and the salinity estimations of mesohaline conditions (Fig. 8.4) confirm the idea of a marine bay and show the mesohaline waters from the Black Sea dominated most of the RSL. Association I (freshwater) and Association II (Pontocaspian) dominated in the northeast, close to the river inflow.

The lagoon underwent further isolation from the Black Sea by a second barrier complex at c. $500 \mathrm{AD}$ (Fig. 8.8B). The Old Dunavăţ (D1) developed into the New Dunavăţ (D2) lobe (Vespremeanu-Stroe et al., 2017), corresponding to the so-called Sinoie Delta (Panin 1997, 1989). The Lupilor (Vespremeanu-Stroe et al., 2013) and the Saele (Bony et al., 2015) sand barriers were created by progradation of the deltaic lobe (Vespremeanu-Stroe et al., 2013). The input of freshwater from the Danube increased in the north as the RSL became increasingly isolated from the Black Sea, expressed by swamp settings in the northwest and exposed lagoon environments near outlets (Fig. 8.2). The relative abundance of Association III decreased, while Association I and II increased, especially in the north.

At around $1000 \mathrm{AD}$, a third barrier complex expanded the lagoon system southwards (Fig. 8.8C). Sediment progradation from the Sf. Gheorghe II lobe had created the Chituc sand barrier (Vespremeanu-Stroe et al., 2017), and further prolonged the Saele sand barrier (Bony et al., 2015). Together they shaped a larger lagoon system, forming the outlines of the modern lakes Razim, Golovița and Sinoie. The outlet became smaller and decreased the influence of the mesohaline Black Sea. Sediments deposited in the south of the system, near the main outlet, indicate exposed lagoon environments, whereas the central and northern parts of the system formed more restricted lagoon and lacustrine environments (Fig. 8.2). Association III (marine) shifted southwards, while Association I (freshwater) dominated near the river mouths. Association II (Pontocaspian) dominated the centre of the system.

This situation continued until the end of the Middle Ages (1500 AD), when the lagoon probably experienced strong coastal erosion causing the opening of a second outlet in the north-east (Fig. 8.8D). Sediment that had eroded in the north drifted southward and further prolonged the Chituc sand barrier (Vespremeanu-Stroe et al., 2017). Marine influence became larger in the northern part, while maintaining river inflow from the west. A 3-fold increase in the relative abundance of Association III and the almost complete disappearance of the Pontocaspian-dominated Association II indicate a strong turnover of species and a salinity change towards mesohaline (5-18 psu) conditions (Fig. 8.4). In the south, where the direct influence of the Black Sea was maintained, 
Association III remained dominant. The western part of the system formed a more protected shallow lacustrine environment (Fig. 8.2), where freshwater Association I was dominant.

Around $1850 \mathrm{AD}$, the outline of the system became very similar to the current RSL (Fig. 8.8E). Sediment progradation had stopped and the coast underwent strong erosion (Dan et al., 2009). Sediments deposited in Lake Sinoie are typical of shallow lagoon environments (Fig. 8.2), but without any input from rivers. Association III remained dominant here. The northern part of the system was a protected shallow lacustrine environment (Fig. 8.2), where Association I gained in relative abundance following increased Danube inflow. Lake Golovița was connected to the Black Sea via the Gura Portiţa outlet but also experienced riverine influence. In this exposed lagoon environment (Fig. 8.2), Pontocaspian species of Association II expanded. They probably had previously found refuge in small patches in the north on the boundary between mesohaline and freshwater.

In the past century (Fig. 8.8F), anthropogenic activities (closure of marine outlets, opening of channels connecting to the Danube) caused a salinity decrease in the RSL (Alexandrov et al., 2004; Brețcan et al., 2009; Romanescu and Cojocaru, 2010). Human interventions started at the beginning of the $20^{\text {th }}$ century with freshening the lagoon system for economic reasons (Alexandrov et al., 2004; Brețcan et al., 2009). Two channels were dredged at the beginning of the $20^{\text {th }}$ century and so were seven additional channels around 1950 in order to increase the influence of the Danube River. Around 1970, the Gura Portiţa outlet was closed to limit marine connections with the Black Sea. In Lake Razim, mollusc associations I and II dominated, while the top samples from the cores indicate a decrease of Association III in the south. Yet, a total freshening of the fauna, as seen in the current species occurrences (see below), has not yet been archived within the active layer.

During the past few years, the isolation of the RSL system led to the development of more restricted lacustrine environments with lowered salinities. Observed living mollusc occurrences show a fauna dominated by freshwater species (Fig. 8.3). A comparable study on fish populations in the RSL showed a similar freshening signal (Alexandrov et al., 2004).

\subsubsection{Optimum habitat and resilience of Pontocaspian species}

The species groups defined by evolutionary origin almost entirely correspond to ecological associations, which in turn relate to environmental settings. Species distributions shifted through the RSL in response to changes in the environment. Increasing Black Sea influence matched with decreasing freshwater species occurrences. In turn, in periods of freshening, strictly mesohaline species such as Mytilaster minimus and Parthenina interstincta disappeared.

Our analyses show various correlations between species associations and salinity and to a lesser extent grain size. In general, freshwater species are found in more muddy-clay environments, marine species in sandy environments, and Pontocaspians in the transition area between clay and sand. Similar correlations between species, salinity and sediment have been demonstrated by other studies (Nanami et al., 2005; Teske and Wooldridge, 2003; Ysebaert and Herman, 2002). 
Optimum Pontocaspian habitats were associated with the presence of large enough areas of freshwater to oligohaline conditions. Pontocaspian species rarely dominated the faunas and always co-occurred with either freshwater or marine species. Pontocaspian species are in general well adapted to salinity fluctuations in the freshwater to mesohaline domain (Krijgsman et al., 2019). Such conditions have existed in the RSL throughout the late Holocene. Since 2000, however, the mixed Pontocaspian assemblages gave way to freshwater assemblages (Catianis et al., 2018).

Around $1500 \mathrm{AD}$, Pontocaspian species abundances dropped throughout the RSL. The western part became dominated by freshwater species, and marine species dominated almost the entire remaining system. The increase in salinity caused by the connection to the Black Sea via the second outlet might have happened suddenly, giving room to marine species to expand and replace Pontocaspian species. Afterwards, the RSL freshened and Pontocaspian species re-established in the central-northern parts.

Some apparent incompatibilities occur, including the presence of the marine Rissoa membranacea in the Pontocaspian community. This incompatibility may have resulted from the mixing of successive communities, e.g. by bioturbation in a single interval. Species that burrow into a layer containing well-preserved molluscs from an earlier period may yield a similar preservation status (Tomašových et al., 2019), even though we tried to avoid such influence by using taphonomic filters.

\subsubsection{Human impact and current species distribution}

Major human impact in the system occurred in the $20^{\text {th }}$ century with the simultaneous increase of Danube input and decrease of Black Sea connectivity leading to an overall freshening of the system. Channels dug around 1900 and 1950, as well as the closure of the main marine outlet around 1970, increased the fresh water inflow from the Danube Delta and limited the marine inflow from the Black Sea into the RSL (Brețcan et al., 2008; Romanescu and Cojocaru, 2010). While the optimum Pontocaspian habitats were usually contained in the central-northern parts of the system, they have shifted throughout the whole system over the past 2000 years. However, the freshening has continued until the present-day, and currently the whole complex has an estimated salinity of between 0 in the north and 0.6 psu in the south (Table S1). This freshening has resulted in the dominance of freshwater species across the entire RSL and the almost complete disappearance of Pontocaspian species. Similar trends in community shifts in the RSL have been reported for Pontocaspian fish (Alexandrov et al., 2004).

The near complete breakdown of the previous salinity gradient has the potential to permanently eradicate Pontocaspian habitat in the RSL. Pontocaspian biota has been able to deal with many salinity changes in the past (Krijgsman et al., 2019) but might not overcome the current situation in the RSL complex, where refuge habitats may be lacking. Previously, there was always a small salinity gradient available somewhere in the system where Pontocaspian could find refuge, but if the entire system freshens further, the remaining Pontocaspian species may face local extinction. 
We see a severe decline in Pontocaspian species numbers based on the observations of living species over the past few years. The only Pontocaspian species we found living in the RSL is Monodacna colorata, which is particularly suited to surviving in lower-salinity ranges (below 4 psu; Bogutskaya et al., 2013). Very small numbers of Adacna fragilis and high numbers of living Hypanis

plicata have been reported in 2007-2008 in Lake Golovița (Popa et al., 2009). No other Pontocaspian mollusc species have recently been reported alive in the RSL. Outside the RSL, but within the Black Sea basin, Clathrocaspia knipowitschii has been reported alive in 2005 in the Lower Dnieper area, Ukraine (Anistratenko, 2013).

\subsubsection{Conservation implications}

Since 1990, the RSL has been part of the Danube Delta Biosphere Reserve, established to preserve the genetic diversity of the local flora and fauna (Rezervatia Biosferei-Delta Dunarii 2017). Although the protection focuses on the restriction of human impact on the deltaic system today, no action has been undertaken to reduce the negative effects of past human activity. Over the past decades, Pontocaspian species occurrences and abundances have declined strongly within the RSL system. We are in need of new detailed observation campaigns that specifically target areas where Pontocaspian species were found in our cores in order to assess whether low numbers of these species locally may be present. The current study demonstrates that a restoration of previous salinity gradients by human intervention is the most likely solution to reversing the steep decline in Pontocaspian species richness and abundance. The development of dynamic barriers that allow limited and manageable influx of seawater, similar to that developed elsewhere (van Banning et al., 2018) might be a strategy to be considered. Such an approach would enable restoration of the salinity gradients and dynamics in the RSL system and also enable mobile organisms such as fish to migrate between low-salinity areas in the RSL and the mesohaline Black Sea. This would benefit both the unique benthic and fish populations in the RSL.

Factors that are typically seen as negative influences on natural systems, such as projected global sea-level rise as well as increased coastal erosion following sediment starvation due to damming of the Danube Delta (Panin and Jipa, 2002), might actually be helpful in the restoration of such conditions as new outlets will be created naturally.

\subsubsection{The value of conservation palaeobiological case studies}

This study serves as an example of how conservation issues can be targeted by analysing a detailed palaeobiological record of environmental and faunal change. The Pontocaspian community lives within a salinity gradient and is constrained between marine and freshwater environments. Its presence can be traced through time and space in the RSL record. Our approach of using a palaeobiological record that is suitable for outlining direct conservation consequences might well be applied to other biota under pressure. Mangrove and reef slope communities are good examples; these can contain high-resolution palaeobiological records (Cramer et al., 2017). However, 
addressing post-depositional mixing of faunas using a taphonomic approach is required to assess the quality and fidelity of the palaeobiological record.

\subsection{Conclusions}

We present a palaeobiological case study of threatened Pontocaspian biota from the Razim-Sinoe lake system along the Romanian Black Sea coast. Our 2000-year record shows the existence of a Pontocaspian community that shifted through the system along salinity gradients that in turn were influenced by both natural processes and human interventions. The near-complete breakdown of the salinity gradients in the past decades corresponds with a major decline of these threatened biota. We argue for the restoration of salinity gradients in order to protect the Pontocaspian habitats and species. Documenting a palaeobiological record can only be successful when postdepositional taphonomic processes are taken into account.

\section{Supplement}

The supplementary material related to this chapter (Table S1-S9) is available online at: https://doi. org/10.5194/bg-16-2423-2019-supplement.

\section{Author contributions}

FPW, WK, SV, ELJ, CVB designed the study; ELJ, SR, MS, ABP, AMG, SV, FPW, LP conducted fieldwork and collected the material; SV, ELJ, SR, ABA processed the material; ELJ, CVB, HS realized the age model; ELJ, HAA performed the sedimentological analysis; SV, FPW, SR, ABP, AMG identified the species; TAN, SV performed the statistical analysis; the manuscript was written by SV, ELJ, TAN and FPW with input from all co-authors. All authors gave final approval for publication.

\section{Acknowledgements}

We are thankful to Andrei Briceag and Dani Grosu (GeoEcoMar, Bucharest) for assisting in the field, Piet van Gaever (NIOZ, Texel) for supporting Pb dating, Pierre Plard-Taine (UniLasalle, Beauvais) for contributing to sedimentary data acquisition, Marjan Helwerda (Naturalis Biodiversity Center, Leiden) for assisting with mollusc samples sorting, Wim Kuijper (Leiden University, Leiden) for helping with freshwater mollusc species identification, and Willem Renema (Naturalis Biodiversity Center, Leiden) for advice on statistical analyses. We thank Marius Skolka (Universitatea Ovidius Constanţa, Bucharest) and Oana Popa (National Museum of Natural History "Grigore Antipa", Bucharest) for sharing information on the currently living species. Furthermore, we are grateful to Paolo G. Albano and John Birks, as well as Christoph Heinze and Gerrit Armbrecht, for their constructive comments. 



\section{APPENDIX: DATA REPORT ON EARLY HOLOCENE PONTOCASPIAN MOLLUSC ASSEMBLAGES FROM THE BLACK SEA}

\section{In preparation:}

van de Velde, S./Wesselingh, F.P., Stoica, M., Radan, S., Jorissen, E.L., Krijgsman, W., Lourens, L., Büyükmeriç, Y., Berdnikova, A., Garova, E., ter Poorten, J.J., Lubbers, M., Neubauer, T.A. Natural dynamics of mollusc faunas from the Black Sea during the early Holocene time period.

\subsection{Introduction}

In this report we present counting data and diversity estimates of Pontocaspian mollusc assemblages from the early Holocene Black Sea. The material is part of a core taken at the Romanian continental shelf and provides an unusual record of environmental and faunal change. Three mollusc faunas were recognized, each representing different stages of Black Sea basin development in the Late Pleistocene-early Holocene transition (pre-Neoeuxinian, Neoeuxinian and Holocene). The aim of the study in preparation is to show how faunal composition and diversity changed through time based on the natural dynamics of the palaeoenvironment. In this Appendix data report, we outline the nature and the diversity of a Pontocaspian mollusc fauna of the Black Sea basin that lived around 8,000 yrs BP, at the end of the Neoeuxinian period. Just prior to the Holocene marine transition, the Black Sea basin was a lake with variable salinity settings and oxygenation regimes and large variations in lake level. It hosted the unique anomalohaline Pontocaspian fauna, which became marginalized by marine assemblages into coastal habitats of the northern Black Sea after a reconnection with the Mediterranean Sea during the Holocene flooding.

\subsection{Material and methods}

Gravity core MN143CT04 was collected by the PRIDE team during a scientific cruise on board of research vessel Mare Nigrum in October 2015. It was taken at $40 \mathrm{~m}$ water depth, at around 30 $\mathrm{km}$ from Constanța $\left(44^{\circ} 04^{\prime} 53.8^{\prime \prime} \mathrm{N}, 2^{\circ} 02^{\prime} 19.6^{\prime} \mathrm{E}\right.$, Black Sea, Romania). From the $124 \mathrm{~cm}$ long core 28 samples were taken at intervals of $3-5 \mathrm{~cm}$. Here we focus on 4 samples that contain in-situ Neoeuxinian faunas as shown by the presence of paired Monodacna colorata. Counting procedures follow van de Velde et al., 2019b. Taxonomy follows Wesselingh et al., 2019 with the exception of Adacna fragilis, that was attributed to A. laeviuscula by these authors but since then has been 
Table 9.1: Species abundance list with Neoeuxinian taphonomic signature

\begin{tabular}{|c|c|c|c|c|c|}
\hline \multirow[t]{2}{*}{ FAMILY } & \multirow[t]{2}{*}{ SPECIES } & \multicolumn{4}{|c|}{ DEPTH $(\mathrm{cm})$} \\
\hline & & $58-61$ & $61-63,5$ & $63,5-66$ & $66-71$ \\
\hline Mytilidae & Mytilaster minimus s.l. (Poli, 1795) & 2.0 & 0.5 & 0.5 & 0.0 \\
\hline Cardiidae & Cerastoderma sp. A [non C. rhomboides (Lamarck, 1819)] & 0.0 & 0.0 & 2.0 & 0.0 \\
\hline Cardiidae & Hypanis plicata (Eichwald, 1829) & 0.5 & 1.0 & 1.0 & 0.0 \\
\hline Cardiidae & Monodacna colorata (Eichwald, 1829) & 67.5 & 95.5 & 171.5 & 23.5 \\
\hline Cardiidae & Adacna fragilis Milaschewitsch, 1908 & 0.0 & 0.0 & 0.0 & 0.5 \\
\hline Cardiidae & Parvicardium exiguum (Gmelin, 1791) & 0.0 & 0.0 & 0.0 & 0.5 \\
\hline Semelidae & Abra segmentum (Récluz, 1843) & 2.0 & 0.5 & 1.0 & 1.5 \\
\hline Corbulidae & Lentidium mediterraneum (Costa, 1830) & 1.0 & 0.0 & 0.0 & 0.0 \\
\hline Dreissenidae & Dreissena bugensis Andrussov, $1897 \dagger$ & 58.0 & 20.5 & 94.0 & 14.0 \\
\hline Dreissenidae & Dreissena caspia Eichwald, 1855 & 3.0 & 21.5 & 9.0 & 20.0 \\
\hline Dreissenidae & Dreissena polymorpha (Pallas, 1771) s.l. & 305.5 & 155.0 & 629.5 & 149.0 \\
\hline Neritidae & Theodoxus fluviatilis (Linnaeus, 1758) & 0.0 & 1.0 & 3.0 & 0.0 \\
\hline Hydrobiidae & Clathrocaspia knipowitschii (Makarov, 1938) & 20.0 & 20.0 & 89.0 & 13.0 \\
\hline Hydrobiidae & Ecrobia maritima (Milaschewitsch, 1916) & 8.0 & 8.0 & 17.0 & 8.0 \\
\hline Hydrobiidae & Clessiniola variabilis (Eichwald, 1838) & 1.0 & 0.0 & 0.0 & 0.0 \\
\hline Hydrobiidae & Clessiniola sp. & 2.0 & 1.0 & 0.0 & 0.0 \\
\hline Hydrobiidae & Laevicaspia lincta (Milaschewitsch, 1908) & 46.0 & 30.0 & 440.0 & 24.0 \\
\hline Hydrobiidae & Laevicaspia sp. & 31.0 & 41.0 & 3.0 & 13.0 \\
\hline Pyamidellidae & Parthenina interstincta (Adams, 1797) & 0.0 & 1.0 & 0.0 & 0.0 \\
\hline Valvatidae & Valvata sp. & 0.0 & 0.0 & 2.0 & 1.0 \\
\hline
\end{tabular}

found to have different conchological and ecological characters (FPW \& JJtP pers. obs.). Molluscs of 12 samples were used for ${ }^{14} \mathrm{C}$ dating. The ${ }^{14} \mathrm{C}$ analyses were performed at the DirectAMS lab (Washington, USA), through AMS processing and measuring following protocols at www.directams. com. The results are reported here as uncalibrated radiocarbon years BP. All results have been corrected for isotopic fractionation with an unreported $\mathrm{d} 13 \mathrm{C}$ value, measured on the prepared carbon by the AMS. A faunal-taphonomic approach was used to disentangle time-averaged records and provide detailed insights into the late Quaternary evolution of the Black Sea basin and its biota, following van de Velde et al. (2019). A rarefaction analysis was performed using R v. 3.5.2 (R Core Team, 2018) with package 'iNEXT' v. 2.0.19 (Hsieh et al., 2016) to estimate the representativeness of the samples for diversity analysis.

\subsection{Results}

Based on the analyses of age dates $\left({ }^{14} \mathrm{C}\right)$, stratigraphic position and taphonomy of mollusc shells three environmental phases and their associated faunas are identified: a pre-Neueuxinian, Neoeuxinian and a Holocene phase (Fig. 9.1). Some admixture of faunas was found that is attributed to bioturbation. In this report we focus on the Neoeuxinian mollusc fauna as it represents a baseline of a natural Pontocaspian assemblage in the Black Sea basin prior to anthropogenic influence. The taphonomy of all species is similar, they have a grey blue preservation status, the surface details are well preserved and they show slight corrosion. The rarefaction curve of the Neoeuxinian fauna is 


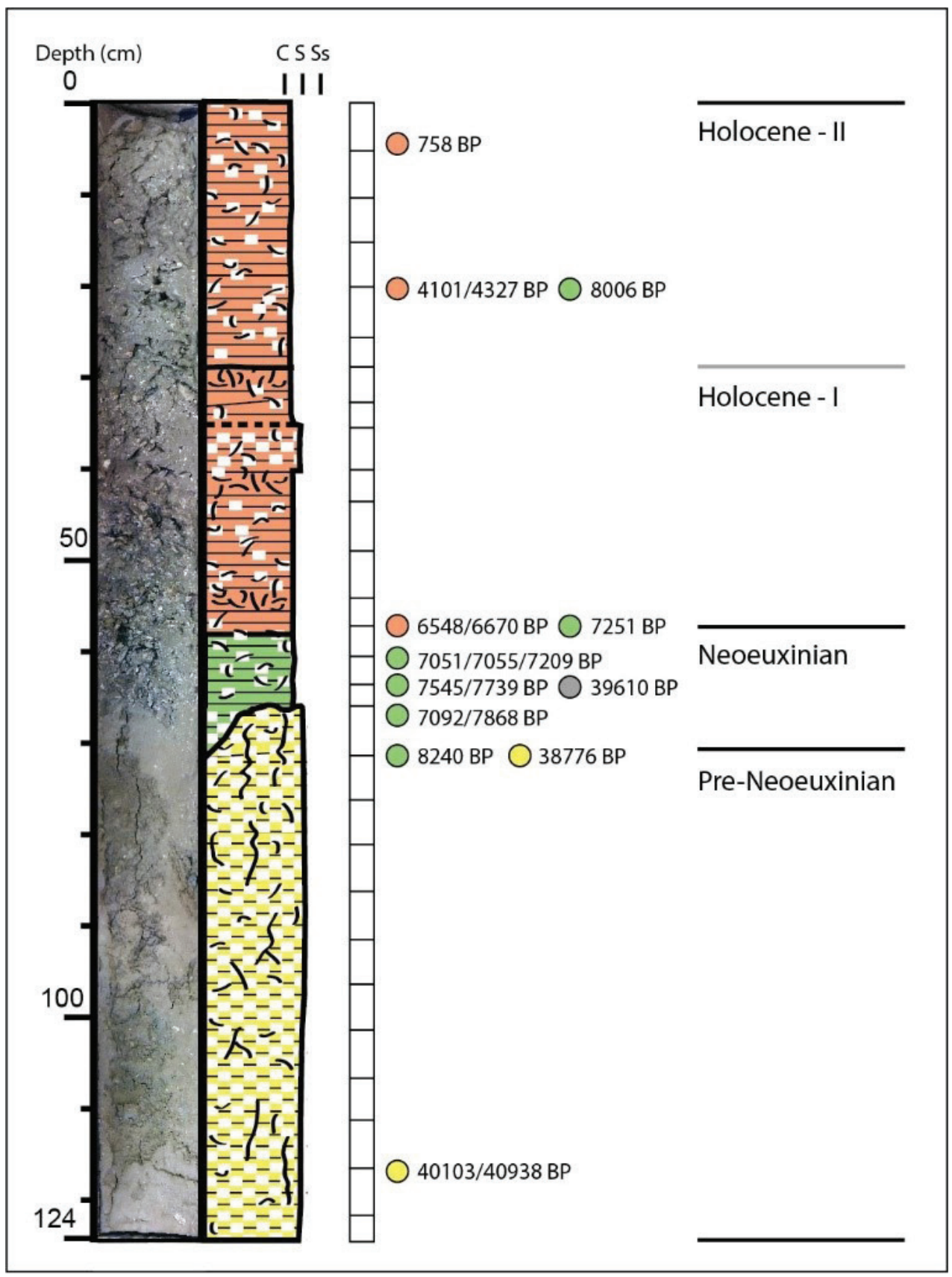

Fig. 9.1: Black Sea core MN143CT04 information. From left to right: depth, core picture, sedimentology, ${ }^{14} \mathrm{C}$ ages, time period. Orange represents Holocene time period, green is the late Neoeuxinian, yellow is associated with the pre-Neoeuxinian. Samples contain reworked material causing the mixing of ${ }^{14} \mathrm{C}$ ages. 


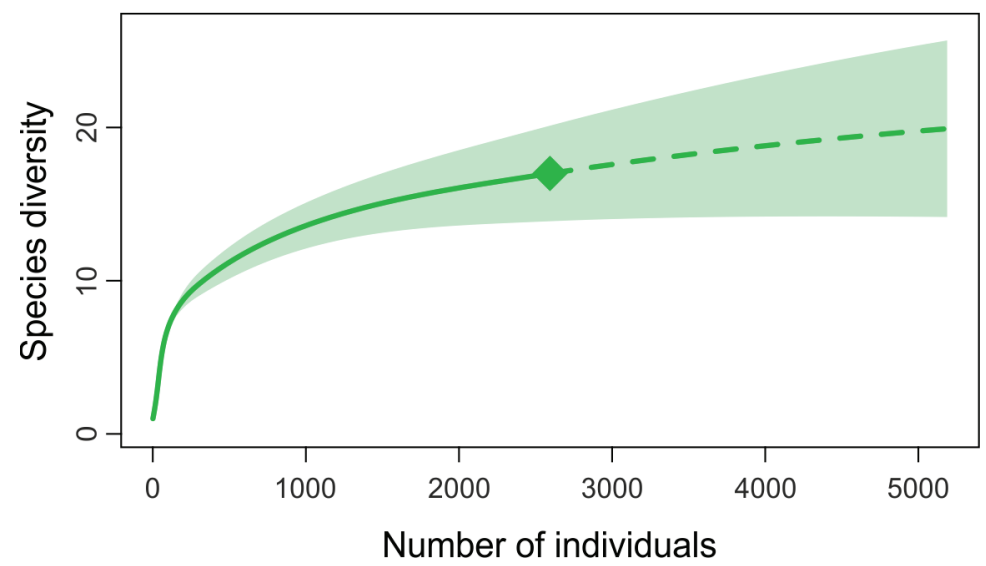

Fig. 9.2: Rarefaction curve of the mollusc assemblage from the Neoeuxinian time period. The curve is nearly saturated, indicating that our samples represent an appropriate estimate of the true richness of the Neoeuxinian species.

nearly saturated (Fig. 9.2), suggesting that our samples represent an appropriate estimate of the true richness. The 2674 individuals contain 20 species (Table 9.1), of which eleven are bivalves (Fig. 9.3) and nine are gastropods (Fig. 9.3). Twelve species are endemic/native to the Pontocaspian origin (Clathrocaspia knipowitschii, Clessiniola variabilis, Clessiniola sp, Dreissena bugensis, D. caspia, D. polymorpha, Adacna fragilis, Hypanis plicata, Monodacna colorata, Theodoxus fluviatilis, Laevicaspia lincta, Laevicaspia sp.,). Seven species have a marine origin (Abra segmentum, Cerastoderma sp. A., Ecrobia maritima, Mytilaster minimus, Parthenina interstincta, Parvicardium exiguum, Lentidium mediterraneum). One species (Valvata sp.) is typical of fresh water. Excluding Valvata, the late Neoeuxinian mollusc fauna shows an estimated species richness of 12 Pontocaspian species and 7 marine species at 5000 specimens. This is well below Pontocaspian richness estimates of the Girkanian (37 Pontocaspian species: van de Velde et al., 2019b) and Novocaspian (26 Pontocaspian species: van de Velde et al., 2019c) in the Caspian basin.

\section{Acknowledgements}

Many thanks go to the Utrecht University College students: A. Drost, F. Timpen, F. Gloerfelt-Tarp and H. Koekkoek for help with washing and pre-sorting. We also thank Arnold van Dijk (Utrecht Geolab) for analytical support.

Fig. 9.3 (opposite page). Overview of late Neoeuxinian molluscs from core MN143CT04: 1. Monodacna colorata (depth 61-63 cm, RGM.962524), 2. Adacna fragilis (depth 66-71 cm, RGM.962536), 3. Hypanis plicata (depth 61-63.5 cm, RGM.962408), 4. Parvicardium exiguum (depth 86-91 cm, RGM.962537), 5. Cerastoderma sp. A (depth 63.5-66 cm, RGM.962527), 6. Abra segmentum (depth 54-58 cm, RGM.962520), 7. Dreissena 


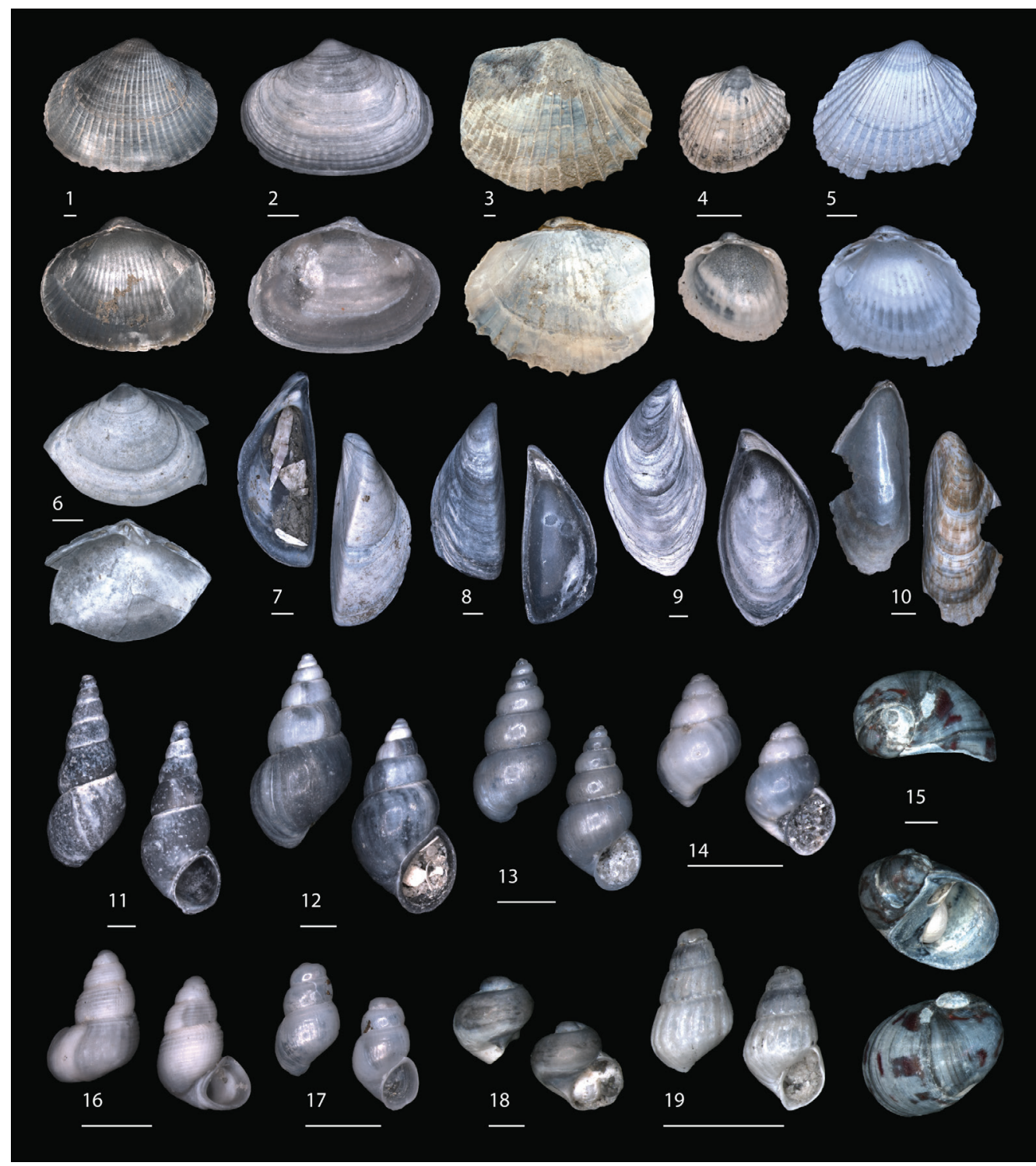

(Fig. 9.3 continuation) polymorpha (depth 54-58 cm, RGM.962519), 8. Dreissena caspia (depth 66-71 cm, RGM.962531), 9. Dreissena bugensis (depth 63.5-66, RGM.962528), 10. Mytilaster minimus s.l. (depth 58-61 cm, RGM.962521), 11. Laevicaspia lincta (depth 71-78 cm, RGM.962532), 12. Clessiniola variabilis (depth 58-61 cm, RGM.962522), 13. Ecrobia maritima (depth 63.5-67 cm, RGM.962529), 14. Clessiniola sp. (depth 58-61 cm, RGM.962523), 15. Theodoxus fluviatilis (depth 71-76 cm, RGM.962411), 16. Clathrocaspia knipowitschii (depth 63.5-66 cm, RGM.962530), 17. Laevicaspia sp. (depth 106-111 cm, RGM.962532), 18. Valvata sp. (depth 63.5-66 cm, RGM.962526), 19. Parthenina interstincta (depth 61.-63.5 cm, RGM.962525). Scale bars $=1 \mathrm{~mm}$. 



\section{0}

\section{SYNTHESIS \& FUTURE PERSPECTIVES}

\section{Highlights}

- Late Quaternary mollusc fauna snapshots show that until the late Holocene endemic species dominated the Caspian communities with minor contributions of native species. Invasive species were no part of the fauna.

- The Pontocaspian mollusc species richness in the Caspian Sea basin is higher than in the Pontocaspian habitats of the Black Sea basin, or the Aral Sea basin.

- The strong natural fluctuations of Caspian Sea level affected shallow water bivalve species of the genus Didacna, but barely changed the overall composition of the mollusc faunas.

- Late Quaternary mollusc fauna snapshots of the Black Sea basin show very little change in the Pontocaspian species community before and after anthropogenic pressure. However, the Pontocaspian mollusc communities are currently under severe threat of habitat destruction.

- Over the $20^{\text {th }}-21^{\text {st }}$ century, Pontocaspian molluscs have experienced a severe decline in species richness and abundance: a strong turnover towards invasive species in the Caspian basin, strong habitat decline in parts of the Black Sea basin and total species obliteration in the Aral basin.

- The Caspian Sea acts as a source for Pontocaspian biota, hence conservation efforts are imperative there. The deeper parts ( $>50 \mathrm{~m}$ water depth) possibly present a (partial) refuge and urgent research is required to assess these habitats and their faunas.

\subsection{Understanding Pontocaspian mollusc diversity}

The previous chapters present new data on late Quaternary Pontocaspian mollusc faunas. These data show different mollusc compositions under natural variation and under human impact. In order to allow for meaningful biodiversity comparisons, similar Pontocaspian habitats in the Black Sea basin and the Caspian Sea basin were investigated in a number of late Quaternary time intervals. In this last chapter, a short overview of the results is presented and the findings are put in a broader perspective. The documented patterns of mollusc diversity are summarized, the faunas in the different basins are compared, and the potential processes that have driven the development of late Quaternary Pontocaspian biodiversity are discussed. Specifically, the question whether there is a Pontocaspian biodiversity crisis is addressed. The relevance of the new data is discussed in terms of understanding the resilience of the fauna and the possibilities of mitigating the current Pontocaspian mollusc diversity crisis. 


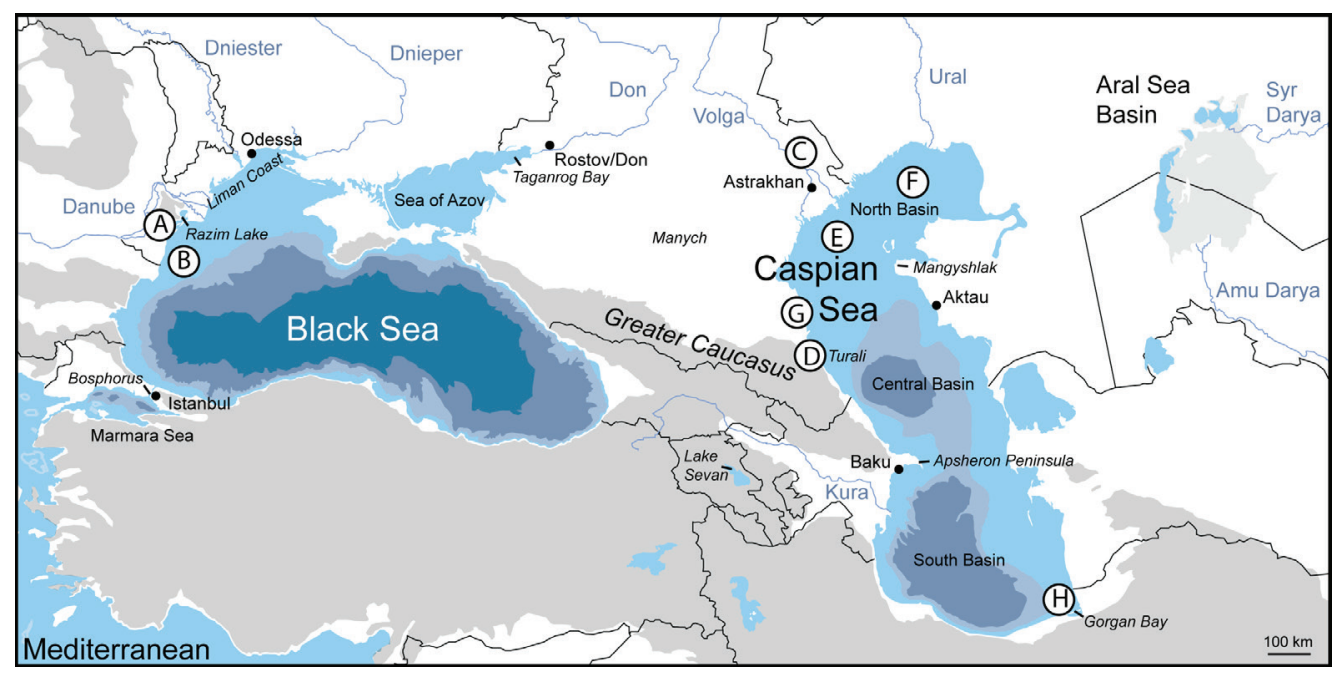

Fig. 10.1: Overview of Pontocaspian site locations used in this thesis. A. Razim-Sinoie lake, B. Western Black Sea, C. Selitrennoye, D. Turali, E. North Caspian Core Project (NCCP), F. NCOC (2017), G. Latypov (2015), H. Leroy et al. (2018).

\subsection{Patterns of Pontocaspian mollusc diversity}

\subsubsection{Late Quaternary mollusc biodiversity in the Caspian Sea basin}

An overview of the site locations is given in Fig. 10.1 and all faunal data are summarised in Fig. 10.2 and Fig. 10.3. The Caspian fauna studied comprises a Late Pleistocene (MIS5) Hyrcanian fauna from Selitrennoye at the lower Volga (Russia) and a Holocene Novocaspian fauna from the Turali region in Dagestan (Russia). Furthermore, six successive faunas from a borehole on the North Caspian Continental Shelf (the NCCP core) were studied. All faunas represent lower mesohaline conditions and shallow depositional depths (mostly above or around storm wave base, $0-50 \mathrm{~m}$ water depth) during relative highstand intervals. The Late Pleistocene faunas are entirely composed of Pontocaspian species and contain between 10 and 32 species. These faunas form a natural baseline. They are dominated by cardiid and dreissenid bivalves and hydrobiid and neritid gastropods. The species are predominantly Caspian endemics (91-100\%); no species presently invasive in the Caspian Sea are part of the assemblages.

The late Quaternary Caspian faunas are dominated by the Pontocaspian bivalve genera Adacna, Didacna, Hypanis, Monodacna and Dreissena and the gastropod genera Theodoxus, Clathrocaspia, Ulskia, Clessiniola, Laevicaspia, Turricaspia, Abeskunus and Andrusovia. As for the bivalves, most of the species living today have occurred throughout the Late Pleistocene and early Holocene. However, different Didacna species occur in different time intervals; their very high turnover rates makes them useful biostratigraphic markers (Nevesskaja, 2007; Yanina, 2005). 
During the early Holocene, the Pontocaspian fauna richness and abundance changed due to the arrival of invasive species. The Novocaspian (NCCP-5) assemblage in the northern Caspian Sea consists of 10 species and contains a 100\% Pontocaspian abundance (99\% endemic, $1 \%$ native). The Novocaspian assemblage from Turali, which lived around 2300-2700 yrs BP, contains 26 Pontocaspian species, but also two invasive species (Cerastoderma glaucum, C. sp. A) are part of the assemblage. Pontocaspian species are still most abundant (78\% Pontocaspian endemic, 12\% Pontocaspian native, $10 \%$ invasive).

The average Pontocaspian species richness is the lowest of all Late Quaternary faunas in the $20^{\text {th }}-21^{\text {st }}$ century. The endemic species abundance decreased to $12-31 \%$ of the total assemblage. In total, seven Pontocaspian species have been reported by Latypov (2015) from Sulaksky Bay in Russia, 18 Pontocaspian species in the species monitoring project of the NCOC (2018) on the Kazakh shelf and eight Pontocaspian species in Gorgan Bay, Iran (Leroy et al., 2018). In addition to the (endemic and native) Pontocaspian species, three recent marine invasive species were found by all three studies (Mytilaster minimus, Cerastoderma glaucum and Abra segmentum). These invasive species dominate the faunas in abundance. Several of the bivalve and gastropod species that were abundant before the $20^{\text {th }}$ century have not been reported alive by inventories or collectors. Dreissena caspia and D. elata, for example, have been replaced by Mytilaster minimus between 1938 and 1957 in the Caspian Sea (Kostianoy et al., 2005), and have the status 'critically endangered, possibly extinct' at the IUCN Red List (von Rintelen and Van Damme, 2011b).

The abundance data of Latypov (2017) and NCOC (2018) studies cannot be directly compared with our data, as they were collected using a different methodology. The Gorgan Bay data have been assembled using the same methods as the studies reported herein and represent dead shell assemblages (Leroy et al., 2018). The communities are dominated (56\%) by the three abovementioned species that became invasive in the past century. The mollusc abundances reported in Latypov (2015) and NCOC (2018) were calculated by measuring the species settlement density (individuals $/ \mathrm{m}^{2}$ ) for the former, and mollusc species biomass $\left(\mathrm{g} / \mathrm{m}^{2}\right)$ for the latter. Both studies show that the majority of density and biomass is composed of invasive species. In ten of the eleven years during which the faunas were monitored by the NCOC, a single species was dominant: the invasive A. segmentum.

A further dataset has been recently published on mollusc abundances at 200-1000 m water depth in the southern Azerbaijan Caspian Sea (Mirzoev and Alekperov, 2017). The reported faunas contain 27 Pontocaspian species. However, it is unclear how the data were acquired and whether they concern living species and/or dead shells, which is why they cannot be unambiguously used to assess modern biodiversity.

During a survey offshore Aktau, (Kazakhstan, 2017) in the frame of the PRIDE project, grab samples were taken on transects between $10 \mathrm{~m}$ and $250 \mathrm{~m}$ water depth. Only few living Pontocaspian species were encountered during the field trip (Dreissena grimmi, Didacna profundicola, D. trigonoides, Theodoxus pallasi). A rich endemic shelly fauna dominated by hydrobiids was found, 

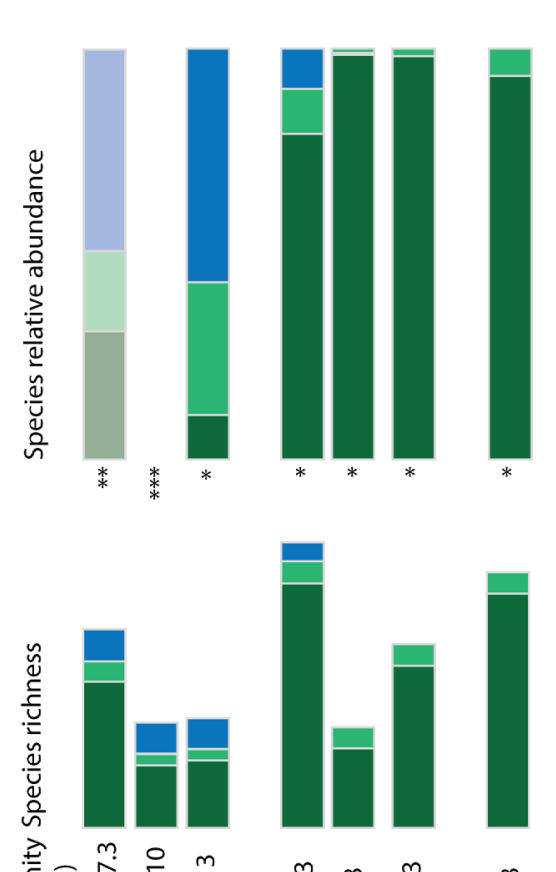

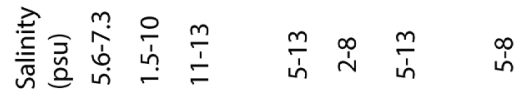

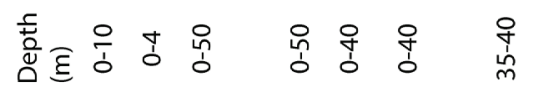

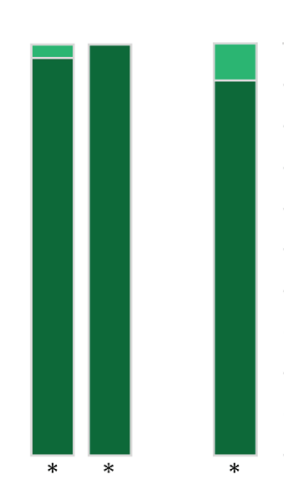

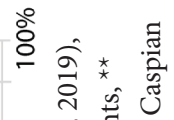

華苛

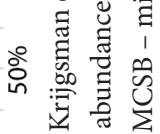

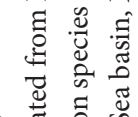

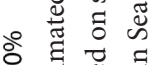

焉莺

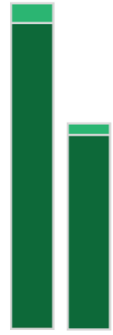

壱苛

요

ช ठ

$\Xi \breve{\Xi}$

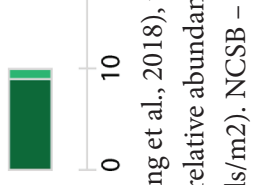

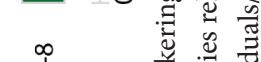

苍芯苛

究

芩艺
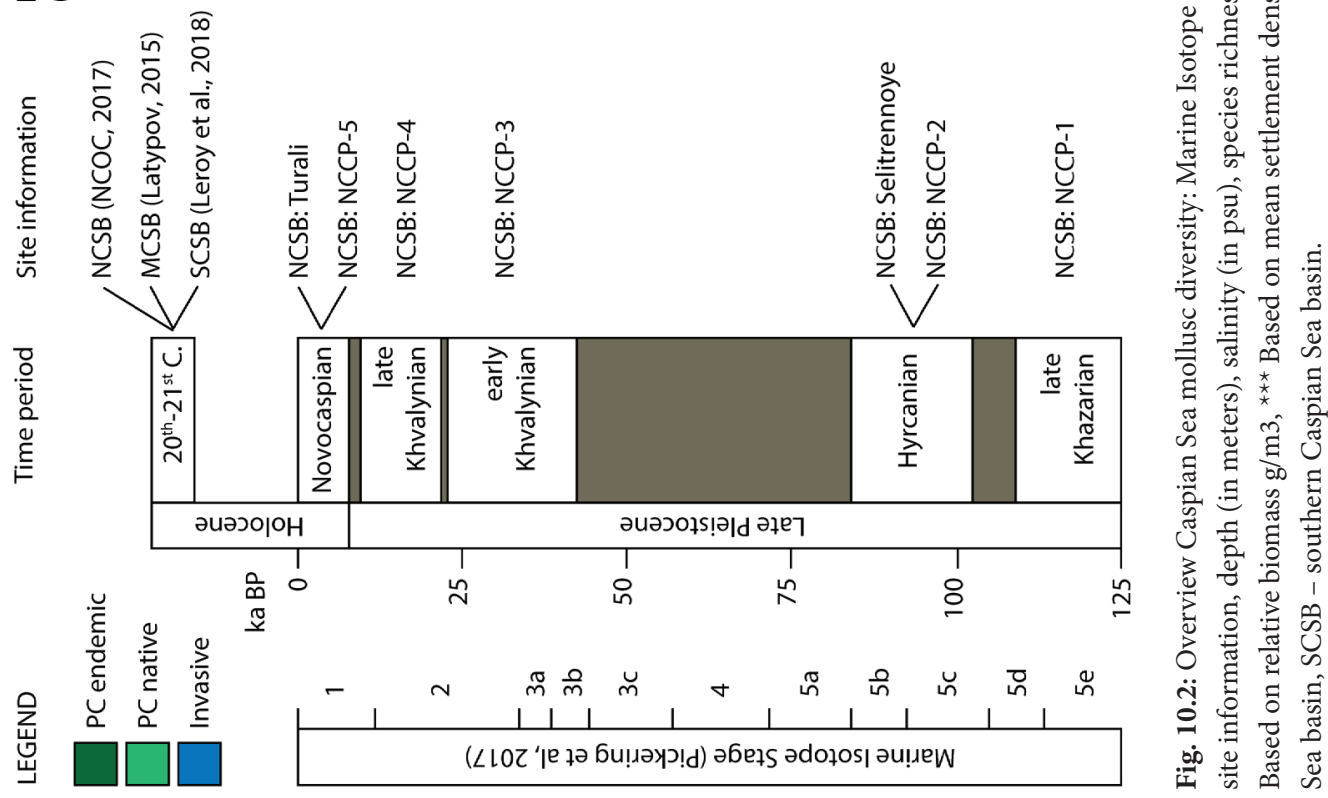
but these concerned all dead shells. A few living endemic hydrobiid species have been found during environmental impact assessments around Azerbaijani oil installations (E. Jafarova, pers. comm. 08/2018), including Turricaspia meneghiniana and T. dimidiata. Living specimens of the bivalve species Didacna profundicola and Dreissena grimmi were also found.

Based on the available data, Lattuada et al. (2019a) established biodiversity hotspots for endemic Pontocaspian molluscs. For bivalves, distribution optima are centred around 31-39 m water depth at the transitional zone between the northern and the middle Caspian Sea basin as well as in the western and eastern parts of the southern Caspian Sea basin. Optima for gastropods were found to be slightly deeper (between 41-74 m water depth) and located mainly in the western parts of the middle and southern Caspian Sea basins.

\subsubsection{Late Quaternary mollusc biodiversity in the Black Sea basin}

No standardised late Quaternary Pontocaspian mollusc biodiversity data have been available from the Pontocaspian habitats in the Black Sea basin previous to this project. Our new records from a borehole on the Romanian shelf (capturing pre-Holocene assemblages) and from the Razim lake system in Romania (covering the past 2000 years) are the first baseline inventories of such faunas (Fig. 10.2).

Throughout the late Quaternary in the Black Sea basin, Pontocaspian communities have been dominated by species of the bivalve genera Adacna, Monodacna and Hypanis. The genus Didacna, which is dominant in the late Quaternary Caspian Sea, is lacking in the basin. Gastropod richness is much lower in the Black Sea compared to the Caspian Sea (Wesselingh et al., 2019). The Black Sea Pontocaspian gastropod fauna is dominated by species of Clathrocaspia, Laevicaspia and Theodoxus. Overall Pontocaspian species richness is lower in the Black Sea basin, and several of the Pontocaspian species are likely sister species of Caspian species, namely: Adacna fragilis vs. A. vitrea, Dreissena bugensis vs. D. grimmi, D. polymorpha vs. D. elata, Theodoxus danubialis vs. T. pallasi and Clathrocaspia knipowitschii vs. C. gmelini. Preliminary analyses on newly collected material show morphological differences as well as different autecological tolerances that might be indicative of different species. In summary, the Black Sea basin Pontocaspian fauna can be characterised as a less diverse fauna and consisting of more generalist species than the Caspian Sea basin Pontocaspian fauna.

The studied late Neoeuxinian mollusc assemblages from the Black Sea contain 18 species. Ten species are endemic/native to the Pontocaspian area (Clathrocaspia knipowitschii, Clessiniola variabilis, Dreissena bugensis, D. caspia, D. polymorpha, Adacna fragilis, Hypanis plicata, Monodacna colorata, Theodoxus fluviatilis, Laevicaspia lincta). Seven species have a marine affinity (Abra segmentum, Cerastoderma sp. A, Ecrobia maritima, Mytilaster minimus, Parthenina interstincta, Parvicardium exiguum, Lentidium mediterraneum). One species (Valvata sp.) is typical of fresh water. Salinities in the Neoeuxinian lake phase were around 7-8 psu (Nevesskaja, 1965; Svitoch, 2010b) and water levels varied between $110 \mathrm{~m}$ b.s.l. (Balabanov and Izmaylov, 1989; Ostrovsky 


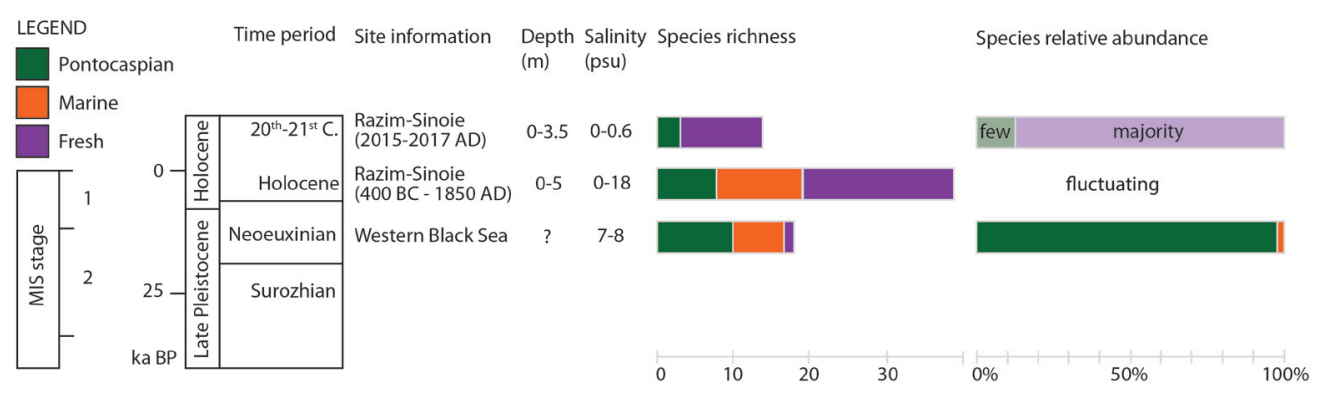

Fig. 10.3: Overview Black Sea mollusc diversity: Marine Isotope stages (Pickering et al., 2018), time period (estimated from Krijgsman et al., 2019), site information, depth (in meters), salinity (in psu), species richness and species relative abundance counts.

et al., 1977) and $30 \mathrm{~m}$ b.s.l. (Mudie et al., 2014; Yanko-Hombach et al., 2014). The exact age of the Neoeuxinian period is still under debate (Svitoch, 2010; and references therin). The Neoeuxinian lake phase existed between $25 \mathrm{ka}$ BP and 6 ka BP (Krijgsman et al., 2019; Svitoch, 2010; and references therein). The end of the Neoeuxinian coincides with the marine inflow from the Mediterranean Sea (Doğan et al., 2019; Fedorov, 1978; Kvasov, 1975; Yanchilina et al., 2017) and the replacement of a Pontocaspian-dominated with a modern marine fauna (Krijgsman et al., 2019).

The late Holocene records in eleven cores of the Razim-Sinoie lake complex contain a total of 41 species: 20 freshwater, thirteen marine, eight Pontocaspian. Different combinations of species with different habitat preferences occur in time and space during the past 2000 years. Within the entire record of the Razim-Sinoie lake complex, the Pontocaspian species, all of which have existed since the Neoeuxinian, have always occurred within the marine-freshwater salinity gradient. They have rarely dominated the fauna but always co-occurred with either freshwater or marine species. A huge turnover has been documented in the Razim-Sinoie lake complex in the past few decades. The fauna assemblages of the years 2015-2017 in the lake complex lack marine species entirely and most of the Pontocaspian species have disappeared. Freshwater species dominate the entire system, and only a single Pontocaspian species (Monodacna colorata) is found alive. The marine-freshwater salinity gradient is largely gone due to anthropogenic activities, and the whole complex now has an estimated salinity between 0 and 0.6 psu.

\subsubsection{Aral Sea}

The Aral Sea is one of the largest ecosystem obliterations of the past century world-wide. Before the mid- $19^{\text {th }}$ century, the Aral Sea was a diverse ecosystem containing intergraded freshwater, brackish and saline habitats (Aladin et al., 2008). In the Atlas of the Aral Sea invertebrates (MordukhaiBoltovskoi, 1974), eight mollusc species are mentioned to have lived there (sensu Wesselingh et al 2019): three Pontocaspian endemic species (Dreissena caspia, Adacna vitrea, A. minima), three native Pontocaspian (Theodoxus pallasi, Ecrobia grimmi, D. polymorpha) and two marine invasive 
species (Cerastoderma glaucum, C. sp. A). Since the 1960s, people started withdrawing water from the two main rivers that fed the system for irrigation purposes (Boomer et al., 2000; Mainguet et al., 1997; Micklin, 2007). This resulted in a water level drop and an increase in salinity (Aladin et al., 2008; Boomer et al., 2000; Micklin, 2007). At about the same time, man successfully introduced Abra segmentum as fish food, and a few years later unsuccessfully introduced Monodacna colorata (Aladin et al., 2004). In the 1980s, attempts to introduce Mytilus galloprovincialis and Mya arenaria also failed due to lack of substrate and the desiccation of the shallow waters (Aladin et al., 2004). In the 1990s, the volume of the lake had decreased by $60 \%$ of the original area (before 1960) and salinities had risen from 9 psu to 30 psu (Boomer et al., 2000). By then, the majority of the aquatic fauna consisted of marine species; all freshwater and most brackish species had disappeared, while Abra segmentum, C. glaucum and C. sp. A, and E. grimmi thrived (Aladin et al., 2008, 2004).

\subsection{Processes influencing Pontocaspian mollusc diversity}

Here, first the drivers of Pontocaspian biodiversity are discussed in the three lake basins and then the faunal exchange during connections between basins.

\subsubsection{Caspian Sea}

The late Quaternary mollusc record prior to the $20^{\text {th }}$ century shows the continuous presence of most Pontocaspian species with the exception of Didacna species, which experienced several major turnovers (Yanina, 2014; Krijgsman et al., 2019). These turnover events appear to be correlated to very deep regressions. Given the fact that mollusc biodiversity hotspots are found in relatively deep water (31-74 m, Lattuada et al., 2019a) and many endemic species occur in even deeper parts of the Caspian Sea (100-400 m; Bogutskaya et al., 2013), the mollusc fauna is likely well adapted to Caspian Sea level changes. Moreover, lake level fluctuations mostly affect the shallow habitats in the northern and south-western Caspian Sea. Further research is required to examine whether limited depth ranges and salinity tolerances of some of the shallow-dwelling species are correlated with increased turnover rates.

New distribution data are required to model species distribution changes under a variety of environmental scenarios. During the Holocene, and especially during the last 100 years, a major shift towards dominance of invasive marine species can be observed. These human induced changes in species composition have had a different effect on the Pontocaspian fauna compared to the changes caused by natural events. Twentieth century Caspian Sea level change were minor compared to previous Quaternary lake level oscillations (Krijgsman et al., 2019). The invasive species, however, arrived suddenly, repeatedly and irreversibly (Yanina, 2012a). They have a high adaptive capability and a high competition potential compared to the specialised endemic and native Pontocaspian species (Kostianoy et al., 2005; Zolotarev, 1996).

Climate simulations show that the predicted global warming will not only increase precipitation in the Caspian catchment area, but also increase evaporation over the Caspian Sea (Nandini-Weiss 
et al., 2019). This will result in a negative water budget and a possible Caspian Sea water level decline of $9 \mathrm{~m}$ to $18 \mathrm{~m}$ by the end of the $21^{\text {st }}$ century (Nandini-Weiss et al., 2019). Such a big water drop will have severe consequences for the size of the Pontocaspian habitats. The shallow northern part of the Caspian Sea basin, which has a depth of less than $5 \mathrm{~m}$, will disappear, and so will the shallow parts in the south east. The newly created Pontocaspian habitats on the steep depth gradient on the border of the northern and middle Caspian Sea basin will be much smaller than the previous habitat, likely putting even more pressure on the already battered Pontocaspian fauna.

\subsubsection{Black Sea}

The paucity of time series from the Black Sea basin imposes limits on our understanding of the drivers of Pontocaspian biodiversity. Since the Middle Pleistocene, the Black Sea basin has alternated between isolated lake phases, whenever global sea levels dropped below the Bosporus threshold, and marginal marine phases during interglacial sea level highstands (Krijgsman et al., 2019). Both in the Holocene, as well as during MIS5 highstand, marine communities established in the Black Sea basin and marginalised Pontocaspian communities in the northern coastal regions. In the intervening periods, lake conditions existed similar to those in the Caspian Sea today, and during some of these intervals the basin became dominated by Pontocaspian species and communities. The Neoeuxinian is the last of such a Pontocaspian phase. The Black Sea biota experienced very large salinity fluctuations, ranging from 5-7 psu during the Neoeuxinian to 30 psu during the MIS5 Karangatian highstand.

In the $20^{\text {th }}$ century, the salinity gradients in the coastal refuges of Pontocaspian biota have become compromised and the Pontocaspian biota appear to be squeezed in between freshwater and marine biota in at least part of the Pontocaspian habitats. Many of the Pontocaspian species still occur in coastal environments within salinity gradients, but several of these species are also known from the lower courses of adjacent rivers indicating they are adapted to survive episodic freshening (Wesselingh et al., 2019). Unlike in the Caspian Sea, where deeper waters host Pontocaspian species hotspots (Lattuada et al., 2019b), it is possible that the development of anoxia during highstands (Eckert et al., 2013; Piper, 2016; Yanko-Hombach et al., 2007) precluded the development of deeper water species and communities in the Black Sea.

\subsubsection{Aral Sea}

The Aral Sea has been a marginal Pontocaspian habitat (Aladin et al., 2008; Boomer et al., 2000; Plotnikov et al., 2016). It has never provided a continuous Pontocaspian habitat through time (Filippov and Riedel, 2009). Evidence for desiccation during the mid-Holocene were presented by Mainguet et al. (1997), Mainguet and Létolle (1997), Micklin (2007), and Micklin et al. (2014). It is uncertain where Pontocaspian species found refuge during adverse conditions. The low richness and dominance of ecologically tolerant and even opportunistic species, before the late $20^{\text {th }}$ century desiccation, is in line with the dynamic environment of the Aral Sea (Filippov and Riedel, 2009). 


\subsubsection{Fauna interactions during highstands}

Within in the late Quaternary, Black Sea basin highstand phases (Chernomorian, Karangatian) were characterized by the immigration of Mediterranean faunas, while Pontocaspian faunas dominated during lacustrine phases (e.g. Neoeuxinian, Chaudian) (Krijgsman et al., 2019). Whenever the basin was occupied by Mediterranean faunas, the Pontocaspian faunas were marginalised into coastal zones similar as today or possibly disappeared (Wesselingh et al., 2019). In the Caspian Sea species abundances varied between highstand intervals, yet Pontocaspian richness remained similar. Repeated Caspian overflow events (Krijgsman et al., 2019; Yanina, 2014) reintroduced Caspian species in the Black Sea basin. The findings of this thesis indicate that the Caspian Sea basin has acted as a source of Pontocaspian taxa from the Middle Pleistocene onwards, and the Black Sea basin mainly as a sink. The Aral basin also acted as a sink. The latter two basins have lower species richness than the Caspian Sea basin, and their habitat shows more instability and higher Pontocaspian extinction rates through time. The magnitude of environmental change has been comparably less than in the other basins, maintaining a habitat availability and quality high enough to continuously sustain Pontocaspian biota. In comparison, the Aral Sea suffered repeated desiccation (Boomer et al., 2000) and the Black Sea experienced repeated shifts to marine phases and widespread development of anoxia in deeper parts (Eckert et al., 2013; Piper, 2016; Yanko-Hombach et al., 2007). Pontocaspian species in the source area have been shielded from competition with marine invasive species until the $20^{\text {th }}$ century and could reintroduce Pontocaspian species to sink areas whenever a connection existed between the basins. The Pontocaspian species in the Black Sea basin sink have repeatedly dealt with competition from marine species, which was likely the cause for them to become marginalized to lower salinity (mostly oligohaline) settings.

\subsection{Implications}

\subsubsection{Understanding resilience}

Most Pontocaspian species have adapted to live in a range of salinities, typically oligohaline to lower mesohaline conditions. Some Pontocaspian species have extended into fresh water habitats, where some became invasive (such as Dreissena species that extended into central-western European and North American fresh water habitats; McMahon, 1996; Orlova et al., 2005, 2004). Many Caspian species appear to be specifically vulnerable in their interaction with (introduced) marine species. During the Neoeuxinian phase of the Black Sea basin, a few marine species co-occurred with the Pontocaspian faunas, likely as a result of the low salinities (5-7 psu), which correspond to the lower tolerance levels of these marine taxa. The establishment of full-marine conditions in the Black Sea basin during interglacial transgressions often resulted in the marginalisation of the Black Sea basin Pontocaspian species. In summary, our data imply that the Pontocaspian fauna can successfully deal with large environmental variations over the Quaternary, but it is not resilient to invasive species. 


\subsubsection{Is there a Pontocaspian biodiversity crisis?}

This study shows that there are indications for a Pontocaspian mollusc diversity crisis. The shallow parts of the Caspian Sea have witnessed a turnover of Pontocaspian communities during the $20^{\text {th }}-21^{\text {st }}$ century due to invasive species. An apparent strong decline in abundances of endemic species and the decline in species richness occur in groups such as hydrobiids and Dreissena which otherwise did not experience notable turnover events during the past 1 Myr. Two species, i.e. Dreissena caspia and D. elata, which were very abundant only 50-100 years ago, are likely to have become extinct since then (von Rintelen and Van Damme, 2011b). The here studied Razim-Sinoie lake complex in the Black Sea basin has witnessed a major decline in Pontocaspian habitat and Pontocaspian diversity over the past decades due to a freshening of the system. As a result of human interventions both species numbers and abundance declined drastically. Little is known about the situation for Pontocaspian biodiversity along the liman coast of Ukraine and in Taganrog Bay. As to the Aral Sea, all Pontocaspian species have vanished in the past 50 years.

The deeper part of the Caspian may still act as a refuge for some endemic Caspian species. Data published by Mirzoev and Alekperov (2017) suggest relatively large numbers of endemic species present between 200 and $1000 \mathrm{~m}$ water depth. However, it is unclear whether these data represent living specimens or (may include) dead shells. Only a few endemic species have been found alive during impact assessments in the south Caspian basin, casting doubt to the occurrence of so many species still living in the southern Caspian Sea. Further collection efforts are crucial in order to assess whether the deeper Caspian Sea still acts as a refuge and how many of the species occur there.

\subsubsection{Mitigating the crisis}

If the Caspian Sea can indeed be shown to function as the source of Pontocaspian species diversity, conservation efforts should focus their objectives towards habitats in this basin. It is vital to prevent Pontocaspian species from further decline and protect the Pontocaspian habitat from introduction of any invasive species. Though, the incomplete distribution data and unresolved taxonomic issues hamper a straightforward approach.

In the Black Sea basin, the restoration and maintenance of existing salinity gradients in Pontocaspian habitats could mitigate the crisis. Where gradients are compromised due to river damming and diversion and closure of coastal inlets this can be achieved by creating dynamic barriers that allow limited and manageable influx of seawater into threatened lagoons (van Banning et al., 2018). Such an approach would also enable mobile organisms such as fish to migrate, which in turn would benefit both the unique benthic fauna and fish populations. Finally, the identity and distribution of Pontocaspian species needs to be established in enough detail to permit detailed conservation strategies.

Factors that are typically seen as negative influences on natural systems, such as the projected global sea-level rise as well as increased coastal erosion (Panin and Jipa, 2002), might actually prove beneficial in the restoration of salinity gradients in Black Sea basin habitats. In the case of 
the Razim-Sinoie lake complex, new outlets will be created naturally along the coastline and the presently freshened lakes might regain the salinity conditions necessary for Pontocaspian species to survive (van de Velde et al., 2019a).

The Aral Sea lost all Pontocaspian habitats and communities. The potential for restoration is low at present given the massive obliteration of the environment and the high salinity conditions.

\subsection{Recommendations for future research and actions}

(1) A sound taxonomic framework is needed to elucidate the identity of Pontocaspian species. This will require an integrated morphometric, ecological and molecular approach, to make informed decisions on species boundaries and test for the presence of cryptic species. The Pontocaspian mollusc species list presented in Chapter 3 acts as a working list of current species in the Pontocaspian area, but many of the gastropods and species of the Cardiidae family are still in need of further update.

(2) More distribution and ecological data of Pontocaspian species are necessary. Without systematic biodiversity assessments on currently living species, population trends cannot be assessed and conservation statuses of individual species cannot be established. Gathering abundance data of assemblages is vital to understand how resilient the species/communities are to changes in their environment. A review of the conservation statuses of the species reported by Wesselingh et al. (2019) is currently being executed, but the far majority of Pontocaspian species is considered as data deficient (F.P. Wesselingh, pers. comm.).

(3) More detailed biodiversity time series coupled with detailed environmental proxies are required to understand the response of Pontocaspian faunas to environmental and biological perturbations. This will require access to more locations (including offshore core material), a wider time frame, and the study of other systematic groups in addition to molluscs.

(4) Awareness of the Pontocaspian biodiversity crisis is very low, apart for some species such as the Caspian seal and the sturgeon species. Increasing awareness among the general public and key stakeholders (governmental organisations, natural reserves, NGOs) is imperative to develop successful conservation efforts to mitigate the Pontocaspian biodiversity crisis.

(5) Open platforms need to be developed where open-access data and views can be shared between participants from the various Pontocaspian countries in order to optimise collaboration. An international (open-access) database with literature and data would greatly improve research in the area. 


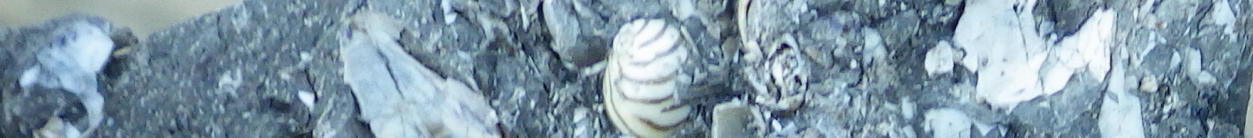
3

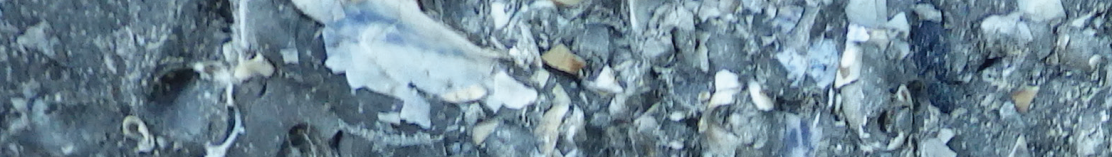

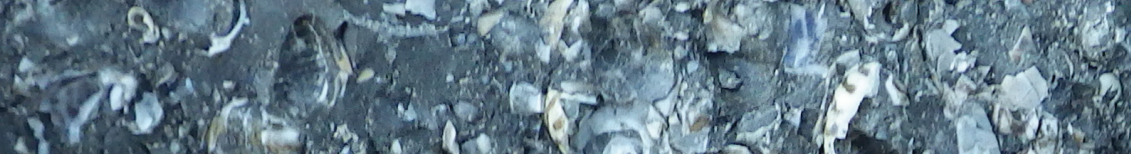

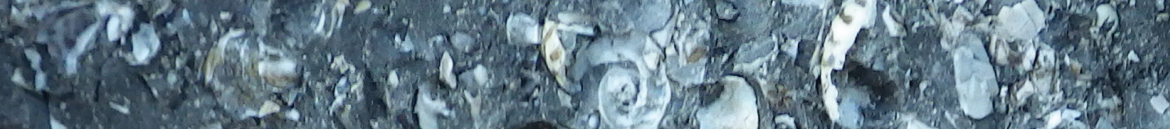

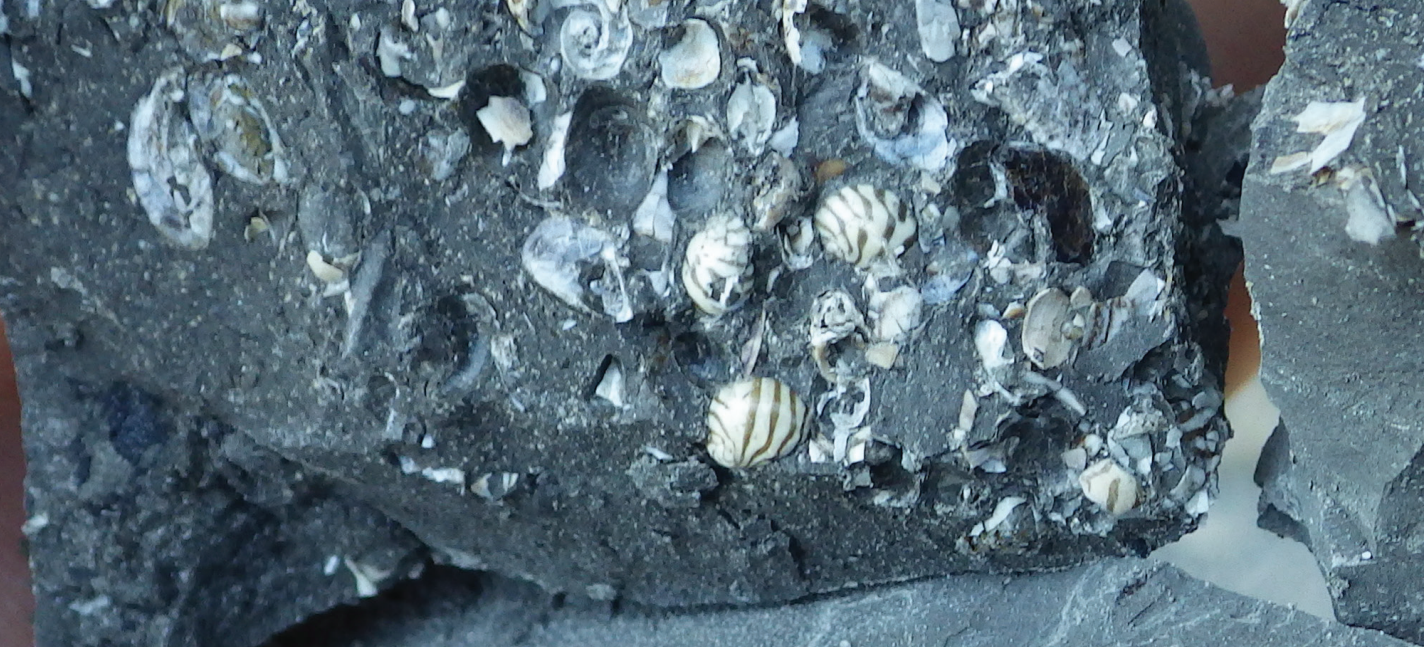

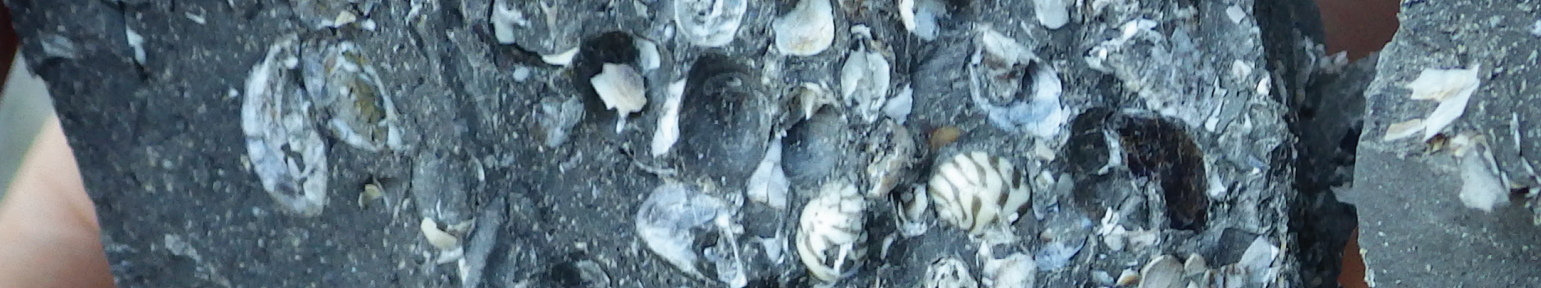

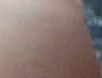

(2)

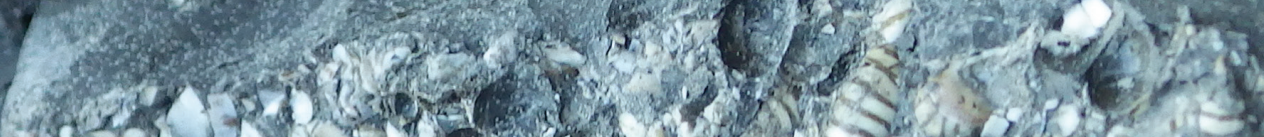
a)

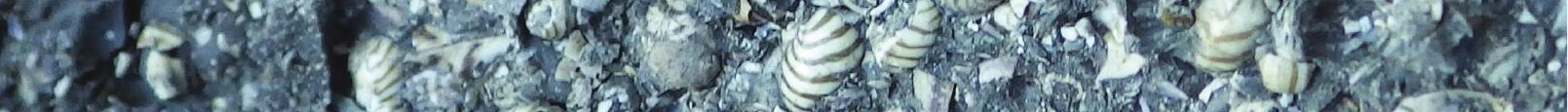

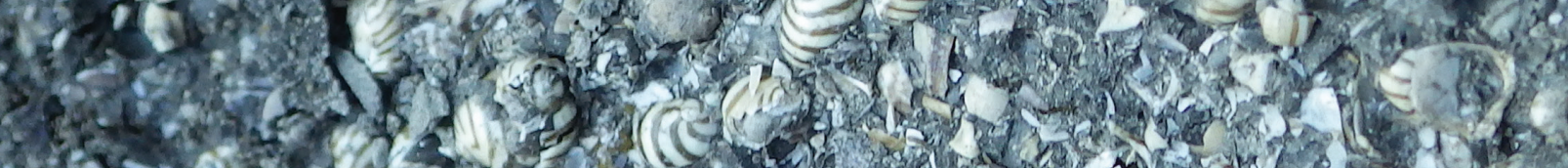

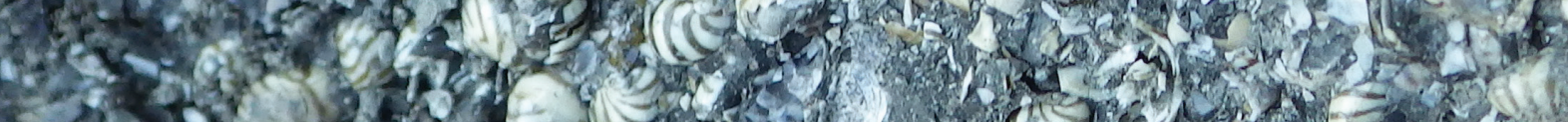

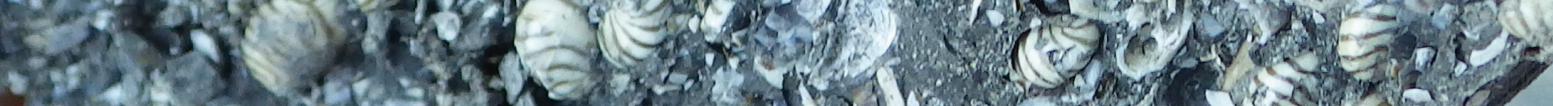

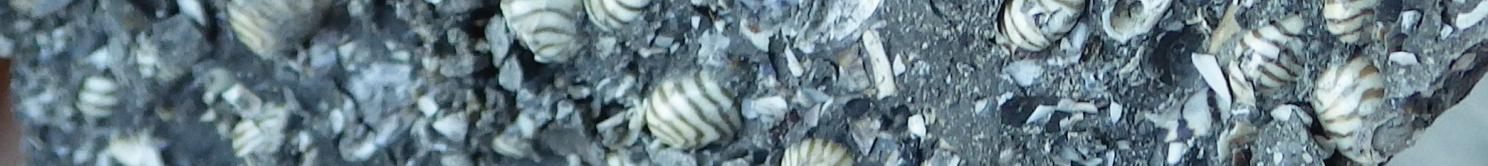

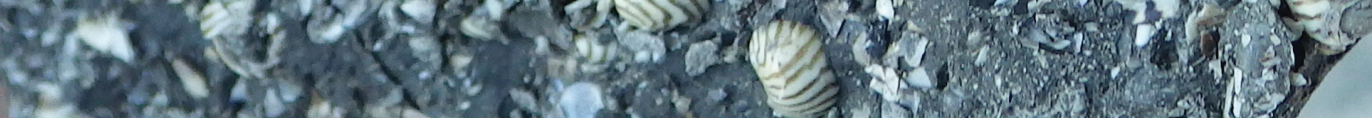

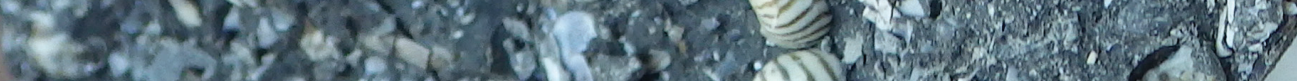

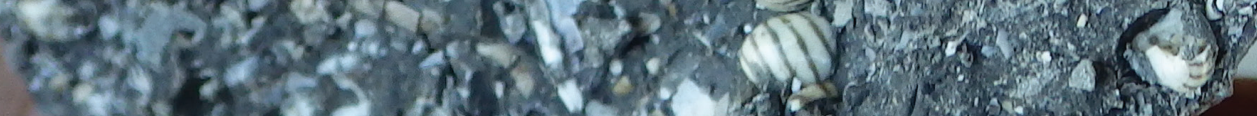

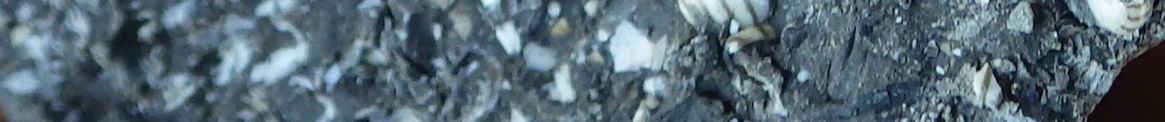




\section{1}

\section{ACKNOWLEDGEMENTS}

The work presented in this thesis could not have been established without the help of many people. Some were there for me scientifically, some supported me mentally, others go back a long time and paved the path that led to the choice of applying for a doctorate. In the end, all of you were somehow involved in the beautiful process of starting and completing this important part of my life: doing a $\mathrm{PhD}$ research.

My first thanks goes out to my main supervisor, Frank Wesselingh. The brain behind the PRIDE project, the wonderful person that decided to hire me for the job, thank you so much for the past four years. I am forever grateful to you for giving me the chance to do this research and for believing in my abilities since day one. You were always there for me with advice, positivity and assistance. Your knowledge of molluscs has been inspiring and invaluable for our research. Without you this thesis would not have existed. Thomas Neubauer, thank you also for supervising me. First as a colleague and a friend and later as second co-promotor. Your support has been essential in the last stretch of this thesis, and you will always be my role-model of what it is like to be a good researcher.

I would also like to thank the members of the reading and dissertation committee and my promotor, Luc Lourens. Thank you all, your interesting questions and conversations have improved this thesis.

My fellow PRIDE PhDs: Diksha Bista, Anouk D’Hont, Aleksandre Gogaladze, Thomas Hoyle, Liesbeth Jorissen, Sifan Koriche, Matteo Lattuada, Sergei Lazarev, Alberto Martínez-Gándarra, Sri Nandini, Lea Rausch, Manuel Sala-Pérez, Arthur Sands, and Justine Vandendorpe, during our three year adventure we have experienced a lot together, there are not enough words to describe it all in the acknowledgements. My personal thank you messages can be found in the photobook, but I will shortly say it again: Thank you so much for all the beautiful moments we have shared, you guys are the best!

I also want to thank all the people that have made my PRIDE fieldworks possible and successful. In Turkey: Cihat and Hüylia Alçiçek, thank you for your hospitality, Marius Stoica, thank you for saving my life when I was lost and paralysed with fear on a steep slope with sinkholes at the foot, Hemmo Abels, Chris van Baak, thanks for inspiration and the PRIDE dance, Kazim Halaclar, Amin Akın, and the other Turkish students who were chasing the scorpions away in the field, my first geology fieldworks would not have been such a great experience without you. In Azerbaijan: Rashad, Aydın, Yusif, Elnara, Gulçin, Yavar, Sevinj, thank you for all the assistance and fun in the field, the amazing food and great times in Baku. The secondment and fieldwork in Russia was a great success thanks to Tamara Yanina (your love for shells is contagious), Katy Taldenkova (thank 
you for the Russian ballet tickets), Denis (the Russian circus), Radik Makshaev (Kolomenskoye park, among many other warm memories), Vasily Dikarev (driving me around), Alexey Tesakov (our collaborations and fun times), Pavel Frolov (our warm conversations), Dasha Aristova (for your friendship and showing me all the secrets of the university and Moscow), Alina Berdnikova (for friendship, research and laughs), Lena Garova (gin tonic adventures), and the guys Nikolay, Nikita Sychev, and the other Nikita. Спасибо for all the fun and scientific discussions, and making my secondment at the Moscow State University so unforgettable. In Kazakhstan: Thank you KAPE, Fedor Klimov, the captain and his Kazakh/Russian sailors crew and cook, Marzhan, Bianca Pavel, ESRs, Frank and Caroline. It was an unforgettable cruise, where we finally made it onto the Caspian Sea thanks to everybody's huge effort.

The PRIDE project could not have existed without Frank \& Caroline. Their positive souls and abilities to get people together is inspiring and resulted in an amazing collection of publications, conferences, travels, new experiences and learning moments. Thank you so much for making this possible and bringing all these great researchers and students together. Everybody involved, project partners, scientific advisory board members, co-authors and fieldworkers, thank you for all that we have experienced and learned from each other during the PRIDE programme. Any colleagues I might have forgotten, forgive me, and thank you too.

Before I arrived to this adventure, many people have inspired me along the way: Thijs van Kolfschoten was always there for me throughout the BSc Archaeology and excited me with fieldworks in Germany and Russia. Martina Stang was there for me during the BSc Biology and thrilled me with numerous fieldworks in the USA and Spain. The MSc European Forestry would not have been the same without the conversations with Jari Kouki, Juanma Rubialis and Luis Serrano. All of your positive attitudes, love for research and love for life in general has been a big inspiration for me to continue doing what I love and to always follow my heart. Thank you so much for that, it brought me where I am now.

Thanks goes also to the Marine Biodiversity team at Naturalis for all the coffee breaks, lunches, group chats and advices: Willem Renema, Nicole de Voogd, Katja Peijnenburg, José Joordens, Debbie Wall-Palmer, Martina de Freitas Prazeres, Paula Silva, Jan Macher, and Renate Helwerda. A very special thanks to all the Naturalis PhDs with whom I shared numerous lunches, cups of coffee, tea, borrels and parties: Esther van der Ent, Lisette Mekkes, Andres Rivera Quiroz, Werner de Gier, Kevin Beentjes, Sofia Fernandes Gomes, Leon Marshall (\&Vicky Alcalde), Sander Hilgen, Leqin Choo, Thomas Swierts. And a warm thanks to other Naturalis colleagues that supported me throughout; Renato Lima, Pascal Velthuizen, Luis Morgado, Nieke Knoben, Lisette van Kolfschoten. You were always there for me with a uplifting conversation, warm cup of tea and supporting words. Thank you Marjan Helwerda and Ronald Pouwer for helping with pre-sorting the shells, without you my research would have taken twice as long.

Furthermore, I am very grateful for the support of my friends throughout the years. Lieve Kronenburgers; Kai \& Inge, Toonssen \& Fleur, Suzanne \& Marco, Dennis \& Fede, Tjipke \& Veronique en Robert. Bedankt voor jullie vriendschap door de jaren heen. Al zien we elkaar 
niet veel, onze borrels en feestjes zijn essentieel in mijn leven en het bleven tijdens mijn Phd steeds hoogtepuntjes om jullie te zien. Frank Stevens, Simone Lemmers, Maikel Kuijpers, Victor Klinkenberg, het is niet alleen de liefde voor de archeologie die we delen. Jullie warmte, reislust en levensenergie haalden me iedere keer weer omhoog als ik het niet meer zag zitten. Bedankt daarvoor. Mede boogschutters van Archery Events, zodra ik met jullie op het veld sta of door de natuur loop verdwijnt alle stress uit mijn lichaam. Het is heerlijk om bij jullie mezelf weer op te kunnen laden voor de volgende uitdagingen in mijn leven. Dank jullie wel voor de ontspannende momenten, ze waren onmisbaar de afgelopen jaren.

During the far away journeys and international life I have met many beautiful people on the way. Although we no longer see each other often, you are still very important to me. The fact that we kept in touch throughout the years and that we still meet each other means a lot to me: Ferry Prins, Joanra Llagostera Pla, Stelios Giannoulis, Julia Bierstedt, Eero Mela-Aho, Joan Rollan Martinez, Ines Vodopija, a very warm thanks to you all. Carlos (Bala) \& Camilla, Adrian Fernandez Vigo, Pedro Camargo \& Debora Fernandez, you also belong to this group. I am glad that we have met and that we have shared many beautiful moments together in between the moments of hard work.

Een enorme dank gaat uit naar mijn hartsvrienden: Arjan Zwamborn, Aleksandre Gogaladze, Marije Verkerk \& Amanda Geertsema. Jullie vier zijn mijn rots in de branding en als ik vier paranimfen had mogen kiezen waren jullie dat allemaal geweest. De band die ik met jullie heb is nergens anders mee te vergelijken. Zonder jullie support, kalmerend woorden, concertjes, knuffels, wandelingen, rode wijnavonden, hardloopsessies, kroeg avonden en telefoongesprekken had ik het al lang opgegeven. Jullie zijn degenen die me geestelijk gezond hebben gehouden tijdens alle stressvolle en eenzame momenten en zonder wie deze $\mathrm{PhD}$ waarschijnlijk niet was gelukt. Ik zal jullie voor altijd dankbaar zijn en koester jullie vriendschap.

Ik kan niet anders dan afsluiten met het bedanken van mijn familie voor alle aanmoediging en steun. Niet alleen tijdens de afgelopen vier jaar, maar ook tijdens de vijf jaar ervoor dat ik in het buitenland studeerde en de fundering legde voor het leven als onderzoeker. Hoewel ik vaak ver weg was, zijn jullie me nooit vergeten en altijd in mij blijven geloven. Pap en mam zonder jullie onvoorwaardelijke liefde, support en begrip had ik het nooit gered. Sean \& Lieke, Artho \& Sandy, Joël \& Annette, bedankt dat jullie er altijd voor me zijn geweest en het me hebben vergeven als ik weer eens een afspraak of verjaardag moest annuleren. Ik ben zo blij dat jullie er voor me zijn! Além disso, muito obrigado à minha família no Brasil, que me abraçou com todo o carinho e amor do mundo. Sempre senti o estresse desaparecer rapidamente quando eu os visitava, sendo cercada por seu amor.

Finally, I want to thank Guilherme Herrero Bastos. Lieve Gui, you have seen me during the moments I really wanted to give up this crazy research mission. Still, every time you surrounded me with renewed energy, calm words and supporting advice. Thank you for always being there for me and helping me through my most difficult moments. You are a beautiful person and I could not have done this without you. I am forever thankful for your endless love and support. 



\section{2}

\section{AbOUt THE AUTHOR}

Sabrina van de Velde was born on the $17^{\text {th }}$ of May, 1985 in Rotterdam (the Netherlands). She completed her Bachelor's degree in Archaeology (20042007) at the University of Leiden with fieldworks in the Netherlands, Germany and Russia. Under the supervision of Prof. van Kolfschoten she wrote her first thesis on Isotopic Research in Archaeology and a second thesis about the Early Pleistocene Mammal Diversity of Tegelen.

To broaden her knowledge on faunal diversity she completed a Bachelor's degree in Biology (2008-2011) at the University of Leiden, including an Erasmus student exchange year at the University of Granada

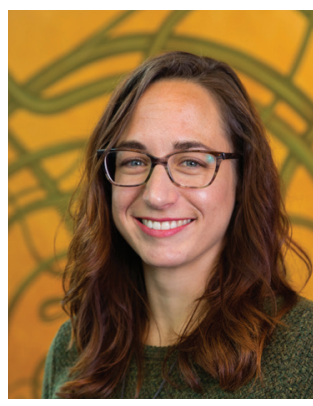
(Spain) and fieldwork in Alicante (Spain). In 2010 Sabrina received a Leiden University Fund scholarship to do her Bachelor internship at the Rocky Mountain Biological Laboratory (RMBL, Gothic, Colorado, Amerika). Three summers (2010-2011-2012) were spent at the RMBL as a research assistant of Dr. Stang to collect data on nectar and plant-pollinator interactions.

Continuing her love for research and observing nature, Sabrina applied for a team-leader position in the Seychelles. From August 2012 until May 2013 she led a semi-autonomous team in a research project on pollination networks and habitat restoration in the Seychelles, under the supervision of Dr. Kaiser Bunbury. While gaining field experience on diversity and restoration, Sabrina realised she wanted to learn more about managing and protection nature.

She returned to Europe and completed a double Master's degree (2013-2015): MSc European Forestry at the University of Lleida (Spain) and MSc Agriculture and Forestry at the University of Eastern Finland (Finland). During this Erasmus Mundus programme, her courses were focussed on natural ecosystems, species conservation, biodiversity and palaeoecology at eight universities: in Sweden, Finland, Germany, France, Austria, Spain, Netherlands and an internship in China. Her final thesis was about the effect of different management techniques on beetle diversity in Finnish forests, supervised by Prof. Kouki.

Sabrina became a Marie Curie Early Stage Researcher (2015-2019) for the PRIDE (Pontocaspian Rise and Demise) project at the Naturalis Biodiversity Center (the Netherlands), where she could pursue her broad interest in both prehistorical and living biodiversity. Part of the research consisted of fieldworks in Romania, Georgia, Turkey, Russia, Azerbaijan, Kazakhstan and a secondment at the Lomonosov Moscow State University (Russia). As a PhD researcher she found a way of combining the multidisciplinary knowledge of previous studies: by examining a currently threatened mollusc diversity in deep time and comparing the diversity with the living biota, she could make informed statements on how to mitigate a biodiversity crisis. 


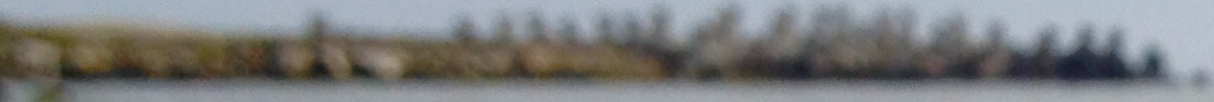
a

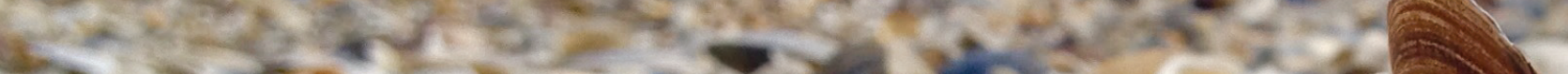

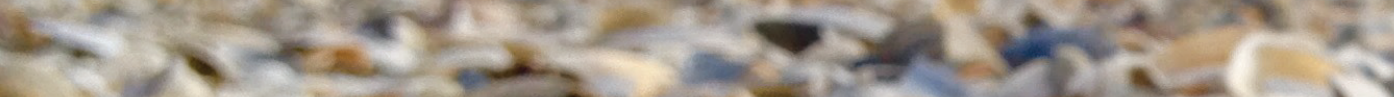

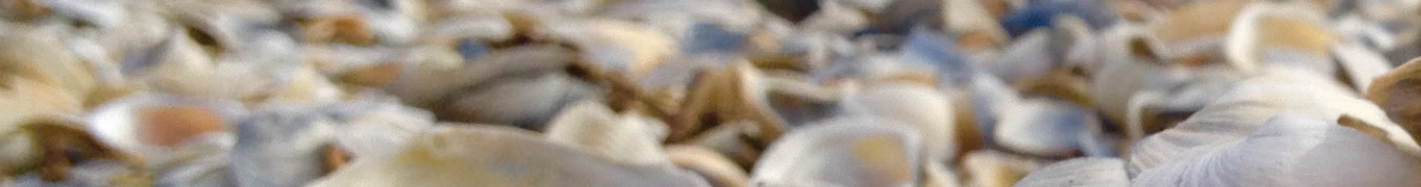

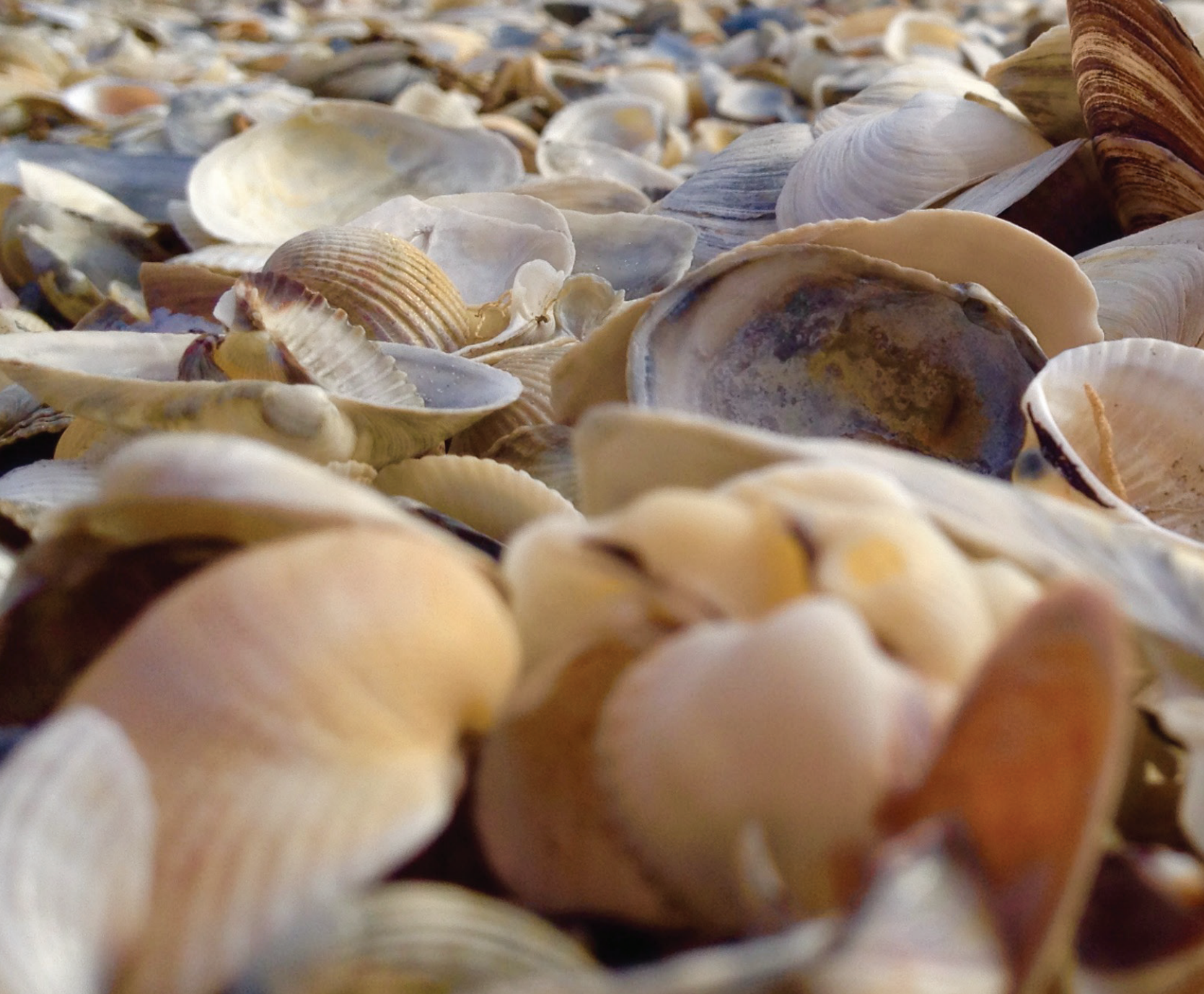




\section{PeER REVIEWEd PUBLICATIONS}

Lazarev, S., Jorissen, E.L, van de Velde, S., Rausch, L., Stoica, M., Wesselingh, F.P., Van Baak, C.G.C., Yanina, T.A., Aliyeva, E., Krijgsman, W., 2019. Magneto-biostratigraphic age constraints on the palaeoenvironmental evolution of the South Caspian basin during the Early-Middle Pleistocene (Kura basin, Azerbaijan). Quat. Sci. Rev. 222, 105895. http://doi.org/10.1016/j.quascirev.2019.105895

van de Velde, S., Wesselingh, F.P., Yanina, T.A., Anistratenko, V.V., Neubauer, T.A., ter Poorten, J.J., Vonhof, H.B., Kroonenberg, S.B., 2019. Mollusc biodiversity in late Holocene nearshore environments of the Caspian Sea: A baseline for the current biodiversity crisis. Palaeogeogr. Palaeoclimatol. Palaeoecol. 109364. http://doi. org/10.1016/j.palaeo.2019.109364

Syromyatnikova, E., Roček, Z., van de Velde, S., 2019. New discoveries in the frog Latonia seyfriedi (Anura: Alytidae) and their impact on taxonomy of the genus Latonia. PalZ. http://doi.org/10.1007/s12542-019-00477-8

van de Velde, S., Yanina, T.A., Neubauer, T.A., Wesselingh, F.P., 2019. The Late Pleistocene mollusk fauna of Selitrennoye (Astrakhan province, Russia): A natural baseline for endemic Caspian Sea faunas. J. Great Lakes Res., 1-13. http://doi.org/10.1016/j.jglr.2019.04.001

van de Velde, S., Jorissen, E.L., Neubauer, T.A., Radan, S., Pavel, A.B., Stoica, M., Van Baak, C.G.C., Martínez Gándara, A., Popa, L.O., de Stigter, H., Abels, H.A., Krijgsman, W., Wesselingh, F.P., 2019. A conservation palaeobiological approach to assess faunal response of threatened biota under natural and anthropogenic environmental change. Biogeoscience 16, 2423-2442. http://doi.org/10.5194/bg-2019-2423-2019

Wesselingh, F.P., Neubauer, T.A., Anistratenko, V.V., Vinarski, M.V., Yanina, T.A., ter Poorten, J.J., Kijashko, P.V., Albrecht, C., Anistratenko, O.Y., D’Hont, A., Frolov, P., Martínez Gándara, A., Gittenberger, A., Gogaladze, A., Karpinsky, M.G., Lattuada, M., Popa, L.O., Sands, A.F., van de Velde, S., Vandendorpe, J., Wilke, T., 2019. Mollusc species from the Pontocaspian region - an expert opinion list. Zookeys 827, 31-124. http://doi.org/10.3897/zookeys.827.31365

Krijgsman, W., Tesakov, A.S., Yanina, T.A., Lazarev, S., Danukalova, G.A., Van Baak, C.G.C., Agustí, J., Alçiçek, M.C., Aliyeva, E., Bista, D., Bruch, A., Büyükmeriç, Y., Bukhsianidze, M., Flecker, R., Frolov, P., Hoyle, T.M., Jorissen, E.L., Kirscher, U., Koriche, S.A., Kroonenberg, S.B., Lordkipanidze, D., Oms, O., Rausch, L., Singarayer, J., Stoica,, M., van de Velde, S., Titov V.V., Wesselingh, F.P., 2019. Quaternary time scales for the Pontocaspian domain: Interbasinal connectivity and faunal evolution. Earth-Science Rev. 188, 1-40. http://doi.org/10.1016/j. earscirev.2018.10.013

Neubauer, T.A., van de Velde, S., Yanina, T.A., Wesselingh, F.P., 2018. A late Pleistocene gastropod fauna from the northern Caspian Sea with implications for Pontocaspian gastropod taxonomy. ZooKeys 770, 43-103. http://doi. org/10.3897/zookeys.770.25365

Fan, J.B., van de Velde, S., Sun, W.B., Yu, H., Zhang, Y.L., Wang, D., 2017. Enhanced toxicity of Cry2Ab with cantharidin and its analogues on Mythimna separata. J. Appl. Entomol. 141(5), 363-371. http://doi:.org/10.1111/ jen.12359 


\section{REFERENCES}

Abdurakhmanov, G.M., Karpyuk, M.I., Puzachenko, Y.G., 2002. The current state and factors defining biological and landscape diversity of the Volga-Caspian region of Russia. Nauka, Moscow (in Russian).

Abich, H., 1859. Vergleichende chemische Untersuchungen der Wasser des Caspischen Meeres, Urmia- und Van-See's. Mémoires l’Académie impériale des Sci. St.-Pétersbourg, 6e série, Sci. mathématiques, Phys. Nat. 7, 1-57.

Abramova, T.A., 1974. Reconstruction of the Paleogeographical Environment of the Quaternary Transgressions and Regressions of the Caspian Sea (On the Data of Paleobotany Investigations). Moscow State University, Moscow (in Russian).

Agapova, G.V., Kulakova, L.S., 1973. Physiographic map of the Caspian Sea. Oceanology-USSR 13, 518-522.

Agusa, T., Kunito, T., Tanabe, S., Pourkazemi, M., Aubrey, D.G., 2004. Concentrations of trace elements in muscle of sturgeons in the Caspian Sea. Mar. Pollut. Bull. 49, 789-800. https://doi.org/10.1016/j.marpolbul.2004.06.008

Akramovskiy, N.N., 1976. Fauna Armyanskoy SSR. Mollyuski [Fauna of the Armeniean SSR. Mollusca]. Izvestiya Akademii Nauk Armyanskoy SSR, Yerevan.

Aksu, A.E., Hiscott, R.N., Kaminski, M.A., Mudie, P.J., Gillespie, H., Abrajano, T., Yaşar, D., 2002. Last glacial-Holocene paleoceanography of the Black Sea and Marmara Sea: Stable isotopic, foraminiferal and coccolith evidence. Mar. Geol. 190, 119-149. https://doi.org/10.1016/S0025-3227(02)00345-6

Aladin, N.V., Filippov, A.A., Plotnikov, I.S., Orlova, M.I., Williams, W.D., 1998. Changes in the structure and function of biological communities in the Aral Sea, with particular reference to the northern part (Small Aral Sea), 1985-1994: A review. Int. J. Salt Lake Res. 7, 301-343. https://doi.org/10.1023/A:1009009924839

Aladin, N.V., Micklin, P., Plotnikov, I., 2008. Biodiversity of the Aral Sea and its importance to the possible ways of rehabilitating and conserving its remnant water bodies., in: Environmental Problems of Central Asia and Their Economic, Social and Security Impacts. Springer, Dordrecht, pp. 73-98. https://doi.org/10.1007/978-1-4020-8960-2

Aladin, N.V., Plotnikov, I.S., Smurov, A.O., Gontar, V.I., 2004. Rol' chuzherodnykh vidov zhivotnykh v ekosisteme Aral'skogo morya [The role of introduced animal species in the ecosystem of the Aral Sea], in: Biological Invasions in Aquatic and Terrestrial Ecosystems. Moscow-St.Petersburg, pp. 275-296 (in Russian).

Albano, P.G., Filippova, N., Steger, J., Kaufman, D.S., Tomašových, A., Stachowitsch, M., Zuschin, M., 2016. Oil platforms in the Persian (Arabian) Gulf: Living and death assemblages reveal no effects. Cont. Shelf Res. 121, 21-34. https://doi.org/10.1016/j.csr.2015.12.007

Albers, J.C., 1850. Die Heliceen, nach natürlicher Verwandtschaft systematisch geordnet. Enslin, Berlin.

Albrecht, C., Trajanovski, S., Kuhn, K., Streit, B., Wilke, T., 2006. Rapid evolution of an ancient lake species flock: Freshwater limpets (Gastropoda: Ancylidae) in the Balkan Lake Ohrid. Org. Divers. Evol. 6, 294-307. https://doi. org/10.1016/j.ode.2005.12.003 


\section{REFERENCES}

Albrecht, C., von Rintelen, T., Sereda, S., Riedel, F., 2014. Evolution of ancient lake bivalves: the Lymnocardiinae (Cardiidae) of the Caspian Sea. Hydrobiologia 739, 85-94. https://doi.org/10.1007/s10750-014-1908-3

Alexandrov, L., Zaharia, M., Ursache, C., Zaharia, T., Telembici, A., Cernişencu, I., Mircea, D., Bostina, A., Smocov, V., 2004. Environmental changes and their impact on fisheries in Sinoe Lagoon-Romania. Cercet. Mar. 35, $237-252$.

Alexenko, T.L., Starobogatov, Y.I., 1987. Vidy Caspia i Turricaspia (Gastropoda, Pectinibranchia, Pyrgulidae) AzovoChernomorskogo basseyna. Vestn. Zool. 21, 32-38.

Algan, O., Ça冈atay, N., Tchepalyga, A., Ongan, D., Eastoe, C., Gökaşan, E., 2001. Stratigraphy of the sediment infill in Bosphorus Strait: Water exchange between the Black and Mediterranean Seas duringthe last glacial holocene. Geo-Marine Lett. 20, 209-218. https://doi.org/10.1007/s003670000058

Ali-Zade, A.A., 1954. Aktshagylian stage of Azerbaijan. Azerbaijan SSR Academy of Sciences Press, Baku.

Anan, Y., Kunito, T., Tanabe, S., Mitrofanov, I., Aubrey, D.G.G., 2005. Trace element accumulation in fishes collected from coastal waters of the Caspian Sea. Mar. Pollut. Bull. 51, 882-888. https://doi.org/10.1016/j. marpolbul.2005.06.038

Andreev, N.I., Andreeva, S.I., 2003. Evolyutsionnye preobrazovaniya dvustvorchatykh mollyuskov Aral'skogo morya v usloviyakh ekologicheskogo krizisa [Evolutionary Transformation of Bivalves in the Aral Sea in Ecological Crisis)]. Omsk. Gos. Pedagog. Univ. Omsk 382.

Andreev, N.I., Andreeva, S.I., Filippov, A.A., Aladin, N.V., 1992. The fauna of the Aral Sea in 1989. 1. The benthos. Int. J. Salt Lake Res. 1, 103-110. https://doi.org/10.1007/BF02904954

Andreeva, S.I., 1989. Macrozoobenthos of the Aral Sea in the initial period of its salinization. USSR Acad. Sci. Proc. Zool. Institute, Leningr. 199, 53-82.

Andrusov, N., 1910. Studien über die Brackwassercardiden. Didacna. (erste Hälfte). Lieferung II. [Studies on the brackish water cardids. Didacna. (first half). Volume II]. Mémoires l’Académie impériale des Sci. St.-Pétersbourg. VIIIe série. Cl. physico-mathématiq 25, 1-84.

Andrusov, N., 1909. Beiträge zur Kenntnis des Kaspischen Neogen. Pontischen Schichten des Schemachinischen Distriktes, Mémories du Comité Géologique, nouvelle série. Trudy Geologicheskago Komiteta, novaya seriya.

Andrusov, N., 1897. Fossile und lebende Dreissenidae Eurasiens. Tipografiya M. Merkusheva, St. Petersburg.

Andrusov, N., 1890. Kerchenskiy izvestnyak i yego fauna. Zap. Imp. S.-Petersburgskago Mineral. Obs. (seriya 2) 26, 193 344.

Andrusov, N.I., 1923. Apsheronian Stage. Proc. Geol. Commettee, new Ser. 110 1-294.

Andrusov, N.I., 1918. Geological structure of the bottom of the Kerch Strait. Izv. Acad. Sci. USSR, Ser. 6 12, 23-28 (in Russian).

Andrusov, N.I., 1896. Expedition of “Selyanik” in the Marmara Sea. Exped. Russ. Geogr. Soc. 1894. 153-171 (in Russian).

Anistratenko, O.Y., 1999. Mollusks of the Genus Theodoxus (Gastropoda, Pectinibranchia, Neritidae) from the Black and the Azov Seas Basin. Vestn. Zool. 33, 11-19 (in Russian).

Anistratenko, V.V., 2013. On the taxonomic status of the highly endangered Ponto-Caspian gastropod genus Caspia (Gastropoda: Hydrobiidae: Caspiinae). J. Nat. Hist. 47, 51-64. https://doi.org/10.1080/00222933.2012.742934 
Anistratenko, V.V., 2008. Evolutionary trends and relationships in hydrobiids (Mollusca, Caenogastropoda) of the Azov-Black Sea Basin in the light of their comparative morphology and paleozoogeography. Zoosystematics Evol. 84, 129-142. https://doi.org/10.1002/zoos.200800001

Anistratenko, V.V., 2007a. Novyye dannyye o sostave, strukture i genezise Ponto-Kaspiyskoy fauny bryukhonogikh mollyuskov v Azovo-Chernomorskom basseyn. Zool. Zhurnal 86, 793-801.

Anistratenko, V.V., 2007b. Finding of the extremely rare hydrobiid Caspia logvinenkoi (Mollusca: Gastropoda) in the estuary of the River Don and its zoogeographical significance. Mollusca 25, 23-26.

Anistratenko, V.V., 2005. Lectotypes for Tricolia pullus, Gibbula divaricata and Theodoxus fluviatilis revisited. Vestn. Zool. 39, 3-10.

Anistratenko, V.V., 1991. Mollyuski gruppy Hydrobia sensu lato Chernogo i Azovskogo morey. Byulleten’ Mosk. Obs. Ispyt. Prir. Otd. Biol. 96, 73-81.

Anistratenko, V.V., Anistratenko, O.Y., Kadolsky, D., 2019. Karl E. von Baer's collection of Caspian Sea molluscs stored in the Zoological Museum of Lviv University, Ukraine. Part 2. Type materials of gastropod species described by Stephan Clessin and Władysław Dybowski in 1887-1888. Arch. für Molluskenkd. 148, 35-62.

Anistratenko, V.V., Anistratenko, O.Y., Shydlovskyy, I.V., 2018. Karl E. von Baer's collection of Caspian Sea molluscs stored in the Zoological Museum of Lviv University, Ukraine. Part 1. Catalogue and general description. Arch. für Molluskenkd. 147, 223-236. https://doi.org/https://doi.org/10.1127/arch.moll/147/223-236

Anistratenko, V.V., Khaliman, I.A., Anistratenko, O.Y., 2011. Mollyuski Azovskogo morya. Naukova dumka, Kiev. Anistratenko, V.V., Prisyazhniuk, V.A., 1992. Novyye dannyye o mollyuskakh golotsenovykh otlozheniy Chernogo morya na Ukraine [New data on mollusks of the Holocene sediments of the Black Sea in Ukraine]. Vestn. Zool. 5, $15-21$.

Anistratenko, V.V., Stadnichenko, A.P., 1995. Fauna Ukraine. Vol. 29: Mollusca. Fasc. 1. B. 2: Orders Littoriniformes, Rissoiformes. Naukova dumka, Kiev.

Anistratenko, V.V., Zettler, M.L., Anistratenko, O.Y., 2017. On the taxonomic relationship between Theodoxus pallasi and T. astrachanicus (Gastropoda: Neritidae) from the Ponto-Caspian regio. Arch. für Molluskenkd. 146, 213-226. https://doi.org/10.1127/arch.moll/146/213-226

Arconada, B., Ramos, M.A., 2006. Revision of the genus Islamia Radoman, 1973 (Gastropoda, Caenogastropoda, Hydrobiidae), on the Iberian Peninsula and description of two new genera and three new species, Malacologia.

Arkhangelsky, A.D., Strakhov, N.M., 1938. Geological structure and history of development of the Black Sea. Publishing house of Academy of Sciences of the USSR, Moscow-Leningrad (in Russian).

Arpe, K., Tsuang, B.J., Tseng, Y.H., Liu, X.Y., Leroy, S.A.G., 2018. Quantification of climatic feedbacks on the Caspian Sea level variability and impacts from the Caspian Sea on the large-scale atmospheric circulation. Theor. Appl. Climatol. 1-14. https://doi.org/10.1007/s00704-018-2481-x

Arslanov, K.A., Lokshin, N.V., Mamedov, A.V., 1988. On the age of Khazarian, Khvalynian and New Caspian deposits of the Caspian Sea. Bull. Com. Investig. Quat. period 57, 28-38 (in Russian).

Arslanov, K.A., Yanina, T.A., Chepalyga, A.L., Svitoch, A.A., Makshaev, R.R., Maksimov, F.E., Chernov, S.B., Tertychniy, N.I., Starikova, A.A., 2016. On the age of the Khvalynian deposits of the Caspian Sea coasts according to $14 \mathrm{C}$ and $230 \mathrm{Th} / 234 \mathrm{U}$ methods. Quat. Int. 409, 81-87. https://doi.org/10.1016/j.quaint.2015.05.067 


\section{REFERENCES}

Artyushenko, A.T., Pashkevich, G.A., Kareeva, E.V., 1972. Development of vegetation of the South of Ukraine in the Anthropogene according to the spore and pollen analysis. Bull. Comis. Investig. Quat. Period 39 (in Rus.

Artyushenko, A.T., Pashkevich, G.A., Parishkura, S.I., Kareeva, E.V., 1973. Paleobotanic characteristic of the basic sections of the Quarternary (Anthropogene) deposits of middle and southern part of Ukraine. Naukova Dumka, Kiev (in Russian).

Badertscher, S., Fleitmann, D., Cheng, H., Edwards, R.L., Göktürk, O.M., Zumbühl, A., Leuenberger, M., Tüysüz, O., 2011. Pleistocene water intrusions from the Mediterranean and Caspian seas into the Black Sea. Nat. Geosci. 4, 236-239. https://doi.org/10.1038/ngeo1106

Badyukova, E.N., Kalashnikov, A.Y., 2009. Dependence of the types of coasts and coastal eolian relief on the variations of the sea level using the example of the Caspian Sea. Oceanology 49, 858-865. https://doi.org/10.1134/ s0001437009060113

Balabanov, I.P., 2006. Holocene sea-level changes in the Northern Black Sea. Extend. Abstr. Second Plenary Meet. F. trip Proj. IGCP-521 Black Sea-Mediterr. Corridor Dur. last 30 ky sea Lev. Chang. Hum. Adapt. Odessa Astroprint $21-23$

Balabanov, I.P., Izmailov, Y.A., 1988. Change of level and hydrochemical mode of the Black and Azov seas for the last 20 thousand years. Water Resour. 6, 54-63 (in Russian).

Balabanov, I.P., Izmaylov, Y.A., 1989. New synthesis of data on chronology of the Late Pleistocene and Holocene of the Azov-Blac Sea basin, in: Geochronology of the Quaternary Period. Nauka, Moscow, p. 42 (in Russian).

Bandel, K., 2001. The history of Theodoxus and Neritina connected with description and systematic evaluation of related Neritimorpha (Gastropoda). Mitteilungen aus dem Geol. Inst. der Univ. Hambg. 85, 65-164.

Bank, R., 2017. Horatiinae D.W. Taylor, 1966. MolluscaBase (2017).

Bar-Yosef, O., Belmaker, M., 2011. Early and Middle Pleistocene Faunal and hominins dispersals through Southwestern Asia. Quat. Sci. Rev. 30, 1318-1337. https://doi.org/10.1016/j.quascirev.2010.02.016

Barannik, V., Borysova, O., Stolberg, F., 2004. The Caspian Sea region: Environmental change. AMBIO A J. Hum. Environ. 33, 45-51. https://doi.org/http://dx.doi.org/10.1579/0044-7447-33.1.45 URL:

Bax, N., Williamson, A., Aguero, M., Gonzalez, E., Geeves, W., 2003. Marine invasive alien species: A threat to global biodiversity. Mar. Policy 27, 313-323. https://doi.org/10.1016/S0308-597X(03)00041-1

Beriozkina, G.V., Levina, O.V., Starobogatov, Y.I., 1995. Revision of Bithyniidae from European Russia and Ukraine. Ruthenica 5, 27-38.

Bezrodnykh, Y.P., Deliya, S.V., Romanyuk, B.F., Sorokin, V.M., Yanina, T.A., 2015. New data on the upper quaternary stratigraphy of the North Caspian Sea. Dokl. Earth Sci. 462, 479-483. https://doi.org/10.1134/S1028334X15050025

Bezrodnykh, Y.P., Romanyuk, B.F., Deliya, S.V., Magomedov, R.D., Sorokin, V.M., Parunin, O.B., Babak, E. V., 2004. Biostratigraphy and structure of the Upper Quaternary deposits and some paleogeographic features of the north Caspian region. Stratigr. Geol. Correl. 12, 102-111.

Bezrodnykh, Y.P., Romanyuk, B.F., Sorokin, V.M., Yanina, T.A., 2017. First data on the radiocarbon age of the Atelian deposits in the North Caspian Region. Dokl. Earth Sci. 473, 277-280. https://doi.org/10.1134/s1028334x17030217

Bezrodnykh, Y.P., Sorokin, V.M., 2016. On the age of the Mangyshlakian deposits of the northern Caspian Sea. Quat. Res. (United States) 85, 245-254. https://doi.org/10.1016/j.yqres.2016.01.004 
Bhattacharya, J.P., Giosan, L., 2003. Wave-influenced deltas: geomorphological implications for facies reconstruction. Sedimentology 50, 187-210.

Birks, H.J.B., 2012. Ecological palaeoecology and conservation biology: controversies, challenges, and compromises. Int. J. Biodivers. Sci. Ecosyst. Serv. Manag. 8, 292-304. https://doi.org/10.1080/21513732.2012.701667

Boeters, H.D., Glöer, P., Georgiev, D., Dedov, I., 2015. A new species of Caspia Clessin et W. Dybowski, 1887

(Gastropoda: Truncatelloidea: Hydrobiidae) in the Danube of Bulgaria. Folia Malacol. 23, 177-186. https://doi. org/http://dx.doi.org/10.12657/folmal.023.014

Bogachev, V.V., 1932a. Vedushchiye iskopayemyye razreza Apsheronskogo polustrova i prilegayushchikh rayonov [Key fossils of the section of the Absheron peninsula and surrounding areas], Chast' 1. ed, Trudy Azerbaidzhanskogo Neftyanogo Instituta.

Bogachev, V.V., 1932b. Geologicheskiye ekskursii v okrestnostyakh Baku [Geological excursions in the vicinities of Baku]. Publishing house of the Geological management Azneft company, Baku.

Bogutskaya, N.G., Kijashko, P.V., Naseka, A.M., Orlova, M.I., 2013. Identification keys for fish and invertebrates. Volume 1: Fish and molluscs. KMK Scientific Press Ltd., St. Petersburg-Moscow.

Bologa, A.S., Bodeanu, N., Petran, A., Tiganus, V., Zaitsev, Y.P., 1995. Major modifications of the Black Sea benthic and planktonic biota in the last three decades, in: Briand, F. (Ed.), Les Mers Tributaires de Mediterranée. Bulletin de l'Institut Oceanographique, Monaco, No. Spécial 15. Bulletin de l'Institut oceanographique, Monaco, pp. 85-110.

Bologa, A.S., Sava, D., 2012. Present state and evolution trends of biodiversity in the Black Sea: decline and restoration.

J. Black Sea/Mediterranean Environ. 18, 144-154.

Bonsall, C., Cook, G.T., Hedges, R.E.M., Higham, T.F.G., Pickard, C., Radovanović, I., 2004. Radiocarbon and stable isotope evidence of dietary change from the Mesolithic to the Middle Ages in the Iron Gates: New results from Lepenski Vir. Radiocarbon 46, 293-300. https://doi.org/10.1017/S0033822200039606

Bony, G., Morhange, C., Marriner, N., Baralis, A., Kaniewski, D., Rossignol, I., Lungu, V., 2015. History and influence of the Danube delta lobes on the evolution of the ancient harbour of Orgame (Dobrogea, Romania). J. Archaeol. Sci. 61, 186-203. https://doi.org/10.1016/j.jas.2015.06.003

Boomer, I., Aladin, N., Plotnikov, I., Whatley, R., 2000. The palaeolimnology of the Aral Sea: A review. Quat. Sci. Rev. 19, 1259-1278. https://doi.org/10.1016/S0277-3791(00)00002-0

Borcard, D., Gillet, F., Legendre, P., 2011. Numerical Ecology with R, Birkhauser. Springer New York, New York, NY. https://doi.org/10.1007/978-1-4419-7976-6

Borcea, I., 1926. Quelques remarques sur les Adacnides et principalement sur les Adacnides des Lacs Razelm. Analele Stiint. ale Univ. din Ias 13, 449-485.

Bouchet, P., Rocroi, J.P.P., Hausdorf, B., Kaim, A., Kano, Y., Nützel, A., Parkhaev, P., Schrödl, M., Strong, E.E., 2017. Revised classification, nomenclator and typification of gastropod and monoplacophoran families. Malacologia 61, 1-526. https://doi.org/10.4002/040.061.0201

Bourguignat, J.R., 1887. Étude sur les noms génériques des petites paludinidées a opercule spirescent suivie de la description du nouveau genre Horatia. Tremblay, Paris.

Bourguignat, J.R., 1884. Histoire des mélaniens du système européen. Ann. Malacol. 2, 1-168. 


\section{REFERENCES}

Bourguignat, J.R., 1876. Species novissimae Molluscorum in Europaeo systemati detectae, notis diagnosticis succinctis breviter descriptae. Paul Klincksieck, Paris. https://doi.org/10.5962/bhl.title.10357

Brețcan, P., Murărescu, O., Samoilă, E., Olimpia, P., Popescu, O., 2008. The modification of the ecological conditions in the Razim - Sinoe lacuster complex as an effect of the antropic intervention, in: XXIVth Conference of the Danubian Countries on the Hydrological Forecasting and Hydrological Bases of Water Management. Geo-EcoMarina, Bled, Slovenia, pp. 1-13.

Brețcan, P., Murărescu, O., Samoilă, E., Popescu, O., 2009. Water Management in the Razim-Sinoie Lacustrine Complex, in: International Symposium on Water Management and Hydraulic Engineering, Ohrid, Macedonia. pp. 791-802.

Brețcan, P., Tâmpu, M.F., 2008. The Razim-Sinoie lacustrine complex. Protection, resources, valorization. Lakes, Reserv. ponds 1-2, 99-112.

Brotsky, Y.Z., Karandeeva, M.V., 1953. Development of the Western Pre-Caspian in the Quarternary time. Vestn. Moscow Univ. Ser. Phys. Math. Nat. Sci. 2, 139-146 (in Russian).

Bruguière, J.G., 1789. Encyclopedie methodique. Histoire naturelle des Vers. Tome sixième. Panckoucke \& Plomteux, Paris \& Liege.

Brusina, S., 1882. Le Pyrgulinae dell'Europa orientale. Boll. della Soc. Malacol. Ital. 7, 229-292.

Brusina, S., 1874. Fossile Binnen-Mollusken aus Dalmatien, Kroatien und Slavonien nebst einem Anhange. Actienbuchdruckerei, Agram.

Bulger, A.J., Hayden, B.P., Monaco, M.E., Nelson, D.M., McCormick-Ray, M.G., 1993. Biologically-based estuarine salinity zones derived from a multivariate analysis. Estuaries 16, 311-322. https://doi.org/10.1007/BF02690088

Büyükmeriç, Y., 2016. Postglacial floodings of the Marmara Sea: molluscs and sediments tell the story. Geo-Marine Lett. 36, 307-321. https://doi.org/10.1007/s00367-016-0446-6

Büyükmeriç, Y., Wesselingh, F.P., 2018. New cockles (Bivalvia: Cardiidae: Lymnocardiinae) from Late Pleistocene Lake Karapinar (Turkey): Discovery of a Pontocaspian refuge? Quat. Int. 465, 37-45. https://doi.org/10.1016/j. quaint.2016.03.018

Catianis, I., Secrieru, D., Pojar, I., Grosu, D., Scrieciu, A., Pavel, A.B., Vasiliu, D., 2018. Water quality, sediment characteristics and benthic status of the Razim-Sinoie lagoon system, Romania. Open Geosci. 10, 12-33.

Chao, A., Gotelli, N.J., Hsieh, T.C., Sander, E.L., Ma, K.H., Colwell, R.K., Ellison, A.M., 2014. Rarefaction and extrapolation with Hill numbers: A framework for sampling and estimation in species diversity studies. Ecol. Monogr. 84, 45-67. https://doi.org/10.1890/13-0133.1

Chepalyga, A.L., 2007. The late glacial great flood in the Ponto-Caspian basin, in: Al., V.Y.-H. et (Ed.), The Black Sea Flood Question. pp. 119-148.

Chepalyga, A.L., 1997. Detailed event stratigraphy of the Pleistocene of the Black Sea. Quart, in: Ernary Geology and Paleogeography of Russia. GEOS, Moscow, pp. 196-201 (in Russian).

Chepalyga, A.L., Mikhaylesku, K.D., Izmaylov, Y.A., 1989. Problems of stratigraphy and paleogeography of the Black Sea Pleistocene, in: Quaternary Period. Stratigraphy. Nauka, Moscow, pp. 113-121. (in Russian).

Chepalyga, A.L., Tarasov, A.G., 1997. Invasion of Atlantic Ocean species in the Caspian Sea: The fate of endemic taxa and biosystems. Okeanologiya 37, 261-268. 
Chernyshova, M.B., 1980. Palynological researches of the bottom sediments on the continental terrace, in: GeologicGeophysical Researches of the Bulgarian Sector of the Black Sea. Bulgarian Acad. of Sci., Sofia, pp. $213-222$ (in Russian).

Chukhchin, 1984. Ecology of the Black Sea gastropods. Naukova dumka, Kyiv.

Chukhchin, V.D., 1975. Sistematicheskoye polozheniye i ekologiya chernomorskikh Hydrobiidae. Mollyuski, ikh sistema, evolyutsiya i rol' v prirode, in: 5 Vsesoyuznoye Soveshchaniye Po Izucheniyu Mollyukov. Avtoreferaty Dokladov. Nauka Publishers, Leningrad, pp. 120-122.

Chumakov, I.S., Byzova, S.L., Ganzey, S.S., Arias, C., Bigazzi, G., Bonadonna, F.P., Hadler Neto, J.C., Norelli, P., 1992. Interlaboratory fission track dating of volcanic ash levels from eastern Paratethys. A mediterranean-paratethys correlation. Palaeogeogr. Palaeoclimatol. Palaeoecol. 95, 287-295. https://doi.org/10.1016/0031-0182(92)90146-V

Cioboiu, O., Son, M., von Rintelen, T., 2011. Turricaspia variabilis. IUCN Red List Threat. Species 2011 e.T155608A4807675. https://doi.org/http://dx.doi.org/10.2305/IUCN.UK.2011-2.RLTS.T155608A4807675.en

Clessin, S., 1886. Binnenmollusken aus Rumänien. Malakozool. Blätter (Neue Folge) 8, 49-56.

Conrad, T.A., 1831. Description of fifteen new species of recent, and three of fossil shells, chiefly from the coast of the United States. J. Acad. Nat. Sci. Philadelphia 6, 256-268.

Coughlan, N.E., Stevens, A.L., Kelly, T.C., Dick, J.T.A., Jansen, M.A.K., 2017. Zoochorous dispersal of freshwater bivalves: an overlooked vector in biological invasions? Knowl. Manag. Aquat. Ecosyst. 418. https://doi.org/10.1051/ $\mathrm{kmae} / 2017037$

Cox, L.R., 1960. Thoughts on the classification of the Gastropoda. Proc. Malacol. Soc. London 33, $239-261$.

Cramer, K.L., O’Dea, A., Clark, T.R., Zhao, J.X., Norris, R.D., 2017. Prehistorical and historical declines in Caribbean coral reef accretion rates driven by loss of parrotfish. Nat. Commun. 8, 1-8. https://doi.org/10.1038/ncomms14160

Cummings, K., 2011. Mytilopsis leucophaeata. IUCN Red List Threat. Species 2011 e.T155623A4809971.

Cummings, K.S., Graf, D.L., 2015. Class Bivalvia, in: Thorp, J.H., Rogers, D.C. (Eds.), Thorp and Covich's Freshwater Invertebrates. Academic Press, Elsevier, Boston, pp. 423-506. https://doi.org/10.1016/B978-0-12-385026-3.00019-X

Cuvier, G., 1795. Second Mémoire sur l’organisation et les rapports des animaux à sang blanc, dans lequel on traite de la structure des Mollusques et de leur division en ordre, lu à la société d'Histoire Naturelle de Paris, le 11 prairial an troisième. Mag. Encycl. ou J. des Sci. des Lettres des Arts 2, 433-449.

d’Orbigny, A., 1850. Prodrome de Paléontologie. Stratigraphique universelle des animaux mollusques et rayonnés faisant suitre au cours élémentaire de paléontologie et de géologie stratigraphique. Victor Masson, Paris.

Dan, S., Stive, M.J.F., Walstra, D.J.R., Panin, N., 2009. Wave climate, coastal sediment budget and shoreline changes for the Danube Delta. Mar. Geol. 262, 39-49. https://doi.org/10.1016/j.margeo.2009.03.003

Danukalova, G.A., 1996. Bivalves and Aktschagylian stratigraphy.

Danukalova, G.A., Yakovlev, A., Osipova, E., Kurmanov, R., van Kolfschoten, T., 2016. Biostratigraphy of the early Middle Pleistocene of the Southern Fore-Urals. Quat. Int. 420, 115-135. https://doi.org/10.1016/j. quaint.2015.09.087

Danukalova, G.A., Zastrozhnov, A.S., Yakovlev, A.G., Kurmanov, R.G., Osipova, E.M., Shterkhun, V.L., 2017. Quaternary Stratigraphy of the Astrakhan arch [planchets L-38-XI, XII], in: Geological Collection, 14 (Informational Materials). DizainPoligraphServis Press, Ufa., pp. 40-64 (in Russian). 


\section{REFERENCES}

De Cristofori, G., Jan, G., 1932. Catalogus in IV. sectiones divisus rerum naturalium in museo exstantium Josephi De Cristofori et Georgii Jan plurium Acad. Scient. et Societ. Nat. Cur. Sodalium complectens adumbrationem oryctognosiae et geognosiae atque prodromum faunae et floriae Italia.

de la Vara, A., Van Baak, C.G.C., Marzocchi, A., Grothe, A., Meijer, P.T., 2016. Quantitative analysis of Paratethys sea level change during the Messinian Salinity Crisis. Mar. Geol. 379, 39-51. https://doi.org/10.1016/j. margeo.2016.05.002

De Leeuw, A., Filipescu, S., Maţenco, L., Krijgsman, W., Kuiper, K., Stoica, M., 2013. Paleomagnetic and chronostratigraphic constraints on the Middle to Late Miocene evolution of the Transylvanian Basin (Romania): Implications for Central Paratethys stratigraphy and emplacement of the Tisza-Dacia plate. Glob. Planet. Change 103, 82-98. https://doi.org/10.1016/j.gloplacha.2012.04.008

Degens, E.T., Ross, D.A., 1972. Chronology of the Black Sea over the last 25000 years. Chem. Geol. 10, 1-16.

Deshayes, G.P., 1861. Description des animaux sans vertèbres découverts dans le bassin de Paris pour servir de supplément a la description des coquilles fossiles des environs de Paris comprenant une revue générale de toutes les espèces actuellement connues. Tome deuxième. J.-B. Baillière et Fils, Paris.

Díaz, S., Settele, J., Brondízio, E., Ngo, H.T., Guèze, M., Agard, J., Arneth, A., Balvanera, P., Brauman, K., Butchart, S., Chan, K., Garibaldi, L., Ichii, K., Liu, J., Subramanian, M.S., Midgley, G., Miloslavich, P., Molnár, Z., Obura, D., Pfaff, A., Polasky, S., Purvis, A., Razzaque, J., Reyers, B., Chowdhury, R.R., Shin, Y.J., Visseren-Hamakers, I., Willis, K., Zayas, C., 2019. Summary for policymakers of the global assessment report on biodiversity and ecosystem services of the Intergovernmental Science-Policy Platform on Biodiversity and Ecosystem Services, IPBES.

Dietl, G.P., Flessa, K.W., 2011. Conservation paleobiology: Putting the dead to work. Trends Ecol. Evol. 26, 30-37. https://doi.org/10.1016/j.tree.2010.09.010

Dietl, G.P., Kidwell, S.M., Brenner, M., Burney, D.A., Flessa, K.W., Jackson, S.T., Koch, P.L., 2015. Conservation Paleobiology: Leveraging Knowledge of the Past to Inform Conservation and Restoration. Annu. Rev. Earth Planet. Sci. 43, 79-103. https://doi.org/10.1146/annurev-earth-040610-133349

Dimitriu, R.G., Oaie, G., Gomoiu, M.T., Begun, T., Szobotka, Ş., Rădan, S.C., Fulga, C., 2008. O caracterizare interdisciplinară a stării geoecologice actuale a complexului lagunar Razelm - Sinoie la începutulsecolului XXI. Geo-Eco-Marina 14, 69-74.

Dinu, I., Umgiesser, G., Bajo, M., De Pascalis, F., Stănică, A., Pop, C., Dimitriu, R.G., Nichersu, I., Constantinescu, A., 2015. Modelling of the response of the Razelm-Sinoe lagoon system to physical forcing. Geo-Eco-Marina 5-18.

Doering, A., 1875. Estudios sistemáticos y anatómicos sobre los moluscos pulmoníferos de los países del Plata. Periódico Zoológico 1, 129-204.

Doğan, B., Karakaş, A., Nazik, A., Meriç, E., 2019. Traces of Mediterranean origin Holocene transgression in the drainage basin of Riva- Çayağzi Creek of the Black Sea (northeastern İstanbul-Turkey). Turkish J. Earth Sci. https://doi.org/10.3906/yer-1907-15

Dollfus, G.F., 1912. Recherches critiques sur quelques genre et espèces d’Hydrobia vivants ou fossiles. J. Conchyliol. 59, 179-270. 
Dornelas, M., Gotelli, N.J., McGill, B., Shimadzu, H., Moyes, F., Sievers, C., Magurran, A.E., 2014. Supplementary Materials for Assemblage time series reveal biodiversity change but not systematic loss. Science (80-.). 344, 296299. https://doi.org/10.1126/science.1248484

Draparnaud, J.P.R., 1805. Histoire naturelle des Mollusques terrestres et fluviatiles de la France. Plassan, R., Paris/ Montpellier.

Dumitrashko, N.V., Milanovsky, E.E., Balyan, S.P., Sayadyan, Y.V., 1977. Ancient glaciation of the Caucasus. Geology of the Quaternary Period (Pleistocene). Publishing house of the Academy of Science of the Armenian SSR, Erevan.

Dumont, H.J., 2000. Endemism in the Ponto-Caspian Fauna, with Special Emphasis on the Onychopoda (Crustacea). Adv. Ecol. Res. 31, 181-196.

Dumont, H.J., 1998. The Caspian Lake: History, biota, structure, and function. Limnol.Oceanogr. 43, 44-52. https://doi. org/1998.43.1.0044

Dumont, H.J., 1995. Ecocide in the Caspian Sea. Nature 377, 673-674. https://doi.org/10.1038/377673a0

Dunker, W., 1861. Beschreibung neuer Mollusken. Malakozool. Blätter 8, 34-45.

Dybowski, B., 1913. Ueber Kaspische Schnecken aus der Abteilung Turribaicaliinae subfam. nova, zum Vergleich mit den Turribaicaliinae subfam. nova. Bull. l’Académie Impériale des Sci. St.-Pétersbourg, sixième série 7 16, $905-906$.

Dybowski, B., Grochmalicki, J., 1917. Studien über die Turförmigen Schnecken des Baikalsees und des Kaspimeeres (Turribaicaliinae-Turricaspiinae). Abhandlungen der Kais. Königlichen Zool. Gesellschaft Wien 9, 1-55.

Dybowski, B., Grochmalicki, J., 1915. Ueber kaspische Schnecken aus der Abteilung “Turricaspiinae” subfam. nova zum Vergleich mit den Turribaikalina nobis. Petrograd.

Dybowski, B., Grochmalicki, J., 1914. Beitrage zur Kenntnis der Baikalmollusken, I. Baicaliidae, 1. Turribaicaliinae subfam. nova. Annu. du Musée Zool. l’Académie Impériale des Sci. St. Pétersbg. 18, 268-316.

Dybowski, W., 1887. Die Gasteropoden-Fauna des Kaspischen Meeres. Nach der Sammlung des Akademikers Dr. K. E. v. Baer. Malakozool. Blätter (Neue Folge) 10, 1-64 (issue 1, 1887), 65-79 (issue 2, 1888), pl. 1.

Eberzin, A.G., 1935. Chaudian Beds of the Taman Peninsula. Dokl. Akad. Nauk SSSR, 2, 580-587.

Eckert, S., Brumsack, H.J., Severmann, S., Schnetger, B., März, C., Fröllje, H., 2013. Establishment of euxinic conditions in the Holocene Black Sea. Geology 41, 431-434. https://doi.org/10.1130/G33826.1

Eichwald, E., 1855. Zur Naturgeschichte des Kaspischen Meeres. Nouv. Mémoires la Société Impériale des Nat. Moscou 10, 283-323.

Eichwald, E., 1853. Lethaea Rossica ou Paléontologie de la Russie, décrite et figurée. Troisième volume. Dernière période. Schweizerbar, Stuttgart.

Eichwald, E., 1841. Fauna Caspio-Caucasica nonnullis observationibus novis illustravit. Nouv. Mémoires la Société Impériale des Nat. Moscou 7, 1-290.

Eichwald, E., 1838. Faune Caspii Maris primitiae. Bull. la Société Impériale des Nat. Moscou 11, 125-174.

Eichwald, E., 1829. Zoologia specialis quam expositis animalibus tum vivis, tum fossilibus potissimum Rossiae in universum et Poloniae in specie, in usum lectionum publicarum in Universitate Caesarea Vilnensi habendarum. paedeuticam zoologiae atque specialem heterozoorum exp. Zawadzki, J., Vilnius.

Erőss, Z.P., Petró, E., 2008. A new species of the valvatiform hydrobiid genus Hauffenia from Hungary. Acta Zool. Acad. Sci. Hungaricae 54, 159-167. 


\section{REFERENCES}

Erthal, F., Kotzian, C.B., Simoes, M.G., 2011. Fidelity of Molluscan Assemblages From the Touro Passo Formation (Pleistocene-Holocene), Southern Brazil: Taphonomy As a Tool for Discovering Natural Baselines for Freshwater Communities. Palaios 26, 433-446. https://doi.org/10.2110/palo.2010.p10-145r

Fedorov, P.V., 1999. Ot Kaspiya do Evksina. Zapiski geologa. [From the Caspian to the Euxinian. The notes of geologist.]. GEOS, Moscow.

Fedorov, P.V., 1993. Early Pleistocene of the Ponto-Caspian. Stratigr. Geol. Correl. 1, 137-143 (in Russian).

Fedorov, P.V., 1982. Postglacial transgression of the Black Sea and problem of Ocean level changes for the last 15000 years., in: Fluctuations of Level of the Seas and Oceans during 15000 Years. Nauka, Moscow, pp. 151-156 (in Russian).

Fedorov, P.V., 1978. Pleystotsen Ponto-Kaspiyskogo regiona [Pleistocene of the Ponto-Caspian Region], Stratigraphy and Geological Correlation. Nauka, Moscow.

Fedorov, P.V., 1963. Stratigraphy of Quarternary deposits of the Crimean-Caucasian coast and some questions of geological history of the Black Sea. Tr. Geol. Inst. Acad. Sci. USSR 88, 1-158 (in Russian).

Fedorov, P.V., 1957. Stratigraphiya chetvertichnykh otlozheniy i istoria razvitiya Kaspiyskogo moray [Quaternary sediments stratigraphy and the history of the development of the Caspian Sea]. Tr. Geol. Inst. Acad. Sci. USSR 10, 1-308 (in Russian).

Fedorov, P.V., 1953. Kaspiyskiye chetvertichnyye mollyuski roda Didacna Eichwald i ikh stratigraficheskoye znacheniye [Caspian Quaternary mollusks of the Didacna Eichwald genus and their stratigraphical impotants], in: Nikolaev, V.I. (Ed.), Stratigrafiya Chetvertichnykh Otlozheniy i Noveyshaya Tektonika Prikaspiyskoy Nizmennosti. Akademiya Nauk SSSR, Moscow, pp. 112-130.

Fedorov, P.V., 1948. Kaspiyskiye mollyuski Zapadnoy Turkmenii [Caspian Mollusks of Western Turkmenistan]. Byulleten' Kom. po Izucheniyu Chetvertichnogo Perioda 13, 54-66.

Fedorov, P.V., 1946. To stratigraphy of the Caspian deposits of the Pre-Balkhanian region of the Western Turkmenistan. Sov. Geol. 11, 33-43 (in Russian).

Fehér, Z., Zettler, M.L., Boszó, M., Szabó, K., Bozsó, M., Szabó, K., Boszó, M., Szabó, K., 2009. An attempt to reveal the systematic relationship between Theodoxus prevostianus (C. Pfeiffer, 1828) and Theodoxus danubialis (C. Pfeiffer, 1828) (Mollusca, Gastropoda, Neritidae). Mollusca 27, 95-107.

Férussac, A.É., 1823. Monographie des espèces vivantes et fossiles du genre Melanopsis. Mémoires la Société l'Histoire Paris 1, 132-164.

Filippov, A., Riedel, F., 2009. The late Holocene mollusc fauna of the Aral Sea and its biogeographical and ecological interpretation. Limnologica 39, 67-85. https://doi.org/10.1016/j.limno.2008.04.003

Folke, C., Carpenter, S., Walker, B., Scheffer, M., Elmqvist, T., Gunderson, L., Holling, C.S., 2004. Regime shifts, resilience, and biodiversity in ecosystem management. Annu. Rev. Ecol. Evol. Syst. 35, 557-581. https://doi. org/10.1146/annurev.ecolsys.35.021103.105711

Folke, C., Carpenter, S.R., Walker, B., Scheffer, M., Chapin, T., Rockstrom, J., 2010. Resilience thinking: integrating resilience, adaptability and transformability. Ecol. Soc. 15, 20. https://doi.org/10.1038/nnano.2011.191 
Forte, A.M., Cowgill, E., 2013. Late Cenozoic base-level variations of the Caspian Sea: A review of its history and proposed driving mechanisms. Palaeogeogr. Palaeoclimatol. Palaeoecol. 386, 392-407. https://doi.org/10.1016/j. palaeo.2013.05.035

Frýda, J., 1998. Higher classification of the Paleozoic gastropods inferred from their early shell ontogeny, in: Bieler, R., Mikkelsen, P.M. (Eds.), 13th International Malacological Congress, Abstracts. Washington, D.C., p. 108.

Gadzhiev, T.M., 1968. Izmenchivost' Didacna baeri Grimm i nekotoryye novyye vidy Didacna novokaspiyskikh otlozheniy ostrovov Bakinskogo arkhipelaga. Paleontol. Sb. 1, 75-85.

Gâştescu, P., 2009. The Danube Delta Biosphere Reserve: Geography, biodiversity, protection and management. Rom. J. Geogr. 53, 139-152.

Giosan, L., Coolen, M.J.L., Kaplan, J.O., Constantinescu, S., Filip, F., Filipova-Marinova, M., Kettner, A.J., Thom, N., 2012. Early anthropogenic transformation of the Danube-Black Sea system. Sci. Rep. 2, 582. https://doi. org/10.1038/srep00582

Giosan, L., Donnelly, J.P., Constantinescu, S., Filip, F., Ovejanu, I., Vespremeanu-Stroe, A., Vespremeanu, E., Duller, G., 2006. Young Danube delta documents stable Black Sea level since the middle Holocene: Morphodynamic, paleogeographic, and archaeological implications. Geology 34, 757-760. https://doi.org/10.1130/G22587.1

Gittenberger, E., Janssen, A.W., Kuijper, W.J., Kuiper, J.G.J., Meijer, T., Van der Velde, G., De Vries, J.N., 2004. De Nederlandse Zoetwatermollusken: Recente en fossiele weekdieren uit zoet en brak water. Nationaal Natuurhistorisch Museum Naturalis.

Glöer, P., 2002. Die Tierwelt Deutschlands. Die Süßwassergastropoden Nord- und Mitteleuropas. Bestimmungsschlüssel, Lebensweise, Verbreitung. ConchBooks, Hackenheim.

Glöer, P., Falniowski, A., Szarowska, M., 2005. Bithynia leachii (Sheppard 1823) and B. troschelii (Paasch 1842), two distinct species? Heldia 49-56.

Glöer, P., Pešić, V., 2015. Two new freshwater mollusk species of the genus Graecoanatolica Radoman, 1973 from Turkey (Gastropoda: Hydrobiidae). Ecol. Montenegrina 4, 46-51. https://doi.org/10.1093/infdis/jix568

Glöer, P., Pešić, V., 2012. The freshwater snails (Gastropoda) of Iran, with descriptions of two new genera and eight new species. Zookeys 219, 11-61. https://doi.org/10.3897/zookeys.219.3406

Gmelin, J.F., 1791. Caroli a Linné, systema naturae per regna tria naturae, secundum classes, ordines, genera, species, cum characteribus, differentiis, synonymis, locis. Vermes. Georg Emanuel Beer, Lipsiae.

Golikov, A.N., Starobogatov, Y.I., 1975. Systematics of prosobranch gastropods. Malacologia 15, 185-232.

Golikov, A.N., Starobogatov, Y.I., 1972. Klass bryukhonogiye mollyuski, in: Mordukhai-Boltovskoi, F.D. (Ed.), Opredelitel' Fauny Chernogo i Azovskogo Morey: Svobodnozhivushchiye Bespozvonochnyye. T.3.

Chlenistonogiye (Krome Rakoobraznykh), Mollyuski, Iglokozhiye, Shchetinkochelyustnyye, Khordovyye. Naukova dumka, Kiev, pp. 65-166.

Golikov, A.N., Starobogatov, Y.I., 1966. Ponto-kaspiyskiy bryukhonogiye mollyuski v Azovo-Chernomorskom basseyne. Zool. Zhurnal 45, 352-362.

Golubyatnikov, D. V., 1908. Svyatoi Island (Baku gubernia). Saint-Petersburg (in Russian).

Golubyatnikov, D. V., 1904. Main results of the geological works on the Apsheron peninsula in 1903. Izv. Geol. Comm. 23, 289-330 (in Russian). 


\section{REFERENCES}

Gomoiu, M.T., Alexandrov, B., Shadrin, N., Zaitsev, Y.P., 2002. The Black Sea - A Recipient, Donor and Transit Area for Alien Species, in: Leppäkoski, E., Gollasch, S., Olenin, S. (Eds.), Invasive Aquatic Species of Europe. Distribution, Impacts and Management. Springer Netherlands, Dordrecht, pp. 341-350. https://doi.org/10.1007/978-94-0159956-6_35

Gontikaki, E., Antoniadou, C., Chintiroglou, C.C., 2003. Population structure of Cerastoderma glaucum and Abra ovata in Vouliagmeni Lagoon (Attiki). J. Mar. Biol. Assoc. United Kingdom 83, 1095-1097. https://doi.org/10.1017/ S0025315403008312h

Goretskiy, G.I., 1957. About Hyrcanian epoch in the history of Pre-Caspian region. News Oil Eng. 6, 6-11 (in Russian).

Gorthner, A., 1994. What is an ancient lake?, in: Martens, K., Goddeeris, B., Coulter, G. (Eds.), Speciation in Ancient Lakes. pp. 97-100.

Graf, D.L., Cummings, K.S., 2018. The Freshwater Mussels (Unionoida) of the World (and other less consequential bivalves). MUSSEL Proj. Web Site.

Gray, J.E., 1843. Catalogue of the Species of Mollusca and their Shells, which have hitherto been recorded as found at New Zealand, with the Description of some lately discovered Species, in: Dieffenbach, E. (Ed.), Travels in New Zealand; with Contributions to the Geography, Geology, Botany, and Natural History of That Country. John Murray, London.

Gray, J.E., 1840a. A manual of the land and freshwater shells of the British Islands, with figures of each of the kinds. By William Turton, MD A new edition, thoroughly revised and much enlarged. Longman, Orme, Brown, Green, and Longmans, Paternoster Row, London.

Gray, J.E., 1840b. Shells of molluscous animals, in: Synopsis of the Contents of the British Museum. G. Woodfall, London, pp. 105-152.

Gray, J.E., 1825. A List and Description of some Species of Shells not taken Notice of by Lamarck. Ann. Philos. new Ser. 9, 134-140.

Grichuk, V.P., 1954. Materials to the paleobotanic characteristic of Quaternary and Pliocene deposits of northwest part of the Caspian Depression., in: Materials on Geomorphology and Paleogeography of the USSR. Vol. 11. Publishing House of Academy of Sciences of the USSR, Moscow, pp. 5-79 (in Russian).

Grigorovich, I.A., MacIsaac, H.J., Shadrin, N.V., Mills, E.L., 2002. Patterns and mechanisms of aquatic invertebrate introductions in the Ponto-Caspian region. Can. J. Fish. Aquat. Sci. https://doi.org/10.1139/f02-088

Grigorovich, I.A., Therriault, T.W., MacIsaac, H.J., 2003. History of aquatic invertebrate invasions in the Caspian Sea. Biol. Invasions 5, 103-115. https://doi.org/10.1023/A:1024050824073

Grimm, O.A., 1877. Kaspiyskoye more i yego fauna. Tetrad' 2. Trudy Aralo-Kaspiyskoy Ekspeditsii 2 (2): i-ii + 1-105. Grimm, O.A., 1876. Kaspiyskoye more i yego fauna. Tetrad' 1. Trudy Aralo-Kaspiyskoy Ekspeditsii 2: i-v + 1-168.

Grossu, A.V., 1986. Le genre Pseudamnicola Paulaci, 1868 en Roumanie et description de quelques nouvelles espèces (Prosobranchia, Hydrobiidae). Apex. Informations Sci. la Société Belge Malacol. 1, 1-17.

Grossu, A.V., 1973. Les Limnocardiides actuelles du bassin Ponto-Caspique. Société belge Malacol. 2, 123-152.

Grossu, A.V., 1951. Potamopyrgus jenkinsi, gasteropod nou pentru apele continentale ale Republicii Populare Romine. Comun. Acad. Republicii Pop. Române 1, 593-596. 
Guerra-Merchán, A., Serrano, F., Garcés, M., Gofas, S., Esu, D., Gliozzi, E., Grossi, F., 2010. Messinian Lago-Mare deposits near the Strait of Gibraltar (Malaga Basin, S Spain). Palaeogeogr. Palaeoclimatol. Palaeoecol. 285, 264276. https://doi.org/10.1016/j.palaeo.2009.11.019

Haase, M., Naser, M.D., Wilke, T., 2010. Ecrobia grimmi in brackish Lake Sawa, Iraq: indirect evidence for long-distance dispersal of hydrobiid gastropods (Caenogastropoda: Rissooidea) by birds. J. Molluscan Stud. 76, 101-105. https:// doi.org/10.1093/mollus/eyp051

Hart, M.B., 2012. Geodiversity, palaeodiversity or biodiversity: Where is the place of palaeobiology and an understanding of taphonomy? Proc. Geol. Assoc. 123, 551-555. https://doi.org/10.1016/j.pgeola.2012.05.006

Hartgerink, P.E., 2005. Analysis and modelling of wave spectra on the Caspian Sea. TU Delft.

Harzhauser, M., Piller, W.E., Steininger, F.F., 2002. Circum-Mediterranean Oligo - Miocene biogeographic evolution - The gastropods' point of view. Palaeogeogr. Palaeoclimatol. Palaeoecol. 183, 103-133. https://doi.org/10.1016/ S0031-0182(01)00464-3

Hauffe, T., Albrecht, C., Schreiber, K., Birkhofer, K., Trajanovski, S., Wilke, T., 2011. Spatially explicit analysis of gastropod biodiversity in ancient Lake Ohrid. Biogeosciences 8, 175-188. https://doi.org/10.5194/bg-8-175-2011

Heiler, K.C.M., Nahavandi, N., Albrecht, C., 2010. A new invasion into an ancient lake-The invasion history of the dreissenid mussel Mytilopsis leucophaeata (Conrad, 1831) and its first record in the Caspian Sea. Malacologia 53, 185-192. https://doi.org/10.4002/040.053.0112

Helama, S., Nielsen, J.K., Valovirta, I., 2007. Conchology of endangered freshwater pearl mussel: conservation palaeobiology applied to museum shells originating from northern Finland. Bolletino Malacol. 43, 161-170.

Hilgen, F.J., Lourens, L.J., Van Dam, J.A., Beu, A.G., Boyes, A.F., Cooper, R.A., Krijgsman, W., Ogg, J.G., Piller, W.E., Wilson, D.S., 2012. The Neogene Period, in: Gradstein, F.M., Ogg, J.G., Schmitz, M.D., Ogg, G.M. (Eds.), The Geologic Time Scale 2012. Elsevier B.V., Amsterdam, pp. 923-978. https://doi.org/10.1016/B978-0-444-594259.00029-9

Hilgendorf, F., 1867. Über Planorbis multiformis im Steinheimer Süßwasserkalk. Monatsberichte der KöniglichPreussischen Akad. der Wissenschaften zu Berlin 1866, 474-504.

Hinds, D.J., Aliyeva, E., Allen, M.B., Davies, C.E., Kroonenberg, S.B., Simmons, M.D., Vincent, S.J., 2004. Sedimentation in a discharge dominated fluvial-lacustrine system: The Neogene Productive Series of the South Caspian Basin, Azerbaijan. Mar. Pet. Geol. 21, 613-638. https://doi.org/10.1016/j.marpetgeo.2004.01.009

Hsieh, T.C., Ma, K.H., Chao, A., 2019. iNEXT: Interpolation and Extrapolation for Species Diversity: Heiberger and Holland R package.

Hsieh, T.C., Ma, K.H., Chao, A., 2016. iNEXT: an R package for rarefaction and extrapolation of species diversity (Hill numbers). Methods Ecol. Evol. 7, 1451-1456. https://doi.org/10.1111/2041-210X.12613

Hughen, K.A., Baillie, M.G.L., Bard, E., Warren Beck, J., Bertrand, C.J.H., Blackwell, P.G., Buck, C.E., Burr, G.S., Cutler, K.B., Damon, P.E., Edwards, R.L., Fairbanks, R.G., Friedrich, M., Guilderson, T.P., Kromer, B., McCormac, G., Manning, S., Ramsey, C.B., Reimer, P.J., Reimer, R.W., Remmele, S., Southon, J.R., Stuiver, M., Talamo, S., Taylor, F.W., van der Plicht, J., Weyhenmeyer, C.E., 2004. Marine04 marine radiocarbon age calibration, 0-26 cal kyr BP. Radiocarbon 46, 1059-1086. https://doi.org/10.1017/S0033822200033002 


\section{REFERENCES}

Humphries, C.J., Williams, P.H., Vane-Wright, R.I., 1995. Measuring biodiversity value for conservation. Annu. Rev. Ecol. Syst. 26, 93-111. https://doi.org/10.1146/annurev.es.26.110195.000521

ICZN, 1999. International Code of Zoological Nomenclature. International Trust for Zoological Nomenclature, London.

Ignatov, Y.I., Kaplin, P.A., Lukyanova, S.A., Solovieva, G.D., 1993. Evolution of the Caspian Sea coasts under conditions of sea-level rise-model for coastal change under increasing greenhouse effect. J. Coast. Res. 9, 104-111.

Ilyjn, S.I., 1930. New data on the Gurian Pliocene. Izv. Hhead Prospect. Dep. 49, 463-471 (in Russian).

Ilyjn, S.I., 1929. Geological researches in the Gurian oil field. Izv. Geol. Com. 48, 69-86 (in Russian).

Interdepartmental Stratigraphic Committee of Russia (ISC), 2003. Provisions of the Interdepartmental Stratigraphic Committee and its permanent Commissions. All-Russian geological institute (VSEGEI) Press, St. Petersburg.

IPBES, 2019. Global assessment report on biodiversity and ecosystem services of the Intergovernmental SciencePolicy Platform on Biodiversity and Ecosystem Services.

Isbell, F., Gonzalez, A., Loreau, M., Cowles, J., Díaz, S., Hector, A., Mace, G.M., Wardle, D.A., O’Connor, M.I., Duffy, J.E., Turnbull, L.A., Thompson, P.L., Larigauderie, A., 2017. Linking the influence and dependence of people on biodiversity across scales. Nature 546, 65-72. https://doi.org/10.1038/nature22899

Islamoğlu, Y.B., Chepalyga, A.L., 1998. The environmental changes determined with Molluscan assemblages during the Neoeuxinian- Holocene stages in the Sea of Marmara. Geol Bull Turkey 41, 55-62.

Issel, A., 1865. Catalogo dei molluschi raccolti dalla missione italiana in Persia aggiuntavi la descrizione delle specie nuove o poco note, Memorie della Reale accademia delle scienze di Torino. Stamperia Reale, Torino.

James, F.C., Rathbun, S., 1981. Rarefaction, relative abundance, and diversity of avian communities. Auk Ornithol. Adv. 98, 785-800.

Jones, C.G., Lawton, J.H., Shachak, M., 1994. Organisms as Ecosystem Engineers, in: Ecosystem Management. Springer, New York, NY., pp. 130-147.

Jorissen, E.L., De Leeuw, A., Van Baak, C.G.C., Mandic, O., Stoica, M., Abels, H.A., Krijgsman, W., 2018. Sedimentary architecture and depositional controls of a Pliocene river-dominated delta in the semi-isolated Dacian Basin, Black Sea. Sediment. Geol. 368, 1-23. https://doi.org/10.1016/j.sedgeo.2018.03.001

Kadolsky, D., 2012. Nomenclatural comments on non-marine molluscs occurring in the British Isles. J. Conchol. 41, 65-90.

Kadolsky, D., 2008. Mollusks from the Late Oligocene of Oberleichtersbach (Rhön Mountains, Germany). Part 2: Gastropoda. Neritimorpha and Caenogastropoda. Cour. Forschungsinstitut Senckenb. 260, 103-137.

Kalitskiy, K.P., 1914. Neftyanaya gora (Zakaspiyskaya oblast'). Tr. Geol. Kom. 95, 1-78.

Kantor, Y.I., Sysoev, A.V., 2006. Morskiye i solonovatovodnyye bryukhonogiye mollyuski Rossii i sopredel'nykh stran: illyustrirovannyy katalog [Marine and brackish-water gastropod mollusks of Russia and adjacent countries: an illustrated catalogue], Moscow: KMK Scientific Press, Ltd. KMK Scientific Press, Moscow.

Kantor, Y.I., Sysoev, A.V., 2005. Katalog mollyuskov Rossii i sopredel'nykh stran. KMK Scientific Press, Moscow.

Kantor, Y.I., Vinarski, M.V., Schileyko, A.A., Sysoev, A.V., 2010. Catalogue of the continental Mollusks of Russia and Adjacent territories. Online version 2.3.1, 350 . 
Kaplin, P.A., Leontiev, O.K., Rychagov, G.I., Svitoch, A.A., 1977. New data on Pleistocene history of the Caspian Sea.

Quaternary Geology. Nauka press, Moscow., pp. 217-224 (in Russian).

Kaplin, P.A., Selivanov, A.O., 1995. Recent coastal evolution of the Caspian sea as a natural model for coastal responses to the possible acceleration of global sea-level rise. Mar. Geol. 124, 161-175. https://doi.org/10.1016/0025-

3227(95)00038-Z

Karpinsky, M.G., 2010a. Review: The Caspian Sea benthos: Unique fauna and community formed under strong grazing pressure. Mar. Pollut. Bull. 61, 156-161. https://doi.org/10.1016/j.marpolbul.2010.02.009

Karpinsky, M.G., 2010b. On peculiarities of introduction of marine species into the Caspian Sea. Russ. J. Biol. Invasions 1, 7-10. https://doi.org/10.1134/S2075111710010029

Karpinsky, M.G., Shiganova, T.A., Karunin, D.N., 2005. Biodiversity, in: The Caspian Sea Environment: The Handbook of Environmental Chemistry. Springer-Verleg, Berlin, pp. 159-173.

Kebapçı, U., Van Damme, D., 2012. Theodoxus fluviatilis (errata version published in 2017). IUCN Red List Threat. Species 2012 e.T165352A113400624.

Keraudren, B., 1970. Les formations Quaternaires marines de la Grece. Bull. Mus. Prehist. Monaco. 16.

Kevrekidis, T., Kasapis, K., Kalpia, V., 2009. Life cycle, population dynamics, growth and production of Abra segmentum (Mollusca, Bivalvia) at low salinities in a Mediterranean lagoon. Helgol. Mar. Res. 63, 277-285. https://doi. org/10.1007/s10152-009-0155-x

Kevrekidis, T., Wilke, T., 2005. Life cycle, population dynamics and productivity of Ventrosia maritima in the Evros Delta (northern Aegean Sea). J. Mar. Biol. Assoc. United Kingdom 85, 375-382. https://doi.org/10.1017/ S0025315405011306h

Kevrekidis, T., Wilke, T., Mogias, A., 2005. When DNA puts ecological works back on the right track: genetic assessment and distribution patterns of mudsnail populations in the Evros Delta lagoons. Arch. für Hydrobiol. 162, 19-35. https://doi.org/https://doi.org/10.1127/0003- 9136/2005/0162-0019

Khain, V.E., 1950. Geotectonic development of the South-Eastern Caucasus. Baku (in Russian).

Khramov, A.N., 1960. Paleomagnetism and Stratigraphic correlation. Gostoptechizdat, Leningrad.

Kidwell, S.M., 2013. Time-averaging and fidelity of modern death assemblages: Building a taphonomic foundation for conservation palaeobiology. Palaeontology 56, 487-522. https://doi.org/10.1111/pala.12042

Kircher, A., 1678. Mundus Subterraneus, in XII libros digestus. Amstelodami: apud Joannem Janssonium a Waesberge \& filios.

Kirscher, U., Oms, O., Bruch, A.A., Shatilova, I., Chochishvili, G., Bachtadse, V., 2017. The Calabrian in the Western Transcaucasian basin (Georgia): Paleomagnetic constraints from the Gurian regional stage. Quat. Sci. Rev. 160, 96-107. https://doi.org/10.1016/j.quascirev.2017.01.017

Kohn, A.J., 1972. Conus miliaris at Easter Island - ecological release of diet and habitat in an isolated population. Am. Zool. 12, 712 .

Kolesnikov, V.P., 1950. Paleontologiya SSSR. Izdatel'stvo Akademii nauk SSSR, Moskva, Leningrad.

Kolesnikov, V.P., 1947. Tablitsa dlya opredeleniya kaspiyskikh gastropod [Table for determination of the Caspian Sea Gastropoda]. Bulleten' Mosk. Obs. Ispyt. Prir. Otd. Geol. 22, 105-112. 


\section{REFERENCES}

Kolesnikov, V.P., 1940. Scheme of the Neogene deposits stratigraphical subdivision of the Ponto-Caspian area., in: Stratigraphy of the USSR, V. 12. USSR. Academy of sciences press, Moscow-Leningrad., pp. 567-574.

Kondrashov, P.E., 2007. New gastropod species from the Pleistocene of the Upper Don basin. Paleontol. J. 41, 513-519. https://doi.org/10.1134/S0031030107050061

Koreneva, E.V., 1980. Palynological researches of late Cenozoic deposits, in: Geological History of the Black Sea by Results of Deep-Water Drilling. p. Moscow, 65-70 (in Russian).

Kosarev, A.N., Yablonskaya, E.A., 1994. The Caspian Sea. SPB Academic Publishing, The Hague.

Kosnik, M.A., Kowalewski, M., 2016. Understanding modern extinctions in marine ecosystems: The role of palaeoecological data. Biol. Lett. 12. https://doi.org/10.1098/rsbl.2015.0951

Kostianoy, A.G., Boer, J. de, Garrigues, P., Gu, J., Jones, K.C., Knepper, T., Newton, A., Sparks, D.L., 2005. The Caspian Sea Environment, The Handbook of Environmental Chemistry. Springer Berlin Heidelberg, Berlin Heidelberg. https://doi.org/10.1007/b138238

Kostianoy, A.G., Kosarev, A.N., 2010. The Aral sea environment. Springer.

Kovacheva, M., Jordanova, N., Karloukovski, V., 1998. Geomagnetic field variations as determined from Bulgarian archaeomagnetic data. Part II: the last 8000 years. Surv. Geophys. 19, 431-460.

Kovacheva, M., Kostadinova-Avramova, M., Jordanova, N., Lanos, P., Boyadzhiev, Y., 2014. Extended and revised archaeomagnetic database and secular variation curves from Bulgaria for the last eight millennia. Phys. Earth Planet. Inter. 236, 79-94. https://doi.org/10.1016/j.pepi.2014.07.002

Krijgsman, W., Stoica, M., Vasiliev, I., Popov, V.V., 2010. Rise and fall of the Paratethys Sea during the Messinian Salinity Crisis. Earth Planet. Sci. Lett. 290, 183-191. https://doi.org/10.1016/j.epsl.2009.12.020

Krijgsman, W., Tesakov, A.S., Yanina, T.A., Lazarev, S., Danukalova, G.A., Van Baak, C.G.C., Agustí, J., Alçiçek, M.C., Aliyeva, E., Bista, D., Bruch, A., Büyükmeriç, Y., Bukhsianidze, M., Flecker, R., Frolov, P., Hoyle, T.M., Jorissen, E.L., Kirscher, U., Koriche, S.A., Kroonenberg, S.B., Lordkipanidze, D., Oms, O., Rausch, L., Singarayer, J., Stoica, M., van de Velde, S., Titov, V.V., Wesselingh, F.P., 2019. Quaternary time scales for the Pontocaspian domain: Interbasinal connectivity and faunal evolution. Earth-Science Rev. 188, 1-40. https://doi.org/10.1016/j.earscirev.2018.10.013

Kroll, O., Hershler, R., Albrecht, C., Terrazas, E.M., Apaza, R., Fuentealba, C., Wolff, C., Wilke, T., 2012. The endemic gastropod fauna of Lake Titicaca: correlation between molecular evolution and hydrographic history. Ecol. Evol. 2, 1517-1530. https://doi.org/https://doi. org/10.1002/ece3.280

Kroonenberg, S.B., Abdurakhmanov, G.M., Badyukova, E.N., van der Borg, K., Kalashnikov, A.Y., Kasimov, N.S., Rychagov, G.I., Svitoch, A.A., Vonhof, H.B., Wesselingh, F.P., 2007. Solar-forced 2600 BP and Little Ice Age highstands of the Caspian Sea. Quat. Int. 173-174, 137-143. https://doi.org/10.1016/j.quaint.2007.03.010

Kroonenberg, S.B., Badyukova, E.N., Storms, J.E.A., Ignatov, E.I., Kasimov, N.S., 2000. A full sea-level cycle in 65 years: Barrier dynamics along Caspian shores. Sediment. Geol. 134, 257-274. https://doi.org/10.1016/S00370738(00)00048-8

Kroonenberg, S.B., Kasimov, N., Lychagin, M., 2008. The Caspian Sea, a natural laboratory for sea-level change. Geogr. Environ. Sustain. 1, 22-37.

Kroonenberg, S.B., Simmons, M.D., Alekseevski, N.I., Aliyeva, E., Allen, M.B., Aybulatov, D.N., Baba-Zadeh, A., Badyukova, E.N., Davies, C.E., Hinds, D.J., Hoogendoorn, R.M., Huseynov, D., Ibrahimov, B., Mamedov, P., 
Overeem, I., Rusakov, G.V., Suleymanova, S., Svitoch, A.A., Vincent, S.J., 2005. Two Deltas, Two Basins, One River, One Sea: The Modern Volga Delta as an Analogue of the Neogene Productive Series, South Caspian Basin, in: River Deltas-Concepts, Models, and Examples. pp. 231-256. https://doi.org/10.2110/pec.05.83.0231

Krynicki, A.J., 1837. Conchylia tam terrestria, quam fluviatilia et e maribus adjacentibus Imperii Rossici indigena, quae pro mutua offeruntur historiae naturalis cultoribus commutatione. Bull. la Société Impériale des Nat. Moscou 10, 50-64.

Kuprin, P.N., Sorokin, V.M., 1982. Reflection in the thickness of Quarternary deposits of changes of the Black Sea level., in: Sea Level Changes. Publishing house of Moscow Univ., Moscow, pp. 221-226 (in Russian).

Kurbanov, R.N., Svitoch, A.A., Yanina, T.A., 2014. New data on marine Pleistocene Stratigraphy of the Western Cheleken Peninsula. Dokl. Earth Sci. 459, 1623-1626. https://doi.org/10.1134/S1028334X14120265

Kurbanov, R.N., Yanina, T.A., Murrey, A.S., Borisova, O.K., 2018. Hyrcanian epoch in the Pleistocene history of the Manych depression. Vestn. Moscow Univ. ser. 5, Geogr. 3, 77-88 (in Russian).

Küster, H.C., 1852. Die Gattungen Paludina, Hydrocaena und Valvata. In Abbildungen nach der Natur mit Beschreibungen, in: Systematisches Conchylien-Cabinet von Martini Und Chemnitz. Bauer \& Raspe, Nürnberg, p. 96.

Kvaliashvili, G., 1976. Molliuski Semeistva Cardiidae Guriiskogo Gorizonta Zapadnoi Gruzii. Metsniereba, Tbilisi.

Kvasov, D.D., 1975. Late Quaternary History of the large lakes and inner seas of the Eastern Europe. Nauka, Leningrad (in Russian).

Kwiecien, O., Arz, H.W., Lamy, F., Wulf, S., Bahr, A., Röhl, U., Haug, G.H., 2008. Estimated reservoir ages of the Black Sea since the Last Glacial. Radiocarbon 50, 99-118. https://doi.org/10.1017/S0033822200043393

Laj, C., Channell, J.E.T., 2007. Geomagnetic excursions. Treatise Geophys. 5, 373-416.

Lake, P.S., Palmer, M.A., Biro, P., Cole, J., Covich, A.P., Dahm, C., Gibert, J., Goedkoop, W., Martens, K., Verhoeven, J., 2000. Global Change and the Biodiversity of Freshwater Ecosystems: Impacts on Linkages between AboveSediment and Sediment Biota. Bioscience 50, 1099. https://doi.org/10.1641/0006-3568(2000)050[1099:gcatbo]2.0 . $\operatorname{co} ; 2$

Lamarck, J.-Bpa., 1819. Histoire naturelle des animaux sans vertèbres, présentant les caractères généraux et particuliers de ces animaux, leur distribution, leurs classes, leurs familles, leurs genres, et la citation des principales espèces qui s'y rapportent; précédée d'une int. Privately published, Paris.

Lamarck, J.-Bpa., 1809. Philosophie Zoologique, ou exposition des considérations relatives à l'histoire naturelle des Animaux; à la diversité de leur organisation et des facultés qu’ils en obtiennent; aux causes physiques qui maintiennent en eux la vie et donnent lieu aux mouvem. Dentu, Paris.

Laskarev, V., 1924. Sur les equivalentes du Sarmatien supérieur en Serbie. Recl. traveaux Ofer. a M. Jovan Cvijic par ses amis Collab. 73-85.

Laskarev, V., Cvijić, J., 1924. Sur les équivalents du Samartien supérieur en Serbie. Imprimerie de l’État royaume des Serbes, Croates et Slovenes.

Lattuada, M., Albrecht, C., Wesselingh, F.P., Klinkenbuß, D., Vinarski, M.V., Kijashko, P.V., Raes, N., Wilke, T., $2019 a$. Endemic Caspian Sea mollusks in hotspot and non-hotspot areas differentially affected by anthropogenic pressures. J. Great Lakes Res. 


\section{REFERENCES}

Lattuada, M., Albrecht, C., Wilke, T., 2019b. Differential impact of anthropogenic pressures on Caspian Sea ecoregions. Mar. Pollut. Bull. 142, 274-281. https://doi.org/10.1016/j.marpolbul.2019.03.046

Latypov, Y.Y., 2015. The bivalve mollusc Abra ovata: role in succession of soft bottom communities on newly flooded area of the Caspian Sea. Am. J. Clim. Chang. 4, 239-247. https://doi.org/10.4236/ajcc.2015.43019

Lazarev, S., Jorissen, E.L., van de Velde, S., Rausch, L., Stoica, M., Wesselingh, F.P., Van Baak, C.G.C., Yanina, T.A., Aliyeva, E., Krijgsman, W., 2019. Magneto- biostratigraphic age constraints on the palaeoenvironmental evolution of the south Caspian Basin during the Early-Middle Pleistocene (Kura Basin, Azerbaijan). Quat. Sci. Rev. 222, 105895. https://doi.org/10.1016/j.quascirev.2019.105895

Legendre, P., 2005. Species associations: the Kendall coefficient of concordance revisited. J. Agric. Biol. Environ. Stat. 10, 226-245. https://doi.org/10.1198/108571105X46642

Legendre, P., Gallagher, E.D., 2001. Ecologically meaningful transformations for ordination of species data. Oecologia 129, 271-280. https://doi.org/10.1007/s004420100716

Lehner, B., Döll, P., 2004. Development and validation of a global database of lakes, reservoirs and wetlands. J. Hydrol. 296, 1-22. https://doi.org/10.1016/j.jhydrol.2004.03.028

Leontiev, O.K., Rychagov, G.I., Svitoch, A.A., 1975. Quaternary history of the Caspian Sea, according to absolute geochronology., in: The History of the Lakes and Inland Seas of Arid Zone. Nauka, Leningrad, pp. 21-24 (in Russian).

Leppäkoski, E., Mihnea, E., 1996. Enclosed Seas under Man-induced Change: A Comparison between the Baltic and Black Seas. Ambio 25, 380-389.

Leroy, S.A.G., Chalié, F., Wesselingh, F.P., Sanjani, M.S., Lahijani, H.A.K., Athersuch, J., Struck, U., Plunkett, G., Reimer, P.J., Habibi, P., Kabiri, K., Haghani, S., Naderi Beni, A., Arpe, K., 2018. Multi-proxy indicators in a pontocaspian system: A depth transect of surface sediment in the SE caspian sea. Geol. Belgica 21, 143-165. https://doi. org/10.20341/gb.2018.008

Levin, S.A., Lubchenco, J., 2008. Resilience, Robustness, and Marine Ecosystem-based Management 58, 27-32. Lindholm, V.A., 1930. Drei interessante Wasserschnecken (Gastropoda) aus dem westlichen Turkestan. Doklady Akademii, Nauka, Moscow.

Lindholm, V.A., 1925. Beitrag zur Systematik und Nomenklatur der Familie Enidae (Buliminidae). Arch. für Molluskenkd. 57, 23-41.

Lindholm, V.A., 1924. K nomenklature nekotorykh kaspiyskikh gastropod. Rus. Gidrobiol. Zhurnal 3, 32-34.

Lindholm, V.A., 1922. Miscellaneous notes on palaearctic land and freshwater Mollusks. Ezhegodnik Zool. Muzeya Imp. Akad. Nauk 23, 304-320.

Lindholm, V.A., 1908. Materialien zur Molluskenfauena [sic] von Südwestrussland, Polen und der Krim. Zap. Novoross. Obs. Estestvoispyt. 31, 199-232.

Lindholm, V.A., 1901. Beiträge zur Kenntniss der Weichthierfauna Süd-Russlands. Nachrichtsblatt der Dtsch. Malakozool. Gesellschaft 33, 161-186.

Linneaus, C., 1758. Systema naturae per regna tria naturae, secundum classes, ordines, genera, species, cum characteribus, differentiis, synonymis, locis. Tomus I. Editio decima, reformata. Laurentius Salvius, Holmiae. 
Logvinenko, B.M., Starobogatov, Y.I., 1969. Tip Mollyuski [Phylum Mollusca], in: Birshtein, Ya.A., Vinogradov, L.G., Kondakov, N.N., Kuhn, M.S., Astakhova, T.V., Romanova, N.N. (Ed.), Atlas Bespozvonochnykh Kaspiyskogo Morya [Atlas of the Invertebrates of the Caspian Sea]. Pishchevaya Promyshlennost (Vsesoyuznyi Nauchnoissledovatel'skii Institut Morskogo Rybnogo Khozyaistva i Okeanografii), Moscow, pp. 308-385.

Logvinenko, B.M., Starobogatov, Y.I., 1967. K izucheniyu vidovogo sostava fauny dvustvorchatykh mollyuskov tanatotsenozov podvodnogo sklona Azerbaydzhanskogo poberezhya Kaspiya., in: Kudritskiy, D.M. (Ed.), Opyt Geologo-Geomorfologicheskikh i Gidrobiologicheskikh Issledovaniy Beregovoy Zony Morya. Nauka, Leningrad, pp. 225-235.

Logvinenko, B.M., Starobogatov, Y.I., 1966a. Novyye dvustvorchatyye mollyuski iz kaspiyskoy profundali. Nauchnyye doklady vysshey shkoly. Biol. Nauk. 2, 13-16.

Logvinenko, B.M., Starobogatov, Y.I., 1966b. Mollyuski semeystva Planorbidae Kaspiya. Zool. Zhurnal 45, $1467-1475$.

Lokhin, M.Y., Maev, E.G., 1990. Late Pleistocene deltas on the shelf of northern part of the Middle Caspian Sea. Vestn. Moscow Univ. ser. 5, Geogr. 3, 33-40 (in Russian).

Mabille, J., 1877. Catalogue des Paludestrines des côtes de France. Rev. Mag. Zool. 3e Série 5, 214-222.

Maev, E.G., 1994. Regressions of the Caspian Sea (there position in the Caspian Quaternary and role in the bottom relief formation). Geomorphology 4, 94-101 (in Russian).

Magurran, A.E., Baillie, S.R., Buckland, S.T., Dick, J.M.P., Elston, D.A., Scott, E.M., Smith, R.I., Somerfield, P.J., Watt, A.D., 2010. Long-term datasets in biodiversity research and monitoring: Assessing change in ecological communities through time. Trends Ecol. Evol. 25, 574-582. https://doi.org/10.1016/j.tree.2010.06.016

Mainguet, M., Létolle, R., 1997. The ecological crisis of the Aral Sea basin in the frame of a new time scale: The “Anthropo-Geological Scale." Naturwissenschaften 84, 331-339. https://doi.org/10.1007/s001140050406

Mainguet, M., Taittinger, P., Reims, F., 1997. The Aral Sea: A Flat Endoreic Lake in a Semiarid Ecosystem 339, $331-339$.

Major, C.O., Goldstein, S.L., Ryan, W.B.F., Lericolais, G., Piotrowski, A.M., Hajdas, I., 2006. The co-evolution of Black Sea level and composition through the last deglaciation and its paleoclimatic significance. Quat. Sci. Rev. 25, 20312047. https://doi.org/10.1016/j.quascirev.2006.01.032

Makarov, A.K., 1938. Rasprostraneniye nekotorykh rakoobraznykh (Mysidacea, Cumacea) i limannykh mollyuskov v ust'yakh i otkrytykh limanakh Severnogo Prichernomor'ya [Distribution of some crustaceans (Mosidakea, Chumachea) and estuary mollusks in the mouths and open estuaries. Zool. Zhurnal 17, 1055-1062.

Malinovskaya, L.V., Zinchenko, T.D., 2011. Long-term dynamics of the biomass of the introduced species Hediste diversicolor Müller and Abra ovata (Philippi) in the North Caspian Sea. Russ. J. Biol. Invasions 2, 20-28. https:// doi.org/10.1134/S2075111711010048

Mamaev, V., 2002. The Caspian Sea - enclosed and with many endemic species, EEA Report No 1/2002.

Mamedov, A.V., 1997. The Late Pleistocene-Holocene history of the Caspian Sea. Quat. Int. 41-42, 161-166. https://doi. org/10.1016/s1040-6182(96)00048-1

Martens, E. von, 1874. Ueber vorderasiatische Conchylien nach den Sammlungen des Prof. Hausknecht. Novit. Conchol. Supplement, 1-127.

Martinelli, J.C., Soto, L.P., González, J., Rivadeneira, M.M., 2017. Benthic communities under anthropogenic pressure show resilience across the quaternary. R. Soc. Open Sci. 4, 1-12. https://doi.org/10.1098/rsos.170796 


\section{REFERENCES}

Matthews, S.C., 1973. Notes on open Nomenclature and on Synonymy Lists. Palaeontology 16, 713-719.

McHugh, C.M.G., Gurung, D., Giosan, L., Ryan, W.B.F., Mart, Y., Sancar, U., Burckle, L., Çagatay, M.N., 2008. The last reconnection of the Marmara Sea (Turkey) to the World Ocean: A paleoceanographic and paleoclimatic perspective. Mar. Geol. 255, 64-82. https://doi.org/10.1016/j.margeo.2008.07.005

McMahon, R.F., 1996. The physiological ecology of the zebra mussel, Dreissena polymorpha, in North America and Europe. Am. Zool. 36, 339-363.

Meinhardt, K.A., Gehring, C.A., 2012. Disrupting mycorrhizal mutualisms: A potential mechanism by which exotic tamarisk outcompetes native cottonwoods. Ecol. Appl. 22, 532-549. https://doi.org/10.1890/11-1247.1

Micklin, P., 2007. The Aral Sea Disaster. Annu. Rev. Earth Planet. Sci. 35, 47-72. https://doi.org/10.1146/annurev. earth.35.031306.140120

Micklin, P., Aladin, N.V., Plotnikov, I., 2014. The Aral Sea. The Devastation and Partial Rehabilitation of a Great Lake. Springer, Berlin.

Milaschewitch, K.O., 1916. Mollyuski russkikh morey. Tom 1. Mollyuski Chernago i Azovskago morey. Imperatorskaya Akademiya Nauk. [The molluscs of the Russian seas. Volume 1. Shellfish of the Black and Azov Seas]. Imperatorskaya Akademiya Nauk, Zoologicheskiy Muzey, Petrograd.

Milaschewitch, K.O., 1908. Mollyuski, sobrannyye vo vremya ekskursii S.A. Zernova na minonostse No. 264 na r. Dunay s 28 iyunya po 3 iyulya 1907 goda. Bull. l’Académie Impériale des Sci. St.-Pétersbourg, sixième série 2, 991996.

Mirzoev, G.S., Alekperov, L.H., 2017. Zoobenthos distribution on biotope in the shelf zone of the Azerbaijan sector of the South Caspian. J. Entomol. Zool. Stud. 2, 43-48.

MolluscaBase, 2018a. MolluscaBase. MolluscaBase.

MolluscaBase, 2018b. Adacna fragilis Milaschewitch, 1908. World Regist. Mar. Species.

Molostovsky, E.A., 1997. Magnetostratigraphy of the Pliocene deposits in the Black Sea, Caspian regions and adjacent areas. Geodiversitas 19, 471-495.

Montagu, G., 1803. Testacea Britannica, or natural history of British shells, marine, land, and fresh-water, including the most minute: systematically arranged and embellished with figures. White, London.

Montfort, P.D., 1810. Conchyliologie systématique et classification méthodique de coquilles; offrant leurs figures, leur arrangement générique, leurs descriptions caractéristiques, leurs noms; ainsi que leur synonymie en plusieurs langues. Ouvrage destiné à faciliter l'étude d. Tome second. Schoell, Paris.

Mordukhai-Boltovskoi, P.D., 1979. Composition and Distribution of Caspian Fauna in the Light of Modern Data. Int. Rev. der gesamten Hydrobiol. und Hydrogr. 64, 1-38.

Mordukhai-Boltovskoi, P.D. (Ed.), 1974. Klass Briukhonogie Molliuski [Class Gastropoda, Mollusca], in: Atlas Bespozvonochnykh Aral'skogo Morya [Atlas of the Aral Sea Invertebrates]. Pishchevaya Promyshlennost, Moscow, pp. 0-275.

Mordukhai-Boltovskoi, P.D., 1960. Kaspiyskaya fauna v Azovo-Chernomorskom basseyne [Caspian fauna in the Azov and Black Sea Basin]. Izdatelstvo Akademii Nauk SSSR, Leningrad. 
Moreno-Mateos, D., Barbier, E.B., Jones, P.C., Jones, H.P., Aronson, J., López-López, J.A., McCrackin, M.L., Meli, P., Montoya, D., Rey Benayas, J.M., 2017. Anthropogenic ecosystem disturbance and the recovery debt. Nat. Commun. 8, 14163. https://doi.org/10.1038/ncomms14163

Mousson, A., 1863. Coquilles terrestres et fluviatiles, recueillies dans l'Orient par M le Dr Alex Schläfli. Vierteljahrsschrift der Naturforschenden Gesellschaft Zürich 8, 368-426.

Mudie, P.J., Yanko-Hombach, V.V., Kadurin, S., 2014. The Black Sea Dating Game and Holocene Marine Transgression. Open J. Mar. Sci. 04, 1-7. https://doi.org/10.4236/ojms.2014.41001

Mullender, T.A., Frederichs, T., Hilgenfeldt, C., de Groot, L.V., Fabian, K., Dekkers, M.J., 2016. Automated paleomagnetic and rock magnetic data acquisition with an in-line horizontal "2G” system. Geochemistry, Geophys. Geosystems 17, 3546-3559. https://doi.org/https://doi.org/10.1002/2016GC006436

Müller, O.F., 1774. Vermium terrestrium et fluviatilium historia, seu animalium Infusoriorum, Helminthicorum et Testaceorum non marinorum succincta historia. Heineck \& Faber, Havniae et Lipsiae.

Müller, P., Geary, D.H., Magyar, I., 1999. The endemic molluscs of the Late Miocene Lake Pannon: Their origin, evolution, and family-level taxonomy. Lethaia 32, 47-60. https://doi.org/10.1111/j.1502-3931.1999.tb00580.x

Munasypova-Motyash, I.A., 2006a. O sovremennoy faune dvustvorchatykh mollyuskov podsemeystva Limnocardiinae (Bivalvia, Cardiidae) Severo-Zapadnogo Prichernomor'ya [On the modern fauna of bivalves subfamily Limnocardiinae (Bivalvia, Cardiidae) in North-Western Shore of Black Sea]. Vestn. Zool. 40, 41-48.

Munasypova-Motyash, I.A., 2006b. Morfometricheskiye priznaki rakoviny dvustvorchatykh mollyuskov podsemeystva Limnocardiinae (Bivalvia, Cardiidae) i ikh znacheniye v taksonomii gruppy [Morphometric features of the shell of bivalve mollusks of the subfamily Limnokardiyinay (Bivalvia, Kard. Vestn. Zool. 40, 521-527.

Murdmaa, I., Ivanova, E., Chepalyga, A.L., Cronin, T., Levchenko, O., Howe, S., Manushkina, A., Pasechnik, I., Platonova, E., 2006. Paleoenvironments on the North Caucasian Black Sea shelf since the LGM. Ext. Abstr. Second Plenary Meet. F. trip Proj. IGCP-521 Black Sea - Mediterr. Corridor Dur. last 30 ky sea Lev. Chang. Hum. Adapt. Astroprint, Odessa 127-129.

Nabozhenko, M.V., Nabozhenko, S.V., 2016. Corbicula fluminalis (O.F. Müller, 1774) - novyy dlya rossiyskogo sektora kaspiyskogo basseyna vid dvustvorchatykh mollyuskov [Corbicula fluminalis (O.F. Müller, 1774) - a new species of bivalve mollusks for the Russian sector of the Caspian. Nauk. Yuga Ross. (Vestnik Yuzhnogo Nauchnogo Tsentra) 12, 61-64.

Nalivkin, D.V., 1915. Die mollusken des berges der Bakustufe.

Nalivkin, D.V., 1914. Mollyuski gory bakinskogo yarusa [Molluscs of the Gora Bakinskogo yarusa section], Trudy Geologicheskogo Komiteta, novaya seriya. Trudy Geologicheskogo Komiteta, novaya seriya.

Nalivkin, D.V., Anisimov, A., 1914. Opisaniye glavneyshikh mestnykh form roda Didacna Eichwald iz postpliotsena Apsheronskogo poluostrova/Beschreidbung der wichtigsten lokalformne der gattung Didacna aus dem postpliozan der halbinsel Apscheron.

Nanami, A., Saito, H., Akita, T., Motomatsu, K.I., Kuwahara, H., 2005. Spatial distribution and assemblage structure of macrobenthic invertebrates in a brackish lake in relation to environmental variables. Estuar. Coast. Shelf Sci. 63, 167-176. https://doi.org/10.1016/j.ecss.2004.11.004 


\section{REFERENCES}

Nandini-Weiss, S.D., Prange, M., Arpe, K., Merkel, U., Schulz, M., 2019. Past and future impact of the winter North Atlantic Oscillation in the Caspian Sea catchment area. Int. J. Climatol. joc.6362. https://doi.org/10.1002/joc.6362

NCOC, 2018. Environmental monitoring of the North-East Caspian Sea during development of NCOC N.V. Oil fields in the period 2006-2016.

Neubauer, T.A., Georgopoulou, E., Harzhauser, M., Mandic, O., Kroh, A., 2016a. Predictors of shell size in long-lived lake gastropods. J. Biogeogr. 43, 2062-2074. https://doi.org/10.111/jbi.12777

Neubauer, T.A., Harzhauser, M., Georgopoulou, E., Kroh, A., Mandic, O., 2015a. Tectonics, climate, and the rise and demise of continental aquatic species richness hotspots. Proc. Natl. Acad. Sci. 112, 11478-11483. https://doi. org/10.1073/pnas.1503992112

Neubauer, T.A., Harzhauser, M., Mandic, O., Kroh, A., Georgopoulou, E., 2016b. Evolution, turnovers and spatial variation of the gastropod fauna of the late Miocene biodiversity hotspot Lake Pannon. Palaeogeogr. Palaeoclimatol. Palaeoecol. 442, 84-95. https://doi.org/10.1016/j.palaeo.2015.11.016

Neubauer, T.A., Kroh, A., Harzhauser, M., Georgopoulou, E., Mandic, O., 2015b. Taxonomic note on problematic Neogene European freshwater Gastropoda. Ann. des Naturhistorischen Museums Wien, Ser. A 117, 95-100.

Neubauer, T.A., Mandic, O., Harzhauser, M., 2015c. The freshwater mollusk fauna of the middle miocene lake Drniš (Dinaride lake system, Croatia): A taxonomic and systematic revision. Austrian J. Earth Sci. 108, 15-67. https://doi. org/10.17738/ajes.2015.0013

Neubauer, T.A., van de Velde, S., Yanina, T.A., Wesselingh, F.P., 2018. A late Pleistocene gastropod fauna from the northern Caspian Sea with implications for Pontocaspian gastropod taxonomy. Zookeys 770, 43-103. https://doi. org/10.3897/zookeys.770.25365

Neumayr, M., 1869. Beiträge zur Kenntniss fossiler Binnenfaunen. Jahrb. der k. k. Geol. Reichsanstalt 19, $355-382$.

Nevesskaja, L.A., 2007. History of the genus Didacna (Bivalvia: Cardiidae). Paleontol. J. 41, 861-949. https://doi. org/10.1134/S0031030107090018

Nevesskaja, L.A., 1965. Pozdnechetvertichnyye dvustvorchatyye mollyuski Chernogo morya, ikh sistematika i ekologiya [Late Quaternary mollusks of the Black Sea, their sistematic and ecology]. Tr. Paleontol. Instituta 105, $1-391$.

Nevesskaja, L.A., 1963. Opredelitel' dvustvorchatykh mollyuskov morskikh chetvertichnykh otlozheniy Chernomorskogo basseyna [Determinant of bivalve mollusks of the marine Quarternary deposits of the Black Sea basin]. Tr. Paleontol. Instituta 96, 1-211.

Nevesskaja, L.A., 1958. Chetvertichnyye morskiye mollyuski Turkmenii [Quaternary marine mollusks of Turkmenistan]. Tr. Paleontol. Instituta 65, 1-82.

Nevesskaja, L.A., Goncharova, I.A., Il'ina, L.B., Paramonova, N.P., Khondkarian, S.O., 2003. The Neogene stratigraphic scale of the Eastern Paratethys. Stratigr. Geol. Correl. 11, 105-127.

Nevesskaja, L.A., Goncharova, I.A., Ilyina, L.B., Paramonova, N.P., Popov, S.V., Babak, E. V., Bagdasarjan, K.G., Voronina, A.A., 1986. Istorija neogenovych mollyuskov Paratetisa [The history of the Neogene mollusk Paratetis], Tr. Paleontol. Inst. AN SSSR. Nauka Press, Moscow (in Russian).

Nevesskaja, L.A., Kovalenko, E.I., Beluzhenko, E. V., Popov, S.V., Goncharova, I.A., Danukalova, G.A., Zhidovinov, N.Y., Zajtsev, A. V., Zastrozhnov, A.S., Pintchuk, T.N., Ilyina, L.B., Paramonova, N.P., Pis'mennaja, N.S., Khondkarian, 
S.O., 2005. Regional Neogene stratigraphic scale of the South of European Russia.]. Otetchestvennaja Geol. 4, 47-59 (in Russian).

Nikula, R., Väinölä, R., 2003. Phylogeography of Cerastoderma glaucum (Bivalvia: Cardiidae) across Europe: a major break in the Eastern Mediterranean. Mar. Biol. 143, 339-350. https://doi.org/10.1007/s00227-003-1088-6

Occhipinti-Ambrogi, A., Savini, D., 2003. Biological invasions as a component of global change in stressed marine ecosystems. Mar. Pollut. Bull. 46, 542-551. https://doi.org/10.1016/S0025-326X(02)00363-6

Oksanen, J., Blanchet, F.G., Kindt, R., Legendre, P., Minchin, P.R., O’Hara, R.B., Simpson, G.L., Solymos, P., Stevens, M.H.H., Wagner, H., 2015. vegan: Community Ecology Package. R package version 2.2-1.

Orlova, M.I., Muirhead, J.R., Antonov, P.I., Shcherbina, G.K., Starobogatov, Y.I., Biochino, G.I., Therriault, T.W., MacIsaac, H.J., 2004. Range expansion of quagga mussels Dreissena rostriformis bugensis in the Volga River and Caspian Sea basin. Aquat. Ecol. 38, 561-573. https://doi.org/10.1007/s10452-004-0311-y

Orlova, M.I., Therriault, T.W., Antonov, P.I., Shcherbina, G.K., 2005. Invasion ecology of quagga mussels (Dreissena rostriformis bugensis): A review of evolutionary and phylogenetic impacts. Aquat. Ecol. 39, 401-418. https://doi. org/10.1007/s10452-005-9010-6

Osikowski, A., Hofman, S., Georgiev, D., Kalcheva, S., Falniowski, A., 2016. Aquatic snails Ecrobia maritima (Milaschewitsch, 1916) and E. ventrosa (Montagu, 1803) (Caenogastropoda: Hydrobiidae) in the East Mediterranean and Black Sea. Ann. Zool. 66, 477-486. https://doi.org/10.3161/00034541ANZ2016.66.3.012

Ostroumov, A.A., 1907. O mollyuskakh Aralskago morya [On mollusks of the Aral Sea]. Izv. Turkestanskogo Otd. Rus. Geogr. Obs. 4, 20-26.

Ostroumov, A.A., 1905. Poyezdka na Kaspiy. Tr. Obs. yestestvoispytateley pri Kazan. Univ. 39, 1-84.

Ostrovsky, A.B., Izmaylov, Y.A., Scheglov, A.P., 1977. New data on a stratigraphy and geochronology of the Pleistocene marine terraces of the Black Sea coast of the Caucasus and Kerch-Taman area., in: Paleogeography and Deposits of the Pleistocene of the Southern Seas of the USSR. Nauka, Moscow, pp. 61-68 (in Russian).

Overeem, I., Kroonenberg, S.B., Veldkamp, A., Groenesteijn, K., Rusakov, G.V., Svitoch, A.A., 2003. Small-scale stratigraphy in a large ramp delta: Recent and Holocene sedimentation in the Volga delta, Caspian Sea. Sediment. Geol. 159, 133-157. https://doi.org/10.1016/S0037-0738(02)00256-7

Paladilhe, A., 1869. Descriptions de quelques Paludinées, Assiminidées et Mélanidées [Descriptions of some Paludines, Assiminidées and Melanidae]. Rev. Mag. Zool. Pure Appliquée, deuxième série 21 21, 225-237, 273-284, 316-325, 379-383.

Paladilhe, A., 1867. Nouvelles Miscellanées malacologiques [Miscellaneaous Malacological News]. Rev. Mag. Zool. pure appliquée, deuxième série 19, 88-95.

Palcu, D.V., Golovina, L.A., Vernyhorova, Y.V., Popov, S.V., Krijgsman, W., 2017. Middle Miocene paleoenvironmental crises in Central Eurasia caused by changes in marine gateway configuration. Glob. Planet. Change 158, 57-71. https://doi.org/10.1016/j.gloplacha.2017.09.013

Pallas, P.S., 1771. Reise durch verschiedene Provinzen des Rußischen Reichs. Kayserliche Academie der Wissenschaften, St. Petersburg.

Panin, G.N., Mamedov, R., Mitrofanov, I.V., 2005. Present-Day State of the Caspian Sea. Nauka press, Moscow. 


\section{REFERENCES}

Panin, N., 1997. On the Geomorphologic and Geologic Evolution of the River Danube-Black Sea Interaction Zone. Geo-Eco-Marina 2, 31-40.

Panin, N., 1989. Danube Delta. Genesis, evolution and sedimentology. Révue Roum. Géologie, Géophysique, Géographie, Série Géographie 33, 25-36.

Panin, N., Ion, G., Ion, E., 2003. The Danube Delta - Chronology of lobes and rates of sediment deposition. Geo-EcoMarina 9-10, 8-12.

Panin, N., Jipa, D., 2002. Danube River Sediment Input and its Interaction with the North-western Black Sea. Estuar. Coast. Shelf Sci. 54, 551-562. https://doi.org/10.1006

Panin, N., Tiron Duţu, L., Duţu, F., 2016. The Danube Delta. Méditerranée 37-54. https://doi.org/10.4000/ mediterranee. 8186

Paramonova, N.P., 1994. History of Sarmatian and Akchagylian Bivalves. (Transactions of the Palaeontological institute, 260, Nauka Press, Moscow., p. 212.

Parr, T.D., Tait, R.D., Maxon, C.L., Newton, F.C., Hardin, J.L., 2007. A descriptive account of benthic macrofauna and sediment from an area of planned petroleum exploration in the southern Caspian Sea. Estuar. Coast. Shelf Sci. 71, 170-180. https://doi.org/10.1016/j.ecss.2006.07.018

Pavlović, P.S., 1903. Građa za poznavanje tercijara u Staroj Srbiji. Ann. Géologiques la Péninsule Balk. 6, 155-189.

Perty, J.A.M., 1833. Delectus animalium articulatorum, quae in itinere per Brasiliam annis MDCCCXVII-MDCCCXX [1817-1820] jussu et auspiciis Maximiliani Josephi I Bavariae Regis augustissimi peracto, collegerunt Dr. J. B. de Spix et Dr. C. F. Ph. de Martius. Friedrich Fleischer, Monachii.

Pfeiffer, C., 1828. Naturgeschichte deutscher Land- und Süsswasser-Mollusken. Dritte Abtheilung. Landes-IndustrieComptoir, Weimar.

Philippi, R.A., 1836. Enumeratio Molluscorum Siciliae cum viventium tum in tellure teriaria fossilium, quae in itinere suo observavit. Simon Schropp, Berlin.

Pickering, J.L., Goodbred, S.L., Beam, J.C., Ayers, J.C., Covey, A.K., Rajapara, H.M., Singhvi, A.K., 2018. Terrace formation in the upper Bengal basin since the Middle Pleistocene: Brahmaputra fan delta construction during multiple highstands. Basin Res. 30, 550-567. https://doi.org/10.1111/bre.12236

Piller, W.E., Harzhauser, M., Mandic, O., 2007. Miocene Central Paratethys stratigraphy-current status and future directions. Stratigraphy 4, 151-168.

Piper, D.Z., 2016. Geochemistry of the Black Sea during the last 15 kyr: A protracted evolution of its hydrography and ecology. Paleoceanography 31, 1117-1137. https://doi.org/10.1002/2016PA002949

Pirogov, V.V., 1971. O nakhozhdenii novogo vida mollyuska iz roda Pyrgula Crist. et Jan. v avandel'tye reki Volgi [On the discovery of a new species of mollusk from the genus Pyrgula Crist. et Jan. in the forefront of the Volga River]. Tr. Astrakhanskogo Zapov. Im. V.I. Lenina 13, 249-253.

Plaziat, J.C., 1991. Paleogeographic significance of the Cardium, Potamids and Foraminifera living in intra-continental salt lakes of North Africa (Sahara Quaternary, Egypt Present lakes). J. African Earth Sci. (and Middle East) 12, 383-389. https://doi.org/https://doi.org/10.1016/0899-5362(91)90087-F

Plotnikov, I.S., Ermakhanov, Z.K., Aladin, N.V., Micklin, P., 2016. Modern state of the Small (Northern) Aral Sea fauna. Lakes Reserv. Res. Manag. 21, 315-328. https://doi.org/10.1111/lre.12149 
Poey, F., 1852. Introduccion a los Ciclostomas con generalidades sobre los moluscos gastropodos y particularmente sobre los terrestres operculados. Memorias sobre la Hist. Nat. la isla Cuba 1, 77-96.

Poiret, J.L.M., 1789. Voyage en Barbarie, ou Lettres écrites de l’Ancienne Numidie. Pendant les années 1785 \& 1786 , sur la Religion, les Contumes \& les Moeurs des Maures des Arabes- Bédouins; avec un Essai sur l'Histoire Naturelle de ce pays. JBF Née de la Rochelle, Paris.

Poli, I.X., 1795. Testacea utriusque Siciliae eorumque historia et anatome tabulis aeneis illustrata. Regio Typographeio, Parma.

Pollonera, C., 1898. Intorne ad alcune Conchiglie del Friuli. Boll. dei Musei di Zool. ed Anat. Comp. della Univ. di Torino 13, 1-4.

Ponder, W.F., 1988. Potamopyrgus antipodarum - a molluscan coloniser of Europe and Australia. J. Molluscan Stud. 54, 271-285. https://doi.org/10.1093/mollus/54.3.271

Ponder, W.F., 1984. A review of the genera of the Rissoidae (Mollusca: Mesogastropoda: Rissoacea). Rec. Aust. Museum, Suppl. 4, 1-221. https://doi.org/10.3853/j.0812-7387.4.1985.100

Popa, L.O., Popa, O.P., Iorgu, E., Kelemen, B.S., Murariu, D., 2012. Molecular insights into the taxonomy of Hypanis (Bivalvia, Cardiidae, Lymnocardiinae) in the Black Sea lagoons. Helgol. Mar. Res. 66, 153-158. https://doi.org/ https://doi.org/10.1007/s10152-011-0256-1

Popa, O.P., Iorgu, E.I., Kelemen, B.S., Murariu, D., Popa, L.O., 2010. Morphometric analysis of some populations of Lymnocardiid species (Mollusca: Bivalvia) from Razelm Lake Complex (Romania). Trav. du Muséum Natl. d’Histoire Nat. "Grigore Antipa” 53, 13-19. https://doi.org/10.2478/v10191-010-0002-y

Popa, O.P., Sarkany-Kiss, A., Kelemen, B.S., Iorgu, E.I., Murariu, D., Popa, L.O., 2009. Contributions to the knowledge of the present Limnocardiidae fauna (Mollusca, Bivalvia) from Romania. Trav. du Muséum Natl. d'Histoire Nat. “Grigore Antipa” 52, 7-15.

Popov, G.I., 1983a. The Pleistocene of the Black Sea - Caspian Sea Straits. Nauka Press, Moscow (in Russian).

Popov, G.I., 1983b. Pleystotsen Chernomorsko-Kaspiyskikh prolivov (stratigrafiya, korrelyatsiya, paleofaunistika, geologicheskaya istoriya) [The Pleistocene of the Black Sea-Caspian Straits (Stratigraphy, Correlation, Paleofaunistics, Geological History)]. Nauka, Moscow.

Popov, G.I., 1970. Significance of fresh water molluscs for correlation of continental and marine Pleistocene of Ponto Caspian. Palaeogeogr. Palaeoclimatol. Palaeoecol. 8, 251-260. https://doi.org/10.1016/0031-0182(70)90017-9 Popov, G.I., 1969. Scheme of the Aktshagylian stage stratigraphy, in: Geology and Mineral Resources of Turkmenia (Stratigraphy): Materials of the Anniversary Schientific-Technical Conference of the Turkmenian SSR Geological Survey. Ashkhabad. pp. 179-223.

Popov, G.I., 1967. Hyrcanian transgression in the Northern Caspian sea. Bull. Comm. Stud. Quat. Period 33, 77-86 (in Russian).

Popov, G.I., 1955. History of the Manych Strait in connection with a stratigraphy of the Black Sea and Caspian Sea deposits. Bull. MOIP. Dep. Geol. 20, 31-49 (in Russian).

Popov, S.V., Rögl, F., Rozanov, A.Y., Steininger, F.F., Shcherba, I.G., Kovac, M., 2004. Lithological-paleogeographic maps of paratethys. CFS Cour. Forschungsinstitut Senckenb. 1-46. 


\section{REFERENCES}

Popov, S.V., Shcherba, I.G., Ilyina, L.B., Nevesskaja, L.A., Paramonova, N.P., Khondkarian, S.O., Magyar, I., 2006.

Late Miocene to Pliocene palaeogeography of the Paratethys and its relation to the Mediterranean. Palaeogeogr. Palaeoclimatol. Palaeoecol. 238, 91-106. https://doi.org/10.1016/j.palaeo.2006.03.020

Pravoslavlev, P.A., 1950. Nekotoryye zamechaniya o gruppe sovremennykh Didacna trigonoides Pall. Uchenyye Zap. Leningr. Gos. Univ. seriya Geol. Nauk 102, 20-27.

Preoteasa, L., Vespremeanu-Stroe, A., Tătui, F., Zăinescu, F., Timar-Gabor, A., Cîrdan, I., 2016. The evolution of an asymmetric deltaic lobe (Sf. Gheorghe, Danube) in association with cyclic development of the river-mouth bar: Long-term pattern and present adaptations to human-induced sediment depletion. Geomorphology 253, 59-73. https://doi.org/10.1016/j.geomorph.2015.09.023

Prié, V., 2011. Heleobia stagnorum. IUCN Red List Threat. Species 2011 e.T155989A4879741. https://doi.org/https://doi. org/10.2305/IUCN.UK.2011-2.RLTS

Primack, R.B., Miller-Rushing, A.J., Corlett, R.T., Devictor, V., Johns, D.M., Loyola, R., Maas, B., Pakeman, R.J., Pejchar, L., 2018. Biodiversity gains? The debate on changes in local- vs global-scale species richness. Biol. Conserv. 219, A1-A3. https://doi.org/10.1016/j.biocon.2017.12.023

Put', A.L., 1972. Do vyvchennya lunkovykh (Neritidae) Ukrayini. Dopovidi Akad. Nauk Ukr. SSR, Seriya B, Geol. Khimiya, Biol. 1, 78-83.

Quintero, C., Morales, C.L., Aizen, M.A., 2010. Effects of anthropogenic habitat disturbance on local pollinator diversity and species turnover across a precipitation gradient. Biodivers. Conserv. 19, 257-274. https://doi.org/10.1007/ s10531-009-9720-5

Rădan, S., Ganciu, A., Strechie, C., 1999. Overview of the Long-Term Ecological Research Performed by GEOECOMAR in the Danube Delta, Romania, in: Proceedings of the IL TER Regional Workshop: Cooperation in Long Term Ecological Research in Central and Eastern Europe. pp. 101-122.

Radoman, P., 1977. Hydrobiidae auf der Balkanhalbinsel und in Kleinasien. Arch. für Molluskenkd. 107, $203-223$.

Radoman, P., 1973. New Classification of Fresh and Brackish Water Prosobranchia from the Balkans and Asia Minor. Prir. Muz. u Beogradu, Poseb. Izd. 32, 1-30.

Rafinesque, C.S., 1815. Analyse de la nature ou tableau de l'univers et des corps organisés. Privately published by author, Palermo.

Ramstein, G., Fluteau, F., Besse, J., Joussaume, S., 1997. Effect of orogeny, plate motion and land-sea distribution on Eurasian climate change over the past 30 million years. Nature 386, 788-795. https://doi.org/10.1038/386788a0

Rao, C., 1995. A review of canonical coordinates and an alternative to correspondence analysis using Hellinger distance. Questiio 19, 23-63.

Raup, 1975. Taxonomic diversity estimation using rarefaction. Palaeobiology 1, 333-342.

Récluz, C.A., 1843. Monographie du genre Syndosmya. Rev. Zool. par la Société Cuvierienne 6, 359-369.

Reeve, L.A., 1845. Monograph of the genus Cardium, Conchologia Iconica: or, Illustrations of the Shells of Molluscous Animals. Privately published, London.

Rehfeldt, N., 1968. Reproductive and morphological variations in the prosobranch 'Rissoa membranacea'. Ophelia 5, 157-173. https://doi.org/10.1080/00785326.1968.10409629 
Rekacewicz, P., Dejouhanet, L., 2002. Transboundary Diagnostic Analysis for the Caspian Sea. Caspian Environment Programme (CEP), Baku, Azerbaijan.

Richter, B.D., Braun, D.P., Mendelson, M.A., Master, L.L., 1997. Threats to imperiled freshwater fauna. Conserv. Biol. 11, 1081-1093. https://doi.org/10.1046/j.1523-1739.1997.96236.x

Riedel, F., Audzijonyte, A., Mugue, N., 2006. Aliens associating with Caspian Sea endemic bivalves. Biol. Invasions 8 , 1067-1071. https://doi.org/10.1007/s10530-005-5920-4

Riedel, F., Healy, J.M.M., Röpstorf, P., Sitnikova, T.Y., 2001. Ecology, shell morphology, anatomy and sperm ultrastructure of the caenogastropod Pyrgula annulata, with a discussion of the relationship between the "pyrgulidae" and Caspian and Baikalian rissooideans. Limnologica 31, 289-302. https://doi.org/10.1016/S00759511(01)80031-1

Rodionov, S.N., 1994. Global and Regional Climate Interaction: The Caspian Sea Experience, Volume 44, Water Science and Technology Library. Springer Netherlands, Dordrecht. https://doi.org/10.1007/978-94-011-1074-7

Rogl, F., 1999. Mediterranean and paratethys. Facts and hypotheses of an Oligocene to Miocene Paleogeography (short overview). Geol. Carpathica 50, 339-349.

Romanescu, G., 2013. Geoarchaeology of the ancient and medieval Danube Delta: Modeling environmental and historical changes. A review. Quat. Int. 293, 231-244. https://doi.org/10.1016/j.quaint.2012.07.008

Romanescu, G., Cojocaru, I., 2010. Hydrogeological considerations on the western sector of the Danube Delta - A case study for the Caraorman and Sărăturile fluvial-marine levees (with similarities for the Letea levee). Environ. Eng. Manag. J. 9, 795-806.

Rosenberg, G., Ludyanskiy, M.L., 1994. A Nomenclatural Review of Dreissena (Bivalvia: Dreissenidae), with Identification of the Quagga Mussel as Dreissena bugensis. Can. J. Fish. Aquat. Sci. 51, 1474-1484. https://doi. $\operatorname{org} / 10.1139 /$ f94-147

Ryan, W.B.F., Pitman, W.C., 1999. Noah's flood. Simon and Schuster.

Ryan, W.B.F., Pitman, W.C., Major, C.O., Shimkus, K., Moskalenko, V., Jones, G.A., Dimitrov, P., Gorür, N., Sakinç, M., Yüce, H., 1997. An abrupt drowning of the Black Sea shelf. Mar. Geol. 138, 119-126. https://doi.org/10.1016/S00253227(97)00007-8

Rychagov, G.I., 2002. Holocene oscillations of the Caspian Sea, and forecasts based on palaeogeographical reconstructions. Quat. Int. 41-42, 167-172. https://doi.org/10.1016/s1040-6182(96)00049-3

Rychagov, G.I., 1997. Pleistocene history of the Caspian Sea. Moscow State University, Moscow (in Russian).

Sands, A.F., Neubauer, T.A., Nasibi, S., Fasihi Harandi, M., Anistratenko, V.V., Wilke, T., Albrecht, C., 2019a. Old lake vs. young taxa: a comparative phylogeographic perspective on the evolution of Caspian Sea gastropods (Neritidae: Theodoxus). R. Soc. Open Sci.

Sands, A.F., Sereda, S., Stelbrink, B., Neubauer, T.A., Lazarev, S., Wilke, T., Albrecht, C., 2019b. Contributions of biogeographical functions to species accumulation may change over time in refugial regions. J. Biogeogr. 00, 1-13. https://doi.org/10.1111/jbi.13590

Scarlato, O.A., Starobogatov, Y.I., 1972. Klass dvustvorchatyye mollyuski [Class bivalved molluscs], in: Mordukhay-Boltovskoy, F.D. (Ed.), Opredelitel' Fauny Chernogo i Azovskogo Morey: Svobodnozhivushchiye 


\section{REFERENCES}

Bespozvonochnyye. T.3. Chlenistonogiye (Krome Rakoobraznykh), Mollyuski, Iglokozhiye, Shchetinkochelyustnyye, Khordovyye. Naukova dumka, Kiev, pp. 178-249.

Scherbakov, F.A., Kuprin, P.N., Zabelina, E.K., 1977. Paleogeography of the Azov-Black Sea in the late Pleistocene and the Holocene, in: Paleogeography and Deposits of the Pleistocene of the Southern Seas of the USSR. Nauka, Moscow, pp. 51-60 (in Russian).

Schultze, F.T.S., 1826. Catalog der Conchylien-Sammlung des verstorbenen Herrn Ober-Einnehmers Freiherrn von der Malsburg, in deren Besitz sich jetzt befindet der Herr Kammerherr Baron v. d. Malsburg zu Escheberg bei Cassel in Cur-Hessen. Berlin.

Sedaikin, V.M., 1988. Opornye razresy chetvertichnykh otlozheniy severozapadnogo Prikaspiya [The Reference Sections of the Quaternary Deposits of the North-western Pre-Caspian Area]. VINITI Moscow).

Seddon, M.B., Van Damme, D., 2016. Corbicula fluminalis. IUCN Red List Threat. Species 2016 e.T98201936A98201989. https://doi.org/10.2305/IUCN.UK.2016-3.RLTS.T98201936A98201989.en

Seddon, N., Mace, G.M., Naeem, S., Tobias, J.A., Pigot, A.L., Cavanagh, R., Mouillot, D., Vause, J., Walpole, M., 2016. Biodiversity in the anthropocene: Prospects and policy, Proceedings of the Royal Society B: Biological Sciences. The Royal Society. https://doi.org/10.1098/rspb.2016.2094

Selifonova, J.P., 2008. Functioning of the Sea of Azov Ecosystem. Inl. Water Biol. 1, 199-203. https://doi.org/10.1134/ S1995082908030012

Selifonova, Z.P., 2008. Taxonomic composition and interannual variations in numerical density of meroplankton in the Sea of Azov. Russ. J. Mar. Biol. 34, 263-269. https://doi.org/10.1134/S1063074008050015

Selivanov, A.O., 1996. Changes of global sea level in the Pleistocene - the Holocene and development of sea coasts., Inst. of Water Problems. RAS, Moscow (in Russian).

Semenchenko, V.P., Son, M.O., Novitsky, R.A., Kvatch, Y.V., Panov, V.E., 2015. Alien macroinvertebrates and fish in the Dnieper river basin. Russ. J. Biol. Invasions 6, 51-64. https://doi.org/10.1134/S2075111715010063

Semenenko, V.N., Sidenko, O.G., 1979. Reflection of deep structures in the marine Quarternary deposits of the central part of the Sea of Azov., in: Late Quarternary History and Sedimentogenesis of the Opened and Closed Seas. Nauka, Moscow, pp. 87-99 (in Russian).

Shalovenkov, N., 2005. Restoration of some parameters in the development of benthos after reduction of anthropogenous loading in the ecosystem of the Sevastopol Bay in the Black Sea. Mitig. Adapt. Strateg. Glob. Chang. 10, 105-113. https://doi.org/10.1007/s11027-005-7833-z

Shatilova, I., Maissuradze, L., Koiava, K., Mchedlishvili, N., Rukhadze, L., Spezzaferri, S., Strasser, A., 2009. Bioevents on the territory of Georgia during the late Cenozoic as evidenced by foraminifers and palynomorphs. Proc. Georg. Acad. Sci. Biol. Ser. B 7, 90-109.

Shiganova, T., Ozturk, B., 2009. Trend on increasing Mediterranean species arrival into the Black Sea, in: CIESM Workshop Monographs. Trabzon, pp. 75-91.

Shiganova, T.A., 2010. Biotic Homogenization of Inland Seas of the Ponto-Caspian. Annu. Rev. Ecol. Evol. Syst. 41, 103125. https://doi.org/doi:10.1146/annurev.ecolsys.110308.120148 
Shishkoedova, O.S., 2010. Pervaya nakhodka mollyuskov roda Caspiohydrobia (Mollusca: Gastropoda) v Chelyabinskoy oblasti, in: Ecology: From the Southern Mountains to the Northern Seas. Materials of the Young Scientists’ Meeting, 19-23 April, 2010, Yekaterinburg. Goschchitsky Publisher, Yekaterinburg, pp. 210-213.

Shkatova, V.K., 2010. Paleogeography of the late pleistocene caspian basins: Geochronometry, paleomagnetism, paleotemperature, paleosalinity and oxygen isotopes. Quat. Int. 225, 221-229. https://doi.org/10.1016/j. quaint.2009.05.001

Sidnev, A.V., 1985. Development History of the Pliocene Hydrographic Network in the Cisuralia Region. Nauka Press, Moscow (in Russian).

Sigwart, J.D., Bennett, K.D., Edie, S.M., Mander, L., Okamura, B., Padian, K., Wheeler, Q., Winston, J.E., Yeung, N.W., 2018. Measuring Biodiversity and Extinction-Present and Past. Integr. Comp. Biol. https://doi.org/10.1093/icb/ icy 113

Singer, B.S., Guillou, H., Jicha, B.R., Zanella, E., Camps, P., 2014. Refining the quaternary geomagnetic instability time scale (GITS): Lava flow recordings of the blake and post-blake excursions. Quat. Geochronol. 21, 16-28. https:// doi.org/10.1016/j.quageo.2012.12.005

Sinzov, I., 1896. Beschreibung einiger Arten neogener Versteinerungen, welche in den Gouvernements von Cherson und Bessarabien aufgefunden wurden. Zap. novorossiiskoe Obs. Estestvoispyt. 21, 39-88 (in Russian).

Sitnikova, T.Y., Starobogatov, Y.I., 1999. Novyye rod semeystva Pyrgulidae (Gastropoda, Pectinibranchia) iz presnykh rod Azovo-Chernomorskogo basseyna (v svyazi s voprosom o Ponto-Kaspiyskikh vidakh v AzovoChernomorskogom basseyne). Zool. Zhurnal 78, 158-163.

Sitnikova, T.Y., Starobogatov, Y.I., Anistratenko, V.V., 1992. Anatomiya i sistematicheskoye polozheniye nekotorykh melkikh Pectinibranchia (Mollusca, Gastropoda) fauny Yevropy [Anatomy and systematic position of some small Pestinbranchia (Mollusk, Gastropod) fauna of Europe]. Vestn. Zool. 6, 3-12.

Solov'ev, B.L., 1977. About a structure of marine Quarternary terraces between the cities of Sukhumi and Sochi. Geol. Quat. Period. Yerevan 148-155 (in Russian).

Son, M., 2011a. Caspia gmelinii. IUCN Red List Threat. Species 2011 e.T155474A4782113.

Son, M., 2011b. Caspia knipowitchi. IUCN Red List Threat. Species 2011 e.T156116A4900657.

Son, M., 2011c. Caspia makarovi. IUCN Red List Threat. Species 2011 e.T155680A4822960.

Son, M., 2011d. Turricaspia lincta. IUCN Red List Threat. Species 2011 e.T155627A4811075.

Son, M., 2011e. Turricaspia chersonica. IUCN Red List Threat. Species 2011 e.T155738A4835520.

Son, M., Cioboiu, O., 2011. Turricaspia ismailensis. IUCN Red List Threat. Species 2011 e.T155600A4806726.

Sorokin, V.M., 2011. Correlation of upper quaternary deposits and paleogeography of the Black and Caspian seas. Stratigr. Geol. Correl. 19, 563-578. https://doi.org/10.1134/S086959381104006X

Sorokin, V.M., Kuprin, P.N., Chernyshova, M.B., 1983. Comparative late Quarternary paleogeography of the Black and Caspian Seas., in: Paleogeography of the Caspian and Aral Seas in the Cenozoic. Part 1. Moscow University, Moscow, pp. 42-52 (in Russian).

Sorokin, V.M., Yanina, T.A., Bezrodnykh, Y.P., Romanyuk, B.F., 2018. Identification and age of submarine Girkanian sediment beds (Upper Pleistocene) in the Caspian Sea. Quat. Int. 465, 152-157. https://doi.org/10.1016/j. quaint.2016.08.044 


\section{REFERENCES}

Sromek, L., Forcioli, D., Lasota, R., Furla, P., Tarnowska-Marini, K. Wolowicz, M., Chenuil, A., 2016. Strong genetic structuring of the cockle Cerastoderma glaucum across Europe: new insights from an intronic marker and multivariate analysis. J. Molluscan Stud. 82, 515-524. https://doi.org/10.1093/mollus/eyw019

Stănică, A., 2011. The Danube Delta. Back to nature through international cooperation, in: Misdorp, R. (Ed.), Climate of Coastal Cooperation. Coastal \& Marine Union-EUCC (Leiden, the Netherlands), pp. 48-49.

Starobogatov, Y.I., 2000. Caspian endemic genus Andrusovia (Gastropoda Pectinibranchia Horatiidae). Ruthenica 10, $37-42$.

Starobogatov, Y.I., 1994. Freshwater Zebra Mussel, Dreissena polymorpha (Pall.) (Bivalvia, Dreissenidae): Systematics, Ecology, Practical Meaning, Species of the Fauna of Russia and Adjacent Countries. Nauk. Moscow 240 (in Russian).

Starobogatov, Y.I., 1974. Phylum Mollusca, in: Dukhay-Boltovskoy, F.D. (Ed.), Atlas Bespozvonochnykh Aral'skogo Morya. Pishchevaya Promyshlennost', Moscow, pp. 237-257.

Starobogatov, Y.I., 1970. Fauna mollyuskov i zoogeographicheskoye rayonirovaniye kontinental'nykh vo do emov zemnogo shara [The mollusk fauna and zoogeographical regionalisation of continental waterbodies of the Earth]. Nauka, Leningrad.

Starobogatov, Y.I., 1968. Prakticheskiye priyomy sistematiki i vopros o kriterii vida [Practical techniques of taxonomy and the question of the type criteria]. Zool. Zhurnal 47, 875-886.

Starobogatov, Y.I., Alexenko, T.L., Levina, O.V., 1992. Rody Fagotia i Microcolpia (Gastropoda Pectinibranchia Melanopsidae) i ikh predstaviteli v sovremennoj faune. Byulleten’ Mosk. Obs. Ispyt. Prir. Otd. Biol. 97, 57-72.

Starobogatov, Y.I., Filchakov, V.A., Antonova, L.A., Pirogov, V.V., 1994. Novyye dannyye o mollyuskakh i vysshikh rakoobraznykh delty Volgi. Vestn. Zool. 4-5, 8-12.

Starobogatov, Y.I., Prozorova, L.A., Bogachev, V.V., Sayenko, E.M., 2004. Mollyuski, in: Tsalolikhin, S.J. (Ed.), Opredelitel' Presnovodnykh Bespozvonochnykh Rossii i Sopredel'nykh Territoriy. T. 6. Mollyuski, Polikhety, Nemertiny. Nauka, St. Petersburg, pp. 9-941.

Ștefãnescu, C.M., 1981. Nouvelles contributions à létude de la formation et de lévolution du delta du Danube: essai d'interprétation de la morphogenèse du delta à lépoque historique à partir de la toponymie, de l'histoire et des cartes anciennes. Mémoires la Sect. géographie 10, 198.

Stepien, C.A., Grigorovich, I.A., Gray, M.A., Sullivan, T.J., Yerga-Woolwine, S., Kalayci, G., 2013. Evolutionary, biogeographic, and population genetic relationships of dreissenid mussels, with revision of component taxa. Quagga and zebra mussels: biology, impacts, and control, Second. ed, Quagga and Zebra Mussels: Biology, Impacts, and Control. CRC Press, Boca Raton. https://doi.org/https://doi.org/10.1201/b15437-33

Stimpson, W., 1865. Researches upon the Hydrobiinae and allied forms: chiefly made from materials in the Museum of the Smithsonian Institution. Smithson. Misc. Collect. 7, 1-59.

Stoica, M., Krijgsman, W., Fortuin, A., Gliozzi, E., 2016. Paratethyan ostracods in the Spanish Lago-Mare: More evidence for interbasinal exchange at high Mediterranean sea level. Palaeogeogr. Palaeoclimatol. Palaeoecol. 441, 854-870. https://doi.org/10.1016/j.palaeo.2015.10.034

Stoker, J.J., 1947. Surface waves in water of variable depth. Q. Appl. Math. 5, 1-54. 
Stolberg, F., Borysova, O., Mitrofanov, I., Barannik, V., Eghtesadi, P., 2013. Global International Waters Assessment - Regional assessment 23 - Caspian Sea, Journal of Chemical Information and Modeling. University of Kalmar, Kalmar, Sweden. https://doi.org/10.1017/CBO9781107415324.004

Stolberg, F.V., Borysova, O., Mitrofanov, I., Barannik, V., Eghtesadi, P., 2006. Global International Water Assessment 23. Caspian Sea. University of Kalmar (on behalf of United Nations Environment Programme), Kalmar.

Stoliczka, F., 1870. Cretaceous fauna of southern India. The Pelycopoda, with a review of all known Genera of this class, fossil and recent. Palaeontologia Indica, being figures and description s of the organic remains procured during the progress of the Geological Survey of. Mem. Geol. Surv. India 6, 1-538.

Strand, E., 1928. Miscellanea nomenclatorica zoologica et palaeontologica. I-II. Arch. für Naturgeschichte, Abteilung A $92,30-75$.

Stratigraphy of the USSR, 1984. Quaternary system, 1984.. Nedra Press, Moscow.

Strydom, N.A., Whitfield, A.K., Wooldridge, T.H., 2003. The role of estuarine type in characterizing early stage fish assemblages in warm temperate estuaries, South Africa. African Zool. 38, 219-243.

Svitoch, A.A., 2014. The Great Caspian Sea: Structure and History.

Svitoch, A.A., 2013. The Pleistocene Manych straits: Their structure, evolution and role in the Ponto-Caspian basin development. Quat. Int. 302, 101-109. https://doi.org/10.1016/j.quaint.2012.03.015

Svitoch, A.A., 2012. The Caspian Sea shelf during the Pleistocene regressive epochs. Oceanology 52, 526-539. https:// doi.org/10.1134/S0001437012030113

Svitoch, A.A., 2010a. Pleistocene history of the Zunda-Tolga uplift (Manych) and its role in development of the PontoCaspian straits. Dokl. Earth Sci. 435, 1471-1475. https://doi.org/10.1134/S1028334X10110139

Svitoch, A.A., 2010b. The Neoeuxinian basin of the Black Sea and the Khvalinian transgression of the Caspian Sea. Quat. Int. 225, 230-234. https://doi.org/10.1016/j.quaint.2009.03.005

Svitoch, A.A., 2008. The Khvalynian transgression of the Caspian Sea and the New-Euxinian basin of the Black Sea. Water Resour. 35, 165-170. https://doi.org/10.1007/s11268-008-2004-8

Svitoch, A.A., 2003. Marine Pleistocene of the coasts of Russia. GEOS, Moscow (in Russian).

Svitoch, A.A., 1967. Atlas-opredelitel' mollyuskov roda Didacna Eichwald iz chetvertichnykh otlozheniy Tsentral'nogo Prikaspiya [Atlas-identifier of the mollusks of the genus Didacna Eichwald from the Quaternary deposits of the Central Caspian Sea]. Nedra, Moscow.

Svitoch, A.A., Badyukova, E.N., Sheikhi, B., Yanina, T.A., 2013. Geological-geomorphological structure and recent history of the Iranian coast of the Caspian Sea. Dokl. Earth Sci. 451, 843-848. https://doi.org/10.1134/ S1028334X13080060

Svitoch, A.A., Parunin, O.B., Yanina, T.A., 1995. Marine Holocene of the coast of Bulgaria (biostratigraphy, chronology, correlation)., in: Correlation of the Paleogeographical Events: The Continent - the Shelf - the Ocean. Publ. House of the Moscow University, Moscow, pp. 203-217 (in Russian).

Svitoch, A.A., Parunin, O.B., Yanina, T.A., 1994. Radio-carbon chronology of deposits and events of the late Pleistocene of the Ponto-Caspian., in: Geochronology of the Quaternary Period. Nauka, Moscow, pp. 75-82 (in Russian).

Svitoch, A.A., Selivanov, A.O., Yanina, T.A., 1998. Paleogeographical events in the Ponto-Caspian and Mediterranean regions: Materials on reconstructions and correlations). RASKhN Press, Moscow (in Russian). 


\section{REFERENCES}

Svitoch, A.A., Yanina, T.A., 2007. Materials on stratotypes for regional and local divisions of the Caspian

Neopleistocene and the Holocene. Stratigr. Geol. Correl. 15, 95-112.

Svitoch, A.A., Yanina, T.A., 2001. New data on the mollusk fauna from the marine Pleistocene of Manych. Dokl Biol Sci 380, 478-481.

Svitoch, A.A., Yanina, T.A., 1997. Quaternary sediments of the Caspian Sea coasts. RASHN, Moscow.

Svitoch, A.A., Yanina, T.A., Khomenko, A.A., Novikova, N.G., 2009. The Khvalynian sediments of the Manych Depression. Dokl. Earth Sci. 428, 1058-1062.

Svitoch, A.A., Yanina, T.A., Novikova, N.G., Sobolev, V.M., Khomenko, A.A., 2010. Pleystotsen Manycha (voprosy stroyeniya i razvitiya) [Pleistocene of the Manych (structure and development)]. Moscow State University.

Svitoch, A.A., Yanina, T.A., Yanko, V. V., 1992. Biostratigraphy of the Gora Bakinskogo Yarusa section. Izv. Acad. Sci. USSR, Ser. Geol. 2, 128-131 (in Russian).

Sychev, N.V., Liping, L.P., Kurbanov, R.N., 2017. New data on the age of the Uzunlar transgression of the Black Sea. Abstr. Int. youth Sch. "Where East meets West Pontocaspia, Hist. Dimens. Evol. a unique biodiversity”. South. Branch RAS, Rostov-on-Don.

Sysoev, A.V., Kantor, Y.I., 1992. Names of Mollusca introduced by Ya.I. Starobogatov in 1957-1992. Ruthenica 2, 119159.

Szarowska, M., 2006. Molecular phylogeny, systematics and morphological character evolution in the Balkan Rissooidea (Caenogastropoda). Folia Malacol. 14, 99-168. https://doi.org/10.12657/folmal.014.014

Szarowska, M., Falniowski, A., 2014. Horatia Bourguignat, 1887: is this genus really phylogenetically very close to Radomaniola Szarowska, 2006 (Caenogastropoda: Truncatelloidea)? Folia Malacol. 22, 31-39. https://doi. org/10.12657/folmal.022.003

Tadjalli-Pour, M., 1977. Les Mollusques marins des côtes Iraniennes de la Mer Caspienne (Astara-Hachtpar) [Marine molluscs from the Iranian shores of the Caspian Sea (Astara-Hachtpar)]. J. Conchyliol. 114, 87-117.

Taktakishvili, I., 1984. Biostratigraphy of the Pliocene of Western Georgia. Metsniereba, Tbilisi.

Tarasov, A.G., 1996. New data on Caspian deepwater Gastropoda. Ruthenica 6, 117-126 [In Russian with English summary].

Tarasov, A.G., Chepalyga, A.L., 1996. Novyye dannyye o vertikal'nom raspredelenii dvustvorchatykh mollyuskov v glubokovodnykh basseynakh Kaspiya [New data on the vertical distribution of Bivalvia in Caspian deep-water basins]. Ruthenica 5, 147-154 (in Russian with English summary).

Taviani, M., Angeletti, L., Çağatay, M.N., Gasperini, L., Polonia, A., Wesselingh, F.P., 2014. Sedimentary and faunal signatures of the post-glacial marine drowning of the Pontocaspian Gemlik "lake“ (Sea of Marmara). Quat. Int. 345, 11-17. https://doi.org/10.1016/j.quaint.2014.05.045

Taylor, D.W., 1966. A Remarkable Snail Fauna from Coahuila, México. The Veliger 9, 152-228.

Team, R.C., 2018. R: A language and environment for statistical computing.

Teodorescu-Leonte, R., Leonte, V., Umitru, M., Soileanu, B., 1956. Observations on the Razelm-Sinoie complex during 1950-1952 [in Romanian]. Ann. Rom. Res. Inst. Fish. 1, 1-50. 
Teske, P.R., Wooldridge, T.H., 2003. What limits the distribution of subtidal macrobenthos in permanently open and temporarily open/closed South African estuaries? Salinity vs. sediment particle size. Estuar. Coast. Shelf Sci. 57, 225-238. https://doi.org/10.1016/S0272-7714(02)00347-5

Therriault, T.W., Docker, M.F., Orlova, M.I., Heath, D.D., MacIsaac, H.J., 2004. Molecular resolution of the family Dreissenidae (Mollusca: Bivalvia) with emphasis on Ponto-Caspian species, including first report of Mytilopsis leucophaeata in the Black Sea basin. Mol. Phylogenet. Evol. 30, 479-489. https://doi.org/10.1016/S10557903(03)00240-9

Thiele, J., 1928. Revision des Systems der Hydrobiiden und Melaniiden. Zool. Jahrbücher, Abteilung Syst. Ökologie und Geogr. der Tiere 55, 351-402.

Thiele, J., 1925. Mollusca = Weichtiere, in: Kükenthal, W., Krumbach, T. (Eds.), Handbuch Der Zoologie. De Gruyter, Berlin \& Leipzig, pp. 15-266.

Tilman, D., Clark, M., Williams, D.R., Kimmel, K., Polasky, S., Packer, C., 2017. Future threats to biodiversity and pathways to their prevention. Nature 546, 73-81. https://doi.org/10.1038/nature22900

Tomašových, A., Gallmetzer, I., Haselmair, A., Kaufman, D.S., Mavrič, B., Zuschin, M., 2019. A decline in molluscan carbonate production driven by the loss of vegetated habitats encoded in the Holocene sedimentary record of the Gulf of Trieste. Sedimentology 66, 781-807. https://doi.org/10.1111/sed.12516

Tomovic, J., Bodon, M., Giusti, F., Manganelli, G., Cioboiu, O., Beran, L., 2010. Theodoxus danubialis. IUCN Red List Threat. Species 2010 e.T165349A6005150.

Totten, J.G., 1834. Description of some new shells, belonging to the coast of New England. Am. J. Sci. Arts 26, $366-369$.

Trubikhin, V.M., 1977. Paleomagnetizm and stratigraphy of Akchagylian deposits of Western Turkmenia. Transactions of the Geological Institute, Nauka press, Moscow (in Russian).

Tryon, G.W., 1866. [Book review of] Researches upon the Hydrobiinae and allied forms by Dr. Wm. Stimpson. Smithsonian Institution, Washington DC.

UNEP [United Nations Environment Programme], 2006. Annual Report.

Urbański, J., 1975. Lithoglyphus jahni n. sp. aus den mitteleuropäischen Ablagerungen des Mindel/Riss Interglazials nebst Bemerkungen über den nordbalkanischen L. fuscus (C. Pfeiffer 1828) (= L. pyramidatus Moellendorf 1873) - (Gastropoda, Prosobranchia, Hydrobiidae). Bull. la Société des Amis des Sci. des Lettres Pozn. 15, 107-111.

Vadineanu, A., Cristofor, S., Ignat, G., Romanca, G., Ciubuc, C., Florescu, C., 1997. Changes and opportunities for integrated management of the Razim-Sinoe Lagoon system. Int. J. Salt Lake Res. 6, 135-144. https://doi. org/10.1007/BF02441890

van Aartsen, J.J., Stoica, M., Grothe, A., Aliyeva, E., Krijgsman, W., 2016a. Mediterranean-Paratethys connectivity during the Messinian salinity crisis: The Pontian of Azerbaijan. Glob. Planet. Change 141, 63-81. https://doi.org/10.1016/j. gloplacha.2016.04.005

van Aartsen, J.J., Vasiliev, I., Palcu, D.V., Dekkers, M.J., Krijgsman, W., 2016b. A greigite-based magnetostratigraphic time frame for the late miocene to recent DSDP leg 42B cores from the black sea. Front. Earth Sci. 4. https://doi. org/10.3389/feart.2016.00060

Van Baak, C.G.C., 2015. Mediterranean-Paratethys connectivity during the late Miocene to Recent. 


\section{REFERENCES}

Van Baak, C.G.C., Grothe, A., Richards, K., Stoica, M., Aliyeva, E., Davies, G.R., Kuiper, K.F., Krijgsman, W., 2019.

Flooding of the Caspian Sea at the intensification of Northern Hemisphere Glaciations. Glob. Planet. Change 174, 153-163. https://doi.org/10.1016/j.gloplacha.2019.01.007

Van Baak, C.G.C., Krijgsman, W., Magyar, I., Sztanó, O., Golovina, L.A., Grothe, A., Hoyle, T.M., Mandic, O., Patina, I.S., Popov, S.V., Radionova, E.P., Stoica, M., Vasiliev, I., 2017. Paratethys response to the Messinian salinity crisis. EarthScience Rev. https://doi.org/10.1016/j.earscirev.2017.07.015

Van Baak, C.G.C., Vasiliev, I., Stoica, M., Kuiper, K.F., Forte, A.M., Aliyeva, E., Krijgsman, W., 2013. A magnetostratigraphic time frame for Plio-Pleistocene transgressions in the South Caspian Basin, Azerbaijan. Glob. Planet. Change 103, 119-134. https://doi.org/10.1016/j.gloplacha.2012.05.004

van Banning, G., van der Baan, J., Bruijne, W. de, 2018. Vismigratierivier Afsluitdijk (Fish migration river Afsluitdijk). Zwolle (Netherlands).

Van Damme, D., 2014. Dreissena polymorpha. IUCN Red List Threat. Species 2014 e.T155495A42428801.

Van Damme, D., 2013. Potamopyrgus antipodarum. IUCN Red List Threat. Species 2013 e.T155980A738398.

Van Damme, D., 2011a. Hydrobia ventrosa. IUCN Red List Threat. Species 2011 e.T155734A4834019.

Van Damme, D., 2011b. Lithoglyphus naticoides. IUCN Red List Threat. Species 2011 e.T155563A4798694.

Van Damme, D., Kebapçı, U., 2014. Theodoxus pallasi. IUCN Red List Threat. Species 2014 e.T165355A42421481.

van de Velde, S., Jorissen, E.L., Neubauer, T.A., Radan, S., Pavel, A.B., Stoica, M., Van Baak, C.G.C., Martínez Gándara, A., Popa, L.O., de Stigter, H., Abels, H.A., Krijgsman, W., Wesselingh, F.P., 2019a. A conservation palaeobiological approach to assess faunal response of threatened biota under natural and anthropogenic environmental change.

Biogeosciences 16, 2423-2442. https://doi.org/10.5194/bg-2019-2423-2019

van de Velde, S., Wesselingh, F.P., Yanina, T.A., Anistratenko, V.V., Neubauer, T.A., ter Poorten, J.J., Vonhof, H.B., Kroonenberg, S.B., 2019b. Mollusc biodiversity in late Holocene nearshore environments of the Caspian Sea: A baseline for the current biodiversity crisis. Palaeogeogr. Palaeoclimatol. Palaeoecol. 109364. https://doi. org/10.1016/j.palaeo.2019.109364

van de Velde, S., Yanina, T.A., Neubauer, T.A., Wesselingh, F.P., 2019c. The Late Pleistocene mollusk fauna of Selitrennoye (Astrakhan province, Russia): A natural baseline for endemic Caspian Sea faunas. J. Great Lakes Res. 1-13. https://doi.org/10.1016/j.jglr.2019.04.001

van der Boon, A., Beniest, A., Ciurej, A., Gaździcka, E., Grothe, A., Sachsenhofer, R.F., Langereis, C.G., Krijgsman, W., 2018. The Eocene-Oligocene transition in the North Alpine Foreland Basin and subsequent closure of a Paratethys gateway. Glob. Planet. Change 162, 101-119. https://doi.org/10.1016/j.gloplacha.2017.12.009

Van Elsas, J.D., Chiurazzi, M., Mallon, C.A., Elhottova, D., Krištůfek, V., Salles, J.F., 2012. Microbial diversity determines the invasion of soil by a bacterial pathogen. Proc. Natl. Acad. Sci. U. S. A. 109, 1159-1164. https://doi.org/10.1073/ pnas.1109326109

Van Geel, B., Renssen, H., 1998. Abrupt climate change around 2650 BP in NW Europe., in: Issar, A., Brown, N. (Eds.), Water, Environment and Society in Times of Climatic Change. Kluwer, Dordrecht, pp. 21-44.

Varuschenko, S.I., Varuschenko, A.N., Klige, R.K., 1987. Izmenenija rezima Kaspijskogo morja i besstochnih vodoemov $\mathrm{v}$ paleovremeni [Variations of the Caspian sea regime and of closed lakes in palaeotimes] 239 (in Russian). 
Vasiliev, Y.M., 1961. Anthropogene of the Southern Volga area. Publ. house Acad. Sci. USSR, Moscow 1-128 (in Russian).

Vegas-Vilarrubia, T., Rull, V., Montoya, E., Safont, E., 2011. Quaternary palaeoecology and nature conservation: A general review with examples from the neotropics. Quat. Sci. Rev. https://doi.org/10.1016/j.quascirev.2011.05.006

Vekilov, B.G., 1969. Antropogenovyye otlozheniya severo-vostochnogo Azerbaydzhana [Anthropocene deposits of the North-Eastern Azerbaijan]. Elm, Baku, Azerbaijan.

Velichko, A.A., 2002. Dynamics of landscape components and internal sea basins of Northern Eurasia for the last 130 thousand years. GEOS, Moscow (in Russian).

Verduin, A., 1977. On a remarkable dimorphism of the apices in many groups of sympatric, closely related marine gastropod species. Basteria 41, 91-95.

Vespremeanu-Stroe, A., Preoteasa, L., Hanganu, D., Brown, A.G., Bîrzescu, I., Toms, P., Timar-Gabor, A., 2013. The impact of the Late Holocene coastal changes on the rise and decay of the ancient city of Histria (southern Danube delta). Quat. Int. 293, 245-256. https://doi.org/10.1016/j.quaint.2012.11.039

Vespremeanu-Stroe, A., Zăinescu, F., Preoteasa, L., Tătui, F., Rotaru, S., Morhange, C., Stoica, M., Hanganu, J., TimarGabor, A., Cârdan, I., Piotrowska, N., 2017. Holocene evolution of the Danube delta: An integral reconstruction and a revised chronology. Mar. Geol. 388, 38-61. https://doi.org/10.1016/j.margeo.2017.04.002

Vinarski, M.V., 2018. The species question in freshwater malacology: from Linnaeus to the present day. Folia Malacol. 26, 39-52. https://doi.org/10.12657/folmal.026.005

Vinarski, M.V., 2012. Turricaspia caspia. IUCN Red List Threat. Species 2012 e.T189493A1927211.

Vinarski, M.V., 2011a. Pyrgula sowinskyi. IUCN Red List Threat. Species 2011 e.T189266A8708984.

Vinarski, M.V., 2011b. Pyrgula isseli. IUCN Red List Threat. Species 2011 e.T189070A8673755.

Vinarski, M.V., 2011c. Pyrgula behningi. IUCN Red List Threat. Species 2011 e.T189386A8724662.

Vinarski, M.V., 2011d. Caspiohydrobia grimmi. IUCN Red List Threat. Species 2011 e.T189337A8717931.

Vinarski, M.V., 2011e. Pyrgula abichi. IUCN Red List Threat. Species 2011 e.T189305A8713559.

Vinarski, M.V., 2011f. Pyrgula cincta. IUCN Red List Threat. Species 2011 e.T189385A8724527.

Vinarski, M.V., 2011g. Turricaspia conus. IUCN Red List Threat. Species 2011 e.T189262A8708478.

Vinarski, M.V., 2011h. Pyrgula ebersini. IUCN Red List Threat. Species 2011 e.T189454A8734554.

Vinarski, M.V., 2011i. Pyrgula kolesnikoviana. IUCN Red List Threat. Species 2011 e.T189244A8705915.

Vinarski, M.V., 2011j. Turricaspia dagestanica. IUCN Red List Threat. Species 2011 e.T189097A8680601.

Vinarski, M.V., 2011k. Pyrgula grimmi. IUCN Red List Threat. Species 2011 e.T189124A8688657.

Vinarski, M.V., 2011l. Pyrgula nossovi. IUCN Red List Threat. Species 2011 e.T189508A8741457.

Vinarski, M.V., 2011m. Pyrgula pulla. IUCN Red List Threat. Species 2011 e.T189458A8735062.

Vinarski, M.V., 2011n. Turricaspia pullula. IUCN Red List Threat. Species 2011 e.T189467A8736127.

Vinarski, M.V., 2011o. Pyrgula rudis. IUCN Red List Threat. Species 2011 e.T188922A8662920.

Vinarski, M.V., 2011p. Turricaspia sajenkovae. IUCN Red List Threat. Species 2011 e.T189280A8710891.

Vinarski, M.V., 2011q. Turricaspia spasskii. IUCN Red List Threat. Species 2011 e.T189404A8727214.

Vinarski, M.V., 2011r. Turricaspia astrachanica. IUCN Red List Threat. Species 2011 e.T188872A8655897.

Vinarski, M.V., 2011s. Pseudamnicola brusiniana. IUCN Red List Threat. Species 2011 e.T189051A8685851. 


\section{REFERENCES}

Vinarski, M.V., 2011t. Pseudamnicola depressispira. IUCN Red List Threat. Species 2011 e.T189477A8737258.

Vinarski, M.V., 2011u. Anisus kolesnikovi. IUCN Red List Threat. Species 2011 e.T189408A8727730.

Vinarski, M.V., Kantor, Y.I., 2016. Analytical catalogue of fresh and brackish water molluscs of Russia and adjacent countries. A.N. Severtsov Institute of Ecology and Evolution of RAS, Moscow.

Vinarski, M.V., Karimov, A.V., Litvinov, K.V., Podoliako, S.A., 2018. Presnovodnaya malakofauna Astrakhanskogo zapovednika: Vzglyad iz 21-go veka. Tr. Astrakhanskogo Gos. Prir. Biosf. Zapov.. Astrakhan’ 17, 65-87.

Vinarski, M.V., Nekhaev, I.O., Glöer, P., Proschwitz, T. von, 2013. Type materials of freshwater gastropod species described by C.A. Westerlund and accepted in current malacological taxonomy: a taxonomic and nomenclatorial study. Ruthenica 23, 79-108.

Vincent, S.J., Davies, C.E., Richards, K., Aliyeva, E., 2010. Contrasting Pliocene fluvial depositional systems within the rapidly subsiding South Caspian Basin; a case study of the palaeo-Volga and palaeo-Kura river systems in the Surakhany Suite, Upper Productive Series, onshore Azerbaijan. Mar. Pet. Geol. 27, 2079-2106. https://doi. org/10.1016/j.marpetgeo.2010.09.007

Vinogradov, A.P., Grinko, V.A., Ustinov, V.P., 1963. Isotope composition of sulfur in the Black Sea. Geochemistry 10 (in Rus.

von Rintelen, T., Van Damme, D., 2011a. Dreissena bugensis. IUCN Red List Threat. Species 2011 e.T188911A8661357. von Rintelen, T., Van Damme, D., 2011b. Dreissena caspia. IUCN Red List Threat. Species 2011 e.T188971A8669278.

von Rintelen, T., Van Damme, D., 2011c. Dreissena rostriformis. IUCN Red List Threat. Species 2011 e.T189369A8722237.

Vonhof, H., Kasatenkova, M.S., Kasimov, N.S., Kroonenberg, S.B., Lychagin, M.Y., Slobodyan, V.Y., 2004. Isotopic composition of biogenic carbonates and holocene paleogeographic reconstructions of the western Caspian seashore. Dokl. Earth Sci. 394, 145-147.

Vronsky, V.A., 1976. Marinopalinology of the Southern Seas. Rostov University, Rostov-on-Don (in Russian).

Vronsky, V.A., 1974. Results of palynological researches of bottom sediments of the Middle Caspian Sea, in: Geographical Researches in the North Caucasus. Publishing house of Rostov University, Rostov-on-Don, pp. 109112 (in Russian).

Weatherall, P., Marks, K.M., Jakobsson, M., Schmitt, T., Tani, S., Arndt, J.E., Rovere, M., Chayes, D., Ferrini, V., Wigley, R., 2015. A new digital bathymetric model of the world's oceans. Earth Sp. Sci. 2, 331-345. https://doi. org/10.1002/2015EA000107

Welter-Schultes, F., 2012. European non-marine molluscs, a guide for species identification. Planet Poster Editions, Göttingen.

Wenz, W., 1939. Gastropoda. Teil 1: Allgemeiner Teil und Prosobranchia, in: Schindewolf, O.H. (Ed.), Handbuch Der Paläozoologie, Band 6. Verlag Gebrüder Bornträger, Berlin, pp. 1-1639.

Wenz, W., 1926. Fossilium Catalogus I: Animalia. Gastropoda extramarina tertiaria. W. Junk, Berlin.

Wesselingh, F.P., Alçiçek, H., Magyar, I., 2008. A Late Miocene Paratethyan mollusc fauna from the Denizli Basin (southwestern Anatolia, Turkey) and its regional palaeobiogeographic implications. Geobios 41, 861-879. https:// doi.org/10.1016/j.geobios.2008.07.003 
Wesselingh, F.P., Kaandorp, R.J.G., Vonhof, H.B., Räsänen, M.E., Renema, W., Gingras, M., 2006. The nature of aquatic landscapes in the Miocene of western Amazonia: An integrated palaeontological and geochemical approach. Scr. Geol. 363-393.

Wesselingh, F.P., Neubauer, T.A., Anistratenko, V.V., Vinarski, M.V., Yanina, T.A., ter Poorten, J.J., Kijashko, P.V., Albrecht, C., Anistratenko, O.Y., D’Hont, A., Frolov, P., Martínez Gándara, A., Gittenberger, A., Gogaladze, A., Karpinsky, M.G., Lattuada, M., Popa, L.O., Sands, A.F., van de Velde, S., Vandendorpe, J., Wilke, T., 2019. Mollusc species from the Pontocaspian region - an expert opinion list. Zookeys 827, 31-124. https://doi.org/10.3897/ zookeys.827.31365

Westerlund, C.A., 1902a. Malacologische Bemerkungen und Beschreibungen. Nachrichtsblatt der Dtsch. Malakozool. Gesellschaft 34, 35-47.

Westerlund, C.A., 1902b. Methodus dispositionis Conchyliorum extramarinorum in Regione palaearctica viventium, familias, genera, subgenera et stirpes sistens. Rad Jugoslavenske Akad. Znan. i Umjet. 151, 82-139.

Westerlund, C.A., 1896. Neue centralasiatische Mollusken. Ezhegodnik Zool. Muzeya Imp. Akad. Nauk 1, 181-198.

Wilke, T., Albrecht, C., Anistratenko, V.V., Sahin, S.K., Yildirim, M.Z., 2007. Testing biogeographical hypotheses in space and time: Faunal relationships of the putative ancient Lake E囚irdir in Asia Minor. J. Biogeogr. 34, 1807-1821. https://doi.org/10.1111/j.1365-2699.2007.01727.x

Wilke, T., Delicado, D., 2019. Hydrobiidae Stimpson, 1865, in: Lydeard, C., Cummings, K.S. (Eds.), Freshwater Mollusks of the World. A Distribution Atlas. John Hopkins University Press, Baltimore, pp. 111-117.

Wilke, T., Haase, M., Hershler, R., Liu, H.P., Misof, B., Ponder, W., 2013. Pushing short DNA fragments to the limit: Phylogenetic relationships of "hydrobioid" gastropods (Caenogastropoda: Rissooidea). Mol. Phylogenet. Evol. 66, 715-736. https://doi.org/10.1016/j.ympev.2012.10.025

Wilke, T., Wagner, B., Van Bocxlaer, B., Albrecht, C., Ariztegui, D., Delicado, D., Francke, A., Harzhauser, M., Hauffe, T., Holtvoeth, J., Just, J., Leng, M.J., Levkov, Z., Penkman, K., Sadori, L., Skinner, A., Stelbrink, B., Vogel, H., Wesselingh, F.P., Wonik, T., 2016. Scientific drilling projects in ancient lakes: Integrating geological and biological histories. Glob. Planet. Change 143, 118-151. https://doi.org/10.1016/j.gloplacha.2016.05.005

Willis, K.J., Bailey, R.M., Bhagwat, S.A., Birks, H.J.B., 2010. Biodiversity baselines, thresholds and resilience: Testing predictions and assumptions using palaeoecological data. Trends Ecol. Evol. 25, 583-591. https://doi.org/10.1016/j. tree.2010.07.006

World Wide Fund For Nature (WWF), 2018. Living Planet Report - 2018: Aiming higher., Environmental Conservation. https://doi.org/10.1080/09528820802312343

Yakhimovich, V.L., Nemkova, V.K., Dorofeev, P.I., Popova-Lvova, M.G., Suleimanova, F.I., Khabibullina, G.A., Alimbekova, L.I., Latypova, E.K., 1986. Pleystotsen nizhnego techeniya r. Ural [The Pleistocene of the lower stream of the Ural River]. Publishing house of the Bashkirian branch of the Academy of Sciences of the USSR, Ufa (in Russian).

Yakhimovich, V.L., Nemkova, V.K., Verbitskaya, N.P., Sukhov, V.P., Popov, G.I., 1970. Cenozoic of the Uralian Forelands in Bashkirian Fore-Urals. v. II, Part 3. Stages of the geological development of the Bashkir Fore-Urals during Cenozoic. Nauka press, Moscow (in Russian). 


\section{REFERENCES}

Yanchilina, A.G., Ryan, W.B.F., McManus, J.F., Dimitrov, P., Dimitrov, D., Slavova, K., Filipova-Marinova, M., 2017. Compilation of geophysical, geochronological, and geochemical evidence indicates a rapid Mediterraneanderived submergence of the Black Sea's shelf and subsequent substantial salinification in the early Holocene. Mar. Geol. 383, 14-34. https://doi.org/10.1016/j.margeo.2016.11.001

Yanina, T.A., 2015. Assessment of anthropogenous transformation of malakofauna of the Caspian Sea. Environ. Assess. 3, 2-10 (in Russian).

Yanina, T.A., 2014. The Ponto-Caspian region: environmental consequences of climate change during the Late Pleistocene. Quat. Int. 345, 88-99. https://doi.org/10.1016/j.quaint.2014.01.045

Yanina, T.A., 2013a. Biostratigraphy of the Middle and Upper Pleistocene of the Caspian Region. Quat. Int. 284, 85-97. https://doi.org/10.1016/j.quaint.2012.02.008

Yanina, T.A., 2013b. Evolution of the Pont-Caspian environment under the global climate change during the late Pleistocene. Vestn. Moscow Univ. Series 5:1.

Yanina, T.A., 2012a. Neopleystotsen Ponto-Kaspiya: biostratigrafiya, paleogeografiya, korrelyatsiya [Neopleistocene Ponto-Caspian: biostratigraphy, paleogeography, correlation]. Moscow University Press.

Yanina, T.A., 2012b. Correlation of the Late Pleistocene paleogeographical events of the Caspian Sea and Russian Plain. Quat. Int. 271, 120-129. https://doi.org/10.1016/j.quaint.2012.06.003

Yanina, T.A., 2012c. Biostratigraphy of the Caspian Pleistocene, in: Quaternary International. Elsevier Ltd, pp. 546-547. https://doi.org/10.1016/j.quaint.2012.08.1923

Yanina, T.A., 2011. Caspian mollusks in the Pleistocene basins of the Black Sea Region. Geol. Miner. Ocean. 3, 106-123.

Yanina, T.A., 2009. Paleogeografiya basseynov Ponto-Kaspiya v pleystotsene po rezul'tatam malakofaunisticheskogo analiza [Paleogeography of the Ponto-Caspian Basins on the Base of Results of Malacofaunal Analyses]. Moscow State University.

Yanina, T.A., 2006. Manych Depression as area of migrations for faunas of Ponto-Caspian in the Pleistocene. Geomorphology 4, 97-106 (in Russian).

Yanina, T.A., 2005. Didakny Ponto-Kaspiya [Didacnas of the Ponto-Caspian]. Majenta, Moscow-Smolensk.

Yanina, T.A., 1981. Salinity ranges Caspian molluscs, in: Marine Pleistocene Mollusks of the Dagestan Coast of the Caspian Sea, Their Stratigraphic and Paleogeographical Importance.

Yanina, T.A., Khomchenko, D.S., 2014. Mollyuski roda Didacna-biostratigraficheskaya osnova korrelyatsii sobytiy neopleystotsena Ponto-Kaspiya (Genus Didacna molluscs - Biostratigraphical basis of correlation of the PontoCaspian Neopleistocene events). Bull. Odessa Natl. Univ. Geogr. Geol. Sci. 19, 188-202.

Yanina, T.A., Sorokin, V.M., Bezrodnykh, Y.P., Romanyuk, B.F., 2017a. Late Pleistocene climatic events reflected in the Caspian Sea geological history (based on drilling data). Quat. Int. 465, 130-141. https://doi.org/10.1016/j. quaint.2017.08.003

Yanina, T.A., Sorokin, V.M., Bezrodnykh, Y.P., Romanyuk, B.F., 2013. Paleogeography of the Caspian late Pleistocene: New data, in: IGCP 610 First Plenary Meeting and Field Trip, Tbilisi. pp. 2-4.

Yanina, T.A., Svitoch, A.A., 1988. Pleystotsenovyye mollyuski Dagestana (opredelitel' roda Didacna Eichwald) [Pleistocene mollusks of Dagestan (genus identifier of Didacna Eichwald]. VINITI, Moscow. 
Yanina, T.A., Svitoch, A.A., Kurbanov, R.N., Murray, A.S., Tkach, N.T., Sychev, N.V., 2017b. Paleogeographic analysis of the results of optically stimulated luminescence dating of Pleistocene deposits of the lower Volga area. Moscow Univ. Bull. Series 5:1.

Yanina, T.A., Svitoch, A.A., Kurbanov, R.N., Murrey, A.S., Tkach, N.T., Sychev, N.V., 2017c. Experience of dating of Pleistocene deposits of the Lower Volga area by method of optically stimulated luminescence. Geography 1, (in Russian).

Yanina, T.A., Svitoch, A.A., Wesselingh, F.P., 2010. Biodiversity of the Caspian Sea mollusks during the last 10 ky., in: Proceedings of the International Conference "The Caspian Region: Environmental Consequences of the Climate Change." Moscow State University (MSU), Faculty of Geography, Moscow, Russia, pp. 138-142.

Yanko-Hombach, V.V., Gilbert, A.S., Panin, N., Dolukhanov, P.M., 2007. The Black Sea Flood Question: Changes in Coastline, Climate and Human Settlement. Springer, Dordrecht.

Yanko-Hombach, V.V., Mudie, P.J., Kadurin, S., Larchenkov, E., 2014. Holocene marine transgression in the Black Sea: New evidence from the northwestern Black Sea shelf. Quat. Int. 345, 100-118. https://doi.org/10.1016/j. quaint.2013.07.027

Yarovaya, S.K., Kurbanov, R.N., Yanina, T.A., Garankina, E.V., Belyaev, V.R., Garova, E.S., 2016. New results on the stratigraphy of Quaternary sediments of the Manych depression, in: From the Caspian to Mediterranean: Environmental Change and Human Response during the Quaternary. p. 213.

Ysebaert, T., Herman, P.M.J., 2002. Spatial and temporal variation in benthic macrofauna and relationships with environmental variables in an estuarine, intertidal soft-sediment environment. Mar. Ecol. Prog. Ser. 244, 105-124. https://doi.org/10.3354/meps244105

Zaitsev, Y.P., Alexandrov, B.G., Berlinsky, N.A., 2004. The Black Sea: an oxygen-poor sea. Black Sea A Hist. 1-296. https://doi.org/10.1093/0199241619.001.0001

Zaitsev, Y.P., Mamaev, V., 1997. Marine Biological Diversity in the Black Sea - A study of change and decline. United Nations Publications, New York.

Zaranko, D.T., Farara, D.G., Thompson, F.G., 1997. Another exotic mollusc in the Laurentian Great Lakes: the New Zealand native Potamopyrgus antipodarum (Gray 1843) (Gastropoda, Hydrobiidae). Can. J. Fish. Aquat. Sci. 54, 809-814. https://doi.org/10.1139/f96-343

Zarbaliyeva, T.S., Akhundov, M.M., Kasimov, A.M., Nadirov, S.N., Hycenova, G.G., 2016. The influence of invasive species on the Caspian Sea aboriginal fauna in the coastal waters of Azerbaijan. Russ. J. Biol. Invasions 7, 227-236. https://doi.org/10.1134/S2075111716030139

Zastrozhnov, A., Danukalova, G.A., Shick, S., van Kolfschoten, T., 2018. State of stratigraphic knowledge of Quaternary deposits in European Russia: Unresolved issues and challenges for further research. Quat. Int. 478, 4-26. https:// doi.org/10.1016/j.quaint.2017.03.037

Zettler, M.L., 2007. A redescription of Theodoxus schultzii (Grimm, 1877), an endemic neritid gastropod of the Caspian Sea. J. Conchol. 39, 245-252.

Zhadin, V.I., 1952. Mollusks of Fresh and Brackish Waters of the U.S.S.R. Nauka, Moskva, Leningrad.

Zhidovinov, N.Y., Fedkovich, Z.N., Kovalenko, N.D., 2000. Correlation of the Pliocene and Eopleistocene deposits of the Volga area, Northern Fore-Caspian and Bashkirian Fore-Urals]., in: Results of the General Geological and 


\section{REFERENCES}

Palaeotological-Stratigraphical Investigations of the NII Geology and Geological Faculty of the Saratov State University. "Nauchnaya kniga" Press, Saratov, pp. 98-107.

Zhizhchenko, B.P., 1933. Fauna kaspiyiskikh terras, in: Archangelsky, A.D., Davitashvili, L.S. (Eds.), Rukovodyashchiye Iskopayemyye Neftyenosnykh Rayonov Krymsko-Kavkazskoy Oblasti, XV. Trudy Gosudarstvennogo Issledovatel'skogo Neftyanogo Instituta, pp. 30-36.

Zhukov, M.M., 1945. The Pliocene and Quaternary history of the Northern Near-Caspian Lowland. Problems of the Western Kazakhstan. Publ. House Acad. Sci. SSSR, Moscow 2, 45-59 (in Russian).

Zhulidov, A.V., Kozhara, A.V., van der Velde, G., Leuven, R.S.E.W., Son, M.O., Gurtovaya, T.Y., Zhulidov, D.A., Nalepa, T.F., Santiago-Fandino, V.J.R., Chuikov, Y.S., 2018. Status of the invasive brackish water bivalve Mytilopsis leucophaeata (Conrad, 1831) (Dreissenidae) in the Ponto-Caspian region. BioInvasions Rec. 7, 111-120. https:// doi.org/10.3391/bir.2018.7.2.02

Zhulidov, A.V., Zhulidov, D.A., Pavlov, D.F., Nalepa, T.F., Gurtovaya, T.Y., 2005. Expansion of the invasive bivalve mollusk Dreissena bugensis (quagga mussel) in the Don and Volga River Basins: Revisions based on archived specimens. Ecohydrol. Hydrobiol. 5, 127-133.

Zhuze, A.P., Koreneva, E.V., Mukhina, V.V., 1980. Paleogeography of the Black Sea according to studying diatom and the sporous and pollen analysis of deep-water deposits, in: Geological History of the Black Sea on Results of Deep-Water Drilling. Nauka press, Moscow., pp. 77-86 (in Russian).

Zolotarev, V., 1996. The Black Sea ecosystem changes related to the introduction of new mollusc species. Mar. Ecol. 17, 227-236. https://doi.org/10.1111/j.1439-0485.1996.tb00504.x

Zonn, I.S., Kosarev, A.N., Glantz, M.H., Kostianoy, A.G., 2011. The Caspian Sea encyclopedia. Choice Rev. Online 48, 48-2443-48-2443. https://doi.org/10.5860/choice.48-2443

Zubakov, V.A., 1988. Climatostratigraphic Scheme of the Black Sea Pleistocene and its Correlation with the OxygenIsotope Scale and Glacial Events. Quat. Res. 29, 1-24. https://doi.org/10.1016/0033-5894(88)90067-1 
REFERENCES 
